\title{
RELATÓRIO DE IDENTIFICAÇÃO E DELIMITAÇÃO DA TERRA INDÍGENA GUARANI DE ARAÇA'Í (VOLUME I - LAUDO ANTROPOLÓGICO)
}

KIMIYE TOMMASINO ${ }^{1}$

$U E L$

\section{APRESENTAÇÃO}

O Grupo Técnico Terra Indígena Guarani de Araça'í (GT Araça'í) foi designado pelo Presidente da Fundação Nacional do Índio/Ministério da Justiça (FUNAI/MJ), Portaria 928 assinada em 06 de setembro de 2000. A equipe foi assim composta: Kimiye Tommasino (antropóloga, LondrinaPR e coordenadora do GT), Antonio de Paula Nogueira Neto (engenheiro agrônomo, DAF/DEF - Brasília), Flávio Luiz Corne (engenheiro agrimensor, FUNAI/AER Bauru) e Mariane Madalena Weber (engenheira agrônoma, INCRA/SC). A Portaria 1036 de 27 de setembro de 2000 alterou a composição dos membros do GT incluindo o servidor Marcelo Antonio Elihimas (engenheiro agrônomo da AER de Maceió-SE) e excluindo o servidor Antonio de Paula Nogueira Neto (DAF/DEF-Brasília), (Anexo I: 50 e 64).

No dia 08 de setembro apenas a coordenadora do GT iniciou suas atividades com a participação da reunião de audiência e conciliação convocada pelo Juiz Federal Dr. Narciso Leandro Xavier Baez, nas dependências da sala de reuniões da Prefeitura de Chapecó. Estavam presentes o Procurador da União, representando a FUNAI, o cacique guarani Pedro Barbosa e alguns membros do Conselho Guarani, o Procurador dos Autores, o Procurador da Prefeitura Municipal de Chapecó, o Procurador dos Sindicatos, a Procuradora da República Dra. Sônia Cristina Niche, o Administrador da AER Chapecó, Sr. Irani Cunha, representantes do CIMI-Sul e um representante kaingang do Conselho Estadual dos Povos Indígenas. Tratava-se de uma audiência referente à Ação Diversa movida por Flaviano Silvano Zimmer de reintegração da

\footnotetext{
${ }^{1}$ Coordenadora e Antropóloga do Grupo Técnico GT Terra Indígena Guarani de Araça'í. Portaria 928 06/09/2000. FUNAI/MJ - Brasília DF. E-mail: kimiye13@gmail.com.
}

Espaço Ameríndio, Porto Alegre, v. 7, n. 2, p. 277-556, jul./dez. 2013. 
KIMIYE TOMMASINO - Relatório de Identificação e Delimitação da Terra Indígena...

posse onde se encontravam as famílias guarani no município de Saudades-SC.

Ao final da audiência, o Juiz decidiu pela prorrogação do prazo para a saída "pacífica" das famílias guarani de 09 de setembro para mais vinte dias. O documento foi lido e assinado por todos os representantes das instituições e pessoas envolvidas na referida ação. Nesse documento o Juiz deliberou que a equipe técnica do GT deveria limitar sua atuação "ao local onde estão atualmente os indígenas e somente executar os trabalhos de campo após a retirada dos indígenas da área litigiosa no prazo de prorrogação postulado" (Anexo I: 52).

É importante registrar que, nessa ocasião, os Guarani disseram aceitar a saída do local, desde que ficassem dentro da área reivindicada enquanto o Juiz decidiu que, dentro do prazo prorrogado, a FUNAI deveria providenciar outro local para a destinação dos Guarani, fora da área de conflito. A Procuradora Dra. Sônia Cristina Niche ressaltou sua discordância em relação à posição do Juiz Dr. Narciso, dizendo que, no seu entendimento, os Guarani deveriam permanecer no local até a conclusão dos estudos do GT. A coordenação deste GT também encaminhou documento ao Administrador da AER Chapecó no sentido de solicitar a permanência dos Guarani na área de Araça'í e o aumento da área onde se encontravam por entender que os sete hectares a que estavam restritos não seria condizente com as necessidades de fazerem roças e acampamento, mesmo que a título provisório, pois essa provisoriedade poderia se estender, na melhor das hipóteses, por dois a três anos e as famílias necessitariam fazer roças de subsistência (Anexo I: 60).

A FUNAI recorreu contra a decisão do Juiz entrando com agravo de instrumento (no 2000.04.115461-5/SC) quanto ao prazo de 20 dias para a saída dos Guarani e contra a limitação da área de atuação do GT para a realização do estudo antropológico e fundiário. O Juiz Relator, Dr. Edgard Lippman Júnior despachou deferindo o pedido nos seguintes termos: "A questão é controvertida e de relevância incontestável, exigindo, para uma decisão mais tranqüila, uma apreciação mais aprofundada a respeito do caso, transcendendo o atual exame perfunctório da cognição sumária. Assim sendo, ante a importância de que se reveste o assunto, inclusive com possibilidade de conflito, defiro 
KIMIYE TOMMASINO - Relatório de Identificação e Delimitação da Terra Indígena...

o pedido de efeito suspensivo nos termos em que foi requerido." Assinado no dia 25 de setembro de 2000 (Anexo I: 62 e 63).

Dado o clima de conflito e impasse em que se encontrava a questão, a Procuradora da República, Dra. Analúcia Hartmann, em nome da Procuradoria Regional dos Direitos Humanos e da Procuradoria da República em Chapecó convidou o governador do Estado para participar de uma reunião da FUNAI com representantes das partes, a ser realizada nas dependências da Prefeitura Municipal de Chapecó. O governador enviou o secretário do Conselho Estadual dos Povos Indígenas para representá-lo. Participaram prefeitos, advogados de sindicatos, colonos, representantes da FUNAI, as procuradoras Dra. Analúcia e Dra. Sônia, a equipe completa do GT e representantes da comunidade do Araça'í. A reunião não resultou em consenso e o impasse continuou (Anexo I: 67 e 69).

Mesmo com o despacho suspensivo à saída dos Guarani assinada pelo Juiz Lippmann, no dia 18 de outubro de 2000, o Juiz João Batista Lazzari, Juiz Federal, titular da la Vara de Chapecó, deu a sentença deferindo a Liminar de Reintegração de Posse aos autores Flaviano Silvano Zimmer e outros e, ainda, declarando que a comunidade indígena que se encontrava no local deveria "retirar-se imediatamente da área invadida sob pena de remoção forçada". O despacho ainda contém ordens de requisição da Polícia Federal para o cumprimento da ordem judicial, da Polícia Militar do Estado de Santa Catarina, oficiandose ao seu Comandante Geral e requisitando ao Município de Saudades, ônibus e caminhões para remoção dos indígenas e seus pertences. Esse despacho não foi comunicado nem ao administrador da FUNAl nem à Procuradora da República. Na madrugada do dia 19 de outubro as Polícias Federal e Militar e o Corpo de Bombeiros com ônibus e caminhões chegaram ao acampamento e as famílias guarani foram retiradas compulsoriamente e sob ameaça de que se não saíssem, a Polícia Militar que estava a postos, entraria em ação (Anexo I: 71).

As famílias guarani foram levadas para a Área Indígena Nonoai e despejadas dos ônibus na estrada próxima à sede do Posto assim como seus pertences. Para complicar os ânimos, os Kaingang de Nonoai, ao serem surpreendidos pela ação da Polícia Federal que não tinha solicitado autorização para entrar em sua área, e por verem os Guarani 
KIMIYE TOMMASINO - Relatório de Identificação e Delimitação da Terra Indígena...

submetidos à situação constrangedora e violenta, em represália, acabaram por sequestrar os caminhões. Na mesma tarde, o cacique Pedro Barbosa e vários membros do Conselho Guarani estiveram na AER Chapecó onde foram relatar os acontecimentos. Estes foram até a Procuradoria da República em Chapecó onde foram lavrados depoimentos de Sebastião Antunes de Oliveira, Maximino Mariano de Morais e João Barbosa, todos Guarani de Araça'í, relativos à ação de despejo e a situação em que se encontravam as famílias (Anexo I: 79, 80 e 81). Os caminhões foram devolvidos quase um mês depois pelos Kaingang.

\section{A Pesquisa de Campo}

\section{Pesquisa com a Comunidade Guarani que Reivindica a sua Terra Tradicional}

- Visita ao acampamento no município de Saudades. Fizemos duas visitas no local onde os Guarani estavam acampados no município de Saudades. Nessas visitas foram levantadas informações sobre as duas aldeias (Tekohá) que existiram no período aproximado entre 1900 a 1963. Coletamos algumas narrativas sobre a descoberta daquela terra como adequada para a fundação de um Tekohá pelos antepassados, pais e avós dos atuais reivindicantes. Foram também levantados dados sobre as experiências de contato com os primeiros brancos que chegaram e principalmente com a Colonizadora Territorial Sul Brasil que loteou as terras guarani e as vendeu para os colonos teuto-brasileiros que constituem a maioria da população que vive na zona rural de Saudades e Cunha Porã. O acampamento e as famílias acampadas foram documentados fotograficamente.

- Foram realizadas gravações de entrevistas em fita cassete e anotações no caderno de campo com os Guarani mais idosos que detêm a memória do grupo guarani de Araça'í nas dependências da FUNAI-AER Chapecó. Foi complementada a parte de campo para a reconstituição da história do grupo em questão: quando chegaram e de onde vieram, como viviam no Tekohá de Araça'í, como e quando foram expulsos, 
quais Guarani nasceram no Araça'í, quem ali faleceu e foi enterrado nos dois cemitérios que ali tinham. Enfim levantamos mais dados para o nosso relatório.

- A terceira e a quarta visitas de campo junto às famílias guarani foram feitas na Área Indígena Nonoai, onde se econtram acampadas dentro de uma matinha rodeada de plantações de soja, já que os Guarani haviam sidos despejados. Nessas visitas esclarecemos muitas dúvidas que ainda estavam pendentes. João Carlos da Silva, professor guarani da escola improvisada no acampamento, colaborou com o GT anotando todos os nomes guarani da população, incluídos os dos parentes já falecidos.

\section{Visita aos Guarani que Vivem na Região da Terra Guarani/Tekohá do Araça'í}

- Visitamos as famílias guarani que vivem e trabalham no município de Maravilha, entre os quais João Ribeiro da Silva, Cecília, Maria e Otília, suas irmãs; Alcides Ribeiro da Silva e sua esposa Zulmira; Dario Alves da Silva, sobrinho de João Ribeiro da Silva.

- O guarani Levino Ribeiro da Silva (irmão de João) que trabalha na propriedade de Verno Bonad não pôde ser entrevistado porque uma comissão presidida pelos prefeitos de Cunha Porã e Saudades e composta por proprietários e advogados desses municípios proibiu que a equipe do GT tivesse acesso a ele.

\section{Visita aos Guarani que Vivem em Outras Áreas indígenas}

- Visitamos a Área Indígena Nonoai. No Posto de Saúde da Seção Pinhalzinho conversamos com Zulmira Morais que nasceu no Araça'í. Entrevistamos Dorico Morais e Cleci na Aldeia Mbaraca Miri; Alcides de Paula e Tereza Nório de Paula, Rosa Nório na Sede da Al Nonoai. Todos são nascidos em Araça'í.

- Visitamos a Aldeia Passo Feio (Al Nonoai) onde vivem alguns Guarani que eram do Araça'í: Pedrinho da Silva e Aldino Morais.

- Foi realizada também uma visita a Sebastião André na cidade de Rio dos Índios. Só encontramos sua esposa. Ele acabou sendo entrevistado 
em Chapecó na sede da AER. Gravamos sua entrevista em fita cassete e vídeo.

- Em várias ocasiões em que as lideranças estiveram na AER em Chapecó, aproveitamos para completar o levantamento de informações sobre a história do grupo, a Terra Guarani/Tekohá de Araça'í e seus limites e dados de parentesco e casamento.

- Paralelamente foram realizados levantamentos de documentação e bibliografia em várias instituições tais como:

- nos arquivos da FUNAI de Chapecó e de Curitiba;

- na UNOESC/Chapecó-SC;

- na UNIJUII, em ljuí-RS;

- no Centro de Estudos Missioneiros da Universidade Regional Integrada do Alto Uruguai, Santo Ângelo-RS;

- no Museu de Santo Ângelo-RS;

- nas livrarias de Chapecó, Santo Ângelo, Curitiba e Londrina;

- pesquisa no Museu Paranaense em Curitiba-PR;

- pesquisa no arquivo da FUNAI/AER Curitiba-PR;

- visita à cidade de São Miguel das Missões e visita às ruínas e ao IPHAN. Não conseguimos nenhum material importante para nossa pesquisa no escritório do IPHAN local;

- contatos com pesquisadores de várias instituições através de correio eletrônico, telefone ou fax;

- contatos com o Museu do Índio-RJ.

- Com pesquisadores de Porto Alegre (Rogério Reus, Rodrigo Venzon, Lúcio Schwingel e Gislene Monticelli-PUCRS), que nos enviaram estudos, documentos e dados de pesquisa, além de informações por correio eletrônico. Recebemos um relatório importante sobre os sítios arqueológicos na região de nosso interesse e em outras regiões enviado por Gislene Montincelli e ainda um documento (artigo) importante escrito por um promotor público que conheceu os Guarani ainda vivendo em Araça'i em 1931 (Anexo II: 2 e 5).

- Contatos com Alceu Werlang, historiador da UNOESC cuja pesquisa de mestrado versa sobre a colonização da região em litígio. Tínhamos acertado que ele faria entrevistas com duas pessoas idosas da 
KIMIYE TOMMASINO - Relatório de Identificação e Delimitação da Terra Indígena...

comunidade teuto-brasileira que conheceram os Guarani quando viviam no Araça'í, mas o pesquisador foi impedido por membros de uma comissão de um movimento de prefeitos, sindicatos e colonos fundada nos municípios de Saudades e Cunha Porã. Um panfleto deste movimento circulou em vários municípios do oeste catarinense e foi distribuído durante a exposição agro-industrial em Chapecó (Anexo I: 31).

- Contato com a pesquisadora Maria Dorothea Post Darella da UFSC que possui material sobre os Guarani do Araça'í e nos enviou material sobre a visita que sua equipe fez à região de Cunha Porã em setembro de 1996 (Anexo II: 6).

- Contato telefônico e por fax com Bartomeu Melià em Assunção, Paraguai. Melià disse não ter material sobre os Guarani que estamos estudando. Nosso interesse em visitar o Centro de Estudos Paraguayos "Antonio Guasch" não se realizou.

- O Museu o Índio do Rio de Janeiro nos enviou pelo correio documentos solicitados pelo GT.

- Rodrigo Venzon nos enviou artigos sobre os Guarani do Rio Grande do Sul realizados por ele e/ou por outros pesquisadores do PETI-Projeto Estudo sobre Terras Indígenas no Brasil, em parceria com a ANAI/RSAssociação Nacional de Apoio ao Índio do Rio Grande do Sul.

- Também recebemos mapas das reduções espanholas realizadas pelo Centro de Estudos Missioneiros da Universidade Regional Integrada do Alto Uruguai.

- Não podemos deixar de registrar a colaboração da equipe do CimiSul de Chapecó que nos cedeu documentos, fotografias, material de campo, cópias de entrevistas com os índios de Araça'í, material extremamente útil para suprir a parte de campo que o nosso GT não pode realizar com os colonos e mesmo com um Guarani.

- Sem a colaboração desses pesquisadores e dessas instituições nossa pesquisa não teria sido possível e registramos aqui nossos sinceros agradecimentos. 


\section{Equipe de Trabalho}

- Durante a pesquisa de campo contamos com a colaboração de vários funcionários da AER-Chapecó que atenderam os membros do GT Araçaí com bastante eficiência e agilidade. A todos registramos os nossos agradecimentos, em especial ao Sr. Irani Cunha da Silva que ocupava o cargo de administrador daquela unidade.

- Em Londrina contei com a valiosíssima colaboração de uma equipe de alunos e ex-alunos do curso de ciências sociais e outros profissionais que foram responsáveis por várias atividades da pesquisa e elaboração de tabelas, gráficos e redação do relatório os quais nominamos: Valéria E. N. Barros, Jorgisnei Ferreira de Rezende, Germano Faria Corrêa, Daniel da Rocha Madeiros e Cássio Roberto Esteche Brito. Dos 20 mapas que são apresentados, 19 foram feitos pelo operador de informática Carlos Eduardo Franzini da Silva. A todas essas pessoas registramos nossos agradecimentos pela dedicação e empenho para que o relatório fosse concluído.

- Declararamos, entretanto, que as incorreções e lacunas cometidas neste trabalho são de nossa responsabilidade.

Kimiye Tommasino Coordenadora do GT Terra Indígena Guarani de Araça'í Londrina, 15 de agosto de 2001

\section{Introdução Geral}

Pela natureza deste trabalho, optou-se por uma estrutura que combinasse as informações da pesquisa realizada (dados etnográficos, arqueológicos, históricos e sociológicos) com as fundamentações teóricas e conceituais fornecidas pelas ciências sociais de tal forma que não houvesse dúvidas quanto ao rigor científico que orientou a pesquisa, a análise e as conclusões apresentadas. Buscamos também o máximo de objetividade e clareza na apresentação como exigências para o bom entendimento do texto.

É importante registrar as principais dificuldades que os membros

Espaço Ameríndio, Porto Alegre, v. 7, n. 2, p. 277-556, jul./dez. 2013. 
KIMIYE TOMMASINO - Relatório de Identificação e Delimitação da Terra Indígena...

deste GT enfrentaram para realizar a presente pesquisa. O quase total apagamento da história guarani após a guerra guaranítica dificultou sobremaneira a reconstituição do processo que explica a presença guarani no oeste catarinense e do grupo de Araça'í em especial. No entanto, com a colaboração de vários pesquisadores e instituições, pudemos reunir um número razoável de informações de várias ordens e fontes que foram sistematizadas e analisadas e ao final, consideramos suficientes para fundamentar nossas conclusões.

No entanto, registramos a necessidade de preencher esta lacuna no conhecimento específico da questão da terra guarani como uma preocupação seja das instituições acadêmicas seja da instituição indigenista tendo em vista as dificuldades encontradas por este GT e que certamente novas demandas poderão surgir dadas as pressões que os Guarani vêm sofrendo por terem sido excluídos das políticas oficiais que no passado delimitaram terras para os grupos indígenas. A maior parte dos grupos guarani vive em terra alheia como inquilinos ou em terras ainda não reconhecidas e demarcadas pelo Estado. Uma série de lacunas sobre o (des)conhecimento da história guarani foram detectadas durante a pesquisa, mas podemos elencar algumas que se relacionam ao estado da arte em relação às pesquisas sobre essa etnia: a) há uma bibliografia muito vasta referente aos Guarani, mas se encontra fragmentada e não permite uma visão de conjunto; b) a maioria dos pesquisadores escolheu um grupo, uma aldeia ou um segmento muito restrito como objeto de estudo e o resultado final não permite integrar cada contribuição num panorama histórico mais geral; c) tornou-se praxe na academia utilizar o recorte espacial oficial (estado, região sul) e que não coincide com a espacialidade ou territorialidade indígenas. Por exemplo, estudou-se o Guarani no Paraná ou no RS resultando uma invisibilidade do território guarani tal como construído historicamente por eles, ou seja, trata-se de um território que ultrapassa as fronteiras estaduais e nacionais; d) outra observação é que há uma profusão de estudos sobre os Guarani Mbyá em detrimento das demais parcialidades. São poucos os que estudaram os Chiripá (Nhandeva) e Kaiowá e mesmo assim quase não há referências sobre as relações entre as parcialidades, além das relações com as populações nacionais e mesmo com outras etnias indígenas; e) são raros os trabalhos 
etnográficos e etnológicos recentes sobre os Guarani, e quando há, se restringem aos Mbyá com as características apontadas acima (fragmentação dos estudos, recortados dentro de um estado no Brasil, estudo de uma aldeia); f) quase todos os trabalhos situam o grupo estudado de forma genérica no contexto histórico de alcance regional e de médio prazo. São identificados como tendo vindo no século XIX ou $X X$ do Paraguai e da Argentina. Evidentemente esses pesquisadores enfrentaram os mesmos problemas que enfrentamos agora: a mesma fragmentação, a falta de um estudo mais abrangente sobre os Guarani em geral e cada parcialidade em específico.

No entanto alguns trabalhos superaram algumas das limitações acima apontadas e puderam contribuir para que retomássemos algumas tentativas de unificação. $\mathrm{O}$ trabalho que fornece um panorama geral dos Guarani e suas parcialidades sem a preocupação de eleger uma como objeto de estudo é o de Egon Schaden (1962). Mesmo levando em consideração que algumas de suas análises devam ser revistas por estarem teoricamente superadas, é inegável a contribuição de Schaden porque ele conheceu pessoalmente a maioria dos grupos guarani e teve uma visão da diversidade das situações que os diferentes grupos enfrentavam. O seu contato com Cadogan e visita aos Guarani do Paraguai confere a este pesquisador uma autoridade inquestionável. Seus trabalhos foram de vital importância em nossa pesquisa.

O grupo de Araça'í se define como Chiripá, embora se trate de um grupo chiripá que incorporou um homem mbyá através da aliança pelo casamento com mulher chiripá, através da regra da uxorilocalidade (o marido vai morar no grupo da esposa), este passou a integrar o grupo chiripá. Encontramos poucas mas importantes informações sobre a origem dos Guarani que foram viver em Nonoai: Rambo (1947) e Venzon (1990/93a). Schaden (1962) visitou os Guarani de Xapecozinho-SC em 1947 e os identificou como sendo Mbyá que vivem até hoje na Aldeia Limeira. De fato, os Guarani de Araça'í disseram não ter parentesco e nunca mantiveram relações com aquele grupo, mas os reconhecem como Guarani. A pesquisa de Simonian (1981) tinha estudado os Guarani de Nonoai como sendo Mbyá originários do Paraguai e do nordeste da Argentina (Misiones) e que, conforme Rambo, teriam vivido antes em Chapecó-SC. O livro Povos Indígenas no Brasil 1991/1995 (ISA 
KIMIYE TOMMASINO - Relatório de Identificação e Delimitação da Terra Indígena...

- Instituto Sócio-ambiental, 1996, p. 769) registra a presença na Al Nonoai de Kaingang e de Guarani Nhandeva e Mbyá, mas não cita a(s) fonte(s).

No caso da história do grupo estudado, desde a sua instalação em Araça'í, sua expulsão e seu destino até os dias atuais pudemos contar com as narrativas dos filhos e netos daqueles primeiros que chegaram ao local. Também utilizamos alguns registros de pesquisadores da UNOESC sobre os primeiros colonos e suas relações com os Guarani que lá estavam e alguns que ainda permanecem dispersos na região. Foi muito útil um artigo publicado em 1972 pelo promotor Dr. José Alberto Barboza que conheceu os Guarani de Araça'í em 1931 e registrou episódios vividos por ele, autoridades municipais e estaduais com as lideranças guarani que aparecem nomeados e são os pais e avós daqueles que hoje reivindicam a terra tradicional (Anexo II: 2).

Por fim queremos registrar que os resultados aqui apresentados, como em qualquer pesquisa, não esgotam o assunto e merecem futuros aprofundamentos. A nossa pesquisa teve por objetivo levantar subsídios científicos sobre a história de um grupo específico e sua territorialidade, inserindo a história local desse grupo num contexto mais abrangente e apontando os principais marcos de sua história particular. Acima de tudo pretendemos mostrar que a história local de Araça'í configura uma história guarani no tempo e espaço que inclui experiências históricas com portugueses, espanhóis e outras etnias indígenas que há 500 anos rompeu com as histórias indígenas que se processavam naquela parte do continente sul-americano e delinearam outras trajetórias. Deu-se ênfase à recuperação mais detalhada da história guarani nos últimos 100 anos período que se processou o apagamento dos Guarani na história oficial que, em parte, justifica terem permanecido desconhecidos até o momento.

Todas as políticas indigenistas sugerem que os Guarani teriam sido abolidos como objeto de preocupação por parte do Estado: ou estavam "aculturados" ou na fase final de aculturação, eram "índios integrados" e, portanto, não necessitavam ser atendidos pelas ações indigenistas; não mais se constituíam "empecilhos ao progresso"; já tinham sido transformados em "trabalhadores nacionais" que era o objetivo do Estado para todos os povos autóctones. Quando aldeados 
em áreas abertas à colonização foram transferidos para terras delimitadas para outros grupos ainda "selvagens" ou "arredios" como os Kaingang e os Xokleng. É significativo que um relatório do SPI realizado por Darcy Ribeiro de 1954 faz referência aos grupos indígenas de várias regiões mas, quando fala da região sul, só se refere aos Kaingang e aos Xokleng, não havendo nenhuma referência aos Guarani. Darcy Ribeiro em seu livro "Os Índios e a Civilização" publicado em 1970, no quadro da situação dos grupos indígenas em 1900, quanto ao grau de integração na sociedade nacional, coloca os Guarani como "integrados". Esta classificação como "índios integrados" acabou produzindo ações indigenistas que justificaram o uso de critério branco para delimitar terras para os índios e, no caso dos Guarani (que estavam) dispersos em pequenos grupos de famílias nucleares, foram arregimentados pelo SPI e colocados a viverem como inquilinos dos Kaingang, e mais tarde, também dos Xokleng. No Estado do Paraná, o tamanho das áreas indígenas teve como critério o módulo mínimo do INCRA que estabelecia para cada família nuclear 100 ha acrescidos de 500 ha para a instalação do Posto Indígena. No Rio Grande do Sul o módulo era de 50 ha. Os postos kaingang que receberam grupos guarani foram: Araribá (SP), Mangueirinha (PR), São Jerônimo (PR), Rio das Cobras (PR), Ivaí (PR), Xapecó (SC), Votouro (RS), Guarita (RS) e Nonoai (RS). Laranjinha (PR) foi criada como área kaingang para abrigar dois grupos arredios que foram pacificados em 1930 (TOMMASINO, 1995), mas um grupo foi transferido para o Ivaí e outro acabou morrendo nas epidemias e dele hoje restam duas ou três pessoas kaingang; os Guarani que lá vivem foram trazidos de Araribá para "amansar os Coroados" e ainda algumas famílias que viviam dispersas na região foram convencidas a viverem na reserva. A área de Votouro é uma exceção à regra: acabou sendo dividida administrativamente em Votouro (área kaingang) e Votouro Guarani (área guarani), cada grupo ficando com sua terra própria.

Um outro problema detectado pela nossa pesquisa foi a dificuldade de integrar os estudos sobre os Guarani que vivem no Paraguai e na Argentina os quais estão historicamente vinculados aos grupos que vivem no território brasileiro e que, da mesma forma que no Brasil, estão sendo estudados de forma fragmentada e seccionada a 
KIMIYE TOMMASINO - Relatório de Identificação e Delimitação da Terra Indígena...

partir de um critério exterior e, apesar de constituírem uma unidade territorial mais ampla, essa unidade nunca é visualizada. Uma integração dos estudos realizados por pesquisadores brasileiros, argentinos e paraguaios seria uma das necessidades para a superação do estado atual dos estudos sobre os Guarani.

Em vista dos problemas apontados, tentamos trabalhar com a unidade territorial guarani como um todo para que as análises não sofressem defeitos de entendimento consequente ao fracionamento. Dessa forma os códigos externos (estados, municípios, países) aparecerão somente na medida em que haja necessidade explicativa para desvelar a história guarani ocultada e não registrada. A perspectiva de análise será a dos Guarani, ao longo do tempo sofrendo a conquista de suas terras, tendo de reorganizar suas vidas nas novas conjunturas, transformando-se em trabalhadores, inquilinos de outras etnias, tentando recriar as condições para preservar o seu modo de ser. Os códigos da sociedade dominante aparecerão na medida em que há de fato superposição de vários códigos nos mesmos espaços físicos que constituem a área pesquisada.

Outro ponto a ser esclarecido é sobre o ajuste do relatório à Portaria 14 que estabelece regras sobre a elaboração do Relatório circunstanciado de identificação e delimitação de terras indígenas em atendimento ao parágrafo $6^{\circ}$ do Artigo $2^{\circ}$ do Decreto 1775 , de 08 de janeiro de 1996.

Em vista das especificidades da comunidade de Araça'í - a maioria das famílias que viviam nas aldeias Passo Feio e Mbaraca Mirim na TI Nonoai passaram a viver em barracos de lona num acampamento na Seção Araça'í no município de Saudades entre julho e outubro de 2000 e depois do despejo, no segundo acampamento próximo à aldeia Sede/Nonoai foi necessário fazer um ajuste para o atendimento à referida Portaria 14 que passaremos a explicar.

O primeiro ponto a esclarecer é que a Portaria 14 não exige uma contextualização histórica e sociológica mais ampla do grupo em estudo. No caso dos Guarani de Araça'í essa contextualização, em nosso entendimento, é imprescindível. As ações e experiências relatadas pelos Guarani que reivindicam a terra Araça'í só podem ser compreendidas dentro de um tempo e espaço muito mais dilatados que os considerados 
em relação a terra Araça'í. Outro ponto a ser destacado é que a história guarani, apesar da extensa bibliografia produzida, ainda não foi suficientemente sistematizada e organizada em termos de uma história geral guarani e nós nos encontramos diante de uma multidão de estudos fragmentados que não permitem uma visão ampla, no tempo e no espaço, capaz de revelar a complexidade da realidade histórica como um todo. O GT Araça'í, para sanar as lacunas existentes acabou por desenvolver uma pesquisa muito ampla que aqui será apresentada a qual, mesmo longe de esgotar o assunto, pode fornecer vinculações históricas e geográficas capazes de situar melhor o grupo objeto de estudo.

Dividimos o relatório em capítulos os quais, em atendimento à Portaria 14, ficam da seguinte maneira:

I. os capítulos I, II e III atendem o item a da Primeira Parte;

II. o capítulo IV atende os itens $\underline{b}$ e $\underline{c}$ da Primeira Parte, todos os itens da Segunda, Terceira e Quarta Partes e os itens $\underline{b}$ e $\underline{c}$ da Quinta Parte.

III. O item a da Quinta Parte ficou parcialmente prejudicado em relação à apresentação das taxas de natalidade e mortalidade pelas seguintes razões: primeiro porque não há informações seguras e sistemáticas sobre natalidade e mortalidade por aldeia e por família para que possamos extrair as taxas das famílias de Araça'í e segundo porque as famílias de Araça'í estão dispersas por várias aldeias de várias Tls do Rio Grande do Sul e outras vivem fora das aldeias em municípios da região.

IV. a Sexta Parte não foi apresentada porque a equipe técnica foi impedida de adentrar as terras de Araça'í que foram loteadas e vendidas para colonos teuto-brasileiros e nacionais por decisão dos prefeitos, advogados e colonos e o levantamento fundiário não foi realizado.

V. O capítulo $V$ atende a Sétima Parte onde apresentamos o Memorial Descritivo de Delimitação com o respectivo Mapa de Delimitação da Terra Indígena Guarani de Araça'í.

Relativamente à reconstituição histórica dos Guarani enfocamos a

Espaço Ameríndio, Porto Alegre, v. 7, n. 2, p. 277-556, jul./dez. 2013. 
KIMIYE TOMMASINO - Relatório de Identificação e Delimitação da Terra Indígena...

sua cultura e a sua história, de acordo com a perspectiva indígena, como estruturadores de sua dinâmica no tempo e no espaço. Os Guarani são sujeitos de sua própria história e já estavam neste continente quando os Juruá (brancos) aqui chegaram e, portanto, estes estarão na história guarani a partir do século XVI; os Kaingang já estavam muito tempo antes do século XVI em contato com os Guarani e continuaram na sua história após a conquista. Todas essas sociedades estarão presentes na história regional como atores de um processo histórico interétnico.

A cultura guarani, como a de qualquer outra sociedade viva, sofreu mudanças impostas pelos acontecimentos que ocorreram ao longo da sua história e, mesmo com as políticas genocidas e etnocidas, eles continuaram tecendo a sua história culturamente ou, em outras palavras, a sua história foi orientada a partir de seus códigos.

Neste trabalho estaremos utilizando uma perspectiva de análise que concilia antropologia e história mostrando que a história guarani tem sua especificidade particular, orientada pelos valores e princípios da cultura guarani, de acordo com a feliz expressão de Sahlins (1990): culturas diferentes, historicidades diferentes. Por outro lado, mesmo optando pela perspectiva guarani o texto será polissêmico, pois a sua história se desenvolveu em situações que sempre envolveram relações com alteridades, seja entre parcialidades seja com os Kaingang e os Juruá.

Estaremos também analisando os casamentos e genealogias das famílias do Tekohá Araça'í entre si, com pessoas de outros Tekohá, com os Kaingang e com os Juruá (brancos) como constituindo uma rede de alianças políticas entre as famílias e os grupos envolvidos. Interessa-nos nesta pesquisa analisar os casamentos que ocorreram dentro da comunidade de Araça'í no sentido de evidenciar que ela é constituída por várias famílias extensas - Honório, Morais, Ribeiro da Silva e Barbosa - as quais ao longo do trajeto por onde vieram, de algum lugar do Paraguai passando pela Argentina até Araça'í e, posteriormente, quando saíram de Araça'í e foram viver em terras kaigang ou dos Juruá foram construindo alianças através da inclusão de pessoas oriundas de outras parcialidades e outros grupos étnicos (Kaingang; Juruá). As famílias de Araça'í também cederam filhos e filhas para esses grupos, configurando a troca recíproca.

Espaço Ameríndio, Porto Alegre, v. 7, n. 2, p. 277-556, jul./dez. 2013. 
Pela regra da reciprocidade, os Guarani se caracterizam tanto como doadores quanto como receptores de pessoas, sejam homens sejam mulheres. Quando o estrangeiro, índio ou juruá é incorporado ao grupo, os filhos pertencerão ao grupo onde serão criados, como no caso de um homem mbyá que se casou com mulher guarani e passou a viver na aldeia da esposa, configurando residência uxorilocal e ficando o Mbyá incorporado ao grupo chiripá. Da mesma forma, quando um Juruá se casa com mulher guarani e passa a viver na aldeia da esposa, os seus filhos, ao serem socializados na cultura guarani, serão considerados do grupo e culturalmente guarani. No caso dos kaingang os brancos incorporados são codificados como "indiano", deixando de ser um branco qualquer.

Por outro lado, também verificamos casos inversos: mulher ou homem chiripá poderá se casar e ir viver com a família do cônjuge e então será incluído no universo das regras do grupo no qual foi incluído(a).

Finalmente um esclarecimento sobre os anexos que seguem em um volume separado. Além dos documentos (Portarias, Atas, Ofícios, etc.), que normalmente seguem como comprovantes dos processos analisados, decidimos anexar também alguns textos ou artigos de interesse, acadêmico ou não, mas de difícil acesso, para que futuros interessados possam utilizá-los. Os anexos seguiram dois critérios: pela importância para o trabalho em si, e que mostrassem os acontecimentos como um todo e em seqüência cronológica.

\section{CAPÍTULO I - DADOS GERAIS SOBRE OS GUARANI}

\section{Informações Gerais Sobre os Guarani}

Os Guarani falam o idioma guarani que pertence à família linguística tupi-guarani do tronco tupi. No Brasil são divididos em três parcialidades: Mbyá, Kaiowá e Chiripá (Nhandeva). As famílias que formam a comunidade de Araça'í se definem como Chiripá.

Cada parcialidade, além do dialeto que a distingue das demais, ainda possui especificidades culturais bem nítidas. Apesar da 
KIMIYE TOMMASINO - Relatório de Identificação e Delimitação da Terra Indígena...

miscigenação entre parcialidades, mantém unidade cultural e lingüística.

A população guarani é atualmente a maior das etnias indígenas no Brasil. No total os Guarani são estimados em 30 mil. Vivem também no Paraguai, Argentina e Bolívia, os quais somados ultrapassam 100 mil (RICARDO, 1995, p. 38).

Os Chiripá vivem espalhados em muitos lugares: no litoral atlântico (TIs Itaoca-SP, Itariri-SP, Mbiguaçu-SC, Peruíbe-SP); interior do Estado de São Paulo (TI Araribá-SP); no Mato Grosso do Sul (TIs Amambai, Caarapó, Cerrito, Dourados, Jaguari, Jarara, Pirajuí, Porto Lindo, Potrero Guaçu, Sassoró e Sete Cerros); no Paraná (TIs Laranjinha, Pinhalzinho, São Jerônimo, Palmeirinha, Avá Guarani/Ocoí, Ivaí, Tekohá Añetete); em Santa Catarina (TI Ibirama-La Klano); no Rio Grande do Sul (TIs Guarani Votouro, TI Nonoai, Cacique Doble e Guarita) (ISA, 2000). Em muitas dessas áreas os Chiripá vivem com outras parcialidades ou com outras etnias.

Os atuais Guarani que vivem no litoral e mesmo no interior dos estados do sul e de São Paulo são provenientes do oeste (regiões do Mato Grosso do Sul, Paraguai e Argentina) através de várias ondas migratórias que vêm se sucedendo desde o primeiro quartel do século XIX. Nimuendajú identificou quatro grupos: os Tañiguá em 1820, os Oguauíva em 1820, os Apapocuva em 1870 e um quarto grupo em 1912 (apud Schaden, 1962, p. 12). Schaden refere-se a algumas levas de Mbyá vindos do leste paraguaio e nordeste argentino que atravessaram o Rio Grande do Sul, Santa Catarina e Paraná e chegaram no litoral. Ele identificou três grupos: um vindo por volta de 1924, outro em 1934 e um terceiro que chegou em 1946, "igualmente vindo do Paraguai meridional, de território contíguo à província argentina de Misiones".

Sintetizamos os principais aspectos da cultura guarani que serão os referenciais utilizados neste trabalho. Melià faz a apresentação dos Guarani da seguinte maneira:

Os Guarani se manifestam hoje como um 'modo de ser'. Com um claro sentimento de singularidade eles falam do ñande rekó - como a expressão mais cabal de sua identidade e de sua diferença. Os significados desta palavra são múltiplos: nosso modo de ser, nosso modo de estar, nosso sistema, nossa lei, nossa cultura, nossa norma, nosso comportamento, nosso hábito, nossa 
KIMIYE TOMMASINO - Relatório de Identificação e Delimitação da Terra Indígena...

condição, nossos costumes. O mais antigo dicionário, o Tesoro de la lengua guaraní, de 1639, do padre Antonio Ruiz de Montoya, já registrava estes significados.

O 'modo de ser' guarani é constituído ainda por duas formas essenciais: o ñande rekó katú (nosso modo de ser autêntico e verdadeiro) e o ñande rekó marangatú (nosso modo de ser bom, honrado e virtuoso enquanto religioso). Perguntar como se forma e como se vive na atualidade esse modo de ser religioso equivale a perguntar sobre a experiência religiosa guarani (MELIÀ, 1989, p. 293).

Melià esclarece ainda sobre a cosmologia e mitologia desse povo, em que os elementos do mundo sobrenatural não se apresentam tão separados como transparecem nas catalogações etnográficas. Por essa razão diz Melià:

O cosmos guarani não insiste demais em um céu e uma terra, segundo um eixo vertical de um embaixo e um em cima. O cosmos guarani se apresenta mais como uma plataforma circular, cujas referências principais são os pontos cardeais este e oeste. Os deuses se situam em função desses pontos cardeais, neles se revelam preferentemente, e a partir deles atuam. A orientação leste-oeste não é apenas uma referência solar; outros fenômenos meteorológicos como trovões, relâmpagos, chuva, vento, têm sua origem num lugar desse espaço. O trovão, personificado geralmente em Tupã, procede do ocidente, e vai em direção ao oriente, manifestado no fulgor do relâmpago.

$[\ldots]$

Junto com uma concepção que poderíamos chamar horizontal do cosmos, segundo a qual o 'céu' estaria nas beiras da plataforma terrestre, coexiste uma concepção de planos superpostos, como se os cosmos tivessem diferentes pisos, ou ceús, que a dança ritual faz atravessar. Esta é a concepção cosmológica que está implícita no 'Canto ritual de Nosso Avô Grande Primigênio', que na forma de um hino relata a criação da terra, a revelação dos deuses que tomarão conta da terra, e dos homens, 'filhos de sua palavra'. Estes se enfeitam ritualmente e se aproximam, através do próprio canto e da dança, das portas do paraíso, as abrem, as transpõem e entram nas moradas que não são senão o lugar onde se celebra a verdadeira liturgia, como a celebrara já o próprio Avê Grande Primeiro" (MELIÀ, idem, p. 327-328).

Espaço Ameríndio, Porto Alegre, v. 7, n. 2, p. 277-556, jul./dez. 2013. 
Dentro dessa perspectiva antropológica é que se pode distinguir o conceito de terra guarani do de terra para os Juruá, reduzida que foi ao longo da história ocidental em mera mercadoria trocável no mercado como qualquer outro produto. Terra guarani não pode ser trocada por outra porque ela faz parte de sua experiência histórica e o seu "modo de ser" está nela fundado, pois "terra boa" para os Guarani é o resultado da socialização dos espaços geográficos que formam seus territórios:

os guarani são povos que se movimentam numa ampla geografia, com migrações eventuais a regiões muito distantes e com freqüentes deslocamentos dentro de uma mesma região. Não são propriamente nômades, mas colonos dinâmicos. Os guarani ocupam terras com características ecológicas bem constantes. São terras mais aptas para seus cultivos de milho, mandioca, batata, feijão e abóboras. Essas terras oferecem um horizonte ecológico muito bem definido cujos limites dificilmente são rompidos. Pode-se falar com muita propriedade de uma 'terra guarani' que, raramente, se desmente.

Os guarani escolheram climas úmidos, com uma temperatura média entre 18 e 22 graus. Localizaram-se preferencialmente às margens de rios e lagoas, em lugares que não passam dos 400 metros sobre o nível do mar, habitando bosques e selvas típicas da região subtropical.

Não obstante, esta terra não constitui um fator inflexível nem imutável. Se bem que a terra imponha suas condições, é o guarani que faz a sua terra. A terra guarani vive com os guarani que nela vivem. A ecologia guarani não se restringe à natureza, nem se define por seu valor exclusivamente produtivo. Com uma expressão que Ihe é bem característica, o guarani refere-se ao seu território como Tekohá. Ora, se tekó é o modo de ser, o sistema, a cultura, a lei e os costumes, o Tekohá é o lugar e o meio em que se dão as condições de possibilidade do modo de ser guarani. 'O Tekohá significa e produz ao mesmo tempo relações econômicas, relações sociais e organização político-religiosa, essenciais para a vida guarani. Embora pareça redundância, temos que admitir, com os próprios dirigentes guarani que, sem Tekohá não há tekó'. O Tekohá, com toda a sua 
materialidade terrena, é sobretudo uma interrelação de espaços culturais: econômicos, sociais, religiosos e políticos. É o lugar - dizem os guarani - onde vivemos segundo nossos costumes.

A estrutura fundamental do Tekohá e a relação de seus espaços se apresentam deste modo: um monte preservado e pouco perturbado, reservado para a caça, a pesca e a coleta de mel e de frutas silvestres; umas faixas de terra especialmente fértil para fazer as roças e os cultivos, e por fim um lugar onde será erguida a grande casa comunal, com seu grande pátio aberto, ao redor do qual crescem alguns pés de banana, de tártago, de algodão e de urucú. São estes três espaços: monte, roça e aldeia que servem para avaliar a boa terra guarani (MELIÀ, 1989, p. 336-37; grifos nossos).

Outro ponto esclarecido agora por Almeida (1985, p. 11) é a distinção entre a noção de Tekohá/aldeia de território/Tetã ou Guará. Segundo o autor, apenas os Paí/Kaiowá mantêm até hoje a noção de um território próprio e também de Tekohá. "Para ambos os casos os Pai/Kaiowá têm uma delimitação relativamente precisa, apontando marcos naturais como limites". Para os Mbyá, esses dois conceitos são difusos de tal modo que território mbyá seria, conforme lhe explicou um deles, “Argentina, Paraguai, Uruguai e Brasil, tudo é terra Mbyá. Que Ñanderú (Deus criador) havia destinado todas aquelas terras aos Mbyá e que, portanto, tinham que ter um lugar para plantar". Dessa forma, os Mbyá não reivindicam uma terra específica dentro desse imenso território mas para erguer seu Tataypy Rupa, os requisitos seriam: que tenha mato, onde se possa plantar, onde não haja conflitos e se possa reproduzir seu modo de ser e que seja distante dos Juruá (/dem, ibidem). Essa diferença em relação à noção de território e Tekoha se deve a distintas situações vividas regionalmente pelos Mbyá e pelos Paí/Kaiowá. Almeida não fez referência específica sobre os Chiripá e, no caso da reivindicação dos Guarani de Araça'í, a reivindicação foi bem definida em relação aos limites naturais de seu Tekohá que está no mapa desenhado por eles e que foi apresentado à nossa equipe técnica. O nome do Tekohá seguia a regra de nomear pelo lugar onde se localizava: os do rio Araça'í (Araçazinho) e também como Karaí Tupã certamente o nome de um líder religioso do grupo.

Espaço Ameríndio, Porto Alegre, v. 7, n. 2, p. 277-556, jul./dez. 2013. 
Aparentemente há uma contradição entre Melià e Almeida com relação às concepções de território para os Guarani. Na verdade, o que Melià chama de "território como Tekohá" é a terra do assentamento de um grupo local ou família extensa, como é o caso da Terra Araça'í que abrigou as famílias Honório, Ribeiro da Silva, Barbosa e Morais que formavam uma rede de famílias vinculadas pelo parentesco. Território guarani, segundo a interpretação de Almeida, Tetã ou Guará seria o conjunto das terras de todos os Tekohá vinculados entre si formando uma comunidade ampla, podendo-se estender por uma grande área geográfica e sobrepondo limites entre estados e mesmo países. Nesse sentido, o território Chiripá inclui partes dos estados de Mato Grosso, São Paulo, Paraná, Santa Catarina, Rio Grande do Sul, norte da Argentina e leste do Paraguai.

A organização social dos Guarani, mesmo tendo desaparecido a casa-grande que abrigava uma família extensa de até 40 pessoas, pode-se perceber que continuam fiéis à hierarquia tradicional e mantêm os padrões de descendência e residência. Schaden $(1962$, p. 80) resume da seguinte forma:

De alguma forma, as malhas da rede de relações econômicas ligam entre si todos os indivíduos de determinada aldeia ou grupo local. Em outros termos: o grupo local constitui comunidade econômica em que, de maneira mais ou menos frouxa, estão vinculadas, pela comunhão de interesses, as diferentes unidades de produção e consumo, que tendem a ser, hoje em dia, as famílias elementares. Parentelas constituídas de duas, três ou mais famílias correspondem a unidades econômicas de ordem superior, refletindo bem, em suas manifestações de solidariedade, $[\ldots]$, em que a família-grande era a unidade econômica propriamente dita. O congraçamento das diferentes famílias-grandes - ou parentelas - para a constituição de unidade mais ampla, seja a aldeia ou parte dela (como grupo local, geograficamente destacado), se dá bem mais acentuadamente sobre a base religiosa, pois assim como o grupo de parentesco é a unidade de produção e consumo, a aldeia constitui a unidade religiosa, pelo menos por ocasião das grandes festas, de transcendental importância.

Outrora, enfim, ao que tudo indica, a famíliagrande - compreendendo o casal, as filhas

Espaço Ameríndio, Porto Alegre, v. 7, n. 2, p. 277-556, jul./dez. 2013. 
KIMIYE TOMMASINO - Relatório de Identificação e Delimitação da Terra Indígena...

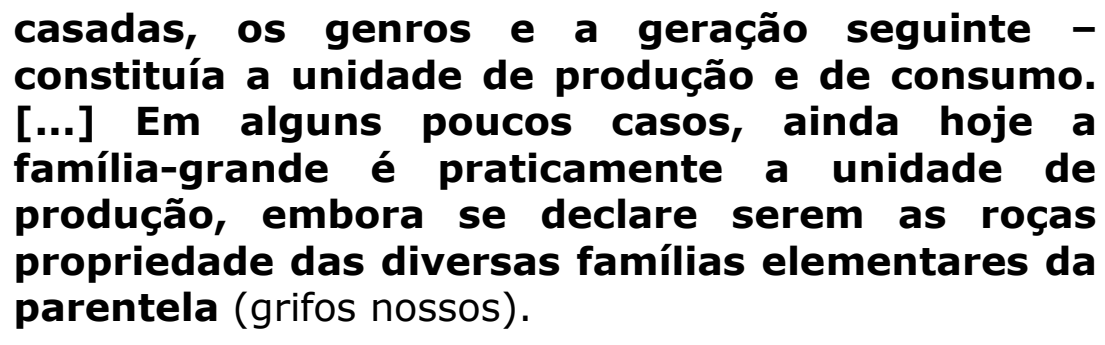

Podemos pois concluir que terra e território guarani em nada se assemelha às concepções ocidentais. A partir das explanações acima é possível elencar as características materiais e simbólicas de terra e território para os Guarani da forma abaixo:

I. Território guarani/Tetã ou Guará é um espaço físico apropriado e transformado socialmente ao longo da história que remonta aos tempos imemoriais. As fronteiras territoriais guarani, como se viu, atravessa e extravasa as fronteiras desenhadas na história recente pelos conquistadores europeus. A sobreposição de nacionalidades exógenas "brasileira", "paraguaia", "argentina"- a de guarani só tem aumentado a confusão porquanto do ponto de vista indígena os deslocamentos sempre se fizeram dentro do território conhecido e reconhecido como sendo sua pátria. Desse modo, os Chiripá possuem um território que abrange parte do Brasil, Paraguai e Argentina e é dentro deste espaço físico que circulam e constróem seus Tekohá.

II. Território guarani/Tetã ou Guará pode ser pensado como o conjunto dos Tekohá que formam uma unidade sociológica. Esses Tekohá formam redes de sociabilidade mais ampla e seus membros compartilham uma identidade histórica e étnica.

III. Tekohá é a terra tradicional de um determinado grupo social ou família extensa/Te'yi que constituem unidades de produção e consumo. Ao Tekohá está associada a casa, as relações com seus parentes; é onde enterram seus mortos, onde rezam, onde radica a possibilidade de exercer o direito divino de fazer suas roças, onde caçam e pescam. Cada família extensa pode formar uma aldeia/Tatay Rupa de modo que cada Tekohá pode ter uma ou mais aldeias. O conjunto das famílias das aldeias forma uma unidade maior que é identificada como uma unidade religiosa e seu nhanderu. Explicando melhor, cada grupo local forma uma parentela que constitui unidade econômica (de produção e 
consumo) e o Tekohá pode ser formado por mais uma família-extensa que se organiza em aldeias/unidades econômicas que no seu conjunto formam o Tekohá/unidade religiosa.

IV. O grau de consciência territorial pode ser mais ou menos específica. Entre os Paí-Kaiowá os limites naturais são bem definidos enquanto para os Mbyá esses limites são difusos. Os Chiripá de Araça'í revelaram com clareza e segurança os limites naturais de seu Tekoha como veremos mais adiante.

V. Terra guarani/Tekohá deve preencher alguns requisitos básicos, materiais, sociais e simbólicos. Deve possuir características ecológicas bem constantes, que sejam aptas ao cultivo de milho, mandioca, batata, feijão e abóbora. Deve ter uma estrutura tríplice em termos de espaço físico: um monte preservado onde possam caçar, pescar e coletar; faixas de terra fértil para fazer roças e cultivos; e finalmente um lugar onde possam construir suas habitações (óy, óga) em torno das quais plantarão bananeiras, pés de tártago, algodão e urucú. Estabelecem-se de preferência no meio da mata, evitando a paisagem aberta dos campos. As aldeias não formam um conglomerado compacto de habitações, consistem em casas isoladas, mais ou menos distantes umas das outras, espalhando-se pelas clareiras abertas na floresta.

VI. Terra guarani não se restringe à natureza e nem se define pelo seu valor exclusivamente produtivo. É onde podem viver segundo seus costumes e podem realizar "seu modo de ser". "O Tekohá, com toda a sua materialidade terrena, é sobretudo uma inter-relação de espaços culturais: econômicos, sociais, religiosos e políticos".

VII. É importante registrar que a descendência entre os Guarani é patrilinear, ou seja, os filhos pertencem ao grupo do pai. A residência contudo é uxorilocal, os genros costumam morar com o sogro e passa a integrar a unidade sócio-econômico-político-religiosa da esposa. No entanto é preciso esclarecer que as regras sociais são suficientemente flexíveis e "arranjos" sociais diversificados podem ser observados na prática para permitir a solução de problemas inter-grupos e interétnicos. A organização social de um Tekohá na atualidade é chefiada por uma autoridade laica (cacique) e outra religiosa (nhanderu), o primeiro voltado "para fora" e o segundo, "para dentro". Isso explica porque os caciques atuais são mais jovens do que o nhanderu, aquele 
KIMIYE TOMMASINO - Relatório de Identificação e Delimitação da Terra Indígena...

mais ligado ao mundo da modernidade e da materialidade, este comprometido com as tradições e o mundo da espiritualidade.

Mas temos de falar ainda da Terra-sem-Mal que mobilizou dezenas de grupos guarani do oeste em direção ao leste, mais especificamente ao litoral atlântico.

\begin{abstract}
A imagem amplamente divulgada do guarani é uma imagem de quem busca, incansavelmente $e$ profeticamente, essa terra-sem-males. A realidade e o significado dessa terra não apenas têm sido objeto de estudos antropológicos, como também têm sido um tema fascinante para sociólogos, historiadores, teólogos e poetas. Deste modo, uma experiência indígena se torna exemplar e paradigmática para pensar e trabalhar uma realidade mais ampla e geral, como seria o projeto - a utopia - de uma sociedade mais solidária e humana (MELIÀ, 1987, p. 335).
\end{abstract}

As migrações de dezenas de grupos guarani mbyá, kaiowá e chiripá no século XIX em direção ao oceano atlântico foram motivadas pela busca da Terra-sem-Mal, yvý marane'y. Os Guarani atuais que vivem no litoral atlântico não são os que viviam no século XVI quando os portugueses e espanhóis chegaram à América do Sul. Os Cários ou Carijós como eram conhecidos foram extintos e os atuais grupos são da mesma etnia, mas provêm de várias ondas migratórias de Guarani vindos nos séculos XIX e XX, de natureza messiânica, orientados pelo mito da Terra-sem-Mal.

Nimuendajú foi o primeiro etnólogo que conseguiu trazer a público o sentido dessas migrações quando conheceu vários grupos guarani, mbyá e chiripá/nhandeva, que estavam em pleno processo de translado do oeste (Mato Grosso do Sul, sudoeste do Paraguai e noroeste da Argentina) para o leste e na convivência coletou informações etnográficas sobre os diversos aspectos da religião guarani. Este autor considerava que os deslocamentos massivos que ocorriam tinham como móvel apenas a crença na Terra-sem-Mal, mas atualmente considera-se que razões conjunturais - pressões sociais e ecológicas, guerras com outras etnias, perseguições dos conquistadores contribuíram para que saíssem em busca de lugares mais adequados

Espaço Ameríndio, Porto Alegre, v. 7, n. 2, p. 277-556, jul./dez. 2013. 
para viverem. Nesse sentido todos os pesquisadores que estudam os grupos guarani na atualidade são unânimes em adotar essa perspectiva multidimensional dos deslocamentos dessa etnia.

Segundo Porto Borges (2000, p. 39) na atualidade apenas dos Mbyá se percebe ainda a impregnação mítica nos seus deslocamentos:

A busca da yvy marane'y é uma experiência religiosa cotidiana e presente em todos os subgrupos guarani, diferindo-se na expectativa e na forma em que se dá essa procura. Porém, se a cautela aconselha a não relacionarmos indistintamente a migração Guarani com religiosidade guarani; em relação ao mbya pode-se afirmar o contrário, que migrações e deslocamentos geográficos encontram-se profundamente marcados por seu caráter mítico, como na recente ocupação da ilha do Cardoso, litoral sul de São Paulo, quando, em meados de 1994, cerca de 40 Guarani oriundos do Rio Grande do Sul chegaram à ilha orientados por líderes espirituais em peregrinação messiânica.

Melià (1989, p. 294) sintetiza o sentido da mobilidade atual dos grupos guarani dizendo:

A migração, como história e como projeto, constitui um traço característico dos guarani, embora muitos de seus grupos tenham permanecido por séculos num mesmo território e nunca tenham realizado uma migração efetiva. [...], a busca da 'Terra-sem-Mal' e de uma 'terra nova' estrutura marcantemente seu pensamento e suas vivências; a 'Terra-sem-Mal' é a síntese histórica e prática de uma economia vivida profeticamente e de uma profecia realista, com os pés no chão. Animicamente o guarani é um povo em êxodo, embora não desenraizado, pois a terra que procura é a que the servirá de base ecológica, amanhã como em tempos passados. Durante os últimos 1500 anos - período em que as tribos guarani podem se considerar formadas com suas características próprias - os guarani se mostraram fiéis à sua ecologia tradicional, não por inércia, mas pelo trabalho ativo que supõe a recriação e a busca das condições ambientais mais adequadas para o desenvolvimento de seu modo de ser. A tradição neste caso é profecia viva. A busca da 'Terra-sem-Mal', como estrutura do modo de pensar do guarani, dá forma ao dinamismo econômico e à vivência religiosa, que lhe são tão próprios.

Espaço Ameríndio, Porto Alegre, v. 7, n. 2, p. 277-556, jul./dez. 2013. 
Sobre as mudanças ocorridas na cultura guarani como resultado do contato com os Juruá, podemos nos apoiar em Schaden (1982, p. 02) que nos explica o seguinte:

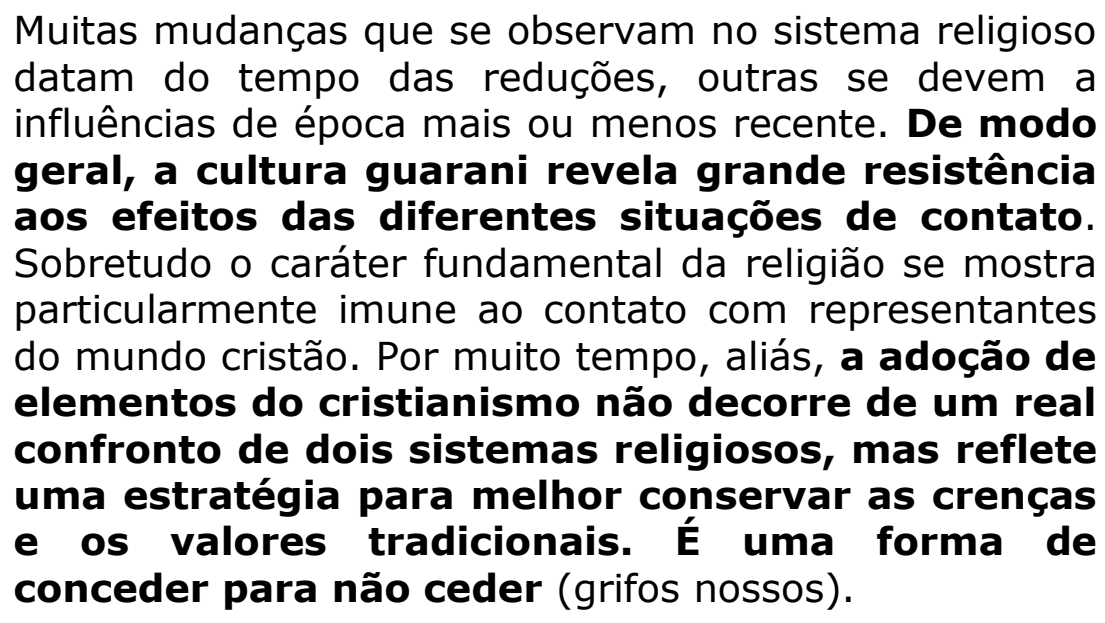

Este modo de interpretar a dinâmica cultural guarani por Schaden está de acordo com as mais recentes teorias da mudança social e cultural propostos por autores como Sahlins (1990) ou Turner (1988 e 1993). A realidade social observada por Schaden no final da década de 40, ao que parece, relacionava-se a uma fase em que os índios tinham espaços de negociação menores ou mais fechados do que hoje. As conquistas constitucionais e a recuperação demográfica posteriores permitiram-Ihes engendrar na atualidade uma série de movimentos sociais através dos quais puderam redirecionar as políticas públicas nas áreas fundiária, de educação e saúde. A questão das terras indígenas, desde o início do contato, se colocou como o ponto crucial para a sobrevivência física e cultural das populações autóctones.

\section{Situação Atual dos Guarani e sua Distribuição Geográfica}

Para termos uma visão geral da situação atual em que vivem os Guarani apresentamos alguns gráficos e tabelas de pesquisas recentes. Ainda não há censos seguros e confiáveis, até porque a população guarani está sempre em movimento entre uma aldeia e outra e as mudanças ocorrem com muita frequência. Há ainda a se levar em conta 
que alguns grupos não gostam de ser recenseados. Outra dificuldade é a identificação da população por parcialidade. Em geral os censos não fazem distinção entre parcialidades e mesmo etnias quando há vários grupos habitando a mesma terra indígena.

O indigenista Francisco Witt fez um levantamento das populações guarani mbyá e chiripá atuais que vivem no litoral dos estados do sul em março de 1993. Como os demais pesquisadores, considera que os Mbyá são mais tradicionais entre as parcialidades. Trata-se de uma importante contribuição de Witt porque, além dos grupos que vivem em aldeias no litoral, ele encontrou grupos "migrantes" que vivem acampados em diversos pontos da região sul.

Baseado nas leituras de Nimuendajú e na sua própria experiência de campo, Witt considera que os Chiripá vieram do Mato Grosso em migrações em busca da Terra-sem-Mal. Relata que esteve com um dos grupos chiripá visitados por Nimuendajú e reconheceu que muito do "clima" descrito pelo eminente etnólogo continuava presente. Tendo lido para os velhos os escritos de Nimuendajú disse que eles ficaram admirados pela fidedignidade do texto. Percebeu ainda que a maioria dos jovens não fala mais o dialeto que vem sendo substituído pelo português, sabendo-se que em outras regiões o dialeto chiripá foi substituído pelo guarani paraguaio ou pelo dialeto mbyá.

As áreas guarani visitadas por Witt são: Al de Barra do Ouro-RS e Al do Camaquã-RS. No Paraná visitou os que vivem na ilha de Cotinga e identificou como originários da área xokleng de Ibirama-SC e da área kaingang de Xapecó-SC. Em 1987 a maioria migrou para a Al Bracuí-RJ, a $35 \mathrm{~km}$ de Angra dos Reis e cinco km da BR 101. A razão da mudança era a falta de água potável na ilha e de condições melhores de vida. Há ainda outros grupos guarani no Paraná, dois na llha das Peças, outros em Superagui na região de Guaraqueçaba. Segundo Witt são famílias que vieram do Rio Grande do Sul, mas não citou qual área.

Witt ainda conheceu outras aldeias: Água Branca, perto de Tapes no RS, Canta Galo-RS e esteve em visita a várias aldeias da Argentina na província de Misiones. Visitou também uma aldeia no Posto Indígena Pindaré, no Maranhão. $O$ indigenista, referiu-se como sendo um grupo mbyá, mas temos a informação de que os Guarani que estão no Maranhão foram levados pela serraria da família Zimmer e são 
originários de Araça'í.

Uma pesquisa realizada por Garlet e Assis em1998 sobre a população mbyá no sul do Brasil levantou 549 famílias num total de 2.640 pessoas dessa parcialidade. Este estudo é o mais completo e atual na apresentação de todos os grupos mbyá incluindo os que vivem no interior dos estados e os acampamentos à beira de estrada. Apesar de algumas dificuldades apontadas pelos pesquisadores quanto à classificação dos Guarani, quando mais de duas parcialidades estão vivendo na mesma terra indígena, consideramos este estudo um avanço no sentido de possibilitar uma visão dessa parcialidade como parte de um todo mais complexo. Os autores elaboraram tabelas com a listagem de todas as áreas de ocupação guarani e a situação jurídica de cada uma. Por essas tabelas fica visível que, comparativamente à situação das terras kaingang e xokleng, os Guarani, com poucas exceções, possuem terras próprias e regularizadas, evidenciando o que nossa pesquisa (e outras anteriores) mostram: que os Guarani foram excluídos das políticas oficiais de delimitação de áreas próprias. No interior dos estados do sul, quase sempre vivem como "inquilinos" dos Kaingang ou dos Xokleng. Concordamos com os autores que classificaram os Guarani nessas terras como "áreas sem providência jurídica" (GARLET e ASSIS, 1998, p. 09). O caso dos Guarani que vivem na TI Nonoai e que agora reivindicam a terra de Araça'í comprova que eles não se sentem em sua terra e, dependendo da conjuntura que enfrentam, podem lutar pela (re)conquista de sua terra tradicional. Pela importância das informações contidas nas tabelas, disponibilizamos o material anexo (Anexo II: 3 e 4).

Por fim, a Tabela 1 mostra a distribuição atual dos grupos guarani nos estados do sul, São Paulo e Mato Grosso do Sul feita a partir dos dados fornecidos pelo ISA (2000) e complementadas parcialmente pela pesquisa realizada por Garlet e Assis (1998) sobre os Guarani-Mbyá no sul do Brasil. 
KIMIYE TOMMASINO - Relatório de Identificação e Delimitação da Terra Indígena...

TABELA 1 - ÁREAS INDÍGENAS GUARANI (SP, PR, SC, RS, MS)

\begin{tabular}{|c|c|c|c|c|c|c|c|}
\hline $\mathbf{N}^{\circ}$ & UF & Al & $\begin{array}{c}\text { SIT. } \\
\text { JURÍDICA }\end{array}$ & EXT. (ha) & LOCAL & POPULAÇÃO & ETNIA \\
\hline 1 & \multirow{11}{*}{$\begin{array}{c}0 \\
\\
0 \\
4 \\
0 \\
0 \\
0 \\
0 \\
0\end{array}$} & 1. Araribá & Homologada & 1930 & Avaí & $\begin{array}{l}\text { 436 Funai } \\
\text { Bauru: } 98\end{array}$ & Chiripá \\
\hline 2 & & 2.Barragem & Homologada & 26 & São Paulo & $\begin{array}{l}502 \\
\text { Funai Bauru: } \\
98\end{array}$ & Mbyá \\
\hline 3 & & $\begin{array}{l}\text { 3. Boa Vista do } \\
\text { Sertão do Pró-Mirim }\end{array}$ & Homologada & 906 & Ubatuba & $\begin{array}{l}53 \\
\text { Funai: } 94\end{array}$ & Mbyá \\
\hline 4 & & $\begin{array}{l}\text { 4.Guarani do } \\
\text { Aguapeu }\end{array}$ & Homologada & 4.372 & Mongaguá & $\begin{array}{l}66 \\
\text { Funai Bauru: } \\
98\end{array}$ & Mbyá \\
\hline 5 & & $\begin{array}{l}\text { 5. Guarani do } \\
\text { Krukutu }\end{array}$ & Homologada & 26 & São Paulo & $\begin{array}{l}82 \\
\text { Funai } \\
\text { Bauru:98 }\end{array}$ & Mbyá \\
\hline 6 & & $\begin{array}{l}\text { 6. Guarani do } \\
\text { Ribeirão Silveira }\end{array}$ & Homologada & 948 & \begin{tabular}{|l|} 
Santos / \\
São Sebastião
\end{tabular} & $\begin{array}{l}240 \\
\text { Funai:94 }\end{array}$ & Mbyá \\
\hline 7 & & 7. Itaoca & Delimitada & 533 & Mongaguá & $\begin{array}{l}199 \\
\text { Funai } \\
\text { Bauru:98 }\end{array}$ & $\begin{array}{l}\text { Mbyá } \\
\text { Chiripá }\end{array}$ \\
\hline 8 & & $\begin{array}{l}\text { 8. Itariri (Serra do } \\
\text { Itatins) }\end{array}$ & Homologada & 1.212 & Itariri & $\begin{array}{l}63 \\
\text { Funai Curitiba: } \\
98\end{array}$ & Chiripá \\
\hline 9 & & 9. Jaraguá & Homologada & 2 & São Paulo & $\begin{array}{l}\text { Funai } \\
\text { Bauru:98 }\end{array}$ & Mbyá \\
\hline 10 & & 10. Peruíbe & Homologada & 480 & Peruíbe & $\begin{array}{l}143 \\
\text { Funai Bauru: } \\
98\end{array}$ & Chiripá \\
\hline 11 & & $\begin{array}{l}\text { 11. Rio Branco (do } \\
\text { Itanhaém) }\end{array}$ & Homologada & 2.856 & $\begin{array}{l}\text { Itanhaém / } \\
\text { São Vicente / } \\
\text { São Paulo } \\
\end{array}$ & $\begin{array}{l}46 \\
\text { Funai Bauru: } \\
98\end{array}$ & Mbyá \\
\hline 12 & & 1. Avá Guarani/Ocoí & $\begin{array}{l}\text { Dominial } \\
\text { indígena } \\
\text { (ISA) } \\
\text { Demarcada } \\
\text { (FUNAI) }\end{array}$ & 251 & $\begin{array}{l}\text { São Miguel do } \\
\text { Iguaçu }\end{array}$ & 454 & Chiripá \\
\hline 13 & & $\begin{array}{l}\text { 2. Barão de Antonina } \\
\text { I } \\
\text { (Gleba I) }\end{array}$ & $\begin{array}{l}\text { Homologada } \\
\text { (ISA) } \\
\text { Demarcada } \\
\text { (FUNAI) }\end{array}$ & 3.751 & $\begin{array}{l}\text { São Jerônimo } \\
\text { da Serra }\end{array}$ & - & Chiripá \\
\hline 14 & $\begin{array}{l}< \\
z\end{array}$ & 3. Cerco Grande & $\begin{array}{l}\text { Identificada } \\
\text { (COMIN) A } \\
\text { identificar } \\
\text { (FUNAI) }\end{array}$ & 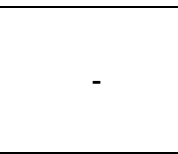 & Guaraqueçaba & - & Mbyá \\
\hline 15 & $\begin{array}{l}\infty \\
\alpha\end{array}$ & 4. Cotinga & $\begin{array}{l}\text { Homologada } \\
\text { (ISA e } \\
\text { COMIN) } \\
\text { Demarcada } \\
\text { (FUNAI) }\end{array}$ & $\begin{array}{l}1.685 \\
\text { (COMIN) } \\
1.701 \text { (ISA) }\end{array}$ & Paranaguá & $\begin{array}{l}165 \\
\text { Funai Curitiba: } \\
98\end{array}$ & Mbyá \\
\hline 16 & & 5. Ivaí & $\begin{array}{l}\text { Homologada } \\
\text { (ISA) } \\
\text { Demarcada } \\
\text { (FUNAI) }\end{array}$ & 7.306 & Pitanga & - & Chiripá \\
\hline 17 & & 6. Laranginha & $\begin{array}{l}\text { Homologada } \\
\text { (ISA) } \\
\text { Demarcada } \\
\text { (FUNAI) } \\
\end{array}$ & 284 & Sta. Amélia & - & Chiripá \\
\hline
\end{tabular}

Espaço Ameríndio, Porto Alegre, v. 7, n. 2, p. 277-556, jul./dez. 2013. 
KIMIYE TOMMASINO - Relatório de Identificação e Delimitação da Terra Indígena...

\begin{tabular}{|c|c|c|c|c|c|c|c|}
\hline 18 & & 7. Mangueirinha & $\begin{array}{l}\text { Dominial } \\
\text { indígena } \\
\text { (ISA) } \\
\text { Demarcada } \\
\text { (FUNAI) }\end{array}$ & 16.375 & \begin{tabular}{|l} 
Mangueirinha (ISA) \\
Laranjeiras do Sul / \\
Quedas do Iguaçu \\
(COMIN)
\end{tabular} & 1.898 & Mbyá \\
\hline $\mathbf{N}^{\circ}$ & UF & Al & $\begin{array}{c}\text { SIT. } \\
\text { JURÍDICA }\end{array}$ & EXT. (ha) & LOCAL & POPULAÇÃO & ETNIA \\
\hline 19 & \multirow{4}{*}{$\begin{array}{l}\mathbf{4} \\
z \\
\mathbf{4} \\
\boldsymbol{\alpha} \\
\mathbf{\alpha}\end{array}$} & 8. Morro das Pacas & $\begin{array}{l}\text { Identificada } \\
\text { (COMIN) }\end{array}$ & - & Guaraqueçaba & - & Mbyá \\
\hline 20 & & 9. Pinhal & Sem provid ${ }^{1}$. & - & $\begin{array}{l}\text { Laranjeiras do Sul / } \\
\text { Queda do Iguaçu }\end{array}$ & - & Mbyá \\
\hline 21 & & 10. Pinhalzinho & $\begin{array}{l}\text { Dominial } \\
\text { indígena } \\
\text { (ISA) } \\
\text { Demarcada } \\
\text { (FUNAI) }\end{array}$ & 593 & Tomazina & $\begin{array}{l}88 \\
\text { Funai Curitiba: } \\
98\end{array}$ & Chiripá \\
\hline 22 & & 11. Rio da Areia & $\begin{array}{l}\text { Demarcada } \\
\text { (FUNAI e } \\
\text { COMIN) } \\
\text { Homologada } \\
\text { (ISA) }\end{array}$ & $1.280,56$ & Inácio Martins & - & Mbyá \\
\hline \multirow{2}{*}{23} & \multirow{15}{*}{ 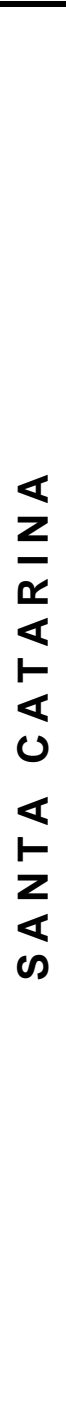 } & 1. Coqueiros & Sem provid. & - & Araquari & - & Mbyá \\
\hline & & 2. Cunha Porã & $\begin{array}{l}\text { Sem provid. } \\
\text { (COMIN) Em } \\
\text { identificação }\end{array}$ & - & Cunha Porã & - & Mbyá \\
\hline 25 & & 3. Dionísio Cerqueira & Sem provid. & - & Dionísio Cerqueira & - & Mbyá \\
\hline 26 & & 4. Espinheiro & $\begin{array}{l}\text { Sem provid. } \\
\text { (COMIN) } \\
\text { A indetificar } \\
\text { (ISA) }\end{array}$ & - & Itajaí & - & Mbyá \\
\hline 27 & & 5. Figueira & Sem provid. & - & $\begin{array}{l}\text { São Francisco do } \\
\text { Sul }\end{array}$ & - & Mbyá \\
\hline 28 & & 6. Gravatá & Sem provid. & - & Navegantes & - & Mbyá \\
\hline 29 & & 7. Guabiruba & Sem provid. & - & Guabiruba & - & Mbyá \\
\hline 30 & & 8. Guaraciaba & Sem provd. & - & Guaraciaba & - & Mbyá \\
\hline 31 & & 9. Ibirama-La Klano & $\begin{array}{l}\text { Identificada, } \\
\text { Aprovada, } \\
\text { Funai. } \\
\text { Sujeita a } \\
\text { Contestação. } \\
\text { (ISA) } \\
\text { Demarcada } \\
\text { (FUNAI) }\end{array}$ & 37.108 & \begin{tabular}{|l|} 
Ibirama \\
Itápolis
\end{tabular} & - & $\begin{array}{l}\text { Chiripá } \\
\text { Mbyá }\end{array}$ \\
\hline 32 & & 10. Itapocu & Sem provid. & - & Araquari & - & Mbyá \\
\hline 33 & & 11. Itoupava & Sem provid. & - & José Boiteux & - & Mbyá \\
\hline 34 & & \begin{tabular}{|l|} 
12. Limeira \\
\end{tabular} & Sem provid. & - & Ipuaçu & - & Mbyá \\
\hline 35 & & 13. Linha Becker & Sem provid. & - & Itapiranga & - & Mbyá \\
\hline 36 & & 14. Massiambu & $\begin{array}{l}\text { A identificar } \\
\text { (FUNAI) } \\
\text { Identificada } \\
\text { (COMIN) }\end{array}$ & \begin{tabular}{|l|}
$0($ ISA $)$ \\
5,6 \\
$(\mathrm{COMIN})$
\end{tabular} & Palhoça & $\begin{array}{l}56 \\
\text { Funai Curitba: } \\
98\end{array}$ & Mbyá \\
\hline 37 & & 15. Mbiguaçu & $\begin{array}{l}\text { Identificada } \\
\text { (COMIN) } \\
\text { Identificada, } \\
\text { Aprovada, } \\
\text { Funai. Sujeita } \\
\text { a contestação } \\
\text { (ISA) Em } \\
\text { demarcação } \\
\text { (FUNAI) }\end{array}$ & $\begin{array}{l}42 \text { (COMIN) } \\
56 \text { (ISA) }\end{array}$ & Biguaçu & 85 & Mbyá \\
\hline
\end{tabular}

Espaço Ameríndio, Porto Alegre, v. 7, n. 2, p. 277-556, jul./dez. 2013. 
KIMIYE TOMMASINO - Relatório de Identificação e Delimitação da Terra Indígena...

\begin{tabular}{|c|c|c|c|c|c|c|c|}
\hline 38 & & $\begin{array}{l}\text { 16. Morro dos } \\
\text { cavalos }\end{array}$ & $\begin{array}{l}\text { A identificar } \\
\text { (FUNAI) / } \\
\text { Identificada } \\
\text { (COMIN) / } \\
\text { Em } \\
\text { identificação } \\
\text { (ISA) }\end{array}$ & \begin{tabular}{|l}
0 (ISA) \\
121,8 \\
(COMIN)
\end{tabular} & Palhoça & $\begin{array}{l}78 \\
\text { Funai Curitiba: } \\
98\end{array}$ & Mbyá \\
\hline 39 & & 17. Reta & $\begin{array}{l}\text { Identificada } \\
\text { (ISA) Sem } \\
\text { provid. }\end{array}$ & - & $\begin{array}{l}\text { São Francisco do } \\
\text { Sul }\end{array}$ & - & Mbyá \\
\hline $\mathbf{N}^{\circ}$ & UF & Al & $\begin{array}{c}\text { SIT. } \\
\text { JURÍDICA }\end{array}$ & EXT. (ha) & LOCAL & POPULAÇÃO & ETNIA \\
\hline 40 & & 18. Tapera & $\begin{array}{l}\text { Homologada } \\
\text { (ISA) Sem } \\
\text { provid. }\end{array}$ & 15.623 & \begin{tabular}{|l} 
Marema \\
Xererê
\end{tabular} & - & Mbyá \\
\hline 41 & & 1. Aguapé & $\begin{array}{l}\text { Identificada } \\
\text { (COMIN) }\end{array}$ & 500 & $\begin{array}{l}\text { Santo Antonio da } \\
\text { Patrulha / Cará }\end{array}$ & - & Mbyá \\
\hline 42 & ـ & 2. Águas Brancas I $^{3}$ & $\begin{array}{l}\text { Identificada } \\
\text { (COMIN) / } \\
\text { Delimitada } \\
\text { (ISA) }\end{array}$ & \begin{tabular}{|l|}
232 \\
(COMIN) \\
230 (ISA)
\end{tabular} & \begin{tabular}{|l|} 
Camaquã / \\
Arambaré
\end{tabular} & $\begin{array}{l}39 \\
\text { Freire (Funai): } \\
94\end{array}$ & Mbyá \\
\hline 43 & $\begin{array}{l}0 \\
\omega \\
0 \\
0 \\
w \\
0 \\
z\end{array}$ & 3. Barra do Ouro & $\begin{array}{l}\text { Identificada } \\
\text { (COMIN) } \\
\text { Delimitada. } \\
\text { Em } \\
\text { demarcação } \\
\text { (ISA) } \\
\text { Em } \\
\text { Demarcação } \\
\text { (FUNAI) }\end{array}$ & \begin{tabular}{|l}
2.885 \\
(COMIN) \\
2.285 (ISA)
\end{tabular} & \begin{tabular}{|l|} 
Maquiné/Sto \\
Antonio da \\
Patrulha/Riozinho
\end{tabular} & $\begin{array}{l}49 \\
\text { Identif. Funai: } \\
93 \text { (ISA) }\end{array}$ & Mbyá \\
\hline 44 & $\begin{array}{l}\varangle \\
\simeq \\
\sigma \\
0\end{array}$ & 4. Cacique Doble & $\begin{array}{l}\text { Homologada } \\
\text { (ISA) } \\
\text { Demarcada } \\
\text { (FUNAI) Sem } \\
\text { provid. }\end{array}$ & 4.426 & Cacique Doble & & $\begin{array}{l}\text { Mbyá } \\
\text { Chiripá }\end{array}$ \\
\hline 45 & $\bar{x}$ & 5. Cantagalo & $\begin{array}{l}\text { Identificada } \\
\text { (COMIN) } \\
\text { Em } \\
\text { identificação } \\
\text { Revisão (ISA) } \\
\text { A identificar } \\
\text { (FUNAI) }\end{array}$ & $\begin{array}{l}286 \text { (ISA) } \\
47,2 \\
\text { (COMIN) }\end{array}$ & Viamão & $\begin{array}{l}\text { 159 } \\
\text { GT/Funai: } 99\end{array}$ & Mbyá \\
\hline 46 & & 6. Cerro grande & Sem provid. & - & Barra do Ribeiro & - & Mbyá \\
\hline 47 & & 7. Fazenda Vargas & $\begin{array}{l}\text { Identificada } \\
\text { (COMIN) }\end{array}$ & 33 & Palmares do Sul & _ & Mbyá \\
\hline 48 & & 1. Aldeia Campestre & $\begin{array}{l}\text { Reservada } \\
\text { Demarcada }\end{array}$ & 9 & Antonio João & $236 \mathrm{PKG}^{2}: 98$ & Kaiowá \\
\hline 49 & ص & $\begin{array}{l}\text { 2. Aldeia Limão } \\
\text { Verde }\end{array}$ & Reservada & 660 & Amambai & $\begin{array}{l}390 \text { Mangolin: } \\
93\end{array}$ & Kaiowá \\
\hline 50 & & 3. Amambai & Homologada & 2.429 & Amambai & $\begin{array}{l}\text { 4.465 PKG: } \\
98\end{array}$ & $\begin{array}{l}\text { Chiripá; } \\
\text { Kaiowá }\end{array}$ \\
\hline 51 & ת & 4. Caarapó & Homologada & 3.594 & Caarapó & $\begin{array}{l}2.896 \text { PKG: } \\
98\end{array}$ & Chiripá \\
\hline 52 & ra & 5. Cerrito & Homologada & 2.040 & Eldorado & 186 PKG: 98 & $\begin{array}{l}\text { Chiripá; } \\
\text { Kaiowá }\end{array}$ \\
\hline 53 & & 6. Cerro Marangatu & $\begin{array}{l}\text { Em } \\
\text { identificação }\end{array}$ & - & Antonio João & ـ & Kaiowá \\
\hline 54 & & 7. Dourados & Reservada & 3.475 & Dourados & $\begin{array}{l}\text { 6.758 PKG: } \\
98\end{array}$ & $\begin{array}{l}\text { Chiripá; } \\
\text { Kaiowá }\end{array}$ \\
\hline 55 & & 8. Guaimbé & Homologada & 717 & Ponta Porã & 256 PKG: 98 & Kaiowá \\
\hline 56 & & 9. Guasuti & Homologada & 930 & Aral Moreira & 164 PKG: 98 & Kaiowá \\
\hline 57 & & 10. Jaguapiré & Homologada & 2.349 & Tacuru & 429 PKG: 98 & Kaiowá \\
\hline
\end{tabular}

Espaço Ameríndio, Porto Alegre, v. 7, n. 2, p. 277-556, jul./dez. 2013. 
KIMIYE TOMMASINO - Relatório de Identificação e Delimitação da Terra Indígena...

\begin{tabular}{|c|c|c|c|c|c|c|c|}
\hline 58 & & 11. Jaguari & Homologada & 405 & Amambai & 150 Funai: 99 & $\begin{array}{l}\text { Kaiowá; } \\
\text { Chiripá }\end{array}$ \\
\hline 59 & & 12. Jarara & Homologada & 479 & Juti & 249 PKG: 98 & $\begin{array}{l}\text { Kaiowá; } \\
\text { Chiripá }\end{array}$ \\
\hline 60 & & 13. Lima Campo & $\begin{array}{l}\text { Em } \\
\text { identificação }\end{array}$ & - & Ponta Porã & - & Kaiowá \\
\hline 61 & & 14. Panambi & $\begin{array}{l}\text { Reservada. } \\
\text { Em revisão }\end{array}$ & 2.037 & Dourados & 551 PKG: 98 & Kaiowá \\
\hline 62 & & 15. Panambizinho & $\begin{array}{l}\text { Delimitada. } \\
\text { Em } \\
\text { demarcação }\end{array}$ & 1.240 & Douradina & 253 PKG: 98 & Kaiowá \\
\hline 63 & & 16. Pirajuí & Homologada & 2.118 & Sete Quedas & $\begin{array}{l}\text { 1.879 PKG: } \\
98\end{array}$ & Kaiowá \\
\hline $\mathbf{N}^{\circ}$ & UF & Al & $\begin{array}{c}\text { SIT. } \\
\text { JURÍDICA }\end{array}$ & EXT. (ha) & LOCAL & POPULAÇÃO & ETNIA \\
\hline 64 & \multirow{10}{*}{ 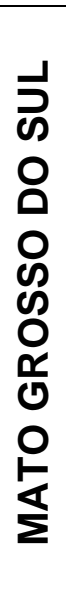 } & 17. Pirakua & Homologada & 2.384 & Bela Vista & 270 PKG: 98 & Kaiowá \\
\hline 65 & & 18. Porto Lindo & Homologada & 1.649 & Mundo Novo & $\begin{array}{l}\text { 1.859 PKG: } \\
98\end{array}$ & Chiripá \\
\hline 66 & & 19. Potrero Guaçu & Delimitada & 4.025 & Paranhos & 620 & Chiripá \\
\hline 67 & & 20. Rancho Jacaré & Homologada & 778 & Ponta Porã & 505 PKG: 98 & Kaiowá \\
\hline 68 & & 21. Sassoró & Reservada & 1.923 & Ponta Porã & $\begin{array}{l}1.351 \text { PKG: } \\
98\end{array}$ & $\begin{array}{l}\text { Kaiowá; } \\
\text { Chiripá }\end{array}$ \\
\hline 69 & & 22. Sete Cerros & Homologada & 8.584 & Cel. Sapucaia & $\begin{array}{l}230 \text { Mangolin: } \\
98\end{array}$ & $\begin{array}{l}\text { Kaiowá; } \\
\text { Chiripá }\end{array}$ \\
\hline 70 & & 23. Sucuriy & Homologada & 535 & Maracaju & 84 PKG: 98 & Kaiowá \\
\hline 71 & & $\begin{array}{l}\text { 24. Takuaraty / } \\
\text { Yvykuarusu }\end{array}$ & Homologada & 2.609 & Paranhos & 360 Funai: 99 & Kaiowá \\
\hline 72 & & 25. Taquaperi & Reservada & 1.886 & Amambai & $\begin{array}{l}1.600 \text { PKG: } \\
98\end{array}$ & Kaiowá \\
\hline 73 & & 26. Taquara & $\begin{array}{l}\text { Em } \\
\text { identificação }\end{array}$ & - & Juti & - & Kaiowá \\
\hline
\end{tabular}

1: Sem provid. = Sem providência, classificação utilizada pelo COMIN. Refere-se tanto a terras particulares quanto a ocupações sobre terras pertencentes a outros grupos étnicos.

2: PKG = Programa Kaiowa Guarani.

Observação: Os dados das áreas indígenas de São Paulo e Mato Grosso do Sul foram obtidos exclusivamente do ISA/2000.

Fontes: Povos Indígenas no Brasil (2000) e Garlet e ASSIS (1998).

\section{A Figura 1 mostra todas as áreas indígenas da região apresentada} e a situação jurídica de cada uma no ano 2000.

Espaço Ameríndio, Porto Alegre, v. 7, n. 2, p. 277-556, jul./dez. 2013. 


\section{Figura 1 - SITUAÇÃO JURÍDICA DAS ÁREAS INDÍGENAS}

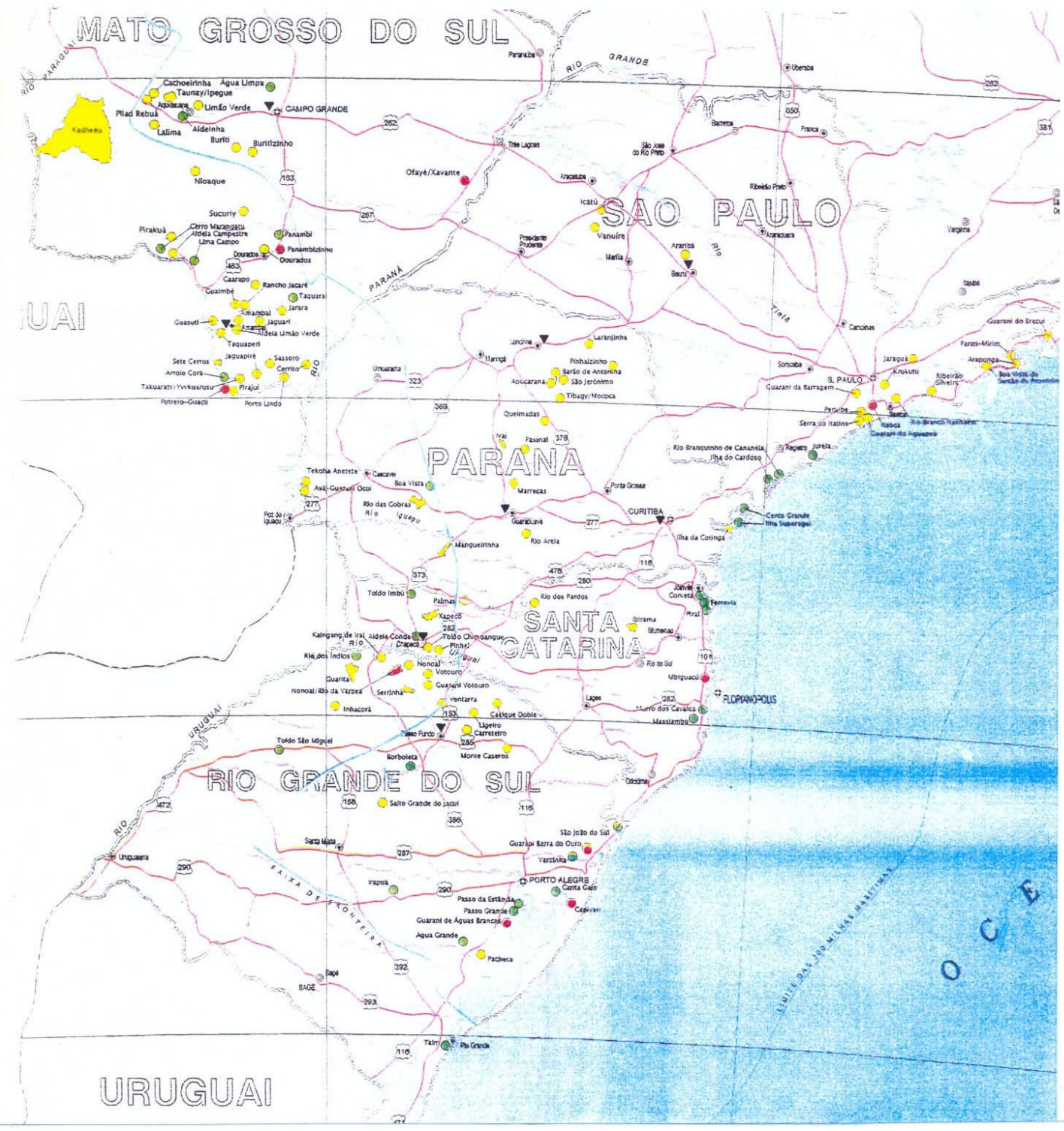
LE G E N D A:
O Demarcada
Em demarcação
O A demarcar

Fonte: Funai;2000

Espaço Ameríndio, Porto Alegre, v. 7, n. 2, p. 277-556, jul./dez. 2013. 


\section{CAPÍTULO II - INFORMAÇÕES GERAIS SOBRE A DISPERSÃO DOS GUARANI NAS FASES PRÉ-HISTÓRICAS E HISTÓRICAS E SUA DISTRIBUIÇÃO GEOGRÁFICA}

Este capítulo busca recuperar em linhas gerais os resultados das pesquisas arqueológicas e históricas que explicam a presença de povos tupi-guarani na vasta região onde foram encontrados pelos primeiros conquistadores europeus quando iniciaram sua expansão. Essa reconstituição tem como objetivo entender tanto a expansão geográfica desses povos como também compreender que subjacente à mobilidade sempre existiu uma lógica cultural que direcionou e modelou essa dispersão. Essa lógica cultural ainda preside a grande mobilidade dos Guarani que continua bastante evidente mas pouco compreendida antropologicamente.

\section{A Dispersão Tupi-guarani nas Fases Pré-históricas e Históricas}

Os Guarani que foram encontrados pelos espanhóis e portugueses nos séculos $X V I$ e $X V I I$, vivendo em um extenso território que inclui parte dos estados do sul e se estende para o norte da Argentina e sudeste do Paraguai, provêm da dispersão dos Tupi que, segundo Brochado, são os portadores da tradição cerâmica tupi-guarani e partiram de um centro provavelmente localizado no alto Paraná, antes do século IV da nossa era, ou seja, há mais de 1.600 anos ou mais de mil anos antes da descoberta do Brasil (Brochado, 1975, p. 72-75).

Neste tópico estaremos utilizando basicamente dois autores: José Proença Brochado (1975) e Francisco Silva Noelli (1999-2000). A preocupação neste item é mostrar a cartografia da dispersão tupiguarani e sua localização quando os conquistadores europeus começaram a sua expansão sobre os territórios guarani.

As evidências de ocupações humanas na bacia do Paraná na região objeto de nossas considerações (Brasil meridional e Mato Grosso do Sul, norte da Argentina e sul do Paraguai) indicam que houve ocupações humanas a partir de 12.000 a 13.000 AP. Segundo uma sistematização feita por Noelli para a região sul do Brasil, 
Grosso modo, houve três levas humanas principais de ocupação que se expandiram a partir de regiões distintas. A primeira leva ocupou o Sul a partir de 12.000 ou 13.000 AP e parece ter se mantido estável, mantendo as mesmas características materiais, reproduzindo comportamentos adaptativos e econômicos de povos 'caçadores-coletores', até cerca de 2.500 AP. Os registros arqueológicos dessas populações são chamados como Tradição Umbu e Tradição Humaitá, e os estudos quantitativos mais recentes de suas indústrias líticas têm revelado uma notável estabilidade no sistema tecnológico e na escolha de matérias-primas por parte dessas populações. Isso torna possível pensar na possibilidade de que alguns aspectos sociológicos, como a organização social e as formas de ocupação do espaço, tenham sido reproduzidos mantendo mais ou menos um padrão constante durante este longo período. [...] Ainda não haja indicadores que definam de qual região da América do Sul vieram essas primeiras populações, assim também ainda não sabemos qual ou quais foram as áreas de entrada para a região sul do Brasil.

É possível que essa primeira leva seja representante de grupos não-mongolóides pertencentes à 'quarta migração', que vem sendo proposta por Walter Neves e colegas (Neves et al. 1996; Neves e Blum, 1999; Munford et al. 1995). Esse modelo, ainda em análise, aponta convincentemente para a ocupação inicial da América do Sul por populações não-mongolóides, representadas por grupos de paleoíndios, mais antigos e com registros arqueológicos distintos das populações mongolóides (NOELLI, 1999-2000, p. 227-228).

Segundo as considerações de Noelli (idem, p. 227-228) essa aparente estabilidade foi alterada por duas novas levas que ele assim caracteriza:

populações 'ceramistas', agricultoras, de matriz cultural distinta, Tupi e Macro-Jê, por volta de 2.500 anos atrás, respectivamente originárias da Amazônia e do Centro-Oeste do Brasil. Elas trouxeram consigo modelos de organização sociopolítica e de economia baseada no manejo agroflorestal e de adaptabilidade, distintos das populações pré-ceramistas que viviam no Sul. Como se pode inferir dos registros arqueológicos regionais, essas populações tinham uma capacidade de

Espaço Ameríndio, Porto Alegre, v. 7, n. 2, p. 277-556, jul./dez. 2013. 
KIMIYE TOMMASINO - Relatório de Identificação e Delimitação da Terra Indígena...

reprodução biológica e cultural tais que em cerca de 1.000 anos dominaram as margens das principais bacias hidrográficas, expulsando, assimilando ou exterminando as populações que ali viveram por cerca de 10.000 anos.

A interpretação mais convincente até agora para explicar porque essas duas últimas levas populacionais Jê e Tupi teriam vindo para o Sul e se espalhado de maneira tão extraordinária foi proposta por Lathrap (1970, 1977) e Brochado (1984; Brochado e Lathrap, 1982). Eles advogam a hipótese de que um grande crescimento demográfico na Amazônia, devido ao suporte dado pelo desenvolvimento da agricultura e de inovações tecnológicas associadas à alimentação, teria pressionado sucessivas levas humanas para fora da região amazônica.

Noelli (idem, p. 230) aponta as inovações trazidas por essas populações jê e tupi as quais teriam trazido várias espécies vegetais, pois

\begin{abstract}
pertencendo a agrupamentos culturais que se caracterizam por dominar diversas técnicas de manejo agroflorestal, essas populações contribuíram para enriquecer o patrimônio genético do Sul, trazendo consigo diversas espécies adotadas, desenvolvidas e aperfeiçoadas na Amazônia, Andes e América Central.
\end{abstract}

Interessa-nos aqui analisar mais detalhadamente a trajetória histórica, geográfica e cultural dos Tupi que migraram para o sul, se expandiram e conquistaram uma vasta área geográfica que comportava partes do Brasil, Argentina, Uruguai, Paraguai e Bolívia. Segundo Brochado (1975), os Guarani foram os primeiros cultivadores que penetraram no Rio Grande do Sul desalojando as populações mais antigas. Os Guarani pertenciam a uma cultura caracterizada arqueologicamente pela sua cerâmica típica e etnograficamente pela sua língua, cujas variantes se reuniam na família linguística tupi-guarani. Os registros de sua presença no sul é estimada em mil anos antes da "descoberta" do Brasil. Diz Brochado:

em, pelo menos duas ondas migratórias sucessivas, desenvolveram um imenso movimento centrífugo. Seguindo pela costa atlântica, chegaram pelo menos

Espaço Ameríndio, Porto Alegre, v. 7, n. 2, p. 277-556, jul./dez. 2013. 
até o nordeste e no interior, desceram para o sudoeste pelos vales dos rios Paraná, Paraguai e Uruguai, até o rio da Prata (1975, p. $72-73$ ).

Os Guarani que estamos analisando provêm da onda que desceu pelo interior e se instalou no Brasil meridional, norte da Argentina e leste paraguaio. A gênese cultural dos Guarani estaria situada na bacia dos rios Madeira-Guaporé, na região sudeste da Amazônia. Apesar da diversidade dialetal entre diversas parcialidades existentes, os Guarani comungavam a mesma língua, organização social, cultura material, simbólica e tecnológica. Noelli (1999-2000, p. 248-249) realizou um balanço sobre os Guarani integrando os resultados das pesquisas arqueológicas, históricas e antropológicas de tal forma que podemos visualizar esta sociedade com suas características específicas. Pela importância de sua contribuição seguiremos acompanhando seu trabalho:

A partir de uma revisão exaustiva da bibliografia Guarani, de estudos arqueológicos e visitas a diversas coleções de museus e sítios arqueológicos do Sul do Brasil, Paraguai, Uruguai e Argentina (Figura 7), feitos nos últimos 12 anos, foi possível concluir que os Guarani tinham a prescritividade como norma. As pessoas não-Guarani e as 'coisas novas' eram incorporadas e enquadradas nos seus códigos e estruturas. As inúmeras fontes indicam que os Guarani eram 'radicalmente' prescritivos, reproduzindo-se continuamente com pouca variabilidade na cultura material. Caso contrário, a contínua assimilação de pessoas de outras etnias e a adaptação aos ambientes do Sul do Brasil poderiam resultar em mudanças significativas e evidentes. É preciso reconhecer que os Guarani representam diversas populações que tinham em comum língua, cultura material, tecnologia, subsistência, padrões adaptativos, organização sociopolítica, religião, mitos, etc. Há, evidentemente, variações em nível dialetal, de adaptabilidade e de etnicidade. Em que pese a necessidade de mais estudos, verifica-se entre os Guarani diferenças que não aparecem em nível material.

O que garantia essa reprodução era a plasticidade da organização social, política e do parentesco de um lado e, de outro lado, a grande capacidade de se adaptar ao meio, adquirindo novidades para a subsistência,

Espaço Ameríndio, Porto Alegre, v. 7, n. 2, p. 277-556, jul./dez. 2013. 
medicina e matérias-primas. Essa reprodução só seria possível através de uma intensa e contínua troca de informações, objetos e pessoas aldeia-a-aldeia, tanto em nível local quanto regional, até alcançar distâncias longínquas no interior do imenso território de falantes do Guarani, descrito pelos europeus nos séculos XVI e XVII. As novas informações e objetos deviam ser rapidamente incorporadas na rede de significados, 0 que pode explicar a notória uniformidade da estrutura que amarra os diversos itens que compõem a cultura Guarani.

A organização sociopolítica e o sistema de parentesco, de acordo com as informações dos séculos XVI e XVII (SOARES, 1997), tinham por base a estrutura complexa e a localidade do tipo kindred. Ou seja, famílias extensas compostas por várias famílias nucleares reunidas em torno de uma liderança política e/ou religiosa a partir de laços de parentesco que poderiam ser tanto sangüíneo, quanto político [por afinidade] e/ou adotivo. Nem a matrilocalidade nem a patrilocalidade funcionavam como fator agregador, mas sim o prestígio de um líder com capacidade de organizar grupos guerreiros ou de trabalho, com qualidades de bom orador, guerreiro, agricultor, caçador, articulista político e provedor de grandes festas. As famílias extensas compunham-se de um número variável de famílias nucleares, que poderia atingir 60 [pessoas] ou mais, residindo em uma única casa. As maiores aldeias podiam conter até 4 ou 5 famílias extensas, havendo relatos de assentamentos com 3.000 habitantes, mas a média parece estar estrita a populações em torno de 600-300 pessoas. Considerando estimativas 'conservadoras', a partir de uma revisão parcial em fontes históricas do século XVII, a família nuclear seria composta em média por 6 membros. Havia possibilidade de existir até 7 gerações convivendo em uma família extensa, o que pode aumentar a média do tamanho local da família nuclear. A poligamia é outro fator que também contribuía para ampliar essa média, especialmente nos assentamentos bem posicionados na hierarquia regional.

Um aspecto importante a ser considerado para explicar o sucesso conquistador dos Guarani é a tendência a incorporar o 'outro', o 'não-Guarani'. Por meio de alianças ou assimilação à custa das contínuas guerras de conquista, tendiam a 'guaranizar' pessoas de outras etnias, incorporando-as. Essa prática de ampliar o fluxo gênico parece ser um comportamento padrão entre os povos Tupi, pois grupos atuais revelaram altos índices de distância genética, devido à existência de uma 
KIMIYE TOMMASINO - Relatório de Identificação e Delimitação da Terra Indígena...

acentuada troca gênica intertribal (SALZANO e CALLEGARI, 1991).

A pesquisa de Brochado sobre a ocupação guarani no Rio Grande do Sul é explicada a partir de duas imigrações sucessivas. Na primeira, ocorrida por volta do século $\mathrm{V}$, os Guarani teriam desenvolvido uma ocupação muito limitada no Estado, seguindo pela faixa costeira.

Se restringiram à várzeas dos rios maiores, como o Uruguai e o Jacuí. Se deslocavam navegando pelos cursos d'água e não se afastavam muito das suas margens, motivo pelo qual vamos encontrar as suas aldeias sempre junto a estas.

Mais ou menos 700 a 800 anos depois, ocorreu a segunda onda migratória também vinda do norte, pela faixa litorânea. Ocuparam primeiro a região dos lagos, instalando-se primeiramente na faixa costeira até o extremo sul, na região da lagoa dos Patos, entre os séculos IX e $X$. Subiram pelo rio Jacuí estabelecendo aldeias junto às margens. Depois subiram pelos tributários do Jacuí,

cultivando as várzeas cada vez mais estreitas. Depois começaram a ocupar a faixa de floresta pluvial da encosta do planalto. Desta maneira rodearam-no para oeste e leste do Jacuí, subindo muitas vezes pelos rios menores que descem da serra, até a altitude de $400 \mathrm{~m}$, excepcionalmente até $700 \mathrm{~m}$.

Não sabemos se ocorreram migrações anteriores ou paralelas pelo rio Uruguai. Mas, ao que tudo indica, os Guarani subiram-no até a sua confluência com o Pelotas e desceram-no, penetrando na vizinha República Oriental del Uruguai. Subiram também por muitos afluentes do rio Uruguai, como o Ijuí; na parte alta de cujos vales muitas vezes se estabeleceram, na falta de florestas de galeria, até mesmo em capões de mato no meio do campo.

Finalmente ocuparam as duas ilhas de florestas subtropicais da encosta do escudo cristalino voltada para a laguna dos Patos, em Camaquã e Canguçu.

Se observa que, à medida que penetraram para o interior, suas aldeias se afastavam dos rios e finalmente passaram a se localizar no alto de coxilhas ou quase no topo da encosta do planalto, em terrenos muito íngremes. Com a necessidade de explorar

Espaço Ameríndio, Porto Alegre, v. 7, n. 2, p. 277-556, jul./dez. 2013. 
KIMIYE TOMMASINO - Relatório de Identificação e Delimitação da Terra Indígena...

ambientes cada vez menos produtivos, a cultura Guarani se empobreceu. As aldeias diminuíram de tamanho e passaram a mudar de lugar mais freqüentemente. As casas ficaram menores $e$ as próprias vasilhas de cerâmica nas quais cozinhavam também diminuíram de tamanho (BROCHADO, 1975, p. 76-79).

Essas informações etnoarqueológicas sistematizadas por Noelli e por Brochado são importantes na nossa pesquisa porque o grupo de Araça'í veio do leste de seus territórios que são parte da Argentina e do Paraguai há cerca de um século. Como se verá mais adiante, as famílias que se instalaram em Araça'í formavam uma família extensa constituída basicamente por um grupo chiripá que incorporou em seu grupo indivíduos da parcialidade mbyá e dos Juruá (brancos). Portanto, as referências sobre a organização social guarani e suas estratégias de conquista e expansão continuaram atuantes até os dias atuais. Algumas mudanças podem ser observadas quanto ao tamanho das famílias extensas e quanto ao tamanho dos territórios que foram significativamente reduzidas e na maioria dos casos foram completamente suprimidas pela ocupação branca. Outra modificação, consequente do processo de dominação branca, foi a fragmentação das terras guarani, dispersas entre espaços dominados por cidades e zonas rurais de colonização capitalista ou dentro da faixa da Mata Atlântica que foram transformadas em áreas de preservação ambiental. Tornouse difícil manter a rede de sociabilidade entre os grupos locais, criandose uma situação de isolamento entre os grupos locais e tem dificultado a manutenção de sua organização social e política mais ampla, fragilizando a sua luta pela garantia de suas terras. Essa situação tem sido em parte resolvida com a aliança que cada grupo local tem buscado junto aos segmentos não-índios, sejam antropólogos sejam instituições governamentais ou não-governamentais. Mas é importante ressaltar que, mesmo depois de conquistados, os Guarani continuaram aplicando seus padrões de organização social e política. Se é certo que indivíduos guarani foram se integrando na sociedade dominante, desaldeando-se e casando-se com Juruá, isso não ocorreu com todos os grupos. Muitos grupos mantiveram-se aldeados e vivendo nos seus Tekohá, orientados por tradições ancestrais, não abdicaram de seguir a sua própria história

Espaço Ameríndio, Porto Alegre, v. 7, n. 2, p. 277-556, jul./dez. 2013. 
e padrões culturais.

Até aqui já podemos elaborar uma primeira abstração do modelo de ecologia e territorialização guarani. São povos que sempre se identificaram com uma vida no interior das áreas florestadas, abundantes em alimentos animais e vegetais e terra boa para fazer suas roças. Tinham profundo conhecimento do seu habitat e desenvolveram técnicas de manejo florestal e sua cultura material denota sua adaptação aos escossistemas de florestas e sua organização apresentava-se adequada ao seu modo de vida. O modo de vida baseada numa subsistência de caça, coleta e agricultura constituiu-se como um constrangimento a viverem em pequenos grupos formando uma família extensa. Cada família extensa formava seu Tekohá e tinha um líder religioso que enfeixava também funções políticas e econômicas. A família extensa era composta por várias famílias nucleares vinculadas entre si por laços de consanguinidade e afinidade. Os casamentos entre os Guarani, como em todas as sociedades indígenas, selava aliança política entre as famílias e expressava o significado sociológico da instituição do casamento para o grupo. Nesse sentido é que os casamentos dentro da mesma parcialidade, mas de Tekohá diferentes, implicava aliança entre os grupos que adquiriam direitos e obrigações recíprocos.

Os Guarani sempre tiveram um modelo flexível para absorver inovações através da prescritividade. Pessoas e coisas externas eram (e são) incorporados no seu sistema através de uma operação simbólica onde o que vem de fora é incorporado em seus códigos e estruturas. No entanto, os Guarani, ao longo da história do contato com os Juruá, sofreram novos constrangimentos que os obrigaram a se adaptar a ambientes menos florestados e menos ricos em flora e fauna e, pela ausência de novos espaços livres que pudessem ocupar (quase sempre já ocupados pelos Juruá) e pela devastação das florestas em toda parte, tiveram diminuídos os seus territórios. A observação da dinâmica no tempo mostrou que os Tekohá diminuíram nas suas dimensões demográficas e territoriais. Consequentemente aumentou a pressão para a expansão e a fragmentação, através da troca de homens e mulheres, a fim de fazer frente aos constrangimentos ecológicos e econômicos. No entanto, se analisarmos a expansão guarani nos 
séculos XIX e XX, veremos que, idealmente e às vezes concretamente, os Guarani continuaram desenvolvendo sua mobilidade no mesmo espaço em que foram encontrados no século XVI e ainda buscam as terras com as mesmas condições que constituem o seu modelo de terra ideal: que tenha muita água boa e corrente, que tenha florestas, que tenha terra para plantar. Não é por acaso que os Guarani continuam a viver preferencialmente nas florestas do Paraguai, da Argentina e ao longo da Mata Atlântica. Observando-se os Guarani no interior dos estados do sul, vê-se que eles preferem viver, mesmo quando inquilinos dos Kaingang ou dos Xokleng, nos remanescentes das matas existentes.

Por outro lado, a expansão por novas áreas já ocupadas por outros grupos humanos implicou em fazer alianças com grupos da mesma etnia ou etnias diferentes (Kaingang, Juruá), estratégia que vem desde o século XVI e segue até a atualidade.

Cabe agora explicitar um corolário desse modo de vida de natureza religiosa e que fundamenta a mobilidade guarani para o leste. Quem melhor estudou as migrações guarani como tendo fundamentação religiosa foi Nimuendaju. Este pesquisador foi o primeiro a estudar a cultura guarani a partir da perspectiva indígena e por ter sido adotado por uma família chiripá do interior de São Paulo (Al Araribá) pôde, melhor que ninguém, compreender os vários aspectos da cultura guarani em seus próprios termos. Sobre a contribuição deste antropólogo diz Melià:

A partir dos dados observados por ele mesmo, apresenta a religião guarani como religião da palavra; vê no mito da criação e da destruição do mundo com seus deuses, heróis culturais e grandes xamãs, o fundamento da religião; descreve, com aquele detalhe que lhe permite a convivência diária, os diversos tipos de pajé e suas atividades assim como as danças sagradas e as suas diversas expressões coreográficas; e estuda de perto, enfim, no bojo da própria experiência, o que é procura da Terra-sem-Mal para o Guarani. A transcrição do mito da origem, que é também o mito dos gêmeos, e a do mito da destruição do mundo, feitas no dialeto dos seus informantes Apapokúva, representam um fato novo e revolucionário na história etnológica dos Guarani. É o primeiro texto religioso, um tanto extenso, de mitologia guarani que conhecemos, dado que o relato oferecido por Telêmaco 
Borba (1908: 62-69) é bem mais sumário e consta somente na versão portuguesa. À luz dos dados recolhidos por Nimunedajú, os principais aspectos da vida guarani, antes conhecidos fragmentária e obscuramente, se esclarecem e podem ser interpretados coerentemente. Algumas de suas hipóteses, como a da migração, por motivos religiosos, e a procura da "terra-sem-mal", tiveram uma ressonância e desdobramentos definitvos (MÉTRAUX, 1927; SCHADEN, 1945; H. CLASTRES, 1975), embora às vezes excessivos (MELIÀ, 1987, p. 35-36).

Nimuendajú (1987) conheceu vários grupos guarani em pleno processo migratório e como indigenista do SPI fez algumas intervenções no sentido de administrar as condições de vida em que esses grupos se encontravam. Nessas condições, ele obteve dos grupos contatados a informação de que a migração que desenvolviam na direção leste se devia unicamente a razões religiosas. Schaden (1962, p. 13) quando esteve em 1947 visitando o grupo mbyá que vive ainda hoje na aldeia Limeira na Al Xapecó-SC ouviu de seu líder que estava "à espera da ordem divina" para retomar a migração em direção ao mar.

As pesquisas com os grupos guarani mbyá realizadas por Ladeira (1990 e 1992) têm indicado que a religiosidade continua sendo o eixo estruturador da vida material guarani. Pode-se dizer que o centro de elaboração de toda cultura guarani está na religião. O litoral atlântico abriga grupos mbyá e chiripá e são remanescentes daqueles que, desde o primeiro quartel do século XIX, provieram do oeste - Mato Grosso do Sul, Paraguai e Argentina. Nimuendajú indica alguns grupos que se deslocaram para o litoral do Estado de São Paulo: os Tañiguá em 1820, os Oguahuíva em 1820, os Apapocuva em 1870 e um outro grupo em 1912. O motivo dessas migrações era o yvý opá, o fim do mundo, profetizado pelos "médicos-feiticeiros" (SCHADEN, 1962, p. 12).

Schaden (idem) fala que as migrações mais recentes foram as de algumas levas mbyá do leste paraguaio e nordeste argentino que, atravessando o Rio Grande do Sul, Santa Catarina e o Paraná, chegaram ao litoral paulista. Ele diz ter notícias de três grupos: um que teria vindo por volta de 1924, outro em 1934 e o terceiro em 1948, do Paraguai meridional. Os primeiros dois grupos teriam estado no Espírito Santo, Minas Gerais e São Paulo (Al Araribá) e viviam por ocasião da pesquisa 
KIMIYE TOMMASINO - Relatório de Identificação e Delimitação da Terra Indígena...

(1946), parte na aldeia do Rio Branco-SP e parte no Espírito Santo. O terceiro grupo morou um tempo com os parentes do Rio Branco e os de Itariri, retiraram-se para Rio Comprido na serra de Itatins (idem, p. 13).

Sobre a parcialidade e o parentesco entre os diversos grupos guarani espalhados pelo sul do Brasil, Schaden identificou nessa época: os de Araribá são Nhandeva (Chiripá); os de Palmeirinha (Al Mangueirinha-PR), os de Xapecó-SC, os do Rio Branco-SP são Mbyá e em parte são aparentados entre si. No Mato Grosso do Sul, a maioria dos grupos era Kayová (aldeias Dourados, Panambi, Teicuê, Amambai e Taquapiri) e alguns grupos eram Nhandeva (Dourados, Teicuê e Jacareí ou Porto Lindo). Fora do Mato Grosso do Sul, os Chiripá viviam em Araribá-SP, Bananal-SP (descendentes dos Tañiguá, Apapocuva e Oguahuíva); no Itariri, na serra dos Itatins; no Rio Branco-SP havia só um velho casal Nhandeva, os demais Guarani eram Mbyá.

Tendo visitado esses grupos ao longo dos anos 40, Schaden pôde verificar a grande diversidade de situações em que os Guarani se encontravam. Essa diferenciação é assim explicada pelo autor:

aqueles grupos remanescentes da antiga 'nação Guarani', que na composição étnica e na forma de vida se conservaram índios, estão longe de apresentar homogeneidade cultural em todos os aspectos. Já em virtude de diferenciações anteriores à chegada do europeu, a cultura Guarani, pelo isolamento dos diferentes subgrupos da tribo, possuía apenas relativa uniformidade no tocante à língua, à religião, à tradição mítica e a outros setores da cultura. A diferenciação se foi acentuando muito nos tempos coloniais, quando parte das populações foi submetida, durante mais de um século, à tutela jesuítica, retornando, algum tempo após a expulsão dos missionários, a suas primitivas condições de existência. Depois, pela progressiva ocupação do antigo território Guarani por elementos de origem portuguesa ou espanhola, empenhados em atividades de economia sobretudo extrativa, mas também produtora, os índios da tribo entraram em situações de contato cultural bastante variadas. E finalmente, nos últimos 130 anos, os movimentos migratórios de uma série de hordas Guarani em direção ao litoral brasileiro vieram aumentar ainda o número das modalidades de experiência cultural, levando mesmo alguns grupos da tribo a contatos mais ou menos freqüentes com a moderna sociedade urbana

Espaço Ameríndio, Porto Alegre, v. 7, n. 2, p. 277-556, jul./dez. 2013. 
KIMIYE TOMMASINO - Relatório de Identificação e Delimitação da Terra Indígena...

(SCHADEN, 1962, p. 18).

Apesar dessa diferenciação apontada por Schaden, os estudos contemporâneos sobre os Guarani, quase todos referentes aos Mbyá, têm-se mostrado firmes em manterem-se fiéis às suas tradições. Por outro lado, os casamentos interétnicos com brancos assim como a aquisição de elementos do mundo moderno não são vistos mais como indícios de descaracterização cultural e sim como incorporações de elementos que são ressignificados e incorporados no patrimônio indígena pois como disse Noelli, "as pessoas não-Guarani e as 'coisas novas' eram incorporadas e enquadradas nos seus códigos e estruturas".

Um dado importante sobre a organização social guarani é que ela se baseia na família-grande. O grupo local constitui comunidade econômica que, de uma maneira ou de outra, liga todos os indivíduos de uma rede social constituída por famílias elementares.

Parentelas constituídas de duas, três ou mais famílias elementares correspondem a unidades econômicas de ordem superior, refletindo bem, em suas manifestações de solidariedade,o estado anterior, pré-aculturativo (sic), em que a família-grande era a unidade econômica propriamente dita (idem, p. 80).

Como bem lembrou Schaden, há variações nas situações em que se encontram os diferentes grupos. No litoral atlântico, os grupos são menores ao passo que no interior os grupos são maiores sendo a variação de 40 a algumas centenas de indivíduos.

As figuras 2, 3 e 4 mostram as informações sobre as migrações guarani e sua área de dispersão nas fases pré-históricas e históricas. É importante observar que, embora haja algumas divergências em relação aos acontecimentos históricos e a certos detalhes, é incontestável a presença guarani numa vasta região que se tornou palco de novas histórias envolvendo velhos e novos personagens vindos de outros continentes. 
KIMIYE TOMMASINO - Relatório de Identificação e Delimitação da Terra Indígena...

\section{Figura 2 - EXPANSÃO GUARANI}

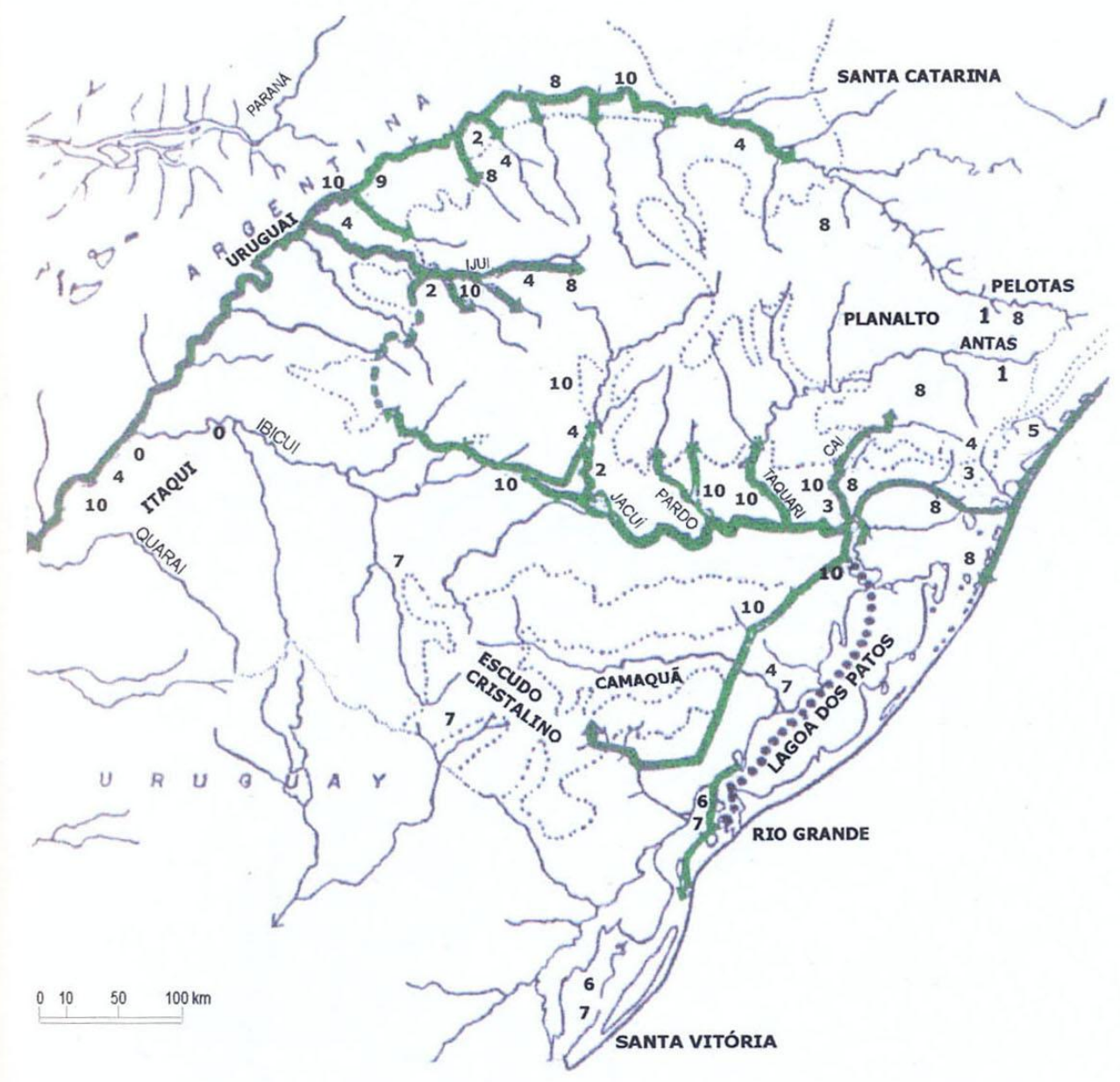

A conquista do Rio Grande do Sul pelos Guarani entre os séculos V e XVIII.

Os caminhos seguidos pelas principais migrações estão comprovados arqueologicamente. Compilado segundo pesquisas de diversos arqueólogos.

Fonte: Brochado, J.P. 1975:73

Espaço Ameríndio, Porto Alegre, v. 7, n. 2, p. 277-556, jul./dez. 2013. 


\section{Figura 3 - SÍTIOS ARQUEOLÓGICOS GUARANI}

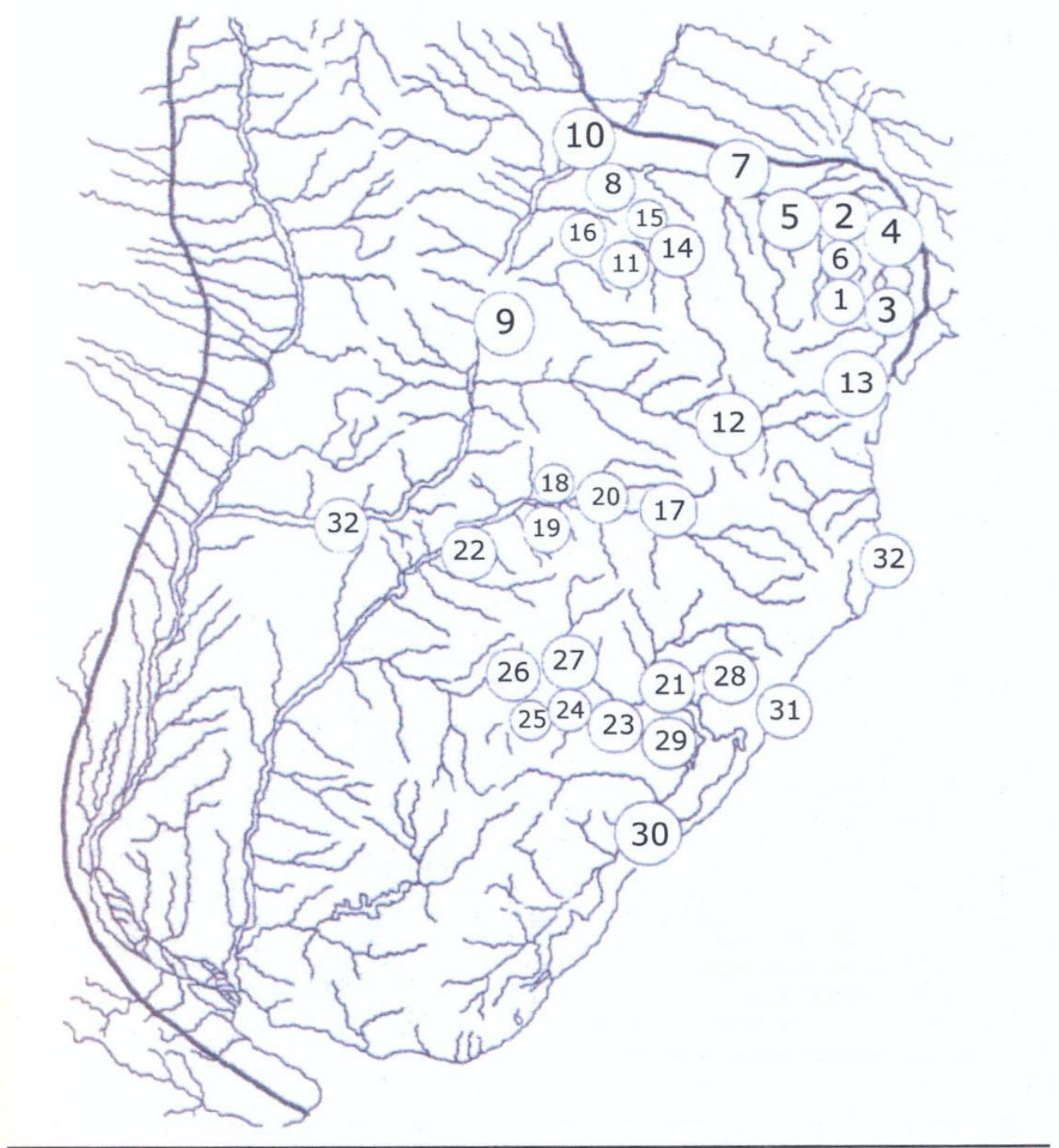

Área Guarani e representação dos pontos datados

Fonte: Noelli, F.S. $1999-2000: 248$

Espaço Ameríndio, Porto Alegre, v. 7, n. 2, p. 277-556, jul./dez. 2013. 
KIMIYE TOMMASINO - Relatório de Identificação e Delimitação da Terra Indígena...

\section{Figura 4 - PRESENÇA TUPIGUARANI: Prous}

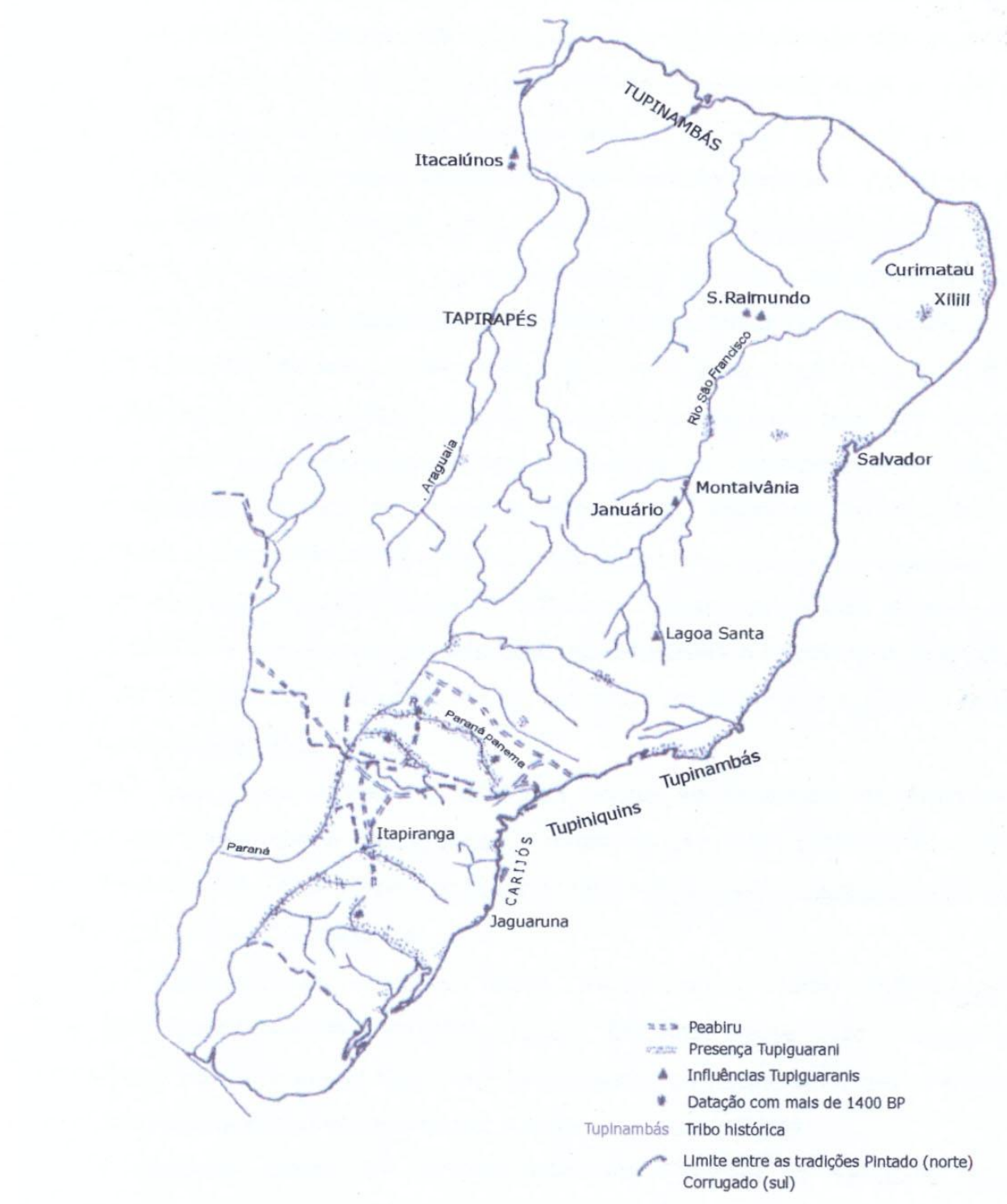

Expansão Tupiguarani e tribos históricas

Fonte: André Prous, 1992:375

Espaço Ameríndio, Porto Alegre, v. 7, n. 2, p. 277-556, jul./dez. 2013. 


\section{A Conquista dos Guarani pelos Portugueses e Espanhóis}

Em razão dos objetivos desta pesquisa, restringiremos os estudos dentro de uma área geográfica que seja suficiente para analisar os fatos históricos que sustentem o presente relatório. A exiguidade do tempo disponível e a complexidade que envolveria uma pesquisa mais abrangente não nos permitem discutir muitas das questões que consideramos importantes para enfocar a totalidade do processo guarani. Isso significa assumir, desde logo, que a área de pesquisa abarca parte do Brasil, do Paraguai e da Argentina, inexequível para uma equipe só. Este capítulo abordará, em linhas gerais, a conquista dos Guarani nos séculos posteriores à conquista européia dos povos guarani que se iniciou no século XVI e cujos territórios atravessam as fronteiras nacionais envolvendo, por essa razão, desde o início da conquista, maior complexidade.

Os diversos grupos indígenas dos territórios conquistados pelos portugueses foram incorporados à sociedade colonial como escravos. Milhares de índios foram aprisionados para o trabalho escravo nas plantações de cana-de-açúcar, nas diversas atividades exigidas nas vilas que foram surgindo. Os Carijós ou Cários que viviam ao longo do litoral sul-brasileiro foram inteiramente exterminados ainda no período colonial. Excetuando a estreita faixa litorânea do atlântico, a maior parte das terras a oeste do meridiano das Tordesilhas eram consideradas pertencentes à Espanha e, por essa razão, a história da conquista dos Guarani impõe um olhar sobre um espaço onde atuaram os conquistadores espanhóis.

Por outro lado, como os territórios onde se localizam os Guarani foram disputados por espanhóis e portugueses - estes conseguiram estender os limites para além do meridiano de Tordesilhas - estaremos situando a história guarani no contexto das disputas entre esses dois reinados.

Os Guarani conquistados foram incorporados como mão-de-obra nas encomendas espanholas na condição escrava. Milhares deles foram dizimados pelas epidemias que se espalhavam logo após os primeiros contatos. Uma das consequências foi a depopulação que ocorreu e a outra, a fuga de muitos grupos. 
A segunda forma de subordinação dos Guarani se verificou quando os missionários da Companhia de Jesus fundaram as reduções e incorporaram milhares de índios no sistema jesuítico. Em parte a adesão às missões religiosas era uma forma de fugir da escravidão nas encomendas. Os índios se sentiam mais seguros sob a "proteção" dos missionários. A obra jesuítica foi uma das experiências mais importantes do período colonial e deixou profundas raízes na vida e cultura dos Guarani até os dias de hoje. Os objetivos religiosos dos jesuítas confrontavam os interesses das elites dos reinos espanhol e português e por essa razão é uma das experiências históricas mais estudadas pelos historiadores.

Havia ainda um contingente de Guarani que não se subordinou aos sistemas coloniais e de dominação implantados no continente. Esses grupos fugiram para as densas florestas que cobriam a Argentina, o Paraguai e o Brasil e conseguiram manter-se livres até o século XIX. Melià assim explica esse grupo:

\begin{abstract}
Durante a época colonial, durante o século XIX e até atualmente, grupos guarani conseguiram sobreviver livres do sistema colinial. Selvas relativamente afastadas dos centros de população colonial, pouco ou nada transitadas pelos 'civilizados', os mantiveram suficientemente isolados para que pudessem perpetuar seu 'modo de ser' tradicional. Considerados apenas como sobreviventes de um mundo já superado, foram denominados genericamente como 'kayguá' e 'montaraces'. Mal conhecidos, raramente eram visitados por um ou outro viajante do século XIX sem interferências exteriores especiais (MELIÀ, 1989, p. 298).
\end{abstract}

\title{
3. Entre a Vida nas Encomendas e a Experiência Missioneira: os Guarani nos Séculos XVII e XVIII
}

Para que possamos entender melhor os antecedentes das Missões, é preciso esclarecer que a região onde elas se localizavam englobava terras que hoje compreendem Paraguai, Argentina e Brasil, mas que, na época, pertenciam à Espanha e formavam, em sua maior parte, a

Espaço Ameríndio, Porto Alegre, v. 7, n. 2, p. 277-556, jul./dez. 2013. 
KIMIYE TOMMASINO - Relatório de Identificação e Delimitação da Terra Indígena...

Província do Paraguai. Desde o século XVI, os interesses espanhóis e portugueses eram conflitantes no que se relacionava com o direito de cada uma das coroas sobre essa região. De acordo com o Tratado de Tordesilhas, apenas uma estreita faixa junto ao litoral leste da América do Sul pertencia a Portugal, e a coroa deste país procurava expandir esse território. As bandeiras são um exemplo disso, pois ainda que seu objetivo principal fosse buscar minas de ouro e pedras preciosas e escravizar índios para o mercado paulista e carioca, quando Portugal libertou-se da Espanha os núcleos de ocupação territorial dos bandeirantes passaram aos portugueses.

Um outro ponto importante foi o papel que os jesuítas espanhóis tiveram no desenvolvimento das Missões. Entretanto, é importante destacar que, por estarem as coroas portuguesa e espanhola disputando territórios, a influência que cada uma tinha na América não ficava em regiões restritas, mas sim uma se sobrepunha à outra, muitas vezes influenciando-se mutuamente. Assim, ainda que o território que compreendia as Missões fosse território espanhol e que os missionários que atuaram para criar as Reduções fossem jesuítas espanhóis, a região não estava livre de outras influências nem de contatos anteriores à chegada desses padres à América. Um exemplo disso é que os jesuítas espanhóis só chegariam à América espanhola em 1568, estabelecendose na Província do Peru, ao passo que já em 1508 várias expedições empreendidas pelos jesuítas portugueses chegavam até o litoral de Santa Catarina e mesmo às regiões mais ao sul (FRANZEN, 1999). É certo que os portugueses utilizavam-se dessas expedições para tentar expandir suas fronteiras, mas a própria Companhia demonstrava interesse nessa expansão territorial, pois a nomeação do padre Manuel da Nobrega como provincial do Brasil outorgava-Ihe direito sobre outras terras, além das de Portugal (FRANZEN, 1999). Além disso, outras ordens religiosas também estavam presentes nos territórios espanhóis e portugueses, como dominicanos, franciscanos, capuchinhos, etc.

Explicando esse contexto de disputas entre Portugal e Espanha, há que mencionar também um outro acontecimento que influenciaria diretamente nessa questão: a morte de D. Sebastião, em 1578, deixando o trono de Portugal sem um sucessor direto. O cardeal D. Henrique assumiu o trono, mas sua morte, dois anos depois, causou um novo 
impasse. Felipe II, rei da Espanha, apoiado por parte da nobreza e dos comerciantes portugueses, tomou posse do trono de Portugal, após a invasão do país pelas tropas espanholas. Tal acontecimento marcou o início da União Ibérica, que duraria até 1640, quando D. João, duque de Bragança, assumiu o trono português. Dentre as inúmeras consequências desta "união" entre Portugal e Espanha estaria o fato de que o Tratado de Tordesilhas passou a ser ignorado, tornando ainda mais confusas as fronteiras existentes na época. Assim, até os momentos finais da União Ibérica, a presença portuguesa teria sido muito forte na rede comercial da região rio-platense e na do ViceReinado Peruano. E após ter sido desfeita a união entre as coroas, Portugal continuaria buscando conquistar posições e território que restabelecessem seu vínculo com a América espanhola.

Até o início do século XVII, a Província Jesuítica do Chile abrangia uma região muito grande, que segundo Astrain (1995, p. 13) fazia fronteira com o Vice Reino do Peru, ao norte, e com o estreito de Magalhães, ao sul. Assim, dadas as dificuldades de comunicação e de governo dentro de um território tão grande, foi criada a Província Jesuítica do Paraguai, em 1607. Seu primeiro provincial foi o padre Diego Torres. Naquela época, essa província compreendia os territórios que atualmente formam parte da Argentina, o Paraguai, parte do Uruguai e algumas regiões do sul do Brasil (ASTRAIN, 1995, p. 13), e essa área cabia à atuação dos jesuítas espanhóis.

Assim, é importante deixar claro que, quando falamos sobre as Missões, não estamos nos referindo a um país ou estado específico, mas a esse grande território que na época pertencia à Espanha e que constituía uma antiga província jesuítica.

E dentro dessa grande extensão territorial, disputada por portugueses e espanhóis, viviam também muitos colonos e muitos grupos indígenas, de diferentes etnias e parcialidades. Para esses grupos, as fronteiras européias não faziam sentido, pois possuíam as suas próprias fronteiras, marcadas no interior de suas culturas e costumes. No caso dos Guarani, por exemplo, Métraux (1948, p. 36) afirma:

pelo lado leste do rio Uruguai, a linha de fronteira entre 
KIMIYE TOMMASINO - Relatório de Identificação e Delimitação da Terra Indígena...

os Charruas e o grosso da nação Guarani passava perto de Yapejú. Pelo lado oeste, os Guaranis ocupavam toda a área de Yapejú até o rio Paraná (SERRANO, 1936, p. 121). A partir da junção entre os rios Paraná e Paraguai, as aldeias dos Guaranis se distribuíam de modo contínuo pelo lado oriental do rio Paraguai acima, e por ambos os lados do rio Paraná acima. Prolongavam-se para 0 norte até o rio Mbotetey (Miranda), e pelo leste provavelmente até as Serras de Amambai e Maracajú. Os Guaranis eram particularmente numerosos na bacia do Paraná e na Província do Guaíra. Havia também inúmeros núcleos ao longo dos tributários do rio Paraná, sendo a fronteira entre Tupinaquins e os Guaranis marcada aproximadamente pelo rio Tietê. Os Guaranis, pelo sul, estendiam-se até a Província de Tapé.

Isso confirma o que muitas pesquisas arqueológicas apontam: que os Guarani formavam a nação indígena dominante nos primeiros séculos da conquista. É claro que neste grande território havia outras etnias, mas elas formavam minorias.

\subsection{A Redução dos Índios Guarani na Província do Paraguai}

De acordo com o padre Montoya (1985, p. 34), os jesuítas chamavam "Reduções" aos povos ou povoados indígenas que, vivendo conforme seu antigo modo em selvas, serras e vales, junto a arroios escondidos, em três, quatro ou seis casas apenas, separadas umas das outras por duas ou três léguas, tivessem sido "reduzidos" pelos padres em povoações maiores, passando a viver segundo regras sociais, políticas e econômicas que os padres julgavam mais "civilizadas". Dentre os diferentes povos indígenas que viviam na região a que nos referimos, muitos não aceitaram ser reduzidos pelos jesuítas, preferindo manter seus costumes e modo de viver livres. Entretanto, a manutenção dos mesmos não seria fácil dentro de um território já ocupado por colonos europeus, e muitos grupos acabaram desaparecendo ou tornando-se "invisíveis" em meio à nova população local. Nas várias reduções, os indivíduos eram predominantemente da etnia guarani. Entretanto, os nomes dados a esse grupo variavam de uma região a outra: os Guarani

Espaço Ameríndio, Porto Alegre, v. 7, n. 2, p. 277-556, jul./dez. 2013. 
que habitavam as proximidades da Lagoa dos Patos eram chamados pelos espanhóis de Arachanes; os que viviam na região que vai do rio Apa até o rio Mbotetey (Miranda) eram chamados Itatins; os que viviam na Serra Geral e no Rio Grande do Sul eram conhecidos como Tapes; ao redor de San Estanislao e San Joaquim chamavam-nos Tobatins; no rio Ipané, Guarambarés; e no rio Ivaiete, Taiobas (MÉTRAUX, 1948, p. 36).

Sob as ordens do padre Diego Torres, os jesuítas começaram a fundar as reduções no início do século XVII. Entretanto, desde que foram criadas, as reduções passaram a sofrer ataques dos bandeirantes paulistas, pois a captura de índios aldeados era mais fácil e rentosa do que as longas buscas nas matas. O padre Montoya, comentando um desses ataques, afirma

\begin{abstract}
juntaram esses homens [os bandeirantes] gente infinita de nossas aldeias e de outros lugares, ainda ocupados por gentios, os quais já se tinham comprometido conosco no sentido de se reduzirem. [...] Soubemos que já pretendiam ir embora [os bandeirantes] e que pensavam em queimar os enfermos e impedidos de viajar. Mandei que fosse ter com eles o Pe. Cristóvão de Mendoza, para que thes pedisse a permissão de antes os batizar ou mesmo a sua não-matança. Responderam, com as suas astúcias costumeiras, dizendo que nos avisariam, mas, retirando-se daquele posto, que é uma espécie de curral maior que a praça de Madri, puseram fogo às choças, que todas são de palha, onde queimaram muitíssima gente (MONTOYA, 1985, p. 127).
\end{abstract}

Esses ataques acabaram engendrando uma forte reação dos jesuítas à ação dos bandeirantes, o que resultaria em um outro ponto de dissidência entre os interesses dos padres e o dos colonos, que queriam o monopólio (ou mesmo o acesso) da mão-de-obra indígena e nesse caso, os jesuítas eram um obstáculo à exploração da tão almejada mãode-obra.

Em dezembro de 1609, alguns padres dirigem-se para a região do rio Paraná. Nessa região o padre Lorenzana fundaria a primeira redução jesuítica no território que então constituía a província do Paraguai, e que foi chamada de Santo Inácio Guaçu (ASTRAIN, 1995, p. 76).

Esta primeira redução foi uma espécie de "entreposto" onde 
ficaram durante algum tempo os padres até que, subindo o rio Paraná, fundaram as reduções do Guairá, às margens dos rios Piquiri, Tibagi e Paranapanema. Segundo Astrain (1995, p. 78) a região do Guairá estaria localizada "en la parte del Brasil que confina com el Nordeste de la actual República del Paraguay". Os principais responsáveis por este fato foram os padres José Cataldino e Simão Masseta, que fundaram em 1610 as duas primeiras reduções da região do Guairá: Santo Inácio e Loreto (ASTRAIN, 1995, p. 79).

Em 1620 o padre Roque González e seus companheiros fundariam a redução que se chamou de Itapúa e também Villa Encarnación, situadas ao sul do rio Paraná, em territórios que atualmente pertencem ao Uruguai. Seis anos depois de sua fundação, esta redução seria transladada para o norte do rio Paraná (ASTRAIN, 1995, p. 81).

O padre Roque González fundou ainda várias outras reduções entre os rios Paraná e Uruguai. Em 1620 fundaria a de "Concepción" e, em 1626, as reduções de São Nicolau, São Xavier e Yapejú. Fundou ainda as reduções de "Candelaria de Gazapamini", a de "Assunción del lyuí" e, em 1628 a redução de "Todos os Santos en el Caró" (ASTRAIN, 1995, p. 82).

Em 1620, o padre Antonio Ruiz de Montoya seria nomeado Superior das missões da região do Guairá, tornando-se mais tarde o responsável por todas as reduções do Paraguai. Era, dessa forma, uma espécie de "vice-provincial" (ASTRAIN, 1995, p. 83).

Entre 1620 e 1630, Montoya fundaria várias reduções:

San Javier, en la comarca de Tayatí; Encarnación, en el território de Nautingui; San José, en la provincia o comarca de Tucutí; San Miguel, en Ibianguí; San Pablo, sobre el río Iñeay. A estos pueblos se añadieron algunos distantes: San Antonio, en el Biticoy; Concepción, en la comarca de los Gualacos; San Pedro, en la misma tierra, Los Siete Angeles, en tierra Tayoba; Santo Tomás, y, por fin, la reducción de Jesús María (ASTRAIN, 1995, p. 83).

Segundo Astrain, as reduções do Guairá desenvolveram-se rapidamente. Entretanto, este desenvolvimento seria interrompido pelas invasões dos bandeirantes paulistas. Das doze reduções fundadas na 
região do Guairá, nove foram destruídas. As três que restaram foram transladadas rio Paraná abaixo e restabelecidas a aproximadamente 200 léguas do sítio anterior.

Por volta de 1631, Montoya inicia as missões da região do Itatim, junto ao rio Paraguai. Entre 1631 e 1632, foram fundadas quatro reduções: "la primera, llamada San José, y las tres siguientes, com los nombres de Los Angeles, San Pedro y San Pablo". Destas quatro, duas foram destruídas pelos paulistas, e as duas restantes, ainda que tenham ficado durante algum tempo no mesmo local onde foram fundadas, foram posteriormente transladadas para a região meridional do rio Paraguai, próximas a Santo Inácio Guaçu (ASTRAIN, 1995, p. 84).

Uma outra região onde os jesuítas fundaram reduções foi a região de Tape, que segundo Astrain "designava vagamente las provincias meridionales del actual Estado del Brasil, situadas entre el río Uruguay y el Océano Atlántico" (idem, p. 85). Em 1632 o padre Romero fundou a redução de Santa Teresa. Em seguida, foram fundadas as reduções de San Miguel e Santo Tomás.

As reduções do Tape estavam localizadas no lado oriental do rio Uruguai. Entretanto, em 1638 os paulistas chegariam a essa região, destruindo as principais reduções fundadas nos anos anteriores. Dessa forma, tentando salvar o que restou delas, os jesuítas levaram os índios para o lado ocidental do rio Uruguai, em locais menos acessíveis (ASTRAIN, 1995, p. 85).

Assim, com essas constantes transladações, as reduções assumiriam as posições que conservaram até o final do século XVIII. Segundo Astrain (1995, p. 85) em 1647 existiam 27 reduções na província do Paraguai e, em 1652, esse número já teria caído para 22. Algumas delas encontravam-se situadas:

en la parte Sudeste de la actual República del Paraguay donde todavía se leen los nombres de San Ignacio Guazú, Villa Encarnación, Santa Rosa, etc. El principal grupo de reducciones echó raíces en el Estado que actualmente se llama de Missiones, y es la parte más septentrional de la República Argentina, entre el Paraná y el Uruguay; algunas, en fin se situaron al Este del Uruguay, pero a poca distância de este río, en territorio que hoy pertence al Brasil (ASTRAIN, 1995, p. 85). 
KIMIYE TOMMASINO - Relatório de Identificação e Delimitação da Terra Indígena...

Ainda a respeito das reduções, Astrain cita o relato do padre Francisco Díaz Taño, que em 1652 foi enviado a Roma para informar seus superiores sobre a origem e o estado das reduções jesuítas da província do Paraguai. Segundo ele:

Hiciéronse en las provincias del Paraná y Uruguay 48 pueblos, todos de indios infieles y bárbaros. Destos, los 26 los han debelado y destruído los rebeldes del Brasil, y llevado tan gran suma de almas, que afirma Su Majestad en una real cédula, que es de las presentadas, haber testigos que afirman pasaban de 300.000. Solamente han quedado 22 reducciones, las 20 en los ríos del Paraná y Uruguay y dos en las provincias de Itatines, donde hoy habrá en las del Paraná, 40.000 almas entre mujeres y niños indios, que aun que eran muchos más millares y estaban ya bautizados, como consta de los libros del bautismo, ciento cincuenta y tantos mil, parte de ellos llevaron los dichos, y parte se han muerto com las pestes. En las reducciones de los Itatines habrá como 3.000 almas, según el número de casados que hay, que son 800 (ASTRAIN, 1995, p. 86).

\subsection{Os Índios Missioneiros, a Ruptura com a Vida Livre das Comunidades Autóctones}

A respeito dos Guarani que viviam na grande região abrangida pela Província do Paraguai, Neumann (1996) faz algumas considerações. Segundo ele, nesta região podíamos encontrar três realidades guarani distintas: a dos Guarani que, passando a viver sob a tutela jesuítica, ficariam conhecidos como Guarani missioneiros; a dos Guarani que viviam sob a tutela de outras ordens religiosas, chamados Guarani provinciais; e a dos que permaneceram independentes, fugindo a qualquer tipo de controle. Escreve Hélène Clastres:

[...] certo número de tribos Guarani tinham escapado dos jesuítas e dos colonos e conservaram a sua autonomia, porque se estabeleceram num território que durante muito tempo permaneceu inacessível: daí a denominação de caainguas ou cainguas (gente da

Espaço Ameríndio, Porto Alegre, v. 7, n. 2, p. 277-556, jul./dez. 2013. 
KIMIYE TOMMASINO - Relatório de Identificação e Delimitação da Terra Indígena...

floresta) que Ihes foi atribuída (CLASTRES, 1978, p. 10).

A essas três realidades de que fala Neumann, acrescentamos ainda a daqueles Guarani que, não estando sob a tutela de nenhuma ordem religiosa, nem vivendo em locais isolados, trabalhavam nas encomendas ou vendiam sua força de trabalho nos centros urbanos que então se formavam.

Desde o século XVI, quando de sua chegada à América, os padres jesuítas foram contrários ao trabalho indígena no sistema que se costumava chamar "encomiendas". E, justamente, a mão-de-obra indígena era a mais significativa na região, pois muitos colonos espanhóis recusavam-se a qualquer tipo de trabalho pesado ou manual. O comentário de D. Juan de Matienzo, que viveu naquela época, nos dá uma idéia da mentalidade dos colonos espanhóis:

porque españoles no sirven ni conviene que sirvan, negros ay pocos y aun que seria mejor no hubierse tantos, y asi sin el servicio de estos [os índios] para lo necesario no se podría conservar la tierra (MATIENZO apud GADELHA, 1980, p. 107).

A respeito das encomendas, Gadelha nos dá uma idéia de seu início quando comenta os relatos de Alvar Nuñez:

[...] antes de cada guerra contra os índios, ou antes de tomar qualquer outra decisão afetando os interesses gerais da população, o governador era obrigado a consultar os clérigos e religiosos existentes, bem como os capitães e oficiais reais. Igualmente, não podia atacar os índios em guerra, antes de inquiri-los uma, duas, e até três vezes, sobre se aceitariam ou não se submeterem ao Rei de Espanha. Era crime não seguir o processo indicado. Assim é que a conquista, toda ela, se processou em nome do Rei e para o Rei. Uma vez estabelecida a paz e feita a aliança, tornavam-se os índios 'vassalos de S. Majestad' e eram 'encomendados aos espanhóis', o que significava que haviam admitido, voluntariamente, a presença dos mesmos em suas terras. Apossava-se o conquistador do território, achando-se com direito às terras, vidas e ao trabalho dos índios (GADELHA, 1980, p. 102).

Espaço Ameríndio, Porto Alegre, v. 7, n. 2, p. 277-556, jul./dez. 2013. 
KIMIYE TOMMASINO - Relatório de Identificação e Delimitação da Terra Indígena...

A legislação espanhola previa duas espécies de prestação de serviços, baseadas na encomenda: o sistema de prestação de serviço pessoal (ou "yaconato") e o de prestação de tributo (ou "mita").

Ao "aceitarem" esse tipo de vassalagem imposta pelos espanhóis, os índios tornavam-se súditos reais, visto que do ponto de vista jurídico eram considerados livres e, como tal, "ficavam sob a égide da Real Coroa espanhola para serem protegidos, doutrinados e policiados" (GADELHA, 1980, p. 104), pois era apenas sob essa condição que eles podiam ser "dados em encomenda" aos colonos espanhóis (e, mesmo assim, apenas por um tempo determinado). Assim, em troca dos serviços prestados pelos índios, o encomendeiro era obrigado a "introduzir" o índio na sociedade espanhola, garantindo suas necessidades básicas, educando-os nas normas da sociedade espanhola e catequizando-os de acordo com a religião católica.

Entretanto, se juridicamente o índio era livre, devendo obediência apenas à Coroa espanhola, na prática sua situação era de escravo, visto que, apesar das tentativas dos reis espanhóis de proteger sua liberdade, eles foram explorados ao máximo pelos colonos.

O relato do padre Montoya sobre o trabalho dos índios nas encomendas da região do Guairá exemplifica esta exploração:

Durante o dia inteiro estes [os índios] não comem mais do que fungos, frutas ou raízes silvestres, que para sua ventura se lhes oferecem os matos, estando eles em contínua ação e trabalho. É que têm, mandando-os, um capataz que, apenas o pobre índio se assentou um pouco para tomar fôlego, faz-lhe sentir a sua ira [...]. $\mathrm{O}$ trabalho naquela erva [erva-mate] tem consumido a milhares de índios. Sou testemunha ocular quanto a existência naqueles matos de ossários bem grandes de índios.

[...] Sou testemunha de que na Província de Guaíra o encomendeiro mais justo ou correto se servisse por seis meses de cada ano de todos os índios que tinha por encomenda, sem pagar-lhes coisa nenhuma. E os que eram menos justos detinham-nos de dez a doze meses. Sendo assim, como na verdade o é, quanto tempo sobra a este desgraçado, para sustentar a sua mulher $\mathrm{e}$ criar seus filhos... (MONTOYA, 1985, p. 41-42).

Dessa forma, a encomenda se tornaria a base da colonização 
KIMIYE TOMMASINO - Relatório de Identificação e Delimitação da Terra Indígena...

espanhola na América, pois através dela se teria processado a utilização em massa da mão-de-obra indígena, suprindo as necessidades dos colonos espanhóis que, ao contrário dos colonos portugueses estabelecidos no litoral da Província do Brasil, não tinham lucros suficientes para comprar e manter escravos negros.

A Coroa espanhola procurava impedir o trabalho pessoal através de leis, mas estas eram ignoradas pelos colonos e mesmo pelos governantes locais.

Sendo os jesuítas contrários a essa extrema exploração dos índios, como já foi dito acima, a forma que eles encontraram para acabar com o trabalho "escravo" a que os índios eram submetidos pelos encomendeiros foi a tributação, pois através de uma vinculação direta com o Rei, eles conseguiram afastar os Guarani da prestação de serviços pessoais.

Assim, se por um lado as diversas parcialidades guarani, ao aceitarem a conversão e consequentemente a vida em redução, sofriam uma espécie de atrelamento ao Estado Colonial, via tutela jesuítica, por outro se distanciavam da sociedade colonial e principalmente da alçada encomendeira. Mesmo que o excedente produzido nas reduções fosse controlado pelos jesuítas, e não pelos índios, os documentos da época não demonstram haver exploração destes últimos por parte dos jesuítas. Entretanto, dizer que não houve exploração não implica a inexistência de um autoritarismo por parte dos padres, pois eles impuseram aos índios seus próprios conceitos de bem e de mal, do que era civilizado ou não, enfim, toda uma nova forma de viver e se organizar. Assim, tirando o que os jesuítas pagavam como tributo ao Rei de Espanha, o restante era controlado e utilizado por eles no interesse dos índios, apesar de esses interesses não serem definidos pelos indígenas, mas pelos próprios jesuítas. Ainda assim, apesar do totalitarismo reinante, os índios reduzidos não constituíam propriamente uma mão-de-obra, pois tirando as requisições ocasionais para obras públicas ou operações militares, eles não estavam a serviço de ninguém.

Quanto a essas requisições, Neumann (1996) afirma que, durante os séculos XVII e XVIII, teriam sido expedidas diversas cartas por parte dos governadores, solicitando aos padres provinciais que enviassem 
KIMIYE TOMMASINO - Relatório de Identificação e Delimitação da Terra Indígena...

índios das reduções para auxiliar contra possíveis invasões de nações estrangeiras e ataques de "índios infiéis", ou ainda para participar de obras públicas, na escolta de governadores, no patrulhamento das terras espanholas, etc. Este autor chega a sintetizar as modalidades de serviço que os Guarani prestaram ao governo colonial em três itens principais: facções de guerra, obras públicas, transporte e construção naval.

Entretanto, é importante deixar claro que esses serviços prestados ao poder público tinham um caráter bastante diferente daqueles prestados nas encomendas. A princípio, os Guarani reduzidos não tinham obrigação de trabalhar/auxiliar nos serviços públicos, visto que já contribuíam com a Coroa através de tributos. Este tributo era pago pelos jesuítas ao Rei espanhol e era fixado por "cabeça", ou seja, pelo número de indivíduos reduzidos juntos aos padres. Com o tempo, o crescimento demográfico dentro das reduções seria intenso, o que aumentaria bastante os impostos. Dessa forma, os jesuítas permitiam que os Guarani trabalhassem para o poder público porque a Coroa recompensava estes serviços descontando dos impostos, numa espécie de mecanismo de compensação.

\subsection{A Guerra Guaranítica e a Expulsão dos Missionários}

A experiência dos povos indígenas nas reduções jesuíticas nos territórios que constituem hoje o Paraguai, a Argentina e o Brasil meridional (Rio Grande do Sul, Santa Catarina e Paraná) ocorreu no período entre 1609 e 1767. A destruição do sistema de reduções tem sua explicação relacionada ao Tratado Madrid, assinado por D. João $\mathrm{V}$ (rei de Portugal) e D. Fernando VI (rei de Espanha) em 13 de janeiro de 1750 e seus desdobramentos. Esse tratado abolia o meridiano de Tordesilhas e estabelecia uma nova linha, ampliando as terras que caberia à Coroa de Portugal e ainda redefinia os direitos coloniais entre as duas coroas. Basicamente, definia a troca entre a Colônia do Sacramento, pertencente a Portugal, pelos territórios dos Sete Povos das Missões (reduções que se situavam na margem esquerda do rio Uruguai e correspondia ao atual estado do Rio Grande do Sul), que pertenciam à

Espaço Ameríndio, Porto Alegre, v. 7, n. 2, p. 277-556, jul./dez. 2013. 
KIMIYE TOMMASINO - Relatório de Identificação e Delimitação da Terra Indígena...

\section{Espanha.}

Por esse acordo, os Guarani que viviam nos Sete Povos teriam de deixar seus territórios ancestrais, gado e plantações, entregando-as aos portugueses. Por outro lado, os jesuítas teriam de abandonar um trabalho de cento e trinta anos, e todas as obras que vinham realizando com os índios seriam interrompidas. Portanto, o Tratado de Madrid, vinha contra os interesses dessas duas categorias e tentaram, de todas as maneiras, a realização do tratado. Essa reação fora prevista pelos reis de Portugal e Espanha, de forma que ambos se comprometiam a retirálos pela força das armas. O prazo estipulado para que os jesuítas e os 30 mil índios guarani se retirassem vencia no dia 03/11/1752. Novo prazo foi marcado, 15 de agosto de 1753 sob ameaça de que, caso não cumprissem, seria declarada guerra aos Sete Povos. Malgrado todas as ameaças, os Sete Povos resistiram e, apesar da desigualdade entre os guerreiros guarani e os exércitos português e espanhol, o desfecho foi a destruição dos Sete Povos que se concretiza na batalha de Caiboaté em 10 de fevereiro de 1756. O líder da resistência guarani Sepé Tiaraju tinha sido morto num combate três dias antes. Os Guarani que sobreviveram ainda tentaram lutar contra os exércitos aliados, mas não tiveram êxito. $O$ avanço dos exércitos inimigos se deu em direção a São Luís diante da frustrada tentativa do exército guarani de impedir o avanço. Em 17 de maio de 1756 o exército português tomou a redução de São Miguel, a mais importante dos Sete Povos. Os espanhóis tomaram Santo Ângelo onde ficaram aquartelados e montaram acampamento em São João e São Lourenço.

O general Gomes Freire inicia uma campanha para conquistar a amizade dos Guarani e em 1757 levou consigo 700 famílias de vários povos e fundou três povoações: Aldeia dos Anjos, em Gravataí; São Nicolau, perto de Rio Pardo e outra também São Nicolau, perto de Cachoeira do Sul (SIMON, 1993, p. 125-129).

O pesquisador Simon nos remete ao pintor e desenhista Jean Baptiste Debret que visitou as aldeias guarani quando viajou pela província do Rio Grande entre 1816 e 1830 e fez referência à Aldeia dos Anjos que ficava a sete léguas de Porto Alegre e a outras duas aldeias: Cruz Alta, "além de Rio Pardo" e São Vicente, perto de Rio Pardo. Debret fica impressionado com a existência de Guarani proprietários e ricos, 
que eram de origem missioneira. Ao que parece devia-se essa situação à atenção que as aldeias receberam do coronel José Marcelino de Figueiredo (idem, p. 129-131). Ainda seguindo o relato de Simon, este diz:

Como o resultado do Tratado de Madrid foi desastroso, em 1761 ele é revogado e tudo volta a ser como era antes do 1750. Padres e índios começam a se reagrupar e a se organizar novamente nas aldeias dos Sete Povos, parcialmente destruídas. E talvez a história dos Sete Povos fosse outra se, sete anos depois da revogação do Tratado de Madrid, em 1768, não tivessem sido expulsos todos os padres jesuítas dos territórios espanhóis (SIMON, 1993, p. 133).

Para substituir os padres jesuítas foram nomeados padres franciscanos, dominicanos e mercedários os quais eram designados apenas para funções espirituais. As funções administrativas ficaram centralizadas numa administração civil espanhola. Esta nova forma não teve sucesso e foi substituída por outra em que cada povo tinha um administrador. Esta nova forma também não obteve bons resultados e finalmente foi criada uma administração central em São Miguel. Pode-se dizer que nenhuma dessas formas conseguiu reerguer as antigas condições do período missioneiro. A decadência era resultado de intrigas entre administradores e padres, e o descontentamento dos Guarani podia ser medido pela sua fuga para as florestas onde podiam viver livremente ou nas estâncias onde podiam trabalhar como peões (SIMON, 1993, p. 134-137).

Em $11^{\circ}$ de outubro de 1777 foi assinado um novo tratado, o de Santo Ildefonso e objetivava resolver os problemas dos limites entre as terras portuguesas e espanholas.

Com o novo Tratado, Portugal ficaria com o que já tinha de posse (Rio Grande, Rio Pardo) e mais terras ao oeste e ao norte destes pontos já povoados.

Como conseqüência imediata, há uma rápida penetração de povoadores portugueses, aquinhoados com sesmarias. Também se estabelece íntimo contato com os índios missioneiros, quer no comércio de gado, quer no trabalho de peão de estância e, ainda, no cruzamento de raças com índias das Reduções (SIMON,

Espaço Ameríndio, Porto Alegre, v. 7, n. 2, p. 277-556, jul./dez. 2013. 
KIMIYE TOMMASINO - Relatório de Identificação e Delimitação da Terra Indígena...

1993, p. 138).

Esse quadro resumido sobre os acontecimentos pós-guerra guaranítica vai ser mais bem percebido nas informações deixadas por Saint-Hilaire e ainda pela pesquisa de J. Belém sobre Santa Maria cujas descrições mais adiante mostram a dispersão guarani, a inserção em diversas atividades em que se inseriram e casamentos interétnicos aparecem esmiuçados. O fato é que a conquista definitiva dos territórios das Missões pelos portugueses foi negociada com os principais caciques que concordaram em obedecer ao Rei (idem, p. 139).

Mesmo com o Tratado firmado, em 1801, com a notícia de que a Espanha declarara guerra a Portugal, houve uma batalha entre os exércitos espanhol e português pela posse dos territórios das Missões, cujo desfecho foi a vitória dos portugueses. Entre 1816 e 1819 houve ainda vários pequenos combates liderados por Adresito Artigas (André Guaicurari) que tentou libertar as Missões das mãos portuguesas. Nessa época a administração portuguesa estava nas mãos de Francisco Chagas Santos, quando se deram grandes reestruturações nas terras de Espanha na América tendo surgido novos estados como o do Uruguai (idem, p. 141).

A extinção definitiva das Missões ocorre em 1828, com a invasão de outro caudilho uruguaio, Dom Frutuoso Rivera. Este invadiu o território e dominou-o por oito meses, sem ser molestado. Quando se retirou, levou junto quase todos os índios missioneiros que restavam, além de tudo que tinha algum valor, chegando a encher 60 carretas. $\mathrm{E}$ o mais interessante deste episódio é que, com promessas de formar um Estado republicano, não convenceu somente aos índios, mas também a muitos soldados e oficiais portugueses que a ele se juntaram. Isto explica, em parte, por que não foi atacado em sua devastadora incursão (SIMON, 1993, p. 141).

Segundo Simon, os Guarani missioneiros levados por Frutuoso Rivera para o território uruguaio eram cerca de 4 mil, mas foram abandonados à própria sorte após a fundação da cidade de Bela Unión. Foram abatidos pela fome e depois passaram a saquear as estâncias em território brasileiro. Em 1833 a lei 36 de 21 de outubro declara serem brasileiros os territórios das Missões (SIMON, 1993, p. 142-143).

Espaço Ameríndio, Porto Alegre, v. 7, n. 2, p. 277-556, jul./dez. 2013. 
Algumas considerações foram feitas por Jorge Francisco Machón (1996, p. 17) que pesquisou a redução dos Guayanas [Kaingang] do alto Paraná de São Francisco de Paula. Diz o autor que os 30 povos alcançaram na primeira metade do século XVIII uma extraordinária prosperidade, tanto na organização econômico-social como em seu desenvolvimento cultural e urbano. Era, segundo ele, o "momento clássico de sua história que começara nos fins do século anterior". O autor recolhe fontes dos missionários que falam da presença de outras etnias minoritárias que foram incorporados a algumas das missões através de visitas que os missionários faziam para convencê-los. Cita Furlong que relata um documento de 1737 em que fala dos vários grupos que viviam na região: Guanãnas, que viviam no "rio Paraná arriba"; os que estavam nas "campañas" do rio Uruguai, da nação Gunao; os Galchaqui que viviam nos bosques acima do povo de Jesus; os Tobati que viviam entre o Paraguai e o Paraná; registra o padre Superior Bernardo Nusdorffer que ele mesmo trouxe 18 pessoas gualchaqui para viver no Povo de Jesus e outras 6 do Paraná acima; anos depois trouxeram mais pessoas dessa nação. Diz ainda que muito mais pessoas, da nação guañana se agregaram ao Povo de Corpus; cita os Guenoa que foram incorporados aos índios de São Francisco de Borja, Concepción, São Xavier e São Nicolau. Os Caribes foram juntados aos de Santo Angelo e os Charruas e Guenoas com os de Yapeju (MACHÓN, 1996, p. 18).

Há ainda uma importante informação de Machón sobre os objetivos dos jesuítas. Diz ele que não era apenas o interesse missional de converter e reduzir os índios. Havia um interesse econômico principalmente junto aos povos que se dedicavam à atividade ervateira, como Jesus, Loreto e Corpus,

non solamente por ser el más septentrional, sino por la composición de sus habitantes, Guaraníes, Paranáes a los que se les habían agregado. Acarayenses trasmigrados, conocedores de la región e de sus vecinos (idem, p. 19).

A partir de 1820 até o final do século XIX assiste-se à repartição do território das Missões entre Brasil, Argentina e Paraguai. Segundo 
KIMIYE TOMMASINO - Relatório de Identificação e Delimitação da Terra Indígena...

Abou (s/d, p. 136-137) ocorreu um triplo fenômeno:

la lenta reorganización de cada región guaraní, con la población de las Reducciones fenecidas y de las que, materialmente abandonadas, sin embargo subsisten; la intensificación del mestizaje entre la población de origen europeo y los indios de las Misiones, comenzado después de la expulsión de los Jesuitas; la constitución de un fondo cultural ibero-guaraní, surgido de un proceso de aculturación recíproca al que se agregarán, a fines del siglo XIX, diversos aportes de inmigrantes de todas las nacionalidades. Sin duda, es este mestizaje físico y cultural lo que constituye el aporte más significativo de los guaraníes de las Misiones a las sociedades y culturas del Paraguay, del nordeste argentino $y$, en menor medida, del sudoeste brasileño.

El mestizaje físico fue una consecuencia de lo que se llamó 'el éxodo misionero', es decir la dispersión geográfica de los indios de las Misiones, ocasionada en primer lugar por la degradación rápida de las condiciones de vida en las Reducciones luego de la partida de los Jesuitas y más tarde por las guerras multilaterales que abarcaran el 'país guaraní'. No hubo una Reducción que no se viera afectada por la emigración. Todos los intentos de los gobernadores o de sus lugartenientes para impedir el éxodo masivo - o frenarlo -, fueron en vano. Cundo era necesario, los indios encontraban mil medios para infringir la orden de permanecer en el pueblo o de regresar; la huída nocturna era lo más corriente.

Abou explica, assim, como os Guarani das missões se dispersaram e as formas como se desvaneceram ao longo do tempo e o que aconteceu com a maioria deles no espaço, agora dividido entre a Argentina, Brasil e Paraguai. Sigamos a sua explanação:

En Argentina, los emigrados guaraníes se establecieron en su mayoría en las provincias de Corrientes, Entre Ríos, Santa Fe y Buenos Ayres, contribuyendo a la fundación de nuevas localidades y dedicándose a la agricultura o a otros oficios; también se los encontraba en la Capital, y 'hasta militando en los fortines de la frontera pampeana'. El contacto permanente entre españoles y criollos por una parte y las mujeres guaraníes por otra llevaba naturalmente a uniones mixtas y a la concreción de un rápido proceso de mestizaje.

Espaço Ameríndio, Porto Alegre, v. 7, n. 2, p. 277-556, jul./dez. 2013. 
En Brasil, en la formación de la sociedad de Rio Grande, 'tuvo mucha significación el aporte guaraní-misionero, pues grupos desprendidos de las Reducciones, pro propia o ajena voluntad, formaron distintas aldeas aportando sus brazos para el desarollo económico de la región. También se unieron, como en los dominios españoles de la cuenca del Plata, portugueses con mujeres guaraníes, originando un proceso de mestización desde casi los inicios del referido poblamiento'.

En Paraguay, los guaraníes de las Misiones se fundieron en una población mestizada desde larga data y por conseguiente no hicieron más que insertase en un proceso ya avanzado. Para convencerse de ello, basta saber que, antes de la fundación de las Reducciones, en el colegio jesuita de Sunción los Padres tenían dificultad para obtener que sus alumnos, hijos de colonos, hablaran español en los recreos: hablaban el idioma de sus madres, el guaraní (ABOU, s/d, p. 137).

Abou ainda comenta que os casamentos mistos não se davam apenas entre homens europeus e mulheres guarani, mas também havia casos de casamentos entre índios e mulheres espanholas ou crioulas sobretudo entre emigrados isolados. O fato de ter permanecido sociologicamente invisíveis se devia à troca de nomes guarani por nomes europeus. Entre as mudanças mais visíveis ocorridas entre os Guarani das missões, Abou (idem, p. 138-139) cita algumas: na língua, onde vários dialetos foram unificados pelos jesuítas; na casa grande que foi substituída por casas menores adaptadas à monogamia imposta pelos padres para comportar uma família nuclear; na estrutura hierárquica criadas pelos missionários necessárias às tarefas que os caciques deveriam exercer na direção das estâncias missioneiras.

No próximo capítulo veremos com mais detalhes e concretamente registros desse processo de mestiçagem física e cultural entre as diversas populações que viviam no sul do Brasil, principalmente no Rio Grande do Sul.

A Figura 5 mostra a localização das reduções espanholas e das estâncias. 


\section{Figura 5 - AS REDUÇõES JESUÍTICAS}

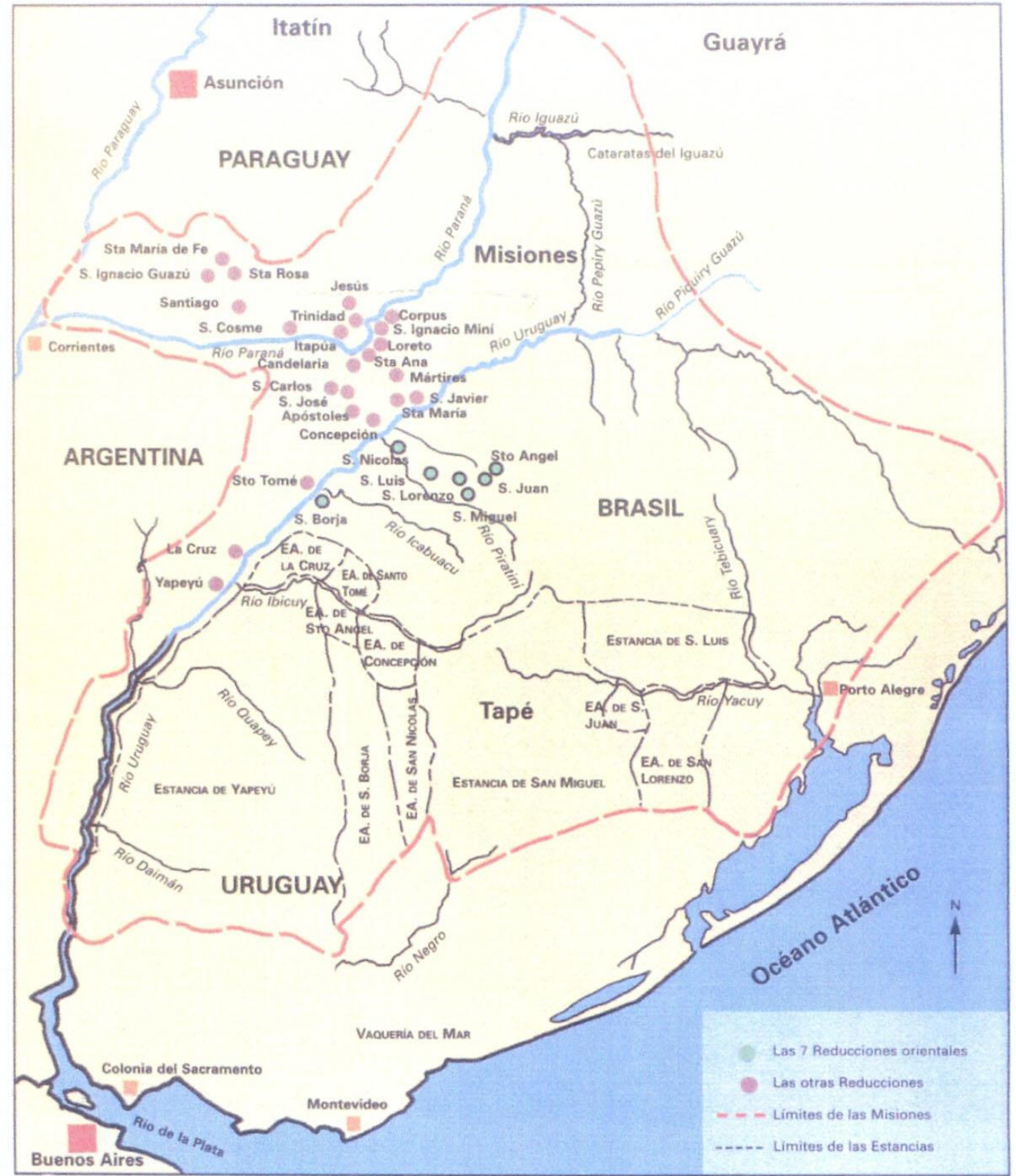

Fonte: URI/CEM - Santo Ângelo, RS. Ano 2.000

Espaço Ameríndio, Porto Alegre, v. 7, n. 2, p. 277-556, jul./dez. 2013. 


\section{CAPÍTULO III - O ENCOBRIMENTO DOS GUARANI DEPOIS DA GUERRA GUARANÍTICA}

Neste capítulo pretendemos buscar algumas pistas deixadas por viajantes, escritores e pesquisadores, pessoas que se encontraram com os Guarani nos séculos XIX e XX e registraram esses encontros, as condições em que viviam e sua distribuição geográfica. Os mapas deixados por esses viajantes-escritores são de grande importância, pois trata-se de uma complexa história interétnica durante a qual os Guarani foram sendo expropriados de suas terras e muitos de sua cultura tradicional até se tornarem invisíveis no panorama local. Alguns poucos grupos mantiveram-se mais ou menos isolados e subsistiram em grupos comunitários.

\section{Os Guarani após a Guerra Guaranítica: da Hipervisibilidade à Invisibilidade}

Após a guerra guaranítica há um grande silêncio sobre os Guarani que sobreviveram à tragédia. Os pesquisadores referem-se ao "desaparecimento" desse povo e sua "transformação" em gaúchos. Assume-se que os poucos sobreviventes acabaram diluindo-se na sociedade regional e misturaram-se com a população mais pobre. Esse processo de fato ocorreu, mas são poucos os autores que fornecem dados concretos sobre as diferentes formas de apagamento e invisibilidade dos Guarani após a guerra guaranítica. Por outro lado, alguns grupos guarani continuaram vivendo em aldeias durante algumas décadas e outros permaneceram mais ou menos isolados dos núcleos nacionais, embora tenham permanecido quase invisíveis porque a perda de seus territórios os obrigou a que sobrevivessem do trabalho em colônias.

Um importante trabalho foi realizado por J. Belém (1933) que escreveu um livro sobre a história de Santa Maria. O autor pesquisou os registros da Capela de Santa Maria-RS entre 1804 a 1811 mostrando quem foram os primeiros habitantes nacionais daquela cidade. Mas registrou dados sobre os Guarani missioneiros após a destruição dos 


\section{Sete Povos.}

Belém expõe a lenda sobre os índios Tape que viviam na região de Santa Maria. Esta lenda, segundo o autor, pode ser uma verdade histórica porque coincide com os relatos do Padre Teschauer: no início do século XVIII estavam os Tapes no sul do Estado do Rio Grande do Sul e no fim do mesmo século eram encontrados repartidos em 6 toldos cada um com 50 pessoas nas margens do rio Ibicuy (BELÉM, 1933, p. 9$10)$.

Relata ainda que entre 1801 e 1803 chegou a Santa Maria da Boca do Monte (nome original de Santa Maria) um grupo guarani com 50 famílias. Vieram descendo das Missões Orientais e fixaram-se em um descampado que onde se acha a atual rua Ipiranga. O terreno que ocuparam passou a ser chamado "A Aldeia". Esses Guarani eram catequizados, todos católicos, uns agricultores, outros operários. Tinham um chefe, mas, assegura Belém, "aceitaram os costumes dos brancos e se misturaram com a população local e formaram a população gaúcha" (idem, p. 31). Mais adiante (idem, p. 89-91) Belém escreve uma "pequena história da Aldeia". Declara que esses Guarani tinham aprendido profissões de ferreiro, carpinteiro e pedreiro que thes garantiam serviços. Outros se dedicavam à agricultura e se empregavam como peões nas estâncias. Aos poucos surgiram casamentos com brancos e negros (como foi demonstrado na pesquisa dos batistérios) e que em 1857 "estavam bem misturados".

Belém traz uma importante informação etnográfica: na aldeia havia uma "igrejinha dos índios" e a "capeloa" era uma mulher que se chamava tia Chica, filha de Joana Manderú, certamente tratava-se de Joana Nhanderú, natural de São Borges das Missões. Não é raro que na sociedade guarani haja mulheres ocupando função de chefe religiosa. Pela importância do relato extraímos algumas informações:

Tia Chica era santamariense. Herdária de sua mãe, Joana Manderú, a mania religiosa, chegando a construir, a sua custa, a igrejinha referida. [...]

A preocupação maior de tia Chica era a Igrejinha de que guardava a chave com zelo aváro.

Todos os anos, por ocasião da Semana Santa, na 'Igrejinha dos Índios' comemorava-se solenemente a Paixão de Cristo, sendo incansável a religiosa mulher

Espaço Ameríndio, Porto Alegre, v. 7, n. 2, p. 277-556, jul./dez. 2013. 
KIMIYE TOMMASINO - Relatório de Identificação e Delimitação da Terra Indígena...

em ornamentar o templo, colocando na parede, acima do altar, uma tela branca, de linho tecido em Missões, sobre o qual estava (e ainda está) pintada, grosseiramente, a imagem de Cristo.

Esta relíquia sua mãe trouxera das Missões, e, morrendo, Iha confiára (BELÉM, 1933, p. 90-91).

Em 1832 o último cacique chamado Inácio Arauhy faleceu aos 70 anos. Era viúvo. O autor diz que ao apresentar no capítulo seguinte o registro de batismo dos índios fica patente a miscigenação e o caldeamento do índio com o português (idem, p. 33-42).

Os registros de batismos e casamentos da capela de Santa Maria efetuados entre 1804 e 1811 mostram as relações de amizade e aliança entre índios Guarani, brancos e negros no Rio Grande do Sul. Por exemplo, nas anotações do ano de 1815 lê-se o seguinte: "Neste período foram batizadas muitas crianças, filhas de negros escravos as quais não são aqui mencionadas, bem como as nascidas do cruzamento de índio com negro" (idem, p. 59). No mesmo ano foi registrado o casamento entre "Bento, escravo do capitão João Machado de Bittencourt, com Gregória, índia guarany" (idem, p. 60). Ao final da listagem dos casamentos lê-se: "Nesse ano foram registrados no livro da Capela, cinco casamentos de índios, três de escravos, um de negro com índia e um de branco com índia" (idem, p. 61). Em 1816 "foram registrados cinco casamentos entre índios, três entre negros escravos, um de negro com índia e dois de branco com índia" e em 1818, "três consórcios entre índios, um entre negros e um de negro com índia" (idem, p. 62). São raros os registros onde há essa discriminação depois que a escravidão foi extinta, mas em todas as regiões do país onde existiram escravos é possível deduzir que houve alianças entre africanos e índios através do fenótipo da população nacional e das populações indígenas.

Outro trabalho importante sobre o que aconteceu com os Guarani depois da guerra guaranítica é o diário de Saint-Hilaire (1987) que viajou pela província do Rio Grande do Sul (chamada então província de São Pedro) entre 1820 e 1821. Traz esse relato informações vivas e detalhadas sobre as diferentes situações a que estavam submetidos os Guarani e outros grupos menores como os Charruas, Minuanos e Guaikuru. Selecionamos as informações que revelam a presença guarani,

Espaço Ameríndio, Porto Alegre, v. 7, n. 2, p. 277-556, jul./dez. 2013. 
as formas como viviam naquele momento e o contexto social. SaintHilaire partiu de Porto Alegre em junho de 1820 e durante um ano percorreu regiões do Rio Grande do Sul, Uruguai, Argentina e Paraguai. O diário foi redigido durante a exploração da Província do Rio Grande do Sul, prosseguida até Montevidéu, às margens do Uruguai e através das antigas missões jesuíticas de onde retornou para Rio Grande em junho de 1821 e embarcou para o Rio de Janeiro.

Saint-Hilaire chega a Torres no dia 5 de junho de 1820. Menciona índios prisioneiros empregados na construção de um forte em Torres. Trinta homens trabalhavam na construção; à exceção de um, os demais eram índios. Segundo ele, alguns teriam vindo das missões, outros de Entre-Rios e do Paraguai. Menciona o comentário do alferes a respeito da docilidade destes homens e ainda o fato de que alguns haviam fugido com o propósito de voltar para os pagos, atravessando a grande cordilheira, mas que, encontrando na passagem vários obstáculos, voltaram e foram capturados. Diz que estes índios conheciam o espanhol e a língua geral, ainda que, ao falar esta última, utilizassem vocábulos diferentes dos encontrados no dicionário dos jesuítas (SAINTHILAIRE, 1987, p. 12).

Em Tramandaí menciona uma leva de índios prisioneiros (entre os quais havia também mulheres) que eram conduzidos a Torres. O Conde da Figueira, governador da Capitania do Rio Grande, é que era o responsável por enviar esses índios. Segundo afirma Saint-Hilaire, ele queria fundar uma aldeia em Torres, visto que, após a saída dos jesuítas, "os índios tiveram como preceptores soldados e homens corrompidos", passando a viver de pilhagens (idem, p. 17).

Em Porto Alegre, faz menção a uma recente invasão da província

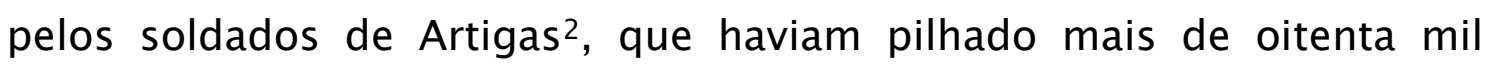
reses. As tropas de Artigas constituíam-se quase inteiramente de índios. Com exceção aos que foram para Torres, os outros índios aprisionados em Taquarembó ficaram em Porto Alegre, sendo empregados em obras públicas. Mas, segundo Saint-Hilaire, entre esses prisioneiros podíamos encontrar "uma dúzia de espanhóis provenientes de Montevidéu e

\footnotetext{
${ }^{2}$ José Gervásio Artigas (1764-1850): militar e político uruguaio, chefiou o movimento de independência da Banda Oriental e tomou Montevidéu. Resistiu à invasão do país por tropas luso-brasileiras de $1816 \mathrm{a}$ 1820 , quando, vencido, retirou-se para o Paraguai.
}

Espaço Ameríndio, Porto Alegre, v. 7, n. 2, p. 277-556, jul./dez. 2013. 
alguns negros foragidos das estâncias desta Capitania; os outros pertencem à tribo dos guaranis". Vários prisioneiros interrogados pelo autor afirmaram ser paraguaios e trabalharem como peões na província de Entre-Rios, tendo sido obrigados por Artigas a pegar em armas. Faz menção a um pequeno Guarani que servira nas tropas de Artigas, mas que fora transformado em criado pelo general Figueira. Menciona a habilidade de Artigas em se fazer querido pelos camponeses e índios, visto que possuía os mesmos costumes que estes últimos (idem, p. 2932).

Saint-Hilaire cita dados fornecidos por José Feliciano Fernandes Pinheiro, que era inspetor da alfândega e que teria publicado uma "História da Capitania", segundo os quais a população desta seria de 32.000 brancos, 5.399 homens de cor livres, 20.611 homens de cor escravizados, e 8.655 índios. Esses dados indicavam ainda que a população das Missões contava com 6.395 índios e 824 brancos (ainda que de acordo com o relatório dos administradores a população das missões não ultrapasse o número de 3.000 guaranis-portugueses) (idem, p. 51).

Segundo o relato do Conde de Figueira a Saint-Hilaire, as aldeias das Missões eram administradas da seguinte forma: os homens e as mulheres trabalhavam para a comunidade; armazenavam-se os produtos; distribuía-se a cada família o necessário para o consumo; vendiam o restante empregando o dinheiro apurado na aquisição de ferramentas e roupas que se partilhavam do mesmo modo. A administração da comunidade era confiada a um "cabildo", composto de índios e dirigido por um português. Entretanto, era difícil encontrar alguém disposto a exercer tal função, pois os rendimentos eram insignificantes (idem, p. 51).

Em Bujuru relata Saint-Hilaire que José Marcelino, Governador desta Capitania, tinha mandado virem índios do aldeamento dos povos das Missões, para localizá-los perto de Porto Alegre, na Aldeia dos Anjos, onde tencionava criar um colégio para jovens de ambos os sexos. A fim de mantê-lo, teria criado a Estância dos Povos (idem, p. 54).

Em Rio Grande, segundo informações do cura, em 1819 a paróquia contava com 5.125 indivíduos: 2.583 brancos, 43 índios, 159 mulatos livres, 70 negros livres, 2.270 negros e mulatos escravos (idem, 
p. 77).

Em 14 de outubro chega Saint-Hilaire à Vila de Rocha [território uruguaio]. Ele afirma que os vastos campos percorridos até ali eram habitados por índios civilizados e por mestiços. Ocasionalmente ajudavam os estancieiros em seus trabalhos, pelo que eram pagos. Mas não economizavam coisa alguma, segundo ele, satisfazendo-se em possuir um ponche e um chiripá e gastando o resto em jogos e bebidas (idem, p. 126).

Sobre o povo de las Víboras o autor diz que a maioria dos habitantes da aldeia eram índios ou mestiços oriundos do Paraguai, das Missões e de Entre-Rios, que provavelmente se fixaram nesta região por haver lá muito gado (idem, p. 181-182).

Chegando a San Domingos Soriano ressalta que em Vila de Rocha as pessoas do campo eram em sua maioria índios e mestiços. Segundo ele, essas pessoas levariam uma vida "alheia a qualquer sentimento moral ou religioso", pois os padres espanhóis não se ocupavam da instrução dos fiéis, assim como não se dedicavam a catequizar as crianças (idem, p. 186). Saint-Hilaire expressava o pensamento dominante da época, desqualificando suas culturas e interpretando etnocentricamente 0 comportamento dos indígenas. Extraído o etnocentrismo, as anotações sobre a situação concreta em que viviam os Guarani e outros povos, são preciosas.

Segundo Saint-Hilaire, apoiado em Azara (no orginal, Arzaio), a aldeia de San Domingos teria sido fundada por uma tribo de Charruas. Os Charruas ter-se-iam misturado aos espanhóis e a outros índios; por isso ele afirma que não existiam mais raças puras e que apenas alguns velhos ainda sabiam a língua de seus pais. Essa aldeia teria sofrido bastante, pois no início da guerra as tropas espanholas teriam aberto fogo contra ela (idem, p. 187).

Saint-Hilaire chega ao acampamento de Rincón de las Gallinas em 29 de dezembro de 1820. Segundo o autor, as tropas de Artigas já não existiam, e todos afirmavam que os habitantes do Paraguai o mantinham como prisioneiro. Assim, Ramírez (antigo capitão de Artigas que acabou opondo-se a ele) passara a comandar Entre-Rios. Este era muito temido e detestado pelos súditos, e muitos procuraram asilo entre os portugueses. Entre os que fizeram isso estavam os Charruas. 
KIMIYE TOMMASINO - Relatório de Identificação e Delimitação da Terra Indígena...

Segundo o autor, esses índios construíam suas palhoças com estacas envolvidas por esteiras, sobre as quais colocavam outras que serviam de telhado. Os homens cavalgavam e boleavam cavalos ou avestruzes, não tendo outra atividade. As mulheres ocupavam-se da cozinha, arrumavam as choupanas, trançavam esteiras, cuidavam das crianças e faziam os caipis, uma espécie de manto que era a vestimenta dos homens. Afirma ainda que os charruas eram um grupo nômade, que se recusava reunir-se em aldeias. A respeito deste parágrafo, Saint-Hilaire acrescenta a seguinte nota:

Creio ter cometido um engano neste artigo. Os charruas não vieram de Entre-Rios. Sempre viveram deste lado do Uruguai. Abraçaram o partido de Artigas e renderam-se aos portugueses, quando estes dominavam a região (idem, p. 197-198).

Em Arroio Daiman faz referência a um campo de milho plantado por índios e tece comentários a respeito dos "inconvenientes" da miscigenação entre índios e brancos (idem, p. 210).

Chega em Campo do Salto em 11 de janeiro de 1821. Comenta sobre o grande número de índios que habitavam o local, os quais, segundo ele, vinham de Entre-Rios para ali se refugiar. Afirma que os homens viviam na ociosidade, enquanto as mulheres se prostituíam com os soldados, transmitindo-Ihes doenças venéreas (idem, p. 211). Afirma ter sido chamado pelo coronel Inácio José Vicente da Fonseca (em casa de quem estava hospedado) para ver algumas índias guaicurus (no original, Baikurus) que recentemente teriam atravessado o Uruguai para escapar da fome. A nação dessas índias tinha tomado o partido de Artigas, apoiando-o por muito tempo. A respeito dos Guaicurus comenta que são cristãos (batizados) e não menos civilizados do que os Guaranis. Saint-Hilaire faz também alguns comentários sobre a língua que eles falavam, comentando serem os sons mais claros e menos guturais (idem, p. 213).

Percorrendo os arredores da campanha em Salto Grande, às margens do rio Uruguai, Saint-Hilaire afirma ter encontrado aldeias habitadas por índios Guarani vindos de Entre-Rios para ali se refugiar. Segundo ele, moravam em choupanas que mediam aproximadamente a 
altura de um homem, e que eram construídas à semelhança de barracas de acampamento, com folhas e haste de uma gramínea muito dura e lisa. Ao lado dessas choupanas, continua ele, havia geralmente um galpão onde se penduravam nacos de carne; mas ao redor delas podiam ser vistos também pés de milho, abóboras e melancias. Segundo ele, os homens nada faziam, mas as mulheres se ocupavam das costuras. Afirma ainda que as aldeias donde esses índios eram originários haviam sido fundadas por jesuítas e que, portanto, eles eram batizados. Falavam o guarani, mas muitos eram mestiços e, assim, todos sabiam falar o espanhol. Dessas aldeias mencionadas por Saint-Hilaire, a mais importante e bem-cuidada recebia o nome de seu chefe: Manduré. Este homem que, de acordo com o autor, era menos pobre do que os índios costumam ser, havia sido nomeado pelos chefes dos revoltosos, comandante de uma pequena aldeia de índios, situada perto do acampamento deles e posteriormente destruída. Assim, ele acabou por se indispor com Artigas e Ramírez e foi com seus subordinados procurar segurança junto aos portugueses. O General Lecor, aprovando tal ato, concedeu-lhe o título de tenente-coronel e um soldo bem alto. SaintHilaire afirma ter feito uma parada na casa de Manduré e comenta que ele, já idoso, recebeu-o com grande indiferença. Saindo do vilarejo de Manduré, teria encontrado um outro, diante da Ilha de Santo Antônio, onde havia uma cabana de palha e alguns galpões. Num desses galpões, ele afirma ter observado a fabricação de ponches, e associa-a à indústria que os jesuítas procuraram confiar às índias. Comenta ainda que o mobiliário dessas choupanas constituía-se de um lampião de barro, um jirau e uma rede de lã. Sob os galpões, pendiam pedaços de carne, e os índios encontravam-se deitados no chão, sobre esteiras de couro (idem, p. 216-217).

O alferes que acompanhava Saint-Hilaire nesta caminhada fala-Ihe sobre os índios chamados Charruas, por uns, e Minuanos por outros. Segundo ele, essas tribos ter-se-iam unido há muito tempo e, por isso, naquela época usavam-se os dois nomes indistintamente. Estavam divididos em pequenos grupos e submetiam-se a chefes que, segundo Saint-Hilaire, tinham poder muito limitado, pois, além dos outros não terem obrigação de obedecerem a ele, podiam deixá-lo e unir-se a outro grupo ou chefe. $\mathrm{O}$ autor comenta o fato de esses índios viverem 
KIMIYE TOMMASINO - Relatório de Identificação e Delimitação da Terra Indígena...

embriagados e de mesmo as crianças consumirem álcool. Ainda de acordo com Azara, vestiam ponches, mas o que Saint-Hilaire observa são apenas os chiripás, denominados caipi. Por armas, usavam lanças compridas e um arco pequeno, levando às costas uma aljava chata e quase quadrada, onde colocavam as flechas. Montavam os cavalos em pelo, utilizando-se apenas de uma corda ou tira de couro para conduzilos. Várias tentativas de reuni-los em aldeias foram feitas, mas elas se mostraram inúteis. "Se Deus quisesse que fôssemos espanhóis ou portugueses", diziam eles, "não nos teriam feito minuanos. Passamos a vida de modo mais agradável que vocês, pois vocês trabalham e nós não fazemos outra coisa senão comer, beber e dormir" (idem, p. 218).

Em Campo de Belém, ao redor do acampamento onde se encontrava, o autor menciona a existência de muitas choupanas de índios. Novamente afirma serem estes remanescentes das aldeias fundadas pelos jesuítas em Entre-Rios que naquela época não mais existiam, pois havia quatro anos, o Marechal Chagas, que chefiava as sete aldeias, agora portuguesas, teriam incendiado todas as que estavam entre o Uruguai e o Paraguai. Os que conseguiram fugir construíram um pouco ao sul de Entre-Rios uma aldeia chamada Cambaí. Por serem os índios apegados a Artigas, Ramírez tornou-se seu inimigo, e como tentou exterminá-los, fugiram de Cambaí, lapeju [Japeju; Yapeju] e outras aldeias existentes em Entre-Rios e buscaram proteção junto aos portugueses. Segundo Saint-Hilaire, desde o último mês de agosto [de 1820], mais de 3 mil índios teriam passado o rio Uruguai pelo vau do Quaraim; muitos outros teriam conseguido atravessá-lo em Salto, Belém e Missões. Estes índios teriam dito que apenas os velhos e doentes, incapacitados de se deslocar, teriam permanecido nas aldeias. A maior parte destes refugiados era composta por mulheres e crianças (pois muitos homens haviam sido mortos na guerra) e foram encaminhados para a Capela de Alegrete. Entre os que ficaram em Belém, os homens alugavam-se como peões na vizinhança, os meninos prestavam pequenos serviços aos oficiais ou aos soldados do acampamento, e as mulheres prostituíam-se ${ }^{3}$. No acampamento

\footnotetext{
${ }^{3}$ Esclarecemos que o termo prostituição utilizado por Sain-Hilaire é um conceito da cultura ocidental cristã e mercantilista. Da perspectiva indígena não há essa conotação moralista. Trata-se, portanto, de um julgamento etnocêntrico do viajante francês.
}

Espaço Ameríndio, Porto Alegre, v. 7, n. 2, p. 277-556, jul./dez. 2013. 
onde se encontrava, o autor fala que a maior parte dos milicianos tinha uma índia como companheira e que um grande problema era que os filhos nascidos dessas uniões transitórias seriam necessariamente abandonados pelos pais e "mal educados". Um outro comentário feito por Saint-Hilaire é que os jesuítas, conhecendo os índios e pressentindo que não poderiam atraí-los para a religião apenas através de seus mistérios e moral, procuraram atraí-los através dos sentidos. Construíram grandes templos onde as cerimônias eram celebradas com grande pompa, além de introduzi-los na música ocidental. Os que demonstravam interesse por essa arte recebiam lições e alguns se tornaram excelentes músicos. E esse conhecimento musical não se teria extinguido totalmente entre os Guarani, pois estando no já mencionado acampamento, o autor teria presenciado uma serenata e julgou que os músicos não eram tão ruins. Por fim, o autor comenta também a excessiva indulgência com que os portugueses tratavam os índios de Entre-Rios refugiados junto deles, já que esse era um meio de se fazerem benquistos na província (idem, p. 222-224).

Em Arroio Santana, Saint-Hilaire refere-se a um Guaicuru que conheceu em Belém. Tal homem, continua o autor, seria de uma aldeia chamada São Xavier, que não ficava muito longe de Santa Fé e de Rio Salgado. Saint-Hilaire afirma que, procurando no livro de Azara o capítulo sobre os Guaicuru, ficou admirado ao ler que, ao tempo do autor, não haveria mais homens dessa tribo, visto que o próprio SaintHilaire conhecera duas famílias, uma em Salto e outra em Belém, e os portugueses haviam garantido a ele que tal tribo estava longe de ser extinta. Menciona ainda ter conhecido em Belém um hamburguês que morara durante muito tempo em Entre-Rios o qual afirmara ter visto, na jurisdição de Santa-Fé, uma aldeia chamada Aé-Garras, inteiramente povoada de Guaicuru. Em seguida, Saint-Hilaire apresenta uma lista de palavras da língua dos Guaicuru e seu respectivo significado (idem, p. 234).

Na estância de São Marcos, Saint-Hilaire menciona, mais uma vez, o fato de que a maioria dos milicianos acantonados nessa parte da fronteira do sul era amasiada com índias (idem, p. 248).

Rincão de Sanclón, estância onde o autor se hospedou em 6 de fevereiro, havia sido destruída durante a guerra e, como tantas outras, 
KIMIYE TOMMASINO - Relatório de Identificação e Delimitação da Terra Indígena...

foi reconstruída. Na época da visita do autor, compunha-se de miseráveis choupanas que em sua maioria eram habitadas por famílias indígenas recém-chegadas da aldeia de Yapeju. Como os estancieiros desta região não tinham escravos negros, os índios eram aproveitados como mão-de-obra, trabalhando como "peões" na estância. Os Guarani, segundo o autor, eram muito indicados para esse serviço, pois sabiam montar e até mesmo domar cavalos. Além disso, ele menciona também a extrema "docilidade destes índios". Saint-Hilaire perguntou a alguns Guarani se tinham ouvido falar dos jesuítas por intermédio de seus pais, ao que eles responderam negativamente. Entretanto, o autor observou que eles ainda mantinham os hábitos que, presumivelmente, aprenderam com os padres jesuítas, porquanto muitos pais continuavam a ensinar os filhos a rezar e a recitar preces diariamente. A aldeia de Yapeju, segundo ele, ficava situada perto da estância em questão, à margem direita do Uruguai, e era uma das mais importantes das Missões jesuíticas de Entre-Rios (idem, p. 249-250).

Saint-Hilaire menciona o fato de que, geralmente, os índios não se movem sem a companhia de suas mulheres. Segundo ele, as de quase todas as tribos acompanham seus maridos à guerra. Os lanceiros guarani que ele conhecera em Belém, por exemplo, todos eles traziam suas esposas; e quando os soldados índios das Missões iam fazer guarda em algum lugar, era sempre em companhia de suas mulheres (idem, p. 254).

$\mathrm{Na}$ estância do Alferes Antônio Francisco Souto, diz que o alferes estaria estabelecido nesta região há onze anos, e durante todo este tempo a província teria estado em decadência, visto que já havia sido invadida duas vezes pelo inimigo. Como havia necessidade de gente, os Guarani foram arregimentados e pararam de trabalhar na agricultura. Segundo Saint-Hilaire, ao se tornarem soldados, os índios acabaram por perder o que ainda thes restava dos seus velhos costumes. Os jovens não aprenderam a cultivar a terra e viviam em completa ociosidade. Muitos fugiram ao serviço militar, dispersando-se em diferentes partes da capitania. Os casamentos começaram a rarear e as índias passaram a se prostituir. As doenças venéreas diminuíram sensivelmente a população (idem, p. 59-260).

Saint-Hilaire retoma o assunto sobre os numerosos índios que 
KIMIYE TOMMASINO - Relatório de Identificação e Delimitação da Terra Indígena...

atravessaram o Uruguai em Salto e Quaraim para se porem sob a proteção dos portugueses. O autor transcreve a narrativa que seu hospedeiro fez a respeito desse acontecimento. Segundo ele, esses índios teriam sido guiados por um mestiço chamado Francisco Xavier Siti, ao qual davam o título de coronel. Esse homem teria nascido numa aldeia das Missões, situada entre o Uruguai e o Paraná. Servira nas tropas do Rio Grande, desertando em seguida e fugindo para o Uruguai. Inicialmente, filiou-se ao partido de Artigas, mas ao cabo de algum tempo, abandona-o com a intenção de restabelecer as aldeias das Missões, que tinham sido destruídas. Submeteu-se a Ramírez com a condição de poder restabelecer as aldeias índias de Entre-Rios, destruídas pelos portugueses, e de não ser obrigado a pegar em armas durante dez anos. Entretanto, resolvendo guerrear os paraguaios, Ramírez quis obrigar Siti a tomar parte no combate. Este teria apelado para sua lealdade, mas foi atacado e banido por Ramírez. Siti pediu auxílio ao Marechal Chagas, que Ihe permitiu refugiar-se em terras portuguesas. O coronel apressou-se então em chegar ao Uruguai, mas foi aí perseguido pelo seu inimigo, e as tropas de Corrientes atiravam ainda sobre os índios quando estes atravessaram o rio; mas o marechal, que lhes enviara barcos para facilitar a passagem, mandou dizer aos de Corrientes que, se não cessassem fogo, seriam atacados por seus soldados. Só então as tropas de Ramírez se retiraram e os índios atravessaram o Uruguai livremente. O marechal apossou-se das armas em nome do rei, mas consentiu que Siti se estabelecesse em uma das aldeias das Missões, dispersando seus homens pela província; estes empregaram-se como peões nas estâncias, e cem deles teriam sido admitidos no regimento de "guaranis-portugueses". Com relação a esta última medida, os brancos revoltaram-se. O comentário de Saint-Hilaire é que, recebendo estes homens em suas terras, o governo português tinha o direito de tomar medidas acauteladoras. E como o Conde de Figueira tivera a idéia de fundar uma aldeia em Torres, o autor não via motivos para que estes índios não fossem mandados para lá. Por fim, Saint-Hilaire afirma que não foi somente depois que os portugueses se tornaram senhores daquela província que os brancos passaram a ocupar terras indígenas, pois antigamente estas estâncias já seriam há muito habitadas por espanhóis (idem, p. 264-265).

Espaço Ameríndio, Porto Alegre, v. 7, n. 2, p. 277-556, jul./dez. 2013. 
KIMIYE TOMMASINO - Relatório de Identificação e Delimitação da Terra Indígena...

Saint-Hilaire esteve na estância do Butuí em 18 e de fevereiro e em São Borja, território português já em 19 de fevereiro. Ele faz menção a algumas cabanas de índios. São Borja era uma aldeia localizada a uma légua do rio Uruguai e abrigava um antigo convento jesuíta. Segundo Saint-Hilaire, o que o impressionou ao entrar na aldeia foi o estado de decadência e abandono a que estava reduzida e, também, o aspecto militar que ela apresentava, uma vez que se viam muitos soldados e fuzis. Fica surpreso com a grandiosidade da igreja, apesar de estar meio destruída. Ele afirma que não conseguia deixar de se surpreender quando imaginava que todas as aldeias das Missões e moradias nelas construídas fossem obras "de um povo selvagem, orientado pelos religiosos. Era preciso que os padres conhecessem todos os ofícios e tivessem paciência de ensiná-los aos índios". Saint-Hilaire refere-se ainda a uma apresentação da banda do regimento dos Guarani, que teria executado a marcha da corporação "com gosto e precisão extremas". Durante a missa, as crianças guarani teriam entoado alguns cânticos em português, "com vozes muito agradáveis e refinadas". Mais uma vez, o autor menciona o fato de que os jesuítas se serviam da música para catequizar e cativar os Guarani. Ainda reafirma que, mesmo após a expulsão dos jesuítas, o gosto pelos instrumentos persistiu entre os Guarani, que continuaram se dedicando à música (idem, p. 271-272). Como se pode perceber, Saint-Hilaire explicita seu etnocentrismo, aprova e admira o trabalho de catequese e civilização dos índios pelos missionários.

O coronel Paulette, comandante do destacamento que ali se encontrava, relata a Saint-Hilaire que depois que os portugueses se apossaram da Província das Missões ela passou a empobrecer mais a cada ano. Durante os oito primeiros anos, os espanhóis teriam seguido o plano traçado pelos padres da Companhia de Jesus, e o número de índios das Missões teria aumentado. Mas como só enviassem protegidos dos vice-reis de Buenos Aires para governar as Missões, e estes só se interessassem em assegurar sua fortuna, a província teria entrado em decadência. O sistema dos jesuítas foi desfeito e os índios foram explorados de todas as maneiras. Acabaram dispersando-se e os que ficaram misturaram-se com brancos, que se apropriaram de suas terras. Quando os portugueses se apoderaram das sete aldeias da margem 
KIMIYE TOMMASINO - Relatório de Identificação e Delimitação da Terra Indígena...

esquerda do Uruguai, encontram lá um número aproximado de 14 mil habitantes. Mas, segundo a narrativa do coronel Paulette, eles já não eram os mesmos, pois que tinham perdido quase inteiramente os hábitos de origem jesuítica (idem, p. 272-273). Conforme Saint-Hilaire já tinha relatado anteriormente, todos os habitantes das aldeias de Entre-Rios (por volta de sete mil pessoas) passaram para o lado do Uruguai e, dessa forma, a população inteira da região, conhecida sob o nome de Missões do Paraguai, teria ficado reduzida ao décimo do que era no tempo dos jesuítas. Saint-Hilaire, assim como em outras passagens do livro, faz comentários bastante preconceituosos ao "caráter infantil e ingênuo dos guaranis". Segundo ele, os índios eram completamente estranhos à idéia de futuro. O coronel Paulette considerava que o sistema dos jesuítas formava um conjunto onde não se poderiam conservar algumas partes e suprimir outras. Assim, como as bases que o conservavam já não existiam, ele teria ruído para sempre. Tais bases seriam as poucas idéias que os índios tinham do que se passava no resto do mundo: sua separação de todos os brancos que não pertencessem à Companhia de Jesus e, também, o fato de que veneravam e respeitavam os padres (idem, p. 273-274).

Saint-Hilaire faz uma rápida descrição da aldeia de São Francisco de Borja (idem, p. 274-276). Segundo ele, a igreja formava, com o antigo convento dos jesuítas, um dos lados de uma praça quadrada. As casas que contornavam essa praça eram anteriormente ocupadas pelos índios, mas à época da visita do autor, eram ocupadas por brancos que pagavam aluguel, ao passo que os índios que ainda se encontravam lá moravam em miseráveis cabanas esparsas nas proximidades da aldeia.

Estando na estância de Santos Reis, Saint-Hilaire explica que o regimento dos Guarani havia sido formado há 12 anos, e à época contava com quinhentos e tantos homens considerados apenas soldados. Afirma que, embora inicialmente tenha sido difícil reunir e submeter estes homens à disciplina, eles logo foram seduzidos pela música militar e pelos longos períodos de repouso que lhes deixavam seus deveres. Menciona ainda que eles se distinguiram em diversas circunstâncias e que Portugal thes devia parte do sucesso obtido em Taquarembó (idem, p. 278). O soldo dos soldados Guarani era o mesmo dos outros milicianos em serviço (três vinténs e meio por dia), mas 
estava sempre em atraso. Eram fornecidos os uniformes e, por única ração, quatro libras de carne por dia. Quase todos eram casados, tendo suas mulheres em São Borja. Elas habitavam miseráveis cabanas ao redor da aldeia, como já foi mencionado. Segundo o autor, essas mulheres e seus filhos viviam da ração dos maridos, ou seja, na pior indigência. Outrora, os habitantes das aldeias cultivavam o algodão; as mulheres o batiam, fiavam e teciam, mas tendo as Missões sido invadidas pelos espanhóis três vezes, tudo havia sido destruído. Os homens que poderiam cultivar a terra tornaram-se soldados, e, dessa forma, as mulheres ficavam privadas do trabalho, porquanto faltavamIhes os meios. Como àquela época a região estava em paz, ele afirma que provavelmente muitos soldados receberiam baixa e poderiam retornar ao cultivo da terra. Entretanto, como a guerra já durava vários anos, os jovens eram estranhos ao trabalho do campo, não tendo aprendido outro ofício que não o de soldado. Saint-Hilaire afirma que não apenas os índios, mas também os pequenos agricultores viviam em grande miséria, já que seus animais eram requisitados para a alimentação das tropas. Como os estancieiros mais ricos eram excluídos deste encargo, o produto anual de todas as vacas da província, afirma o autor, não era suficiente para as rações distribuídas, e os fornecimentos de carne nunca eram pagos. O alto custo das outras mercadorias contribuía ainda mais para arruinar os agricultores (idem, p. 279). Afirma que embora vivessem no meio dos homens civilizados há anos, ainda guardavam muitos hábitos selvagens, pois sentiam-se muito a vontade andando sem camisa e, ainda, preferiam as choupanas baixas e estreitas que constroem no meio do mato às habitações dos brancos (idem, p. 281-282).

Saint-Hilaire chega ao Camaquã, afluente do rio Uruguai na estância do Silva. Um destacamento de índios Guarani, acantonado à margem do rio, era encarregado de transportar, de uma margem à outra, as pessoas que precisassem. Esses homens tinham construído algumas palhoças à beira da água, onde viviam com suas mulheres. Enquanto as bagagens e pertences do autor eram transportados à outra margem, ele menciona que as índias, inteiramente nuas, ocupavam-se em lavar roupas e não se incomodaram com a presença de estranhos (idem, p. 285-286). 
$\mathrm{Na}$ estância do Souza, Saint-Hilaire volta a afirmar que restava em São Borja apenas um número reduzido de índios descendentes daqueles que, antes, tinham composto a população dessa aldeia. Mesmo assim, ele diz que toda a juventude das Missões se concentrava na aldeia, formando um regimento de aproximadamente 500 homens, na maioria casados ou amasiados. Em 1820, ter-se-iam realizado em São Borja duzentos batizados, dos quais cento e quarenta e um de índios; e do começo de janeiro até fins de fevereiro de 1821 já tinham sido feitos trinta e sete batizados, sendo trinta e seis de índios (idem, p. 288-289).

Segundo ele, antes havia em todas as aldeias das Missões um "cabildo" composto de diversos oficiais que, sob a direção dos jesuítas se encarregavam de policiar a região. Tanto os espanhóis quanto os portugueses mantiveram essa forma de administração. Entretanto, à época em que o autor escreve, São Borja era considerada apenas uma praça de guerra, e como não existia mais comunidade nessa aldeia, não havia mais o "cabildo", apenas um administrador mestiço de branco e Guarani, que nas palavras do autor, não passava de um comissário do comandante, limitando-se a transmitir ordens aos operários. Quanto a estes últimos, representavam um número muito pequeno na época. Eram idosos e o último comandante não se preocupou em providenciar aprendizes. Entre eles contavam-se um torneiro, um serralheiro e alguns carpinteiros, e como pagamento recebiam apenas uma ração semelhante a que se dava aos soldados. Além do administrador, ainda se conservava em São Borja dois cargos que remontavam ao tempo dos jesuítas: o cunhanrequaro (guardião de mulheres) e o avanuquaro (guardião de homens), encarregados de vigiar o trabalho das mulheres e dos homens, respectivamente (idem, p. 293).

Na estância de São José, o autor menciona que, como em todas as outras estâncias construídas pelos jesuítas, havia a presença de uma capela já destruída e algumas outras construções (idem, p. 289). A respeito da estância de Itaroquém, diz que ela pertencia aos índios de São Nicolau. Segundo o autor, no tempo dos jesuítas, todas as aldeias das Missões possuíam estâncias onde se criava gado, e geralmente, elas estavam muito distantes da aldeia da qual dependiam, como por exemplo Pai Sandu de Yapeju. Várias aldeias da margem direita do Uruguai tinham, como as da margem esquerda, estâncias que, há muito 
tempo, se tornaram propriedades de agricultores portugueses. Na época em que o autor escreveu, a única estância que conservava alguma importância era a de São Vicente, onde se contavam 14.000 bovinos, pertencentes a São Miguel. Os animais de Itaroquém teriam desaparecido quando os gaúchos entraram em São Nicolau. O Marechal Chagas teria remetido para lá alguns animais, que somavam um número aproximado de um milhar. Menciona ainda que as construções dessa estância (sobretudo a capela) eram consideráveis. Existiam ali índios e brancos que faziam parte daqueles que à época atravessaram o Uruguai. À noite, era costume porem-se a dançar e cantar (idem, p. 290).

$\mathrm{Na}$ chácara de Chico Penteado, Saint-Hilaire menciona o fato de que o Marechal Chagas teria expulsado vários portugueses das terras que se encontravam na área comandada por ele, restando apenas um ou dois brancos estabelecidos nas terras da aldeia de São Nicolau, do outro lado do rio Piratini. Segundo o autor, ainda que isso possa parecer uma tentativa de garantir aos índios as terras que lhes pertenciam, na sua opinião pessoal o que o Marechal Chagas realmente pretendia era não ter ninguém para testemunhar sua péssima administração (idem, p. 292).

O autor fala de São Nicolau e do estado deplorável de decadência em que ela estava quando os gaúchos lá entraram em abril de 1819, acabando por destruí-la. Os habitantes de lá fugiram, dispersaram-se, e alguns jamais regressaram. Além disso, ele também afirma terem sido recrutados todos os jovens para o alistamento militar. Portanto, à época não havia mais do que algumas casas, cujos moradores eram velhos, mulheres e crianças. Saint-Hilaire descreve as construções do local e afirma que o Marechal Chagas mandara construir novos cômodos e prédios, que não tinham sido terminados mesmo após anos de trabalho dos índios. Enquanto eles se ocupavam disso, suas estâncias eram destruídas, e faltavam-lhes até mesmo os meios de subsistência. Assim, os índios de São Nicolau viviam numa situação de extrema miséria. A comunidade ainda existia entre eles, mas não havia nada para ser repartido. Àquela época, o autor afirma que havia cerca de vinte e cinco índios, todos velhos, empregados nos trabalhos da comunidade. Possuíam plantações situadas a cerca de uma légua da aldeia as quais consistiam em alguns alqueires de milho e um alqueire e meio de 
KIMIYE TOMMASINO - Relatório de Identificação e Delimitação da Terra Indígena...

algodoeiros. Essas plantações não poderiam ser maiores, visto que a comunidade não possuía bois, nem jovens disponíveis para o trabalho (idem, p. 300).

O autor menciona ainda que havia em São Nicolau um mestreescola de origem guarani, e que este ensinava algumas crianças a ler, escrever e contar. Como retribuição, o professor recebia da comunidade gêneros alimentícios. Fala também do asseio que observou entre as mulheres guarani, que apesar de andarem com vestes esfarrapadas, conservam-nas sempre limpas. A vestimenta dessas índias consistia unicamente de uma camisa e um vestido de algodão; andavam sempre descalças e os cabelos, muito compridos, traziam enrolados atrás da cabeça. Quando iam à igreja, acrescentavam a essas vestes um véu branco. Saint-Hilaire afirma também ter visto em São Nicolau um hospital construído pelos jesuítas. Entretanto, à época em que o autor escreve, ele tornara-se inútil, pois não havia mais leitos nem remédios na aldeia (idem, p. 301).

Segundo o autor, esta aldeia de São Luís havia sido construída sob o mesmo plano da de São Borja e São Nicolau. Ele faz uma breve descrição do local. Estimava-se em quatrocentas pessoas a população de São Nicolau e das terras que dependiam dessa aldeia, mas em São Luís não havia mais que trezentas pessoas, entre idosos, mulheres e crianças, pois os jovens, a exemplo do que acontecera em outros lugares, foram recrutados e encontravam-se em São Borja. Em São Luís havia vários artífices trabalhando para a comunidade, sobretudo tecelões, mas também lá o Marechal Chagas não providenciara para que eles ensinassem seu ofício às crianças. Segundo Saint-Hilaire, os índios de São Luís eram mais saudáveis e satisfeitos que os de São Nicolau, pois, nas palavras do autor, tinham um administrador inteligente, que os fazia trabalhar e que cuidava para que nada lhes faltasse. No convento estavam armazenados sacos de arroz, milho e feijão, resultantes dos trabalhos da comunidade e destinados a alimentar a aldeia. O excedente das colheitas e tecidos de algodão era trocado por bovinos. À exceção dos artífices, todos trabalhavam nas plantações da comunidade, mas tinham também plantações particulares, autorizadas pelo administrador, que lhes dava dias de folga para que pudessem cuidar delas. O que os índios cultivavam era o milho, várias espécies de 
feijão, mandioca doce, batatas, abóboras e melancias. Segundo o autor, eles construíam pequenas choupanas no meio das plantações para nelas morar durante a colheita, impedindo possíveis roubos. Saint-Hilaire menciona ainda que a varíola foi uma das principais causas do despovoamento desta província, pois desde o tempo dos jesuítas ela vinha causando inúmeras mortes. Somente os habitantes de Santo Ângelo foram poupados, porquanto o administrador fizera vacinar a população logo que soube das mortes nas outras aldeias (idem, p. 302304).

Chácara do administrador de São Lourenço, 15 de março, o autor também menciona índios que ali viviam e trabalhavam, cultivando as terras sob as ordens do administrador. Nesse dia, chegaram à chácara trezentos índios, conduzidos por um cabo. Tais índios faziam parte de um destacamento de quatrocentos homens que tinham acabado de atravessar o Uruguai e pediam auxílio ao Comandante, que indagara se havia entre eles quem quisesse entrar para o regimento de guaranisportugueses; cem deles ofereceram-se e os restantes se dirigiam a São Miguel, onde se encontrava Siti (idem, p. 304-306).

Chegada de Saint-Hilaire a São Lourenço: no caminho percorrido pelo autor de um local a outro, ele encontrou os índios acima mencionados. Eles se faziam acompanhar das mulheres e filhos, e estavam todos em andrajos, possuindo apenas seus magríssimos cavalos. As mulheres, bastante cansadas, iam a pé; segundo o autor, as montarias não as aguentavam mais. Em seguida, ele faz uma breve descrição da aldeia, que tinha uma população menor que as anteriores: duzentos indivíduos, entre crianças, velhos e mulheres. Eram "sujos e mal vestidos", o que Saint-Hilaire atribui aos maus tratos infligidos pelo chefe e a uma má administração. Quando sai para herborizar, o autor encontrou uma vasta plantação de erva-mate, limítrofe com a aldeia, e que datava do tempo dos jesuítas. Alguns índios da margem direita do Uruguai estavam ocupados em preparar a erva. Os jesuítas, que faziam considerável comércio de erva-mate, procuraram fazer plantações ao redor de suas povoações, mas à época elas estavam todas destruídas. Após atravessar as plantações, o autor encontrou várias chácaras. Entrou em uma delas e encontrou apenas mulheres com as quais tentou conversar, o que acabou não sendo possível, visto que só conheciam a 
língua guarani (idem, p. 307-308).

Saint-Hilaire chega a São Miguel em 18 de março. Conta que, no começo da guerra, foram enviados para essa província apenas 300 soldados catarinenses, e que, com exceção destes, apenas os milicianos da província a defenderam contra os inimigos, guerreando às próprias custas, visto que durante onze anos só tinham recebido dois anos e meio de soldo e um uniforme. Segundo ele, depois que o Conde de Figueira viera governar a Capitania do Rio Grande, a fazenda real gastara algum dinheiro com o regimento dos Guarani, que até então tinha sido sustentado pelo trabalho das mulheres e de alguns velhos. Também essa aldeia fora construída conforme o mesmo plano das outras povoações e o autor a descreve. Havia no local um cura e um jovem guarani que ensinava as crianças a ler. Esta aldeia era menos pobre que as outras. Possuía uma considerável plantação de mate e uma importante estância onde se contavam três mil animais. Menciona ainda que um soldado guarani o acompanhara de São Borja até ali, onde encontrara sua família. $O$ autor espanta-se com a pouca importância que o índio atribui a esse encontro (idem, p. 309-310).

São Miguel tinha sido designada pelo Marechal Chagas para ser a residência do General Siti. Saint-Hilaire menciona que pretendia encontrar-se com Siti tão logo tivesse chegado, mas tal não foi possível, porque ele estava bêbado. Quando se encontraram, o autor levou a conversa para o tema da guerra e ficou sabendo pelo General Siti que ele já estava à frente dos índios quando Ramírez assumiu o comando da província de Entre-Rios. Ramírez lhe havia prometido dez anos sem guerrear, mas ao fim de alguns meses, mandara-lhe ordem de se manter preparado para marchar com seu pessoal. Siti tentara negociar, mas Ramírez o atacou com suas tropas. Então, ele ordenou a todos os índios que se juntassem a ele para atravessarem o Uruguai. A maioria o seguiu, mas alguns ficaram com medo de serem vendidos aos portugueses e permaneceram ali, ainda que depois de um tempo tenham também atravessado o Uruguai e se espalhado pelas aldeias. Mais uma vez Saint-Hilaire comenta a exagerada bondade com que os portugueses tratavam os índios. Entretanto, sua opinião era que essa situação não seria viável para sempre e que, mais cedo ou mais tarde, eles exigiriam dos índios alguma coisa em troca pelo tempo que foram 
sustentados (sic) (idem, p. 311-312).

O autor chega a Santo Ângelo em 22 de março. Menciona que se fazia acompanhar por um indiozinho e um jovem guia que foram dados a ele pelo administrador de São João. Segundo ele, Santo Ângelo era a última das aldeias das Missões do lado leste; adiante dela, elevavam-se grandes florestas que se ligavam às do Sertão de Lages e serviam de asilo aos índios selvagens ${ }^{4}$. Essa aldeia era a mais escondida de todas, situava-se numa região florestal e montanhosa, cujo acesso exigia a travessia de dois rios perigosos. Segundo ele, os "índios selvagens" apareciam frequentemente nos arredores de Santo Ângelo, matando "guaranis" e brancos quando iam colher mate nas florestas vizinhas. Descreve as construções, rapidamente, e afirma ser a população do local composta por aproximadamente 80 indivíduos, sem incluir as crianças com menos de dez anos. Desse total, não havia mais do que quinze homens em condição de trabalhar. As mulheres é que cuidavam das plantações e, para tanto, percorriam por dia um total de quatro léguas para ir ao trabalho. Menciona ainda que, numa conversa com o cura, este afirmara que havia alguns anos a miséria nessa aldeia era tão grande que os índios roubavam couro de bois para comer, havendo mesmo os que quem morresse de fome (idem, p. 313-314).

Saint-Hilaire parte de Santo Ângelo para São João pelo mesmo caminho. Como tinha chovido, os dois rios tiveram que ser atravessados numa piroga. Os encarregados dessa travessia eram índios, e, segundo o autor, não thes era assegurada nenhuma retribuição. Em São João, Saint-Hilaire se diz impressionado com as plantações dessa aldeia, maiores que as de outras, e afirma terem sido elas feitas por mulheres e velhos. Descreve em seguida a forma como esses Guarani aravam a terra, o que o deixa ainda mais surpreso com a abundância das colheitas (idem, p. 314-316).

Contavam-se em São João perto de 200 pessoas, entre as quais um pequeno número de homens, todos já de idade avançada. Tal população teria aumentado de uns sessenta indivíduos, recrutados entre aqueles que tinham atravessado o Uruguai nos últimos tempos. Em seguida, Saint-Hilaire faz alguns comentários e descrições a respeito de

\footnotetext{
${ }^{4}$ Certamente o autor se refere aos Xokleng ou Kaingang que ainda viviam livres nas florestas da região sul e resistiam ao contato com os brancos.
}

Espaço Ameríndio, Porto Alegre, v. 7, n. 2, p. 277-556, jul./dez. 2013. 
KIMIYE TOMMASINO - Relatório de Identificação e Delimitação da Terra Indígena...

São João. Dessa aldeia até o local em que se encontrava então, não tinha visto nenhuma casa ou traço de cultura e não havia ninguém nos campos (idem, p. 319).

Em Piratini havia duas choupanas construídas razoavelmente e habitadas por índios. Não havia plantações nos arredores, mas dada a presença de milho e abóboras ele acreditava que elas deveriam se localizar em algum lugar mais afastado. Os homens deste local só falavam o guarani, o que impediu o autor de obter mais informações. Como ele já mencionara, apenas os índios de São Borja, pela convivência prolongada com os portugueses, sabiam falar português. O próprio índio que Ihe fora dado como guia em São Miguel só falava guarani. Ele afirma ainda que as choupanas dos índios eram muito pequenas e "mal arrumadas", podendo-se ver nelas espigas de milho suspensas em varais, um pouco de algodão, abóboras, uma rede, alguns farrapos, uma marmita, uma chaleira para mate, alguns bancos e catres de pinho guarnecidos de tiras de couro cruzadas. Este último móvel podia ser encontrado em todas as casas dos índios (idem, p. 320-321).

$\mathrm{O}$ autor chega à estância de Santiago. Essa estância havia sido habitada por um espanhol, e conservou o seu nome. Na época em que o autor a visitou, era habitada por um brasileiro que tivera as propriedades devastadas pelos gaúchos e até pelos portugueses durante a guerra, e que viera se refugiar ali. Ele diz a Saint-Hilaire que só havia comprado a casa, pois as terras pertenciam aos índios. Por fim observou que não restava em toda a Província das Missões nenhuma inscrição ou epitáfio que lembrasse os jesuítas. Os monumentos desse gênero haviam provavelmente sido destruídos pelos espanhóis com o objetivo de fazer os índios esquecerem a influências desses padres. Entre os índios, ele encontrara apenas uma mulher que vivera sob o governo dos jesuítas. Mas muitos Guarani se lembravam de haver ouvido seus pais ou avós falar deles, dizendo-lhe que no tempo em que os padres administravam a região viveram com muita felicidade (idem, p. 322323).

$\mathrm{Na}$ estância de Salvador Lopes, entre a estância de Santiago e o local em que se encontrava no momento, o autor afirma ter encontrado duas casas habitadas por índios (idem, p. 324).

Em São Xavier, Saint-Hilaire devolveu o índio que the servira de 
KIMIYE TOMMASINO - Relatório de Identificação e Delimitação da Terra Indígena...

guia de São Miguel até ali. Afirma tê-lo "recompensado largamente" e revolta-se com a "falta de gratidão" do índio (idem, p. 327).

Em Toropi-Chico, conversando com o proprietário da estância onde estava hospedado, o autor transcreve os comentários que este the fez a respeito da região e do fato de que os homens que ali se estabeleciam cometiam tantas extravagâncias por causa das índias que não enriqueciam nunca (idem, p. 327). Continua dizendo que os índios das aldeias eram muito mal-vestidos, visto que as distribuições de roupas dependiam inteiramente da vontade dos administradores. Segundo ele, as mulheres não possuíam sequer uma cobertura para protegê-las do frio, que era amenizado com o costume de colocarem brasas sob o leito (idem, p. 328).

Às margens do Toropi-Grande, Saint-Hilaire menciona um índio estabelecido na vizinhança que, segundo o autor: "era uma exceção entre os de sua raça, pois sabia ler e escrever, falava bem o português, andava bem vestido e 'era honesto'”. "Este índio", continua ele, "gozava de certa riqueza: possuía uma estância, cavalos e gado. Administrava metodicamente os negócios e conseguira (sic) casar suas filhas com homens brancos" (idem, p. 329).

Segundo Saint-Hilaire, acabava de se instalar às margens do Toropi-Chico uma guarda encarregada de só deixar entrar na Província das Missões, ou dela sair, pessoas munidas de passaporte. Tal medida tentava impedir a deserção dos índios guarani das aldeias e o roubo de crianças pelos brancos. Entretanto, na opinião do autor, tal medida não correspondia ao objetivo, já que os índios eram excelentes nadadores e não precisavam transpor o rio junto à guarda, da mesma forma que os brancos também poderiam tomar outro caminho, a cavalo (idem, $\mathrm{p}$. 329).

Na estância do Durasnal de São João da Coxilha do Morro Grande, o autor menciona a existência de vários índios trabalhando na casa em que estava hospedado (idem, p. 331).

Saint-Hilaire escreve que em quase todas as estâncias dos arredores de Santa Maria havia índios desertados das vilas. Eram empregados como peões, e traziam consigo toda a família. Os patrões costumavam queixar-se muito da inconstância desses homens, que muitas vezes iam embora sem nenhuma explicação (idem, p. 338). 
KIMIYE TOMMASINO - Relatório de Identificação e Delimitação da Terra Indígena...

Saint-Hilaire comenta que os índios das Missões eram muito pobres para ter cavalos e que, sendo assim, criavam burros para servir de montaria. Também em Santa Maria ele havia visto burros pertencentes aos índios (idem, p. 340).

Entre a vila de Cachoeira e o rio Botucaraí, o autor indica a existência de miseráveis palhoças, separadas umas das outras, cuja reunião tomava o nome de "Aldeia". Tais choupanas eram habitadas por índios vindos da aldeia de São Nicolau, vizinha de Rio Pardo, para lançar as fundações dessa vila. Tinham permanecido ali mesmo após concluída a empreitada. São João de Cachoeira era o primeiro povoado que se encontrava na rota das Missões e do Paraguai, e formava uma espécie de entreposto (idem, p. 354).

Vila de Rio Pardo, 2 de maio: Saint-Hilaire afirma que, conforme ouvira dizer durante a viagem, quando os portugueses conquistaram a província das Missões, ela ainda estava longe do estado atual de decadência. Sua população somava 14 mil indivíduos, os índios eram bem-nutridos e bem-vestidos, e costumavam caçar animais selvagens para os deixar engordar em suas terras. Com a vinda dos portugueses, tinham sido obrigados a abandonar a caça, pois esta se fazia nas terras que continuaram a pertencer aos espanhóis. Com a má administração, as aldeias foram perdendo suas riquezas e recursos (idem, p. 362).

A vista da Ponta dos Lençóis, 24 de junho: no final de sua viagem, quando retornava ao Rio Grande, o autor menciona que o Conde de Figueira escreveu ao Marechal Chagas recomendando que ele desse um pequeno Guarani a Saint-Hilaire. O Marechal procurou o Coronel Paulette e the pediu um refugiado espanhol, órfão de pai e mãe. $O$ coronel trouxe de São Borja um menino de aproximadamente nove anos cujos pais haviam sido mortos durante a guerra. Menciona ainda que o coronel Paulette pediu-lhe que conseguisse um outro pequeno índio espanhol e que o enviasse, tão logo chegasse ao Rio de Janeiro, ao Marquês de Bellas, irmão do Conde de Figueira (idem, p. 380-381).

Assim percorremos com Saint-Hilaire várias regiões do Rio Grande do Sul, Uruguai, Argentina e Paraguai, cujas vivas descrições falam das várias situações em que viviam os Guarani. Interessa enfatizar que a maioria vivia como escravos e em condições de miserabilidade. Praticamente todos os homens adultos eram convocados nas milícias 
espanholas e depois nas portuguesas. As vilas se esvaziaram restando apenas velhos, mulheres e crianças. A única mão-de-obra disponível naquelas regiões era a indígena e por isso a grande disputa entre espanhóis e portugueses em tê-los sob sua responsabilidade. Pelo que se depreende da leitura, grande parte dos Guarani que Saint-Hilaire conheceu em sua viagem não falava português ou espanhol, apenas a língua guarani e portanto, pode-se supor que parte significativa dos Guarani que fugiram do lado ocidental do rio Uruguai para o oriental não tinham experiência nas missões dos jesuítas espanhóis mas viviam submetidos aos espanhóis no regime das encomendas.

Pode-se ainda perceber o quadro de destribalização a que estavam sujeitos os Guarani cujos adultos jovens eram recrutados como soldados e eram desligados de suas aldeias. Por outro lado, SaintHilaire viu que os soldados guarani casados levavam consigo suas mulheres e filhos para onde quer que fossem. As guerras e as epidemias que assolaram as aldeias também devem ser levadas em consideração para que possamos compreender como uma nação de milhares de pessoas tiveram ceifadas a quase totalidade de sua população missioneira.

Outras fontes históricas dão conta de que algumas aldeias guarani remanescentes das Missões subsistiram até o século XIX. Os relatórios do presidente da Província de São Pedro do Rio Grande do Sul referente ao ano de 1849 registram a existência de aldeias de índios guarani em S. Luiz das antigas missões que habitavam anteriormente o Rincão de S. Vicente. Nesse relatório o autor, Tenente José de Souza Soares de Andrea, explica a situação dos índios e expõe seu pensamento:

Sendo indispensável deitar fora do Rincão de S. Vicente todas as famílias de Índios que ali existem, por ser este Rincão destinado à Cavalhada do Exército, não quiz ser o perseguidor desta gente, e mandei preparar o Povo de S. Luiz, que tem ainda muitos edifícios aproveitáveis, para receber essa nova espécie de Colonia.

O meu pensamento é que todas as terras e propriedades do Povo de S. Luiz, fiquem sendo próprios [dos] Nacionais, e que às famílias dos Índios, só conceda o uzo fructo. Esta presunção é de absoluta necessidade, que não podem eles sair da Tutela; e sem ela não faltarão especuladores que os roubassem a 
KIMIYE TOMMASINO - Relatório de Identificação e Delimitação da Terra Indígena...

título de compra, e eles ficarão caídos na miséria, e se extinguirão de todo, como tem acontecido a muitas outras famílias ${ }^{5}$.

O relatório de 1 o de outubro de 1850 fala da existência da aldeia de S. Nicolau do Rio Pardo que tinha:

duzentos e noventa e três indivíduos, tem uma capela e escola de primeiras letras.

São agricultores, e alguns se aplicam a artes mecânicas. Contribui com três menores para a Armada Nacional. O governo nada despende com este aldeamento: é seu Director especial o Capitão Joaquim José da Fonseca Souza Pinto ${ }^{6}$.

O Relatório de 1852 volta a falar da aldeia de S. Nicolau, "reduzida a 273 indivíduos de origem Guarani, acha-se na maior decadência". Mas o relatório faz referência à "antiga Aldeia de Nossa Senhora dos Anjos, no município desta capital" já referida por Saint-Hilaire cujos habitantes teriam vindo das Missões por ordem do governador da capitania (SAINTHILAIRE, 1987, p. 4).

O Relatório de 1912 relata sobre a vinda de um grupo de 69 índios guarani "provenientes do Paraguai" e que se instalaram em Santo Cristo, município de Santo Ângelo, sob a diereção do cacique Vinites. É interessante que o relatório diz que essa informação foi dada pelo "chefe da colônia Guarany" que aponta para a existência nessa região de outros Guarani já estabelecidos na região. Simonian (1990/93b, p. 122), dá um quadro sobre os Guarani nessa época:

A presença de Guarani Mbyá e Xiripá no Rio Grande do Sul remonta a muitas décadas, mas em torno de 1910 diversos grupos já ocupavam várias áreas, principalmente nas regiões noroeste e central do estado. Pelas evidências disponíveis, por esta época grupos Guarani encontravam-se em Santa Rosa, em Santo Cristo e em Lagoão (GONÇALVES, 1912, 1913,

\footnotetext{
${ }^{5}$ Relatório do Presidente da Província de S. Pedro do Rio Grande do Sul, o Tenente Central Fsc. José de Souza Soares de Andrea na Abertura da Ass. Legislativa Provincial no dia $1^{\circ}$ de junho de 1849 . Porto Alegre: Typog. Porto-Alegrense, 1849. p. 29.

${ }^{6}$ Relatório do Presidente da Província de S. Pedro do Rio Grande do Sul, o Conselheiro José Antonio Pimenta Bueno. Na abertura da Ass. Legislativa Provincial no dia $1^{\circ}$ de outubro de 1850 . Porto Alegre: Typog. de F. Pomatelli, 1850.
}

Espaço Ameríndio, Porto Alegre, v. 7, n. 2, p. 277-556, jul./dez. 2013. 
KIMIYE TOMMASINO - Relatório de Identificação e Delimitação da Terra Indígena...

1915), sendo que outros localizavam-se nas terras Kaingang de Nonoai, onde vivem desde o início da Revolução de 1893 e em Guarita, para onde se deslocaram após o término da guerra contra o Paraguai (TOPÉ, 1978 apud SIMONIAN, 1981, p. 33). O governo estadual começou então a estabelecer uma política de proteção às suas ocupações, mas deixou de levá-la até as últimas conseqüências, pois cedeu às pressões das frentes de expansão, especialmente aos interesses das frentes dos latifundiários já estabelecidos com posses e/ou propriedades, ou, ainda, ao projeto expansionista em torno da colonização por imigrantes europeus.

Dentre as medidas então tomadas pelo governo estadual em relação às terras dos Guarani, tem-se a discriminação e a demarcação. O Toldo Lagoão, localizado no município de Soledade, por exemplo, foi a primeira área a ser considerada para a demarcação, em 1910 (GONÇALVES, 1910, p. 155). Mas o estado também interviu em outras ocupações Guarani ao longo dos anos, como no caso dos Toldos Santo Christo, Santa Rosa, Paiol Grande, Guarani, Liso e Santa Lúcia. Pelo que se tem notícia, os Toldos Lagoão, Liso e Santo Christo foram apenas discriminados. Malgrado tais medidas, os Guarani sofreram um amplo processo de expropriatório; de todas estas áreas eles conseguiram manter apenas uma pequena gleba no Toldo Guarani, município de São Valentim.

Simonian, baseando-se na sua pesquisa documental, fornece a seguinte hipótese em relação aos Guarani do Toldo Lagoão: eles seriam os mesmos da área contígua às TIs Serrinha e Votouro. Esse grupo terse-ia dispersado por outras áreas por causa da exiguidade das terras e os que vivem na TI Nonoai seria um ramo daquele grupo original. É o que deduz a pesquisadora que entrevistou o Guarani Topé, morador da TI Nonoai. Pela importância dessas informações para a nossa pesquisa sobre os Guarani de Araça'í continuaremos seguindo a exposição de Simonian:

Grande parte da dispersão da população de Lagoão a partir do Toldo Guarani ocorre, não só devido às pressões locais e 'ao aperto' [...] em que se encontravam, conforme informou o Guarani Topé, mas também pelo fato de o estado ter contratado mão-deobra indígena para abrir estradas e picadas (TOPÉ, 1978 apud SIMONIAN, 1978). Ainda segundo Topé, algumas famílias de Guarani já se encontravam em

Espaço Ameríndio, Porto Alegre, v. 7, n. 2, p. 277-556, jul./dez. 2013. 
KIMIYE TOMMASINO - Relatório de Identificação e Delimitação da Terra Indígena...

Nonoai desde 1893, mas é por ocasião da revolução de 1922/1923 que aldeias se consolidaram naquela área, quando parte dos Guarani provenientes de Lagoão, como ele próprio, decidiram permanecer, após o término dos trabalhos. Seu pai Natalício Mariano, por muito tempo o líder dos grupos de trabalho a soldo do governo estadual, decidiu ir para a área indígena Guarita (idem, ibidem). Outras famílias saíram do Toldo Guarani, tendo se estabelecido na área indígena Cacique Doble, no município de Cacique Doble, de onde muitos posteriormente partiram para a área indígena Ibirama no Estado de Santa Catarina (SIMONIAN, 1981, 1982), e provavelmente também para outros locais (idem, p. 123).

Pelas informações acima podemos inferir que a família de Natalício Mariano, um Guarani Mbyá, era originária do Toldo Lagoão que se dispersou para o Toldo Guarani, TI Guarita e parte ficou em Nonoai. A hipótese mais provável é que a história dos Chiripá que se estabeleceram em Araça'í, vindos da Argentina e Paraguai, quando passaram pela região de Soledade, certamente selaram alianças casando seus filhos e filhas e depois continuaram seus deslocamentos. O grupo chiripá, tendo incorporado um Mbyá (casamento entre Joaquim Mariano e Paulina Morais) seguiu na direção norte, atravessou o rio Uruguai e se instalou às margens do rio Araçá. Este elo entre as parcialidades guarani, com Kaingang e Juruá é importante para compreendermos as regras da sociabilidade que garantiu aos diferentes grupos uma estabilidade mínima para que cada grupo pudesse seguir em frente na realização de seus projetos como grupos específicos.

Por outro lado, centenas de outros grupos não inseridos na experiência missioneira - os que viviam livremente nas florestas do Paraguai e Argentina e os que viviam como encomendeiros atravessaram o rio Uruguai e se fixaram no território codificado pelo branco como Rio Grande do Sul. O deslocamento desses grupos guarani que começou em direção leste do rio Uruguai, ainda no período em que os limites espanhóis e portugueses estavam em disputa, continuou pelo século XIX e XX e ainda não se encerrou.

Vale lembrar que os Guarani continuaram sua mobilidade dentro do seu território que, como vimos no início, ultrapassava (e ainda ultrapassa) as fronteiras inventadas pelos portugueses e espanhóis. 
KIMIYE TOMMASINO - Relatório de Identificação e Delimitação da Terra Indígena...

Nesse sentido, ao atravessarem o rio Uruguai, os Guarani não saíram de seu território porque o nordeste da Argentina, sudeste do Paraguai (incluindo o atual estado do Mato Grosso do Sul) até o litoral atlântico formava o território guarani. Isso vale tanto para o passado como para o presente pois queremos registrar que, da perspectiva indígena, que é o adotado neste relatório, não cabe o argumento muito usado pelos brancos de que os Guarani seriam "do Paraguai" ou "da Argentina" e deveriam voltar para lá. Os Guarani vivem no Paraguai, na Argentina e no Brasil, mas dentro de seu território.

Uma das dificuldades encontradas nas pesquisas sobre os atuais Guarani que vivem tanto no litoral quanto no interior dos estados do sul são acerca das informações sobre esses grupos e suas relações com os remanescentes daqueles que viveram nas Missões e os que, saindo das densas florestas do nordeste da Argentina e sudeste do Paraguai, fugindo da Guerra do Paraguai (1864-1870), atravessaram o rio Uruguai em busca de melhores condições de vida e tiveram de enfrentar a guerra federalista e depois a do Contestado (1912-1916). Mesmo sabendo que houve mudanças significativas na vida dos Guarani missioneiros, os grupos que fugiram do Paraguai e passaram para o lado brasileiro certamente se vincularam aos "parentes" que aqui viviam. Muitos grupos que não foram submetidos ao sistema missioneiro ou nas encomendas deviam ter conhecimento dos grupos livres das florestas e certamente constituíram entre si redes de sociabilidade e mesmo de alianças pela troca de pessoas e objetos. Venzon com muita propriedade relata que:

Muito já foi dito com respeito ao processo de missionarização promovido pelos jesuítas a partir do século XVII entre os Guarani, de sua rede produtiva de aldeamentos organizada com base na mão-de-obra indígena, ou mesmo do genocídio praticado nas guerras contra os Guarani promovidas por disputas territoriais entre Portugal e Espanha. Pouco se disse quanto ao processo de expropriação de seus territórios, ou mesmo da sobrevivência de contingentes aldeados até meados do século XIX, e que guardam a identidade e cultura indígenas. Delinear alguns dados, ainda que precários, com respeito às tentativas de assimilação destas populações Guarani, é imprescindível para que mais uma vez não se passe ao largo da existência concreta deste povo indígena, mesmo que tal questão não

Espaço Ameríndio, Porto Alegre, v. 7, n. 2, p. 277-556, jul./dez. 2013. 
KIMIYE TOMMASINO - Relatório de Identificação e Delimitação da Terra Indígena...

implique reivindicações territoriais. Ou seja, consiste em não negar nem a expropriação sofrida pelos Guarani nem a existência de pequenos grupos sobreviventes, que conservam hoje a identidade e a cultura Guarani missionarizada, ainda que transoformados de modo profundo em função do processo histórico que Ihes foi imposto (VENZON, 1990/93a, p. 118).

Há muitos elementos que permitem pensar a hipótese de ter havido, antes, durante e depois da experiência missioneira, contatos dos Guarani submetidos aos jesuítas e às encomendas com os que viviam livres nas florestas.

$\mathrm{O}$ argumento mais importante é que o território missioneiro eram territórios tradicionais guarani que já viviam nas duas margens do Uruguai e do médio Paraná. Mesmo espalhados num amplo espaço geográfico os grupos vinculados por consanguinidade e afinidade mantinham (como ainda mantêm) vínculos de sociabilidade. Cabe lembrar, como já foi afirmado no início do relatório que constituem-se um padrão sociocultural guarani as alianças com outros grupos sociais através da troca de pessoas e objetos.

O segundo argumento é que os Guarani missioneiros não tinham sido inteiramente dissolvidos quando viviam em grupos aldeados, ao começarem as migrações dos grupos que viviam no Mato Grosso do Sul, sudeste do Paraguai e nordeste da Argentina que atravessaram os rios Paraná e Uruguai em busca do litoral atlântico. Nimuendajú indica os seguintes grupos que se deslocaram para o litoral atlântico: os Tañiguá, a partir de 1810, os Oguauíva, a partir de 1820, os Apapocuva, desde 1870 e um outro grupo, em 1912. Escreve que isso se deu "por volta de 1870 , depois que numerosos outros bandos haviam imitado o exemplo dos Tañiguá e Oguauíva, com maior ou menor sucesso" (NIMUENDAJú, 1987, p. 11-12). Simonian acredita que havia um outro "corredor de entrada" dos Guarani pelo Rio Grande do Sul:

Ao deixarem o Paraguai no começo do século, estes indígenas em geral passaram pela Província de Misones, na Argentina, vindo a se instalar posteriormente no território brasileiro, mais precisamente no Rio Grande do Sul (SIMONIAN, 1980, p. 11). Pelas evidências disponíveis é provável que no

Espaço Ameríndio, Porto Alegre, v. 7, n. 2, p. 277-556, jul./dez. 2013. 
começo do século os Guarani estivessem a tratar a região de Santa Rosa como uma espécie de 'corredor de entrada', embora mais recentemente inúmeros grupos tenham passado quase que sistematicamente pela área indígena Guarita, onde chegam depois de permanecer um tempo na aldeia Peperiguassú, localizada na Província de Misiones, antes de tomarem outros rumos (SIMONIAN, 1983/1989). Guarita constituiu-se em local privilegiado para sua chegada ao Brasil, pois nesta área existia uma população Guarani permanente pelo menos desde 1870/1890. Ao longo das décadas passadas muitos destes indígenas foram, dentre outros, os aldeamentos de Rio Branco e Boa Vista em São Paulo, e o de Boa Esperança no Espírito Santo (LADEIRA e AZANHA, 1988, p. 16).

Outras rotas de migração Guarani podem ser identificadas, na medida que os estudos são intensificados. Ladeira e Azanha, por exemplo, identificaram a rota que parte do Paraguai pelo Estado do Paraná, '... onde formará vários aldeamentos (Palmeirinha, Rio das Cobras, etc.) e que, mais tarde, será responsável pelo grosso da população Mbyá dos aldeamentos de São Paulo e Rio de Janeiro' (idem, ibidem). Simonian localizou uma outra, pois mais recentemente muitos Guarani passaram do aldeamento do Peperiguassú em Misiones, diretamente para o interior do Estado de Santa Catarina, onde se reúnem tanto em Chapecó, Xanxerê, Ibirama, Morro dos Cavalos, etc... (SIMONIAN, 1981, 1986, 1989). Mas há também de se considerar tais rotas com certa flexibilidade, pois não são raros os casos de indígenas que retornam principalmente à Misones, na Argentina (1989). Por sua vez, Venzon se encontra trabalhando numa hipótese que vê as migrações Guarani para o leste como uma busca de antigas ocupações, cujas identificações estariam gravadas na memória social, e de onde seus ancestrais haviam sido expulsos em tempos mais remotos (VENZON, 1989) (SIMONIAN, 1990/1993b, p. 125).

No Relatório da Secretaria de Estado dos Negócios das Obras Públicas apresentado ao presidente do Rio Grande do Sul em 13/09/1912, o diretor Torres Gonçalves relata sobre os acontecimentos ocorridos no ano de 1911 entre os quais um de interesse para a nossa pesquisa:

Vindos do Paraguay, estabeleceram-se ultimamente em

Espaço Ameríndio, Porto Alegre, v. 7, n. 2, p. 277-556, jul./dez. 2013. 
KIMIYE TOMMASINO - Relatório de Identificação e Delimitação da Terra Indígena...

Santo Christo, no município de Santo Angelo, conforme informação do chefe da colonia Guarany, 12 famílias de índios, com 69 pessoas, sob a direção do cacique Florencio Vinites ${ }^{7}$.

São duas as informações desse, aparentemente pequeno, relato de Torres Gonçalves que apontam: a) a vinda de um grupo guarani "vindos do Paraguai" e b) esta informação lhe foi dada pelo cacique da colônia guarani, apontando a existência de uma aldeia guarani na mesma região. Os relatórios feitos anualmente por Torres Gonçalves falam basicamente dos toldos dos Kaingang que estão naquele momento sendo alvo de uma política de atração visando a que fossem implantadas em terras delimitadas pelo Estado.

Portanto, temos muitos elementos para pensar uma continuidade histórica, geográfica e cultural guarani não apenas nos estados do sul do Brasil mas num território que extrapola os limites das nações modernas implantadas pelos conquistadores. Esse território indígena não desapareceu, mas sobreviveu e continuou sendo produzido ao longo dos últimos 500 anos. Pode-se dizer que o mesmo espaço físico contém vários códigos que se superpõem ficando vísível o código das sociedades hegemônicas. O território guarani, como se pode ver pelos mapas apresentados, abrange parte do Paraguai, Argentina e Brasil.

\section{A Presença Guarani nas Fontes Históricas}

Pesquisando os mapas produzidos por vários autores ao longo dos cinco séculos da história da ocupação branca na América do Sul podemos ver que os Guarani estavam presentes praticamente nas mesmas áreas geográficas que incluem a região norte da Argentina, sudeste do Paraguai e no Brasil numa região que toma desde o Mato Grosso do Sul todos os estados das regiões sudeste e sul.

A Figura 6 foi elaborada por Métraux em 1928 e mostra com clareza a presença guarani nas áreas do sul, sudoeste e litoral atlântico.

\footnotetext{
${ }^{7}$ Relatório da Secretaria de Estado dos Negócios das Obras Públicas apresentado ao Exmo Sr. Dr. Carlos Barbosa Gonçalves, Presidente do Rio Grande do Sul, pelo Secretário de Estado Candido José de Godoy. Porto Alegre, 1912. p. 151.
}

Espaço Ameríndio, Porto Alegre, v. 7, n. 2, p. 277-556, jul./dez. 2013. 
A Figura 7 de Nimuendajú é resultado de uma pesquisa exaustiva das fontes históricas desde o século XVI e mostra a distribuição das populações indígenas na região sul, parte do sudeste e estado de Mato Grosso do Sul.

A Figura 8, de Reinhardt Maack (1981), tenta reconstituir o itinerário da viagem de Ulrich Schmidl entre dezembro de 1552 e junho de 1553 a partir de Assunção até São Vicente. Nesse mapa estão registrados dados sobre os grupos indígenas. Na região do oeste catarinense aparecem os seguintes registros importantes para nossa pesquisa: a) a região era habitada por grupos indígenas "Tupi" e b) um ramal da Estrada ou Caminho de Peabirú atravessava a região no sentido norte-sul, o que significa, no nosso entendimento, que o oeste catarinense foi área de passagem dos Guarani desde tempos imemoriais, portanto, era uma região conhecida por muitas gerações de Guarani.

A Figura 9, de Júlio Cezar Melatti (ano 2001), também mostra a presença dos Guarani em várias regiões do Brasil. Observa-se que o noroeste do Rio Grande do Sul e oeste de Santa Catarina aparecem como áreas de ocupação guarani. 
KIMIYE TOMMASINO - Relatório de Identificação e Delimitação da Terra Indígena...

\section{Figura 6 - PRESENÇA TUPIGUARANI: Métraux}

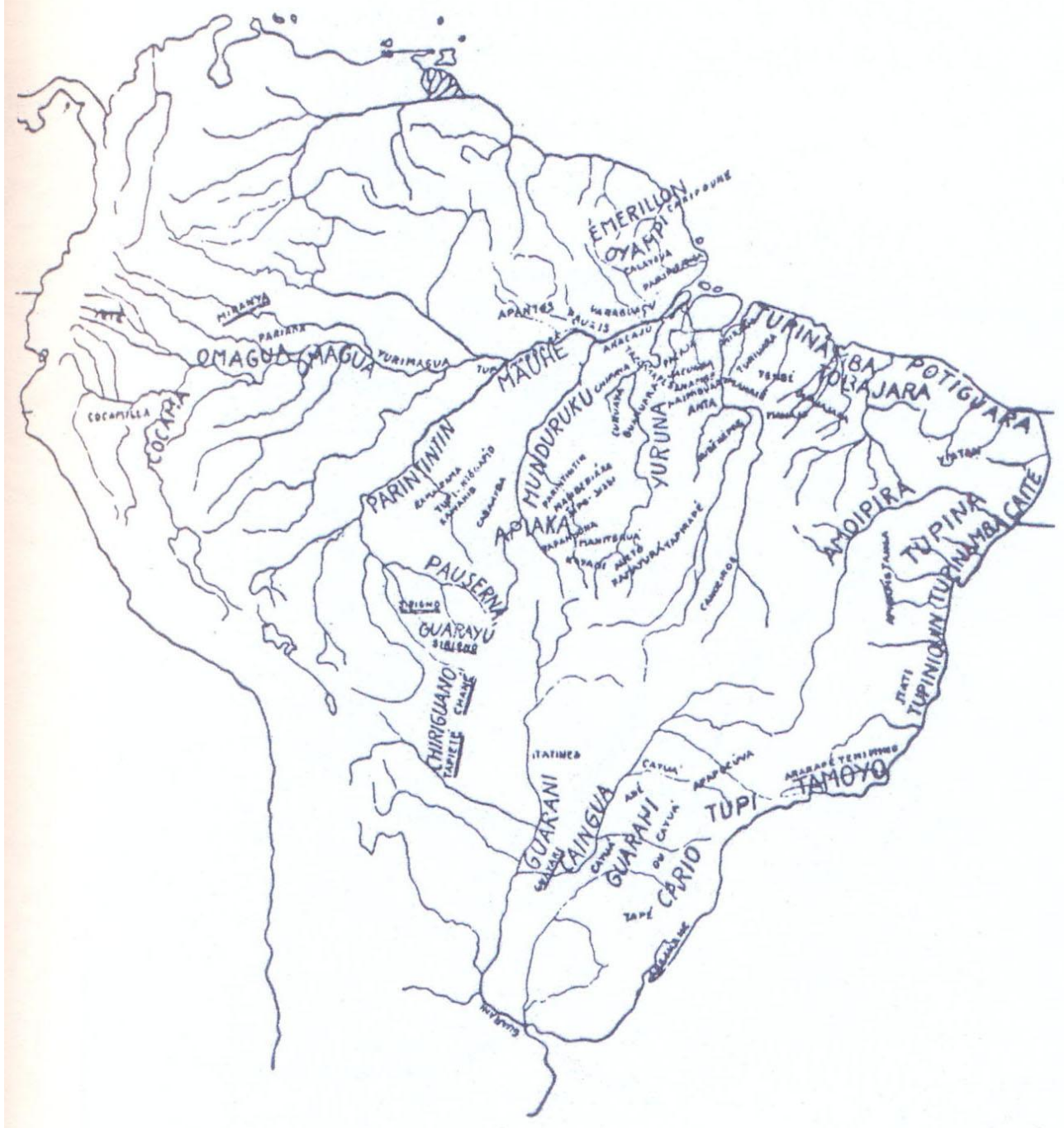

Situação das tribos Tupi-Guarani (Métraux)

Fonte: A. Métraux, 1928:43 apud Gadelha, R.M.A.F. 1980:79

Espaço Ameríndio, Porto Alegre, v. 7, n. 2, p. 277-556, jul./dez. 2013. 


\section{Figura 7 - PRESENÇA TUPIGUARANI: Nimuendajú}

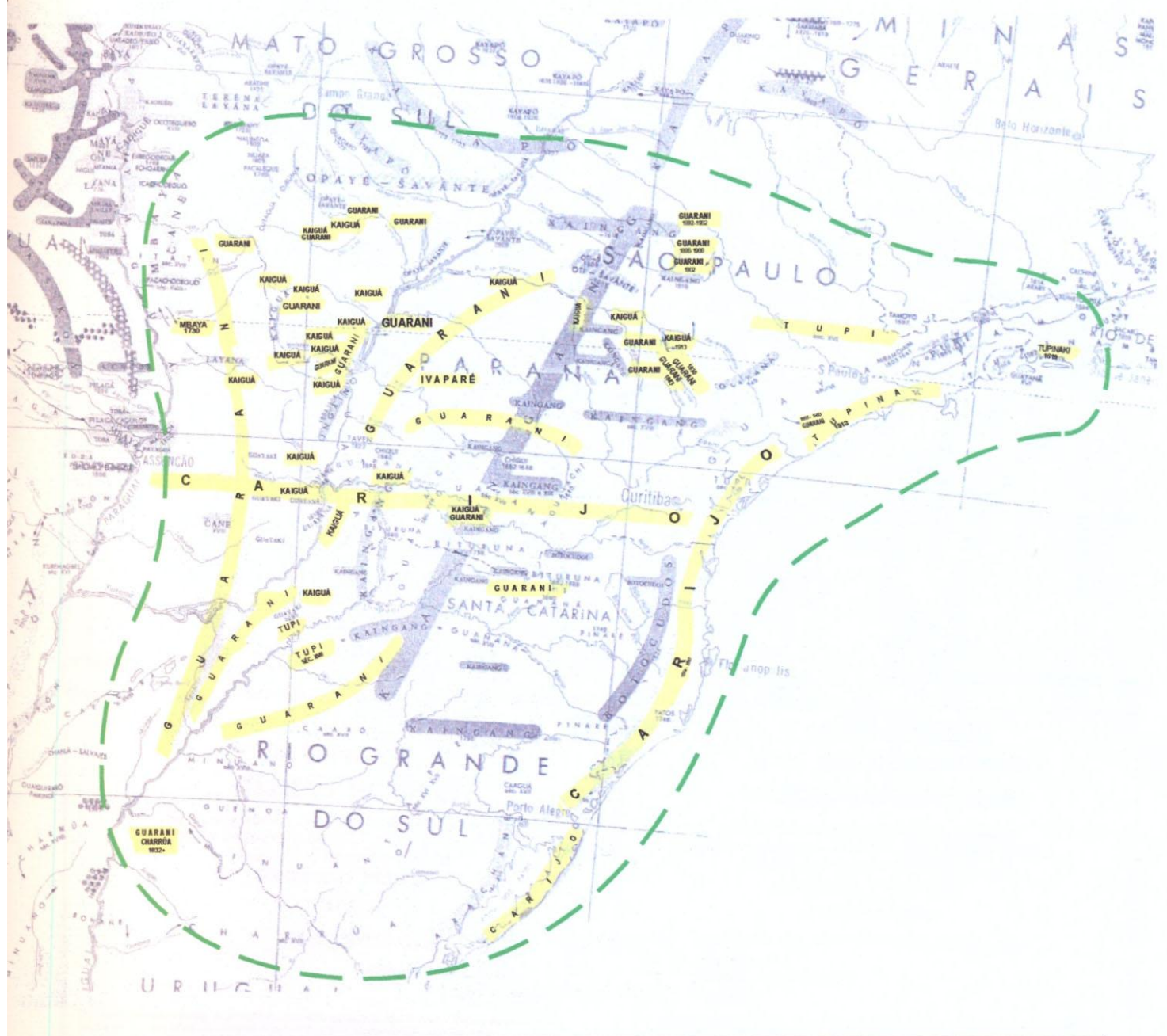

Mapa Etno-histórico do Brasil e Regiões Adjacentes. Adaptado do Mapa de Curt Nimuendajú. 1944

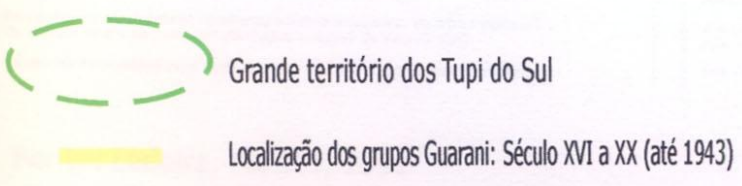

Espaço Ameríndio, Porto Alegre, v. 7, n. 2, p. 277-556, jul./dez. 2013. 
KIMIYE TOMMASINO - Relatório de Identificação e Delimitação da Terra Indígena...

\author{
Figura 8 - PRESENÇA TUPI - GUARANI: Maack
}

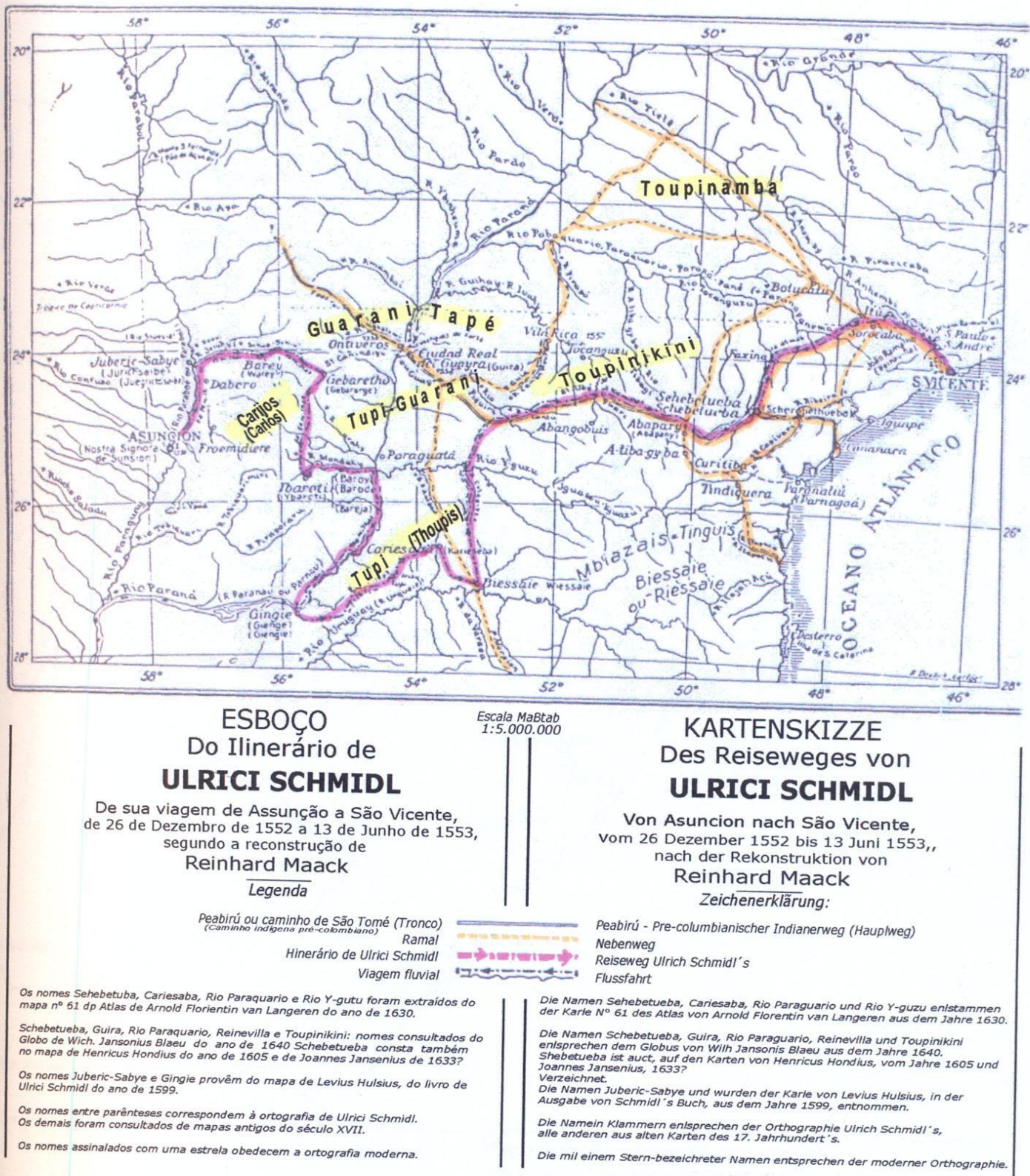

Fonte: Ladeira, MI/CTI, 1992

Espaço Ameríndio, Porto Alegre, v. 7, n. 2, p. 277-556, jul./dez. 2013. 
KIMIYE TOMMASINO - Relatório de Identificação e Delimitação da Terra Indígena...

Figura 9 - DISTRIBUIÇÃo GEOGRÁFICA DOS GUARANI: Melatti

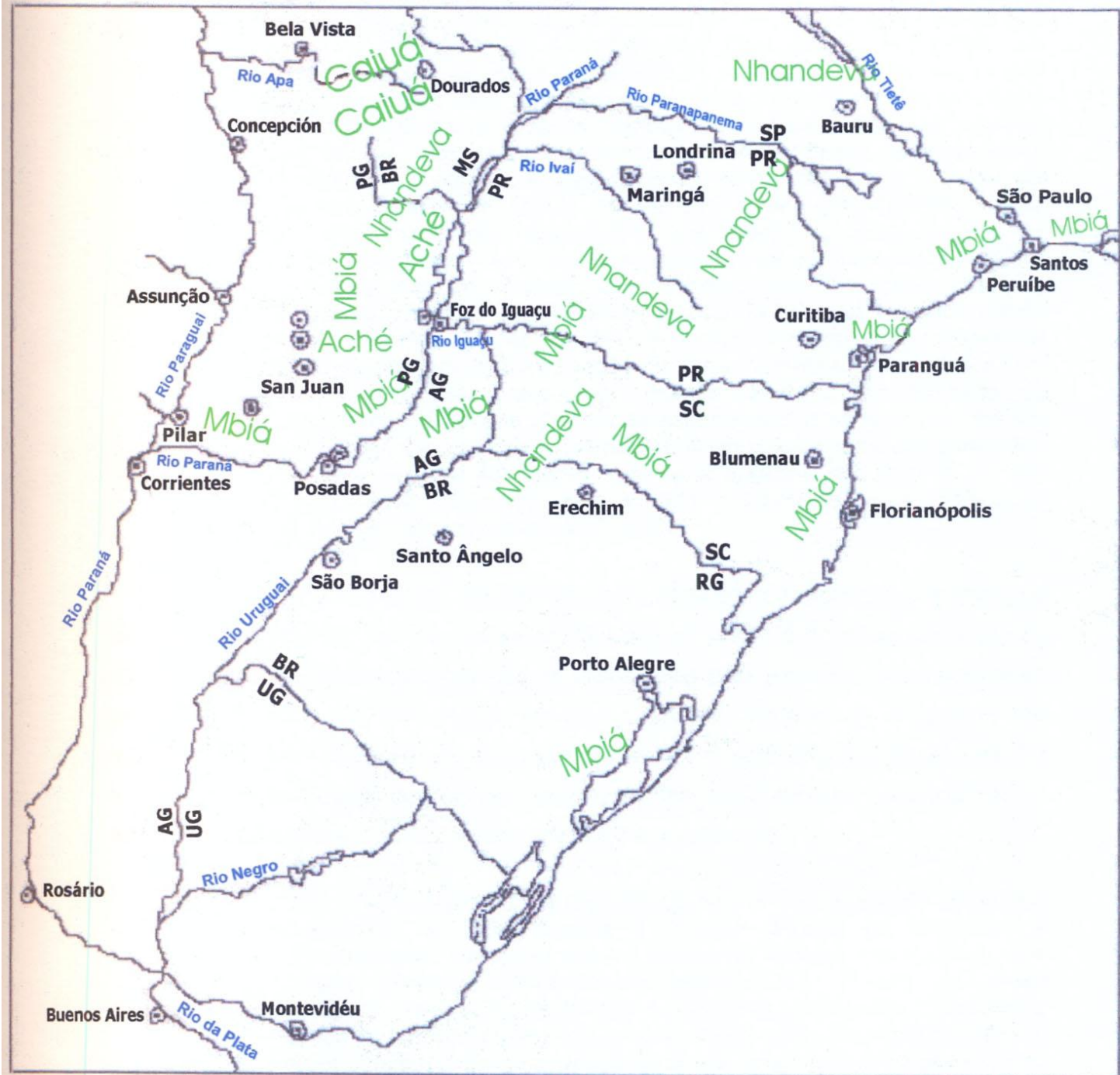

Mapa extraido do endereço virtual

www.geocities.com/RainForest/Jingle/6885/cv.htm e elaborado por Julio Cézar Melatti:2001

Espaço Ameríndio, Porto Alegre, v. 7, n. 2, p. 277-556, jul./dez. 2013. 


\title{
3. A Política do Estado para os Povos Indígenas (Xokleng, Kaingang e Guarani) e a Colonização da Região Sul
}

Moreira Neto, ao estudar o caso dos Kaingang, analisa o contexto vivido por todos os povos indígenas na província do Rio Grande do Sul como sendo

\begin{abstract}
essencialmente semelhantes aos relatados para definir o caráter geral da problemática indígena durante o século XIX em S. Paulo, Paraná e Santa Catarina. Acossados pela ocupação rápida de partes vitais de seu território tradicional nas duas primeiras províncias, grupos inteiros se deslocam continuamente em direção às regiões menos ocupadas das duas províncias mais meridionais do Império, intensificando as tensões e conflitos intertribais nessas regiões de refúgio, além de sortidas ocasionais contra as comunidades nacionais. Esses deslocamentos sucessivos começam a intensificar-se aproximadamente a partir da terceira década do século XIX, e são contemporâneos das várias migrações dos Apapocuva-Guarani em direção ao litoral paulista. As migrações Guarani aqui referidas prolongam-se por todo o século XIX e puderam ainda ser observadas em processo por Curt Nimuendajú nos primeiros anos do século atual. Apesar do caráter essencialmente mítico-religioso que as define, orientadas segundo uma perspectiva escatológica que coloca na busca da Terra-Sem-Males a esperança final da salvação dos Guarani num mundo prestes a ser destruído, as migrações Kaingang e Guarani se assemelham e se explicam, em um nível mais profundo, pelas causas gerais de agravamento das condições de opressão, de espoliação, miséria e angústia decorrentes de seu envolvimento cada vez mais estreito e inexorável pela sociedades nacionais (MOREIRA NETO, 1971, p. 395).
\end{abstract}

Moreira Neto acrescenta um segundo fator presente na história dos Kaingang no século XIX na província do Rio Grande do Sul que se refere à contínua luta entre os chefes dos grupos locais e a cooptação de vários deles pelo governo na sua política de pacificação e conquista dos grupos arredios ou hostis, tornando-se "bugreiros" ou "batedoresdo-mato". Embora esse fator também tenha influenciado a história

Espaço Ameríndio, Porto Alegre, v. 7, n. 2, p. 277-556, jul./dez. 2013. 
KIMIYE TOMMASINO - Relatório de Identificação e Delimitação da Terra Indígena...

guarani, é o terceiro fator considerado por Moreira Neto que mais nos interessa para explicar as migrações e deslocamentos dos grupos guarani. Ele expõe:

\begin{abstract}
Um terceiro elemento de importância para a caracterização da política indigenista no RGS durante o Império decorre do conjunto de circunstâncias, interesses e fatos de caráter histórico e geográfico, que deram origem à província no século XVIII. Região de posse tradicionalmente contestada entre os domínios da Espanha e Portugal, e sendo finalmente transferida a este último após uma guerra longa e difícil contra os Guarani missioneiros da antiga província jesuítica do Uruguai e Tape [que englobava as terras do atual estado do Rio Grande do Sul], a província se define fundamentalmente por seu caráter de área fronteiriça, onde guarnições militares, antigos soldados transformados em colonos, mestiços e índios se opõem tradicionalmente. A sucessão de guerras com os países limítrofes, que cobre a maior parte do século XIX, e a longa e cruenta revolução popular da República de Piratini, em começos do regime imperial, marcariam a província com um caráter marcial inconfundível que se estendera aos próprios aldeamentos indígenas (idem, p. 395-96).
\end{abstract}

Moreira Neto analisa a política do governo gaúcho de concentrar num único aldeamento os vários grupos locais kaingang, muitos dos quais inimigos entre sí e ainda alguns grupos guarani, inimigos históricos dos Kaingang. Esse fato ocorreu em muitos aldeamentos do sul e mereceria um estudo mais aprofundado dessa questão porque muitas das questões internas conflituosas têm sua origem nessa política iniciada no século XIX e continuou no XX. A política indigenista no sul do país não reservou terras para os Guarani como ocorreu com os Kaingang. Ao contrário, os Guarani foram colocados como "hóspedes" em áreas reservadas aos Kaingang e aos Xokleng. No Mato Grosso do Sul vivem em áreas Terena. Moreira Neto acrescenta:

[...] intensifica-se a tendência a transformar Nonoai em centro de reunião de todos os grupos indígenas da área. É provável que data dessa época [1847-48] a introdução de grupos Guarani nesse aldeamento Kaingang, apesar das profundas diferenças culturais e

Espaço Ameríndio, Porto Alegre, v. 7, n. 2, p. 277-556, jul./dez. 2013. 
KIMIYE TOMMASINO - Relatório de Identificação e Delimitação da Terra Indígena...

lingüísticas e de que fossem já citados como inimigos tradicionais e rancorosos nas primeiras crônicas sobre a região, ao início do século XVI. Já vimos que prática idêntica era usada em alguns aldeamentos do Paraná, como Jataí e S. Pedro de Alcântara. Em 1854 já haviam sido transferidos para Nonoai todos os índios do aldeamento vizinho de Guarita, acompanhados por seu diretor (MOREIRA NETO, 1971, p. 396).

Importante é a informação sobre a situação conflitiva criada em Nonoai por conta dessa política do governo imperial analisada por Moreira Neto, referindo-se aos dados do Relatório do presidente da província do Rio Grande do Sul, Correia Câmara. Diz ele:

O resultado desses conflitos em Nonoai foi severo em termos de depopulação: em 1857, restavam apenas 547 índios no aldeamento. Enquanto isso, na velha redução de $\mathrm{S}$. Nicolau, última remanescente da Província Guaranítica das Missões, criada pelos Jesuítas, eram recenseados 264 índios, a maior parte velhos e aleijados das guerras nesta província e Estado Oriental; e o Diretor Geral queixa-se de que os moços sejam todos recrutados (idem, p. 397).

\section{Aspectos Fundamentais da Colonização de Santa Catarina}

O objetivo imediato deste tópico é caracterizar os principais aspectos de um processo específico da colonização européia no Brasil, qual seja, a que ocorreu no território conhecido hoje como o Estado de Santa Catarina, enfatizando a região oeste. Desse modo, iniciar-se-á, de maneira geral, pela colonização do Brasil Meridional, chegando até o oeste catarinense. Para essa região, elencaram-se algumas questões, tais como: de que modo a colonização do oeste catarinense foi idealizada? Havia habitantes nessa região? E os imigrantes? Quem eram e de onde vieram? O que resultou desse processo? Esses são exemplos de algumas questões que ajudam a tecer o fio condutor do que segue abaixo.

Na tentativa de buscar respostas às questões acima, valeu-se de pesquisa bibliográfica, desde memórias de personagens, que participaram dessa "epopéia", até trabalhos acadêmicos de cunho científico, aliás, de muita valia, haja vista que contêm relatos de

Espaço Ameríndio, Porto Alegre, v. 7, n. 2, p. 277-556, jul./dez. 2013. 
KIMIYE TOMMASINO - Relatório de Identificação e Delimitação da Terra Indígena...

"pioneiros" e "caboclos" da época. O recorte temporal vai desde decênios de 1820 até meados da década de 1960, época em que a Companhia de Terras Sul Brasil, praticamente, já tinha dividido toda a área. Ressalta-se que não há um limite estanque, pois o cotidiano atual não esgotou desdobramentos e/ou consequências daquele processo.

O termo Brasil Meridional compreende os três estados do Sul do país: Paraná, Santa Catarina e Rio Grande do Sul. Desde já adverte-se que em relação ao Estado do Paraná se passará a "lo largo". Isso por se constituir o mais novo dos três estados, desmembrado da Província de São Paulo em 1853 e cuja imigração mais numerosa é eslava: polacos, russos, rutênios e ucranianos, não que a italiana e a alemã não repercutissem (WAIBEL, 1988, p. 219 e JAMES, 1947, p. 31), mas essas não interferem de maneira enfática nos propósitos desta análise.

De qualquer modo, a colonização do Brasil Meridional se origina a partir da independência do Brasil, em 1822. Justamente, através do resgate dos seus objetivos, também se compreendem os seus "porquês". Assim, de acordo com Waibel (1988), Renk (1997), Angeli (1998), Falcão (1999) e Werlang (1992), os principais objetivos eram: a substituição/complementação da mão-de-obra escrava; o povoamento de regiões de fronteiras com problemas políticos, principalmente fronteiras com o Paraguai, Argentina e Uruguai (soldados para o exército) nota-se que "entre 1824 e 1830, chegaram cerca de 2.500 soldados, engajados no Rio de Janeiro, que haviam sido alistados como colonos na Alemanha" (WERLANG, 1992, p. 94); o "amansamento", o aprisionamento ou mesmo o extermínio de grupos indígenas (exemplo, Botocudos, na Mata Atlântica); o povoamento extensas áreas de terras visando, primeiro, garantir as fronteiras e, segundo, sua valorização; e, por fim, o branqueamento da população constituída de índios, mestiços, mulatos e negros. A confluência de duas variáveis, o tempo e o local, é que vai sugerir a presença de alguns, se não de todos esses objetivos ao mesmo tempo.

Desse modo, procura-se aqui, buscando a objetividade, pôr em relevo as principais fases ou etapas da colonização. Estas, por sua vez, são subdivididas por acontecimentos históricos importantes pelo fato de atingirem a colonização como um todo. Ao mesmo tempo, será citada a ocupação espacial datando-se a fundação de colônias mais expressivas 
e visando-se proporcionar ao leitor uma localização geográfica (nortesul, leste-oeste) e, implicitamente, a presença, ou não, dos objetivos relacionados acima.

Despreende-se da leitura de Waibel (1988, p. 211-215) que se pode considerar o processo de colonização como marcado por duas etapas distintas: no Império (1822 a 1889) e na República (1889 aos dias de hoje). Já Espírito Santo (1999, p. 47), tratando da colonização do litoral catarinense, também indica duas etapas ou fazes: a organização oficial com características militares (1829 a 1850) e a organização privada com a instalação de grandes colônias (a partir de 1851). Entende-se, aqui, que há uma complementação entre esses dois autores.

Ao contrário da "colonização espontânea", no Brasil sempre houve um órgão planejador/gestor: governo imperial e federal, das províncias ou estados e municípios, as companhias particulares e proprietários de terras individualmente. Note-se que, se por um lado o objetivo de órgãos oficiais "aparecesse" ser o povoamento e demarcação de fronteiras, por outro lado, o objetivo das companhias particulares era estritamente o lucro. Não cabe aqui uma análise aprofundada da questão, porém, para o Estado a vantagem era não ter despesas e não aparecer como agente "colonizador", "pairando acima de todos" (RENK, 1997 , p. 115) e, para as companhias particulares, agiam sob a ótica mercadológica: tanto as florestas como as terras eram mercadorias a serem "transformadas" em lucros, e foram (WAIBEL, 1988; RENK, 1997; ANGELI, 1998; ESPÍRITO SANTO, 1999; ARAÚJO, 1999; WERLANG, 1992 e KRINDGES, 1999).

Com relação ao perfil dos colonos, nos moldes de um "ideal tipo", estes teriam que ser pequenos proprietários livres que exercessem regime de pequena economia familiar, tendo que ser, também, soldados (WAIBEL, 1988 e RENK, 1997). Esse "ideal tipo" foi encontrado na Europa Central com soldados "desengajados" do exército de Napoleão e pequenos agricultores "oprimidos". Também, era comum o fato de os colonos preferirem a zona de mata, de florestas, devido à pretensa fertilidade do solo. Inicialmente as "frentes pastoris" ocuparam os campos (séc. XVIII). Desse modo, enquanto os luso-brasileiros criavam gado em grandes fazendas, empregando índios, mestiços, mulatos e 
negros (descendentes de escravos), os imigrantes europeus, segundo Waibel (1988, p. 209) "cerca de 99,9\% dessa gente estabeleceu suas casas ou propriedades agrícolas na mata". De acordo com RENK (1997, p. 32), essa ocupação das matas pelos imigrantes ocorreu devido a essas terras estarem "livres", serem devolutas em sua maioria.

Quanto ao povoamento, este era disperso ou do tipo aglomerado. Os aglomerados localizavam-se de 8 a 16 quilômetros de distância, em geral em cruzamentos de estradas. Eram vilas onde se construíam moradias, pequenas indústrias (moinhos, fabricação de rodas); serviços (ferreiro); comércio; escola e cemitério, tudo ao redor da igreja. A vantagem era o convívio social, a desvantagem era a distância das terras de cultivo. Já os dispersos, ao longo de linhas, picadas abertas pelos pioneiros (linhas de comunicação e estrada), ou em ambas as margens de rios, áreas "compridas", entre 20 e 35 hectares $^{8}$, chegando as linhas a terem de 10 a $20 \mathrm{~km}$ de extensão, imperando "por toda a parte nas terras de matas do sul do Brasil, terras de povoamentos dispersos" (WAIBEL, 1988, p. 241-242).

Tomando esses pressupostos como válidos, as primeiras colônias alemãs no Brasil Meridional foram instaladas em locais estratégicos. $O$ antigo "Caminhos do Sul", o qual ligava Porto Alegre, Vacaria e São Paulo (Tropeirismo), entrava e saía das matas. Nessas, era comum a ocorrência de ataques de índios Botocudos (Xokleng) aos tropeiros. Visando a "proteção" contra esses ataques, em 1824, fundou-se a colônia alemã de São Leopoldo (RS), no vale inferior do rio dos Sinos, onde inicia a mata, para defender a "saída" da mata no "Caminhos do Sul". Por extensão, no rio Negro (hoje divisa entre Paraná e Santa Catarina), local onde o "Caminhos do Sul" saía da região florestal para atravessar o Rio Negro, foi fundada em 1829 a colônia alemã de rio Negro, para defender a "entrada" na mata. Fato similar ocorreu em Santa Catarina (na época não era incluída a região oeste), onde também em 1829 é estabelecida a colônia alemã de São Pedro de Alcântara no caminho de Lages a Florianópolis, no local onde a estrada saía das matas e atingia regiões já ocupadas pela frente pastoril (WAIBEL, 1988, p. 209-211).

Após esse primeiro momento, de maneira geral, até a

\footnotetext{
${ }^{8}$ Essa medida varia de autor para autor; foi tomada a menor medida inferior e a maior superior.
} 
Proclamação da República, três acontecimentos são importantes para a compreensão do processo de colonização: em 1830 é baixada uma lei proibindo gastos do governo imperial com imigração, reiniciando-se o processo em 1834 a cargo das províncias; em 1850 é promulgada a Lei de Terras proibindo a doação/concessão de terras. A aquisição de terras é possível somente através da compra; em 1859, a Prússia promulga o "reescrito de Heydt" proibindo a vinda de imigrantes alemães para o Brasil (revogada em 1896, somente para a região sul do Brasil), o que leva a busca de novos imigrantes.

Tendo esses acontecimentos como pano de fundo, fundaram-se "zonas" de colonos alemães e italianos em ambos os estados. Especificamente, quanto ao Rio Grande do Sul, após a Revolução Farroupilha (1835-1845), novas colônias foram fundadas: Colônia de Santa Cruz (1849), oeste de São Leopoldo; Colônia de Santo Ângelo (1855), vale do Jacuí, mais a oeste de Santa Cruz. Com a expectativa da Lei de Terras, companhias particulares compraram terras e colonizaram a região de São Leopoldo, Santa Cruz e Taquari, de modo que em 1870 já estava formada uma região de colonos alemães. Com o "reescrito de Heydt", formou-se uma região de colonização italiana ao lado da alemã. No período entre 1870 e 1871, foram fundadas as colônias de Caxias, Garibaldi e Bento Gonçalves na região superior do rio Taquari. Depois, em 1844, fundou-se a colônia de Alfredo Chaves (hoje Veranópolis) e, em 1876, a de Antônio Prado na margem norte do rio Taquari. Até aqui, praticamente, a colonização se deu no Leste do Estado, à exceção das colônias de Cruz Alta e de Santo Ângelo.

Com a Proclamação da República (1889), as terras devolutas passaram a pertencer aos estados, o que conferiu novo fôlego à colonização. No caso gaúcho, ela se expandiu para o extremo oeste, onde surgiu a colônia de ljuí em 1890 e a colônia de Guarani em 1891, formadas por poloneses, russos, italianos, alemães e luso-brasileiros; em 1912, as colônias de Cerro Azul e Panambi, ambas de origem alemã; e no centro-oeste, em 1897, as colônias de Não-me-Toque e General Ozório (também alemãs). Para o norte e noroeste do Estado, as margens do rio Uruguai, quando a estrada de ferro de Passo Fundo atinge Erechim, até meados de 1920, essas terras foram ocupadas por italianos, alemães, polacos e luso-brasileiros. Com a fundação de 
Guarita (1917) e Santa Rosa (1915), praticamente, acabaram-se as áreas para colonização no Estado gaúcho. Essa última frente pioneira para noroeste é apontada como uma das causas da migração para o oeste de Santa Catarina (os três últimos parágrafos foram compilados de Waibel, 1988 e Espírito Santo, 1999).

Com relação ao Estado de Santa Catarina, a exemplo do Rio Grande do Sul, a colonização foi do sentido leste para o oeste: o litoral, depois o planalto e, por último, o oeste (meio oeste ao extremo oeste). Digno de nota é que, apesar da colonização do Estado gaúcho ter sido realizada também por companhias particulares, de acordo com Waibel (1988, p. 216), ela é "aplicada pela primeira vez, em larga escala" na colonização do Estado catarinense. Segundo Werlang (1992, p. 10) e Espírito Santo, (1999, p. 44-45), uma primeira frente de colonização atingiu a ilha de São Francisco fundando a Vila Nossa Senhora do Desterro (atual Florianópolis) em 1662 e Santo Antônio dos Anjos da Laguna em 1682 (hoje Laguna), pelos "Vicentistas" (São Vicente e Piratininga, de São Paulo). Desterro, devido à sua localização estratégica, foi elevada a "Capitania Subalterna de Santa Catarina" em 1738, subordinada ao Rio de Janeiro. Já no século XVIII, colonos portugueses de Açores juntamente com paulistas, se fixaram no litoral desde Desterro até Laguna, entre 1748 e 1756.

Ainda, segundo Espírito Santo (1999, p. 47), os primeiros colonos alemães "fundaram a colônia de São Pedro de Alcântara em 1829", nas proximidades de Florianópolis (já mencionada anteriormente). Em 1851, também fundaram a colônia Dona Francisca, hoje Joinvile. De acordo com Waibel (1988, p. 216), foram para o interior, fundando uma "colônia-filha", São Bento (1870), subindo o planalto da escarpa da serra. Blumenau foi organizada a 100 quilômetros ao sul de Joinvile (rio Itajaí), pelo Dr. Hermann Blumenau. A companhia "Hanseatische Kolonisationsgesellschaft" ou "Hansa", como era conhecida, juntamente com a companhia "Hamônia" (cuja sede hoje é Ibirama), em meados de 1897, foram responsáveis pela colonização da bacia dos rios Itajaí, Itajaí do Norte, do Oeste, do Sul e Itajaí-Mirim. Deste modo, desde Joinville até Brusque (colônia alemã da década de 1860), a colonização predominante era a alemã. Ao norte de Joinville, estabeleceram colônias menores, ao longo do rio Iguaçu e Negro as quais se expandiram no 
sentido oeste, servindo-se do rio Iguaçu (WAIBEL, 1988, p. 217-218).

Os italianos iniciaram a colonização em 1836 na bacia do rio Tijucas. Eles fundaram municípios como: Nova Trento e Nova Itália. Entre 1870 e 1880, fundaram no litoral sul as colônias de Orleães, Uruçanga e Crisciúma. A colônia polonesa é instalada em 1882, estes formaram os municípios de Turvo (1882), Grão-Pará (1900), Major Gercino (1895) e Guaramirim (1890). Quanto ao planalto, como foi visto acima, o "Caminhos do Sul" ía de Porto Alegre (RS) até Sorocaba (SP) passando pelo planalto de Lajes e influenciando na sua povoação. De acordo com Espírito Santo (1999, p. 47-49), a fundação de Lajes data de 1771, porém, há registro de povoamento já em 1766 (THOMÉ, 1984, p. 08). Essa povoação faz parte da "Frente Pastoril" que formou grandes fazendas criadoras de gado, indo desde "os 'questionados Campos de Palmas', ao norte e ao 'Vale do Rio do Peixe', ao oeste" (Idem, ibidem).

Até então, os "limites" do Estado catarinense eram o rio Uruguai ao sul, o rio Iguaçu ao norte e proximidades do rio do Peixe ao oeste. Indo mais para o interior, para o meio e extremo oeste, a região que compreende ao sul o rio Uruguai, ao oeste o rio Peperi-Guaçu e a leste o rio do Peixe, era uma área de fronteira litigiosa entre o Paraná e a Argentina. Isso porque durante a vigência do Tratado de Tordesilhas essa região pertencia aos espanhóis e, depois, com o Tratado de Madri, passou a pertencer a Portugal, não obstante isso, formou-se uma comissão com integrantes dos dois países buscando concretizar o que foi estabelecido no Tratado de Madri, entre

[...] 1775 e 1777, anos em que percorreram a região os componentes da comissão mista, formadas por representantes de Portugal e Espanha, objetivando a execução do que havia sido estabelecido pelo Tratado de Madri (BRANCHER, 1999, p. 202).

Porém, os limites da fronteira continuaram sendo questionados pela Argentina, como diz Werlang (1992, p. 01), "Em 1895, sob a arbitragem do Presidente Cleveland, dos Estados Unidos, a região passou a pertencer definitivamente ao Brasil". Espírito Santo (1999, p. 49) expõe o desfecho do conflito em que a disputa do extremo oeste catarinense pela Argentina e Brasil foi resolvida em 1903, "conhecida 
como 'questão das Missiones' ou 'Palmas', foi resolvida em favor do Brasil", tendo como fronteira o rio Peperi-Guaçu, sob a administração do Estado do Paraná.

Aliás, cabe comentar aqui que essa região será tida como "Território Federal do Iguaçu", acrescentando-se a nordeste as cidades de Mangueirinha e Laranjeiras do Sul e a noroeste a cidade de Guaíra. Com "[...] o objetivo de fomentar o desenvolvimento dessa região, o Governo Getúlio Vargas criou, em 1943, o Território do Iguaçú" (FOLADOR, 1991, p. 58-62). Também, conforme afiança Lohn (1999, p. 44) "[...] mais tarde, entre 1943 e 1947, a região oeste chegou a formar o Território do Iguaçu", e Brancher (1999, p. 202), referindo-se a região enfatiza "[...] alguns intelectuais daquela época defendiam, inclusive, a criação de um novo Estado, o do Iguaçu, resultado da fusão de Santa Catarina com o Paraná". Porém, conforme Angeli (1998, p. 158) "[...] se os políticos de Santa Catarina e Paraná, introduziram, em Disposições Gerais na constituição de 1946, o artigo que extinguia o Território Federal do Iguaçu", a campanha para o reconhecimento do Estado do Iguaçu ainda é atual, tendo seu início na década de 1960. Continuando diz o autor "[...] a Câmara municipal (Dionísio Cerqueira), em memorável reunião a dois de fevereiro de 1962, aprovou uma monção de apoio à campanha, e lançou um manifesto, que teve repercussão nacional" (Idem, p. 130).

Logo após a atual região oeste de Santa Catarina passar para a administração do Paraná, teve início um novo conflito conhecido como "Guerra do Contestado". O governo imperial, em 1889, através do Decreto número 10.432, autorizava a Teixeira Soares e a Estrada de Ferro de São Paulo - Rio Grande do Sul a construção de uma estrada de ferro ligando os dois estados. Como pagamento da obra, receberiam 30 quilômetros de terras ao longo de cada lado da estrada. O governo republicano reconhece o Decreto Imperial, porém diminuiu para 15 quilômetros as terras concedidas. Depois, em 1907, a Companhia Brazil Railway assumiu o controle acionário para a construção da estrada obtendo a concessão das faixas de 15 quilômetros de terra. A estrada atinge o Estado catarinense em Porto União, depois São João, Caçador e, seguindo a direção do vale do rio de Peixe, chega a Marcelino Ramos já em solo gaúcho. Como mão-de-obra para a construção da estrada, a 
KIMIYE TOMMASINO - Relatório de Identificação e Delimitação da Terra Indígena...

companhia havia trazido cerca de 10.000 pessoas, já com o compromisso de colonizar as terras à beira dos trilhos (RENK, 1997, p. 42; ESPÍRITO SANTO, 1999, p. 50; WERLANG, 1992, p. 19, 20 e 34 e PIAZZA, 1982, p. 213).

Como a companhia não foi bem-sucedida nesse intento e a concessão caducava em 1932, a partir de 1911, o Governo autorizou a companhia a vender as terras obtidas através de concessão às companhias particulares de colonização. Ocorre que aquelas terras já eram habitadas por "sertanejos" e/ou "caboclos" havia alguns anos e mesmo por ex-trabalhadores da própria companhia, "abandonados à própria sorte". Na eminência de perderem suas "terras" e sob a orientação do monge José Maria, eles organizaram um movimento reivindicatório e se dirigiram para o oeste do rio do Peixe, já nas proximidades do rio Irani. Como essa região, à época, era administrada pelo Paraná, este, auxiliado pelo exército Federal, ataca os "contestadores" ocorrendo a primeira batalha em 1912 (ESPÍRITO SANTO, 1999, p. 50-51). Conforme Werlang (1992, p. 01), o ataque ocorreu pela "[...] polícia particular da Estrada de Ferro São Paulo - Rio Grande e o Exército Brasileiro". Houve ainda resistências além do Contestado, porém eram grupos pequenos e isolados de posseiros facilmente derrotados pelas companhias, sem maiores repercussões em nível de país. O último reduto dos "contestadores" foi destruído em 1915: "[...) chegou a envolver 20.000 caboclos, 6.000 soldados e 1.000 vaqueanos, cujo desfecho deu-se em 1915" (ESPÍRITO SANTO, 1999, p. $50)$.

Outro acontecimento relevante é a "questão fundiária" que, com a República, passa para a responsabilidade dos estados. Quando a companhia de Estrada de Ferro São Paulo-Rio Grande começa a colonização pelo lado oeste do rio do Peixe "já havia títulos de terras expedidos desde o século XVIII". Para não causar prejuízos para a companhia, o Paraná concedeu grandes áreas de terras no extremooeste do Estado "nos anos de 1911, 1912 e 1913" (RENK, 1997, p. 42). Após a Guerra do Contestado, o Estado de Santa Catarina ganhou na justiça aquela região do oeste, até então administrada pelo Paraná, "questão resolvida em 1915, com a intermediação do Governo Federal", sendo o acordo "assinado em 20 de outubro de 1916 no Palácio do 
KIMIYE TOMMASINO - Relatório de Identificação e Delimitação da Terra Indígena...

Catete, Rio de Janeiro e reconhecido pelas Assembléias Estaduais do Paraná e de Santa Catarina em 1917". Assim, "em 15 de agosto de 1917, através da Lei número 1.147, Santa Catarina cria os municípios de Mafra, Porto União, Cruzeiro e Chapecó" assumindo o Estado as atuais delimitações geográficas, "sendo que somente o município de Chapecó fica com a metade da área, 14.000 quilômetros quadrados, situado onde era o então Passo dos Índios" (WERLANG, 1992, p. 01, 20-21).

Conforme demonstra a figura $\mathrm{n}^{\circ} 10$, referente ao ano de 1917 , os limites da região oeste catarinense são o rio Uruguai ao sul (divisa com o Rio Grande do Sul), rio Iguaçu ao norte (divisa com o Paraná), rio Peperi-guaçu a oeste (fronteira com a Argentina) e, interiormente ao Estado catarinense, o rio do Peixe a leste. Também, demonstra a área do recém-criado município de Chapecó que, conforme relatou-se acima, foi criado em 15 de agosto de 1917, com sede na localidade de Passo Bormann. Em setembro de 1919, a sede do município foi transferida para a vila de Xanxerê ficando até abril de 1931, sendo transferida novamente para Passo dos Índios, local onde hoje existe a cidade de Chapecó. Em março de 1938, a sede municipal passou a chamar-se Chapecó. Dionísio Cerqueira foi criado como distrito de Chapecó em dezembro de 1917 com a denominação de Barracão; em 1938 passou a chamar-se Dionísio Cerqueira e foi emancipado em dezembro de 1953. Campo Erê foi criado como distrito do município de Chapecó em dezembro de 1917, emancipou-se em junho de 1958. São Domingos foi criado como distrito do município de Chapecó em dezembro de 1917; quando Xaxim foi emancipado em 1953, São Domingos passou a ser seu distrito, do qual se emancipou em novembro de 1962. Chapecó Grande foi criado como distrito do município de Chapecó em dezembro de 1917; em março de 1922 passou a chamar-se Abelardo Luz, emancipou-se em julho de 1958. Xanxerê foi criado em dezembro de 1917 como distrito do município de Chapecó; em 1923 passou a chamar-se Rui Barbosa, mas retomou o nome de Xanxerê em 1929; foi sede do município de Chapecó de 1919 a 1931, emancipou-se do mesmo em dezembro de 1953. 
KIMIYE TOMMASINO - Relatório de Identificação e Delimitação da Terra Indígena...

\section{Figura 10}

\section{7}

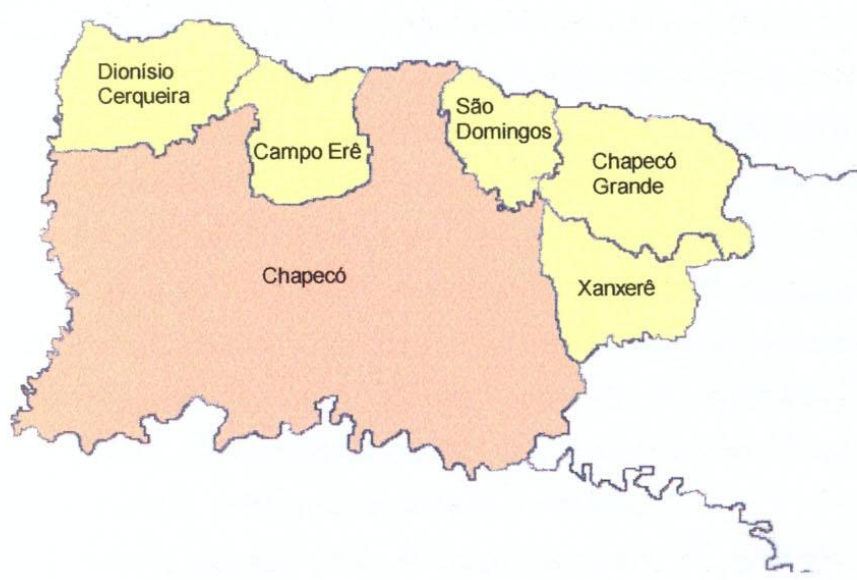

Municípios

Distritos

Fonte:

Werlang, Alceu Antonio. 1992.

Censo Demográfico - IBGE - Anos 40, 50, 60, 70 e 80.

Espaço Ameríndio, Porto Alegre, v. 7, n. 2, p. 277-556, jul./dez. 2013. 
KIMIYE TOMMASINO - Relatório de Identificação e Delimitação da Terra Indígena...

A intenção do governo catarinense era a colonização dessa região, pois na sua ótica era necessário ocupar o território "vazio" para incorporá-lo efetivamente. Segundo Waibel (1988, p. 218), em 1916, com o fim da Guerra do Contestado, a região oeste "era habitada principalmente por foragidos da lei provenientes de áreas vizinhas" tanto do Paraná, do Rio Grande do Sul, como da Argentina e do Paraguai. Porém, essa é uma faceta da concepção que se tinha da região pelas elites catarinenses. Ao explicitarmos os entraves para a colonização, de acordo com essas elites, temos uma noção mais ampliada de como aquela região era concebida. Assim, de acordo com Renk (1997, p. 50-51), para o projeto de colonização, basicamente, havia três obstáculos: 1) o "caos" e a "violência" a que a área era associada - esse obstáculo ter-se-ia se resolvido com o Contestado; 2) O "caudilhismo", isto é, a disputa no campo político entre coronéis locais em Chapecó e Cruzeiro - a questão foi solucionada por pessoas de fora que assumiram as demais superintendências dos dois municípios. Se, para as elites do governo, com essas duas questões resolvidas a região estava "pacificada", caberia solucionar o último obstáculo, 3) a "desnacionalização" da população local, que teria que ser "nacionalizados", pois

[...] Dionísio Cerqueira, na fronteira da Argentina, por seus 'fracos' vínculos com Santa Catarina. Esta localidade dependia quase totalmente da Argentina, onde as crianças freqüentavam escola, onde eram registrados os nascimentos, casamentos e óbitos, bem como os contratos comerciais; além disso, de Buenos Aires vinha o café consumido, bem como a cerveja e o fósforo.

Esses fatores servem para embasar, por parte do governo, a colonização da região. Porém, não tocam na questão relevante que confere fundamentos àquele discurso, ou seja, se é que havia "caos", "violência", "caudilhismo" e "desnacionalização", é porque havia pessoas habitando aquela região. Esses termos são utilizados, no discurso oficial, de forma vaga, podendo ser atribuídos a todos e, ao mesmo tempo, a ninguém.

Espaço Ameríndio, Porto Alegre, v. 7, n. 2, p. 277-556, jul./dez. 2013. 
De fato, de acordo com Thomé (1984), Renk (1997), Brancher (1999), Wollf (1999) e Espírito Santo (1999), o primeiro grupo de bandeirantes paulistas que adentrou para explorar especificamente essa região é datado de 1641 (para Thomé é 1679), "coincidindo" com a criação dos Sete Povos das Missões. O grupo atingiu o "Velho Chapecó", indo em direção ao Rio Grande do Sul e encontrou populações nativas, grupos "caigangues" e "alguns elementos guaranis". Em 1720, o bandeirante Zacarias chegou, também, ao rio Anhanguera (rio Chapecó). Como foi visto anteriormente, em 1717 representantes de Portugal e Espanha percorreram a região para verificar a questão do Tratado de Madri. No período de 1730 a 1870, ocorreu o "Ciclo do Tropeirismo", rota de transporte de mulas e gado para Minas Gerais e São Paulo. Interessante é o roteiro do caminho: desde Guarapuava, passando por Palmas, rios Chapecó e Chapecozinho, Campina do Xanxerê, Serra do Tigre, Passo Ferreira, Passo Carneiro, depois o chamado Passo Bormann, Goio-En, indo até Nonoai e Cruz Alta no Rio Grande do Sul.

Com o declínio do Tropeirismo, também declinaram as fazendas de criação ocorrendo a dispersão das famílias dos fazendeiros. Os excedentes da população das "fazendas de criar", desde Palmas, Erê, Irani e Lages, expandiram-se para Chapecó ao sul e Mangueirinha ao norte, região de pinheiros e matas, cultivavam pequenas lavouras e extraíam erva-mate. A grande maioria dessa população era composta de brasileiros e argentinos. Devido ao litígio com a Argentina, instalaramse duas colônias militares: Chopim ao norte e Chapecó ao sul, com o objetivo de proteger contra os índios e de catequizá-los. Nessas colônias, era possível haver a distribuição de terra aos colonos nacionais, mestiços e estrangeiros. Com as revoluções Farroupilha e Federalista (1835 e 1893), ocorreu a migração de colonos em fuga, daí resultando que

da Colônia Militar de Chapecó, ao sul, Goio-En, ao norte e até próximo ao Peperi-Guaçu, teve sua população com um importante incremento, como exemplo, a colônia de Xanxerê elevou sua população a 800 habitantes em 1898 (RENK, 1997, p. 40).

"Nessa época já havia povoamento relativamente consolidado 
tanto em Chapecó como em Campo Erê, pois já em 1838/39, o mineiro José Raymundo Fortes [...] se estabelecera [...] a menos de 6 quilômetros da atual cidade de Chapecó". "Também eram conhecidos os primeiros moradores dos Campos do Erê [...] as famílias Lara, Machado, Joaquim Afonso, entre outros, que habitavam essa região desde 1858" (FOLADOR, 1991, p. 86). Já, no século XX, Werlang (1995, p. 36), relata a formação de "novos núcleos" de caboclos durante o processo recente de colonização do oeste catarinense. Assim,

Num cadastro feito pela Companhia (Sul Brasil), em agosto de 1952, nas seções de Burro Branco, Lageado Grande, Mundo Novo, Cedro, Rabicó, Jundiá e Lageado, demonstra-se que residiam somente ali 402 famílias posseiras, num total de 3.191 indivíduos, numa média de 7,93 elementos por família.

Em resumo, de acordo com Thomé (1984, p. 09), no início do século $\mathrm{XX}$, a região era habitada por

alguns grupos indígenas de remanescentes tribos Guarani e Kaigangue; Famílias e ex-trabalhadores da estrada de ferro São Paulo-Rio Grande; antigos caboclos, oriundos das frentes expansionistas paulistas; remanescentes da Revolução Farroupilha e Guerra do Paraguai; grupos isolados de imigrantes poloneses e alemães vindos do Paraná para o sertão do Contestado; fazendeiros, caudilhos gaúchos com posses de grandes fazendas.

Em que pese o argumento do governo em colonizar essa região para preencher o "vazio" populacional, havia um importante contingente de "brasileiros" nessas paragens, o que foi visto acima são as suas "origens". Segundo Renk (1997, p. 11), essas pessoas possuem uma singularidade, que Ihes confere características próprias, constituindo um "grupo étnico". Saliente-se que, a autora realizou um estudo com pioneiros, "brasileiros" e colonos em Ponte Serrada (desmembrada de Joaçaba) e Vargeão (desmembrada de Chapecó), mas que devido às características similares, esse estudo pode ser estendido a toda a região, "Apesar de se tratar de um caso particular, a trajetória desse grupo pode ser estendida a toda a região oeste, pelos antecedentes

Espaço Ameríndio, Porto Alegre, v. 7, n. 2, p. 277-556, jul./dez. 2013. 
KIMIYE TOMMASINO - Relatório de Identificação e Delimitação da Terra Indígena...

históricos comuns" (idem).

A autora constatou, em sua pesquisa de campo, que há uma autodenominação por parte dessa população "nesse tempo 'era tudo brasileiro', 'só brasileiro', pois habitavam na 'nação brasileira', daí a autodenominação de brasileiros" (RENK, 1997, p. 138-139). Entre os brasileiros, raramente há família nuclear; podem ser encontradas duas, até três gerações e "criadinhos" (um agregado com vínculo de parentesco, compadrio ou mesmo sem nenhum vínculo), vivendo sobre o mesmo teto formando "uma unidade indivisível de produção". A autoridade pertencia aos mais velhos, pais (chefes) de família, principalmente por trazerem o sustento para dentro de casa. Era ele quem governava a família. Em relação aos filhos homens, saíam da autoridade do pai com a maioridade (entre 18 e 22 anos), ou com o casamento, já as filhas saíam da autoridade do pai só quando casassem e passavam para a autoridade do marido. A divisão do trabalho, onde a "luta" era na roça, toda família trabalhava, ficando o trabalho pesado para o homem adulto e o mais leve para as mulheres e crianças. Quando a "luta" era na erva, poderiam ocorrer duas situações: 1) os homens adultos iam para a extração da erva e as mulheres e crianças ficavam "tocando" a roça, e 2) a família toda ia para a extração da erva-mate, onde os homens realizavam o trabalho pesado, perigoso (a poda da erva) e as mulheres e crianças o serviço mais leve. Quanto maior for a ocorrência da expropriação, mais ocorre essa segunda situação, sendo a que predomina atualmente. As mulheres, tanto no rancho como nas cabanas de lona nos ervais, são responsáveis pelo serviço doméstico e o cuidado das crianças, assim, é ela quem administra a casa, quem gerencia a casa.

Era uma população católica (hoje há uma parcela de crentes) praticando o "catolicismo popular", a "devoção antiga", "o católico forte", com diferenças em relação ao catolicismo oficial, sobretudo, devido à escassez de clero e de igrejas. Como exemplo, cita-se o batismo em casa (quando fosse possível se batizava na igreja) e as crenças nos monges São João Maria Agostinho (ou Agostini), conhecido por São João Maria e o Monge José Maria (o que atuou no Contestado). Na ausência destes, cabia ao "capelão", alguém do lugar, "oficiar" as rezas. Em relação à violência "só se morria de mandado (raio), de pontada 
(pneumonia) e de bala, por motivos políticos, questões de terra, assassinatos de honra e, em menor escala, de roubos". Sendo que a "defesa da honra não era considerada crime, mas algo que deveria ocorrer". Vem daí os "valores considerados nobres a lealdade, a honra e a coragem, esta era a maior virtude". Permeando esse cotidiano, não havia avareza e o pensamento estava sempre voltado para o presente, para o "dia-de-hoje". "Era tudo pobre, mas pobre era modo de dizer, porque tinha fartura de comida, de terra e de saúde". Porém, essa "pobreza com fartura" será tida como algo negativo, "a esta população, pesava e pesam acusações de ser fatalista, preguiçosa, pobre e resignada a pobreza", pois "o economizar, o poupar, o acumular e investir não eram incluídos no rol de suas atividades econômicas. Mesmo a fração abastada da população demonstra desapego ao dinheiro" (RENK, 1997, p. 51, 59, 100-102, 125, 144-145, 149). Dentre outros elementos, destaca-se a abundância de terra; ela "sempre foi apresentada como abundante e sem concorrência, não era vista como mercadoria, nem como patrimônio moral". É interessante pôr em relevo como os brasileiros concebiam a terra e sua posse; não a viam como mercadoria, conforme as palavras de dois brasileiros, "Naquele tempo diziam, pra que comprar? É do Brasil. Ninguém comprava, tinha fartura de terra. Enjoava aqui, ia prá lá. Depois, foram entrando os gringos com ganância de terra, a terra foi escasseando".

[...] Naquele tempo era tudo folgado. Terra tinha à vontade.

- De quem era a terra?

- Mas era do governo. Não precisava pedir para fazer um ranchinho, agora tá tudo mudado.

- Tinha aquele ditado que dizia: 'o Brasil é nosso, pra que comprar a terra?' A terra era do governo, do Estado. Depois ele (Estado) vendeu pra companhia e ela vendeu tudo.

De acordo com a autora, "a propriedade da terra foi remetida ao estado, mas na seguinte lógica: se era do estado era também do ocupante, a forma costumeira da apropriação da terra era a posse" (RENK, 1997, p. 111-112).

Nesse contexto, a subsistência era garantida através de duas 
áreas distintas: 1) a área da mata, a grande maioria, onde cultivavam pequena lavoura, criação de animais, extração de madeira e de ervamate, e 2) área de pecuária, na "lida campeira", eram a minoria e "desprezavam a lavoura pelo seu imobilismo". Quanto à extração da madeira, segundo Brancher (1999, p. 204), era cortada e transportada pelos "balseiros", através do rio Uruguai, para ser comercializada na Argentina. Essa atividade foi responsável pela criação do município de São Miguel do Oeste - seu primeiro rancho de taquara foi construído em 23 de março de 1940 - elevado a município em 1953. Nas palavras de Angeli (1998, p. 151) "[...] transportavam a madeira rio Uruguai abaixo, até São Borja (San Thomé) na Argentina".

A pequena lavoura ou a "roça cabocla" era dividida em "terras de plantar" e "terras de criar". As de plantar se localizavam longe de casa, onde havia cursos d'água. Derrubava-se a madeira, efetuava-se a queimada e plantava-se nas cinzas. Na próxima safra, era escolhida outra área realizando a rotação de terras. As "terras de Criar" eram próximas à casa; criavam-se porcos, galinhas, cavalos e alguns bovinos soltos $^{9}$. A colheita era armazenada num paiol feito de taquara na própria roça e transportada para a casa num cargueiro (mula com dois sextos de cada lado) somente o que era consumido no dia. Tanto a casa como as "terras de criar tinham menos imobilidade", já as "terras de plantar", eram mudadas a cada safra (RENK, 1997, p. 96-97). Segundo Waibel (1988, p. 225), os colonos antigos do Brasil Meridional também praticavam esse sistema de plantio, "cuja população rural denomina de roça, capoeira ou coivara", assim,

Tanto os alemães como todos os demais colonos europeus, receberam dos índios não somente o sistema de rotação de terras, mas também as plantas cultivadas por estes (milho, feijão preto, mandioca, batata doce) e até a ferramenta indígena, a cavadeira ou bastão de plantar.

O sistema de "pequena Lavoura" era realizado nos períodos de entresafra da extração de erva-mate, atividade que proporcionava a maior renda (e proporciona hoje, talvez, a única renda). É uma atividade

${ }^{9}$ Com a colonização, será criada a "Lei de criar Preso" para não prejudicar as lavouras dos colonos.

Espaço Ameríndio, Porto Alegre, v. 7, n. 2, p. 277-556, jul./dez. 2013. 
perigosa, pois há que "trepar" no pé de erva-mate (llex paraguaiensis) e cortar os galhos com um facão; um descuido pode ocasionar mutilação. Também, os "ervais" existiam em "manchas", áreas da mata onde se encontravam os pés de erva-mate, depois de podado, o erval necessitava (e necessita) de um período de carência de três anos para ser podado novamente, levando a população ao "nomadismo": "[...] a atividade extrativa sempre esteve vinculada à população nômade" (RENK, 1997, p. 96).

Como já foi enfatizado, para o governo era necessário preencher o "vazio" populacional na região oeste catarinense. Para alguns autores, numa perspectiva evolucionista, a região oeste era vista como em estado de "barbárie", sendo necessário fazê-la passar para a "civilização", favorecendo a "vocação agrícola inerente ao país". Isso seria possível com a vinda de colonos europeus, denominados colonos de origem (RENK, 1997, p. 48). Novamente, o "ideal tipo" é a família européia, agricultora, o agente capaz de levar a cabo o "progresso", a "civilização" para a região trabalhando em regime de agricultura familiar, com "braços laboriosos" (RENK, 1997 e WERLANG, 1992). Notese que "em 1950, a região oeste já era apontada como o celeiro do Brasil" (RENK, 1997, p. 52). Nesses termos, a questão era como realizar tal empreitada e a resposta veio através das companhias de colonização particulares, aliás, um processo que já havia sido iniciado com as concessões de terra conferidas a BRAZIL RAILWAY. Assim, as principais companhias que atuaram na região oeste catarinense, foram:

- BRAZIL RAILWAY COMPANY: Companhia Norte Americana. Recebeu terras do Estado pela construção da Estrada de Ferro São Paulo-Rio Grande, totalizando 4.799.236.000 metros quadrados de terra (WERLANG, 1992, p. 19-20).

- BRAZIL DEVELOPMENT E COLONIZATION COMPANY: Subsidiária da BRAZIL RAILWAY, com sede em Portland, EUA. Em 1925, delegou suas terras a outras companhias (WERLANG, 1992, p. 04-40).

- Empresa Construtora e Colonizadora Oeste Catarinense: Foi criada em três de maio de 1920, com capital de empresários gaúchos. Recebeu do Estado, como pagamento pela construção de estradas de rodagem, um total de 2.772.835.111 metros quadrados de terras, equivalente a 11.091 colônias de 25 hectares cada. O limite de suas terras ia desde o 
rio Chapecó ao leste, rio da Anta ao oeste até o rio Uruguai ao sul. Em 1925 ela é sucedida pela Companhia Territorial Sul Brasil (WERLANG, 1992, p. 03, 05, 30-34, 49).

- Bertazo \& Maia: Criada em Passo Fundo em 1920, transfere a sede para Chapecó sendo a última a receber terras do Estado pela construção de estradas de rodagem (WERLANG, 1992, p. 27, 43-44).

- Companhia Territorial Sul Brasil: Criada a 23 de maio de 1925 (faliu em 1955), com sede em Porto Alegre, sucessora da colonizadora Oeste Catarinense. Colonizou a maior parte do oeste catarinense. Podem-se citar os municípios de São Carlos, Saudades, Pinhalzinho, Caibi, Riqueza, Palmitos, Cunha Porã, Maravilha, Iraceminha, Modelo, Serra Alta, Sul Brasil e São Miguel da Boa Vista no território de sua atuação (KRINDGES, 1999, p. 21-22 e WERLANG, 1992, p. 02, 49-50).

- Empresa Colonizadora Chapecó Peperi Ltda: Fundada entre 1922 e 1924 em Carazinho (RS). Instalou-se em Mondaí (SC) (FOLADOR, 1991, p. 79). Comprou terra da Brazil Development (WERLANG, 1992, p. 27; 40-42).

- Firma Colonizadora Barth, Benetti \& Cia Ltda: Fundada em 27 de janeiro de 1940, com sede em Caxias do Sul (RS), comprou terras da Brazil Development (WERLANG, 1992, p. 27-43).

- Colonizadora Pinho e Terra; Colonização e Madeiras Oeste Ltda: Também compraram terras da BRAZIL DEVELOPMENT, atuam na colonização do extremo oeste catarinense (ANGELI, 1998 e FOLADOR, 1991).

- Wolksverein: Sociedade gaúcha de alemães católicos, comprou terras da Brazil Development e da Chapecó Peperi (WERLANG, 1992, p. $27,42-43)$.

Segue abaixo a Figura $\mathrm{n}^{\circ} 11$, que contém a "área de atuação das companhias colonizadoras", colocando em relevo a área de atuação da Companhia Territorial Sul Brasil: 


\section{O OESTE CATARINENSE E AS CIAS COLONIZADORES}

Figura 11

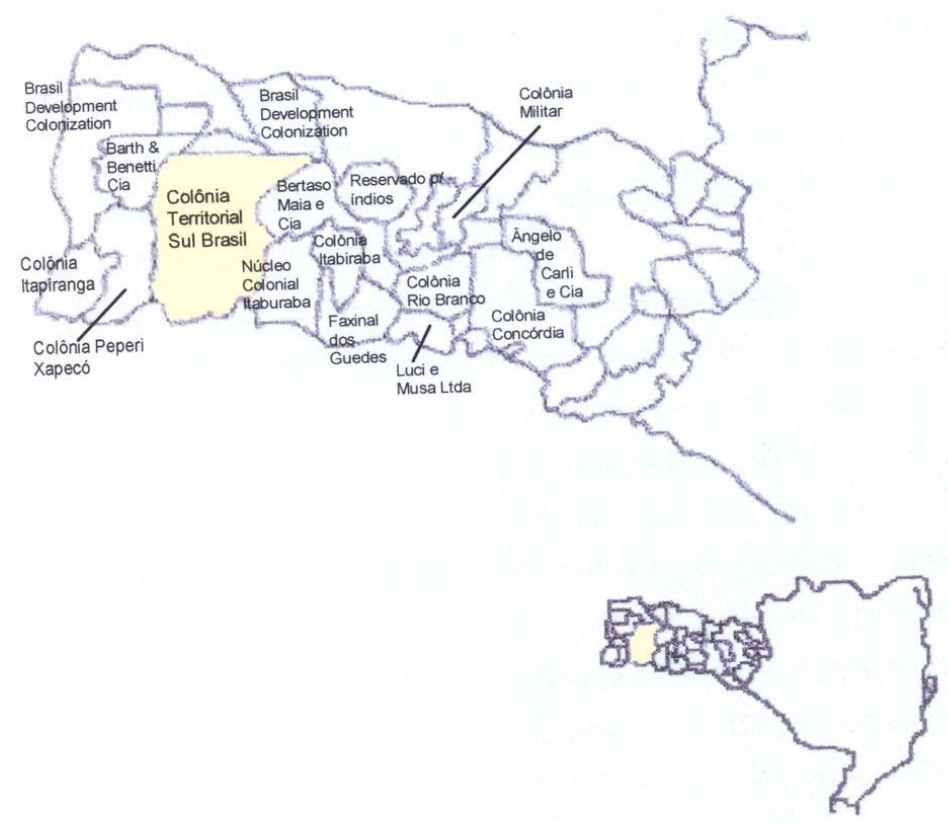

Fonte: Piazza, 1982:214

Espaço Ameríndio, Porto Alegre, v. 7, n. 2, p. 277-556, jul./dez. 2013. 
Para os propósitos deste relatório, será analisada a atuação da Companhia Oeste Catarinense e sua sucessora Companhia Territorial Sul Brasil, responsáveis pela colonização da Terra Indígena Araça'í. Segundo Werlang (1992, p. 04-06; 1995, p. 10), a partir de 1895 é que se inicia a "ocupação mais efetiva da região" oeste catarinense. As concessões de terras eram realizadas pelo governo com "preço bem abaixo do valor real", gerando uma disputa pelas mesmas entre as companhias colonizadoras, "acabava vencendo quem tivesse o maior poder político", através de "influência política", junto ao Estado catarinense. Como exemplo, sabe-se que as áreas colonizadas pela Sul Brasil também eram requeridas pela Brazil Development, nas palavras do autor "Pesou, no caso, a força dos deputados estaduais Henrique Rupp Junior e Abelardo Luz, filho do então governador Hercílio Luz, acionista da empresa Construtora e Colonizadora Oeste Catarinense". Como já foi enfatizado, as terras eram concedidas como pagamento pela construção de estradas. No caso da Companhia Oeste Catarinense (depois Sul Brasil) "para cada metro linear de estrada construída em terrenos regulares, o Estado cedia em torno de 10.000 metros quadrados de terra" (WERLANG, 1992, p. 30). Resulta que as companhias lucravam duplamente, pois recebiam as terras com valor abaixo do valor real e contratavam empreiteiras para a construção da estrada, também abaixo do valor contratado com o Estado (WERLANG, 1992, p. 165-166).

As terras colonizadas pela Sul Brasil eram loteadas previamente, já delimitadas as áreas rurais, lotes ou chácaras, e as áreas urbanas, já preestabelecido onde seria efetuada a construção de, por exemplo, a igreja e a escola (WERLANG, 1992 e FOLADOR, 1991). A ocupação ocorria a partir da melhores áreas, próximas a nascentes de águas, planas e sem madeira, depois, as áreas com um declive não muito acentuado, mas já com madeira, e por último as áreas acidentadas, com madeira e "enguiçadas", sendo que o "enguiço" era a "presença de intrusos" (termo usado para designar os posseiros pela companhia) (RENK, 1997, p. 114). Nesse sentido, a companhia efetuava a "limpeza" da área. De fato "a companhia teve a seu encargo a 'limpeza da área' ocupada por posseiros, para 'não prejudicar os colonos'" (RENK, 1997, p. 65). Aliás, não bastava desocupar as terras, "era necessário para o 
empreendimento da companhia que os brasileiros não retornassem, obrigava-o a assinar um termo no qual se comprometia a deixar definitivamente as terras da Sul Brasil" (WERLANG, 1992, p. 76). Nas palavras de um colono pioneiro de Varjão e Ponte Serrada, a companhia "tomava a seu encargo a retirada e a dispersão dos estabelecidos, a fim de não comprometer o seu empreendimento comercial e 'não prejudicar a gente', isto é, o comprador" (RENK, 1997, p. 107).

A Companhia Sul Brasil utilizou de táticas como forma de expropriação dos posseiros (limpeza da área), uma delas era o "não enfrentamento" (WERLANG, 1992, p. 81). Assim, segundo Royer (1999, p. 105), em relação ao município de Saudades, em torno de 1930, os caboclos que ali residiam foram "solicitados" pela companhia a deixarem a área para ser realizada a demarcação. Em troca receberam a

promessa de que poderiam escolher uma área de terra em lugar que eles desejassem a qual thes seria doada pela Companhia. Por meio de diversos depoimentos, sabe-se, que as terras ficaram apenas na promessa.

Outra tática foi a da compra e venda dos lotes, "assim os caboclos podiam comprar, mas era estratégia da companhia para que deixassem as terras pacificamente, pois sabia que não poderia pagar" (WERLANG, 1992, p. 76). De acordo com o Sr. Fontoura de Castro (informante do autor),

se dizia compra ou te arranca ... não podiam comprar dava aquela folia. Mas tinha que saí, chegava uns colono mais reforçado, bem armado de espingarda. As vezes dava morte. Quem era de bem agarrava e saía quieto pra diante. E aquele que era bonzote ficava lá mesmo (WERLANG, 1992, p. 78; 1995, p. 35-38).

No caso de haver resistência ao pretenso "não enfrentamento", ocorreu à prática de despejo. Um intermediário ou preposto da companhia e de madeireiras, mais a força policial, em geral, executavam o despejo, "segue a ação arbitrária, com atos de 'pinchar fora às tralhas', isto é, jogar fora os objetos, como móveis e utensílios. Pode ser acrescida da derrubada e queima dos ranchos" (RENK, 1997, p. 116). Também Werlang (1992, p. 78), enfatiza que houve conflitos em 
Pinhalzinho com expropriação de caboclos; foi até instaurado um processo contra a companhia,

a Companhia Sul Brasil foi acusada no processo protocolado na divisão de Terras e Colonização do Ministério da Agricultura, sob número 5.285, de 07 de agosto de 1951, de maltratar e expulsar os posseiros de suas terras. A Companhia Sul Brasil, em resposta a acusação não nega tal prática, apenas justifica que era preciso desocupar os lotes coloniais já vendidos a terceiros e que não puderam ser entregues aos mesmos pela permanência de intrusos (WERLANG, 1992, p. 82).

A companhia também acusa os intrusos de aventureiros que desmatavam as terras e iam embora. $O$ autor afirma que 0 desmatamento era em pequena escala, somente para a sobrevivência "enquanto a Companhia Sul Brasil devastou em torno de sete milhões de metros quadrados com o intuito de acumular capital" (WERLANG, 1992, p. 83).

Quanto às possibilidades de regularização das terras ocupadas, a Lei de Terras de 1850 já previa que as terras ocupadas ou por concessão deveriam ser registradas. Werlang (1995, p. 30), reportandose a D'Angelis, informa que

A nova Lei de Terras teve seu regulamento aprovado pelo decreto número 1318 , de janeiro de 1854 , e as exigências legais e de recursos para a regularização das posses, então existentes, estavam longe das possibilidades dos sertanejos agricultores (caboclos) e dos próprios índios.

Também, o decreto número 21 , do mês de março de 1925, estabeleceu um prazo de 10 meses para a regularização das terras "[...] fica estabelecido o prazo até 31 de dezembro de 1925, a regularização das posses criminosas (invasão ou ocupação ilegais). Os posseiros após esse prazo serão despejados, com a perda das benfeitorias". Houve requerimentos de registros de terras pelos posseiros, mas "foram indeferidos, sob a alegação de que não eram 'terras devolutas'" (WERLANG, 1992, p. 26-27). Renk (1997, p. 107, nota $\mathrm{n}^{\circ} 09$ ), citando 
como exemplo o que ocorreu em Faxinal do Tigre (Chapecó), enfatiza que em 1919 ocorrem 90 pedidos de compra de terras ocupadas naquele local, variando o tempo de posse de 25 a mais de 50 anos, "estes requerimentos foram, invariavelmente, indeferidos, pelo fato da terra ter sido titulada pelo Paraná e revalidada por Santa Catarina". Elenca, também, dois entraves graves para o requerimento de usucapião: 1) grande parte dos brasileiros não contava com existência civil (certidão de nascimento, por exemplo), vindo a ser "incorporados à sociedade nacional na década de 70", e 2) falta de recursos para as despesas de legalização.

Fato relevante é que a grande maioria dos posseiros "nem sabia dos trâmites legais para requerer a posse, o que, aliás, seria completamente inútil. A sorte dos posseiros já estava selada: ou estes adquiriam as terras das companhias ou seriam desalojados". Nesse sentido, "a legislação vigente dificultava ao máximo para o posseiro conseguir a escritura das terras" (WERLANG, 1992, p. 26-27, 75; 1995, p. 32).

Desse contexto, depreende-se que, se as companhias atuaram ativamente na expropriação dos colonos, o Estado não "pairou acima de todos", pois através da Legislação também atuou naquele processo. Assim, a

população brasileira das matas, (o caboclo) alheia e alheada a esses trâmites legais falava em ir adiante, iam para oeste do Paraná, onde também seriam alcançados pela colonização, ou ficavam trabalhando para os colonos, madeireiras e na extração da erva mate.

Dessa forma, "o direito de propriedade prevaleceu ao de ocupação [...]. Esta, de um modo geral, foi ignorada enquanto direito, visto unicamente enquanto infração: intrusamento" (RENK, 1997, p. 42, 104106 e WERLANG, 1995, p. 40). Aliás, é importante comentar que a Companhia Sul Brasil realizou, em seu discurso oficial, uma inversão dos termos "posseiro" e "intruso", conferindo-Ihes um novo significado, que inverte, por sua vez, o real, falsificando-o, assim, "Primeiramente, a Companhia tentou caracterizar os brasileiros que trabalhavam para os colonos de origem, geralmente italiana, de posseiros e os verdadeiros 
posseiros de intrusos" (WERLANG, 1995, p. 39). Ainda, um pouco mais recentemente Lohn (1999, p. 56) afirma que na década de 1950 há o registro de várias denúncias onde os proprietários de terras "despejam" famílias moradoras há vários anos nos locais, tendo que ir para a cidade.

Entrementes a esse processo de demarcação e "limpeza" das áreas, a companhia realizou a sua "Campanha de Marketing", principalmente no Rio Grande do Sul, origem das principais companhias colonizadoras. Era realizada em jornais e revistas ou através de algum colono "com credibilidade e um círculo de amizade", sendo que o agente de venda receberia $10 \%$ das transações comerciais realizadas. Nelas, as terras do oeste catarinense seriam melhores que as do Rio Grande do Sul, boas, novas, não necessitando de adubo, com água boa, "onde não se achava pedra nem pra matar passarinho" e em cada pau oco tinha uma colméia. A companhia construiria escolas e igrejas, providenciando professores, padres e pastores. Havia uma "diversidade" de médicos e parteiras, boas estradas e pontes e outras vantagens (RENK, 1997, p. 66; KRINDGES, 1999, p. 24-25; WERLANG, 1992, p. 59-60).

De fato, atraídos pela propaganda e por outros fatores que se verão adiante, vieram para a região colonos descendentes de alemães e italianos, aos quais Renk (1999, p. 09) denomina de "colonos de origem", "oriundos de colônias velhas do Rio Grande do Sul", a exceção dos teuto-russos que imigraram da Rússia (WERLANG, 1992, p. 62 a 66). Espírito Santo (1999, p. 49-50) enfatiza que essa onda migratória se inicia entre 1910 e 1920, indo até a década de 1960. Folador (1991, p. 79) relata que em 1919 "colonos alemães de Nonoaí, chegam ao atual Mondaí". Dentre as principais causas apontadas para essa migração, segundo Werlang (1992, p. 96-99), no Rio Grande do Sul ocorria:

1) O esgotamento do solo: terra fraca e sem condições de adubar, motiva-os a irem para Santa Catarina atraídos pela pretensa fertilidade do solo.

2) Proliferação de pequenas propriedades para famílias numerosas não havendo possibilidades de subdivisão. Estas não produziriam o suficiente para a sobrevivência.

3) Terras acidentadas: erosão e dificuldades de cultivá-las.

4) Grande incidência de formigas saúvas. 
5) Descapitalização dos minifundios.

6) Mecanização da lavoura, liberando mão-de-obra.

7) Frente colonizadora do noroeste gaúcho. A migração se inicia por essa região, desde Marcelino Ramos até o rio ljuí.

8) Fazer futuro para os filhos garantindo terras.

A essas causas Krindges (1999, p. 18-24) aponta também a crise de 1929, as terras baratas em Santa Catarina, e cita como exemplo que em Lajeado e Santa Cruz (RS), uma colônia de terras custava entre 15 e 20 contos de réis, já em Santa Catarina, no oeste, custava em torno de 2 contos de réis, e a "tradição da herança por motivo de casamento: um pedaço de terra, instrumentos de trabalho agrícola e alguns animais de criação para poder fazer um começo". Ainda, de acordo com Renk (1997, p. 170) "o deslocamento espacial do Rio Grande do Sul à Santa Catarina fazia parte da estratégia dos colonos para aumentarem suas terras e assegurar a alguns destes a reprodução nas mesmas condições".

O processo de ocupação das áreas ocorreu no sentido sul-norte. Somente em 1940 os colonos descendentes de italianos chegam a Campo Erê, região norte de Santa Catarina. A Companhia atuava agrupando os colonos de acordo com a etnia e o credo. Desse modo, "as terras localizadas entre os rios Chapecó e Barra Grande foram destinadas aos alemães católicos e teuto-russos católicos, surgindo dessa colonização os municípios de São Carlos, Saudades e Pinhalzinho". Já do

rio Barra Grande até o rio São Domingos, atual município de Palmitos, os alemães evangélicos, depois também por descendentes de italianos. Do rio São Domingos até o rio Iracema, os de origem italiana, os quais deram origem a Caibi. Por último, entre os rios São Domingos e Antas, os teuto-russos evangélicos, originando o município de Riqueza. Esta divisão está caracterizada nos dias de hoje (WERLANG, 1992, p. 62 a 66).

Segue abaixo uma sequência de mapas procurando demonstrar a dinâmica interna das fronteiras dos municípios e distritos a medida em 
que são criados, de acordo com o ritmo da colonização na região oeste até o ano de 1965.

Na Figura 12, no ano de 1930, destaca-se a criação dos seguintes distritos: Mondaí, foi desmembrado do município de Chapecó em junho de 1926 com a denominação de Peperi, desmembrou-se do distrito de Cascalho (depois Passarinhos e hoje Palmitos); em dezembro de 1926 passou a chamar-se Mondaí; emancipou-se do município de Chapecó em dezembro de 1953. Cascalho foi desmembrado do município de Chapecó em junho de 1921 com a denominação de Henrique Rupp Junior; em março de 1922 passou a chamar-se Cascalho, assim permanecendo até março de 1938, quando passou a chamar-se Passarinhos, emancipou-se em dezembro de 1953, com o nome de Palmitos. Caxambu foi desmembrado de Chapecó em abril de 1919, emancípou-se em dezembro de 1962 com o nome de Caxambú do Sul; Abelardo Luz, vide distrito de Chapecó Grande no mapa de 1917; Xaxim foi desmembrado de Chapecó em junho de 1921 com o nome de Hercílio Luz, separado do distrito de Passo Bormann, foi instalado no lugar Xaxim em fevereiro de 1922; passou a chamar-se Xaxim em outubro de 1929 e emancipou-se em 1953; Fachinal dos Guedes, foi desmembrado de Chapecó em julho de 1919, separado do distrito de Xanxerê e com sede no lugar "Gramado dos Guedes", emancipou-se em 1958.

Conforme a Figura 13, no ano de 1940 foram criados os distritos de Itapiranga, integrante do município de Chapecó, foi criado no local chamado de Porto Novo e desmembrou-se do distrito de Mondaí em fevereiro de 1932, emancipou-se em 1953; Passarinhos, vide Cascalho no mapa de 1930; e São Carlos, foi desmembrado de Chapecó em dezembro de 1938, separou-se do ex-distrito de Passarinhos e emancipou-se em dezembro de 1953.

A Figura 14, relativa ao ano de 1950, quando são criados os distritos de: Vila Oeste, foi desmembrado do município de Chapecó em dezembro de 1949 e emancipou-se em dezembro de 1953 com o nome de São Miguel do Oeste; Cunha Porã, foi desmembrado do município de Chapecó em novembro de 1950, depois, quando Palmitos se emancipou em 1953, Cunha Porã passou a ser distrito desse município e emancipou-se em junho de 1958; Saudades, foi desmembrado do 
município de Chapecó em novembro de 1950; com a emancipação de São Carlos em 1953, Saudades passou a ser distrito desse município, emancipou-se em dezembro de 1961; Coronel Freitas, foi desmembrado do município de Chapecó em novembro de 1950 e emancipou-se em outubro de 1961; e São Lourenço, foi desmembrado do município de Chapecó em agosto de 1951, emancipou-se em junho de 1958 com o nome de São Lourenço do Oeste.

De acordo com a Figura 15, em 1953 elevaram-se a municípios os seguintes distritos: Dionísio Cerqueira, São Miguel do Oeste, Itapiranga, Mondaí, Palmitos, São Carlos, Xaxim, Xanxerê e foi criado o distrito de Palmitos, vide Cascalho no mapa de 1930.

Conforme a Figura 16, em 1956, Descanso elevou-se a município desmembrado de Mondaí. Também, foram criados os distritos de Guaraciaba em outubro de 1956, pertencente ao município de São Miguel do Oeste, emancipou-se em julho de 1961. Anchieta desmembrou-se do municicípio de São Miguel do Oeste em maio de 1956 e emancipou-se em fevereiro de 1963; Romelândia, também distrito de São Miguel do Oeste, foi criado em maio de 1956 e emancipou-se em dezembro de 1963. Maravilha desmembrou-se do município de Palmitos em maio de 1956 e emancipou-se em junho de 1958. Vila Modelo, desmembrou-se do município de São Carlos em setembro de 1956 e emancipou-se com nome de Modelo em dezembro de 1961. Pinhalzinho desmembrou-se do município de São Carlos em maio de 1956 separado do ex-distrito de Saudades, emancipou-se em dezembro de 1961. Águas dos Chapecó desmembrou-se do município de Chapecó em março de 1956 e emancipou-se em dezembro de 1962. Quilombo, desmembrou-se do município de Chapecó em maio de 1956 e emancipou-se em outubro de 1961. A Figura 17 demonstra os distritos criados e os municípios emancipados no ano de 1958. Assim, São José do Cedro, foi criado como distrito do município de Dionísio Cerqueira em fevereiro de 1957 com o nome de Cedro, emancipou-se em junho de 1958; Guarujá foi criado como distrito do município de Dionísio Cerqueira em fevereiro de 1957 e emancipou-se em dezembro de 1961 com o nome de Guarujá do Sul. Caibi, foi criado como distrito do município de Palimitos em junho de 1957, emancipou-se em março de 1955; e Palma Sola, foi criado como distrito do município de Dionísio 
Cerqueira em fevereiro de 1957, emancipou-se em dezembro de 1961. Também, foram criados os municípios de Cunha Porã; Maravilha; Campo Erê; São Lourenço do Oeste; Abelardo Luz e Faxinal dos Guedes. Conforme a Figura 18, todos os distritos criados até então foram elevados a categoria de município no ano de 1965.

\section{Figura 12}

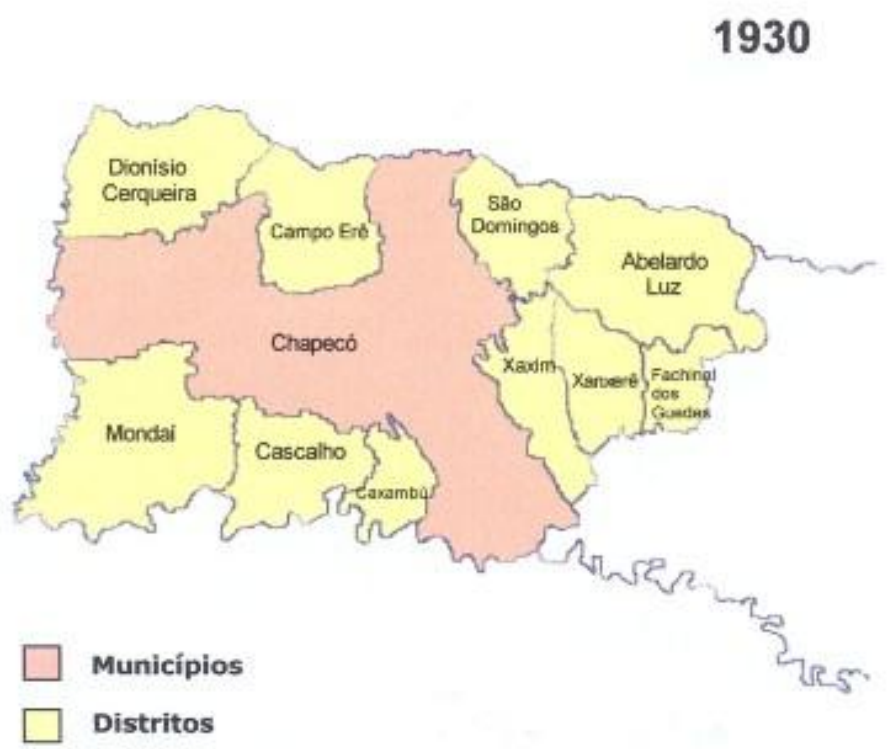

Fonte:

Werlang, Alceu Antonio. 1992.

Censo Demográfico - IBGE - Anos 40, 50, 60, 70 e 80.

Espaço Ameríndio, Porto Alegre, v. 7, n. 2, p. 277-556, jul./dez. 2013. 
KIMIYE TOMMASINO - Relatório de Identificação e Delimitação da Terra Indígena...

\section{Figura 13}

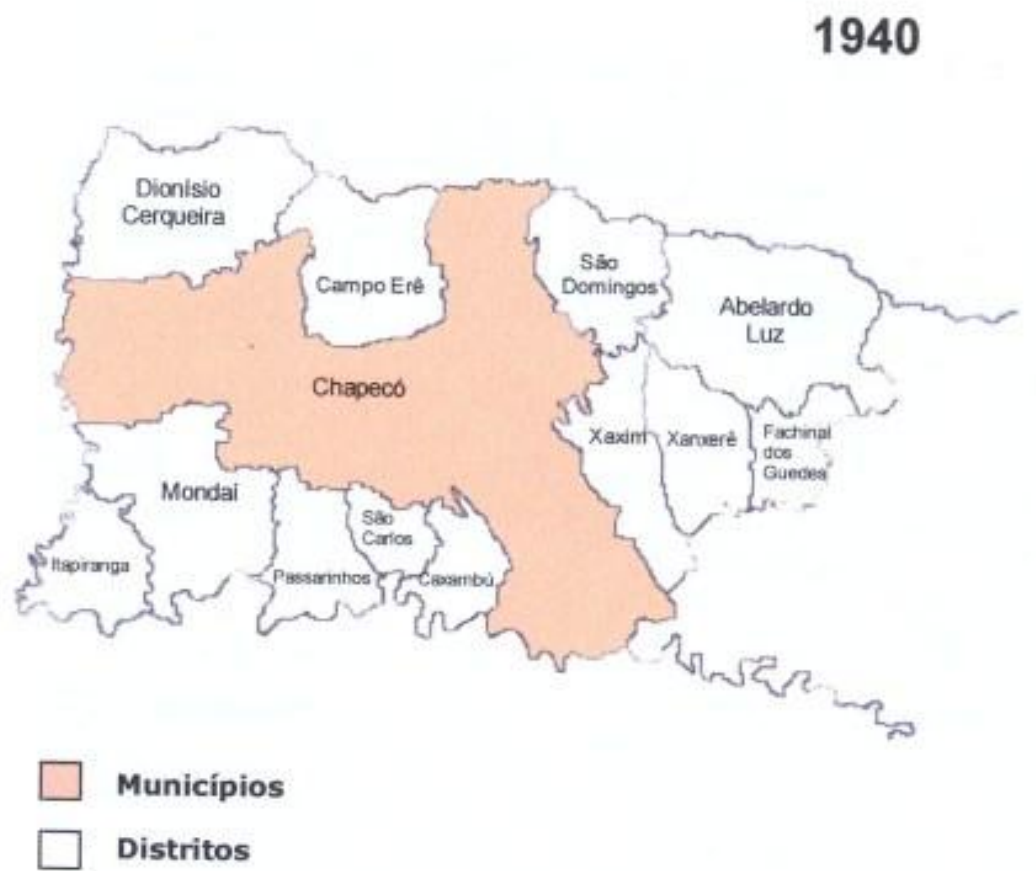

Fonte:

Werlang, Alceu Antonio. 1992.

Censo Demográfico - IBGE - Anos 40, 50, 60, 70 e 80.

Espaço Ameríndio, Porto Alegre, v. 7, n. 2, p. 277-556, jul./dez. 2013. 
KIMIYE TOMMASINO - Relatório de Identificação e Delimitação da Terra Indígena...

\section{Figura 14}

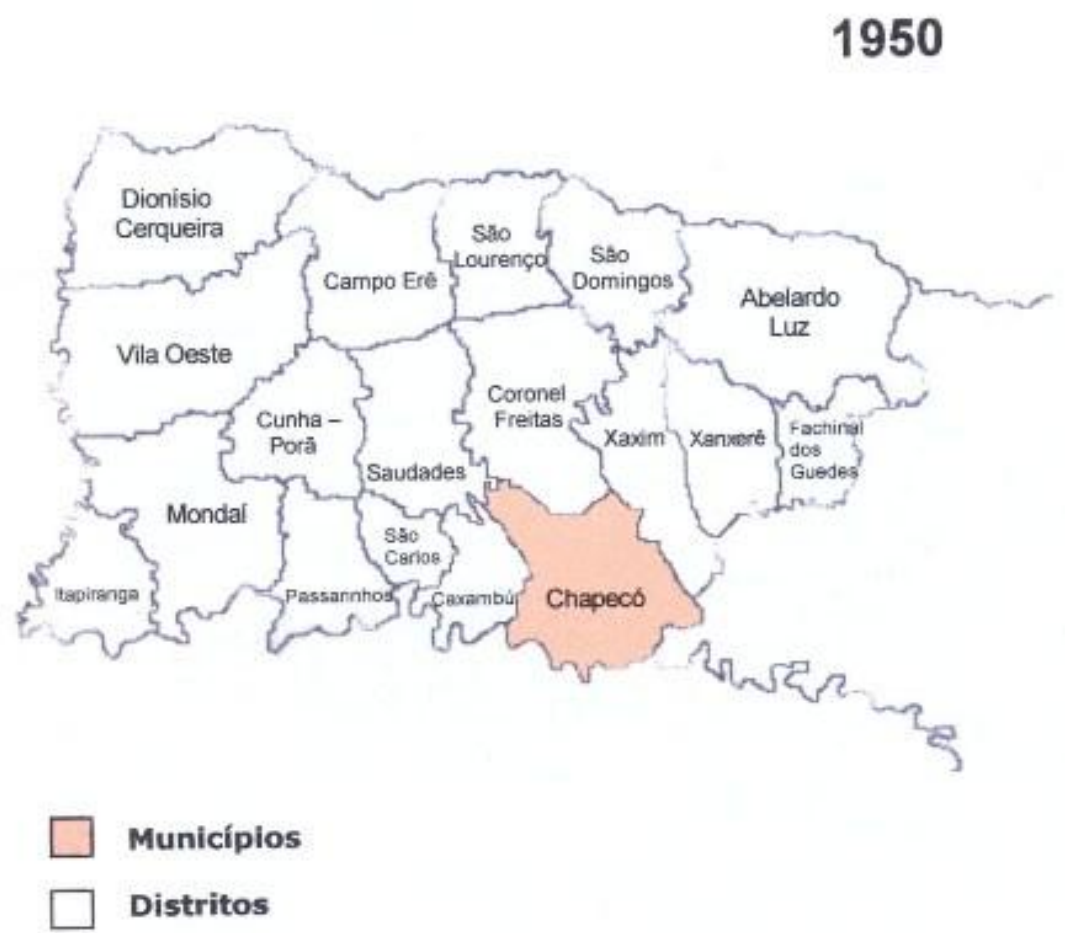

Fonte:

Werlang, Alceu Antonio. 1992.

Censo Demográfico - IBGE - Anos 40, 50, 60, 70 e 80.

Espaço Ameríndio, Porto Alegre, v. 7, n. 2, p. 277-556, jul./dez. 2013. 
KIMIYE TOMMASINO - Relatório de Identificação e Delimitação da Terra Indígena...

\section{Figura 15}

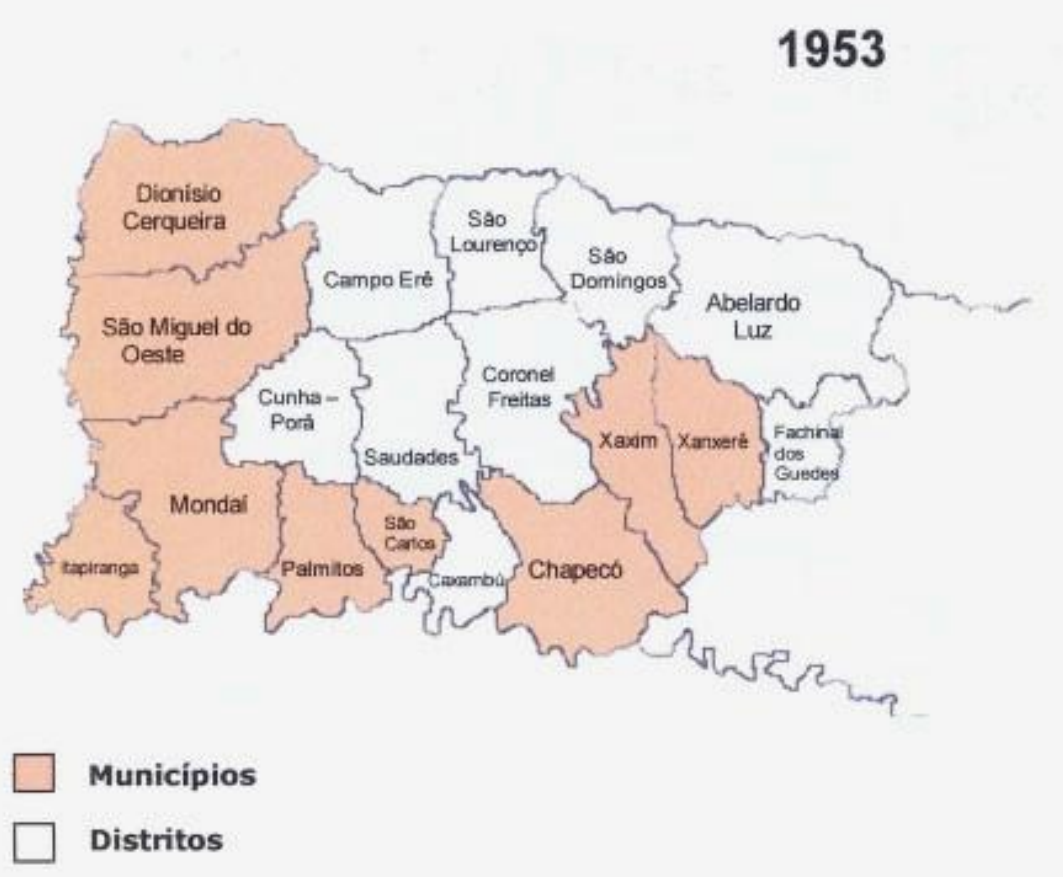

Fonte:

Werlang, Alceu Antonio. 1992.

Censo Demográfico - IBGE - Anos 40, 50, 60, 70 e 80.

Espaço Ameríndio, Porto Alegre, v. 7, n. 2, p. 277-556, jul./dez. 2013. 
KIMIYE TOMMASINO - Relatório de Identificação e Delimitação da Terra Indígena...

\section{Figura 16}

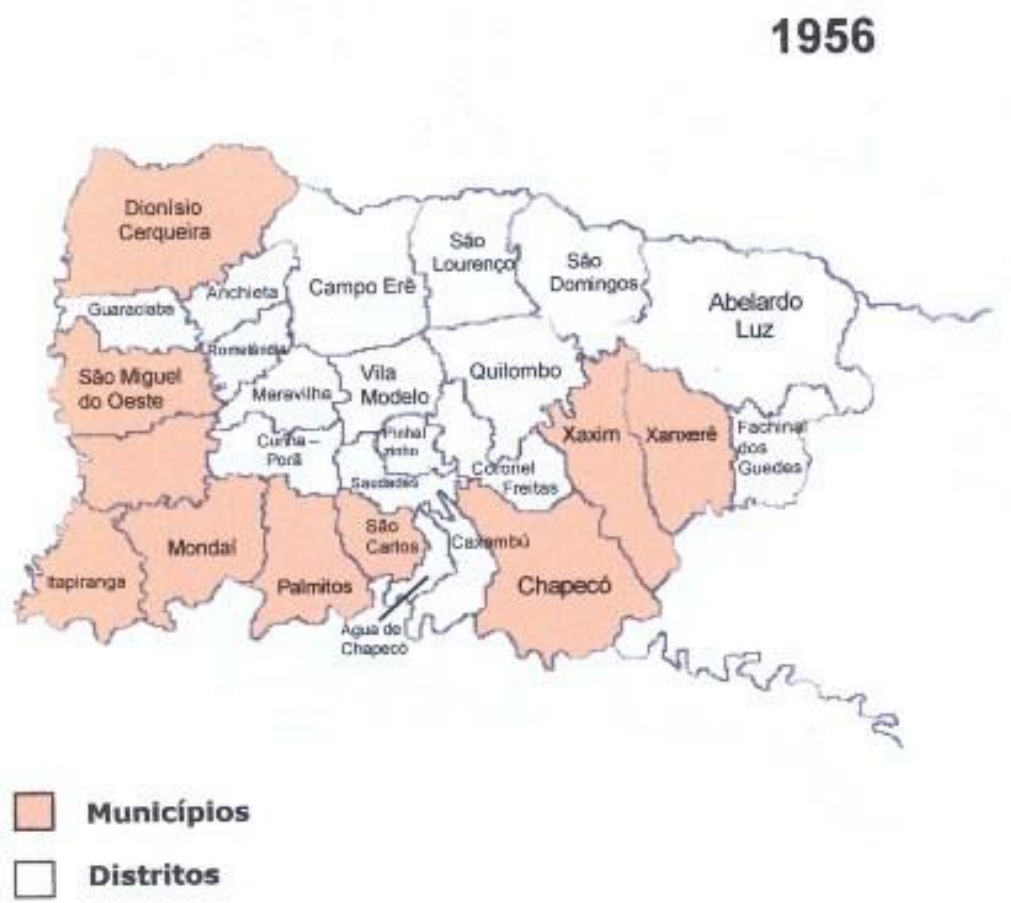

\section{Fonte:}

Werlang, Alceu Antonio. 1992.

Censo Demográfico - IBGE - Anos 40, 50, 60, 70 e 80.

Espaço Ameríndio, Porto Alegre, v. 7, n. 2, p. 277-556, jul./dez. 2013. 
KIMIYE TOMMASINO - Relatório de Identificação e Delimitação da Terra Indígena...

Figura 17

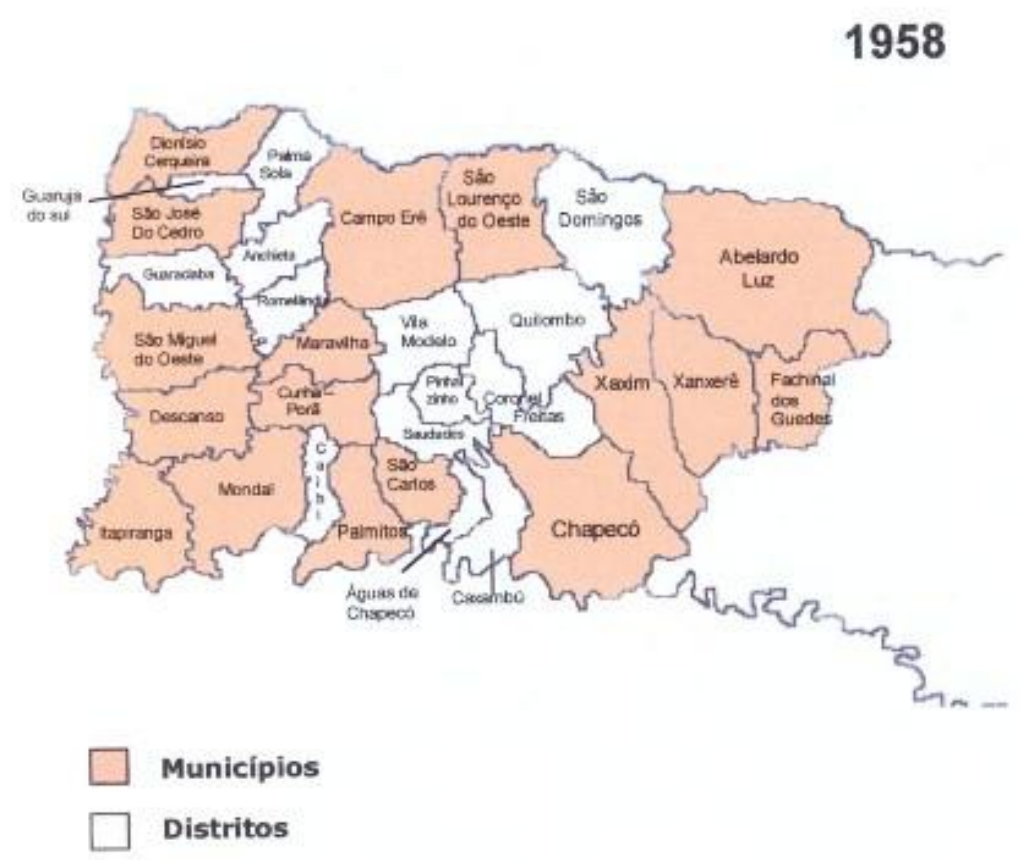

Fonte:

Werlang, Alceu Antonio. 1992.

Censo Demográfico - IBGE - Anos 40, 50, 60, 70 e 80 .

Espaço Ameríndio, Porto Alegre, v. 7, n. 2, p. 277-556, jul./dez. 2013. 
KIMIYE TOMMASINO - Relatório de Identificação e Delimitação da Terra Indígena...

\section{Figura 18}

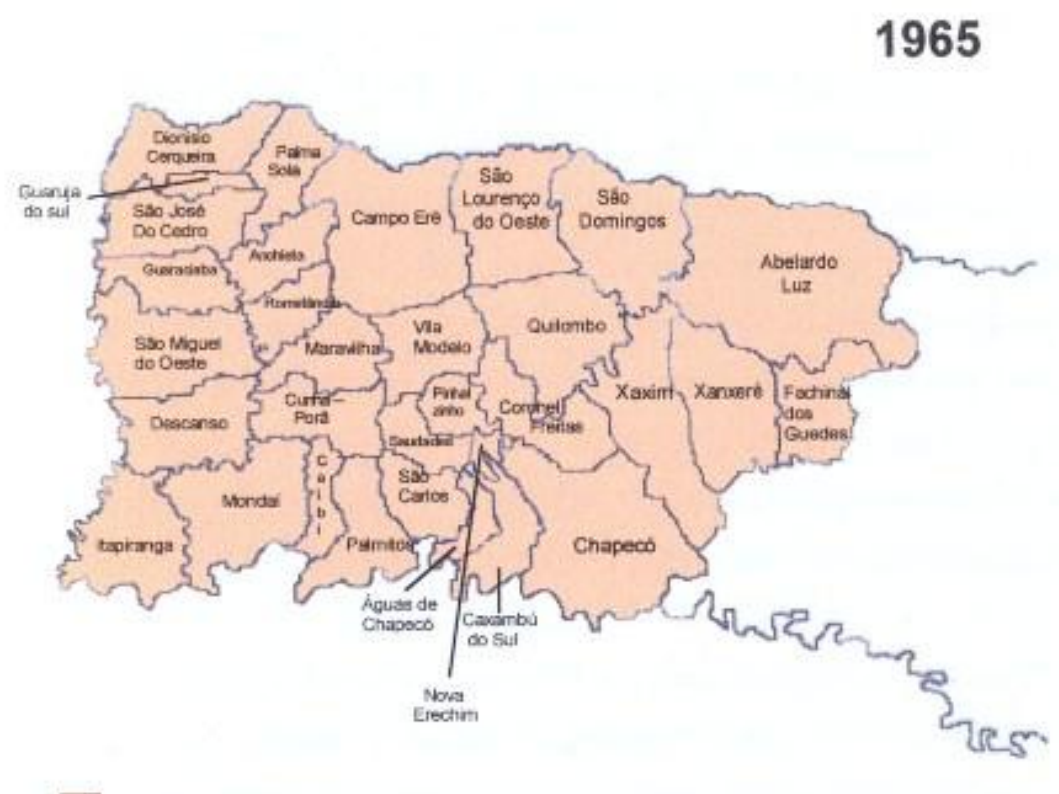

Municípios

Fonte:

Werlang, Alceu Antonio. 1992.

Censo Demográfico - IBGE - Anos 40, 50, 60, 70 e 80.

Espaço Ameríndio, Porto Alegre, v. 7, n. 2, p. 277-556, jul./dez. 2013. 
Em linhas gerais, quanto aos "colonos de origem", para os alemães evangélicos de tradição luterana, há uma valorização do trabalho (KRINDGES, 1999, p. 75), ocorrendo o mesmo com os italianos, pois o "padrão comportamental do italiano [...] elegeria como valores o trabalho metódico, sistemático, a poupança, o investimento e a frugalidade" (RENK, 1997, p. 143). Nessa concepção de trabalho voltada para a "compulsão e a organização" a pobreza representa a "falta de vontade de trabalhar" (RENK, 1997, p. 83). A terra é tida como propriedade em duplo sentido, como "patrimônio moral" (RENK, 1997, p. 111) e como valor econômico. A casa do colono de origem teria que ter uma horta, jardim, plantas medicinais, "tudo muito bem cuidado" (RENK, 1997, p. 80). O trabalho era realizado em família (famílias numerosas) e "cada família era uma unidade de produção, realizando o cultivo de subsistência". No início os homens trabalhavam fora, na construção de estradas (picaretas e enxadas) e na extração de madeira (ficando até 15 dias dentro do mato), restando para as mulheres o trabalho na roça, serviços domésticos e o cuidado dos filhos (WERLANG, 1992, p. 120). Era realizada a queima para a limpeza da terra, principalmente onde havia moitas de taquara, tornando inaproveitável boa parte do solo e ocorrendo um rápido esgotamento, visto que o mesmo já estava enfraquecido, não proporcionando uma boa colheita (KRINDGES, 1999, p. 82), ademais, boa parte daquele era constituído de "morro e pedra" (WOLLF, 1999, p. 59), sendo o tabaco e, depois, a criação de suínos (na década de 1940), os primeiros produtos com algum valor comercial (WERLANG, 1992, p. 103-104).

Para os colonos, embora houvesse dificuldades no Rio Grande do Sul, essas não eram tantas como em Santa Catarina (WERLANG, 1992, p. 109); segundo eles, foram enganados pela propaganda da companhia (KRINDGES, 1999, p. 24-25 e WERLANG, 1992, p. 70), além disso, não levaram nem alguns pequenos animais para iniciarem uma criação. Dentre as dificuldades relatadas, citam-se: a viagem de mudança, pois na colônia havia pouca ou nenhuma estrada; falta de tábuas para a construção das casas; falta de comércio para vender a produção e comprar mercadorias que necessitavam; enchentes do rio Uruguai, ocasionando até a falta de alimentos, pois este provinha do Rio Grande do Sul; falta de recursos para pagar os lotes; falta de estudos para as 
crianças; epidemias, como a do tifo; falta de médicos e "parteiras"; epidemia de mosquitos de dia e de noite, esta apontada como uma das principais dificuldades. Diante desse quadro, muitos colonos retornaram ao Rio Grande do Sul e outros, mesmo querendo, não puderam nem retornar (WERLANG, 1992; KRINDGES, 1999; RENK, 1997; WOLLF, 1999). Se essas são as dificuldades iniciais, é importante salientar novamente que em 1950 a região oeste era apontada como o "celeiro do Brasil", ocorrendo o "complexo Agroindustrial de frangos, suínos, milho e soja, cuja produção representa mais de $50 \%$ do Valor Bruto da Produção Agropecuária Catarinense" (ESPÍRITO SANTO, 1999, p. 88).

Porém, não se pode esquecer, conforme lembra Krindges (1999, p. 96), que "se o oeste é fruto de trabalho de homens e mulheres, o certo é que este trabalho de construção incluiu também o índio e o caboclo". Esse "contato" entre "colonos de origem" e "caboclos", ocorre como uma "Fricção Interétnica". Assim, "sistemas de referências culturais que 'moldam' um significado e um sentido ao viver são diferentes, ocorrendo da friç̧ão interétnica" (RENK, 1997, p. 107). Notese que se, por um lado para os colonos os "negros brutos" do início da colonização são diferentes dos "caboclos civilizados de hoje", onde, por extensão "a cultura do caboclo também esteve permeando o processo de elaboração cultural [...] contribuindo para que os alemães aprendessem a produzir a terra [...] a cultivar a erva e a tomar chimarrão"10 (KRINDGES, 1999, p. 98-99), por outro lado, o próprio termo "caboclo" é utilizado pelo colono devido a eles não terem "uma origem definida" e, também, pela "diferenciação cultural" (KRINDGES, 1999, p. 97).

Os caboclos, no dizer de Renk (1997, p. 10): "[...] de nativos são transformados em estrangeiros. A condição de alienígena é extremada pelas representações dos colonizadores, como: 'não são filhos daqui'; 'não são filhos de italianos'[...]". São até estigmatizados, naturalizandose certas situações ou condições sociais,

tais como: falta de higiene; promiscuidade; casamentos consuetudinários; separações freqüentes e novos

\footnotetext{
${ }^{10}$ Palavras da Senhoa Brunhildes (informante de Krindges): "Ah, sabe como nóis aprendemo: com o caboclo. Caboclo daqui! Tinha caboclo pra trabalhá as veis né" (KRINDGES, 1999, p. 98-99), sobre a língua portuguesa.
}

Espaço Ameríndio, Porto Alegre, v. 7, n. 2, p. 277-556, jul./dez. 2013. 
KIMIYE TOMMASINO - Relatório de Identificação e Delimitação da Terra Indígena...

casamentos; evasão escolar dos filhos; mudança de credo religioso; mau aproveitamento dos salários da safra da erva-mate; problemas financeiros na entresafra; e a espera pelo assistencialismo do Estado.

Era tido como um "caçador inato", povo de vida itinerante, com um modo de vida irracional, cuja roça, no "sistema dos brasileiros", "sempre foi apresentada como primitiva, atrasada e praticada em pequena escala" (RENK, 1997, p. 96-155, nota $n^{\circ} 03$ ).

Tal estado de coisas leva ao estabelecimento de uma hierarquia, estando no topo os colonos de origem, os "bem sucedidos" (RENK, 1997 e KRINDGES, 1999). Na base, os caboclos "permaneciam na condição de 'coitados', 'pobres', empregados, peões de serrarias ou arrendatários" (KRINDGES, 1999, p. 98). Na entressafra da erva-mate até pediam (pedem) as coisas na rua. São apontados como os "únicos pobres, os pobres, mas pobres mesmo só eles" (RENK, 1997, p. 10, 191-192). Já para os caboclos, os colonos eram denominados como "gringos" e estigmatizados como os "seguros", os que "já vieram atipados", os "morto de fome”, "mão fechada", "pão duros”, "come unha”, "orgulhoso", "presunçoso com falta de humildade", "os maior", "com ganância de terra", querendo só "acumular capital", daí para os caboclos os tempos de hoje serem "estragados", de "miséria" (RENK, 1997, p. 143).

Como consequência, ocorreu novo tipo de expropriação, agora por parte dos colonos, seja por atitudes mais sutis, podendo ocorrer pela "confluência da diferença escolar, finalidade da atividade econômica”, segundo a autora, “'o povo bobo' vendia terras, pinheiros, 'a troco de nada', 'por não saber o valor', acabou entregando pros 'maior', pros gringo com 'ganância de terra'” (RENK, 1997, p. 117). Desse modo,

as ranhuras, os conflitos, não aconteceram talvez, de forma exposta, mas se deram nas relações cotidianas, seja na indiferença com outras culturas [...] também faz discriminar outras formas de ver 0 mundo (KRINDGES, 1999, p. 104).

Porém, ela também ocorria de maneira mais explícita, "atuando pelo 'lado fraco', isto é, da superstição dos posseiros, atemorizando e 
intimidando-os" (RENK, 1997, p. 109-110 e WERLANG, 1995, p. 34), obrigando-os a se retirarem. "De certo modo, a 'limpeza' das áreas é tratada como um tabu. Para alguns colonos 'não havia ninguém', 'era puro mato', o que pode ter ocorrido em parte. Para outros a companhia já 'havia limpado o terreno'" (RENK, 1997, p. 110).

Procurou-se demonstrar, ao longo deste relato, que o processo recente da colonização do oeste catarinense representa um capítulo específico na história da colonização do Brasil Meridional. Por um lado, a omissão do Estado "pairando acima de todos" e, em alguns casos, atuando como agente no processo de expropriação dos caboclos, como no caso da legislação para a regularização das terras já ocupadas, visto que criar, aplicar e fazer cumprir a legislação é exclusividade do Estado. Por outro lado, a atuação das companhias colonizadoras, objetivando a maximização dos lucros.

Resulta desse processo, para os colonos de origem, se é que é válida a comparação, a "ilusão" em relação às terras do oeste catarinense como se fossem a "terra prometida", pois foram alojados num "sertão inóspito" e, além disso, já havia uma população habitando aquele local, com um "modus vivendi" singular, um esquema de referencias materiais e espirituais que proporcionava um sentido e um valor às ações do cotidiano. E para os caboclos, o desalojamento, tornando eles "estranhos em sua própria terra", por força de coerção, seja física, seja moral, obrigados a passar do "tempo da largura", da fartura, para o "tempo estragado", da miséria.

\section{Os Guarani da Aldeia do Arroio Passo Feio Reivindicam Terra de Araça'í}

A maioria dos grupos guarani que vivem no interior dos estados de São Paulo, Paraná, Santa Catarina e Rio Grande do Sul está alojada em áreas indígenas demarcadas para os Kaingang e, em Santa Catarina, também para os Xokleng. Isso significa que, ao longo da história recente, os Guarani não receberam do Estado terra própria para se estabelecerem. Este relatório trata de um grupo que, a partir da segunda década do século XX e seguintes, foi viver na terra kaingang de Nonoai à

Espaço Ameríndio, Porto Alegre, v. 7, n. 2, p. 277-556, jul./dez. 2013. 
KIMIYE TOMMASINO - Relatório de Identificação e Delimitação da Terra Indígena...

medida que as famílias iam sendo expulsas da Terra de Araça'í, sua terra tradicional no oeste catarinense. Na TI Nonoai formaram as aldeias Passo Feio e Mbaraca Mirim.

Em 22 de março de 1998 as famílias da aldeia Passo Feio elaboraram um documento para a FUNAI-AER Chapecó onde expuseram sua intenção de retornar à sua terra tradicional no local denominado Araça'í, parte no município de Saudades e parte no de Cunha Porã.

No documento expuseram a intenção de lutar para terem uma área delimitada "só para os Guarani". Sendo Nonoai uma terra kaingang, os Guarani lá vivem na condição de "hóspedes" forçados e como os Kaingang vivem também um processo de recuperação de suas terras perdidas, aquelas habitadas pelos Guarani também passaram a ser reivindicadas pela comunidade kaingang.

Ao documento foi anexada uma lista com os nomes dos Guarani residentes, àquela época, na aldeia Passo Feio, que tinham a intenção de viver na Terra Araça'í. Conforme pode-se ler nos documentos, são 38 famílias num total de 133 pessoas, contando apenas os residentes no Arroio Passo Feio (Anexo I: 2).

No dia 31 de março do mesmo ano o administrador regional da Funai em Chapecó encaminhou um memorando ao Departamento de Assuntos Fundiários solicitando a criação de um Grupo Técnico para identificação e delimitação da terra reivindicada pelos Guarani (Anexo I: 3). Mais de dois anos se passaram e os Guarani residentes na aldeia Passo Feio não tinham sido atendidos. No dia 9 de julho de 2000 mais de 20 famílias entraram numa área da seção Araça'í (município de Saudades-SC), entre os rios Araçá e Araçazinho, montando um acampamento com barracas de lona à beira de uma estrada vicinal.

A reação da sociedade local foi imediata e explosiva. Todas as forças políticas locais, regionais, estaduais e federais foram acionadas e o pensamento anti-indígena se concretizou em ações políticas efetivas. A Secretaria de Estado da Justiça e Cidadania, através de seu diretor, encaminhou solicitação à FUNAl e a todas as autoridades com responsabilidade na questão indígena a fim de que tomassem todas as providências cabíveis para a solução do problema da "presença indígena em terras particulares" (Anexo I: 11, 12, 22 e 42).

Em 23 de agosto o Ministro de Estado da Justiça José Gregori 
determinou que fosse criado, em caráter de urgência, um grupo técnico para realizar estudos de identificação e delimitação da área reivindicada pelos Guarani (Anexo I: 38). A AER-Chapecó, depois de vários contatos com outras administrações regionais, com o INCRA e outras instituições, através da Portaria 928 de 6 de setembro de 2000 criou o Grupo Técnico para realizar estudos e levantamentos de identificação e delimitação da Terra Indígena Guarani do Araça'í. O GT foi constituído com o seguinte quadro: 1) Kimiye Tommasino, antropóloga da Universidade Estadual de Londrina, coordenadora; 2) Antônio de Paula Nogueira Neto, engenheiro agrônomo do DAF/DEF; 3) Flávio Luiz Corne, engenheiro agrimensor, FUNAI/AER Bauru e 4) Mariane Madalena Weber, engenheira agrônoma, INCRA/SC. A Portaria 1036/PRES de 27 de setembro de 2000 substituiu o servidor Antonio de Paula Nogueira Neto pelo engenheiro agrônomo Marcelo Antônio Elihimas da AER Maceió (Anexo I: 44, 46, 47, 50, 51, 55, 58 e 64).

Paralelamente a esses trâmites burocráticos que viabilizaram a criação do GT Terra Indígena Guarani do Araça'í, ocorreram outros fatos diretamente relacionados à reivindicação dos Guarani e à ocupação da terra na Seção Araçaí no município de Saudades. Flaviano Silvano Zimmer e outros (Processo no 2000.72.02.001916-1) entraram com ação contra a FUNAl na Justiça Federal, Seção Judiciária de Santa Catarina. No dia 26 de julho de 2000 foi realizada audiência de conciliação na Vara federal de Chapecó com a presença dos representantes das partes envolvidas e seus respectivos advogados. Da reunião entre as partes ficou acordado o seguinte: a) a FUNAl se comprometeu a promover a retirada dos indígenas no prazo de 45 dias; b) durante o referido prazo, a FUNAl se comprometeu a formar o grupo técnico para a elaboração do estudo de identificação e delimitação da terra indígena reclamada pelos Guarani e, ainda, a que, neste prazo, os estudos seriam iniciados concretamente; c) nesse prazo a FUNAl se comprometeu a manter os índios exatamente na área onde se encontravam naquele momento, considerada "economicamente improdutiva" e d) que o não cumprimento de qualquer dos itens determinaria a retirada coercitiva dos Guarani e ainda a FUNAI seria multada em R\$302,00. Assinaram o Termo de Audiência: Roberto Fernandes Júnior, Juiz Federal Substituto; Claudio Dutra Fontella, 
KIMIYE TOMMASINO - Relatório de Identificação e Delimitação da Terra Indígena...

representante do Ministério Público Federal; João Batista Oselane, representante da FUNAI; Pedro Barbosa, representante da Comunidade Indígena; Dr. Aldino Ângelo Trombeta, Patrono dos Autores; Flaviano Silvano Zimmer, Carlos Francisco Zimmer e Terezinha Felicita Zimmer, Autores da Ação (Anexo I: 28).

No dia 8 de setembro de 2000 nova audiência foi marcada pelo Juiz Federal no mesmo local com a presença dos representantes das partes envolvidas e com a presença da Procuradora da República Dra. Sônia Cristina Niche. Desta audiência resultou o seguinte: 1) foi acordada uma prorrogação do prazo de 20 dias para uma solução pacífica para os índios desde que o grupo técnico nomeado pela Presidência da FUNAI limitasse sua atuação ao local onde os índios estavam acampados e somente executasse os trabalhos de campo após a retirada dos Guarani da área litigiosa. A Procuradora da República aceitou a prorrogação do prazo, mas insistiu que a solução poderia ser alcançada não necessariamente com a saída dos indígenas do local. $O$ cacique Pedro Barbosa disse que aceitava a saída do local desde que fosse dentro dos limites da área reivindicada. O Juiz deferiu o pedido de prorrogação do prazo solicitado pela FUNAl e também de que os membros do grupo técnico deveriam limitar sua pesquisa de campo à área onde estavam os Guarani, sem ingressar nas demais áreas de terras da região. Findo o prazo prorrogado, o Juiz determinou que, no caso de a FUNAI não ter encontrado uma solução, o processo viesse concluso para a apreciação do pedido de liminar de reintegração de posse formulado pelos autores. Assinaram o Termo de Audiência e Conciliação: o Juiz Federal Dr. Narciso Leandro Xavier Baez; Dra. Sônia Cristina Niche, Procuradora da República; Irani Cunha da Silva, representante da FUNAl; o Procurador da FUNAI; o Procurador dos Autores e Pedro Barbosa, representante da Comunidade Indígena (Anexo I: 52 ).

A FUNAI interpôs Agravo de Instrumento contra determinação do Juiz de retirada compulsória dos índios e limitação de ação do grupo técnico ao local do acampamento indígena sem que fosse possível proceder ao estudo antropológico e fundiário em toda a terra reivindicada. O Agravo foi julgado pelo Tribunal Regional Federal da $4^{\mathrm{a}}$ Região e teve despacho assinado no dia 25 de setembro de 2000 que 
deferiu o pedido de efeito suspensivo nos termos em que foi requerido pela FUNAI (Anexo I: 62 e 63).

Em 18 de outubro de 2000 foi julgada a ação de reintegração de posse (Processo 2000.72.02.001916-1) ajuizada por Flaviano Silvano Zimmer e outros. O Juiz Federal da $1^{\text {a }}$ Vara de Chapecó/SJSC, Dr. João Batista Lazzari, deferiu o pedido de reintegração de posse nos seguintes termos: a) "que a ação de reintegração de posse proposta pelos autores não é a via adequada para o reconhecimento dos direitos indígenas. Caberia à FUNAI ou ao Ministério Público Federal a propositura de ação própria para o reconhecimento dos direitos indígenas sobre a área reivindicada"; b) que "a decisão a ser tomada neste processo fica limitada ao reconhecimento do direito à reintegração de posse dos autores, cujos requisitos foram comprovados"; c) que "Nas audiências conciliatórias realizadas por este juízo, a solução apontada foi a desocupação amistosa das áreas invadidas. Infelizmente, a retirada que deveria dar-se de forma espontânea não ocorreu. Diante de tal situação e a para que seja mantida a ordem pública, mostra-se necessária a determinação judicial para a imediata desocupação do imóvel ocupado, sob pena de utilizar-se de força policial para cumprimento da ordem deste juízo"; d) que "Os indígenas poderão retornar para a reserva de origem, e lá aguardar o resultado dos trabalhos do grupo técnico formado para identificação das áreas reivindicadas". Foi enviado ofício à Delegacia de Polícia Federal de Dionísio Cerqueira para acompanhar o cumprimento da ordem judicial com a requisição de apoio da Polícia Militar do Estado de Santa Catarina e ao Município de Saudades foram requisitados ônibus e caminhões para remoção dos indígenas e seus pertences (Anexo I: 71).

$\mathrm{Na}$ madrugada de 19 de outubro, as famílias guarani foram surpreendidas pela chegada das Polícias Federal e Militar e ainda do Corpo de Bombeiros. O cacique teve sete minutos para avisar todas as pessoas do acampamento a pegarem seus pertences e adentrarem os ônibus que os levariam para a TI Nonoai. Sob protestos do cacique que pediu para que os deixassem na beira da rodovia próxima a Terra Araça'í, os índios foram levados para a TI Nonoai. Cumpre esclarecer e registrar que nem a FUNAI nem a Procuradoria da República foram comunicadas da decisão tomada e assinada no dia anterior. $O$

Espaço Ameríndio, Porto Alegre, v. 7, n. 2, p. 277-556, jul./dez. 2013. 
KIMIYE TOMMASINO - Relatório de Identificação e Delimitação da Terra Indígena...

administrador da AER Chapecó tomou conhecimento de que os Guarani estavam sendo despejados por volta das nove horas, através de um telefonema de uma emissora de rádio da cidade de Pinhalzinho que ligara para saber se era verdadeiro o boato de que os índios estariam sendo despejados (Anexo I: 73, 75, 79, 80 e 81).

Levados para a TI Nonoai, os Guarani não retornaram para Passo Feio, mas foram deixados próximo da aldeia sede de Nonoai e se instalaram numa pequena mata onde permanecem até o presente momento (Anexo I: 83, 84, 85 e 86).

\section{CAPÍTULO IV - OS GUARANI DE ARAÇA'Í: HISTÓRIA E MEMÓRIA}

Neste capítulo apresentaremos as narrativas dos Guarani colhidas em nossa pesquisa de campo e algumas colhidas pelos membros do CIMI-Sul, narrativas de alguns colonos teuto-brasileiros, dados de arqueologia e de história de pesquisas realizadas na UNOESC, PUCRS e UFSC. O objetivo é reconstituir a história dos Guarani de Araça'í desde que lá chegaram, como viveram na terra onde erigiram seu Tekohá até as diferentes formas de pressão e violência que as famílias sofreram até serem expulsas. Esse processo vivido pelos Guarani de Araça'í será pensado a partir da perspectiva guarani e seus significados. Nesse sentido, a primeira e importante observação a se fazer é que, quando falamos que esse grupo migrou do Paraguai e da Argentina para o Brasil, essas fronteiras foram criadas com a formação dos estados modernos e não se confundem com as fronteiras dos territórios guarani que já existiam muito antes da chegada dos primeiros europeus e seus descedenntes. Esse grupo guarani, conforme o Mapa de Nimuendajú (Figura 7 deste relatório) o território histórico guarani é transnacional. Portanto, quando os ascendentes do grupo guarani de Araçá'í migraram do oeste para o leste, estavam e continuaram dentro de seu território.

\section{A História dos Guarani de Araça'í Através de Suas Narrativas}

Os Guarani de Araça'í contaram a história vivida pelo grupo desde 
o final do século passado até os dias atuais. Essa história faz parte de um processo histórico mais amplo experienciado pelos Guarani desde o século XVI quando foram conquistados pelos europeus e tiveram seus territórios ocupados e colonizados. Os povos indígenas do Brasil meridional e as formas como vivem na atualidade têm uma linha de continuidade com os acontecimentos que se iniciaram há 500 anos. Trata-se de uma história que envolve processos complexos que alteraram completa e drasticamente o destino dos povos que viviam neste continente. Como afirmou Brochado, os Guarani se instalaram no sul do Brasil como povo vencedor das populações que anteriormente lá viviam. A história do grupo guarani de Araça'í é um fragmento deste grande processo histórico global, isto é, trata-se de um processo local e específico de um segmento indígena que se insere num contexto amplo que, para ser compreendido, precisou ser recuperado, ao menos em linhas gerais, como vimos nos capítulos II e III.

A história particular dos Guarani de Araça'í se insere num processo regional que ocorreu nas terras que envolvem os estados do sul do Brasil e parte da Argentina e do Paraguai. O grupo que se instalou nas terras que hoje fazem parte dos municípios de Saudades e Cunha Porã era composta por quatro famílias nucleares vinculadas por laços de afinidade, ou seja, formava uma família extensa (Te'yi): os Honório, os Ribeiro da Silva, os Morais e os Barbosa. Todas as famílias que hoje reivindicam a volta para sua terra tradicional são descendentes em linha direta daquelas que formaram os Tekohá no Araça'í, como pode ser comprovado pelos gráficos de parentesco.

João Ribeiro e Clementino Barbosa relatam que a família extensa original se estabeleceu no Araça'í, vindo de algum lugar do lado oeste, em terras pertencentes ao Paraguai e à Argentina:

Pois é, daí que a história vai ser continuado, que o meu pai e o pai do Clementino vieram pequenos de lá, do Paraguai e daí o tempo da guerra mundial do Paraguai e eles diziam que era guerra da Europa. Então naquela época, meu pai entrava sertão adentro, salvo daquela guerra mundial, e daí entraram mato adentro, sertão adentro e não tinha nem sinal de morador nem nada. No mesmo sertão, se colocaram embaixo do mato, porque não tinha chance [d]a derrota nem nada. Então eles 
moraram muitos anos no meio do mato e aí pela cabeceira, mais ou menos agora na cabeceira do Araçá, por lá moraram dois anos debaixo do mato e ali vieram e vem vindo às margens do rio, prá baixo do rio e acompanhando o rio Araçá. Aí chegaram e ali eles moraram, naquela localidade do engenho do Fio. Então lá eles se colocaram e vieram pras margens do rio e daí eles podiam abrir a roça já naquele tempo, mas também sinal de morador [branco] sinal de povo não tinha nada, era puro sertão e a comida que eles tinham só a carne de caça, eles caçavam e quando eles matavam a anta e ali eles tinham a comida. Fome eles não passavam, mas o sacrifício maior que eles passavam era a falta de sal e um tempo que o salzinho terminou e depois daquilo como é que eles iam arrumar o sal? E daí, por ali se aguentaram... e daí então eles vieram e moraram no Araçá. Daí abriram a roça e moraram muitos anos lá e ali que o vovô do Clementino faleceu e daí enterraram ele lá (no cemitério da primeira aldeia) e depois daquilo entraram mais prá banda de, hoje em dia, é Cunha Porã e daí eles abriram a picada de novo e passaram por uma picada lá prá poder plantar naquele tempo.

Essas narrativas esclarecem sobre as razões dos deslocamentos que os Guarani desenvolveram desde o século XIX quando fugiram do Paraguai por causa da "guerra mundial", da "guerra da Europa". Muitos grupos guarani tiveram de se esconder nas matas de seu grande território e alguns deles atravessaram o rio Uruguai, entrando na parte conquistada pelos luso-brasileiros, no atual estado do Rio Grande do Sul. Esse grupo certamente permaneceu nas terras à margem esquerda do Uruguai, no território onde havia os Sete Povos das Missões. O grupo formado pelas famílias de Antonio Ribeiro da Silva, Rufino Honório e Clementino Barbosa, era um grupo chiripá, o que fugiu da Guerra do Paraguai (1864-1865). No trajeto que realizaram, antes ou depois de atravessarem para leste do rio Uruguai, esse grupo entrou em contato com grupo mbyá na região das missões e, através do casamento, integrou-se ao grupo que se instalou no Araça'í, no final do século XIX ou início do XX.

Confrontando as narrativas colhidas pelo GT Araça'í com os fatos apontados pelos Guarani em 1947 quando foram visitados pelo Padre

Espaço Ameríndio, Porto Alegre, v. 7, n. 2, p. 277-556, jul./dez. 2013. 
Rambo, sabe-se pelos depoimentos, conforme atesta o mesmo padre, que o grupo teria vindo do Paraguai 60 anos antes, isto é, em 1887. Disseram-lhe que antes de chegarem no arroio do Passo Feio tinham estado em Santa Catarina, entre os rios Chapecó e Chapecozinho, referindo-se, desse modo, a Araça'í. Naquela época os Guarani ainda mantinham relações com os parentes do Paraguai e de Misiones, Argentina. Esse confronto permite localizar a migração desse grupo guarani no contexto da Guerra do Paraguai.

A família mbyá que fez a aliança com o grupo chiripá era de Joaquim Mariano Tupã, pai de Maximino Mariano. Joaquim se casou com Paulina Morais Kerexu, filha de Pedrinho Morais e Maria Barbosa. Joaquim Mariano foi incorporado ao grupo chiripá, adotando o princípio da residência uxorilocal (o genro vai morar com o sogro). Essa aliança entre os Chiripá e os Mbyá ocorreu antes de irem para o Araça'í quando passaram pelo Rio Grande do Sul, e, como dizem eles, "então, quando se juntaram, ficaram um grupo só", "conversaram e se entenderam que eram tudo Guarani". Maximino, sendo filho de pai mbyá é reconhecido como Mbyá pela regra da descendência guarani que é patrilinear mas, ao ser integrado ao grupo chiripá e dele ter-se tornado membro, seus filhos foram socializados segundo costumes chiripá. Isso é comprovado pelo fato de Maximino ter adotado o nome da família de sua mulher que é uma Morais. Nesse sentido, na (sócio)lógica guarani, a pessoa estrangeira incorporada adota os padrões do grupo adotivo e os filhos se tornam Chiripá porque o grupo continua Chiripá, mesmo com a incorporação de várias pessoas ao longo do tempo, sejam elas de outras parcialidades ou etnias. Conforme nossa tese o grupo chiripá, para poder estabelecer-se ou permanecer na terra de outro(s) grupo(s), estabeleceu aliança através do casamento, garantindo, assim, o direito de viver na região até poder continuar a busca de uma terra própria, onde pudesse estabelecer-se definitivamente.

Como vimos no capítulo III, Simonian levantou informações sobre os Guarani do Toldo Lagoão e sugeriu a hipótese de que estes formariam um só grupo com os de Serrinha e Votouro, isto é, formariam uma família extensa ou Te'yi e desse grupo faria parte a família nuclear de Natalício Mariano, pai de Joaquim Mariano que se casou com mulher chiripá de Araça'í, Paulina de Morais (gráfico Ma1).

Espaço Ameríndio, Porto Alegre, v. 7, n. 2, p. 277-556, jul./dez. 2013. 
Outra aliança foi feita entre o grupo de Araça'í e o que vivia na região de Iraí-RS pois Antonio Ribeiro da Silva, segundo informou seu filho João, foi buscar sua mãe em Iraí. Encontramos referências históricas sobre a presença guarani em Iraí (FISCHER, 1954, p. 16 e MENDES, 1954, p. 38). Apesar de essa terra ser conhecida como sendo kaingang pela maioria dos pesquisadores, esses autores dizem que os Kaingang disputavam as águas termais de Iraí e informam que a esposa de Nonoay era Guarani daquela localidade.

A existência de casamentos entre as diferentes parcialidades foi registrada por vários autores. Cadogan, por exemplo, informa que eram frequentes as uniões entre chiripá-mbyá e vice-versa, isto é, pessoas de uma parcialidade eram incorporadas na outra. Diz ainda:

Del cruzamiento chiripá-mbyá, conservan reminiscencias en sus tradiciones desde el tiempo de las Misiones [...], y hallándome durante el decenio 1920-30 en el Alto Monday, escuché quejas de los Mbyá acerca de irrupciones de los Chiripá, quienes raptaban mujeres (CADOGAN, 1959, p. 67-68)

O grupo que instalou o Tekohá no Araça'í tinha, como disseram, umas 40 pessoas, e pelo estudo do parentesco realizado pela nossa equipe, tratava-se de uma parentela ou família extensa (Te'yi), constituída por quatro famílias unidas por laços de consanguinidade ou afinidade. Antonio Ribeiro da Silva (filho do casal Euzébio Ribeiro dos Santos e Josefa da Silva) era casado com Ana Maria, filha de Rufino e Joaquina Honório; José Barbosa era casado com Maria, outra filha de Rufino Honório (vide gráficos $\mathrm{H} 1$ e Rs 1 ). Os filhos do casal Morais casaram seus filhos com os filhos das famílias Barbosa (Pedrinho Morais com Ana Maria da Silva Barbosa) e da família Honório (Gregório casouse com Ernestina e Pedrinho com Ana Maria); um dos filhos, Angelino, casou-se com mulher juruá, Rosa, a qual foi incorporada ao grupo (vide gráfico Mo1), indicando que foi feita também aliança com as populações nacionais estabelecidas nas regiões por onde andaram.

A região de Araça'í era completamente coberta de matas e o grupo primeiro se instalou à margem do rio Araçá, próximo ao local onde acamparam em julho de 2000 e permaneceram até outubro, quando foram despejados. Próximo a essa aldeia fizeram o primeiro 
cemitério, onde os primeiros que faleceram foram enterrados como o avô de Clementino Barbosa (vide Figura 20)

Permaneceram na primeira aldeia/Tataypy Rupa até o início de uma outra "guerra mundial", quando o grupo teve de abandonar a primeira aldeia e se refugiar na mata; depois se fixaram à margem do rio Araçazinho. Apesar da confusão de datas fornecidas pelos depoentes indígenas, é certo que por volta de 1914 já tinham se estabelecido numa segunda aldeia, agora perto do rio Araçazinho que na língua guarani se diz Araça'í (Araça + í = pequeno). Nessa época a região ainda era "puro sertão" e não havia outras famílias senão as da comunidade de Araça'í. No Araçazinho viveram mais tempo e fizeram roças maiores e o grupo passou a ter contatos com os primeiros Juruá que começaram a instalar os primeiros núcleos que deram origem às cidades e aos primeiros brancos que começaram a invadir suas terras. Mais tarde, a Cia. Territorial Sul-Brasil viria a lotear as terras da região até incluir as terras do Tekohá Araça'í ou Karaí Tupã. Assim eles narraram os fatos:

Abriram mato adentro picadas e daí saíram de [para] São Carlos. São Carlos tinha só quatro moradores naquele tempo, no costado do Uruguai. Então o finado pai pegaram lá naqueles moradores e daí arrumaram casa e ficaram morando lá e trabalhando um pouco prá aqueles moradores e daí em $1923^{11}$ tinha [teve] outra guerra de novo com os Chimangos e Maragatos $^{\mathbf{1 2}}$. Então daí que a última guerra em 1923, guerra mundial ainda. Com isso, o finado pai e eles entraram novamente no Araçazinho, daí abriram maiorzinho um pouco mais a picada para poder então puxar o que comer de lá já. Entraram de novo e aí sim vieram [se] colocar no Araçazinho, onde tem o cemitério (o cemitério da segunda aldeia) agora. Daí se colocaram, se não me engano, em 1914 já estavam morando lá, no Araçazinho e nem sinal de povo de Cunhataí, nada de Cunha Porã, Maravilha, nada, nada, é puro sertão aquele. Tinha pinhal, bastante naquele lugar, erval, jabuticabal, então aí já fica pro lado de Maibu [Maipu], aquela parte de lá. Então naquele tempo era puro sertão e o finado meu pai abriu a roça lá no Araçazinho. Só no caso do rancho dele que ele abriu a roça e na maioria é puro sertão. $E$ ali se passou naquele tempo, nós já

\footnotetext{
${ }^{11}$ Guerra do Contestado (1912-1916)?

${ }^{12}$ Revolução Federalista (1893-1894)?
} 
estávamos morando lá já vinte anos e ali foi que o pai dele foi prá lá no Rio Grande que tem outros parentes por lá, e aí encontraram os parentes deles por lá e foram prá morar lá. E aí, sempre nós ia passear, só de passeio prá Rio Grande, na casa dos meus tios, João Honório, né? E daí a cada 30 dias nós voltávamos prá lá e nós sempre tava indo prá passear.

Tudo junto naquele tempo, no Araçazinho. Tudo junto, o pai dele [de Clementino] e depois o tio João Honório, o Gregório [Morais], o Emílio [Morais], o Pedrinho Morais... e o Angelino [Morais] também. Então são esses que moravam lá" (João Ribeiro).

Mais ou menos 40 pessoas naquele tempo. Eram os Morais, Barbosa... (Clementino).

E da minha gente também naquele tempo, o pai, tudo... Naquele tempo nós viemos com o finado pai [Antonio Ribeiro da Silva]. Foi mais ou menos em 1914 [referindo-se à época em que viviam na segunda aldeia no Araçazinho/Araça'í] (João Ribeiro).

Outros relatos de Clementino Barbosa e João Ribeiro da Silva falam de aldeias localizadas no Paraguai e na Argentina de onde saíram os seus avós e lá deixaram vários parentes. João lembra que deixou duas tias (irmãs da mãe) lá, mas nunca mais teve notícias e não sabe se ainda vivem. Sabe que tem um primo que é cantor e se apresenta nas emissoras de rádio no Paraguai. Eles ainda disseram que quando viviam no Paraguai todos só falavam na língua guarani e os seus pais não falavam o português, língua que os mais novos aprenderam quando vieram para o lado oriental do Uruguai. Os costumes que seguiam eram apenas os guarani sendo que o hábito de consumir sal é recente e ainda assim usam em pouca quantidade. A rede de sociabilidade que mantêm restringe-se aos grupos do interior do Rio Grande do Sul. Disseram não ter aldeia de seus parentes próximos ao litoral. Devido à distância não puderam manter contato com esses parentes distantes, mas em 1947 quando Padre Rambo os visitou eles mantinham relações com os parentes do Paraguai e de Misiones (RAMBO, 1947, p. 86).

João Ribeiro, num depoimento dado a um membro do CIMI-Sul em 1998, referiu-se à aldeia/localidade Capi in Cacin, no Paraguai de onde teria vindo seu pai e à aldeia/localidade Tajy in Care, de onde teria vindo sua mãe. De acordo com esse mesmo depoimento, o pai de João 
Ribeiro veio do Paraguai e chegou na região de São Carlos em torno de 1901. Na época da revolução federalista, os Guarani já estavam na região de Araça'í. Nos dados fornecidos à nossa equipe, João Ribeiro disse que sua mãe nascera na aldeia Kapié Kasin, na Argentina ou Paraguai.

Juntando esses dados é possível, então, pensar o trajeto em partes: o grupo (ou parte) saiu do Paraguai e da Argentina/Misiones, fugindo da Guerra do Paraguai, no último quartel do século XIX. Permaneceram algum tempo na região missioneira, talvez nas imediações de Soledade-RS e mantiveram relações com grupos guarani e juruá lá estabelecidos. A migração para Araça'í deve ter-se iniciado nos últimos anos do século XIX, pois Antonio Ribeiro da Silva, pai de João Ribeiro, teria chegado na região de São Carlos em 1901. Nossa hipótese é que a migração pode ter sido originada pela Revolução Federalista que os obrigou a permanecer no meio da mata em acampamentos provisórios nos primeiros anos. Depois que fizeram o Tataypy Rupa às margens do rio Araçá novamente tiveram de abandonar o lugar por causa de nova guerra que, segundo hipótese mais provável seria a Guerra do Contestado (1912-1916), que obrigou as famílias a retornar para o mato e a procurar lugar mais seguro. Em 1914, disseram, já estavam fixados na margem do rio Araçazinho.

Mesmo depois que se instalaram à margem do rio Araçazinho toda a região continuou habitada apenas pelos Guarani e as densas florestas eram interrompidas apenas pelas clareiras que abriram para fazer roças e ranchos.

Ficaram morando na aldeia do Araça'í durante cerca de 20 anos quando uma parte da família Honório (João Honório) resolveu morar na TI Nonoai, onde "já tinham parentes morando", segundo disseram Clementino e João Ribeiro. Maria Cecília Barbosa acrescentou outra informação dizendo que os primeiros que entraram em Mbaraca Mirim, que até então não existia, foram os Morais, Pedrinho, Gregório e Emílio. Primeiro fundaram a aldeia/Tataypy Rupa de Mbaraca Mirim, depois foram para a aldeia Purungos (que já não existe) e por fim, Passo Feio, que era lugar de passagem, acabou virando aldeia.

Se já tinham parentes vivendo na TI Nonoai, seria necessário elucidar, quando a parentela que migrou para Araça'í foi cindida de um 
grupo maior, ficando uma parte no Rio Grande do Sul, na TI Nonoai ou nas próximidades.

É importante ressaltar, no entanto, que os Guarani disseram que naquele tempo a região onde fundaram as aldeias Passo Feio e Mbaraca Mirim era completamente desabitada e não tinham contatos com os Kaingang. Lá também "era puro mato". A partir do momento que parte dos Honório e dos Morais foram viver no Mbaraca Mirim/Passo Feio, os parentes de Araça'í passaram a fazer visitas periódicas, segundo eles, mensais.

Não foi especificado se a mudança de João Honório deveu-se (ou não) a alguma pressão externa. É certo que dessa época em diante começam a chegar à região oeste catarinense os primeiros Juruá que passam a invadir as terras guarani, como veremos mais adiante.

\section{Meio Ambiente, Atividades Produtivas, Organização Social e Demografia}

Como vimos nas narrativas acima, quando os Guarani chegaram em Araça'í, a região era completamente coberta de florestas e nos primeiros anos as famílias viveram "debaixo do mato", ou seja, como estavam fugindo da guerra, viveram cerca de dois anos em acampamentos provisórios, vivendo apenas da caça e da coleta. Como as florestas eram preservadas, os alimentos que elas forneciam eram abundantes e "comida não faltava". A região era rica em pinheirais, ervais e frutíferas como jaboticabeiras.

o finado pai sempre fazia a erva... Palmito também, do miolo da palmeira que socava prá fazer a farinha. Misturava com a erva.

mel, caça, peixe. Dourado, ..., piau. A senhora conhece aquele peixe gosta mais de gabiroba, então na beirada do Araçá, só gabirobeira que tinha e naquele tempo de maduro que tinha aquela fruta, a gabiroba, então aquele peixe, piracajú, sempre vinha aí e então gostavam mesmo.

Depois de dois anos fizeram a primeira aldeia, à margem do rio

Espaço Ameríndio, Porto Alegre, v. 7, n. 2, p. 277-556, jul./dez. 2013. 
KIMIYE TOMMASINO - Relatório de Identificação e Delimitação da Terra Indígena...

Araçá. Só então abriram as primeiras roças. No meio das densas florestas, os Guarani abriram apenas as clareiras onde levantaram seus ranchos (óga, óy).

Nós plantava, naquele tempo, que a roça já estava, quer dizer aberto, plantava tudo, batata doce, mandioca, erva mate...

Clementino e Maximino disseram que a aldeia/Tataypy Rupa que fizeram no Araça'í se chamava Karaí Tupã porque,

nós costumamos colocar onde que nós ficava e morava, chamava o lugar dos Guarani sempre assim. Como lá em Nonoai tem os nomes dos lugarzinhos, é sempre o nome da tribo lá. Então essa tribo lá era de Karaí Tupã, em Guarani.

A escolha do local onde construíram seu Tekohá possuía as condições ideais para viver segundo seu modo de ser/Tekó. Da mesma forma como Noelli sintetizou o ambiente preferencial para seus assentamentos, Schaden verificou, em suas pesquisas, a preferência por se estabelecerem em regiões de floresta.

Portadores de uma cultura característica de região florestal, em que as atividades de subsistência incluem as lides da caça em combinação com o amanho da terra, os Guarani se estabelecem, sempre que possível, no seio da mata, evitando a paisagem aberta dos campos. As suas aldeias, longe de constituírem conglomerados compactos de habitações, consistem em casas isoladas, mais ou menos distantes umas das outras, espalhando-se pelas clareiras abertas na floresta. Em geral não é possível determinar um "centro" da aldeia, a não ser que se considere como tal a habitação do ñanderú, médico-feiticeiro, ou o oýguatsú, casa de festas religiosas. De fato, a construção em que se realizam as cerimônias é ponto de convergência das atividades sociais e religiosas do grupo, de modo que as aldeias maiores, em que haja dois ou mais chefes religiosos, tendem a decompor-se em outros tantos núcleos bastante independentes, cada qual com vida própria. Na maioria dos casos, essas unidades sociais constituem parentelas sob a direção de um chefe da 
KIMIYE TOMMASINO - Relatório de Identificação e Delimitação da Terra Indígena...

família-grande (SCHADEN, 1962, p. 33).

Pedro Barbosa explicou-nos que os Guarani nunca têm uma só aldeia/Tataypy Rupa. Sempre existe mais de uma e pode acontecer de uma família perder (por morte) uma pessoa, então, por desgosto, saem para outra aldeia onde ficam morando. "Quando passa a tristeza, podem voltar" (ou não).

As atividades de subsistência eram, nos dois primeiros anos, baseadas na caça, coleta e pesca, como disseram. Depois que construíram seus ranchos passaram a fazer roças em clareiras que abriram na floresta. Todas as atividades de subsistência eram realizadas segundo padrões e regras sociais guarani. O chefe de cada família nuclear exercia liderança sobre os membros de sua família que incluía filhos solteiros, filhas e genros. Havia tarefas femininas e masculinas e outras que podiam ser realizadas pelos dois sexos.

Os produtos de agricultura eram plantados em roças de coivara, costume de quase todos os povos da América do Sul não-andino. Os Guarani não conhecem a propriedade privada, sistema que vigora na sociedade moderna ocidental. Ninguém é proprietário da terra, mas cada produtor é dono dos produtos que plantou e enquanto uma pessoa estiver explorando uma determinada área, este será reconhecido como tendo direito de uso daquele terreno e dos produtos que tenha plantado. Alguns produtos, como melancia e abóbora, eram plantados em "todo lugar" e "não tinha divisa", isto é, não formavam roças e pertencia a todos. Cada família plantava entre um e dois hectares e cada roça tinha sua divisa com as de outras. Apesar de cada família ter a sua roça e ser "dono" dela, no momento do consumo essa produção acaba sendo democratizada através da reciprocidade generalizada ${ }^{13}$.

Porque nosso costume é assim. Como o João estava dizendo, nós plantamos o milho, o bananal, prá todos, prá toda a comunidade. Quer dizer, quem quiser comer junto, então come junto. Nós não podemos vender um para o outro, nós não vendemos. Então todos nós, qualquer planta que madure, nós sempre dividimos um

\footnotetext{
${ }^{13}$ Reciprocidade generalizada "é uma forma de troca baseada na suposição de que as retribuições se equilibrarão a longo prazo. Tão sólida é essa expectativa que, quando alguma coisa é dada ou feita a outrem, a questão da retribuição não é especificada - habitualmente, nem mesmo sugerida" (SERVICE, 1971, p. 28).
}

Espaço Ameríndio, Porto Alegre, v. 7, n. 2, p. 277-556, jul./dez. 2013. 
KIMIYE TOMMASINO - Relatório de Identificação e Delimitação da Terra Indígena...

pouco cada um, é assim nosso costume.

Que nem melancia, não tem divisa, e quando dá bastante é prá comer. Todo mundo chega e come.

As famílias guarani de Araça'í casaram seus filhos entre si, como pode ser comprovado pelos gráficos de parentesco. Mas casaram também com filhos de outros grupos guarani, kaingang e juruá da região onde construíram sua rede de sociabilidade. Essa rede social mais ampla reflete a geografia que realizaram no percurso que fizeram ao longo das décadas, isto é, desde que saíram do Paraguai e Argentina, passaram pelo Rio Grande do Sul, atravessaram para Santa Catarina e depois voltaram para o Rio Grande do Sul.

Teoricamente a descendência guarani é patrilinear e a residência é uxorilocal. No entanto, como já vem sendo observado pelos antropólogos da atualidade, as regras sociais indígenas nunca foram tão rígidas as quais, dependendo do contexto, podem ser instrumentalizadas de acordo com interesses coletivos. Os dados empíricos coletados junto aos Guarani de Araça'í revelam a flexibilidade das regras sociais, seja em relação à residência, seja em relação à descendência. No caso de casamento entre pessoas de dois Tekohá diferentes, Maximino disse que a residência é patrilocal (o casal vai viver no grupo do pai do noivo), mas lembrou que a filha de Clementino mora em Nonoai porque o marido é de lá. Mas, completou Maximino, "se eles quiserem vir morar prá cá [junto ao grupo da esposa] podem vir também".

Os gráficos de parentesco revelam as principais alianças entre as famílias da comunidade guarani de Araça'í e as incorporações (sistema inclusivo) de pessoas de outra parcialidade, alguns Juruá e, mais recentemente, alguns Kaingang. Alguns Juruá foram incorporados antes de chegarem a Araça'í e são naturais do Rio Grande do Sul, indicando que alguns Guarani se casaram com os Juruá "caboclos" da região missioneira.

Os gráficos foram montados segundo dados levantados na pesquisa de campo realizados pelo GT Araça'í. A genealogia da família Mariano foi fornecida por Rodrigo Venzon, pesquisador de Porto Alegre que gentilmente colaborou com nossa equipe. Esclarecemos que a 
família Mariano é da parcialidade mbyá que foi doadora de um filho (Joaquim Mariano) ao grupo de Araça'í, firmando uma aliança entre os dois grupos porque "se entenderam e formaram um grupo só". Essa aliança ocorreu quando Paulina de Morais, nascida no Tekohá Araça'í, foi viver na TI Nonoai aos 12 anos de idade e lá se casou com o Mbyá Joaquim Mariano e depois voltou para Araça'í. Os Mariano fazem parte dos Mbyá que estão espalhados nas Als kaingang do Rio Grande do Sul, como se pode ver pelos gráficos de parentesco Ma1, Ma2 e Ma3. O casal adotou a residência matrilocal ao viver em Araça'í e depois retornou para Al Nonoai/Passo Feio onde viveram até o ano 2000 quando vieram a falecer. Joaquim Mariano nasceu no Paraguai e foi para Araça'í com 18 anos; faleceu aos 100 anos $^{14}$.

Apresentaremos os gráficos de parentesco das famílias de Araça'í, desde as primeiras famílias que fundaram o Tekohá Araça'í até as gerações atuais que reivindicam o retorno à sua terra tradicional.

Observa-se pelas genealogias que os Guarani, tendo vivido em regiões habitadas por vários grupos étnicos, buscou fazer aliança política com tais segmentos. Essa parece ter sido uma das estratégias de sobrevivência que o grupo encontrou para poder se fixar com alguma estabilidade nas regiões por onde passou. Observa-se que a regra geral é as mulheres guarani se casarem com homens de grupos estrangeiros. Mas os gráficos revelam também que homens guarani se casaram com mulheres estrangeiras, como é o caso de brancas de diferentes origens étnicas.

Essa rede de alianças através do casamento interétnico aponta para um fato óbvio, mas pouco explicitado: nem sempre os contatos entre índios e brancos foram de conflito. Houve muitos espaços de negociação e o sucesso está evidenciado no número de casamentos intergrupos.

Para que o leitor possa entender os gráficos apresentamos notas e comentários com informações complementares que poderão facilitar o acompanhamento das alianças travadas entre as famílias chiripá e dessas com outras etnias, kaingang e juruá.

\footnotetext{
${ }^{14}$ Essas informações sobre o casal Joaquim Mariano e Paulina Morais Kerexú foram colhidas por Jussara Capucci, coordenadora do CIMI-SUL, em maio de 1999. Anotações de campo manuscrito.
}

Espaço Ameríndio, Porto Alegre, v. 7, n. 2, p. 277-556, jul./dez. 2013. 


\section{Genealogia das Famílias de Araça í: Casamento como Aliança Política}

\subsection{Notas e Comentários aos Gráficos de Parentesco}

\section{Barbosa - B1}

- José Barbosa e Maria da Silva Barbosa nasceram no Paraguai ou Argentina. Seus parentes moram todos em Araça'i e duas filhas do casal moram em Nonoai.

- Clementino Barbosa nasceu no Paraguai. É o atual nhanderu da comunidade de Araça'i.

- Anacleto de Oliveira nasceu em Soledade/RS, e tem parentes em Nonoai. Alcídia dos Santos nasceu em Nonoai, onde tem parentes. Ambos são Tierê Tará, isto é, misturado.

- Clementino tem parentes na TI Nonoai/Pinhalzinho, onde moram seu irmão e seu primo.

- Levino mora na TI Votouro.

- Albino mora na TI Serrinha.

- Elza e Natalina são casadas com Kaingang e moram na TI Votouro.

- Observam-se as alianças entre as famílias Honório e Barbosa (ambas Chiripá); Barbosa e Morais (Chiripá); e entre os Barbosa (Chiripá) e os Oliveira ("mestiços" ou "caboclos") da região de Soledade e Nonoai, RS.

\section{Barbosa - B2}

- Pedro Barbosa nasceu na TI Votouro, depois morou na TI Nonoai/Mbaraca Mirim. Integra a comunidade de Araça'i.

- Alzira Barbosa e seus filhos nasceram na aldeia Mbaraca Mirim.

- Os pais de Alcides Siqueira moram na TI Votouro.

- Observa-se que tanto os Morais quanto os Barbosa incorporaram mulheres "caboclas" da região missioneira já na primeira geração, antes de chegarem a Araça'í. Vê-se também o casamento de um Barbosa com mulher Morais. 
KIMIYE TOMMASINO - Relatório de Identificação e Delimitação da Terra Indígena...

\section{Barbosa - B3}

- Antônio Barbosa nasceu na TI Nonoai/Pinhalzinho. É integrante da comunidade de Araça'i.

- Loreni nasceu na TI Votouro.

- Loreci, Márcio e Joana nasceram na TI Nonoai/Mbaraca Mirim.

- Paulo Barbosa e seus filhos nasceram na aldeia Mbaraca Mirim. Integram a comunidade de Araça'i.

- Jurema Benitez nasceu na TI Guarita, morou na aldeia Mbaraca Mirim. É integrante da comunidade de Araça'i.

- Dado etnográfico importante é a incorporação de um homem Mbyá na comunidade chiripá de Araça'í através do casamento de Joaquim Mariano com Paulina Morais (mulher chiripá de Araça'í) cujos filhos foram socializados chiripá.

- Vê-se também o casamento entre Antonio Barbosa com Joana, filha de Joaquim Mariano e Paulina Morais.

\section{Barbosa - B4}

- Nair Barbosa, João Barbosa e seus filhos nasceram em Mbaraca Mirim. Integram a comunidade de Araça'i.

- Observa-se o casamento entre João Barbosa com Nair, filha de Dorico Morais.

\section{Barbosa - B5}

- Miguel nasceu na aldeia Caeté/TI Votouro, depois morou na aldeia Mbaraca Mirim e na TI Serrinha. Miguel é integrante da comunidade de Araça'i.

- Terezinha e seus filhos (com exceção de Matias) nasceram em Mbaraca Mirim, moraram na TI Serrinha. São integrantes da comunidade de Araça'i.

- Matias nasceu no dia 11 de outubro de 2000 em Araça'i no acampamento onde estiveram até dia 19 de outubro quando foram despejados.

- Nota-se o casamento entre Miguel, filho de Clementino Barbosa, com Terezinha, filha de Darci Morais. 


\section{Barbosa - B6}

- Luis nasceu na TI Votouro, morou em Mbaraca Mirim. É integrante da comunidade de Araça'i.

- Domicilia é filha de Vitorino da Silva e Júlia da Silva, ele nascido na Terra Araça'í, ela em Mbaraca Mirim. Domicília e seus filhos nasceram em Mbaraca Mirim. São integrantes da comunidade de Araça'i.

- Clementino tem um sobrinho de seu pai, Luís Mariano, que mora em área indígena em Florianópolis; uma irmã do pai de sua mãe mora em área indígena em São Paulo.

\section{Barbosa - B7}

- Alcindo nasceu na Al Votouro. Mudou-se para Mbaraca Mirim. Pertence à comunidade de Araça'i.

- Marlene e Maristela nasceram em Mbaraca Mirim. São integrantes da comunidade de Araça'i.

- Marlene é filha de mulher chiripá da comunidade de Araça'í casada com o Juruá Osmar Rodrigues incorporado à comunidade indígena.

\section{Barbosa - B8}

- Valmir Barbosa nasceu na TI Votouro, mudou-se para Mbaraca Mirim. É integrante da comunidade de Araça'i.

- Maria Helena Barbosa nasceu em Planalto/TI Nonoai. Morou em Mbaraca Mirim. É integrante da comunidade de Araça'i.

- Esmael nasceu na TI Votouro e Thiago nasceu na aldeia Caeté/TI Votouro. Os dois moraram em Mbaraca Mirim. São integrantes da comunidade de Araça'i.

- Raquel nasceu na aldeia Passo Feio, morou em Mbaraca Mirim. É integrante da comunidade de Araça'i.

- Maria Helena, casada com Valmir Barbosa, é uma mulher juruá incorporada à comunidade chiripá de Araça'í; tem irmãos em Bagé RS.

Barbosa - B9

- Maximino pertence à parcialidade mbya pela regra da 
KIMIYE TOMMASINO - Relatório de Identificação e Delimitação da Terra Indígena...

descendência patrilinear, mas pela residência uxorilocal, foi socializado na comunidade chiripá de sua mãe. Trata-se, pois, de aliança entre Mbyá e Chiripá em que um homem mbyá foi incorporado aos Chiripá. Note-se que os descendentes de Joaquim e de Paulina se tornaram Morais que é a família da mãe, comprovando a incorporação.

- Eva de Paula e Darci Isaías moram na TI Serrinha; o casal nasceu na TI Votouro.

- Maximino e Cecília nasceram em Mbaraca Mirim. Integram a comunidade de Araça'i.

- Notam-se os casamentos entre Maximino Mariano de Morais com Cecília, filha de Clementino Barbosa. Na geração seguinte, observase o casamento entre Marcos, filho de Maximino com mulher kaingang da TI Serrinha a qual foi incorporada à comunidade chiripá. Pela regra da descendência patrilinear, os filhos são considerados Chiripá.

\section{Barbosa - B10}

- Adão Daniel nasceu na Al Carreteiro.

- Serinérgio Daniel nasceu na Al Carreteiro e residiu na TI Serrinha. Ele é um Kaingang incorporado ao grupo chiripá de Araça'í, porque se casou com Neusa, filha de Clementino Barbosa e adotou a residência uxorilocal. É, portanto, integrante da comunidade de Araça'i.

- Neusa nasceu na Al Nonoai.

- Observa-se que, Adriana Daniel Yotakua Mirim, filha de Daniel e Neusa, recebeu nome guarani, tornando-se pessoa chiripá, havendo uma inversão na regra de descendência, de patri para matrilinear.

Honório - $\mathrm{H} 1$

- João Rupp foi adotado pela família Rupp, um dos diretores da Cia. Territorial Sul Brasil. Segundo João Ribeiro, seu tio recebeu educação tendo feito carreira militar. Ele não se casou, faleceu na região de Araça'í e foi enterrado em cemitério dos Juruá.

- Ana Maria Ribeiro da Silva nasceu em Kapié Kasín, na Argentina ou Paraguai.

Espaço Ameríndio, Porto Alegre, v. 7, n. 2, p. 277-556, jul./dez. 2013. 
KIMIYE TOMMASINO - Relatório de Identificação e Delimitação da Terra Indígena...

- Observam-se os casamentos ocorridos entre as famílias Honório, Ribeiro da Silva e Morais.

Honório - $\mathrm{H} 2$

- Não há informações sobre os pais ou irmãos de Alcides de Paula.

- Tereza nasceu em Araça'i e hoje mora em Nonoai-Sede, assim como sua irmã Rosalina. Tereza casou-se com Alcides de Paula, Kaingang da Al Nonoai/aldeia Sede e foi incorporada à comunidade kaingang onde vive. Nesse caso, os filhos seguiram a regra comum às duas etnias de descendência patrilinear e todos os filhos são Kaingang. Os Guarani denominam filhos de suas etnias indígenas cujo pai é não-guarani de Ponguê, isto é, quando a mãe é Guarani e o pai, índio de outra etnia.

Honório - H3

- Sebastião Honório André teve seu primeiro casamento com mulher juruá de origem alemã. Todos os dez filhos não vivem em área indígena e estão integrados à sociedade nacional. O segundo e atual casamento de Sebastião André se deu com mulher kaingang e o casal não vive em área indígena, mas na zona urbana de Rio dos Índios-RS. Pela regra da descendência patrilinear, as filhas são consideradas Guarani.

\section{Honório - $\mathrm{H} 4$}

- O primeiro marido de Rosalina, filha de Roberto Honório, era Guarani de Araça'í. Separaram-se quando ainda viviam em Araça'í e não tiveram filhos. O segundo casamento se deu com um Kaingang (João Pedro Lopes) da TI Nonoai/aldeia Sede e foi viver na comunidade do marido. Nesse caso, ela e os filhos foram incorporados à comunidade kaingang, filhos que, pela regra da patrinearidade, são Kaingang e na classificação dos Guarani são Ponguê.

\section{Honório - $\mathrm{H} 5$}

- Não há dados suficientes para determinar quem são os pais de João Carlos da Silva (Ver B2) e Domicilia Barbosa (Ver B6). Não é 
possível determinar os filhos de cada casamento de Maria da Silva (filha de Dinarte Mariano - Ver Ma2), se ela é de fato casada com Artur da Silva (filho de João Honório - Ver H1) e Vitorino da Silva. O que podemos afirmar é a existência de duas Maria da Silva, uma é filha de Dinarte Mariano e Leonora, a outra é filha de Otília Ribeiro da Silva e Pedrinho da Silva (ver Rs4).

- Artur Honório da Silva teve dois casamentos. Do primeiro não temos informações. O segundo casamento se deu com mulher mbyá, Maria da Silva, filha de Dinarte Mariano. O casal Artur e Maria adotaram a residência patrilocal e Maria foi incorporada à comunidade chiripá.

\section{Morais - Mo 1}

- Lídia, Otavino, Darci e João são casados e moram na TI Nonoai/Pinhalzi-nho/Prata.

- Darci nasceu em Araça'i.

- Orildes nasceu em Nonoai.

- Observa-se que dois filhos do casal Morais se casaram com mulheres da família Honório; um terceiro filho se casou com mulher da família Barbosa e o quarto com mulher juruá.

- Na terceira geração nota-se a aliança dos Chiripá com Kaingang e com Juruá.

\section{Morais - Mo2}

- Aldino nasceu em Mbaraca Mirim e hoje mora em Passo Feio.

- Nome guarani de Ernestina é Para'y (GT Araça'i) ou Jetuhuá Nhemboité (CIMI).

- Nota-se a aliança entre as famílias Honório e Morais: dois irmãos Morais casaram-se com duas irmãs Honório.

- Aldino, Loreni e seus filhos moram em Passo Feio há cinco anos. Os filhos mais novos nasceram em Passo Feio e os mais velhos em Mbaraca Mirim.

- Nair, mãe de Loreni, é Kaingang, mas "se criou entre os Guarani".

- Observam-se os casamentos dos filhos do casal Gregório Morais e Ernestina (Honório) Morais: a filha Irma se casou com Juruá; a outra, Vani, se casou com o Kaingang Amâncio Lopes e foi incorporada à 
comunidade do marido; o filho Aldino se casou com Loreni, Kaingang nascida na TI Serrinha, adotou a residência patrilocal e foi incorporada à comunidade do marido chiripá.

\section{Morais - Mo3}

- Waldemar e sua família moram na Aldeia Passo Feio/Al Nonoai.

- Observa-se o casamento/aliança das famílias Morais e Honório, Emílio e Zulmira. Seu filho Rufino se casou com Natália, filha de Joaquim Mariano (Mbyá) e Paulina (Chiripá). Como Joaquim foi incorporado ao grupo chiripá, a filha também foi incorporada.

- Na terceira geração, Waldemar se casou com Lourdes, mulher kaingang que se incorporou à comunidade chiripá tal como sua irmã Loreni (Mo3). Pela descendência patrilinear, os filhos são Chiripá.

\section{Morais - Mo4}

- Pedrinho Morais e Ana Maria Barbosa nasceram em Araça'i. Têm parentes em Nonoai.

- Paulina e Dorico Morais nasceram em Araça'i.

- Dorico Morais nasceu em Araça'i e tem parentes em Mbaraca Mirim.

- Cleci Antunes de Oliveira nasceu em Planalto-RS onde tem parentes. É "cabocla".

- Anastácio de Souza e Marina de Souza e a filha Maria Francisca de Oliveira são Juruá.

- Maria Francisca é Juruá, nasceu em Planalto (Al Nonoai), residiu em Mbaraca Mirim. Casou-se com Sebastião, filho de Dorico Morais e foi incorporada à comunidade de Araça'i. Seus filhos, Alessandra e Adílio de Oliveira, nasceram em Mbaraca Mirim. Hoje integram a comunidade de Araça'i.

\section{Morais - Mo5}

- Nelinho Rodrigues, Marlúcia, Neodi e Ana Maria nasceram em Mbaraca Mirim.

- Rosane e Rosimara nasceram em Planalto/Al Nonoai.

- Nelinho, Rosane e Rosimara moravam em Mbaraca Mirim. Integram a comunidade de Araça'i. 
- Neri mora em Mbaraca Mirim.

- Osmar Rodrigues nasceu em Lageado Grande/Mbaraca Mirim, residia em Mbaraca Mirim. É integrante da comunidade de Araça'i.

- Nelson, Nersi, Marilete e Néri moram em Mbaraca Mirim.

- Marlene é integrante da comunidade de Araça'i.

- Angelina de Paula é Kaingang de Nonoai e se casou com um "indiano" (classificação dos Kaingang de branco casado com mulher kaingang e incorporado à comunidade kaingang).

- Observa-se que Osmar Rodrigues, Juruá incorporado à comunidade chiripá de Araça'í, teve dois casamentos: o primeiro com Angelina, filha de Dorico Morais e Cleci. Quando Angelina faleceu, ele se casou com Ana Maria, irmã da finada Angelina, portanto, sua cunhada. Este é também um padrão guarani.

- Observa-se que Néri Rodrigues, filho do primeiro casamento de Osmar Rodrigues e Nelinho Rodrigues, filho do segundo casamento de Osmar, se casaram com duas irmãs, filhas do casal Angelina (mulher kaingang) com Clementino Gigolete ("indiano", incorporado à comunidade kaingang).

\section{Morais - Mo6}

- Joaquim Mariano nasceu na Al Ventarra, é da parcialidade mbyá. Este gráfico mostra bem a aliança entre o grupo chiripá de Araça'í com o grupo mbyá dos Mariano.

- Maximino teria mais um irmão nascido no Araça'i que hoje mora na TI Nonoai/Pinhalzinho, mas este não aparece no gráfico que deve estar incompleto.

- Joaquim foi sepultado no Passo Feio. O nome guarani de Joaquim é Tupã (fonte: CIMI) ou Karai (fonte: GT Araça'í). Talvez venha daí o nome do Tekohá Karaí Tupã como também era conhecido.

- Observa-se que o gráfico Mo6 mostra bem a aliança entre as famílias mbyá e chiripá onde o marido mbyá foi incorporado ao grupo chiripá. Na segunda geração há o casamento entre um dos filhos com mulher da família Barbosa e na terceira vê-se aliança com os Kaingang através da incorporação de mulher kaingang com homem da comunidade de Araça'í. 


\section{Ribeiro da Silva - RS1}

- Antônio Ribeiro nasceu na Argentina ou Paraguai. Ajudou a fundar o Tekohá Araça'í e quando morreu em 1942, foi enterrado em Araça'i.

- João Ribeiro, Maria e Otília (separada ou viúva) moram na zona rural de Maravilha-SC, na região oeste catarinense.

- Ana Maria nasceu em Iraí-RS.

- O casamento de Antônio (de Araça'i) com Ana Maria (de Iraí) é uma aliança entre os dois grupos. Essa informação é importante porque aponta a existência de um grupo guarani em Iraí, indício já existente em outras fontes históricas como em Fischer (1954, p. 16) que afirma que os Kaingang disputaram com os Guarani a posse das fontes termais de Iraí.

- Observa-se o casamento dos filhos das famílias Ribeiro da Silva e Honório.

\section{Ribeiro da Silva - RS2}

- Hilário nasceu no Tekohá Araça'i. Hoje ele trabalha e mora na zona urbana de Maravilha-SC.

- Todos os filhos de Alcides nasceram em Maravilha, com exceção de Hilário que nasceu em Araça'i.

- Alcides, Zulmira, Nelci e Vanessa moram na zona rural de Maravilha-SC.

- Salete casou-se com Juruá e mora em Itajaí.

- Alcides nasceu no Tekohá Araça'i e saiu de lá quando o filho (hoje com 42 anos) tinha 15 anos.

- Observam-se os descendentes de Antonio Ribeiro da Silva/Ana Maria (Honório) Ribeiro da Silva e de um de seus filhos, Alcides.

\section{Ribeiro da Silva - RS3}

- Lídia e Mário moram perto de Cunhataí, em direção a Maipu.

- Dario vive na zona rural de Maravilha-SC.

- Observa-se a genealogia do casal Antonio Ribeiro da Silva/Ana Maria (Honório), do casal João Honório/Doralina da Silva Jasuká, vinculados pela aliança estabelecida pelo casamento dos filhos Angelina e Sebastião. 


\section{Ribeiro da Silva - RS4}

- Note-se a descendência da família Ribeiro da Silva.

\section{Mariano - Ma 1}

- Nota importante: os Mariano formam um grupo/comunidade mbyá cujos membros vivem distribuídos em várias aldeias do Rio Grande do Sul, conforme pode-se ver pelas informações. Um membro dessa comunidade, Joaquim Mariano, se casou com uma mulher da aldeia chiripá, Paulina de Morais, efetuando aliança entre os dois grupos, como se pode ver no gráfico Mal/Descendentes de Anastácio Mariano-2.

- Otacílio faleceu na TI Guarita.

- Fernandes Mariano e sua esposa são residentes na TI Ligeiro.

\section{Mariano - Ma2}

- João Maria Mariano e Alice Mariano não tiveram filhos e estão sepultados na TI Cacique Doble.

- Luís Natalício e família residem na TI Salto Grande do Jacuí.

- Leonora e Mário residem na aldeia Limeira, TI Xapecó.

- Tereza e Maximina residem no Toldo Guarita.

- Otília e Norberto residem na aldeia Passo Feio/TI Nonoai.

- Observa-se no gráfico Ma2-5 que Artur Honório da Silva, Chiripá da comunidade Araça'í se casou com mulher mbyá da família Mariano. Ficaram morando na Al Nonoai/aldeia Passo Feio, portanto, a mulher mbyá foi incorporada ao grupo do marido chiripá.

\subsection{Genealogia das Famílias de Araça'í}

A seguir apresentamos os gráficos de parentesco com o objetivo de revelar que as famílias que reivindicam a terra do Tekohá Araça'í formam uma parentela, estabeleceram alianças com outro grupo da parcialidade mbyá, com os Juruá e, mais recentemente, com os Kaingang precedidos da legenda dos símbolos de parentesco e termos classificatórios.

Os dados de todas as famílias e pessoas que pertencem à 
comunidade do Tekohá Araça'í, devido à sua dispersão por várias aldeias kaingang do Rio Grande do Sul, aldeias guarani de Passo Feio e Mbaraca Mirim e zona rural de vários municípios do oeste catarinense e outros, não permitem uma avaliação precisa em termos de sua demografia.

O documento apresentado pela comissão da comunidade de Araça'í listou 133 pessoas distribuídas em 24 famílias. No entanto, cabe esclarecer que muitos parentes consanguíneos e afins não foram listados porque moram fora das aldeias de Mbaraca Mirim e Passo Feio e não foram consultados à época em que elaboraram a reivindicação da terra de Araçá'í (Anexo I: 2). Foi feita uma estimativa a partir da genealogia dos gráficos de parentesco a qual, relacionada às possibilidades culturalmente estabelecidas, chegou-se a 151 pessoas. Esse número poderá ainda ser alargado se levarmos em conta que as regras de descendência e residência guarani não são rígidas.

A tabela 2 mostra as pessoas que estavam no acampamento de Saudades. Os dados foram levantados pela equipe da FUNAI-AER Chapecó e complementadas pelo GT Araça'í. Em seguida apresentamos o gráfico da população que estava no acampamento e que permite observar a distribuição das pessoas de Araça'í segundo faixa etária. 
KIMIYE TOMMASINO - Relatório de Identificação e Delimitação da Terra Indígena...

\section{LEGENDA DOS SÍMBOLOS DE PARENTESCO E TERMOS CLASSIFICATÓRIOS}

$\triangle$ Pessoa guarani da parcialidade chiripá.

Pessoa guarani da parcialidade chiripá incorporada a um grupo juruá.

Pessoa guarani da parcialidade chiripá incorporada a um grupo kaingang.

Pessoa guarani da parcialidade mbyá.

Pessoa guarani da parcialidade mbyá incorporada à parcialidade chiripá.

Pessoa juruá.

Pessoa juruá incorporada a um grupo guarani da parcialidade chiripá.

Pessoa juruá incoporada a um grupo kaingang.

Pessoa kaingang.

Pessoa kaingang incorporada a um grupo guarani da parcialidade chiripá.

? ? Pessoa que não foi possível determinar a etnia ou parcialidade.

\. Pessoa falecida.

Juruá - branco; não-indígena; quando o pai é branco e a mãe guarani.

Ponguê - índio; filho de mãe guarani e pai indígena não-guarani.

Tierê Tará - misturado; filho de pai guarani e mãe juruá.

Espaço Ameríndio, Porto Alegre, v. 7, n. 2, p. 277-556, jul./dez. 2013. 


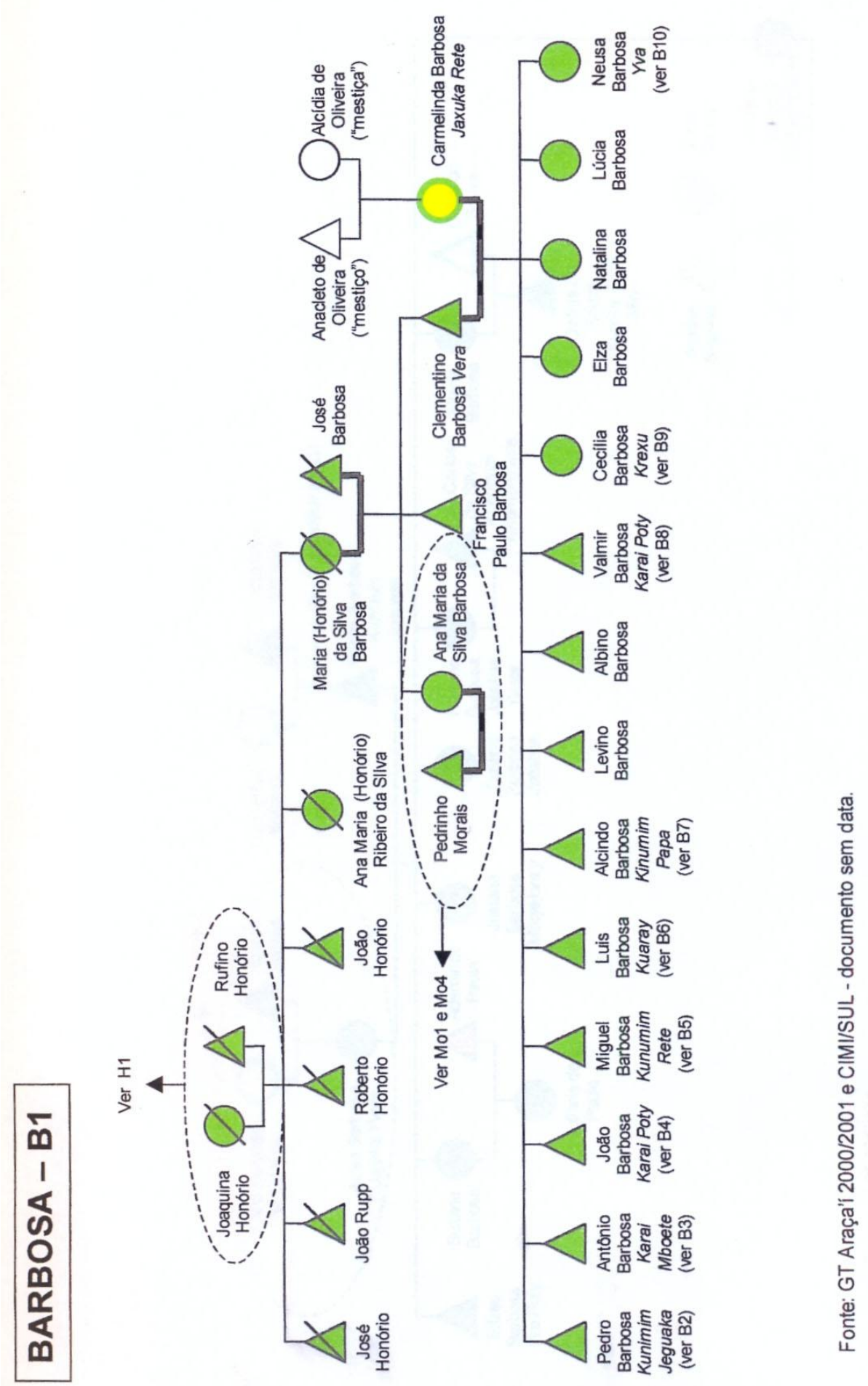

Espaço Ameríndio, Porto Alegre, v. 7, n. 2, p. 277-556, jul./dez. 2013. 


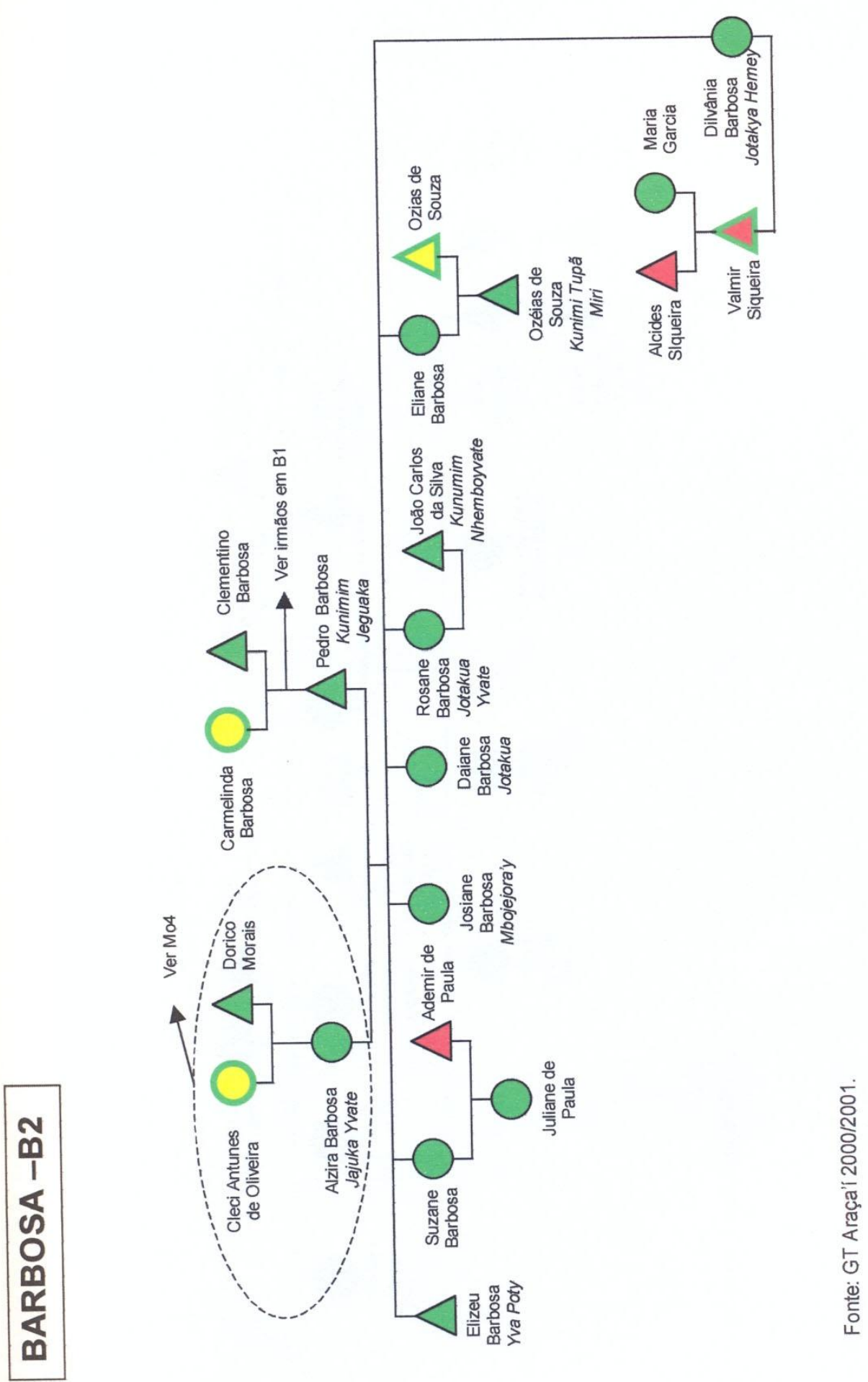

Espaço Ameríndio, Porto Alegre, v. 7, n. 2, p. 277-556, jul./dez. 2013. 


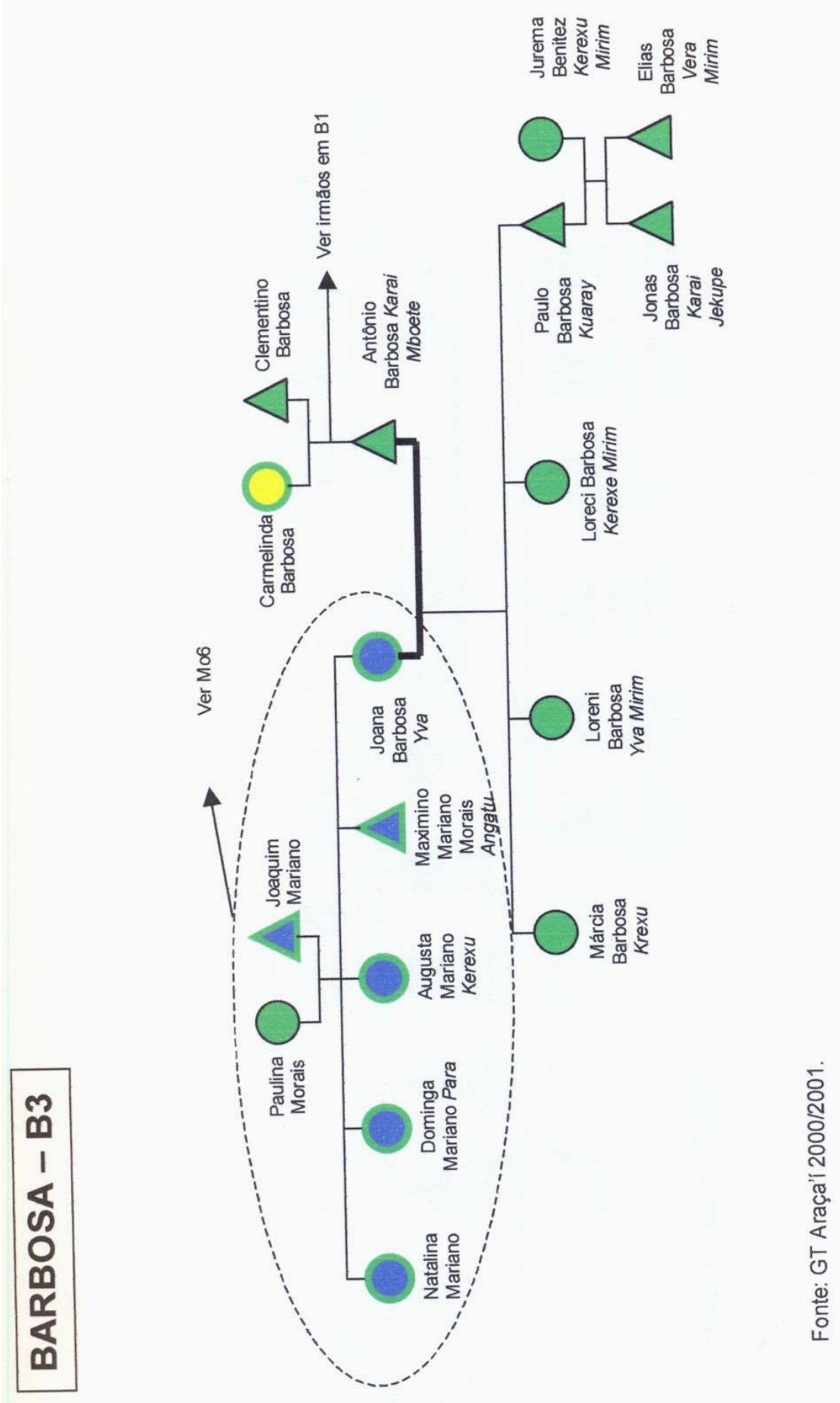

Espaço Ameríndio, Porto Alegre, v. 7, n. 2, p. 277-556, jul./dez. 2013. 
KIMIYE TOMMASINO - Relatório de Identificação e Delimitação da Terra Indígena...

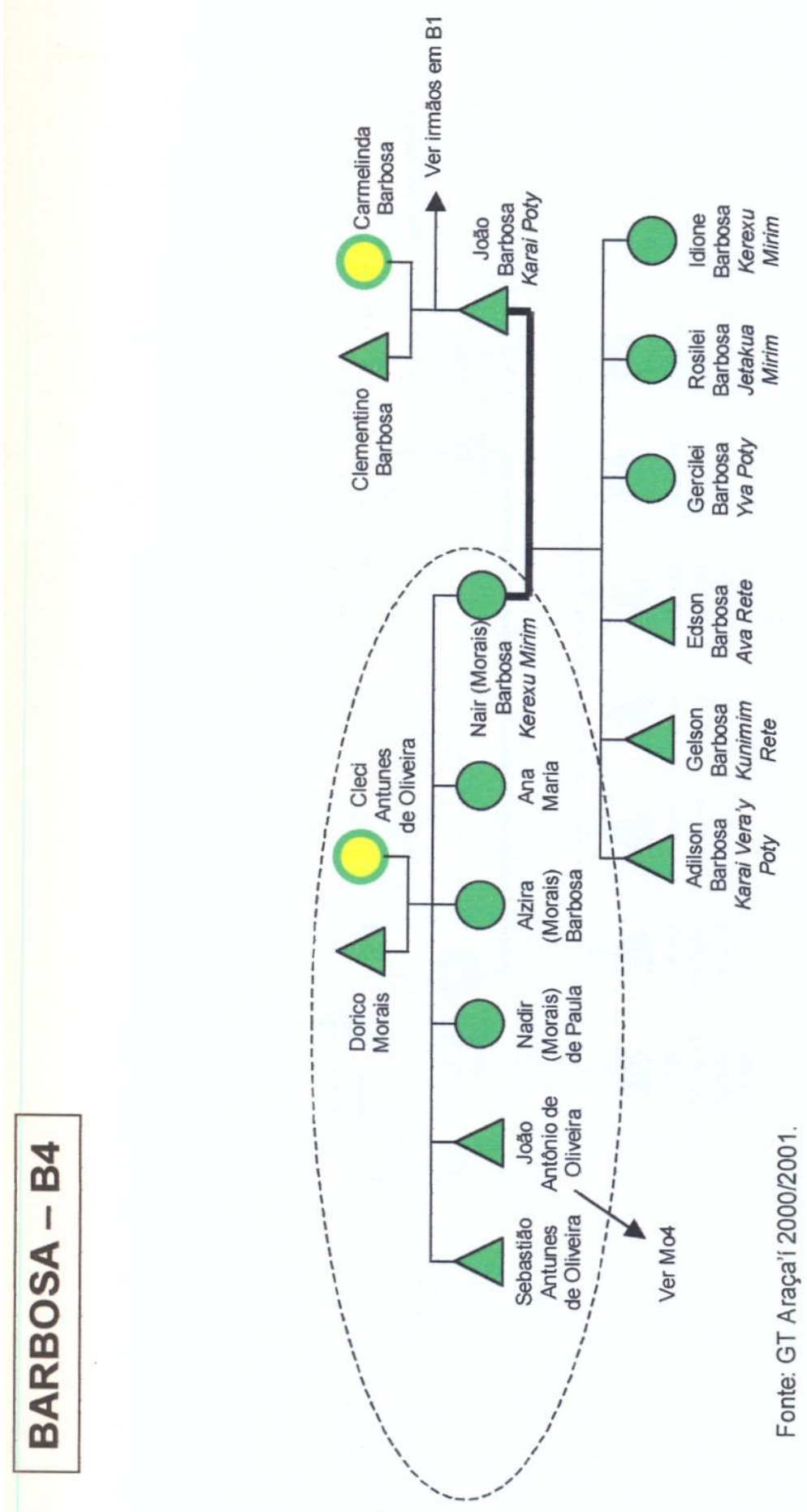

Espaço Ameríndio, Porto Alegre, v. 7, n. 2, p. 277-556, jul./dez. 2013. 
KIMIYE TOMMASINO - Relatório de Identificação e Delimitação da Terra Indígena...

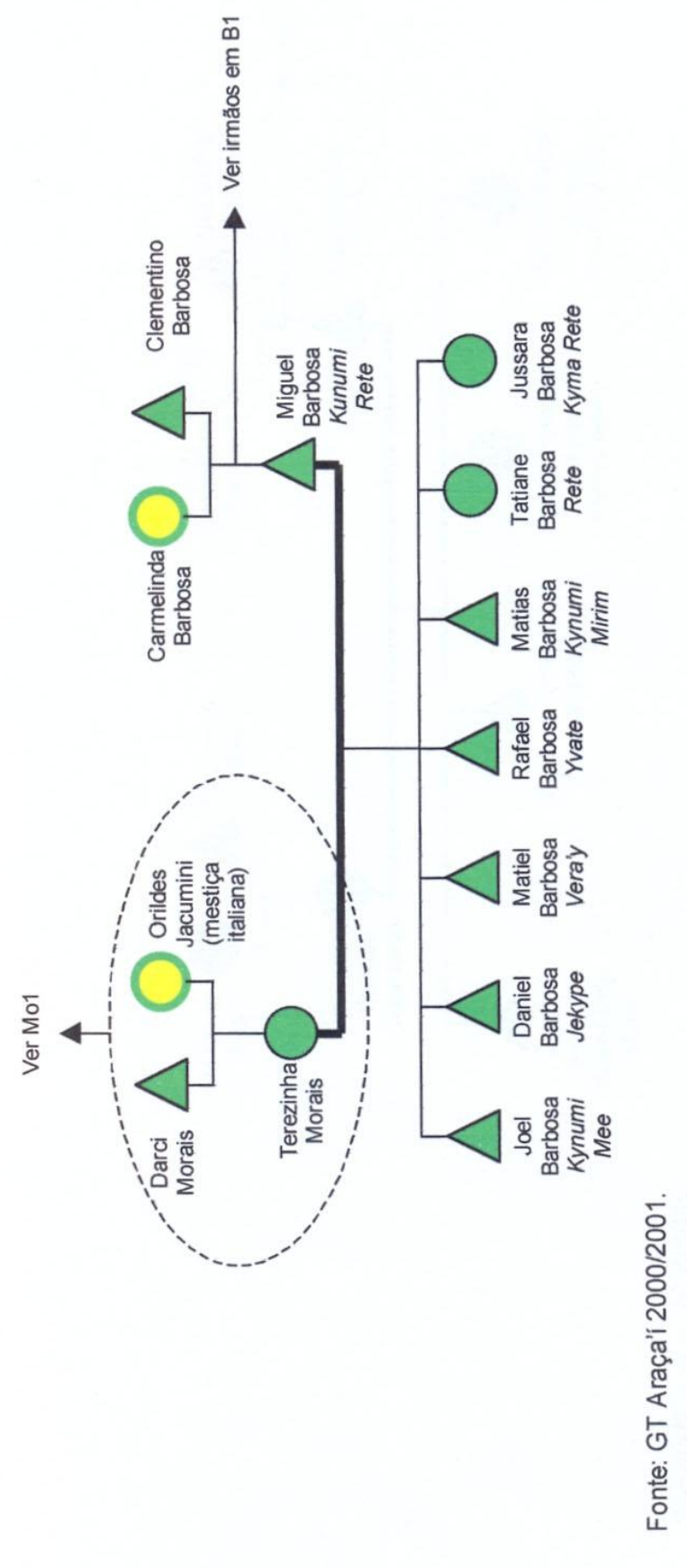

Espaço Ameríndio, Porto Alegre, v. 7, n. 2, p. 277-556, jul./dez. 2013. 
KIMIYE TOMMASINO - Relatório de Identificação e Delimitação da Terra Indígena...

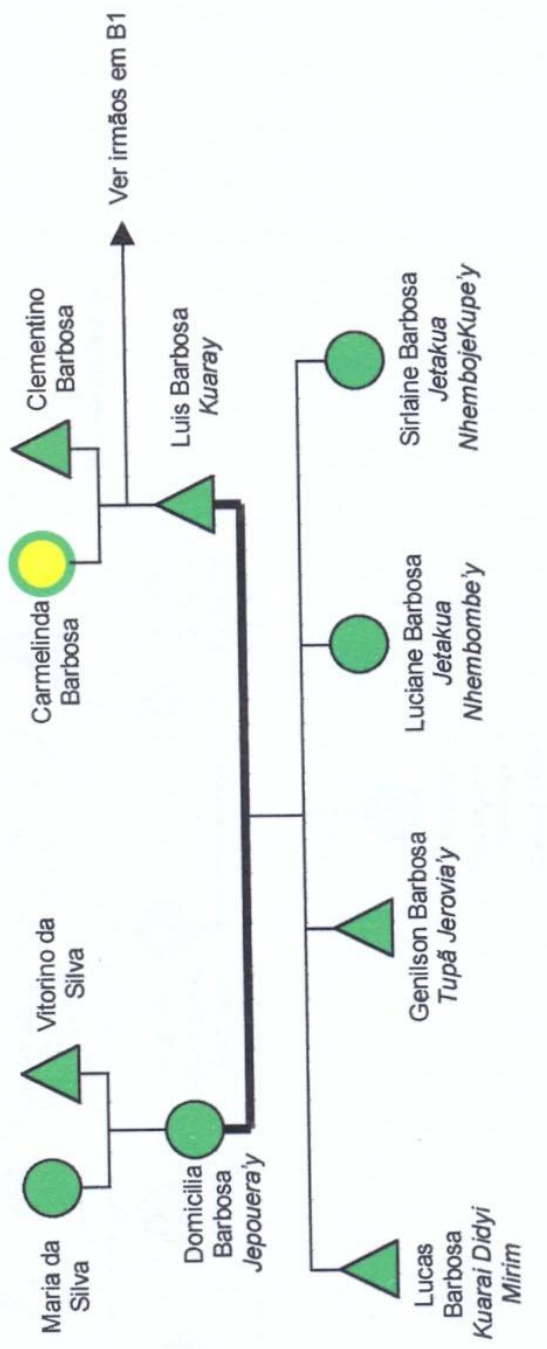


KIMIYE TOMMASINO - Relatório de Identificação e Delimitação da Terra Indígena...

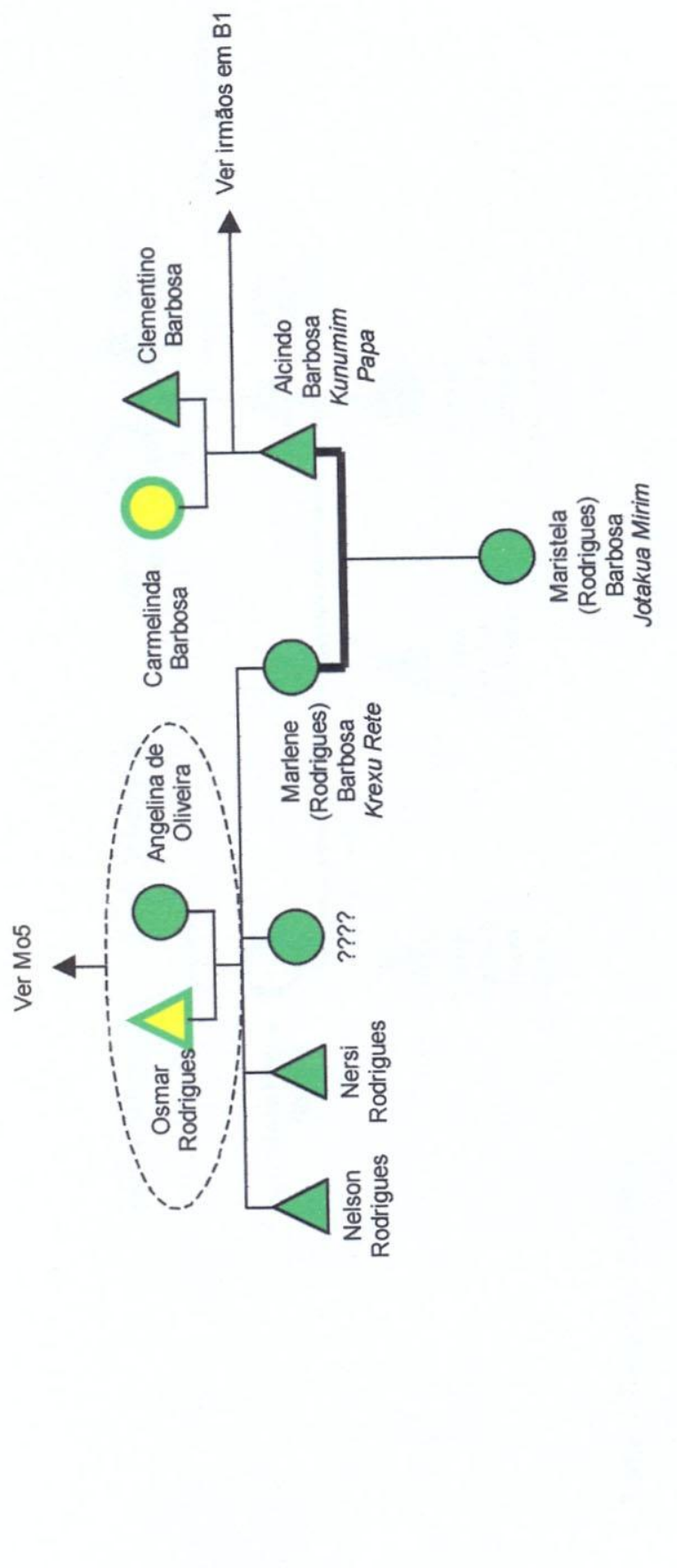

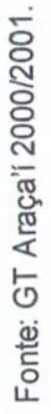

Espaço Ameríndio, Porto Alegre, v. 7, n. 2, p. 277-556, jul./dez. 2013. 
KIMIYE TOMMASINO - Relatório de Identificação e Delimitação da Terra Indígena...

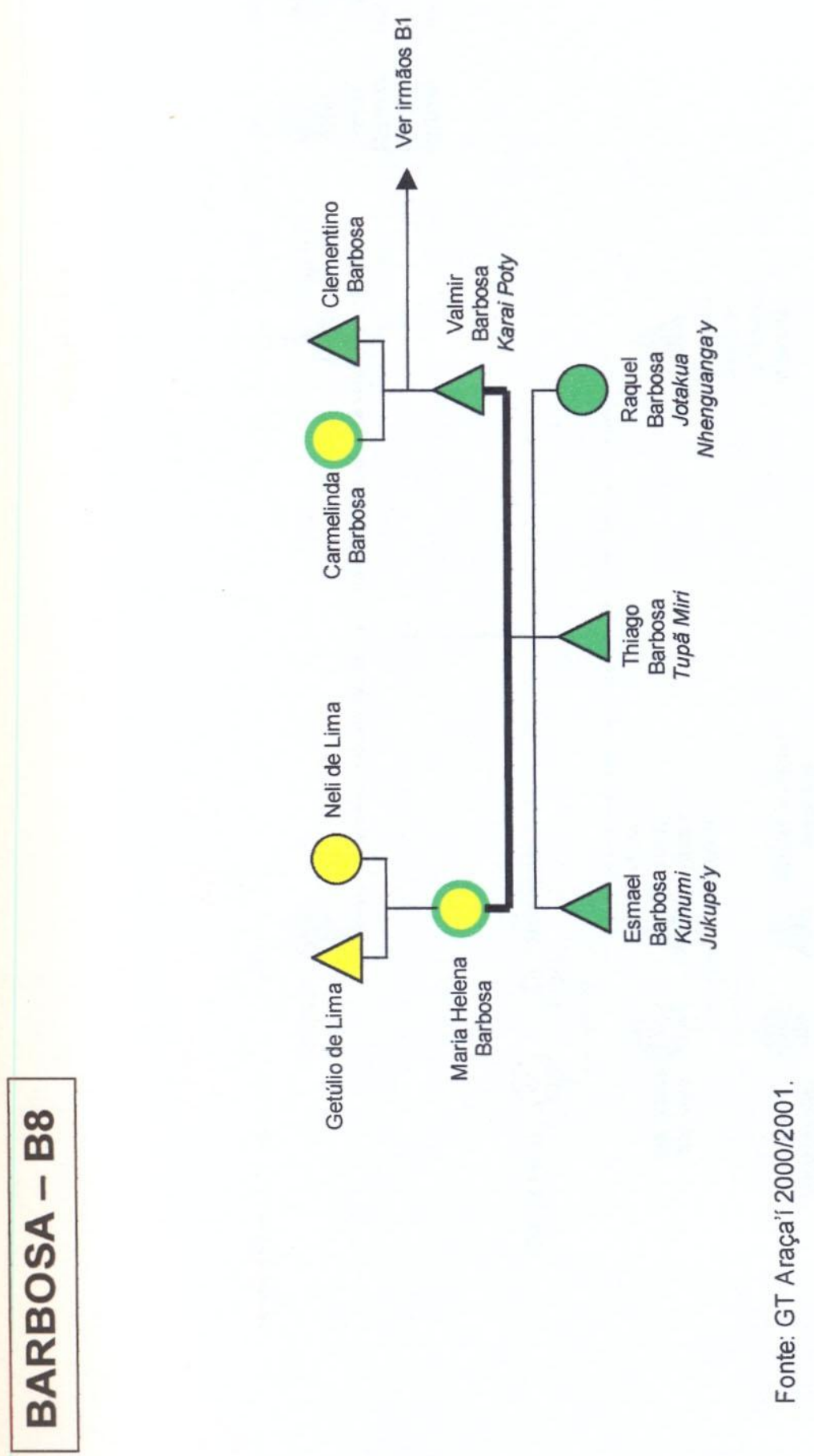

Espaço Ameríndio, Porto Alegre, v. 7, n. 2, p. 277-556, jul./dez. 2013. 


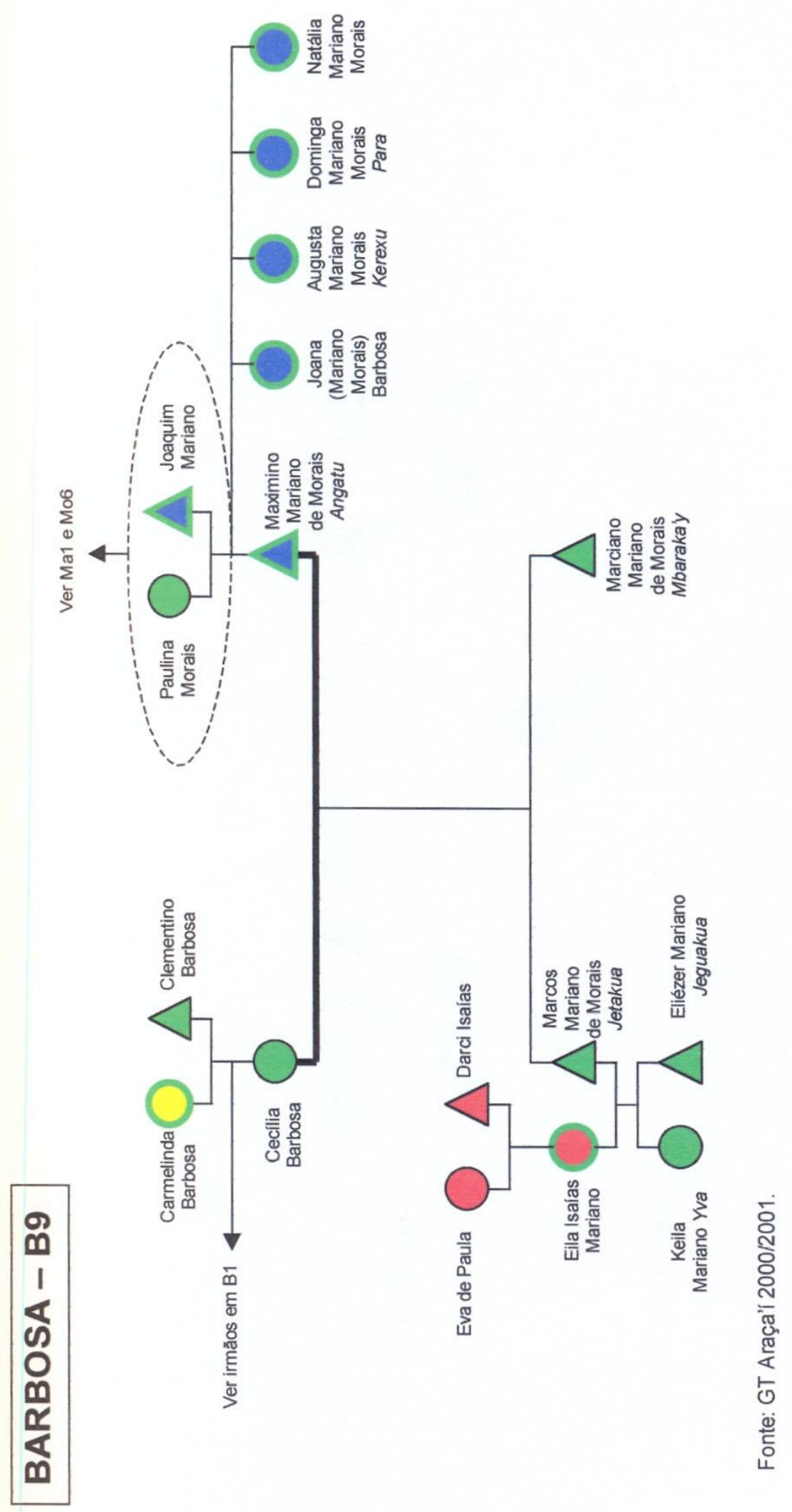

Espaço Ameríndio, Porto Alegre, v. 7, n. 2, p. 277-556, jul./dez. 2013. 
KIMIYE TOMMASINO - Relatório de Identificação e Delimitação da Terra Indígena...

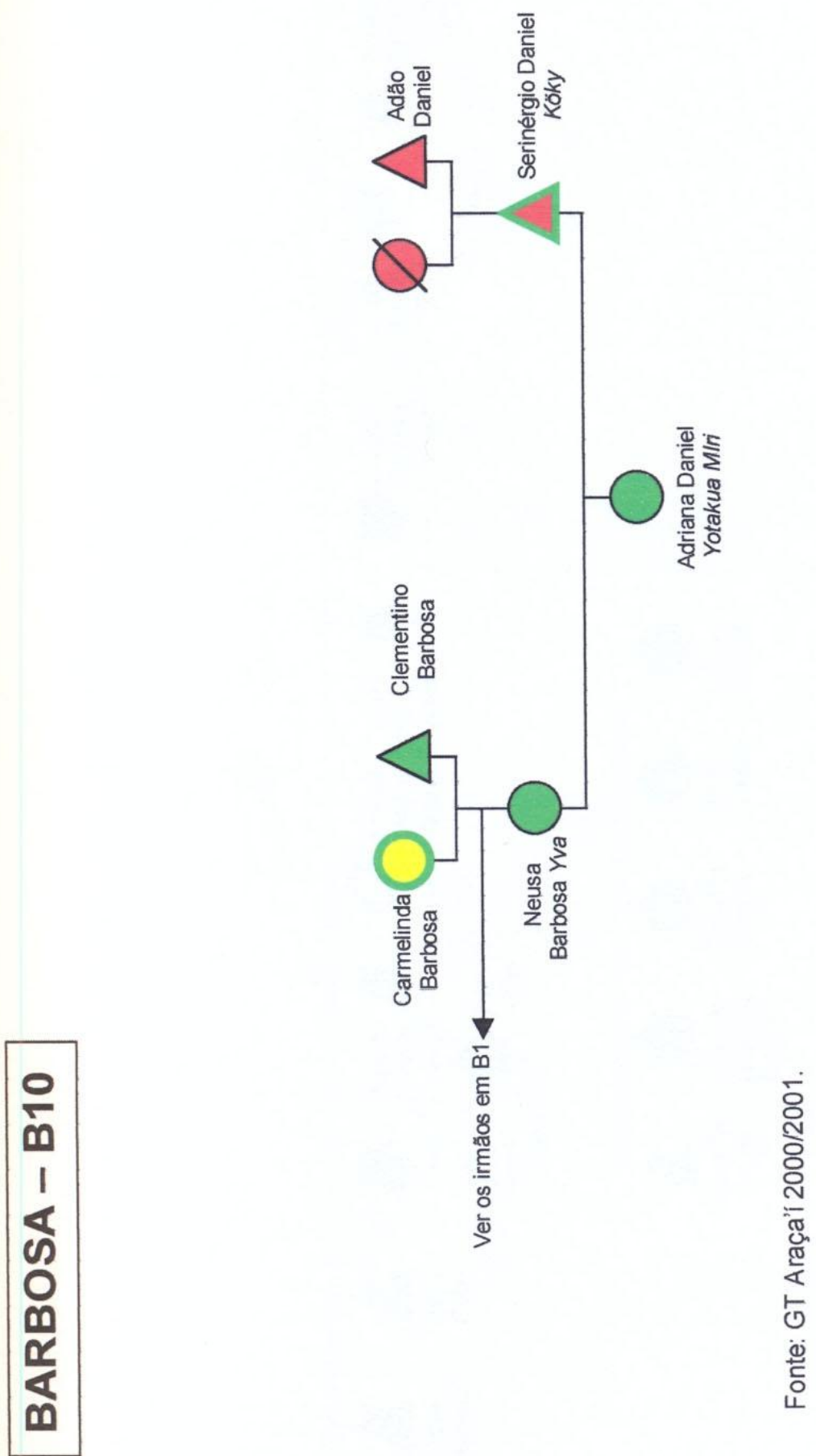

Espaço Ameríndio, Porto Alegre, v. 7, n. 2, p. 277-556, jul./dez. 2013. 


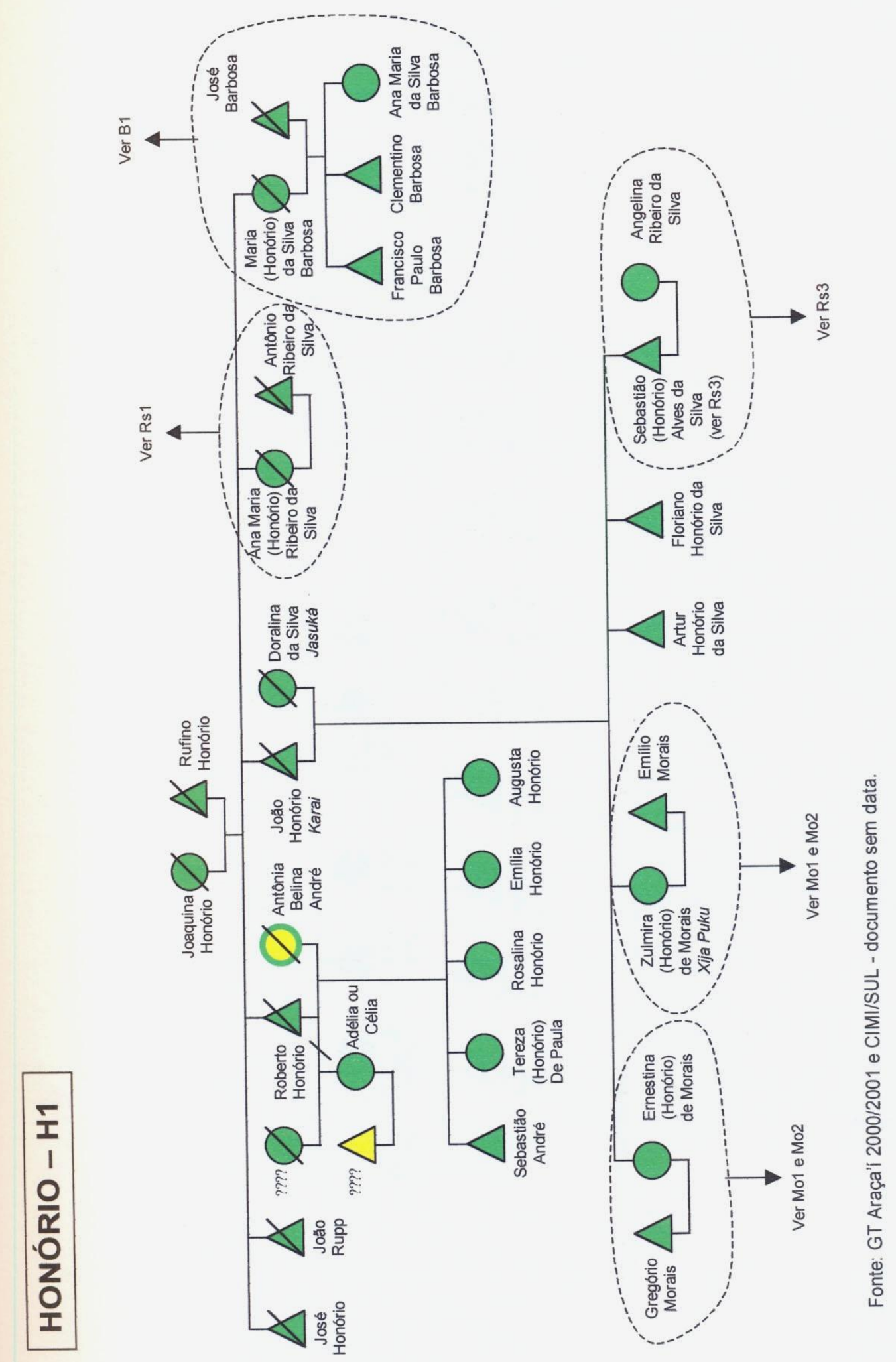

Espaço Ameríndio, Porto Alegre, v. 7, n. 2, p. 277-556, jul./dez. 2013. 
KIMIYE TOMMASINO - Relatório de Identificação e Delimitação da Terra Indígena...

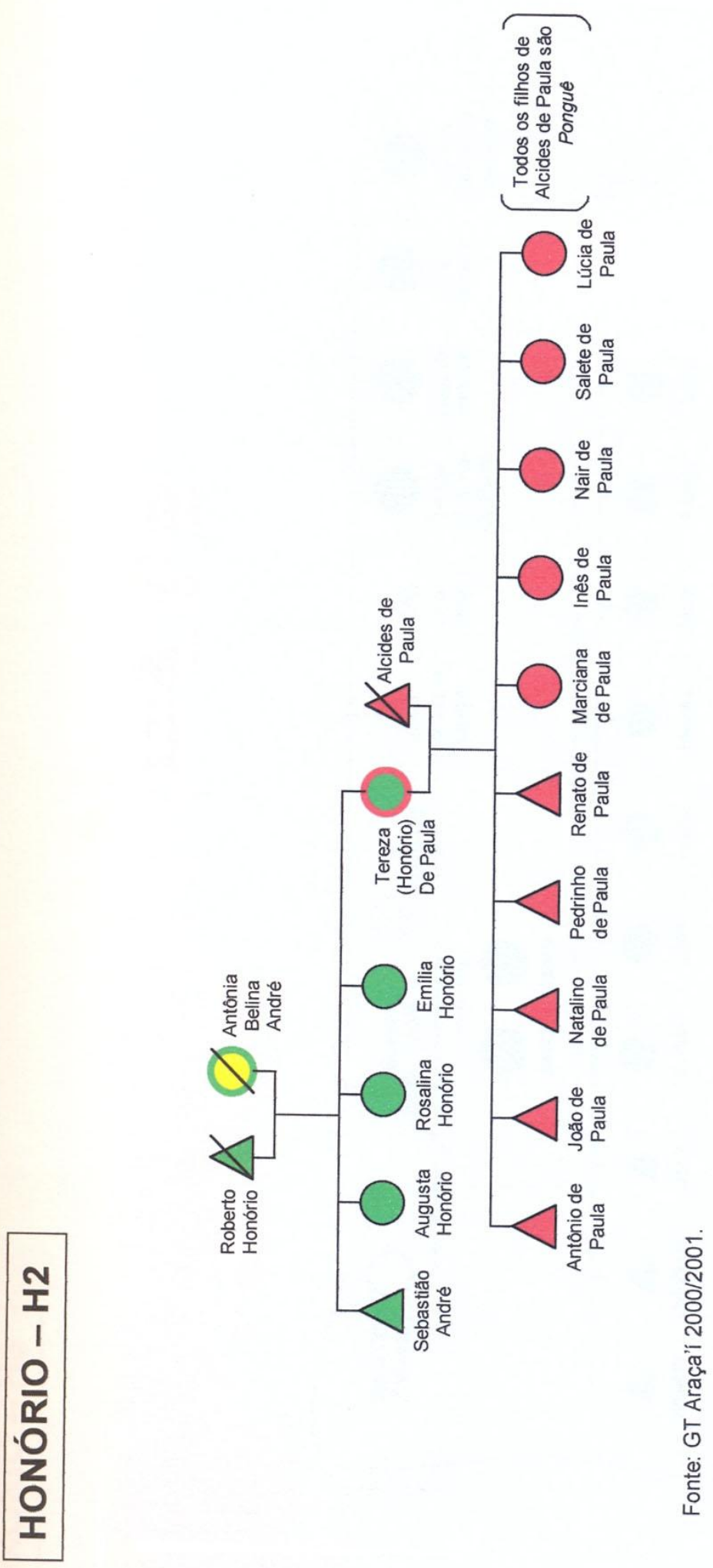

Espaço Ameríndio, Porto Alegre, v. 7, n. 2, p. 277-556, jul./dez. 2013. 


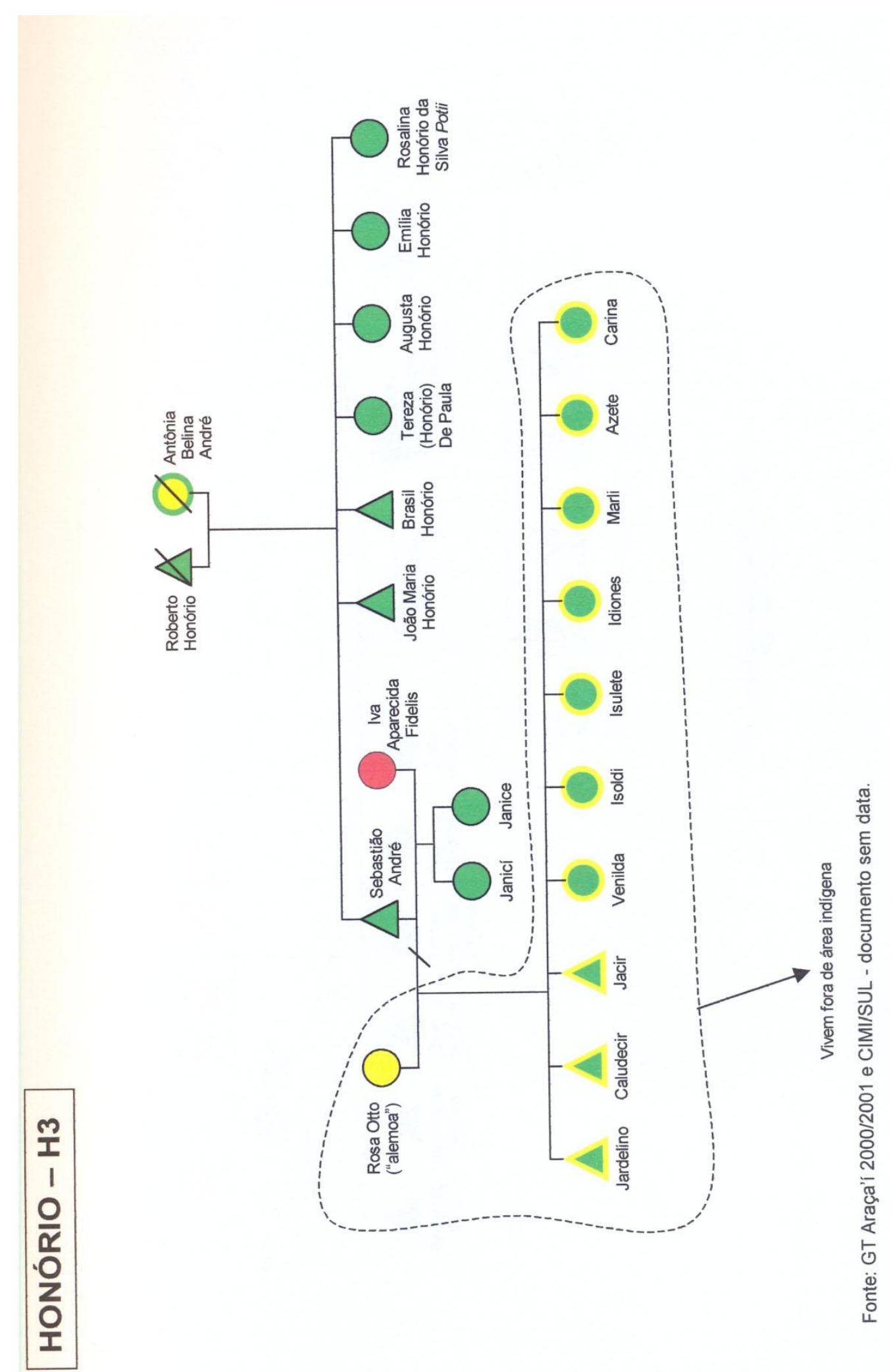

Espaço Ameríndio, Porto Alegre, v. 7, n. 2, p. 277-556, jul./dez. 2013. 


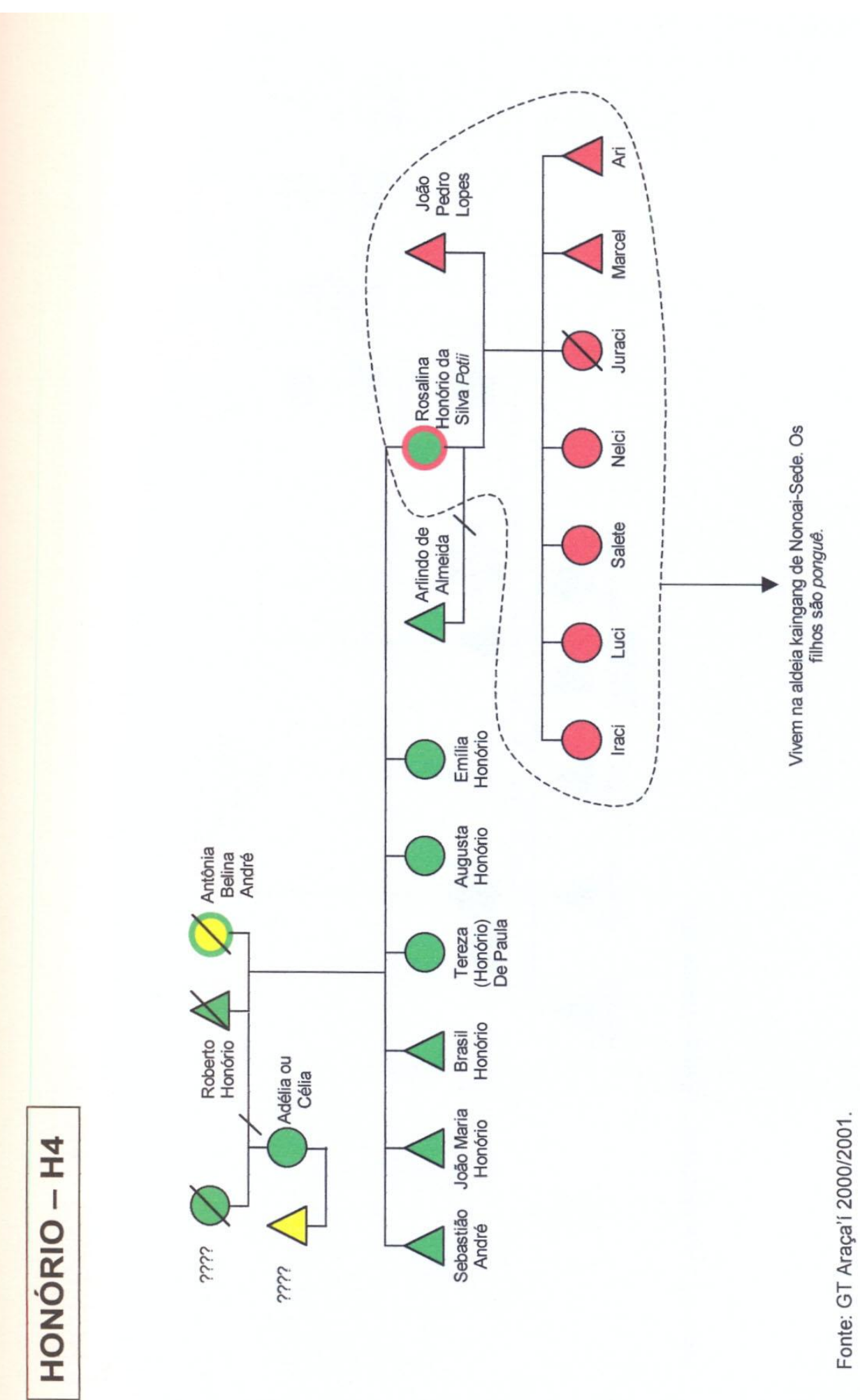

Espaço Ameríndio, Porto Alegre, v. 7, n. 2, p. 277-556, jul./dez. 2013. 
KIMIYE TOMMASINO - Relatório de Identificação e Delimitação da Terra Indígena...

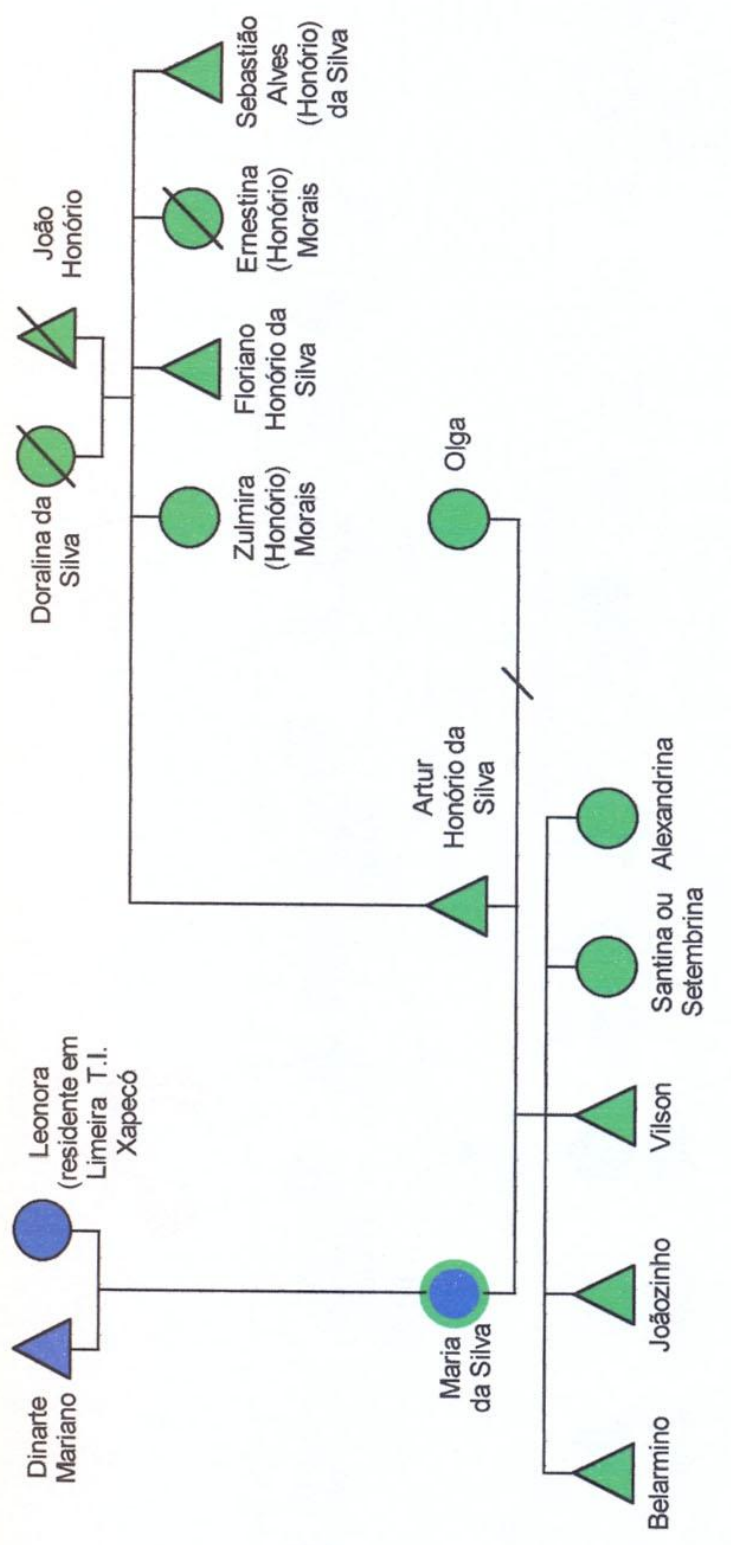

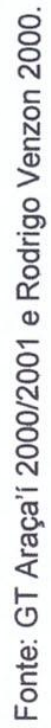

Espaço Ameríndio, Porto Alegre, v. 7, n. 2, p. 277-556, jul./dez. 2013. 


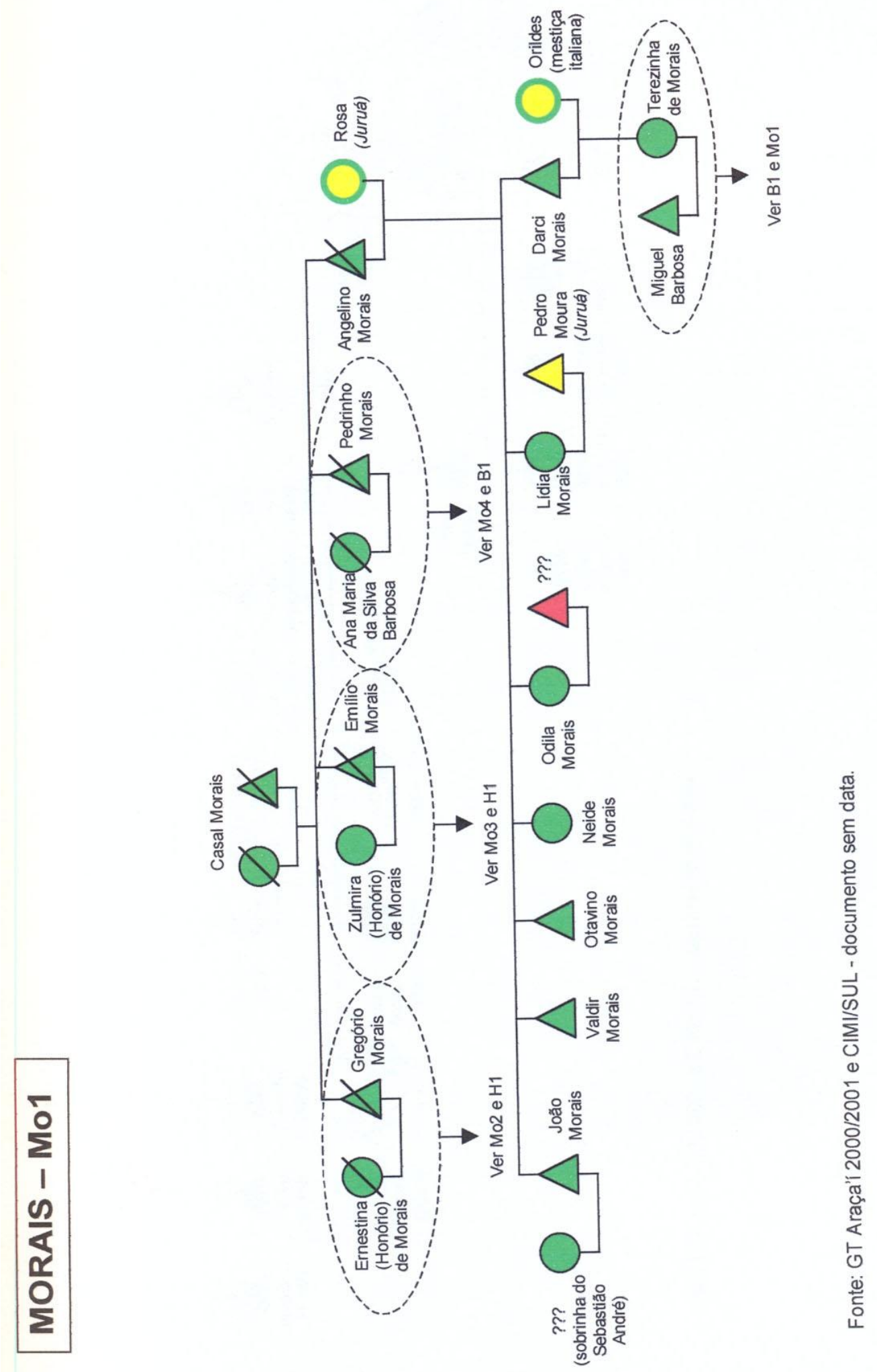

Espaço Ameríndio, Porto Alegre, v. 7, n. 2, p. 277-556, jul./dez. 2013. 


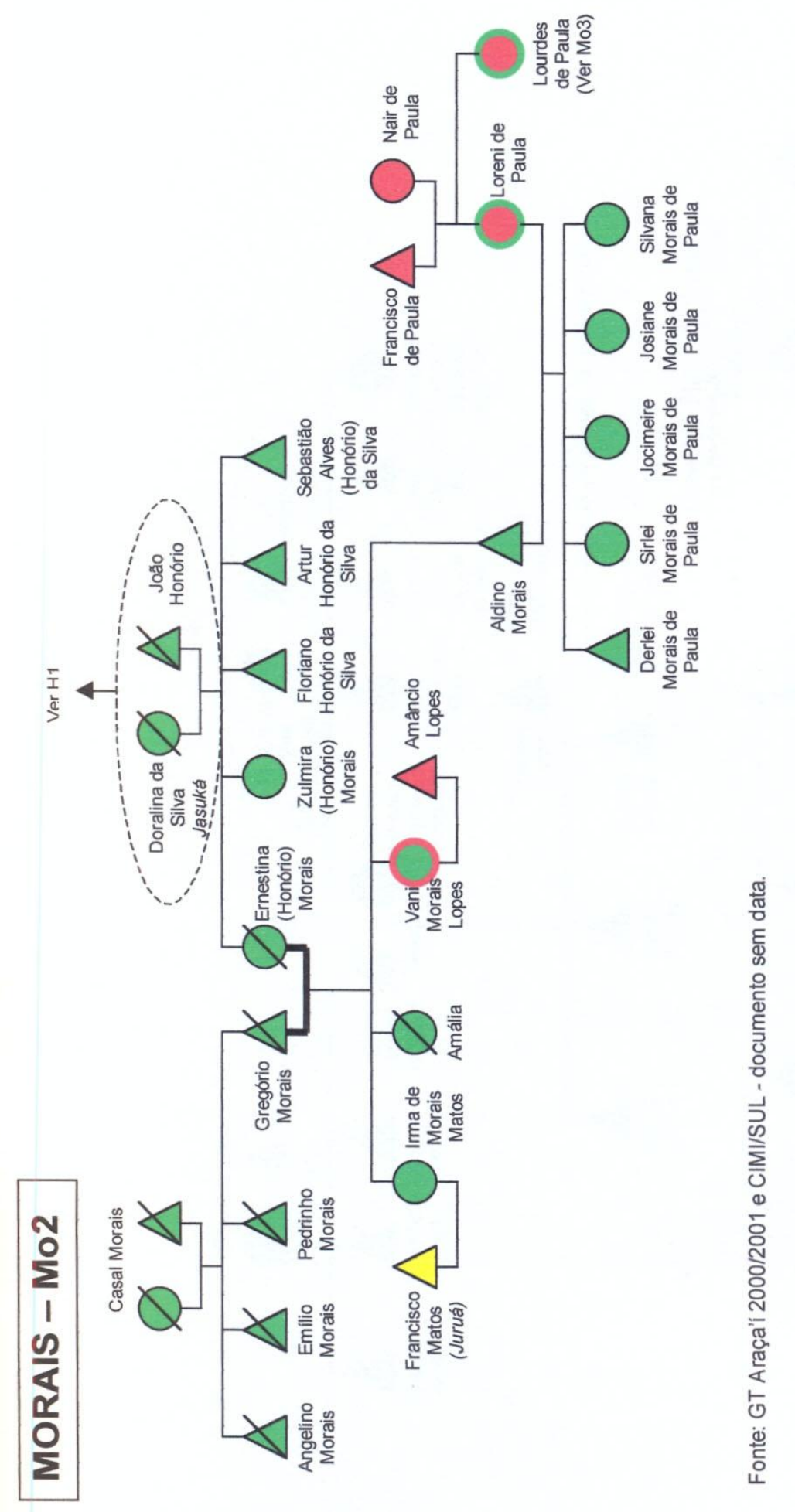

Espaço Ameríndio, Porto Alegre, v. 7, n. 2, p. 277-556, jul./dez. 2013. 


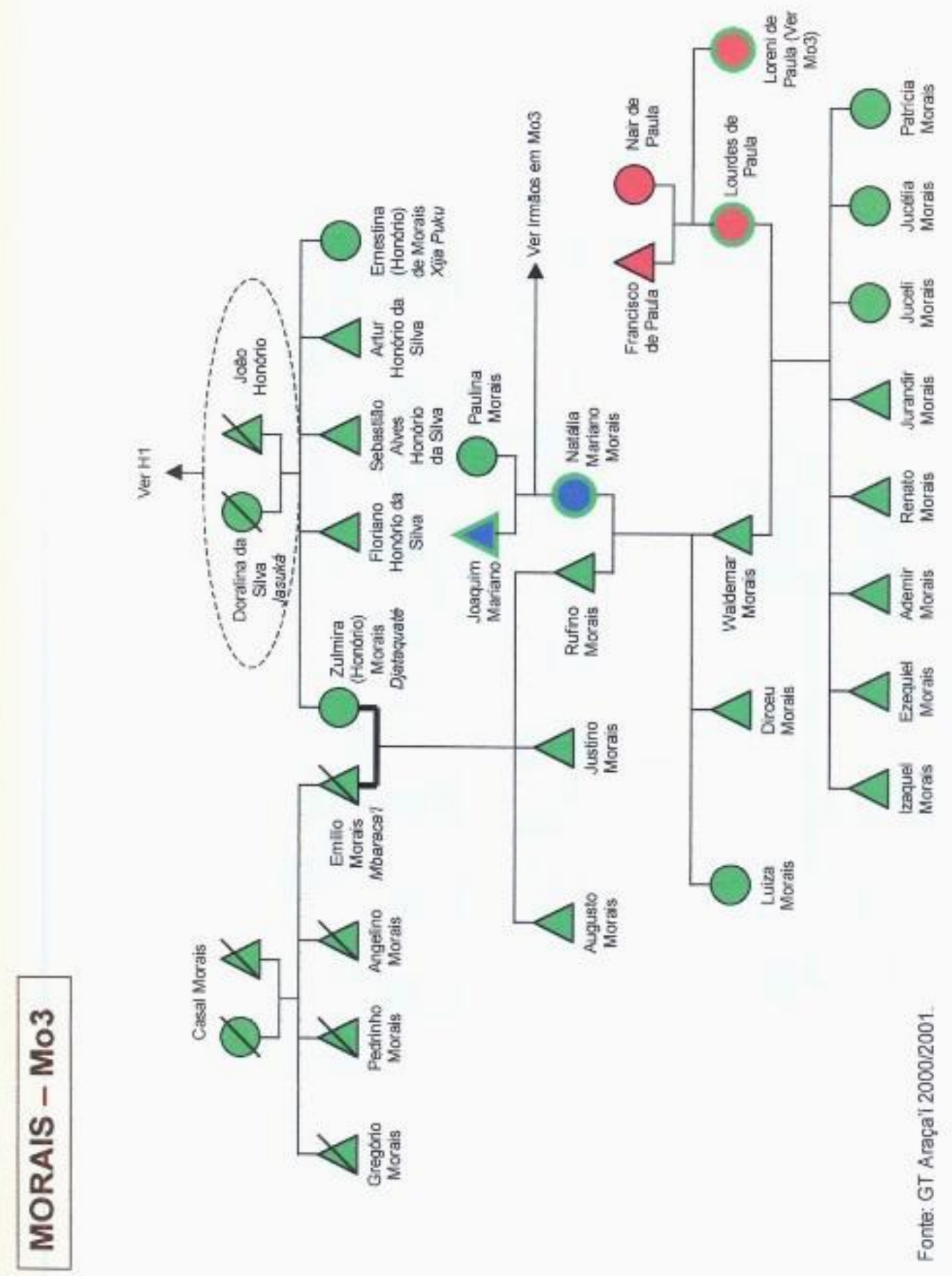

Espaço Ameríndio, Porto Alegre, v. 7, n. 2, p. 277-556, jul./dez. 2013. 


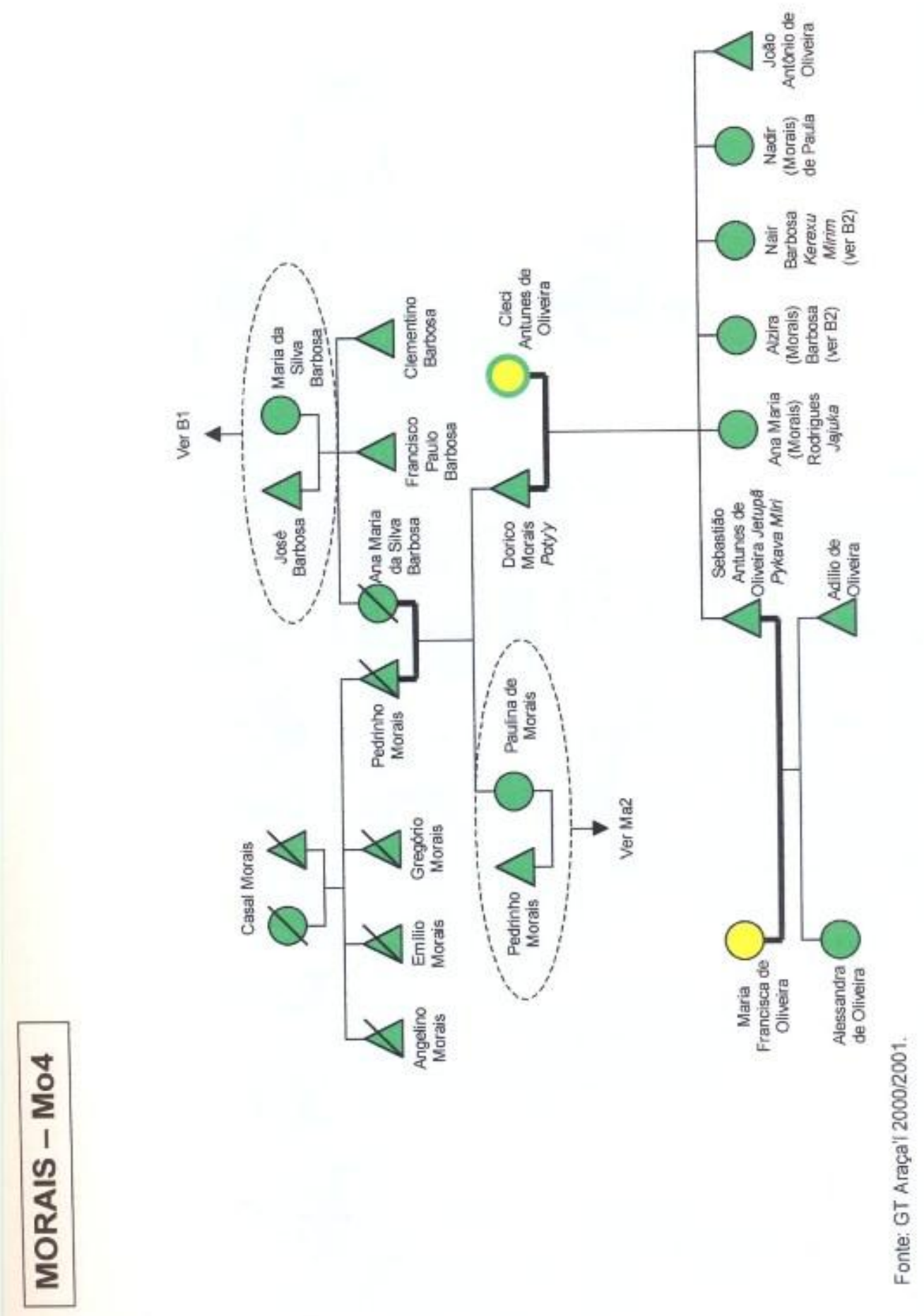

Espaço Ameríndio, Porto Alegre, v. 7, n. 2, p. 277-556, jul./dez. 2013. 


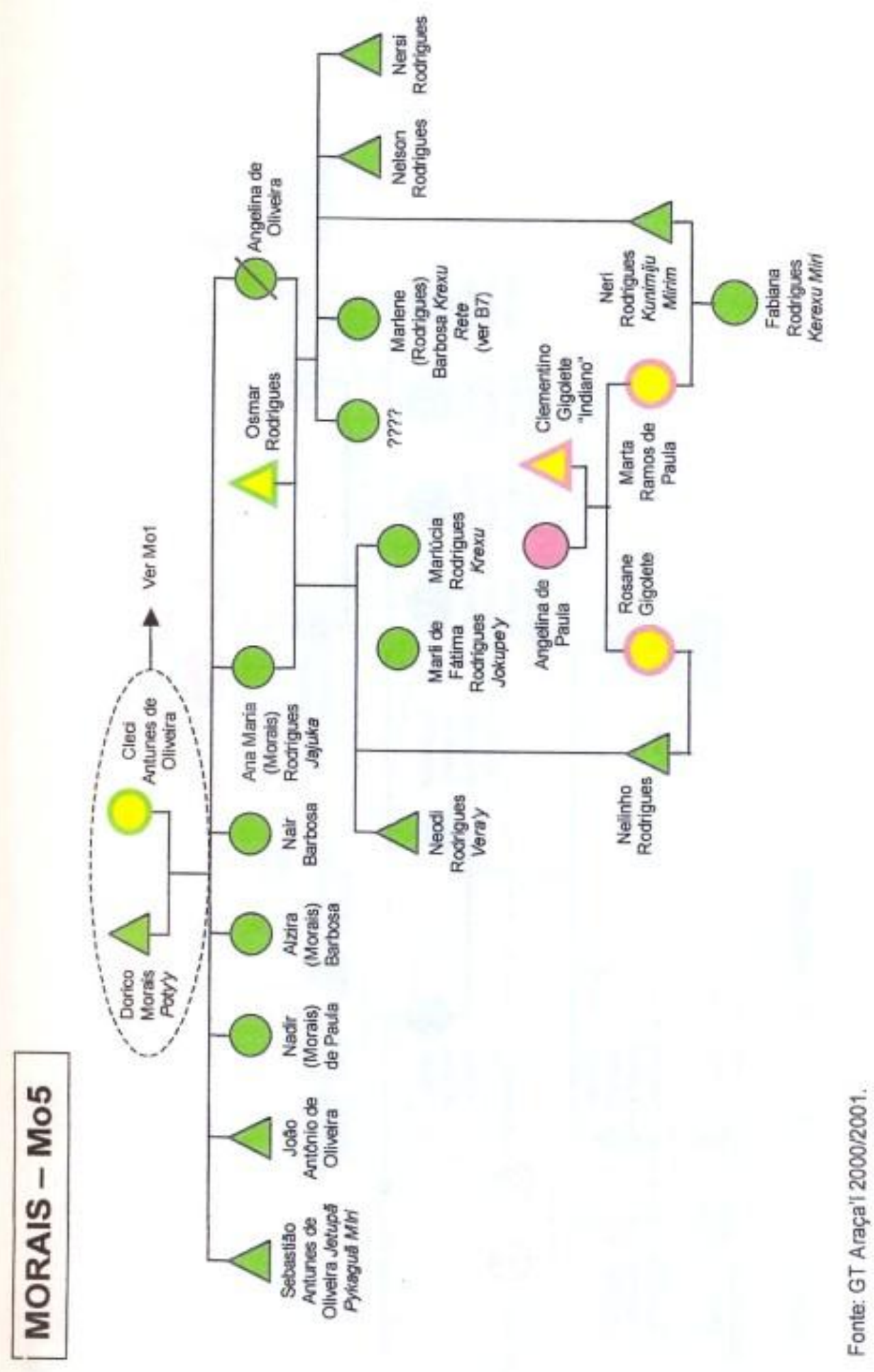

Espaço Ameríndio, Porto Alegre, v. 7, n. 2, p. 277-556, jul./dez. 2013. 


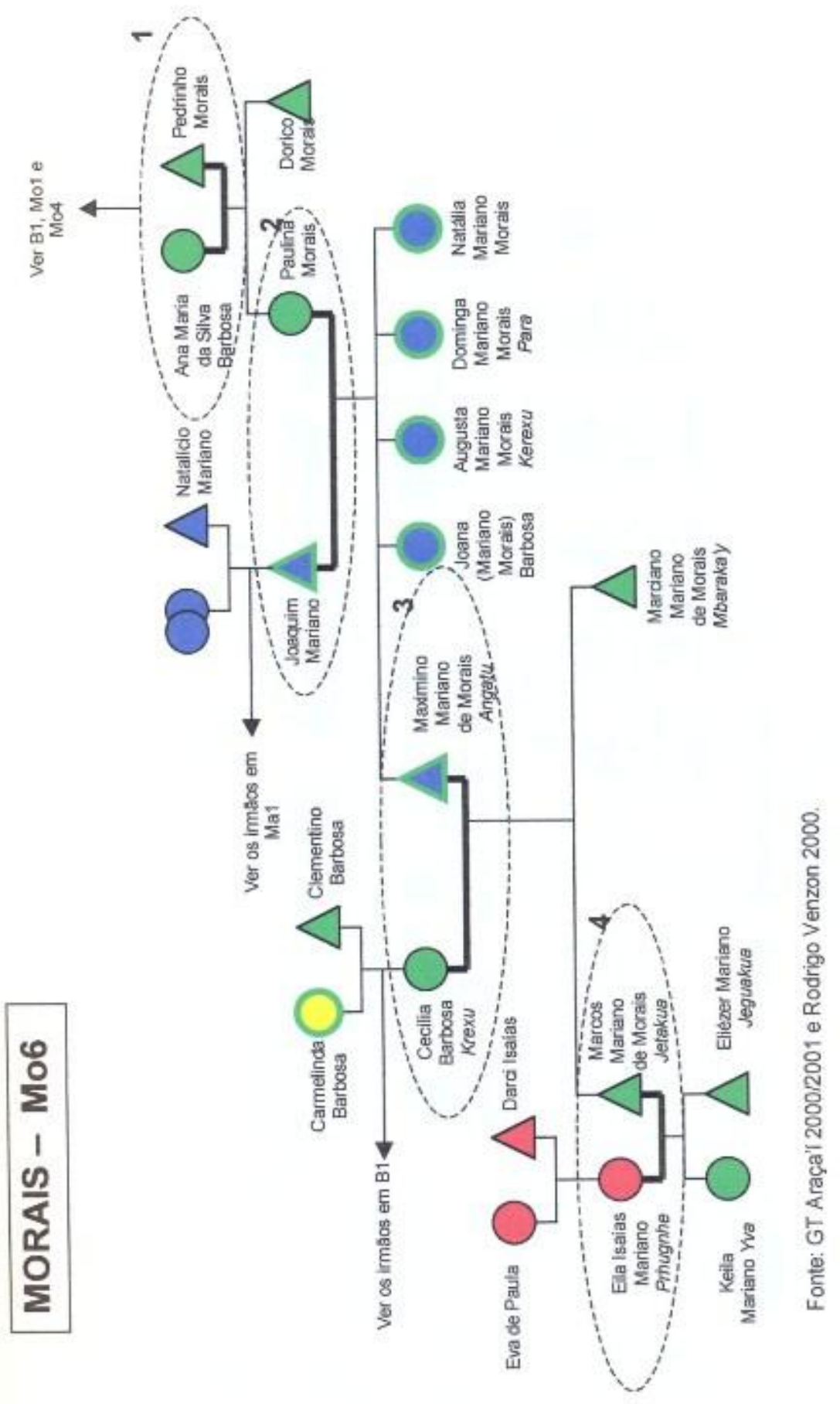

Espaço Ameríndio, Porto Alegre, v. 7, n. 2, p. 277-556, jul./dez. 2013. 
KIMIYE TOMMASINO - Relatório de Identificação e Delimitação da Terra Indígena...

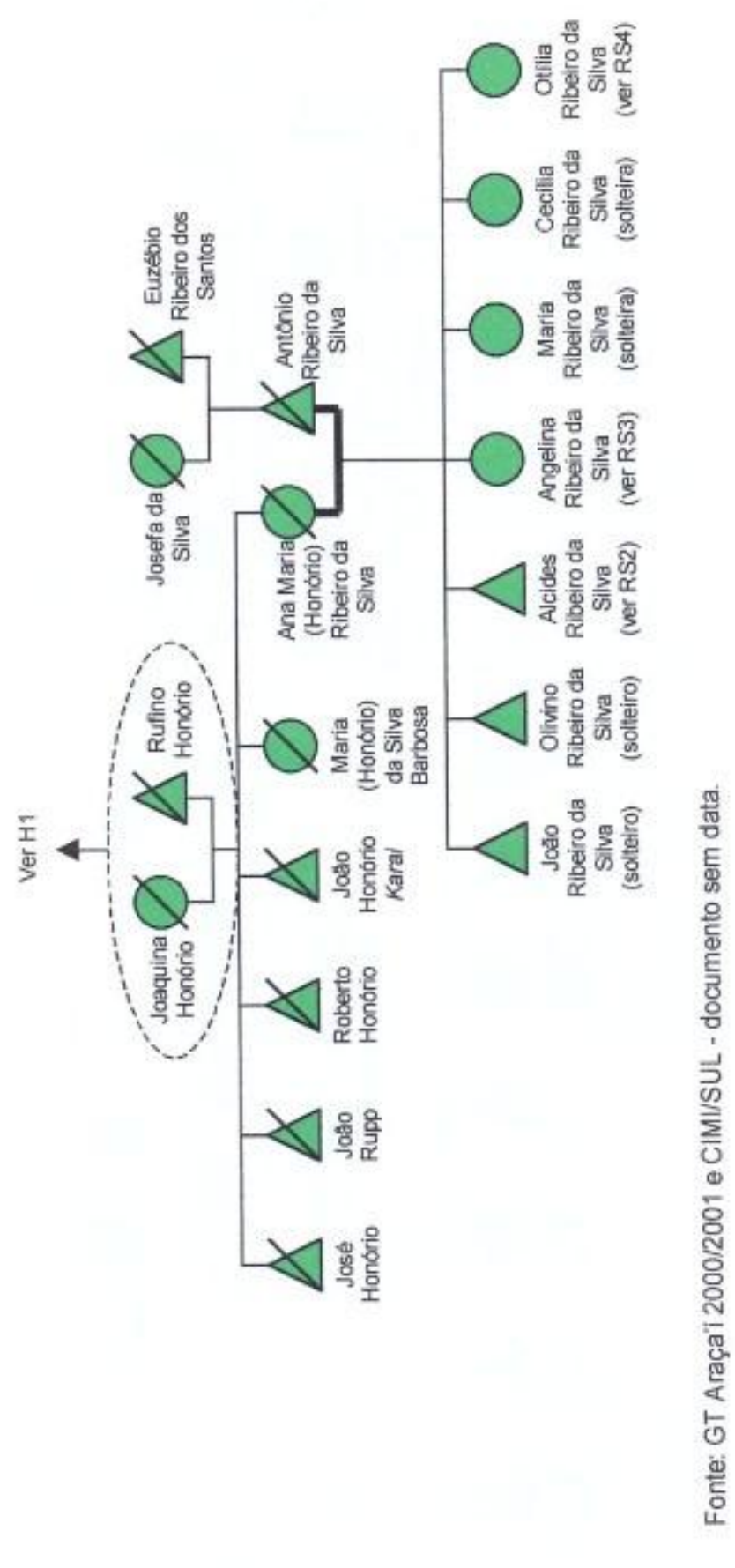

Espaço Ameríndio, Porto Alegre, v. 7, n. 2, p. 277-556, jul./dez. 2013. 


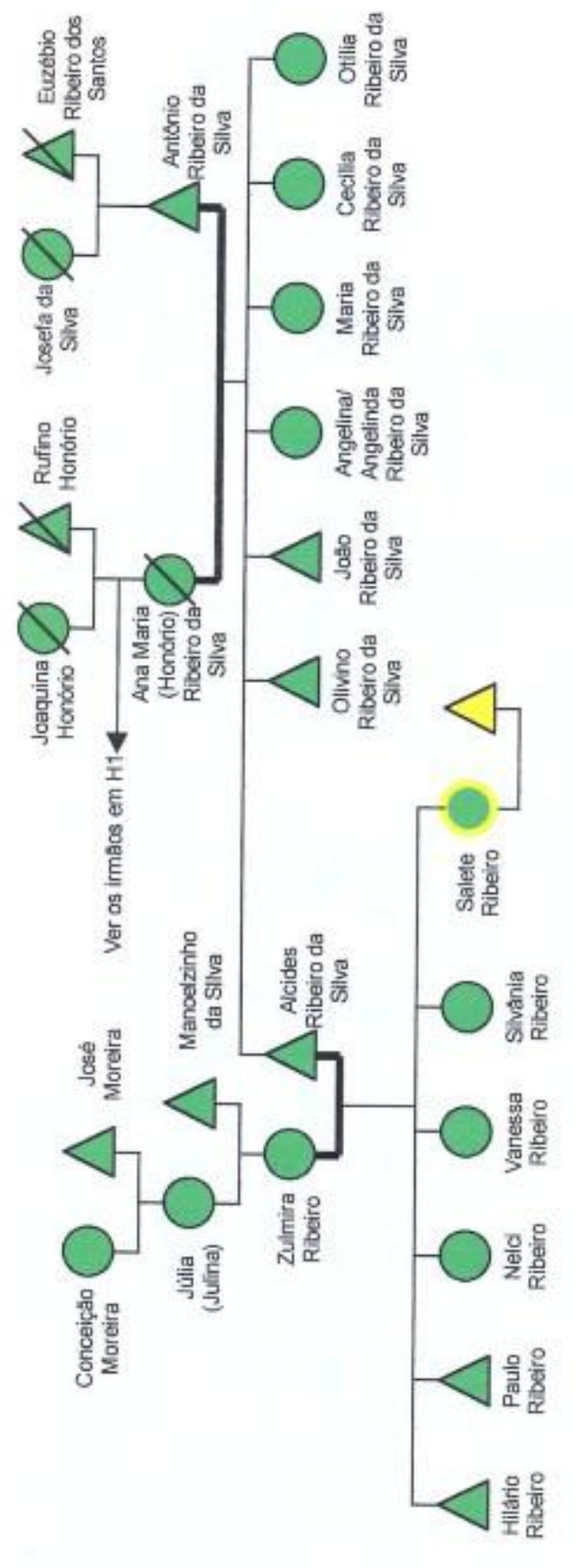


KIMIYE TOMMASINO - Relatório de Identificação e Delimitação da Terra Indígena...

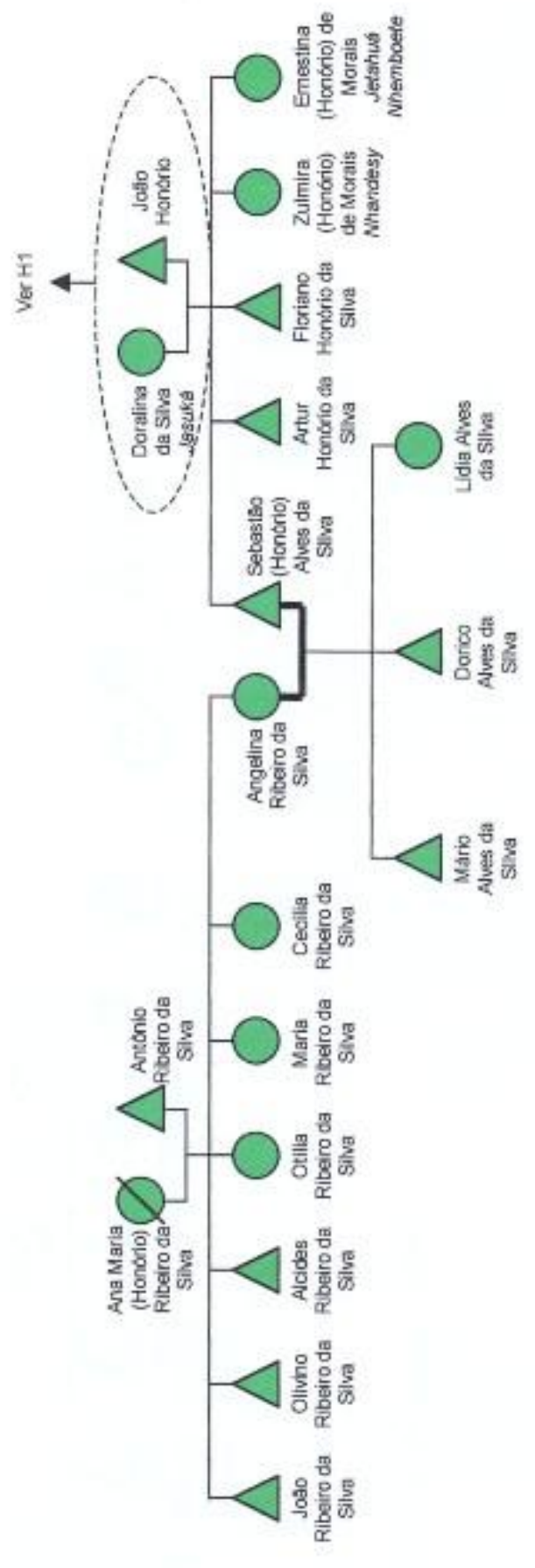

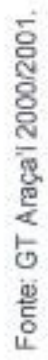

Espaço Ameríndio, Porto Alegre, v. 7, n. 2, p. 277-556, jul./dez. 2013. 
KIMIYE TOMMASINO - Relatório de Identificação e Delimitação da Terra Indígena...

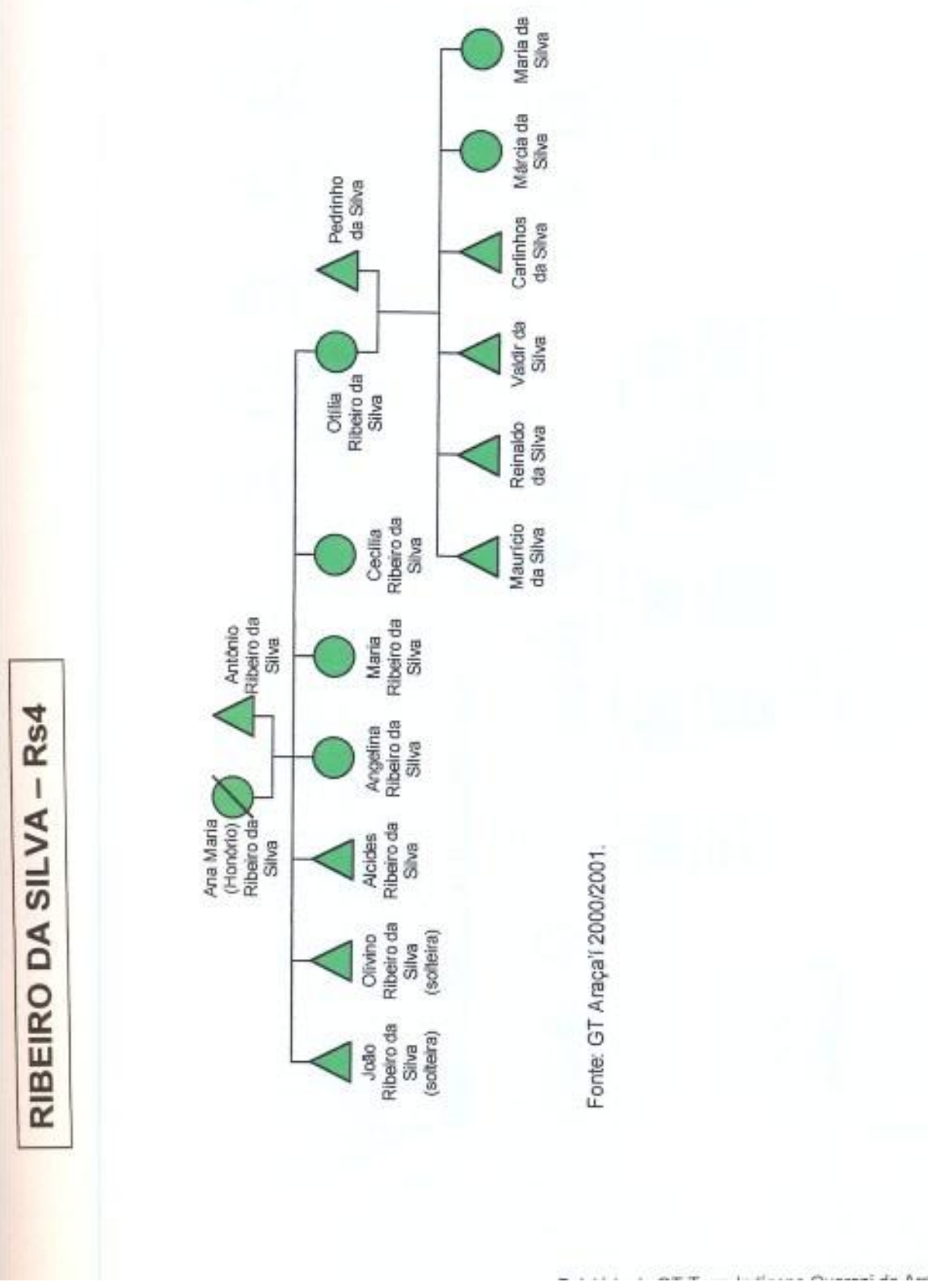

Espaço Ameríndio, Porto Alegre, v. 7, n. 2, p. 277-556, jul./dez. 2013. 

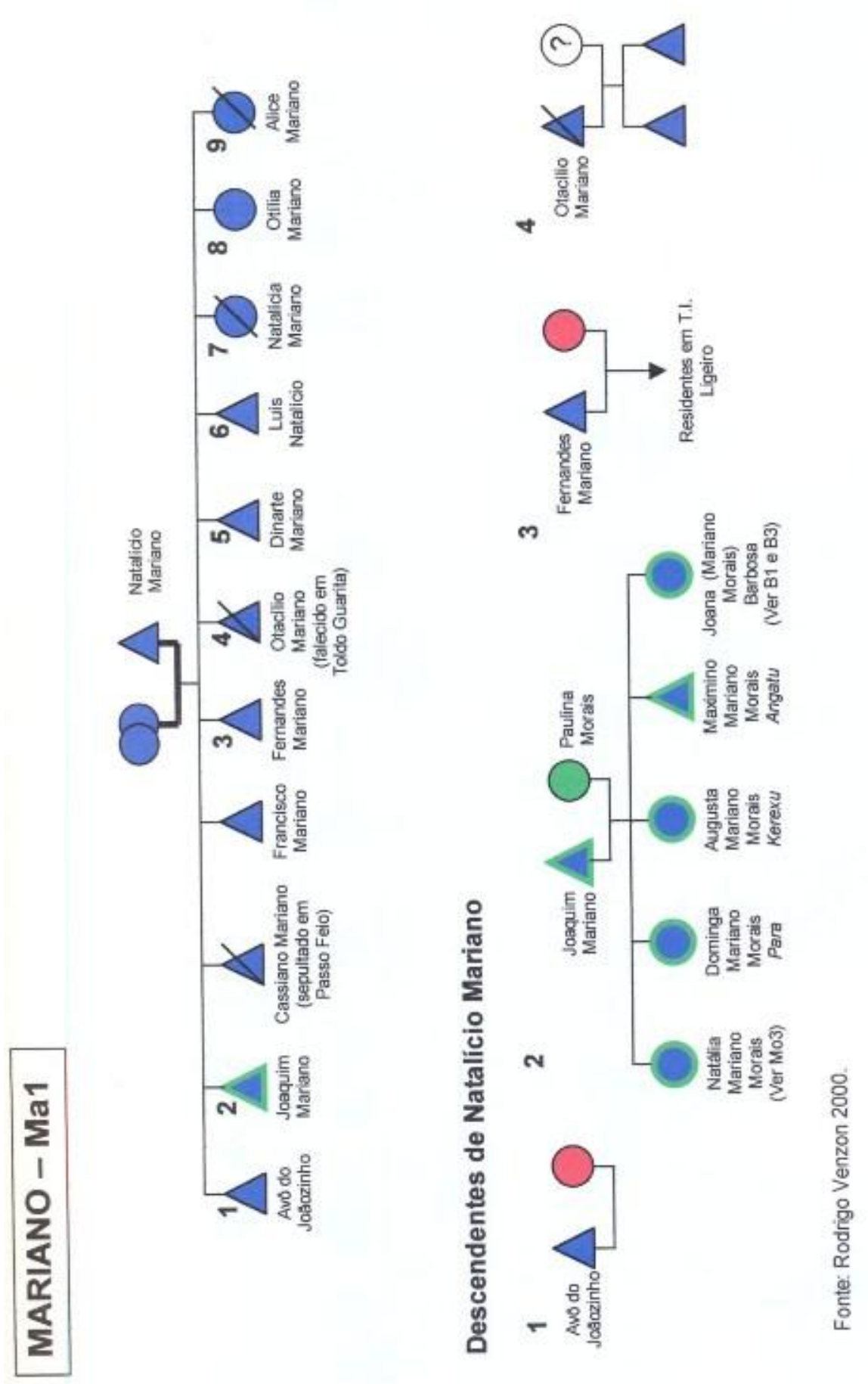

Espaço Ameríndio, Porto Alegre, v. 7, n. 2, p. 277-556, jul./dez. 2013. 
KIMIYE TOMMASINO - Relatório de Identificação e Delimitação da Terra Indígena...
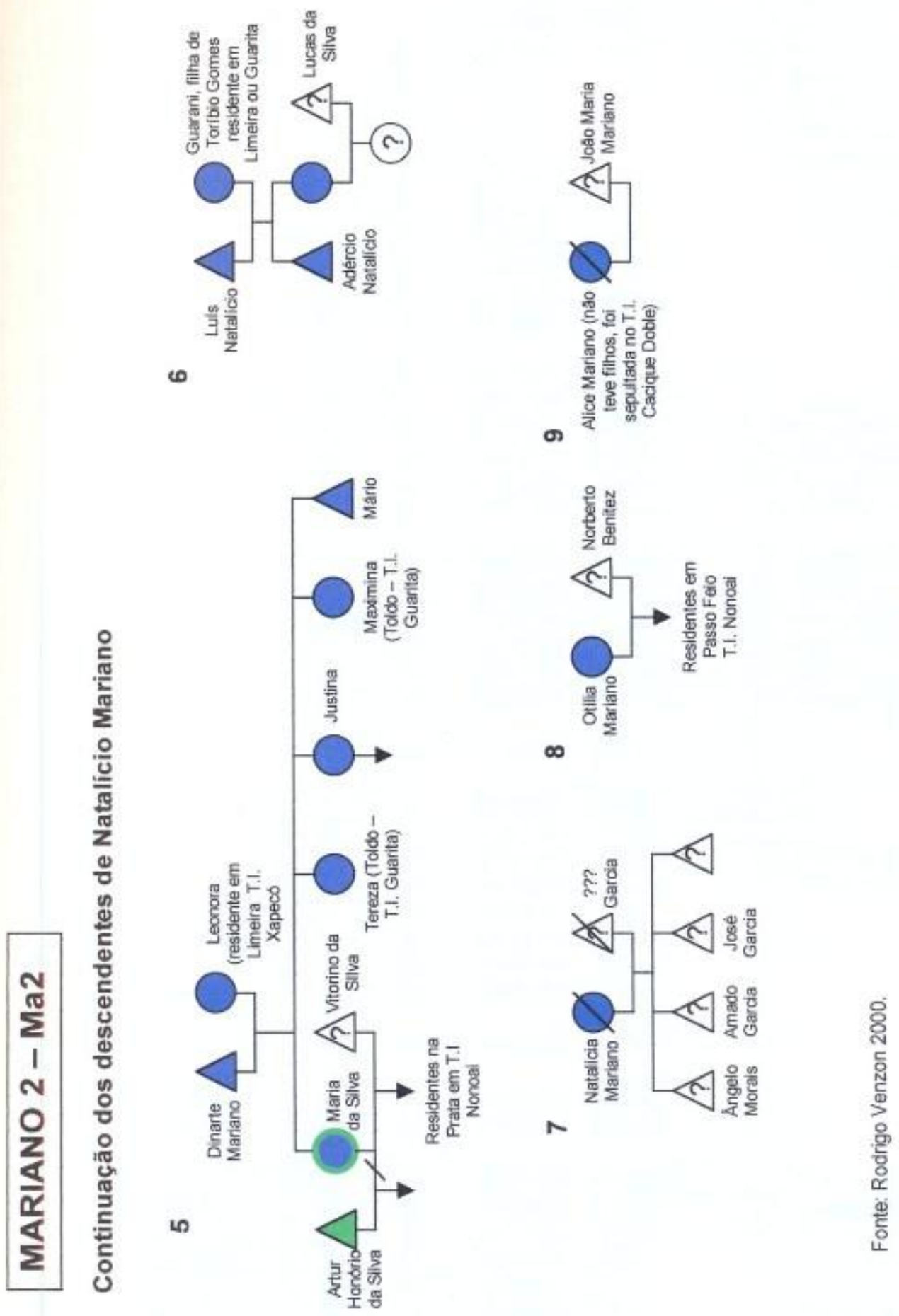

Espaço Ameríndio, Porto Alegre, v. 7, n. 2, p. 277-556, jul./dez. 2013. 
KIMIYE TOMMASINO - Relatório de Identificação e Delimitação da Terra Indígena...

TABELA 2 - DADOS DAS FAMÍLIAS ACAMPADAS EM ARAÇAI / MUNICÍPIO DE SAUDADES - SET/OUT DE 2000

\begin{tabular}{|c|c|c|c|c|c|c|}
\hline $\mathrm{N}^{0}$, & NOME & SEXO & IDADE & $\begin{array}{l}\text { DATA } \\
\text { NASCII }\end{array}$ & PARENTESCO & LOCAL DE NASCIMENTO \\
\hline 1 & $\begin{array}{l}\text { 1.Pedro Barbosa Kunimim } \\
\text { Jeguaka }\end{array}$ & M & 40 & $03 / 11 / 61$ & Esposo & T1. Votouro \\
\hline 2 & Alzira Barbosa Jajuka Yvate & $\mathbf{F}$ & 41 & $12 / 03 / 60$ & Esposa & TI. Nonoai/Mbaraca Mirim \\
\hline 3 & Elizeu Barbosa Yva poty & M & 12 & $11 / 10 / 89$ & Filho & TI. Nonoai/Mbaraca Mirim \\
\hline 4 & Daiane Barbosa Jotakua & $\mathrm{F}$ & 10 & $27 / 08 / 91$ & Filha & TI. Nonoai/Mbaraca Mirim \\
\hline 5 & Josiane Barbosa Mbojejora'y & $\mathrm{F}$ & 08 & $02 / 07 / 93$ & Filha & TI. Nonoai/Mbaraca Mirim \\
\hline 6 & 2.Marcos Mariano Jetakua & M & 21 & $11 / 06 / 80$ & Esposo & TI. Nonoai/Mbaraca Mirim \\
\hline 7 & Cila Isaias Mariano Prhugnhe & $\mathrm{F}$ & 23 & $12 / 06 / 78$ & Esposa & TI. Votouro \\
\hline 8 & Eliézer Mariano Jeguakua & M & 01 & $15 / 02 / 00$ & Filho & TI. Nonoai/Mbaraca Mirim \\
\hline 9 & Keila Mariano Yva & $\mathrm{F}$ & 04 & $23 / 10 / 97$ & Filha & TI. Nonoai/Mbaraca Mirim \\
\hline 10 & 3.Ademir de Paula & M & 25 & $07 / 02 / 76$ & Esposo & - \\
\hline 11 & Suzane Barbosa & $\mathrm{F}$ & 22 & $02 / 11 / 79$ & Esposa & - \\
\hline 12 & Juliane de Paula & $\mathrm{F}$ & 07 & $01 / 07 / 94$ & Filha & - \\
\hline 13 & 4.João Barbosa Karai Poty & M & 35 & 24/06/66 & Esposo & TI. Nonoai/Mbaraca Mirim \\
\hline 14 & Nair Barbosa Kerexu Mirim & $\mathrm{F}$ & 31 & $22 / 12 / 69$ & Esposa & TI. Nonoai/Mbaraca Mirim \\
\hline 15 & $\begin{array}{l}\text { Adilson Barbosa Karai Vera'y } \\
\text { Poty }\end{array}$ & M & 17 & $01 / 08 / 84$ & Filho & TI. Nonoai/Mbaraca Mirim \\
\hline 16 & Gercilei Barbosa Yva Poty & $\mathrm{F}$ & 13 & $26 / 11 / 88$ & Filha & TI. Nonoai/Mbaraca Mirim \\
\hline 17 & Gelson Barbosa Kumumim Rete & M & 11 & $15 / 01 / 90$ & Filho & TI. Nonoai/Mbaraca Mirim \\
\hline 18 & Rosilei Barbosa Jetakua Mirim & $\mathrm{F}$ & 09 & $09 / 10 / 92$ & Filha & TI. Nonoai/Mbaraca Mirim \\
\hline 19 & Edson Barbosa Ava Rete & M & 06 & $26 / 10 / 95$ & Filho & TL. Nonoai/Mbaraca Mirim \\
\hline 20 & Idione Barbosa Kerexu Mirim & $\mathrm{F}$ & 03 & $11 / 10 / 98$ & Filha & TI. Nonoai/Mbaraca Mirim \\
\hline 21 & $\begin{array}{l}\text { 5.Antonio Barbosa Karai } \\
\text { Mboete }\end{array}$ & M & 47 & $29 / 04 / 54$ & Esposo & TI. Pinhalzinho \\
\hline 22 & Joana Barbosa Yva & $\mathrm{F}$ & 68 & $15 / 07 / 33$ & Esposa & TI. Nonoai/Mbaraca Mirim \\
\hline 23 & Loreni Barbosa Yva Mirim & $\mathrm{F}$ & 13 & $12 / 02 / 88$ & Filha & TI. Votouro \\
\hline 24 & Loreci Barbosa Kerexu Mirim & $\mathrm{F}$ & 09 & $12 / 02 / 92$ & Filha & TI. Nonoai/Mbaraca Mirim \\
\hline 25 & Márcia Barbosa Krexu & $\mathrm{F}$ & 08 & $12 / 07 / 93$ & Filha & TI. Nonoai/Mbaraca Mirim \\
\hline 26 & 6.Clementino Barbosa Vera & M & 89 & $12 / 10 / 12$ & Esposo & Argentina \\
\hline 27 & $\begin{array}{l}\text { Carmelinda Barbosa Jexuka } \\
\text { Rete }\end{array}$ & $\mathrm{F}$ & 80 & $02 / 12 / 21$ & Esposa & Soledade-RS \\
\hline 28 & $\begin{array}{l}\text { Lisane Barbosa Jotakua } \\
\text { Nhoguanga'y }\end{array}$ & $\mathrm{F}$ & 08 & $15 / 08 / 93$ & Neta & - \\
\hline 29 & Lizandra Barbosa Guêty & $\mathrm{F}$ & 06 & $26 / 05 / 95$ & Neta & - \\
\hline 30 & Josiel Barbosa Karai & M & 11 & $22 / 03 / 90$ & Neto & - \\
\hline 31 & 7.Serinérgio Daniel Köki & M & 31 & $30 / 10 / 70$ & Esposo & TI. Carreteiro \\
\hline 32 & Neuza Barbosa Yva & $\mathrm{F}$ & 21 & $04 / 10 / 80$ & Esposa & TI. Nonoai/Mbaraca Mirim \\
\hline 33 & Adriana Daniel Jotakua Mirim & $\mathrm{F}$ & 01 & $16 / 04 / 00$ & Filha & TI. Serrinha \\
\hline 34 & 8.Valmir Barbosa Karai Poty & M & 25 & $25 / 12 / 76$ & Esposo & TI. Votouro \\
\hline 35 & Maria Helena Barbosa & $\mathrm{F}$ & 25 & $27 / 07 / 76$ & Esposa & TI. Nonoai/Planalto \\
\hline 36 & $\begin{array}{l}\text { Esmael Barbosa Kunimi } \\
\text { Jekupe'y }\end{array}$ & M & 02 & $03 / 04 / 99$ & Filho & TI. Votouro \\
\hline 37 & $\begin{array}{l}\text { Raquel Barbosa Jotakua } \\
\text { Nheguănga'y }\end{array}$ & $\mathrm{F}$ & 04 & $16 / 03 / 97$ & Filha & TI. Passo Feio \\
\hline 38 & Thiago Barbosa Tupå Mirim & M & 06 & $09 / 05 / 95$ & Filho & TI. Votouro/Caeté \\
\hline 39 & $\begin{array}{l}\text { 9. Miguel Barbosa Kunumim } \\
\text { Rete }\end{array}$ & M & 34 & $17 / 08 / 67$ & Esposo & TI. Votouro/Caeté \\
\hline 40 & Terezinha de Morais & $F$ & 32 & $25 / 01 / 69$ & Esposa & TI. Nonoai/Mbaraca Mirim \\
\hline 41 & Joel Barbosa Kynumi Mee & M & 15 & $07 / 09 / 86$ & Filho & TI. Nonoai/Mbaraca Mirim \\
\hline 42 & Daniel Barbosa Jekype & M & 14 & $24 / 10 / 87$ & Filho & TL. Nonoai/Mbaraca Mirim \\
\hline 43 & Jussara Barbosa Kyma Rete & $\mathrm{F}$ & 11 & $12 / 01 / 90$ & Filha & TI. Nonoai/Mbaraca Mirim \\
\hline 44 & Matiel Barbosa Vera'y & M & 09 & $01 / 08 / 92$ & Filho & TI. Nonoai/Mbaraca Mirim \\
\hline 45 & Rafael Barbosa Yvate & M & 06 & $29 / 03 / 95$ & Filho & TI. Nonoai/Mbaraca Mirim \\
\hline 46 & Tatiane Barbosa Rete & $\mathrm{F}$ & 03 & $30 / 06 / 98$ & Filha & TI. Nonoai/Mbaraca Mirim \\
\hline
\end{tabular}

Espaço Ameríndio, Porto Alegre, v. 7, n. 2, p. 277-556, jul./dez. 2013. 
KIMIYE TOMMASINO - Relatório de Identificação e Delimitação da Terra Indígena...

\begin{tabular}{|c|c|c|c|c|c|c|}
\hline$N^{2}$. & NOME & SEXO & IDADE & $\begin{array}{l}\text { DATA } \\
\text { NASCI/ }\end{array}$ & PARENTESCO & LOCAL DE NASCIMENTO \\
\hline 47 & Matias Barbosa Kynumi Mirim & M & $8 \mathrm{~m}$ & $11 / 10 / 00$ & Filho & Terra de Araçaí \\
\hline 48 & 10.Ozias de Souza & M & 19 & $27 / 12 / 82$ & Esposo & - \\
\hline 49 & Eliane Barbosa & $\mathrm{F}$ & 18 & $16 / 05 / 83$ & Esposa & - \\
\hline 50 & $\begin{array}{l}\text { Ozeias Barbosa de Souza } \\
\text { Kunumim Tupã Mirim }\end{array}$ & M & 03 & $23 / 07 / 98$ & Filho & - \\
\hline 51 & $\begin{array}{l}\text { 11. Maximiniano M. Morais } \\
\text { Angatu }\end{array}$ & M & 78 & $12 / 03 / 23$ & Esposo & TI. Nonoai/Mbaraca Mirim \\
\hline 52 & Cecilia Barbosa Krexu & $\mathrm{F}$ & 41 & $01 / 05 / 60$ & Esposa & TI. Nonoai/Mbaraca Mirim \\
\hline 53 & $\begin{array}{l}\text { Marciano M. de Morais } \\
\text { Mbaraka'y }\end{array}$ & M & 07 & $08 / 04 / 94$ & Filho & TI. Nonoai/Mbaraca Mirim \\
\hline 54 & 12. Valmir Siqueira & M & 18 & $01 / 10 / 83$ & Esposo & TI. Votouro \\
\hline 55 & Dilvầnia Barbosa Jotakya Hemey & $\mathrm{F}$ & 19 & $30 / 07 / 82$ & Esposa & TI. Nonoai/Mbaraca Mirim \\
\hline 56 & $\begin{array}{l}\text { 13.Joăo Carlos da Silva } \\
\text { Kunumim Nhemboyvate }\end{array}$ & M & 15 & $26 / 03 / 86$ & Esposo & TI. Nonoai/Mbaraca Mirim \\
\hline 57 & Rosane Barbosa Jotakua Yvate & $\mathrm{F}$ & 19 & $23 / 04 / 82$ & Esposa & TI. Nonoai/Mbaraca Mirim \\
\hline 58 & $\begin{array}{l}\text { Ivan Carlos da Silva Kunumu } \\
\text { Nhemboyvate }\end{array}$ & M & 01 & $08 / 01 / 00$ & Filho & TI. Nonoai/Mbaraca Mirim \\
\hline 59 & 14.Luis Barbosa Kuaray & M & 29 & $30 / 08 / 72$ & Esposo & T1. Votouro \\
\hline 60 & Domicilia Barbosa Jepovera'y & $\mathrm{F}$ & 30 & $14 / 08 / 71$ & Esposa & TI. Nonoai/Mbaraca Mirim \\
\hline 61 & $\begin{array}{l}\text { Lucas Barbosa Kuarai Didyi } \\
\text { Mirim }\end{array}$ & M & 12 & $07 / 07 / 89$ & Filho & T1. Nonoai/Mbaraca Mirim \\
\hline 62 & Genilson Barbosa Tupâ Jerovia'y & M & 06 & $29 / 01 / 95$ & Filho & TI. Nonoai/Mbaraca Mirim \\
\hline 63 & $\begin{array}{l}\text { Luciane Barbosa Jetakua } \\
\text { Nhemombe'y }\end{array}$ & $M$ & 04 & $29 / 10 / 97$ & Filho & TI. Nonoai/Mbaraca Mirim \\
\hline 64 & $\begin{array}{l}\text { Sisley Barbosa jetakua } \\
\text { Nhembejekupe'y }\end{array}$ & $\mathrm{F}$ & 02 & $30 / 01 / 99$ & Filha & TI. Nonoai/Mbaraca Mirim \\
\hline 65 & 15.Paulo Barbosa Kuaray & M & 19 & $26 / 11 / 82$ & Esposo & TL. Nonoai/Mbaraca Mirim \\
\hline 66 & Jurema Benites Kerexu Mirim & $\mathrm{F}$ & 21 & $05 / 05 / 80$ & Esposa & TI. Guarita \\
\hline 67 & Jonas Barbosa Karai Jekupe & M & 04 & $25 / 01 / 97$ & Filho & TI. Nonoai/Mbaraca Mirim \\
\hline 68 & Elias Barbosa Vera Mirim & M & 02 & $20 / 01 / 99$ & Filho & TI. Nonoai/Mbaraca Mirim \\
\hline 69 & 16.Dôrico Moraes Poty'y & M & 74 & $23 / 12 / 27$ & Esposo & Terra de Araça'i \\
\hline 70 & Cleci Antunes de Oliveira & $\mathrm{F}$ & 97 & $01 / 08 / 94$ & Esposa & TI. Nonoai \\
\hline 71 & 17.Lidia Alves da Silva & $\mathrm{F}$ & - & $05 / 04 / 52$ & Solteira & - \\
\hline 72 & Mário Alves da Silva & M & - & $11 / 04 / 42$ & Immāo & - \\
\hline 73 & $\begin{array}{l}\text { 18.Neri Rodrigues Kunumiju } \\
\text { Mirim }\end{array}$ & M & 24 & - & Esposo & $\cdot$ \\
\hline 74 & Marta Ramos de Paula & $F$ & 16 & - & Esposa & - \\
\hline 75 & $\begin{array}{l}\text { Fabiana Rodrigues Kerexu } \\
\text { Minim }\end{array}$ & $\mathrm{F}$ & 03 & - & Filha & - \\
\hline 76 & $\begin{array}{l}\text { 19.Sebastião Antunes Oliveira } \\
\text { Jekupe Pikava Mirim }\end{array}$ & M & 45 & - & Esposo & TI. Nonoai \\
\hline 77 & Maria Francisca de Oliveira & $\mathrm{F}$ & 42 & - & Esposa & TI. NonoairPlanalto \\
\hline 78 & Alesandra de Oliveira & $\mathrm{F}$ & 07 & - & Filha & Tl. Nonoai/Mbaraca Mirim \\
\hline 79 & Adilio de Oliveira & M & 17 & - & Filho & TI. Nonoai/Mbaraca Mirim \\
\hline 80 & 20. Osmar Rodrigues & M & 63 & $\cdot$ & Esposo & Planalto \\
\hline 81 & Ana Maria Rodrigues Jajuka & $\mathrm{F}$ & 42 & - & Esposa & TI. Nonoai/Mbaraca Mirim \\
\hline 82 & $\begin{array}{l}\text { Marli de Fátima Rodrigues } \\
\text { Jokupe'y }\end{array}$ & $\mathrm{F}$ & 18 & $\cdot$ & Filha & TI. Nonoai/Mbaraca Mirim \\
\hline 83 & Marlúcia Rodrigues Kerexu & $\mathrm{F}$ & 16 & - & Filha & TI. Nonoai/Mbaraca Mirim \\
\hline 84 & Neodi Rodrigues Vera'y & M & 14 & $\cdot$ & Filho & TI. Nonoai/Mbaraca Mirim \\
\hline 85 & $\begin{array}{l}\text { 21.Alcindo Barbosa Kinumim } \\
\text { Papa }\end{array}$ & M & 29 & $20 / 08 / 71$ & Esposo & TI. Votouro \\
\hline 86 & Marlene Rodrigues Krexu rete & $F$ & 29 & $06 / 09 / 70$ & Esposa & TI. Nonoai/Mbaraca Mirim \\
\hline 87 & Maristela BarbosaJotakua Mirim & $\mathrm{F}$ & 01 & $20 / 12 / 98$ & Filha & TI. Nonoai/Mbaraca Mirim \\
\hline 88 & 22.João Ribeiro da Silva & M & 74 & $14 / 10 / 27$ & Solteiro & Terra de Araça'i \\
\hline
\end{tabular}

Espaço Ameríndio, Porto Alegre, v. 7, n. 2, p. 277-556, jul./dez. 2013. 


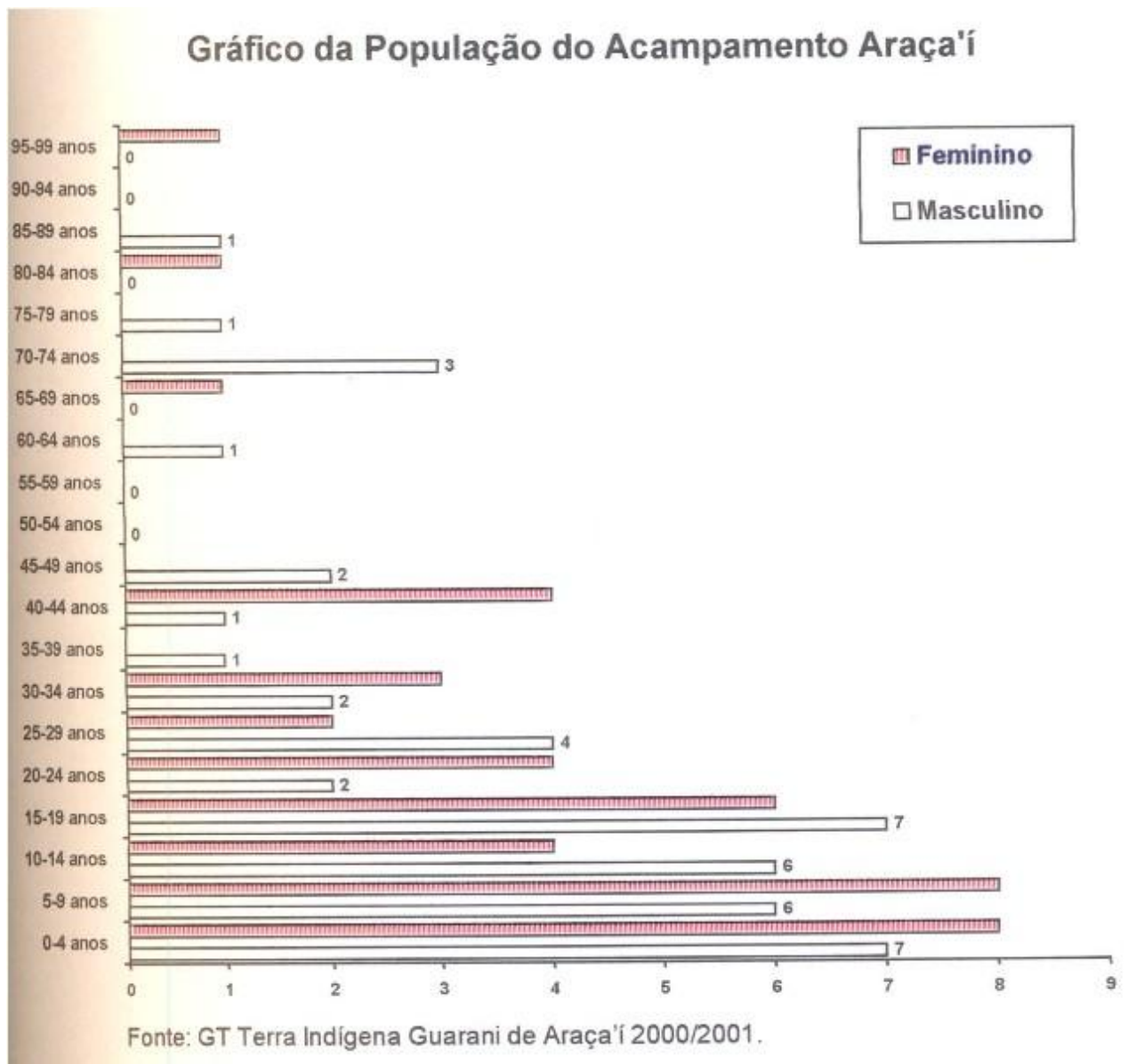

\section{Narrativas sobre a Chegada dos Juruá}

O ano de 1923 marca a chegada dos primeiros brancos à região do oeste catarinense e uma parte do grupo acabou migrando para o Rio Grande do Sul. Vejamos as narrativas:

Ali naquele tempo, desde 1923, quase 20 anos que morava lá naquele Araçá, aí morreu finado avô e daí pai falou que vamos pro Rio Grande, porque já começava chegar os brancos, tocando nós, então naquele momento, naquela hora, naquele tempo, o tio Antonio Ribeiro, o Bastião [Sebastão André Honório], ficaram ali e no tempo que ficaram ali, tomaram aquele lugarzinho deles, queimaram a casa deles, surraram eles, quebraram 0 finado Bastião (Clementino Barbosa).

Espaço Ameríndio, Porto Alegre, v. 7, n. 2, p. 277-556, jul./dez. 2013. 
A narrativa de Clementino resume o processo, da chegada dos primeiros Juruá, por volta de 1923, quando o grupo já estava no Tataypy Rupa do rio Araçazinho, por morte do pai de Clementino, mas também por pressões dos Juruá que chegavam "tocando" as famílias guarani, deu-se a migração de um grupo do Araça'í para o Rio Grande do Sul. As pressões sobre as famílias que permaneceram em Araça'í continuaram aumentando à medida que os Juruá foram chegando às terras que foram sendo loteadas até que o loteamento chegou ao Tekohá Araça'í. Vejamos como eles narram esses fatos:

Então com isso é que nós se arretiremos. Não é abandonar nosso lugar lá... Mas que é mais certeza que é [quem queimou as casas] o Clarindo de Oliveira. Esse que entrou antes que eles [os colonos alemães] entravam e que eles não gostam de nós, eu conheço. Isso foi mais ou menos em 1948 por aí. Em 1948 em diante que eles entraram e fazendo ameaças prá nós. Então com aquilo, também que nós saímos por último tempo que nós saímos. Naquele tempo já tinha serraria colocada, então o trabalhador deles fazia aquela ameaça e então atirava de espingarda assim por cima de nossa casa e ouvi falar que tinha um que estava puxando munição prá aqueles brancos assustar nós. Daí foram fazendo mais um pouco, foram entrando e daí ajustaram quem faz a estrada.

Os agrimensores [da medição das terras, funcionário da Cia Territorial Sul Brasil] eu sei, o nome dele é Deodato e o Jupir. Tudo é morto esses dois. Vieram do Rio Grande. A profissão deles, daqueles e daí eles entraram prá medir e depois eu acompanhei essa medição, quer dizer, o agrimensor eu acompanhei até Maravilha foi nós que dividimos prá cidade lá Maravilha e Modelo também eu ajudei a dividir aquela terra e agora o Pinhalzinho aqui também, naquele tempo [era] puro sertão ainda, eu ajudei dividir até o rio Burro Branco. De Burro Branco subimos e fomos dividir na divisa de Campo Erê, Lageado Saltinho e Lageado Branco também que tem nome de Lageado e aquele Toldo Tigrinho e hoje em dia é Tigre Velho e o Bom Jesus do Oeste, fomos nós que dividimos tudo. Nós trabalhávamos para a companhia [Cia Territorial Sul Brasil]. Naquele tempo eu já trabalhava só por dia, mas quatro anos... A Companhia registrou [a gente]. Pois é, começamos a dividir a terra em 1940. Daí por diante. Eu trabalhei quatro anos.

Espaço Ameríndio, Porto Alegre, v. 7, n. 2, p. 277-556, jul./dez. 2013. 
Eu trabalhei prá eles já, né? Porque então daí, pegou nós de surpresa. A mãe, muito medrosa, naquele tempo quando viram, já estavam abrindo a divisa [na terra dos Guarani]. Mas daí é que a finada mãe disse que tinha que sair. Mas era muito medrosa e daí então dizia que nós tinha que se arretirar. Fomos morar em Cunhataí, onde nós estávamos morando. Fica encostado no município de São Carlos. Arrumemos um serviço prá ir trabalhando e até na serraria nós trabalhamos um pouco. Na serraria do Osvaldo Sênimo [Sehmen] Ele tinha serraria em Cunha Porã e também em Bom Jesus do Oeste. Lá eu não trabalhei mas trabalhei aqui na Barra Pequena. Agora isso já pertence prá Cunhataí. O rapaz [filho] dele, o mais velho, mora em Maravilha, e o nome dele é Nelson Sênimo (João Ribeiro).

Pelas narrativas percebe-se que a chegada dos primeiros Juruá e depois da colonizadora que passou a lotear e vender as terras do oeste catarinense aceleraram a entrada de mais colonos e os próprios indígenas foram contratados para trabalhar na medição junto aos agrimensores e mesmo nas colônias, em serviços variados e na serraria dos irmãos Sehmen. Para melhor situar esses acontecimentos, a serraria a que se referem os Guarani foi instalada em 1929 (WERLANG, 1992, p. 145). Ao mesmo tempo em que ocorriam os fatos, a aldeia indígena sofria profundas alterações, pois que os homens adultos saíam para o trabalho junto a empresas dos Juruá e ficavam muito tempo sem retornar. Alguns indígenas tornaram-se biscateiros e também passavam bastante tempo fora da aldeia, ficando apenas os velhos e as crianças. Isso, de certa forma, significava uma desarticulação do modo de vida no Tekohá. Vejamos ainda as narrativas:

$\mathrm{Na}$ época, é que minha mãe faleceu, eu estava com cinco anos, prá você ver quantos anos faz, nós víviamos uma vida de dificuldades, nós éramos pequenos, meus pais eram remedieiros, curandor. Saíam muito prá fazer remédio e parava nos biscateiro. Então nós ficávamos sozinhos com essa nossa tia. Então nós íamos na casa da nossa tia que é Ana e que é mãe desse João Ribeiro. Eles também viviam lá e eles não plantavam lá, ela tocava alguma coisa mas ele [João Ribeiro] quando trabalhava, trabalhava fora, não plantava ali. [Trabalhava] prá todo mundo, onde achava serviço, na enxada, na foice, era o que mais 
fazia.

Olha, a maioria trabalhou mesmo prá esse próprio que morou lá, um tal de Clarindo de Oliveira, na década de 40. Trabalharam mais prá eles. E daí o Sr. Walter, falecido já né? Que eu saiba, trabalhavam prá muita gente e naquela época a gente era pequeno e não sabia de depois de grande daí nunca trabalhava. Saíam vender balaio, peneira, maioria das mulheres e eu ficava em casa. Vivia em aldeia mas, [por último] foi três famílias. Família do Sebastião Alves e essa minha tia [Ana] que é a mãe da mulher do Sebastião Alves e o que era meu padrinho que era o Roberto. E ele saiu de lá três anos depois que eu. Eu saí em 1960 e ele saiu em 1963.

Eu saí dali fui para São Miguel do Oeste, porque eu estava plantando nessa terra lá e aconteceu de essa gente queimar minha casa e daí eu queria ficar ali ainda o tempo que eu pudesse (Sebastião André).

Além das narrativas indígenas sobre a construção do Tekohá Araça'í nos dois Tataypy Rupa e do modo de subsistência que experimentaram, inicialmente vivendo dos recursos florestais e depois, com a chegada dos primeiros brancos, como trabalhadores nas várias atividades, como derrubar matas, abrir estradas e mesmo como auxiliares no loteamento das terras para a Cia. Territorial Sul Brasil. Na verdade, como ficou evidente, a família de Antonio Ribeiro da Silva e seus filhos aceitaram trabalhar para a colonizadora. João Ribeiro trabalhou de 1940 a 1944 para a Companhia e foi auxiliar dos agrimensores na medição das terras dos municípios daquela região: Maravilha, Modelo, Pinhalzinho, Bom Jesus do Oeste e outras localidades identificadas nas narrativas pelos principais rios. A figura 11 mostra a área colonizada pela Companhia Territorial Sul Brasil.

Segundo a pesquisa de Werlang (1992, p. 136), a venda de lotes urbanos em São Carlos começou em 1928 e foi quando João Ribeiro disse que passaram a frequentar aquele primeiro núcleo onde podiam comprar o sal que precisavam e outros produtos. Em Cunha Porã os primeiros lotes começaram a ser vendidos em março de 1932 e em Caibi e Saudades iniciaram em 1938. Fica assim bem localizada, geográfica e cronologicamente, a ocupação das terras guarani. As pressões foram aumentando a tal ponto que a mãe de João Ribeiro, temerosa de tantas ameaças, acabou convencendo João a se mudar para 
KIMIYE TOMMASINO - Relatório de Identificação e Delimitação da Terra Indígena...

Cunhataí onde arrumaram trabalho. A pressão aumentou a partir de 1948, como vimos e foi nessa época que espancaram Sebastião Alves e o deixaram aleijado.

Segundo os depoimentos dos Guarani, João Ribeiro da Silva, Sebastião André e outros, a Cia. Territorial Sul Brasil deixou uma terra reservada para os Guarani que seriam dois lotes. No entanto, um branco de nome Clarindo de Oliveira pressionou João Ribeiro e Sebastião André a assinarem um documento de desistência dos lotes. João Ribeiro afirmou que o Clarindo tomou-lhe o documento e, ao que parece, acabou assinando a desistência pela pressão. Sebastião André não cedeu e certamente por essa razão, teve sua casa incendiada em 1960. Esse episódio parece ter provocado uma cisão interna no grupo porque a família de João Ribeiro (ele e seus irmãos e irmãs) permaneceu na região e vive até hoje dispersa em vários municípios trabalhando nas colônias. Outra parte foi viver na Al Nonoai e fundou as aldeias de Mbaraca Mirim e Passo Feio. Alguns membros da família ainda passaram a viver fora de Nonoai, como é o caso de Sebastião André que rompeu relações com João Ribeiro e, mesmo casado com mulher kaingang, vive na cidade de Rio dos Índios-RS. Trata-se de um assunto que eles não gostam de lembrar e ainda produz um certo mal-estar falar das dissenções internas por causa desse documento.

$O$ fato é que as famílias pressionadas de diferentes formas foram saindo da aldeia e indo morar nas colônias onde conseguiam casa para morar e muitas ainda vivem nessa condição, tanto na própria região de Araça'í quanto em locais mais distantes. No entanto, é importante ressaltar que na aldeia de Araça'í permaneceram três famílias até os anos 60. Sebastião André saiu quando a sua casa foi incendiada em 1960, por insistência de sua mãe. Sebastião Alves e Roberto Honório saíram em 1963. Por terem ficado apenas três ranchos na área dos dois lotes, é possível que a aldeia tenha perdido visibilidade, e, também por ter-se desestruturado o Tekohá como comunidade organizada internamente, tornou-se completamente invisível.

Registramos aqui algumas informações sobre a existência de outros grupos guarani no oeste catarinense fornecidas pelas famílias de Araça'í. Disseram que havia um Tekohá no alto Maembu, perto de Cunha Porã e Cunhataí. Falaram de outro, na localidade de Limeira no 
município de Paraiso, próximo à fronteira com a Argentina: havia, segundo eles, seis casinhas e eles plantavam mandioca. Um terceiro grupo deu mais referências: em 1945 teriam vindo da Argentina 30 famílias que o pai de João Ribeiro teria levado para ficar com as famílias de Araça'í, mas não eram seus parentes e elas não aceitaram e, por isso, Antonio Ribeiro da Silva os levou para Pesqueira. Esse Tekohá ficava à margem do rio Pesqueira, divisa entre Irati e Sul Brasil onde o rio forma um "joelho" e teria mais ou menos 600 ha.

Outra informação importante a ser registrada é que algumas famílias de Araça'i foram levadas pelos donos da Serraria do Zimmer para trabalhar numa outra serraria que a empresa tinha no estado do Pará.

\section{Tekohá Araça'í: o Lugar do Tekó Guarani}

Retomaremos as principais informações sobre o sistema cultural guarani que foram expostas no capítulo I com o objetivo de compreender os aspectos cosmológicos, seus mitos e rituais que se constituem como fundamentos das suas práticas sociais.

Como disse Melià, a expressão "mais cabal de sua indentidade e de sua diferença" é o nhande rekó, a qual se refere ao modo de vida guarani como uma totalidade vivida em suas múltiplas dimensões: mítica e histórica; terreal e divinal; individual e coletivo. Segundo ele, o "modo de ser" guarani está consubstanciado em duas formas: "o ñande rekó katú (nosso modo de ser autêntico e verdadeiro) e o ñande rekó marangatú (nosso modo de ser bom, honrado e virtuoso enquanto religioso)" (MELIÀ, 1989, p. 293).

Na cosmologia e mitologia guarani, como foi visto, não há uma separação entre os mundos natural, social e sobrenatural. Muito ao contrário estas esferas se interpenetram constantemente e influenciamse reciprocamente. Os acontecimentos humanos são sempre representados como obras da vontade de um Deus, o Nhanderú Eté e nada acontece que não seja por sua interferência e vontade. $O$ contato com a esfera sobrenatural se faz ritualmente através de seus karaí ou nhanderú (pajé) os quais 
KIMIYE TOMMASINO - Relatório de Identificação e Delimitação da Terra Indígena...

se enfeitam ritualmente e se aproximam, através do próprio canto e da dança, das portas dos paraísos, as abrem, as transpõem e entram nas moradas que não senão o lugar onde se celebra a verdadeira liturgia, como a celebrara já o próprio Avô Grande Primeiro (idem, p. 328).

Importante é compreender o conceito de Terra Guarani, pois é o argumento que alimenta a luta política das famílias guarani de Araça'í. Sobre a concepção de terra e seus fundamentos ainda nos apoiamos em Melià (1989, p. 339).

A boa terra guarani é tão real porque seu fundamento não é a natureza em si, mas o ato religioso que lhe dá princípio e a conserva. Cada uma das nações guarani tem uma concepção e símbolos próprios para significar este fundamento e este centro de seu cosmos, mas todas concordam em fazer depender a bondade da terra e sua conservação, sua perfeição e sua estabilidade, da salvaguarda deste fundamento central. $[\ldots]$

A terra guarani, ..., ordena-se e se 'cosmiza' não em função de um templo nem de um lugar sagrado, mas em relação com um canto e uma festa, contexto sacramental da palavra e do gesto ritual; ora, a festa é também e sobretudo o sacramento do amor mútuo e da participação.

$[\ldots]$

Deste modo, o fundamento da terra guarani acaba sendo a festa onde se compartilha a alegre bebida da chicha: kawí, fruto da terra e do trabalho de muitos, unidos em mutirão: potyrõ, onde também o homem se torna palavra e essa palavra é compartilhada por todos. Onde há uma festa guarani, aí está enfim o centro da terra e a terra boa e perfeita e que se aspira.

Almeida (1985, p. 10) complementa as informações acima sobre a concepção de Tekohá cujo interesse não está apenas na terra (Yvy), mas no mato (Ka'aguy):

O Tekoha, ..., não é apenas a terra. [...] Ao Tekoha está associada a casa (óy), as relações com seus parentes; é onde enterram seus mortos, onde rezam, onde radica a possibilidade de 
KIMIYE TOMMASINO - Relatório de Identificação e Delimitação da Terra Indígena...

\begin{abstract}
exercer o direito divino de fazer suas roças (kokue); são os animais de caça e, eventualmente, o rio onde se pesca. 'Quando amadurecem os frutos de tua roça, darás de comer aos da tua tribo, sem exceção alguma. Para que se fartem todos é que os frutos chegam a madurar, e não para que sejam objeto de avareza. Dando de comer a teu próximo, verão os de cima que amas aos do assento de teus fogões (Tataypy Rupa/Tekoha) e eles adicionarão dias à tua vida para que repetidas vezes possas voltar a semear. Este preceito sagrado, transmitido textualmente através de séculos, de geração em geração, é cumprido religiosamente; mas, como ficou dito, a lei que ordena a todo homem casadoiro a cultivar uma extensão determinada para assegurar a alimentação da tribo tem caído em desuso' (CADOGAN, 1948 , p. 139), em muito por não ter onde realizá-la
\end{abstract}

Neste estudo estaremos utlizando as informações fornecidas por Melià e Almeida para a análise da experiência dos Guarani de Araça'í. Estaremos, para efeito de melhor instrumentalização, fazendo uma distinção entre Tekohá e Tataypy Rupa. Tekohá será entendido como Terra Tradicional guarani, incluindo o espaço onde fazem suas casas (óy) e suas roças (kokue); as matas e rios onde caçam, coletam e pescam; os cemitérios onde enterram seus mortos; os espaços onde fazem seus rituais. É, portanto, todo o espaço físico onde vivem e realizam o tekó. Por outro lado, Tataypy Rupa será distinguido num sentido mais restrito, como assento de fogões, ou seja, é onde eles fazem sua aldeia, no sentido do conjunto das casas (ón) das famílias que formam a família extensa e que habita a Terra Tradicional/ Tekohá.

Feitos esses esclarecimentos, podemos dizer que os Guarani da Terra Araça'í fizeram dois Tataypy Rupa: o primeiro à margem do rio Araçá, o segundo perto do rio Araçazinho. No Tataypy Rupa do rio Araçá fizeram um cemitério onde enterraram os seus primeiros mortos. Por causa da "guerra mundial" tiveram de abandonar o rio Araçá e mais tarde o refizeram à margem do Araçazinho e lá ficaram mais tempo. Também enterraram os seus mortos, sacralizando assim o Tekohá Araça'í que abrigou para sempre os seus corpos. O nome que davam ao rio Araçá era Canguaçu.

Como era costume guarani, o Tekohá podia receber o nome do grupo referido pelo seu nhanderú ou pelo nome do lugar e por isso era

Espaço Ameríndio, Porto Alegre, v. 7, n. 2, p. 277-556, jul./dez. 2013. 
KIMIYE TOMMASINO - Relatório de Identificação e Delimitação da Terra Indígena...

conhecido como Tekohá Karaí Tupã e Tekohá Araça'í (Araça'í = Araçá pequeno).

Pelas narrativas dos Guarani cuja memória continua muito viva em relação à vida que tinham no Tekohá Araça'í, do ponto de vista ecológico, aquela região preenchia os requisitos de "terra boa" e lá fizeram o assentamento de seus fogos/Tataypy Rupa. As matas Ihes forneciam toda a alimentação que necessitavam. A mata era a "farmácia" dos índios, pois seu nhanderú - naquela época era João Honório, pai de Artur - fazia rituais onde os espíritos lhe diziam qual era a doença e ele Ihes dava o tratamento. Atualmente o nhanderú é Clementino Barbosa que, mesmo quando estavam acampados no município de Saudades, não deixava de fazer as rezas e danças com acompanhamento de violão para que Nhanderú Eté lhes guiasse naquela luta política para reconsquistar a Terra de Araça'í.

No Tekohá Araça'í nasceram os filhos das quatro famílias que formavam a comunidade. Outros lá faleceram e continuam enterrados nos dois cemitérios que jazem sob as terras de cultivo e pastagem dos colonos que lá se estabeleceram.

Nasceram no Tekohá Araça'í: Paulina de Morais (mãe de Maximino Mariano de Morais), Pedrinho de Morais, Maria Barbosa, Tereza (Honório) de Paula, Antonio de Paula, Alcides Ribeiro, Hilário Ribeiro, Zulmira Ribeiro, Dario Ribeiro, os irmãos Cecília, Maria, Otília, João e Levino Ribeiro da Silva, Mário Ribeiro da Silva, Zulmira (Honório) de Morais, Dorico Morais, os irmãos Lídia e Mário Alves da Silva.

Nasceram nos municípios da região: João de Paula e Inês de Paula, filhos de Alcides de Paula (falecido) e Tereza (Honório) de Paula, nasceram no município de Palmitos, porque os pais estavam trabalhando nas colônias. Nelci, Vanusa, Silvânia, Salete e Paulo, filhos de Alcides e Zulmira Ribeiro, nasceram no município de Maravilha onde vivem até hoje.

Próximo a cada um dos Tataypy Rupa foi feito um cemitério. $O$ primeiro fica "encostado no rio Araçá, quase no encontro com o rio Jaiçá", perto da serraria do Zimmer. Estão enterrados nesse primeiro cemitério: José Barbosa (avô de Clementino), Maria da Silva (avó de José Barbosa), irmã da mãe de João Ribeiro e mãe do pai de Clementino. $O$ segundo cemitério ficava próximo ao segundo Tataypy Rupa tendo sua 
localização "no segundo passo do rio Araçazinho, mais ou menos dois quilômetros abaixo do rio Mborevi, 200 metros abaixo do segundo passo. Fica mais ou menos 40 metros da margem do rio Araçazinho".

Estão enterrados nesse segundo cemitério: Antonio Ribeiro da Silva (pai de João Ribeiro, falecido em 1942); tia de João Ribeiro/esposa de Roberto Honório; dois irmãos de João Ribeiro; dois filhos de Azelinda, irmã de João Ribeiro; Dalci, um menino de dois anos filho adotivo de João Ribeiro.

Quando morreu o pai de Clementino, os Guarani disseram que isso motivou alguns a se mudarem para a TI Nonoai onde já tinham parentes. Esse fato aponta para a existência de outro Tekohá vinculado pela rede de parentesco que certamente fazia parte de um Tetã ou Guará.

A lembrança das famílias de Araça'í foi bem definida em relação aos limites naturais de seu Tekohá que está no mapa desenhado por eles e que foi apresentado à nossa equipe técnica. O nome do Tekohá seguia a regra de nomear pelo lugar onde se localizava: o do rio Araçazinho (Araça'í) e também como Karaí Tupã que poderia ser o nome do grupo. O agrimensor do GT Araça'í, nas reuniões realizadas nas dependências da AER-Chapecó e nas visitas ao acampamento em Saudades não teve dificuldades na delimitação da área porque os limites naturais do Tekohá estavam bem vivos na sua memória.

Por outro lado, sabe-se que as migrações guarani nos séculos XIX e XX tiveram como argumentos a busca do Ivy Maraney, a Terra-semMal que ficaria no litoral atlântico. Durante nossa pesquisa de campo todas as argumentações para a reconquista do Tekohá Araça'í iam no sentido de terem terra própria porque os Kaingang estariam pressionando-os a saírem da TI Nonoai. Não querem mais ser submetidos aos Kaingang como ocorre com os grupos guarani que vivem em terras de outra etnia. No entanto, vejamos o que escreveu o Padre Rambo (1947, p. 86) em 1947 quando esteve com esse grupo:

Perguntados sobre os motivos dessas migrações, afirmam que 'os jesuítas' Ihes disseram que fossem sempre pelo mato até chegar ao Paraguaçu (mar grande). Parece que nisto sobrevive o impulso atávico dos tupis-guaranis para o Leste. 
Portanto, neste movimento de retorno à Terra Tradicional, os Guarani estão mais interessados e movidos por uma necessidade material imediata que é a busca de uma terra que seja deles e onde possam viver não como inquilinos, mas na Terra que era dos seus antepassados. Evidentemente existe uma dimensão mítica e religiosa nesse movimento porque, como foi visto, Tekohá não é apenas a terra, mas ela possui dimensões cosmológicas mais amplas. Buscar a terra onde viveram segundo seu modo de ser e onde estão enterrados os seus mortos, onde muitos nasceram e cresceram é um movimento ao mesmo tempo político e religioso.

Apresentamos a Figura 19 que é uma representação gráfica feita pela Comissão da Comunidade Guarani de Araça'í mostrando a área que reconhecem como sendo sua Terra Tradicional/Tekohá. Em seguida, a Figura 20 elaborada pelo GT Araça'í apresenta, aproximadamente, os locais das duas aldeias/Tataypy Rupa, os dois cemitérios e o local onde estiveram acampados entre julho e outubro de 2000. 
Figura 19 - REPRESENTAÇÃO GUARANI DO TEKOHÁ ARAÇA'Í

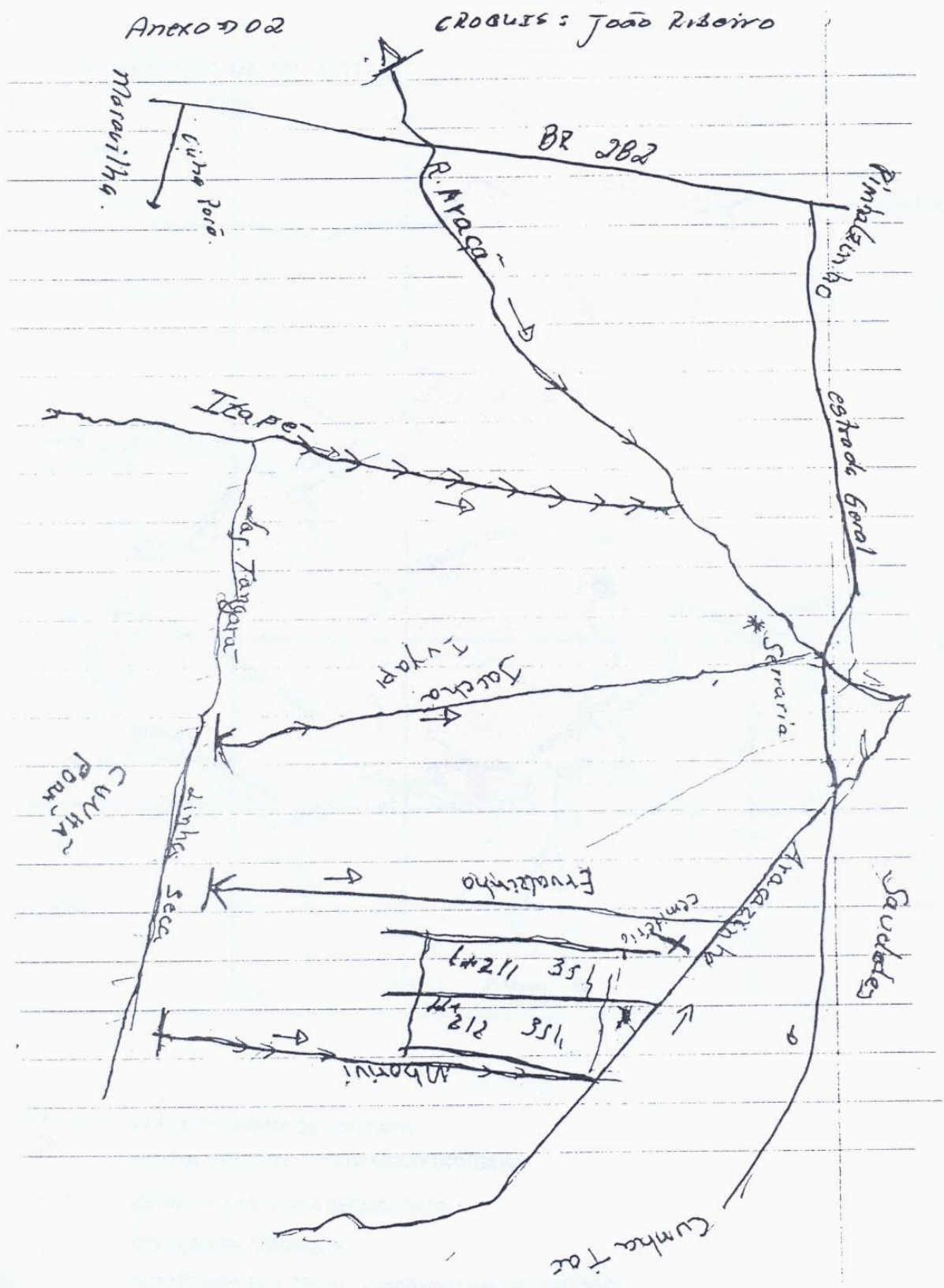

Espaço Ameríndio, Porto Alegre, v. 7, n. 2, p. 277-556, jul./dez. 2013. 
KIMIYE TOMMASINO - Relatório de Identificação e Delimitação da Terra Indígena...

\section{Figura 20 - LOCALIZAÇÃO APROXIMADA DAS ALDEIAS E CEMITÉRIOS DOS GUARANI DO TEKOHÁ ARAÇAÍ}

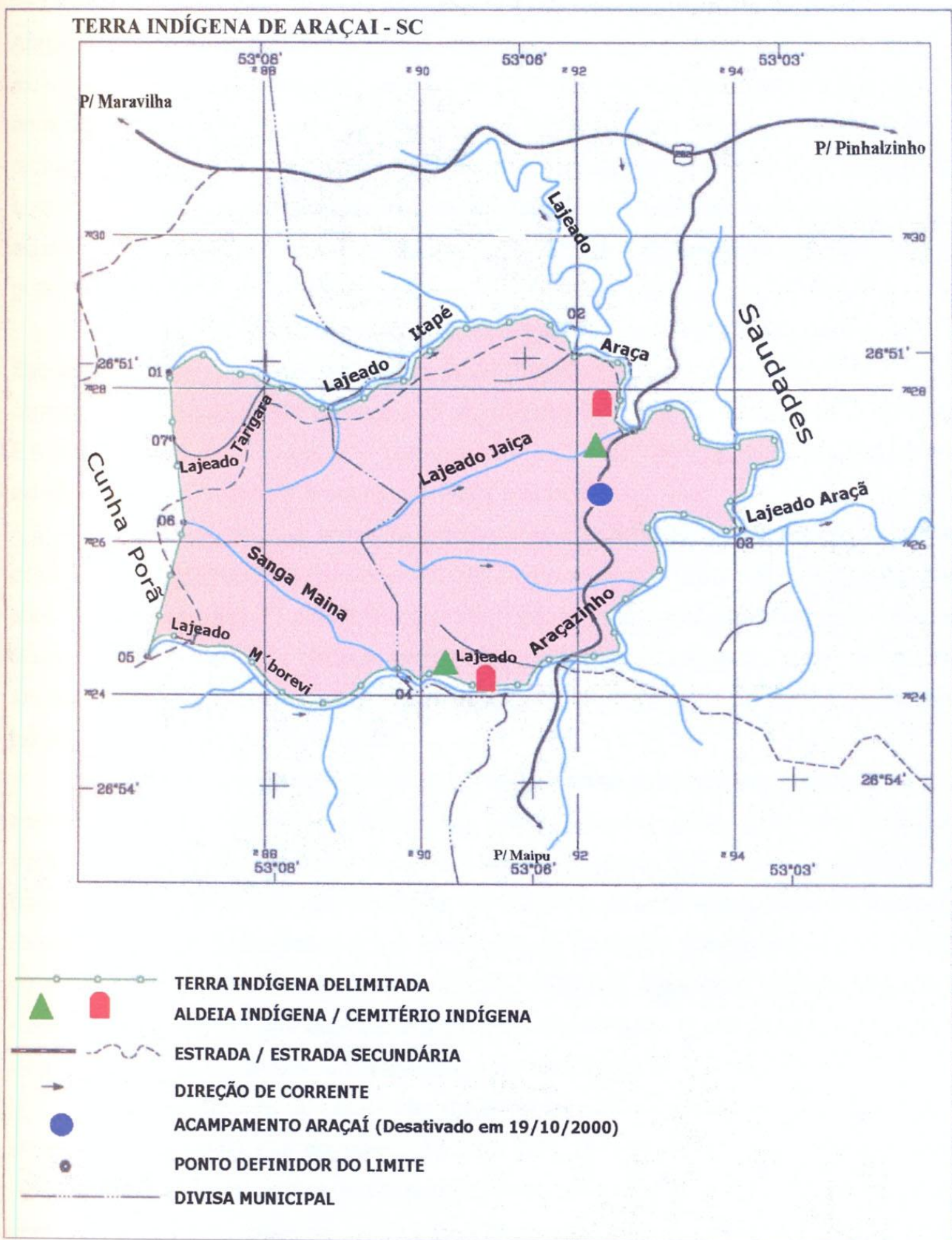

Fonte: Pesquisa GT. Araçaí/2000-2001

Espaço Ameríndio, Porto Alegre, v. 7, n. 2, p. 277-556, jul./dez. 2013. 


\section{A Presença Guarani em Araça'í através da Memória e da Ótica dos Juruá}

O que em primeiro lugar chama a atenção na região oeste catarinense são os nomes indígenas dos principais acidentes geográficos: rios, serras, nomes de lugares, municípios, distritos e localidades. Muitos rios da região pesquisada, não por coincidência, são nomes guarani: municípios de Cunha Porã, Cunhataí, Mondaí; rios Borevi, Araçá, Araçazinho, Jaiça, Maipu, Itapé. Esses nomes foram dados pelos índios que tiveram experiência histórica no passado, à época em que os jesuítas nomearam os lugares por onde passaram, reconhecendo os lugares já codificados pelos Guarani. Outros lugares receberam nomes novos, de origem estrangeira e apagaram os nomes indígenas. No entanto, a quantidade de nomes guarani é uma referência incontestável de que realmente aqueles locais do oeste catarinense eram conhecidos e habitados por diversos grupos guarani.

Os primeiros colonos que chegaram na região de São Carlos, Cunha Porã e Saudades tiveram contatos bem próximos com os Guarani que lá viviam. Estes índios constituíram a primeira mão-de-obra que os colonos contrataram quando lá chegaram. Era tudo coberto com matas e a primeira atividade das famílias teuto-brasileiras era derrubar as matas para formarem as primeiras plantações.

Algumas pesquisas sobre o processo de colonização foram realizadas pelos pesquisadores da UNOESC (Univerisdade do Oeste de Santa Catarina) de Chapecó nos anos 90 e, alguns desses colonos registraram os contatos que estabeleceram com os Guarani. Mesmo que de forma tangencial, os relatos, somados com os dados arqueológicos constatam o (re)conhecimento científico e popular de que a região era habitada originalmente pelos Guarani.

Além das informações colhidas por esses pesquisadores, era intenção do GT entrevistar algumas pessoas não-índígenas, indicadas pelos próprios Guarani, para que pudessem expor suas memórias sobre as famílias guarani que lá viviam. O clima de conflito gerado era tal que não pudemos viabilizar essas entrevistas. Os professores e alunos que fizeram monografias sobre a colonização da região sofreram muitas pressões do Movimento... e mesmo as pessoas que pretendíamos 
entrevistar (alguns colonos, a viúva do primeiro pastor que atendeu a população local e outra viúva, esposa do médico e ex-prefeito de Cunha Porã) foram impedidos de nos atender.

Seria importante a coleta de mais depoimentos porque poderíamos trazer informações mais precisas do ponto de vista dos colonos, sobre as relações sociais estabelecidas entre os índios e os primeiros brancos que lá chegaram. No entanto, acreditamos que os dados já existentes corroboram, de forma incontestável, que os primeiros colonos chegaram à região de Cunha Porã e Saudades, quando os Guarani já viviam naquela região. Além disso, o fato de terem contratado sua mão-de-obra e de terem produzido uma rede de sociabilidade intercultural, comprova essa realidade.

Vários colonos tornaram-se padrinhos das crianças guarani que foram batizadas pelos primeiros padres que lá ministraram serviços religiosos. Os filhos dos Guarani de Araça'í foram batizados na igreja de Saudades e tinham, invariavelmente, padrinhos brancos da região. Tereza e Rosalina, filhas de Roberto Honório e de Belina André, foram batizadas pelo padre que fazia batismo em Saudades. Rosalina, que vive hoje na sede da Al Nonoai, disse que os batismos eram feitos na casa de um colono porque no início não havia igreja e seus padrinhos foram Fredolino e Kátia Zimmer. Ela tinha entre 4 e 5 anos de idade. $O$ padre vinha de São Carlos. Na ocasião ela não se lembrou do nome, mas disse que era parecido com o nome do padrinho, certamente, seria um colono alemão.

Um dos diretores da Empresa Oeste Catarinense (sucedida em 1925 pela Cia Territorial Sul Brasil), José Rupp (sua esposa era Sueli Rupp) adotou uma criança guarani, conhecido como João Rupp, irmão de Antonio Ribeiro da Silva. João Ribeiro, sobrinho de João Rupp conta que ele foi adotado e teve estudo e se tornou um militar de carreira. Tinha ido participar da guerra.

De todas as relações sociais estabelecidas entre brancos e índios, o mais sistêmico e que teve continuidade desde a chegada dos primeiros brancos até os dias de hoje foram, sem dúvida, as relações de trabalho, isto é, da contratação da força de trabalho guarani pelos colonos. Os membros da família Ribeiro da Silva continuam vivendo nos municípios de Cunha Porã, Maravilha e Saudades porque continuaram se 
empregando nas propriedades dos colonos e alguns poucos já começam a trabalhar nas cidades.

O historiador Alceu A. Werlang, em sua dissertação de mestrado em história (1992) pesquisou a colonização do oeste catarinense da região que nos interessa. Embora tenha analisado a colonização realizada pela Cia Territorial Sul Brasil, de 1925 a 1954, colheu preciosas informações sobre a presença guarani quando chegaram as primeiras famílias teuto-brasileiras que compraram os lotes da companhia. Os depoimentos dos colonos mostram que à época de suas chegadas havia habitantes indígenas e caboclos, sendo ambas categorias utilizadas como mão-de-obra nos trabalhos pesados. Ao mesmo tempo, informaram que toda a área loteada era coberta de matas e não havia estradas e as famílias tiveram de entrar nos lotes por trilhas e picadas que eram abertas pelos colonos e pela mão-de-obra indígena e cabocla.

Werlang publicou nos Cadernos do CEOM (1995) o capítulo onde faz referências à memória dos colonos sobre os índios e caboclos que já viviam nas terras colonizadas pela Cia Territorial Sul Brasil. Utilizaremos nas nossas referências bibliográficas tanto a dissertação quanto o capítulo publicado na revista.

Os depoimentos colhidos por Werlang são de Oscar Sehenm e de Guilherme Mess:

Oscar Sehnem conta que em 1929, quando chegou a São Carlos, havia ali um acampamento com mais de 100 índios. Segundo ele, os mesmos ajudavam os brancos, não havia nenhuma briga, retirando-se em seguida, pois estavam ali só de passagem, ou seja, acampados. Guilherme Mess confirma a existência deste acampamento de indígenas que ali permaneceu por pouco tempo. Conta ainda, que na seção de Araçá, interior de Saudades, moravam 3 famílias indígenas que, segundo ele, falavam português 'meio quebrado'. Os demais entrevistados são unânimes em informar que não havia indígenas quando da sua chegada. A maioria, no entanto, encontrou vestígios arqueológicos, principalmente os que se instalaram próximos dos rios: [...] se achavam aqueles panelotes, uma maior, bem redondo, tipo panelão e, mas tudo vazio. Se encontrava na beira dos rios, mas índios mesmo não existia, diz Pedro Rodoi em entrevista (WERLANG, 1992, p. 72-73;

Espaço Ameríndio, Porto Alegre, v. 7, n. 2, p. 277-556, jul./dez. 2013. 
KIMIYE TOMMASINO - Relatório de Identificação e Delimitação da Terra Indígena...

1995 , p. 30-31).

As informações sobre a presença de vários sítios arqueológicos e as pesquisas já realizadas pelos pesquisadores de Santa Catarina e Rio Grande do Sul demonstram, claramente, ser aquela região parte do grande território dos guarani, conforme capítulo mais adiante.

Nanci Laufer Krindges elaborou uma monografia de TCC (trabalho de conclusão de curso) de História na UNOESC em 1999 e registrou alguns depoimentos de colonos e de índios Guarani além de consultas aos registros históricos.

Krindges, baseada nos depoimentos dos colonos, mostra que estes, quando chegaram, contratavam mão-de-obra dos "caboclos" e dos "índios" que viviam na região nos anos 40 do século XX. Os "caboclos" eram contratados para "derrubar mato", "roçar capoeira", "derrubar árvores", pois "eram pessoas pobres" e "por alguns trocados eles trabalhavam" (KRINDGES, 1999, p. 98). As relações interculturais se deram entre colonos e "caboclos", pois foi com estes que os alemães aprenderam a "produzir a terra e explorar melhor as riquezas naturais da região" e é com esses mesmos caboclos que aprenderam "a cultivar a erva e tomar chimarrão".

Além do "caboclo", Krindges (1999, p. 99) afirma:

o índio já vivia nestas terras, muito antes dos colonos chegarem. Segundo documento elaborado pelos índios Guaranis que residem na Reserva de Nonoai, anterior a chegada dos colonos, houve conflitos na região sul, do qual a aldeia Guarani que povoava a região foi vítima. Esse conflito ocasionou a debanda de boa parte dos aldeães. provavelmente relacionado a Revolução federalista ou então a questão do Contestado, fatos que não são esclarecidos no documento.

Sobre a localização da aldeia guarani, Krindges, adianta:

Esta aldeia se localizava na Linha Araçazinho, às margens do rio Araçazinho. Apesar do ocorrido, muitos índios permaneceram na região até iniciar o processo colonizador como nos conta seu ]oão [João Schitz, colono entrevistado pela pesquisadora]:

'Ah, índios... Nóis tava junto em Cristo Rei. Nóis tinha

Espaço Ameríndio, Porto Alegre, v. 7, n. 2, p. 277-556, jul./dez. 2013. 
KIMIYE TOMMASINO - Relatório de Identificação e Delimitação da Terra Indígena...

\begin{abstract}
acampamento na terra, no terreno deles. Nóis até comemo muito milho verde. Eles tinha uma roça, de uma quarta e poco, os Guarani lá, nóis comia milho verde. Os Guarani deram pra nóis. Eles trabalhavam junto até. $\mathrm{Na}$, na medição, porque isso cada um pode fazê. ... trabalhar com facão, abri picada [...].'

Como podemos perceber no depoimento anterior, os colonos foram bem recebidos por parte dos guaranis. Os mesmos ajudaram na medição das terras, bem como efetuaram alguns serviços para a companhia colonizadora e também para os colonos. Segundo senhor Silvério Osmaro, também trabalharam na abertura das primeiras estradas (idem, ibidem, p. 99).
\end{abstract}

Há um importante depoimento da senhora Brunhilda Salfner que dá mais detalhes sobre o trabalho que os Guarani faziam para os colonos:

Eles só tinha muita prática com foice, sabe. Com a foice no mato eles eram muito ligero. Eles trabalhavam bem nessa época [anos 40], com esse servicinho no mato. As outras coisas práticas eles não sabiam fazê. Só cestinhas, peneras e flechas (idem, ibidem, p. 101).

A autora da pesquisa fornece ainda sua análise sobre o conteúdo desses depoimentos:

podemos perceber nestas falas alguns aspectos do etnocentrismo europeu. Quando no diminutivo é denominado "servicinho", culturalmente as atividades relacionadas a cultura guarani eram consideradas inferiores. Também o fato de fazerem cestos, peneras e flechas, era muito pouco, para a visão capitalista dos colonos que valorizavam atividades rentáveis que favorecessem o processo acumulativo (idem, ibidem, $\mathrm{p}$. 102).

Mesmo sendo informações periféricas na dissertação de Werlang e na monografia de Krindges, estes pesquisadores puderam fornecer subsídios fundamentais para o desvendamento das relações sociais que as primeiras famílias de colonos estabeleceram com os índios, corroborando a memória dos próprios Guarani. Mesmo tendo Werlang assumido, pela leitura do trabalho de D'Angelis, que "quando da 
chegada da Companhia, os indígenas já haviam sido pacificados ou dizimados" e que os "índios 'civilizados' haviam sido, na sua maioria, aldeados, não criando atritos com a companhia colonizadora”, o certo é que os Guarani lá estavam, de fato, como lembraram os colonos entrevistados, Oscar Sehnem e Guilherme Mess. Mais ainda, eles se lembram que na seção Araçá viviam três famílias indígenas, os quais, como vimos na entrevista com os Guarani, eram as últimas famílias que deixaram o Tekohá: Sebastião Alves e Zelinda Ribeiro (irmã de João Ribeiro), Roberto Honório e Ana Maria [Honório] Ribeiro da Silva (sogra de Sebastião Alves e viúva de Antonio Ribeiro da Silva) e Sebastião André (filho de Roberto Honório e Ana Maria). Estas foram, portanto, as últimas famílias que tiveram de se retirar por causa das ameaças: Sebastião Alves foi espancado em 1948 e teve pernas e braços quebrados e, segundo disseram os Guarani, ficou aleijado para o resto da vida. Sebastião André, quando estava trabalhando em outro município, encontrou na volta, sua casa queimada. Por insistência de seus familiares, disse Sebastião André que se mudou, embora fosse sua vontade permanecer no lugar.

Os dados empíricos coletados em nossa pesquisa de campo mostram que a ocupação não foi tão pacífica como aparece na memória dos colonos. É possível que os colonos, de fato, não percebessem as formas de violência a que estavam sujeitos os Guarani que insistiam em permanecer no Araça'í. Mas, segundo constatamos, é de conhecimento geral, também dos colonos, que Sebastião André teve sua casa queimada.

Outro documento que nos chegou às mãos através da arqueóloga Gislene Montincelli refere-se a um artigo escrito e publicado por José Alberto Barbosa, promotor público de Porto União, assinado em 13 de junho de 1972, no jornal "Traço de União". Relata o promotor que estivera em 1931, visitando os Guarani de Cunha Porã (Anexo II: 2). Reproduzimos os dois primeiros parágrafos pela importância das informações:

Em 1931, o Delegado de Polícia de Cunha Porã, senhor WILLIBALDO WEIMER, foi conduzido pelo velho cacique JOÃO HONÓRIO, último chefe dos guaranis de Cunha Porã, até um local denominado "Pedra dos Bugres", na 
Seção Borivi, naquele Município. Acompanhava-os EMILIO HONÓRIO, irmão do cacique, e o motivo da caminhada, era a intenção do velho índio, agraciado pelo Delegado com uns presentes, de mostrar àquela autoridade uma pedra, cheia de gravações, e colocada sobre uma formação natural de basalto já por si de curioso aspecto. E, realmente, lá estava a curiosa pedra, apresentando desenhos curiosos: um jacaré, um pinheiro, ribeiros, marcos e sinais. $E$, mais curioso ainda, na parte central, uma estranha escrita. $\mathrm{Na}$ ocasião, JOÃO HONÓRIO disse que, de geração a geração, os chefes indígenas transmitiam o conhecimento daquele local, afirmando, mais, que havia por ali tesouro dos jesuítas.

Duas vezes, ainda, em vários idos, WILLIBALDO WEIMER esteve naquele lugar, e numa delas, foi para ali levar o Padre ANTONIO HALLMENSTEIN, M. S. F., de Maravilha. Segundo diz WILLIBALDO, tal padre disse que a inscrição na pedra era latina e que podia entendê-la perfeitamente bem, e que mediante rápida leitura, fôra mostrando e instruindo sobre certos locais, evidenciando que a pedra retratava a topografia do lugar, dizendo, porém, que para compreender os sinais, necessitaria de um roteiro complementar, e que havia possibilidade de que houvesse mesmo dinheiro escondido na região. Essa visita, deu-se, todavia, no mesmo ano em que o padre deixou Maravilha, indo para Alemanha, onde segundo consta, veio a falecer em anos passados (BARBOSA, 1972).

Mais adiante, o promotor relata outro fato relacionado à "Pedra dos Bugres":

Em 21 de novembro de 1970, sábado ensolarado, organizamos, de Maravilha, uma verificação do local. Nosso objetivo, adiantamos, não era ouro, e sim obtermos a pedra gravada, verdadeira riqueza... para os arqueólogos. Participaram da empreitada, além deste autor, também o próprio senhor WILLIBALDO WEIMER, pessoa de reconhecida idoneidade e excelente memória, e o agrônomo de ACARESC Dr. ARO NOMURA, o professor FRANCISCO GIALDI, então Adjunto de Promotor, mais NELSON DREWS e OSMAR WEIMER, estes de Cunha Porã, sendo que o Prefeito dessa cidade, senhor GUIDO DREWS, forneceu-nos viatura da municipalidade. Esse foi o grupo que chegou a "Pedra dos Bugres", terras de URBANO SCHMIDT, além do Lageado Barra Grande, próximo às terras do

Espaço Ameríndio, Porto Alegre, v. 7, n. 2, p. 277-556, jul./dez. 2013. 
KIMIYE TOMMASINO - Relatório de Identificação e Delimitação da Terra Indígena...

senhor SCHUMANN.

As informações que nos interessam, no momento, são as referentes a essa "pedra dos bugres" que os Guarani de Araça'í conheciam e passavam de geração a geração. Além disso, os nomes dos Guarani, o cacique João Honório e seu irmão Emílio Honório, tão presentes na memória dos seus descendentes, confirmam, mais uma vez, a incontestabilidade de que Araça'í era terra guarani: tinha o reconhecimento do prefeito de Cunha Porã e demais autoridades locais que lá retornaram em 1970.

\section{A Presença Guarani na Região do Oeste Catarinense através das Pesquisas Antropológicas e Históricas}

Há poucas pesquisas arqueológicas na região de nosso estudo. No entanto, os resultados existentes, se não são muitos, são suficientes para comprovar a antiguidade da ocupação guarani. A bacia do Uruguai foi pesquisada pelos arqueólogos que realizaram o EIA/RIMA das barragens projetadas para a referida bacia e, somada aos resultados de pesquisas anteriores, podemos considerar que, para os objetivos deste relatório, as fontes arqueológicas dão sustentabilidade à afirmação de que o oeste catarinense abrigou, no passado antigo e recente, populações guarani.

Monticelli15 diz no seu relatório enviado ao GT Araça'í que, segundo depoimento pessoal do professor José Proença Brochado sobre a área de Araça'í e região, este considerou que a área é desconhecida do ponto de vista arqueológico porque não houve pesquisa local. Há registro de apenas um (1) sítio arqueológico no município de Cunha Porã; três (3) em São Carlos; um (1) em Xaxim; um (1) em Águas de Chapecó; seis (6) em Mondaí; sessenta e nove (69) em Itapiranga e cinquenta e sete (57) em Palmitos. A pesquisadora ainda faz referência a dois (2) sítios identificados em 1978 pelo Pe. João Alfredo Rohr, com urnas e ossadas, três sítios no município de Caxambu (Volta Grande) em

\footnotetext{
${ }^{15}$ Queremos registrar nossos agradecimentos a Gislene Monticelli pela enorme contribuição dada ao GT Araça'í.
}

Espaço Ameríndio, Porto Alegre, v. 7, n. 2, p. 277-556, jul./dez. 2013. 
1968 pelo mesmo padre, sendo dois com vasilhas guarani. Ainda foram localizados vários sítios arquelógicos por Rohr e por Maria José Reis sendo três (3) sítios com material associado a antigas ocupações guarani.

No mesmo relatório Monticelli refere-se às descrições de Piazza (1969 apud MONTICELLI, 2001) das pesquisas realizadas no oeste catarinense. Foi localizado um grande número de sítios arqueológicos ao longo do rio Chapecó, tributário do rio Pelotas. "Piazza estabeleceu duas fases arqueológicas: uma não-Guarani - fase Xaxim -, e outra, com 40 sítios, - fase Mondaí - pertencente à Tradição arqueológica Guarani". Diz ainda que a

ocupação guarani é comprovada através da presença de sítios arqueológicos identificados pelo autor (idem) como da fase Mondaí, principalmente no rio Uruguai e nas barras do rio das Antas e rio Chapecó, quando estes desembocam no rio Uruguai (MONTICELLI, 2001, p. 4-5).

Outros pesquisadores localizaram sítios arqueológicos na região oeste do estado: Lazzarotto encontrou sítios arqueológicos em Palmitos e Itapiranga; Mariland Goulart e sua equipe levantaram mais de uma centena de sítios arqueológicos na bacia do Uruguai e 28 que já haviam sido localizados pelo Pe. Rohr foram revisitados nos municípios de Itapiranga, Mondaí, Palmitos e Caibi.

Diz ainda Monticelli (idem, p. 6) que no

ano de 1998, foi realizada vistoria arqueológica preliminar com o objetivo de prospectar sítios arqueológicos na área a ser afetada pela barragem de Foz de Chapecó (LEVANTAMENTO, 1999). Naquela oportunidade localizamos dez (10) sítios na margem esquerda do Uruguai em municípios de Alpestre e Rio dos Índios. A equipe catarinense, por sua vez, localizou vinte e oito (28) sítios arqueológicos nos municípios de São Carlos, Águas de Chapecó, Caxambu do Sul e Guatambu (grifos nossos).

A pesquisadora da UFSC, Maria Dorothea Post Darella (e equipe) esteve na região de Araça'í em setembro de 1996 e entrevistou um 
colono teuto-brasileiro de nome Rodolfo Salfner que tem uma propriedade rural no município de Cunha Porã no limite do perímetro urbano. Este colono informou Darella que a região era, no passado, habitada pelos Kaingang e Guarani. Disse que seu pai, quando ali chegou, há 70 anos atrás, encontrou aldeias indígenas e a região era coberta por floresta de araucária. Mostrou também à equipe artefatos líticos encontrados em sua propriedade e disse haver grande profusão de cacos de cerâmica e pontas de flecha nas redondezas. Indicou ainda os locais na beira do rio S. Domingos onde achou artefatos líticos, cacos, pontas de flecha; mostrou-Ihe os locais de coleta de argila, onde existia a segunda aldeia e o cemitério. O colono se dispôs a levar a equipe para conhecer Levino Rodrigues que vive e trabalha numa propriedade rural de Cunha Porã, mas a equipe não pode fazer a visita por falta de tempo.

Francisco Silva Noelli, em artigo recente (NOELLI, 1999-2000), apresenta uma tabela dos sítios arqueológicos na região sul onde lista alguns sítios na região oeste de Santa Catarina com localização, fonte e datação. São seis (6) os sítios arqueológicos guarani próximos a Araça'í que reproduzimos abaixo.

Tabela 3. Sítios Arqueológicos no Oeste Catarinense

\begin{tabular}{|l|l|l|l|}
\hline Município & Fonte & Data AP & $\mathbf{N}^{\circ}$ no mapa* \\
\hline Mondaí & Brochado, 1973 & $1.070+$ ou -100 & 18 \\
\hline Itapiranga & Brochado et al, 1969 & $770+$ ou - 100 & 18 \\
\hline São Carlos & Brochado, 1973 & $620+$ ou - 80 & 20 \\
\hline São Carlos & Smithsonian & $510+$ ou - 70 & 20 \\
\hline São Carlos & Brochado, 1973 & $490+$ ou - 70 & 20 \\
\hline São Carlos & Brochado, 1973 & $250+$ ou - 90 & 20 \\
\hline
\end{tabular}

Fonte: Noelli (1999/2000, p. 252)

* Veja Figura 3 neste relatório.

Analisando a tabela de Noelli vemos que o oeste catarinense, nos municípios da região em estudo (a oeste do rio Chapecó) apresenta apenas sítios arqueológicos guarani. As populações kaingang se encontram a leste daquele rio. Além disso, a expansão maciça dos Kaingang pelo oeste catarinense e noroeste gaúcho é um fato que vai 
ocorrer após a guerra guaranítica, quando as missões são destruídas e os Guarani missioneiros são exterminados ou se dispersam pela região. Os dados históricos indicam que, antes dessa época, os Kaingang eram grupos minoritários, formando enclaves em territórios dos grupos hegemônicos tupi-guarani.

De qualquer modo, somando as informações de Monticelli e de Noelli, podemos afirmar que há muitas comprovações arqueológicas da presença guarani nos municípios do oeste catarinense.

No dia 29 de novembro de 2000, na última viagem de campo que fizemos aos Guarani de Araça'í no acampamento de Nonoai, levamos o artigo de Rambo para identificar os personagens citados por Rambo quando ele esteve em Nonoai em 1947 e escreveu sobre os Guarani.

Rambo inicia o artigo falando dos Guarani no Rio Grande do Sul cuja existência é ignorada pela maioria do público e justifica isso em razão de se considerar que os Guarani "desapareceram" das reduções jesuíticas. Sobre os de Passo Feio ele escreveu que "se acham localizadas em Nonoai, há poucas dezenas de anos" (RAMBO, 1947, p. 84). Naquela época, os encontrou vivendo "reunidos num toldo junto ao rio Passo Feio, afluente do Uruguai, a 25 quilômetros de Nonoai e 18 do Posto de Proteção". Descreve a paisagem que encontrou como sendo uma "região selvática bastante cortada. Uma picada, de trânsito precário, permite o acesso até lá, a cavalo" (idem, p. 84).

Quanto à localização do toldo diz que se situava do lado esquerdo do arroio Passo Feio, numa pequena planície, que formava uma "língua de campo com pinheiros ao redor". As elevações circundantes estavam cobertas de mata virgem. O toldo era constituído de cerca de 18 ranchos habitados e dois galpões abertos, espalhados pelo território. Sobre as famílias que encontrou vivendo na aldeia, Rambo nomeou alguns:

- cacique Vera com sua mulher Eva e três filhos homens: Caraí, Tataende, Quarai; uma filha, Eva e um neto pequeno, Caraí.

- "coronel" Oquendá com sua mulher Quereçu, dois filhos: CaraíPotã e Caraí; e uma filha: Potejá.

- "tenente" Cavê (geralmente chamado Sabino) com sua mulher laroquê (Catarina) e dois filhos: Tupaniú e Baracaú.

- Tupaniú (Manoel) com sua mulher Nhorosé e duas filhinhas: Catuê

Espaço Ameríndio, Porto Alegre, v. 7, n. 2, p. 277-556, jul./dez. 2013. 
e Cunhaparaí.

- Eduardo, com sua senhora Eva e um filhinho: Caraí.

- Caraí, com sua mulher Cajierê, e dois filhos: Tendavaiú e Jacaiú, e uma filha, Taquaia.

- Tajú com sua mulher Titi, um filho crescido, Nhenondebaé, e uma filha Nhemonpironé.

- Naan, com sua mulher laiucá, sem filhos.

Rambo contou 33 pessoas, mas disse haver outras famílias que moravam mais longe da aldeia de modo que seriam 40-45 pessoas. Os Guarani "estudaram" o artigo do Padre Rambo e concluíram: "todos eles vieram de Araça'í, são gente nossa!".

Nessa conversa com alguns Guarani que estavam no acampamento, obtivemos os seguintes resultados:

- Reconheceram Cavê/Sabino. Morou no Passo Feio e era "parente" dos Mariano.

- Catarina: era parente do finado Joaquim, pai do Maximino.

- Lembram-se de Eduardo e sua mulher Eva. Moravam no Passo Feio na Al Nonoai.

- "todos eles vieram de Araça'í. Falavam que moravam no Araça'í, era assim que se referiam ao lugar de onde vieram".

- Naam, se chamava Artur Honório e vivia no Araça'í e depois em Passo Feio.

- Essa gente que aparece no livro do Padre Rambo era gente do Araça'í.

- Quem era o cacique era o finado pai de Maximino, o Pedrinho de Morais. O nhanderu era o pai do Artur, que é o João Honório, ambos falecidos.

- O grupo dos pais vieram da Argentina, como escreveu Rambo.

- Quem sabe mais sobre essas pessoas são o Dorico que mora no Mbaracá Miri e Pedrinho Mariano que mora na sede de Nonoai.

- Tataendé ainda é vivo e é conhecido como Lucídio Mariano. Esse dado foi confirmado também por Dorico de Morais.

- Quaraí é o nome de Pedrinho Mariano que ainda é vivo e mora em Nonoai-sede. Cacique Vera seria seu pai.

- Caraí pode ser João Maria que mora em Cacique Doble. 
Outras informações de Padre Rambo sobre como viviam: eram agricultores, plantavam milho, feijão, batata-doce e algodão e suas roças ficavam num vale lateral e "bem cuidadas". Não faziam provisões: só o feijão era colhido em conjunto. Os outros produtos eram colhidos na roça à medida que amadureciam ou deles se precisavam. Não criavam gado, apenas galinhas. As casas eram unifamiliais, "cobertas e tapadas nos lados com palha amarrada entre sarrafos de taquara" e sem janelas, sem assoalho ou compartimentos internos. Preferiam alimentação vegetal como batata-doce, milho verde. Tomavam a bebida ritual à base de milho fermentado chamado cauim.

Rambo (1948, p. 85) diz ainda que os Guarani eram "grandes caçadores, mais do que os caingangues". Usavam o arco e várias espécies de mundéus. Fala da pesca e de outras técnicas dos Guarani como tecelagem, cerâmica e outras. Mas a informação mais importante para o presente laudo é sobre Tradições Históricas que ele assim apresenta:

Os guaranis do Passo Feio são de origem paraguaia. Vieram de lá há uns 60 anos. Ainda hoje mantêm relações com parentes do Paraguai e de Missiones [Argentina]. Estabeleceram-se primeiramente no rio Chapecó, afluente catarinense do Uruguai, distante uns 50 quilômetros do Passo Feio. Vindos de lá, transpuseram o Uruguai faz uns 10 ou 15 anos. Parte do povo ficou no reservado, entre o Chapecó e o Chapecozinho.

Perguntados sobre os motivos dessas migrações, afirmam que "os jesuítas" Ihes disseram que fossem sempre pelo mato até chegar ao Paraguaçu (mar grande). Parece que nisto sobrevive o impulso atávico dos tupis-gruaranis para o Leste (idem, p. 86).

Rambo ainda se refere detalhadamente aos cantos e danças dos Guarani que ele chama de "Boraí". Fala de um moço chamado Nhacã que chefiava a dança. Como se vê, os Guarani nessa época mantinham relações com os parentes do Paraguai e da Argentina e estavam imbuídos da idéia de chegar ao Yvy Marane'y. 


\section{Documentação Fotográfica}

Esta parte tem como objetivo apresentar registros fotográficos sobre as famílias Guarani pertencentes ao Tekohá Araça'í. Inicialmente apresentamos as famílias que estavam acampadas no município de Saudades, dentro da área do referido Tekohá e depois na TI Nonoai quando as famílias foram despejadas.

A pesquisa do GT Araça'í também fotografou as famílias que vivem na TI Nonoai nas aldeias Passo Feio, Mbaraca Mirim e na aldeia Sede. Também visitamos algumas famílias no município de Maravilha as quais deixaram de viver no Tekohá Araça'í por causa das pressões, perseguições e violências, mas permaneceram trabalhando nas colônias dos municípios da região.

Fotografamos também faixas afixadas em vários pontos da cidade e da zona rural de Cunha Porã, confeccionadas e patrocinadas pela Prefeitura e Sindicatos locais.

O GT Araça'í conseguiu fotos antigas de Guarani trabalhando nas colônias nos primórdios da colonização do oeste catarinense. Também conseguimos imagens de um Guarani centenário e sua esposa, fundadores do Tekohá Araça'í e fotografados pela equipe do CIMI-Sul de Chapecó. Quando o GT Araça'í começou seus trabalhos, ambos já eram falecidos.

Por fim, a AER-Chapecó da FUNAI, num trabalho realizado pela equipe local com a comissão de representantes da comunidade de Araça'í, captaram imagens do local onde ficava a segunda aldeia, do local onde se situa o cemitério guarani e do rio Araçazinho, que faz o limite sul da Terra Tradicional Guarani de Araça'í. Seguem fotos ilustrativos das famílias pertencentes à Comunidade de Araça'í. 
KIMIYE TOMMASINO - Relatório de Identificação e Delimitação da Terra Indígena...

\title{
8.1. FAMÍLIAS NOS ACAMPAMENTOS I E II
}

\author{
ACAMPAMENTO (1) - ARAÇA'I - MUNICÍPIO DE SAUDADES I SC
}

Foto 1 - Vista do acampamento de Araça'i.

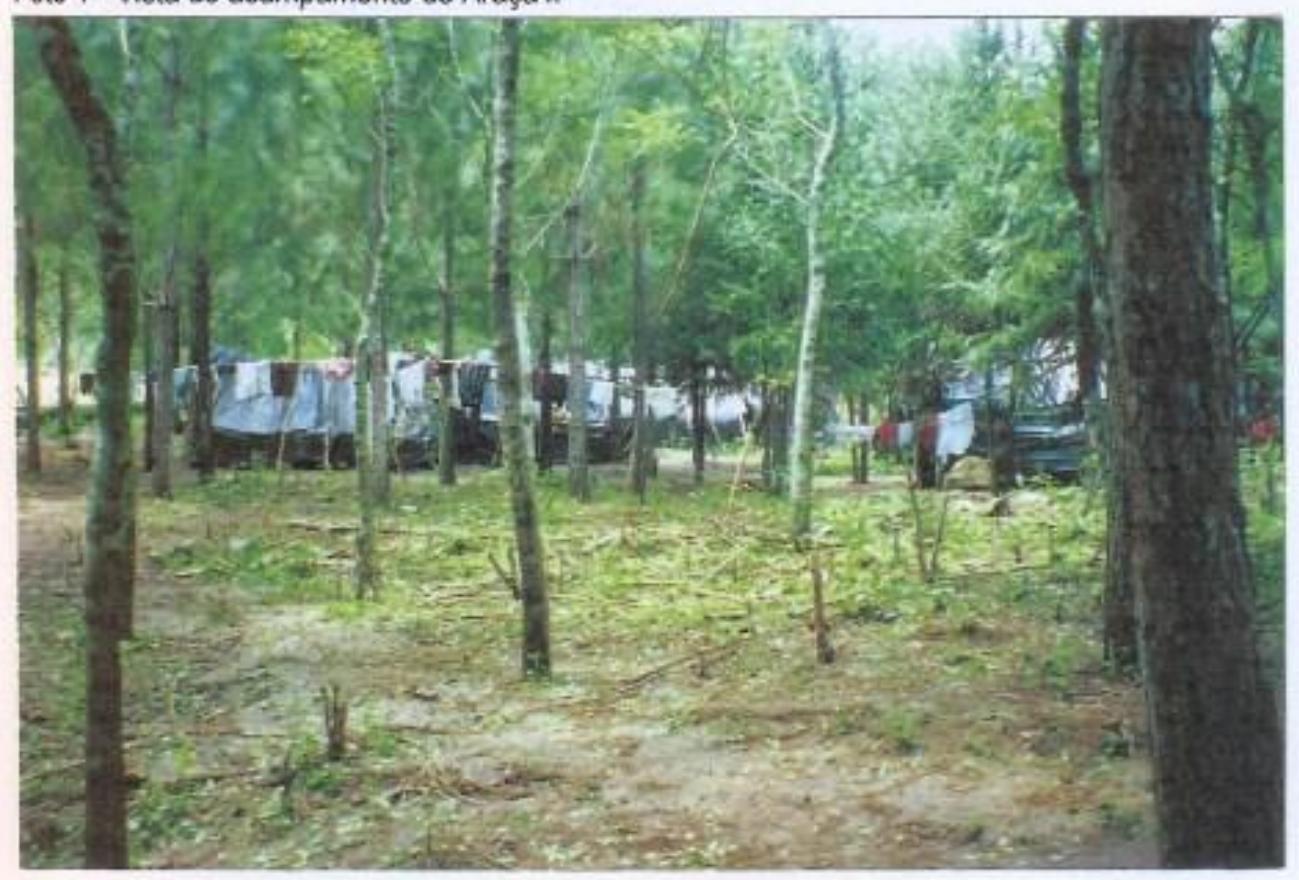

Foto 2 - Vista de uma habitaçã̃o no acampamento (1).

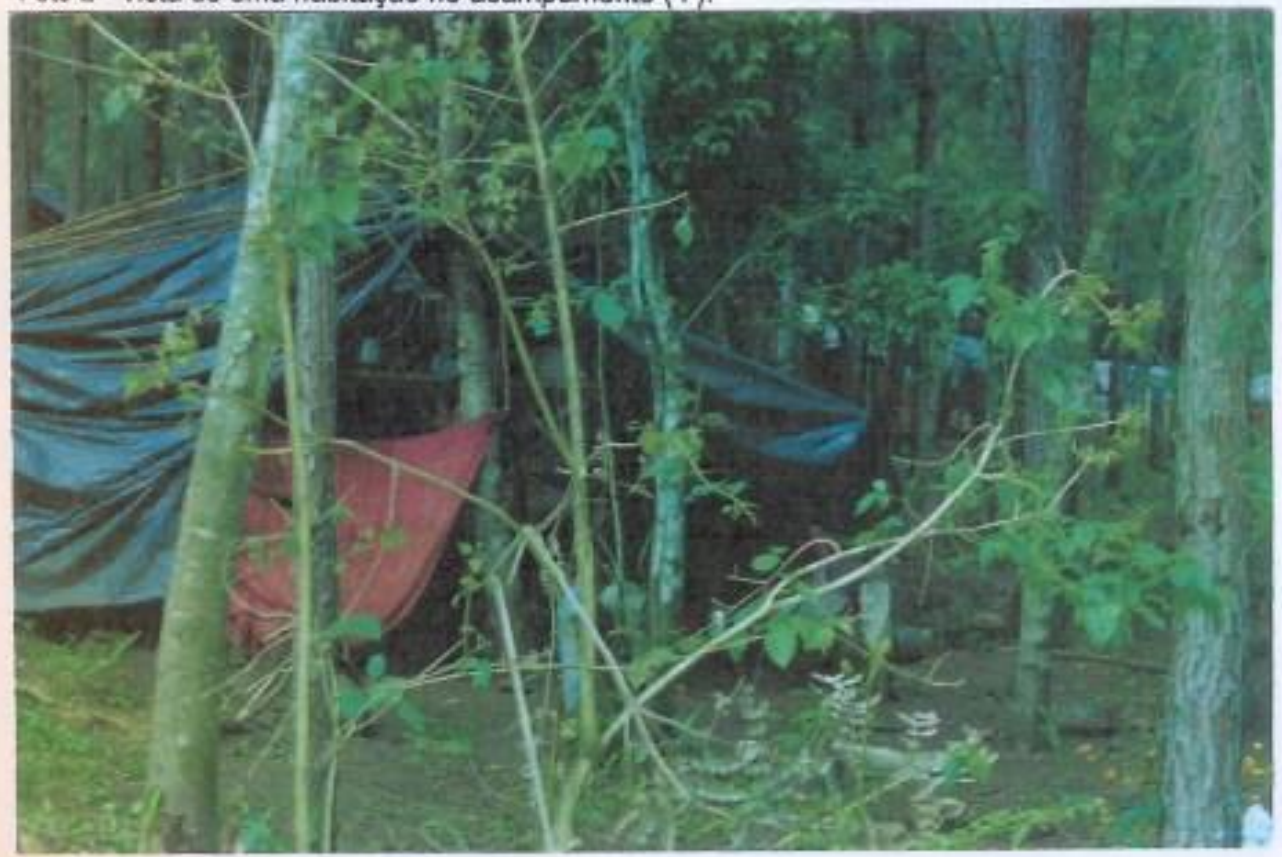

Espaço Ameríndio, Porto Alegre, v. 7, n. 2, p. 277-556, jul./dez. 2013. 
KIMIYE TOMMASINO - Relatório de Identificação e Delimitação da Terra Indígena...

\section{ACAMPAMENTO (I) - ARAÇA'I - MUNICIPIO DE SAUDADES / SC}

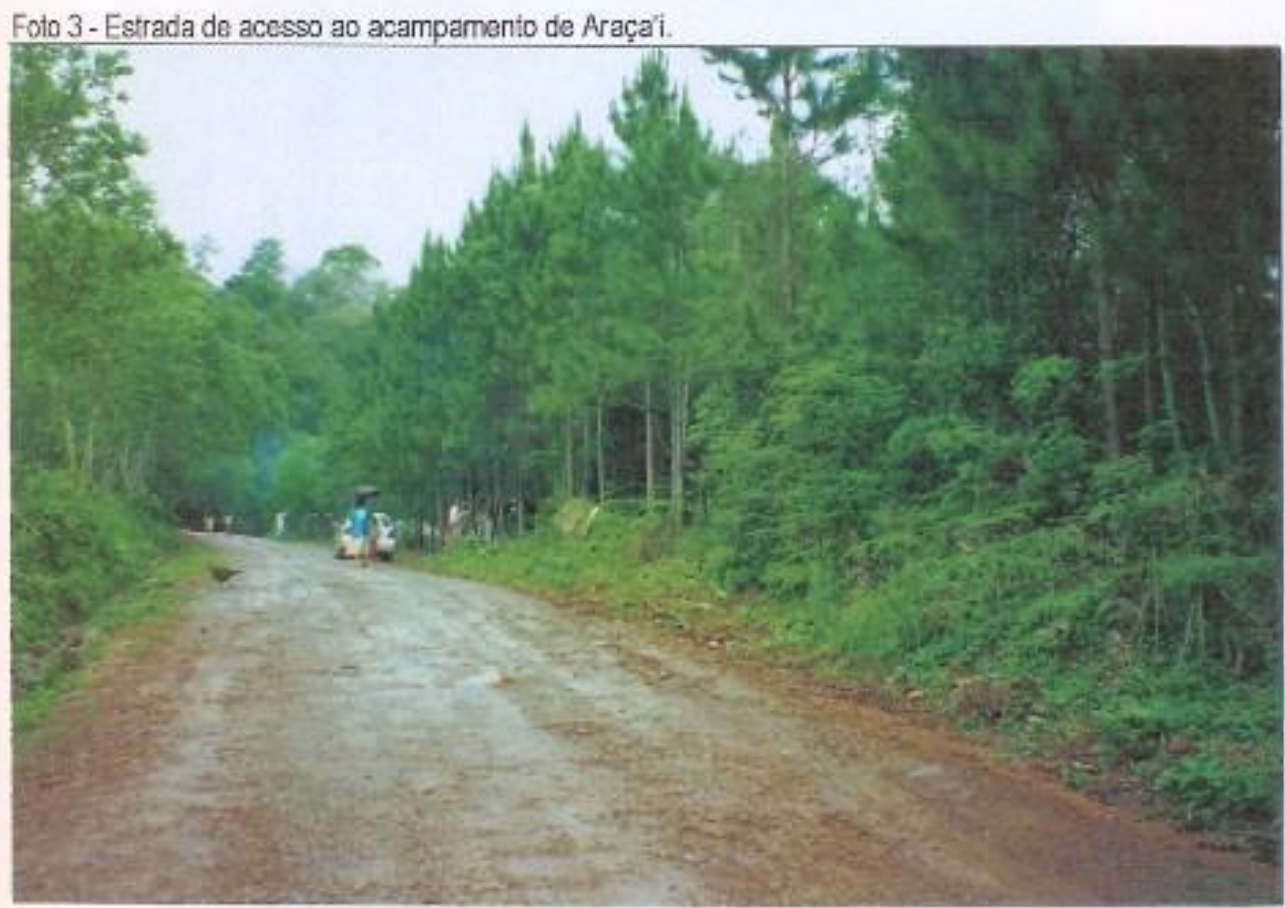

Foto 4- Familias da comunidade de Araça'i.

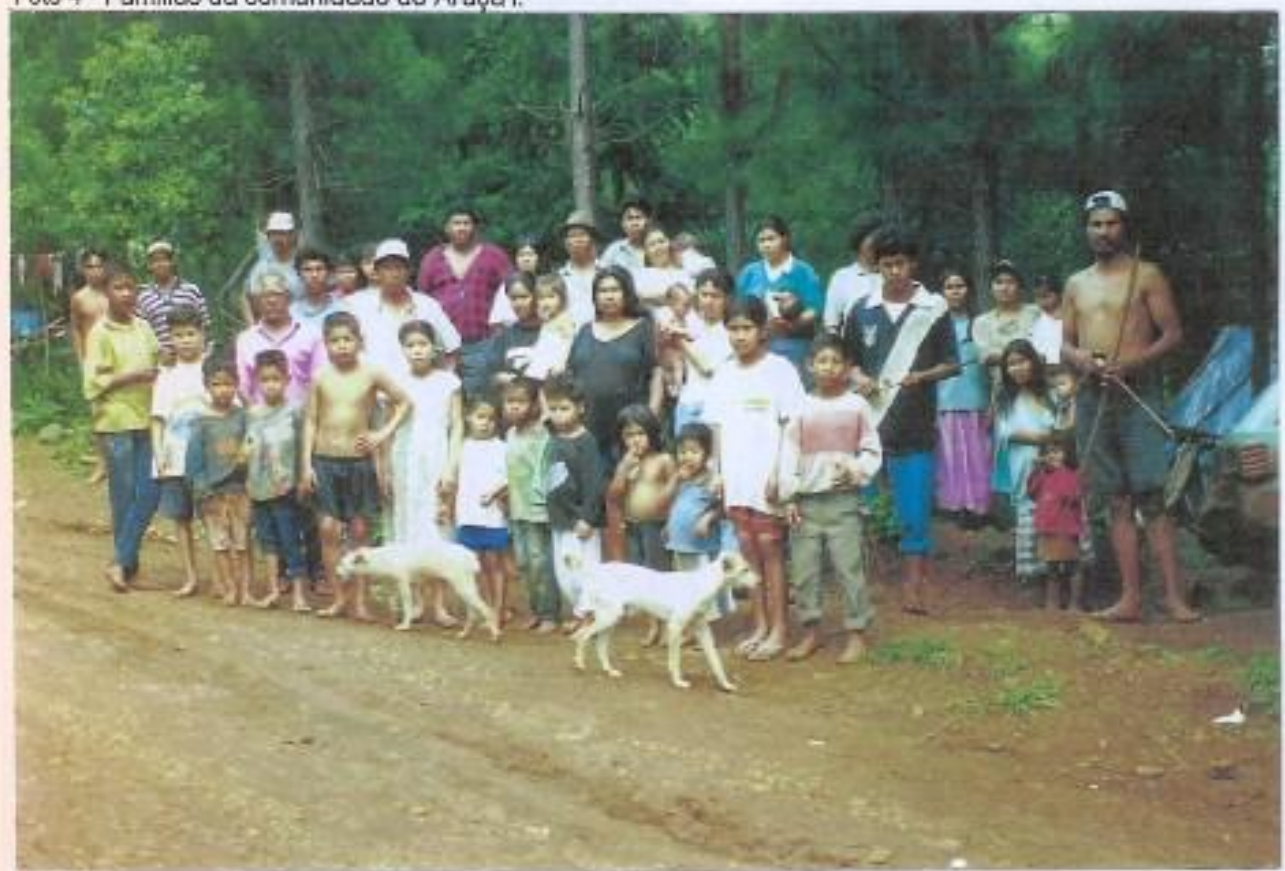

Espaço Ameríndio, Porto Alegre, v. 7, n. 2, p. 277-556, jul./dez. 2013. 
KIMIYE TOMMASINO - Relatório de Identificação e Delimitação da Terra Indígena...

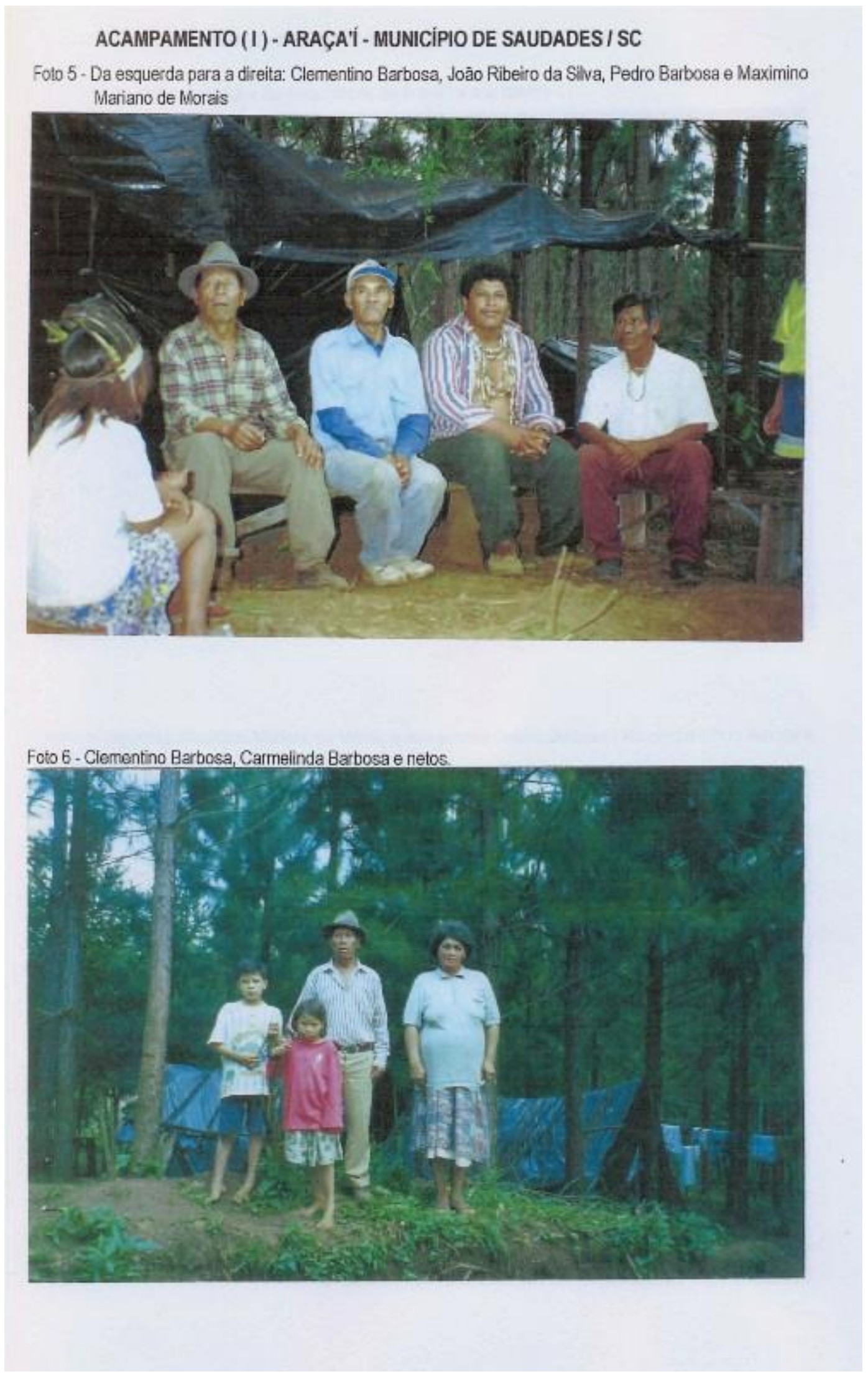

Espaço Ameríndio, Porto Alegre, v. 7, n. 2, p. 277-556, jul./dez. 2013. 
KIMIYE TOMMASINO - Relatório de Identificação e Delimitação da Terra Indígena...

ACAMPAMENTO (l) - ARAÇA'I - MUNICIPIO DE SAUDADES I SC

Foto 7 - Pedro Barbosa, cacique da comunidade de Araça'i e sua familia.

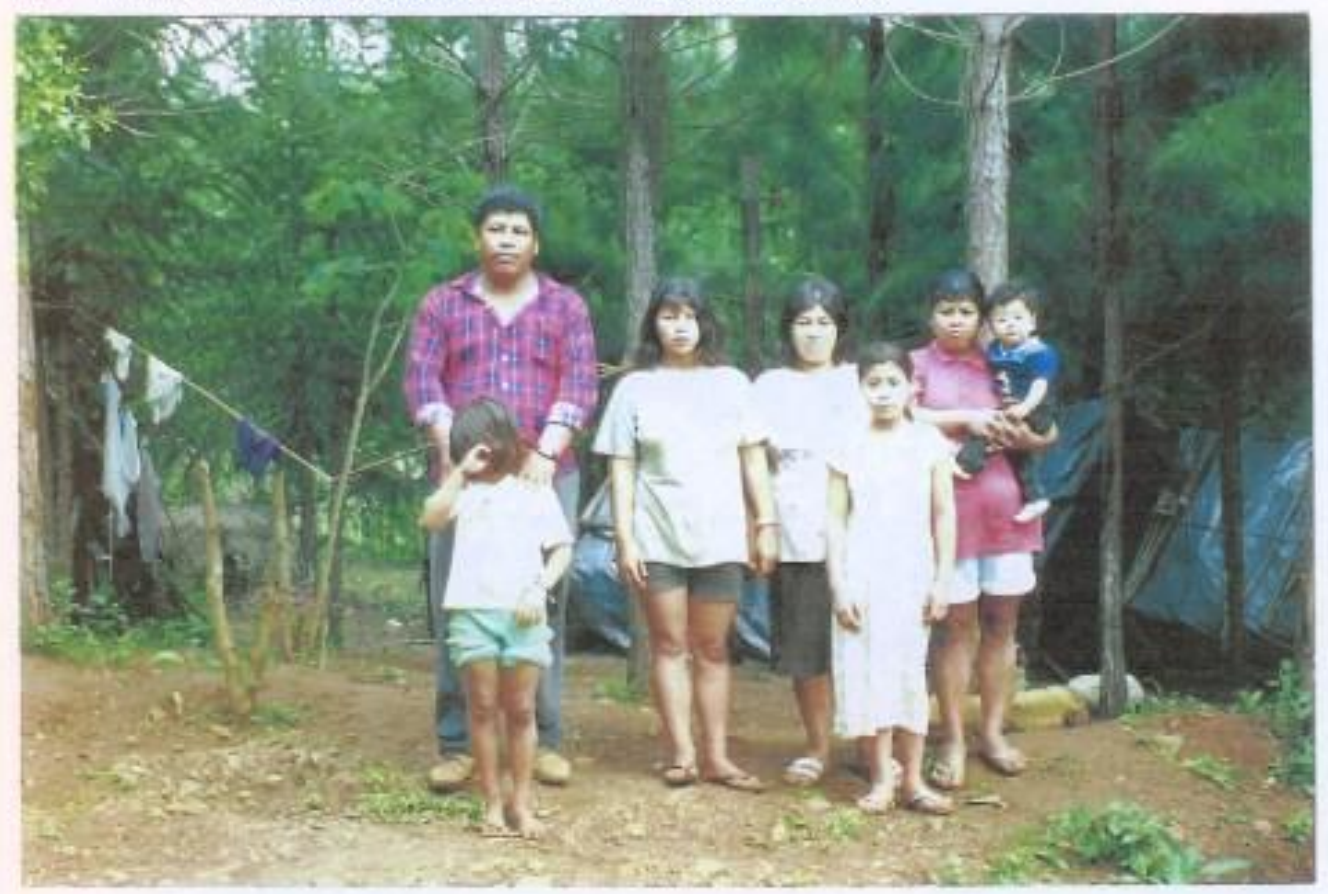

Foto 8- A esquerda, Maximino Mariano de Morais e sua esposa Cecilia Barbosa. No centro o filho Maroos e o neto.

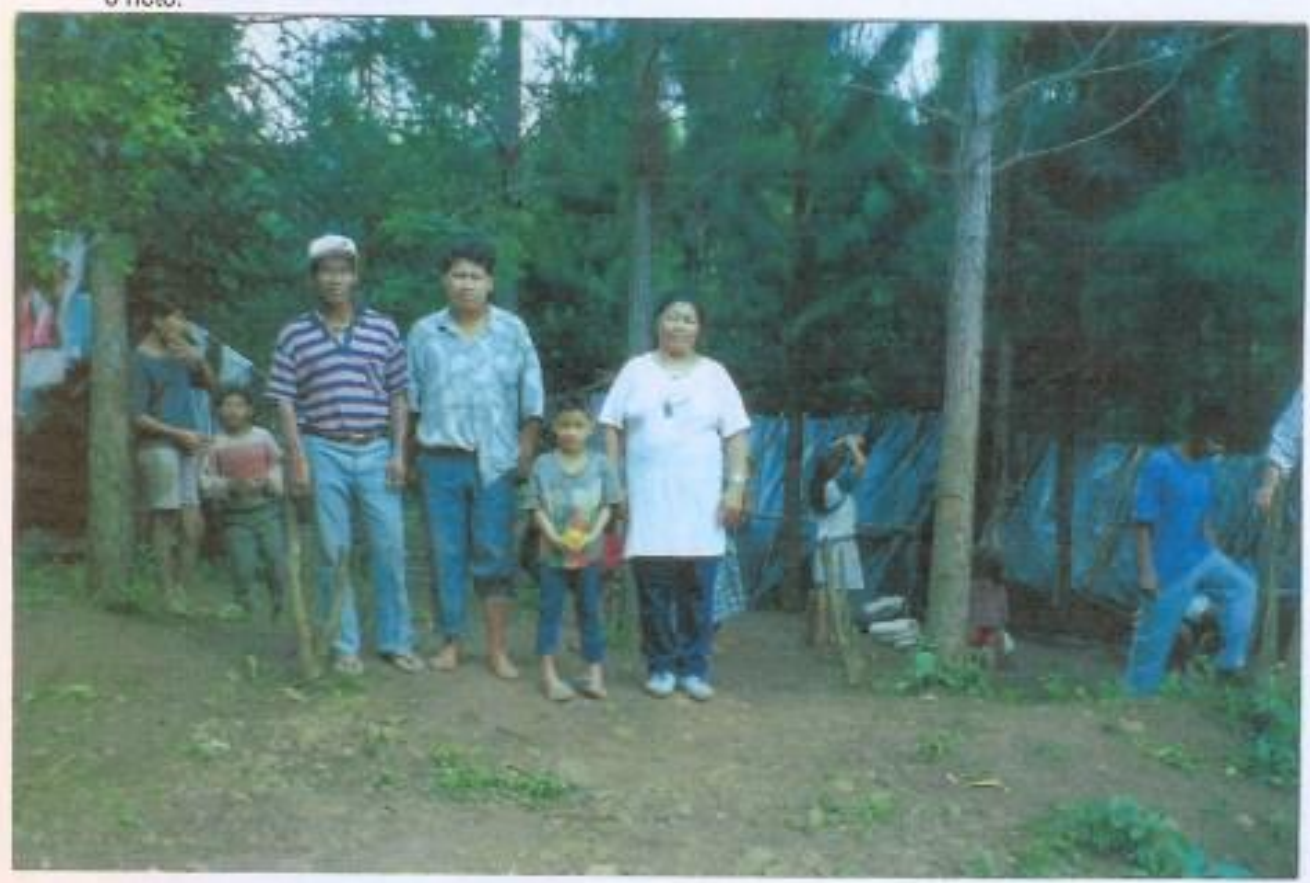

Espaço Ameríndio, Porto Alegre, v. 7, n. 2, p. 277-556, jul./dez. 2013. 
KIMIYE TOMMASINO - Relatório de Identificação e Delimitação da Terra Indígena...

\section{ACAMPAMENTO (1) - ARAÇA'I - MUNICIPIO DE SAUDADES / SC}

Foto 9 - Trés gerações da familia Barbosa.

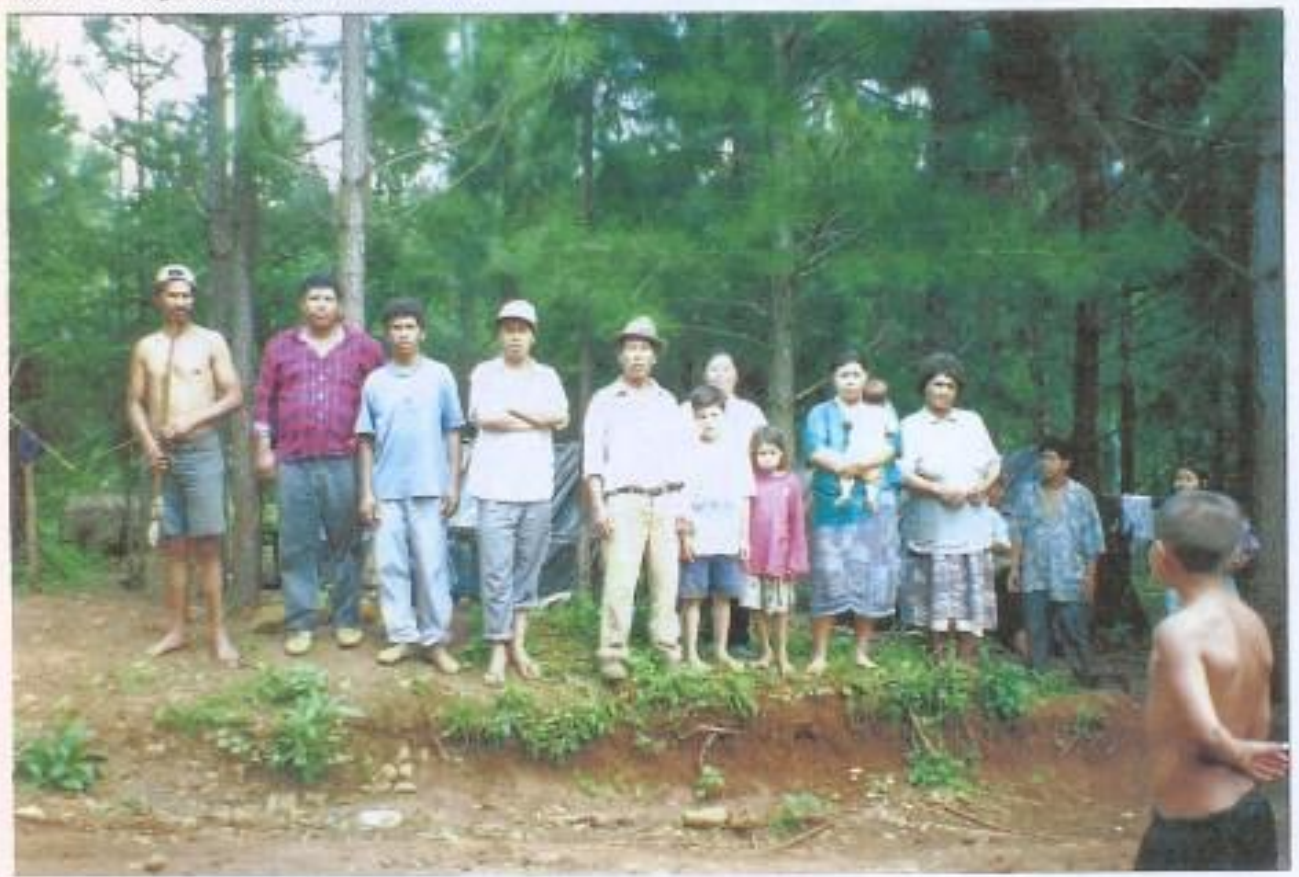

Foto 10 - Da esquerda para a direita: Marlene Rodrigues e filha, Osmar Rodrigues, Ana Maria Rodrigues, Marli Rodrigues, Nelinho Rodrigues e filho.

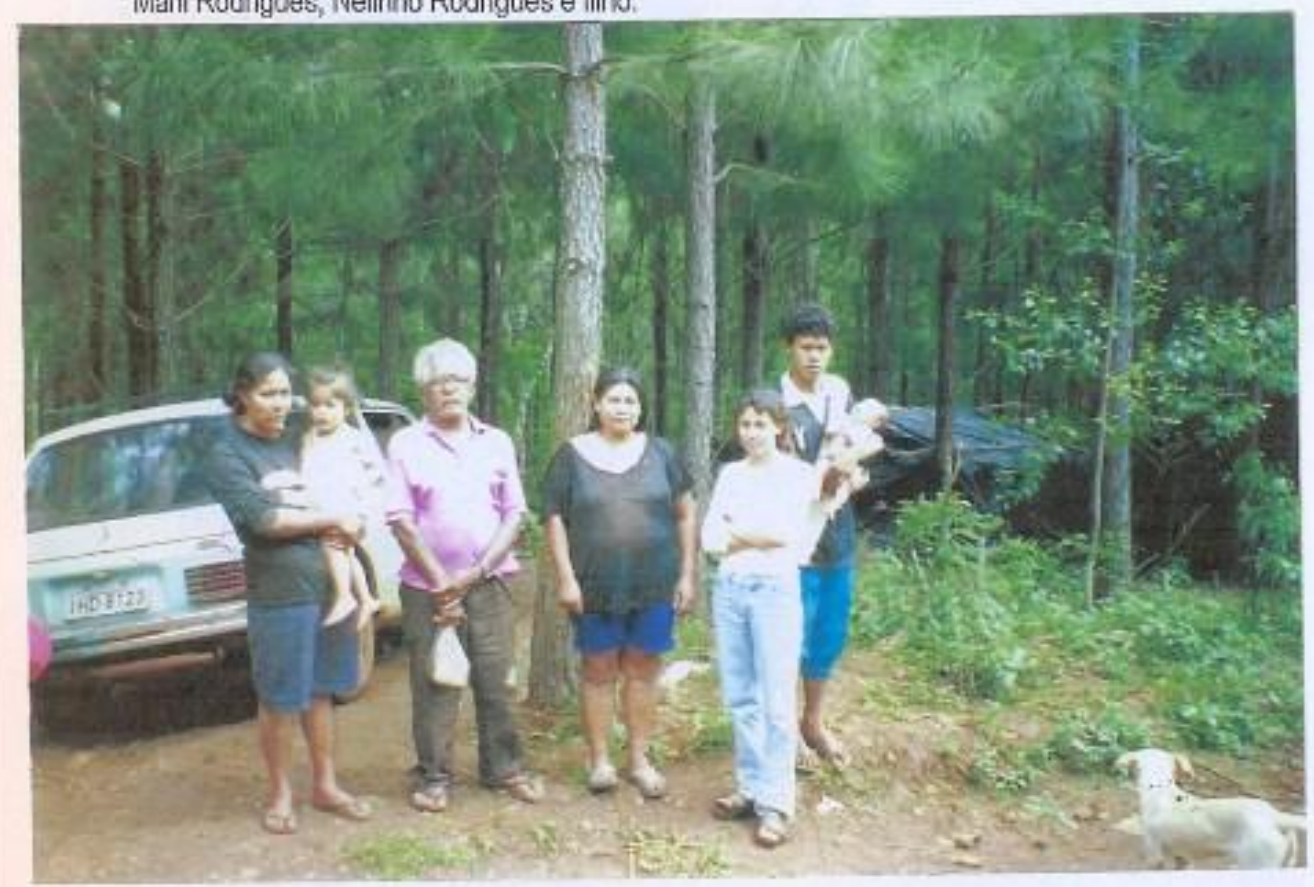

Espaço Ameríndio, Porto Alegre, v. 7, n. 2, p. 277-556, jul./dez. 2013. 
KIMIYE TOMMASINO - Relatório de Identificação e Delimitação da Terra Indígena...

ACAMPAMENTO (I) - ARACCA'I - MUNICIPIO DE SAUDADES I SC

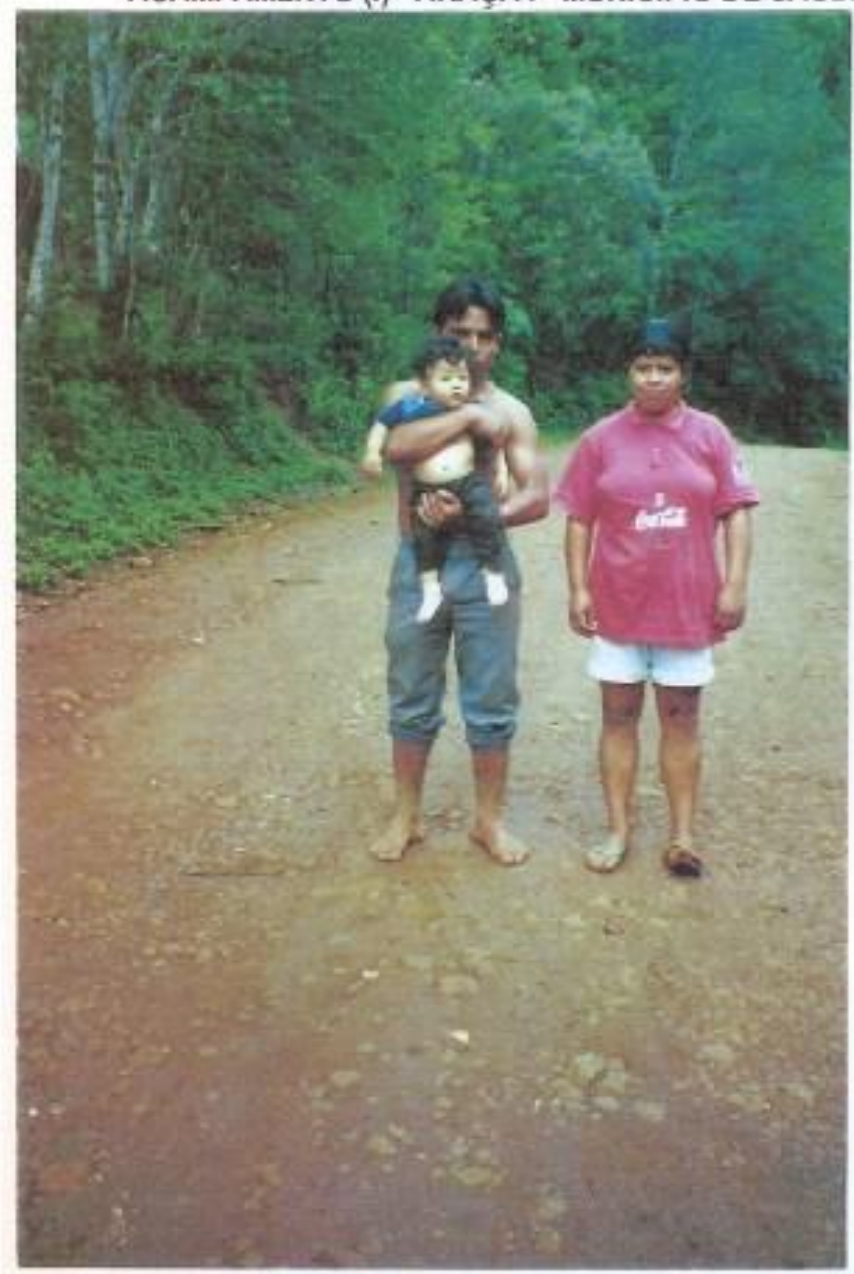

Folo 11 -Valmir Siqueira,

Dilvània e o sobrinho.

Foto 12 - Marcos Mariano de Morais, sua esposa Cila 6 seus filhos.

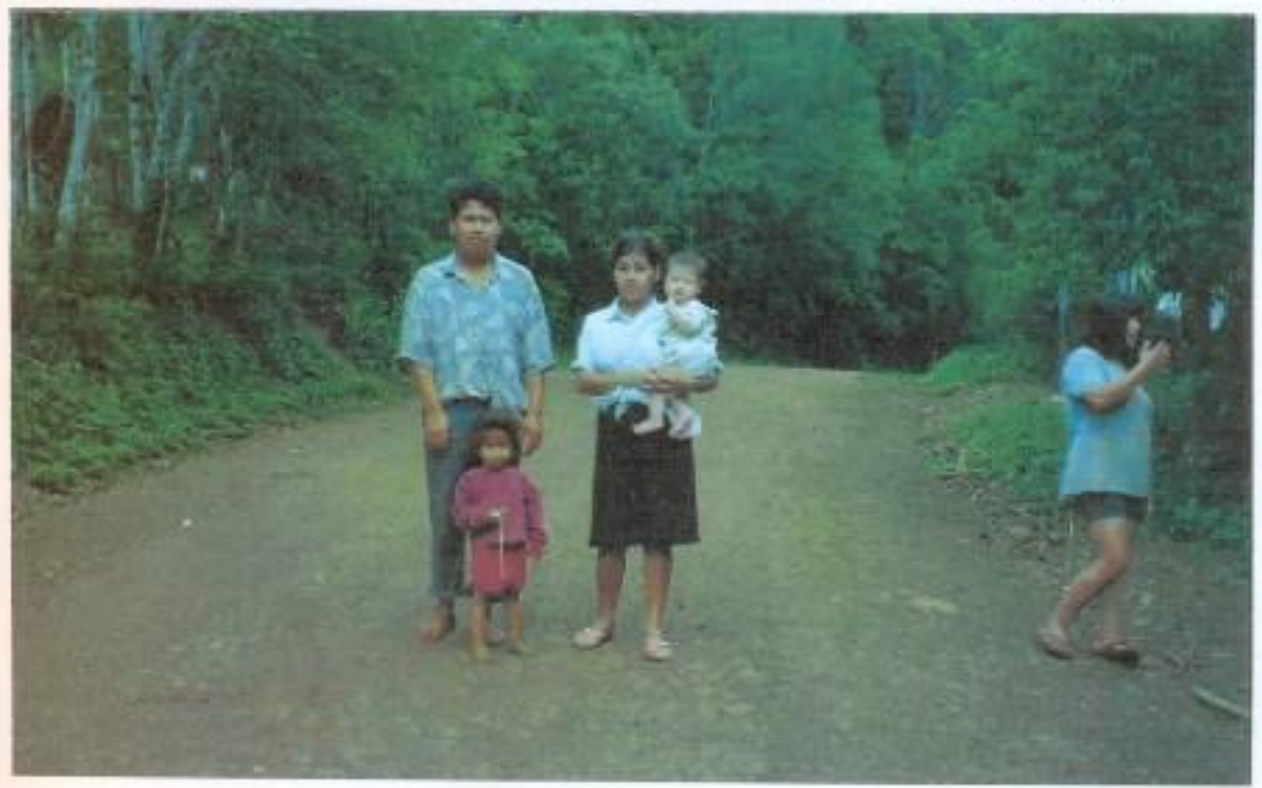

Espaço Ameríndio, Porto Alegre, v. 7, n. 2, p. 277-556, jul./dez. 2013. 
KIMIYE TOMMASINO - Relatório de Identificação e Delimitação da Terra Indígena...

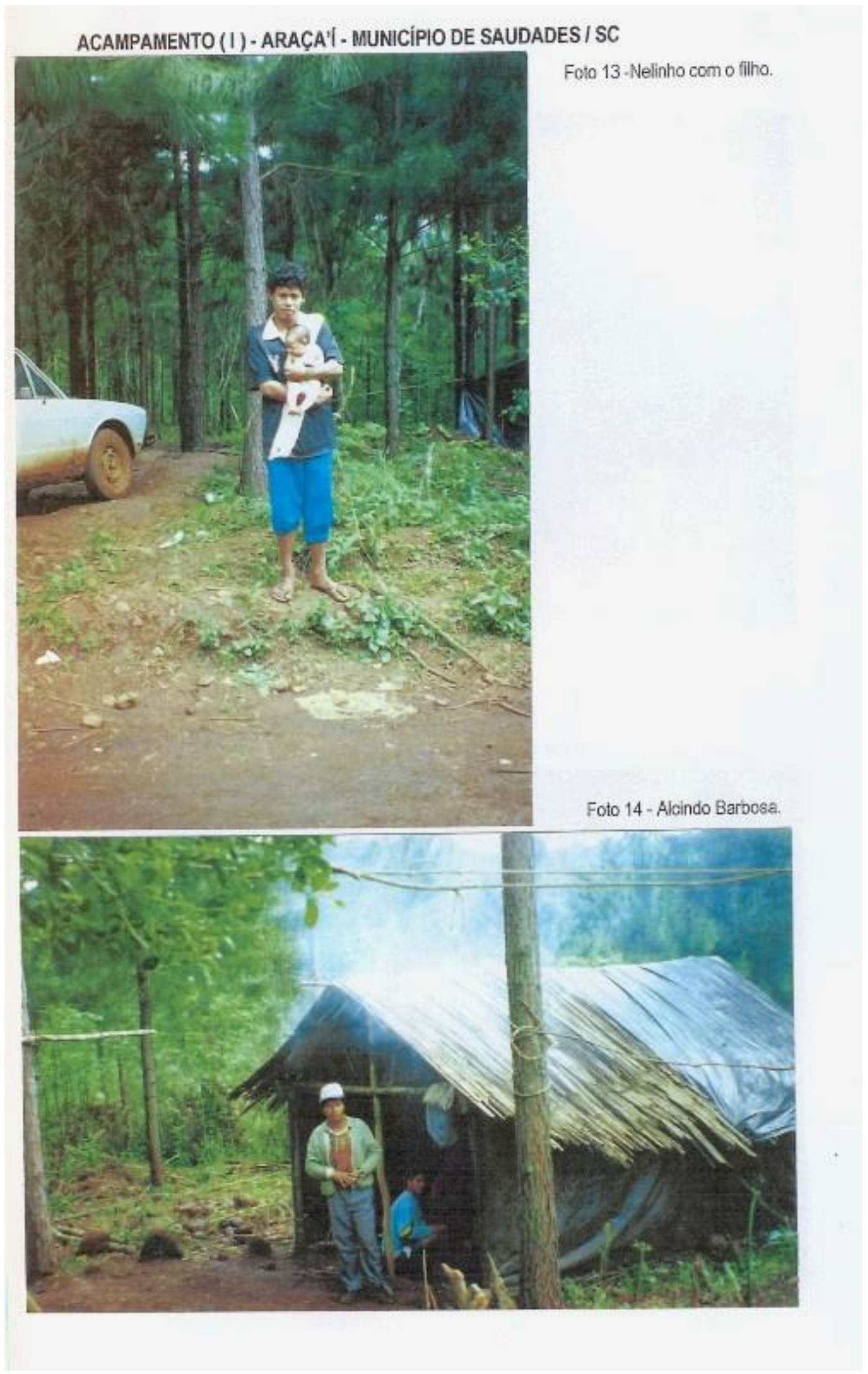

Espaço Ameríndio, Porto Alegre, v. 7, n. 2, p. 277-556, jul./dez. 2013. 
KIMIYE TOMMASINO - Relatório de Identificação e Delimitação da Terra Indígena...

\section{ACAMPAMENTO (I) - ARAÇA'I - MUNICÍPIO DE SAUDADES I SC}

Foto 15 - Luis Barbosa e familia.

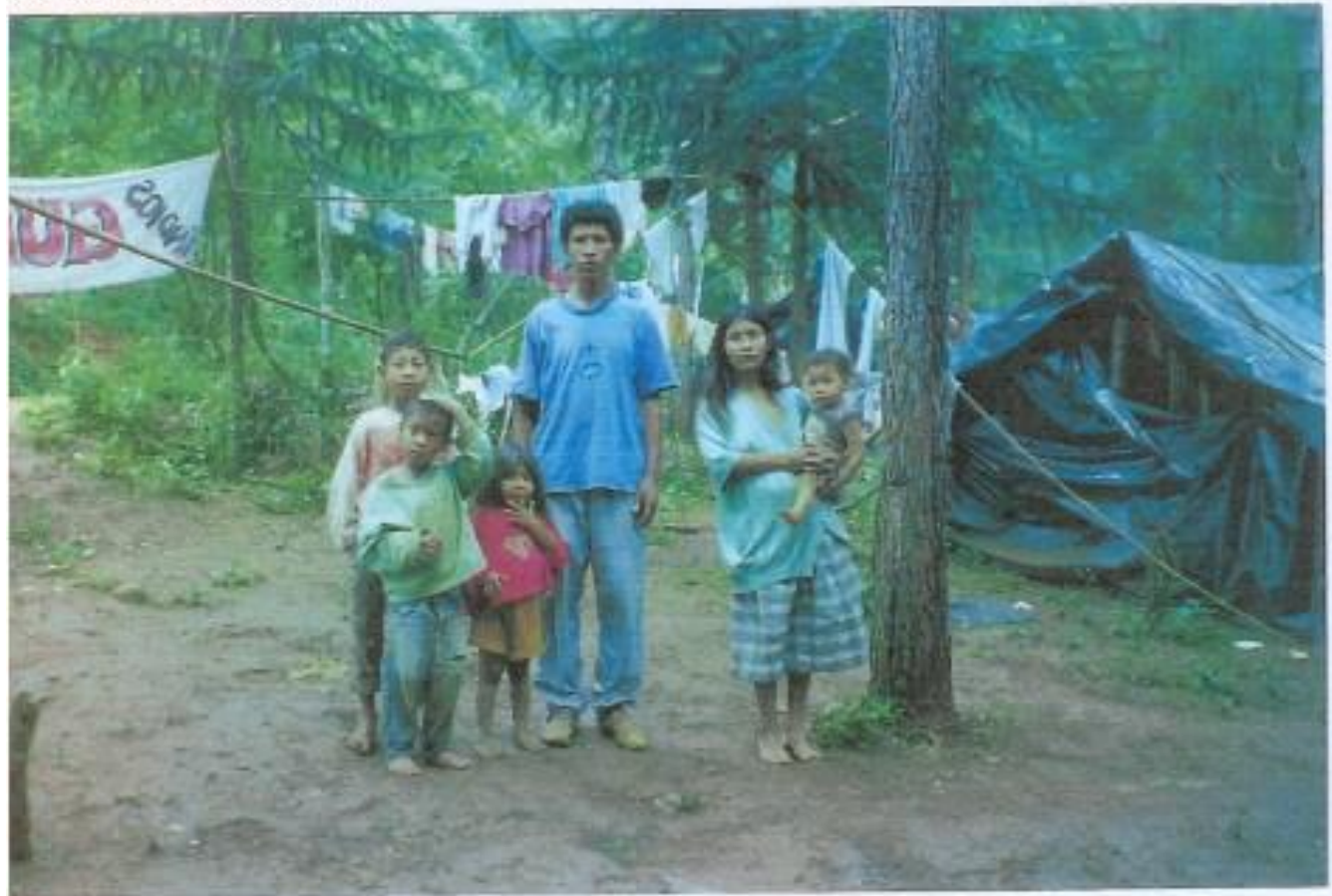

Foto 16 - No centro, o casal Alcindo Barbosa e Marlene Rodrigues com sua filha.

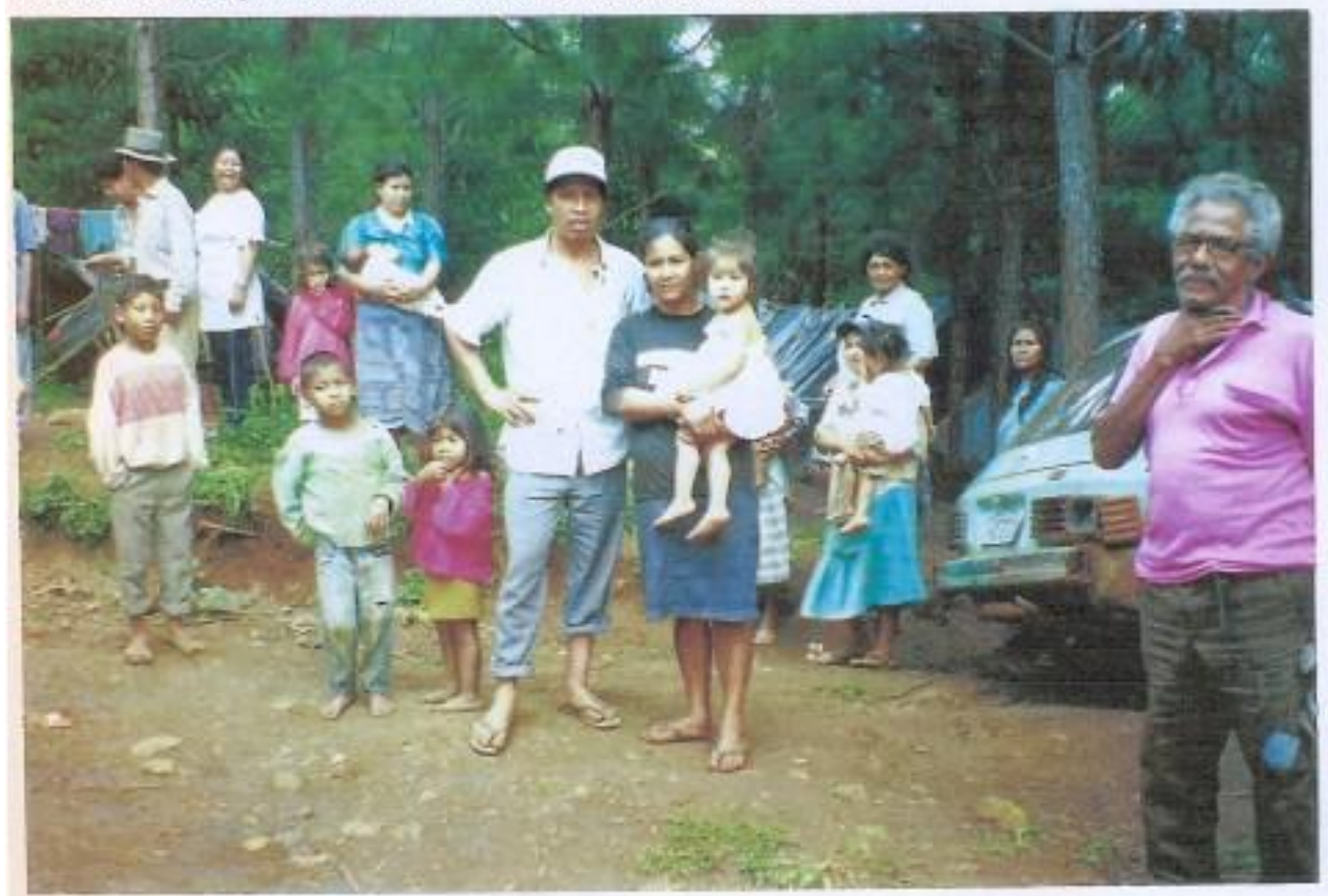

Espaço Ameríndio, Porto Alegre, v. 7, n. 2, p. 277-556, jul./dez. 2013. 
KIMIYE TOMMASINO - Relatório de Identificação e Delimitação da Terra Indígena...

\author{
ACAMPAMENTO (1) - ARAÇA'I - MUNICIPIO DE SAUDADES I SC
}

Foto 17 - Vista da mata em Aracail onde os Guarani fizeram o acampamento.

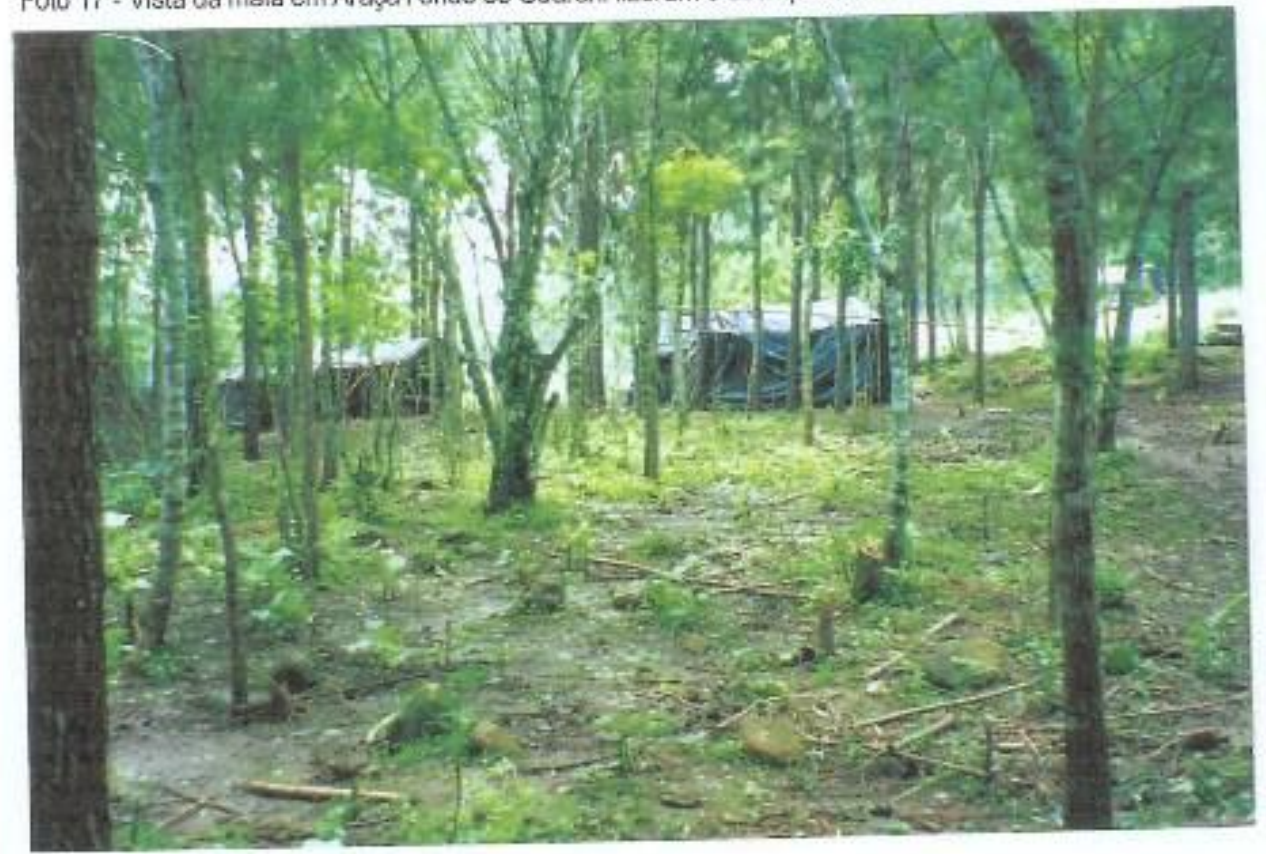

Foto 18 - "Esqueleto" da escola, destruido antes de sua conclusăo.

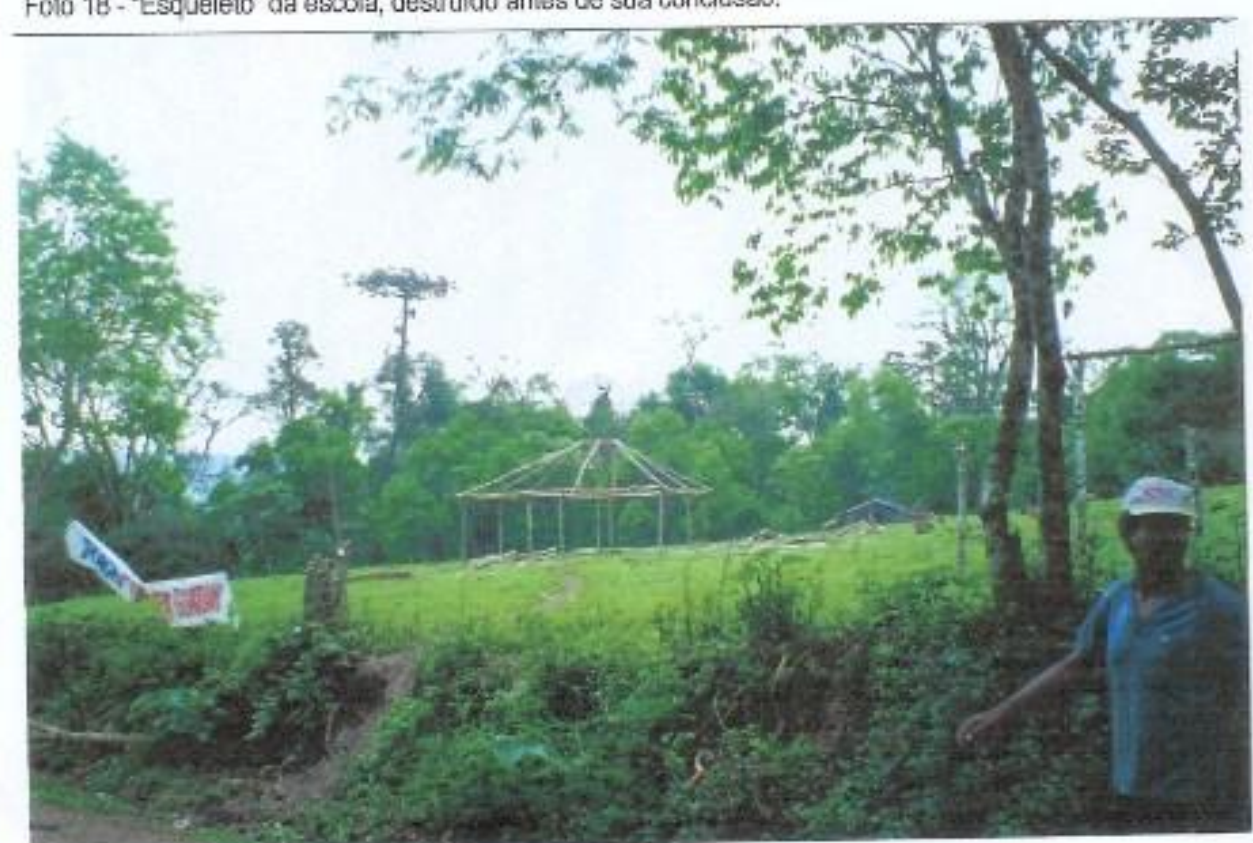

Espaço Ameríndio, Porto Alegre, v. 7, n. 2, p. 277-556, jul./dez. 2013. 
KIMIYE TOMMASINO - Relatório de Identificação e Delimitação da Terra Indígena...

\section{ACAMPAMENTO (II) - TI NONOAI / RS}

Folo 19 - O segundo acampamento na TI Nonoai / RS.

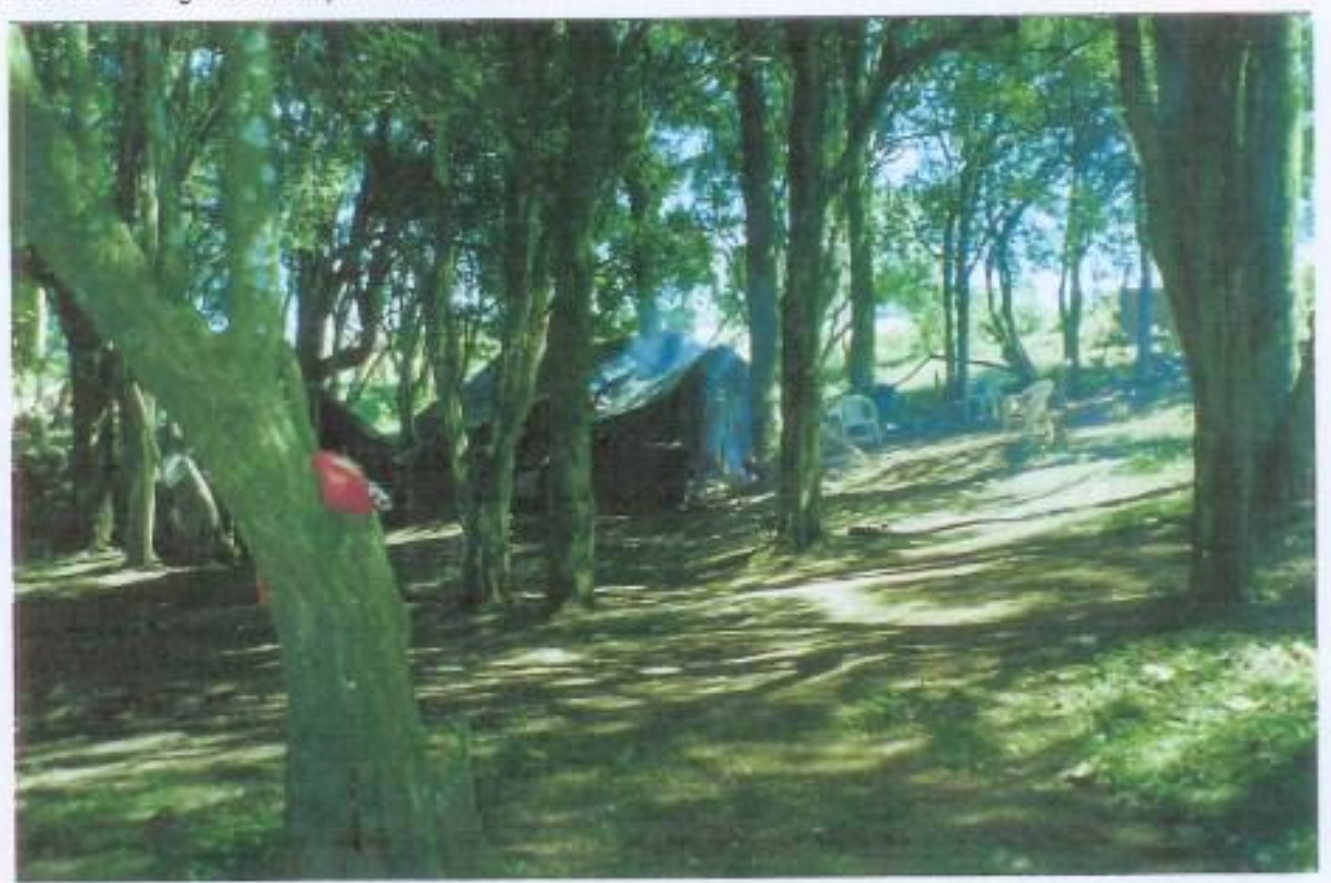

Foto 20 - Imagem do novo acampamento, perto da Addeia Sede / Nonoai.

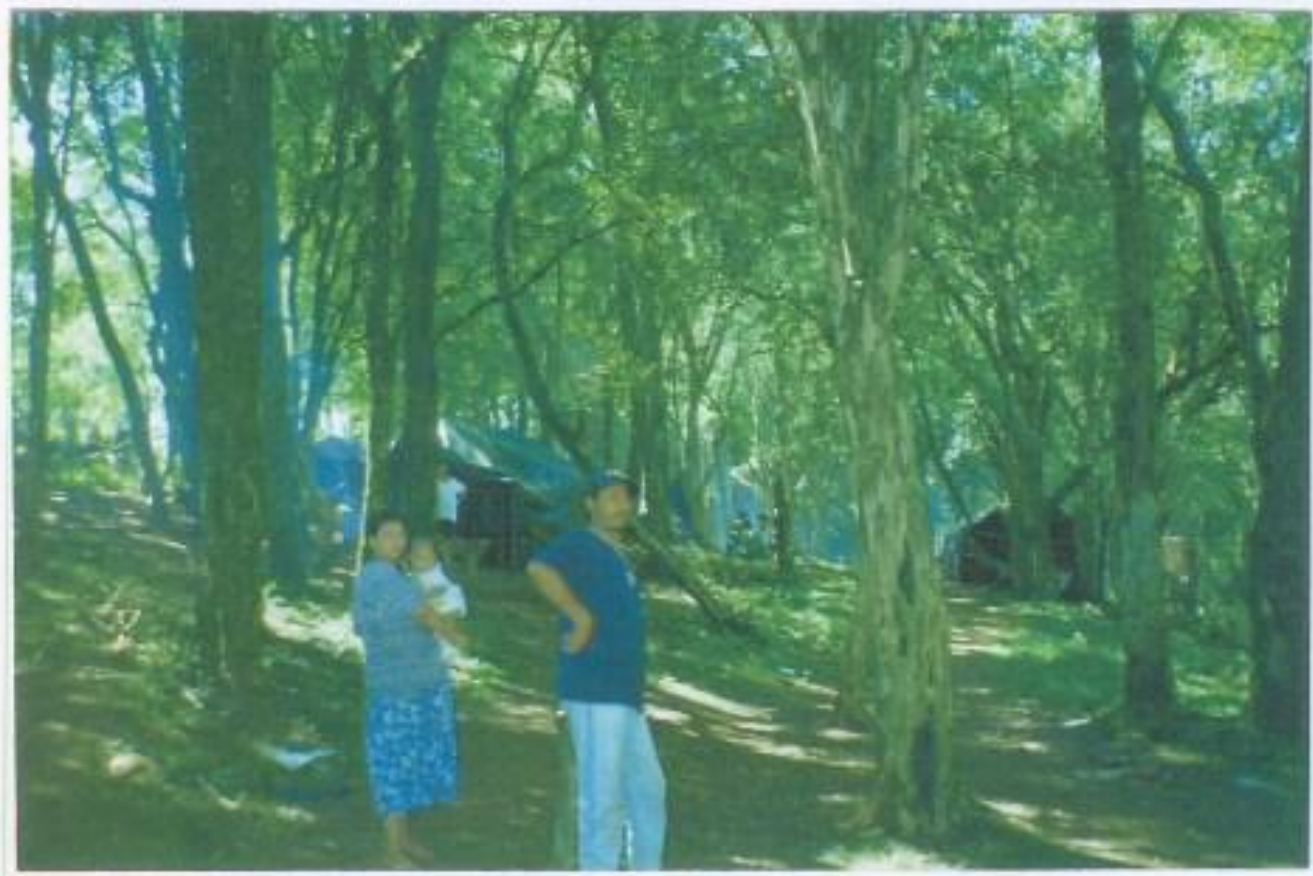

Espaço Ameríndio, Porto Alegre, v. 7, n. 2, p. 277-556, jul./dez. 2013. 
KIMIYE TOMMASINO - Relatório de Identificação e Delimitação da Terra Indígena...

\section{ACAMPAMENTO (II) - TI NONOAI I RS}

Foto 21 - Visła geral do local do acampamento (II) Guarani em Nonoai / RS (Acervo FUNAiAER/ChapecolsC - 20/11/2000).

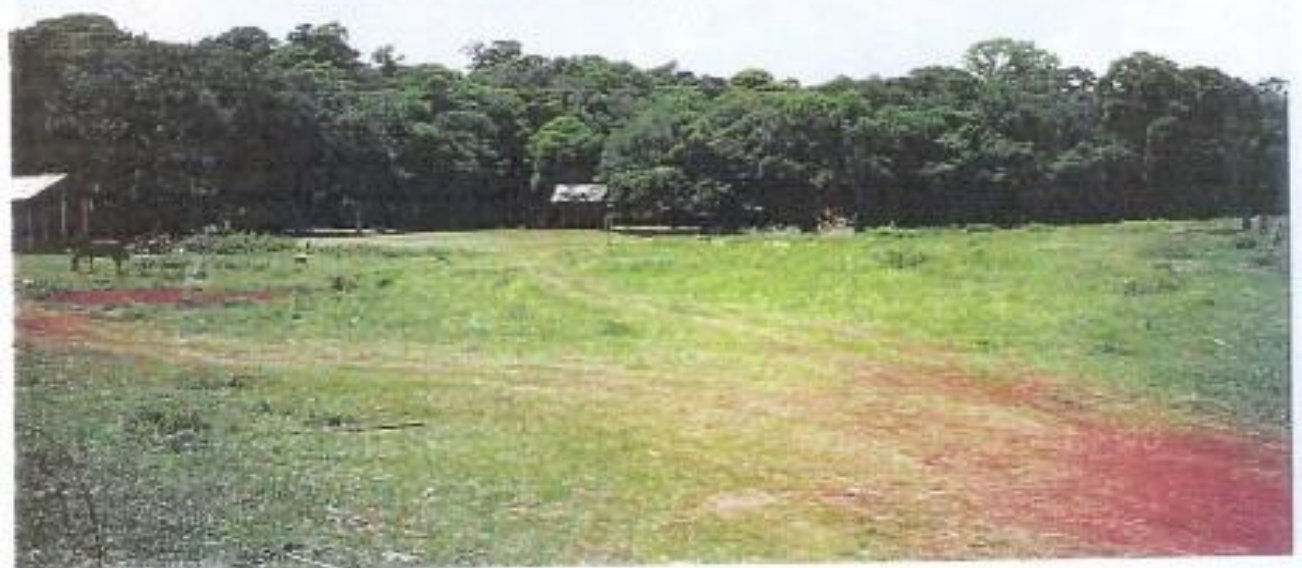

Folo 22 - Barracos do acampamento (II) em Nonoai / RS (Acervo FUNAI-AERJChapeca/SC - 20/11/2000),

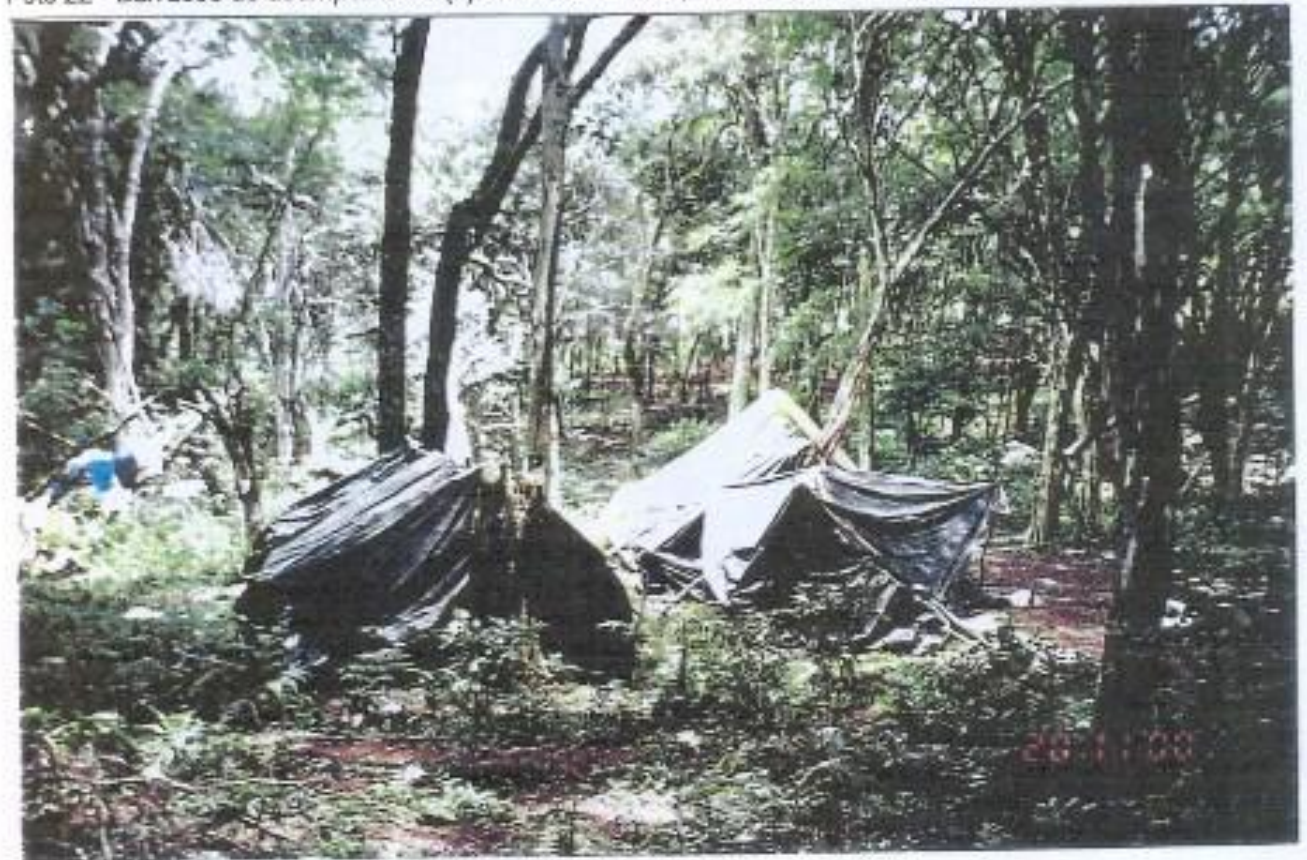

Espaço Ameríndio, Porto Alegre, v. 7, n. 2, p. 277-556, jul./dez. 2013. 
KIMIYE TOMMASINO - Relatório de Identificação e Delimitação da Terra Indígena...

\section{ACAMPAMENTO (II) - TI NONOAI I RS}

Fơo 23 - Pedro Barbosa Djeguaká Mïrim (sentado e usando calça preta), cacique do povo Guarani (Acervo FUNAI-AERIChapacolSC - 20/11/2000).

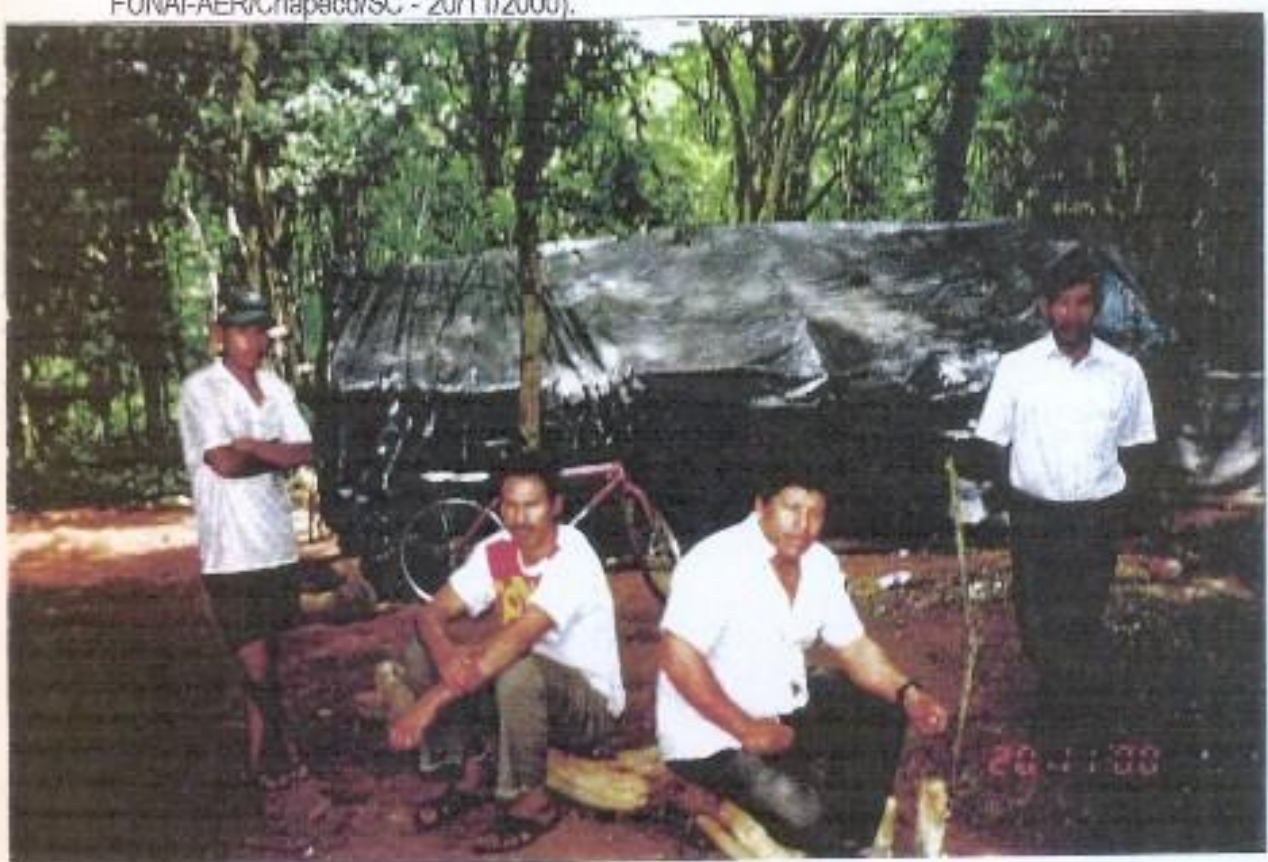

Foto 24 - Vista dos Guarani no acampamento (II) Nonoai / RS (Acervo FUNAI-AER/Chapecó/SC -

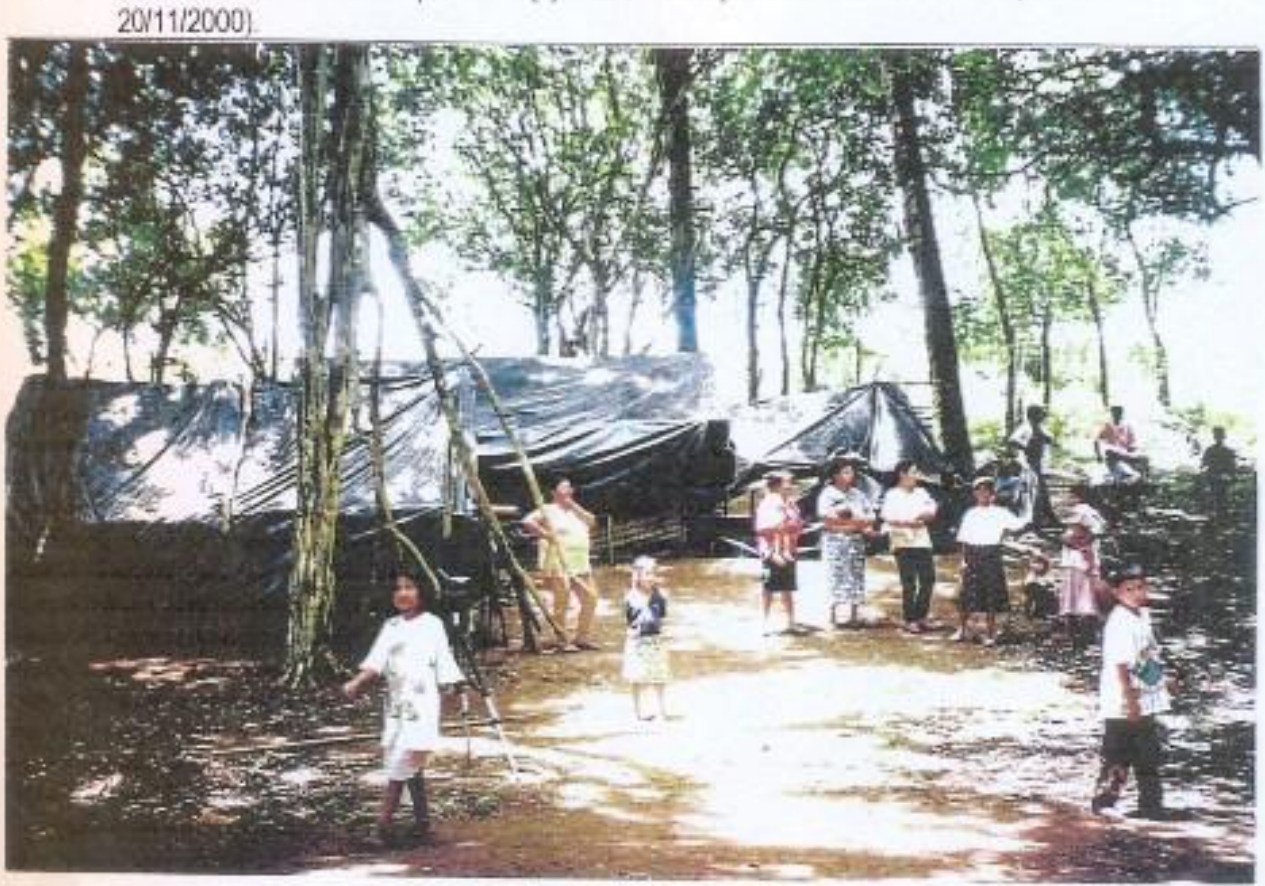

Espaço Ameríndio, Porto Alegre, v. 7, n. 2, p. 277-556, jul./dez. 2013. 
KIMIYE TOMMASINO - Relatório de Identificação e Delimitação da Terra Indígena...

\title{
8.2. FAMÍLIAS QUE VIVEM NA TERRA INDÍGENA NONOAI
}

\author{
OS GUARANI NA ALDEIA PASSO FEIO - TI NONOAI/RS
}

Foto 25 - Waidemar Morais, sua esposa Lourdes de Paula e filhos.

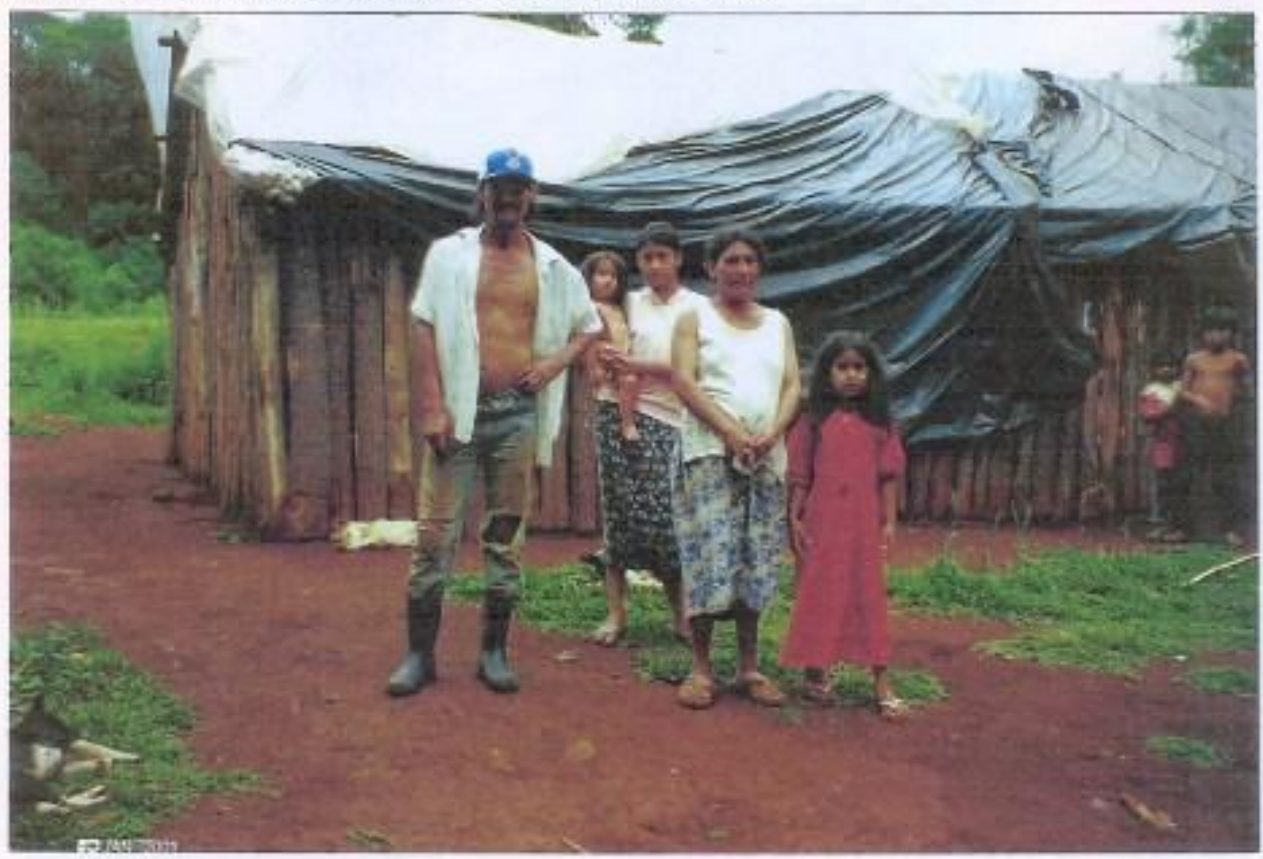

Foto 26 - As imås Kaingang Lourdes de Paula e Loreni de Paula com seus filhos.

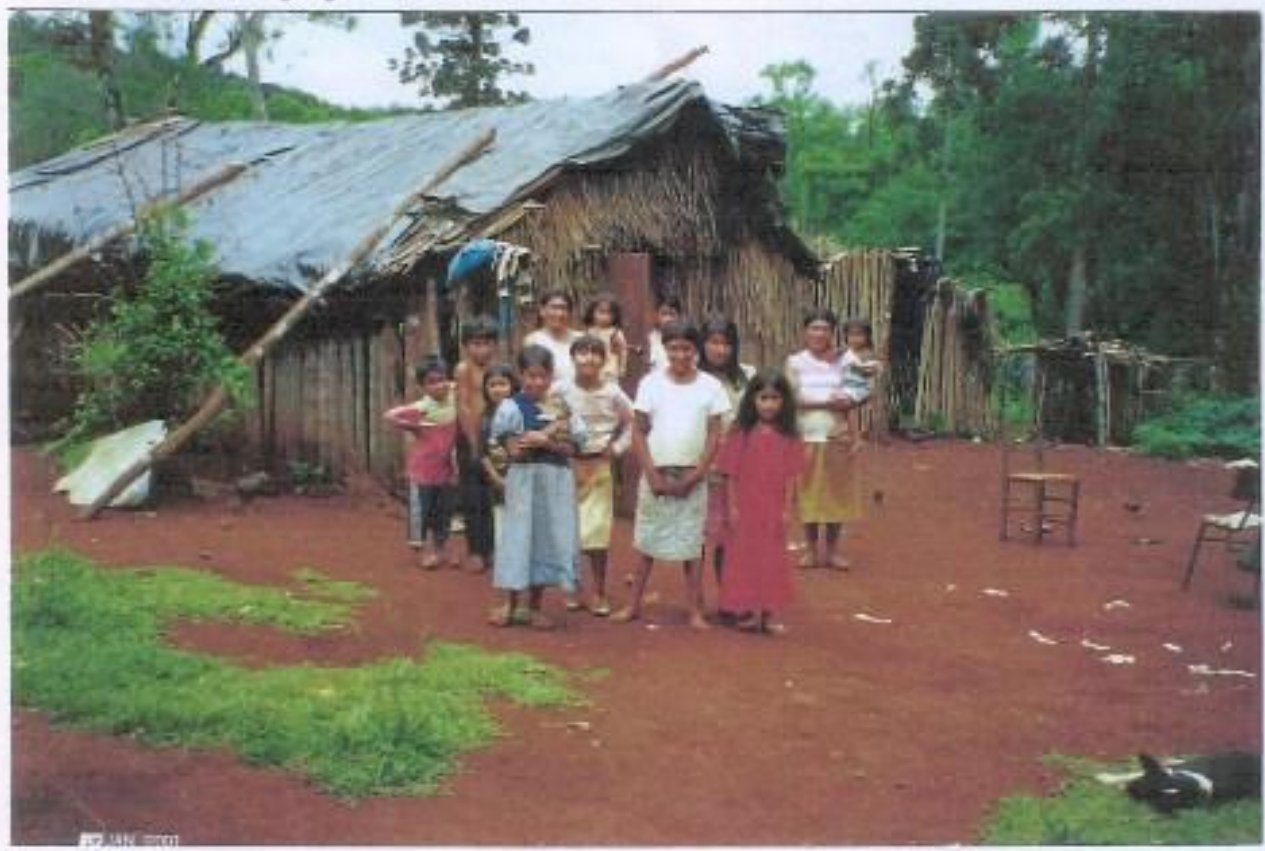

Espaço Ameríndio, Porto Alegre, v. 7, n. 2, p. 277-556, jul./dez. 2013. 
KIMIYE TOMMASINO - Relatório de Identificação e Delimitação da Terra Indígena...

\section{OS GUARANI NA ALDEIA PASSO FEIO - TI NONOAI / RS}

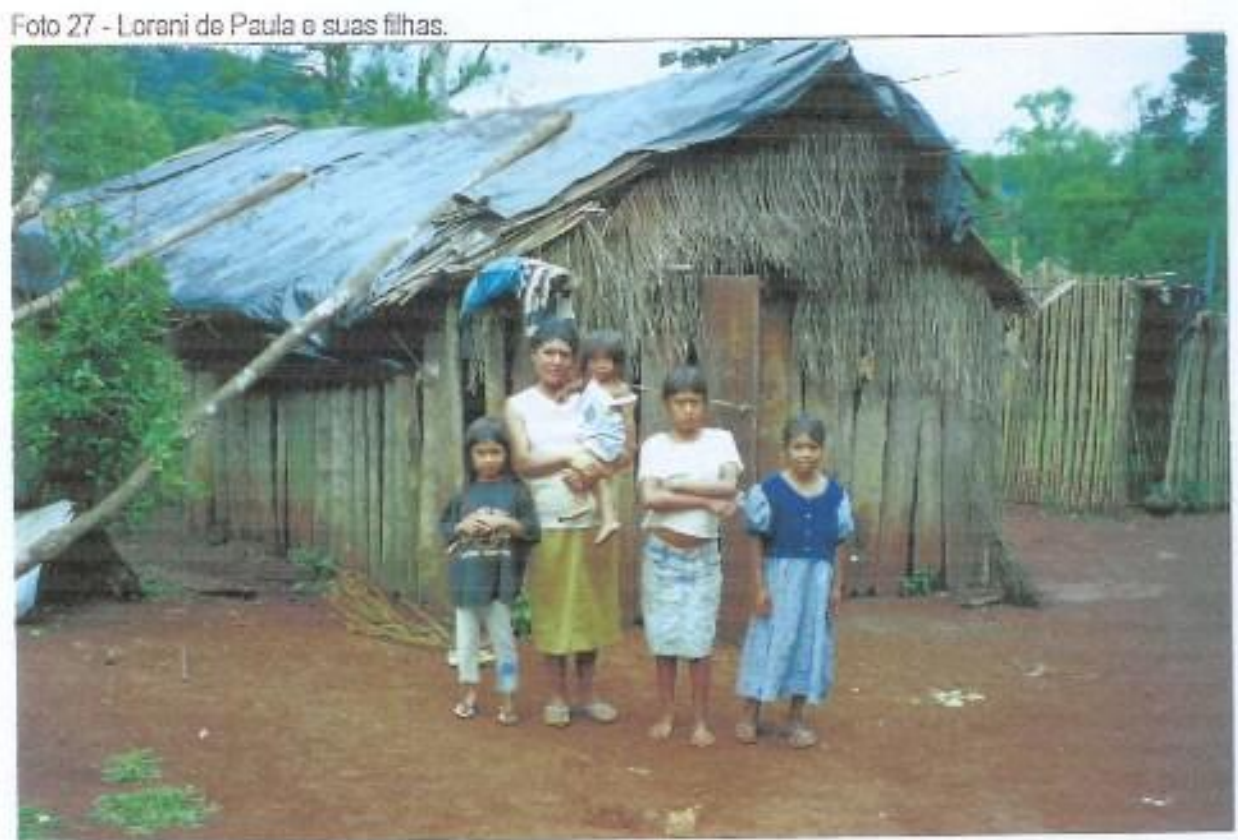

Foto 28 - Crianças Guarani da Addeia Passo Feio.

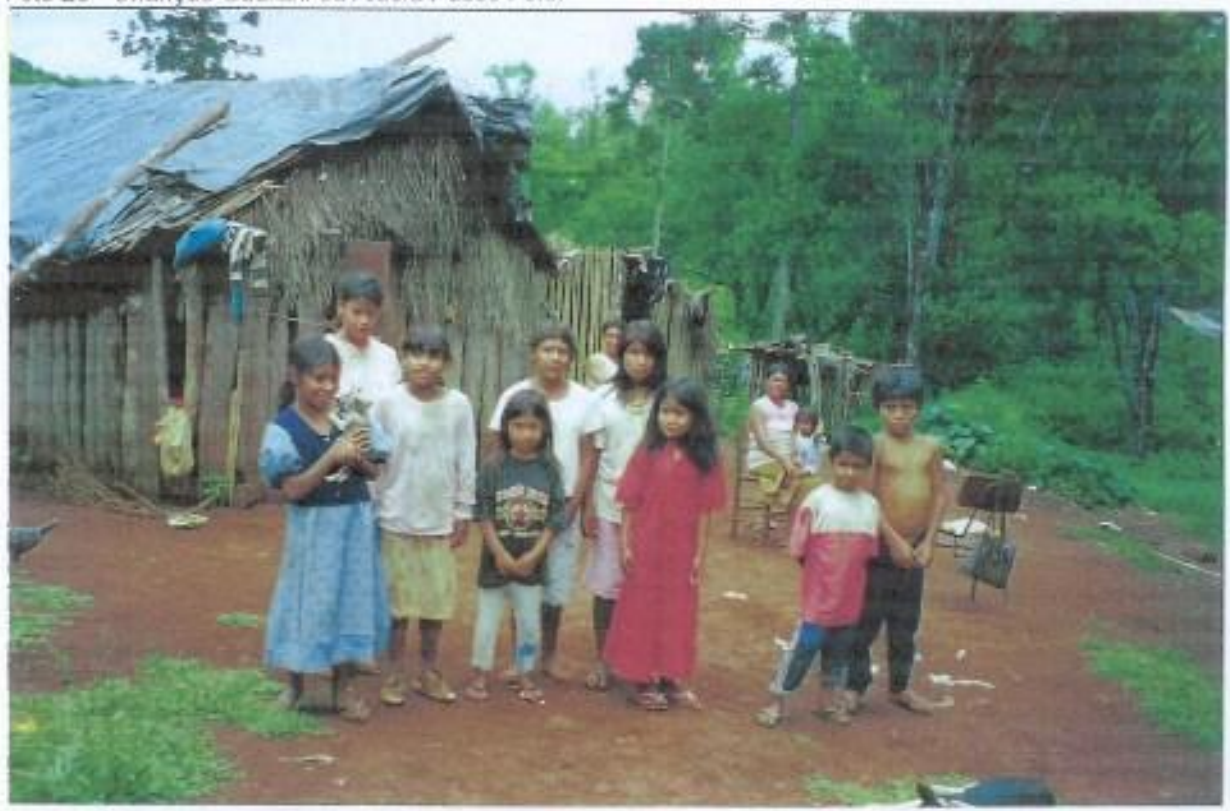

Espaço Ameríndio, Porto Alegre, v. 7, n. 2, p. 277-556, jul./dez. 2013. 
KIMIYE TOMMASINO - Relatório de Identificação e Delimitação da Terra Indígena...

\section{OS GUARANI NA ALDEIA PASSO FEIO - TI NONOAI / RS}

Foio 29 - A escola da Aldeia Passo Feio.

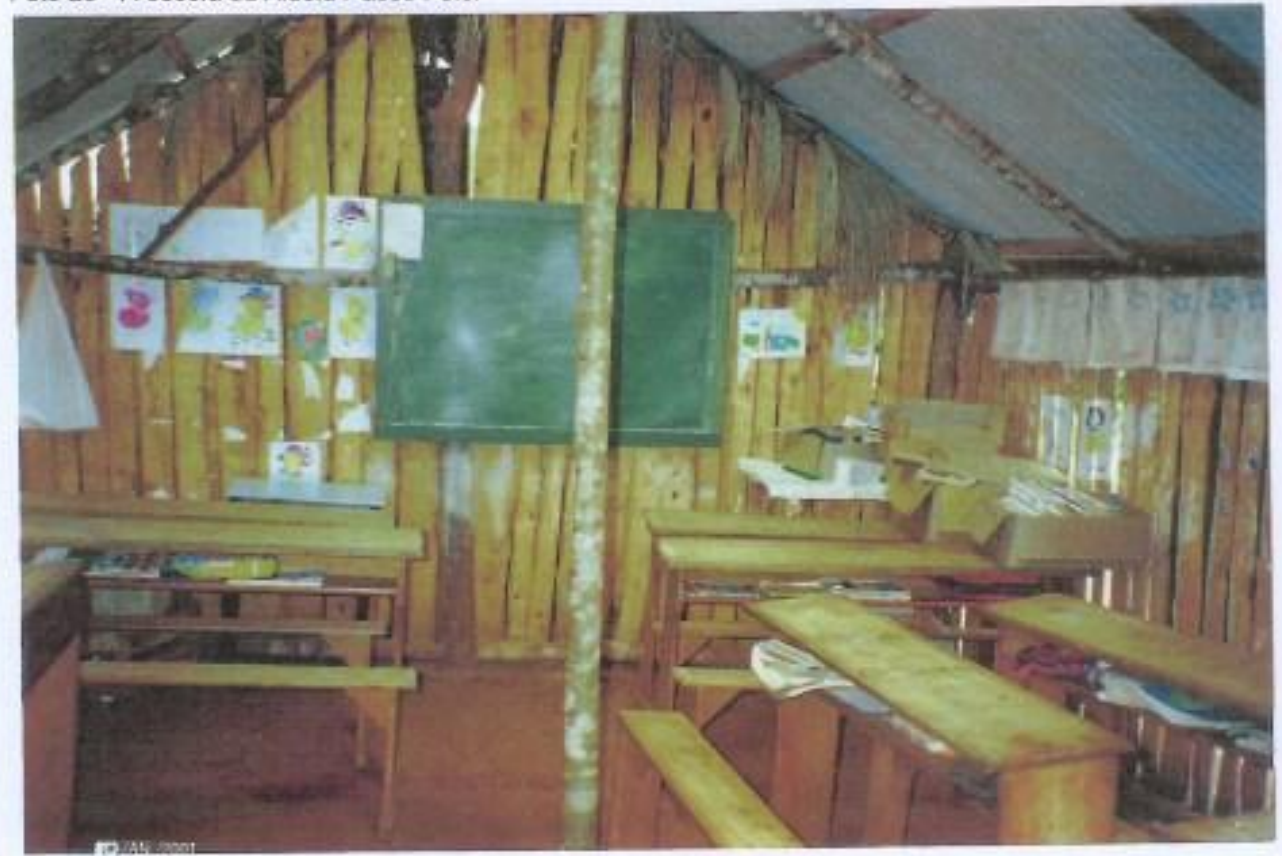

Foto 30 - Alunos Guarani a porta da escola da Aldeia Passo Feio.

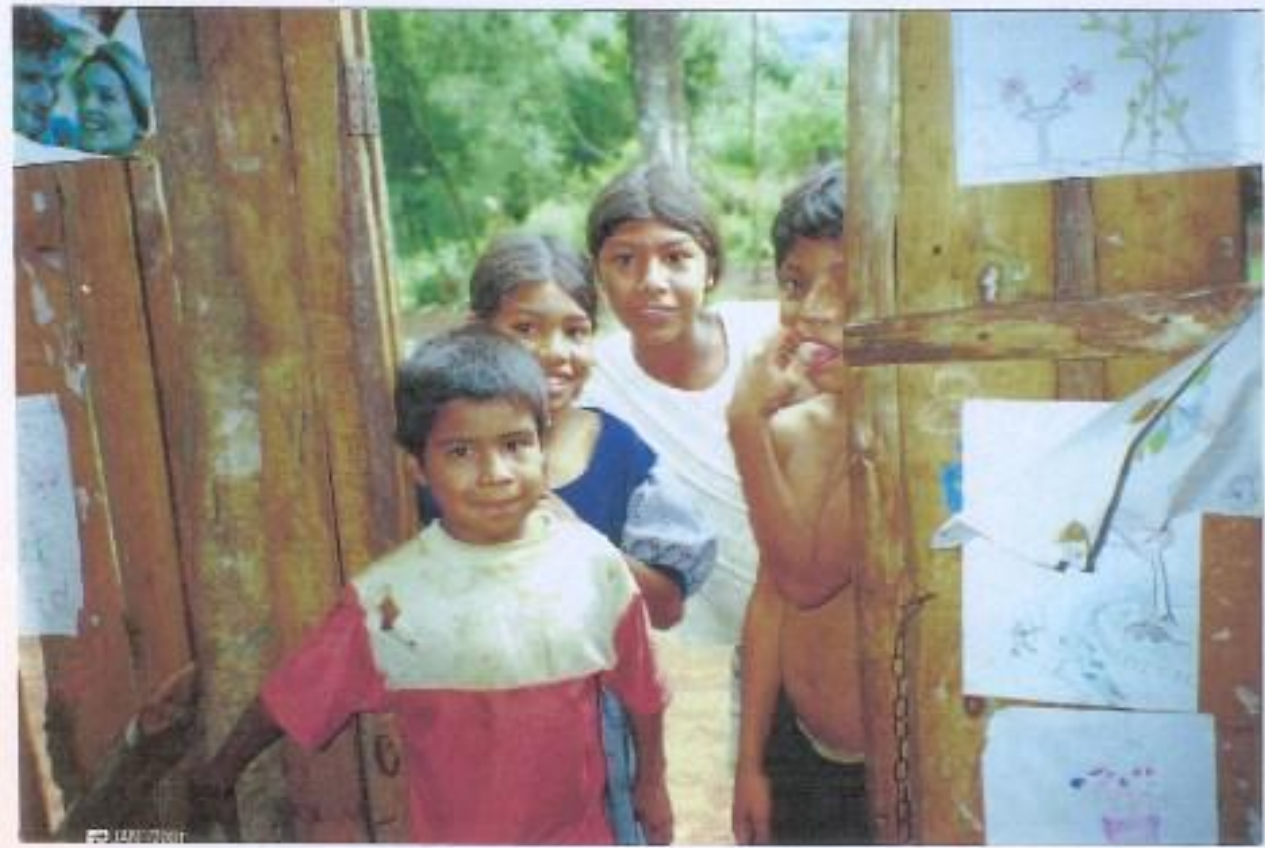

Espaço Ameríndio, Porto Alegre, v. 7, n. 2, p. 277-556, jul./dez. 2013. 
KIMIYE TOMMASINO - Relatório de Identificação e Delimitação da Terra Indígena...

\section{OS GUARANI NA ALDEIA MBARACA MIRIM - TI NONOAI}

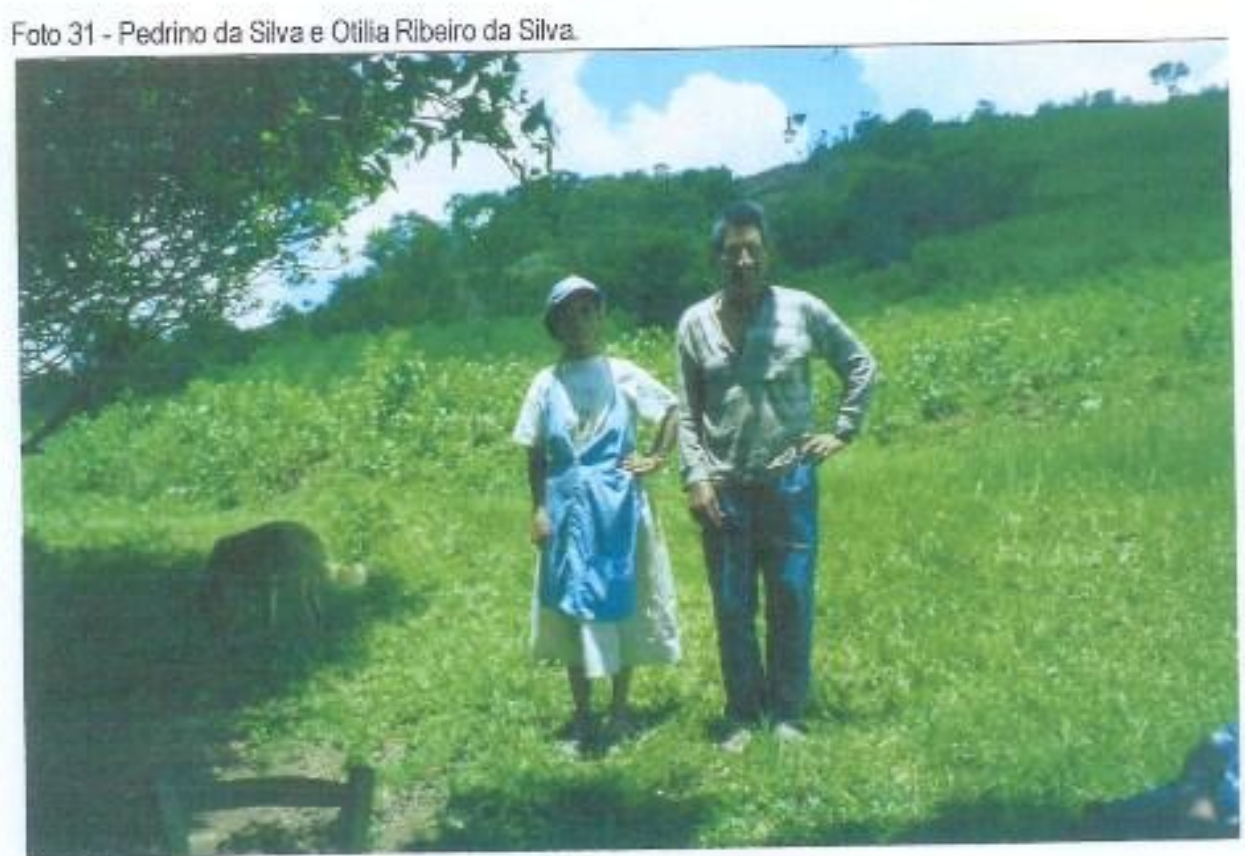

Foto 32 - A esquerda a casa de Pedrinho da Silva e Otlia a meio caminho da Aldeia Mbaraca Mirim.

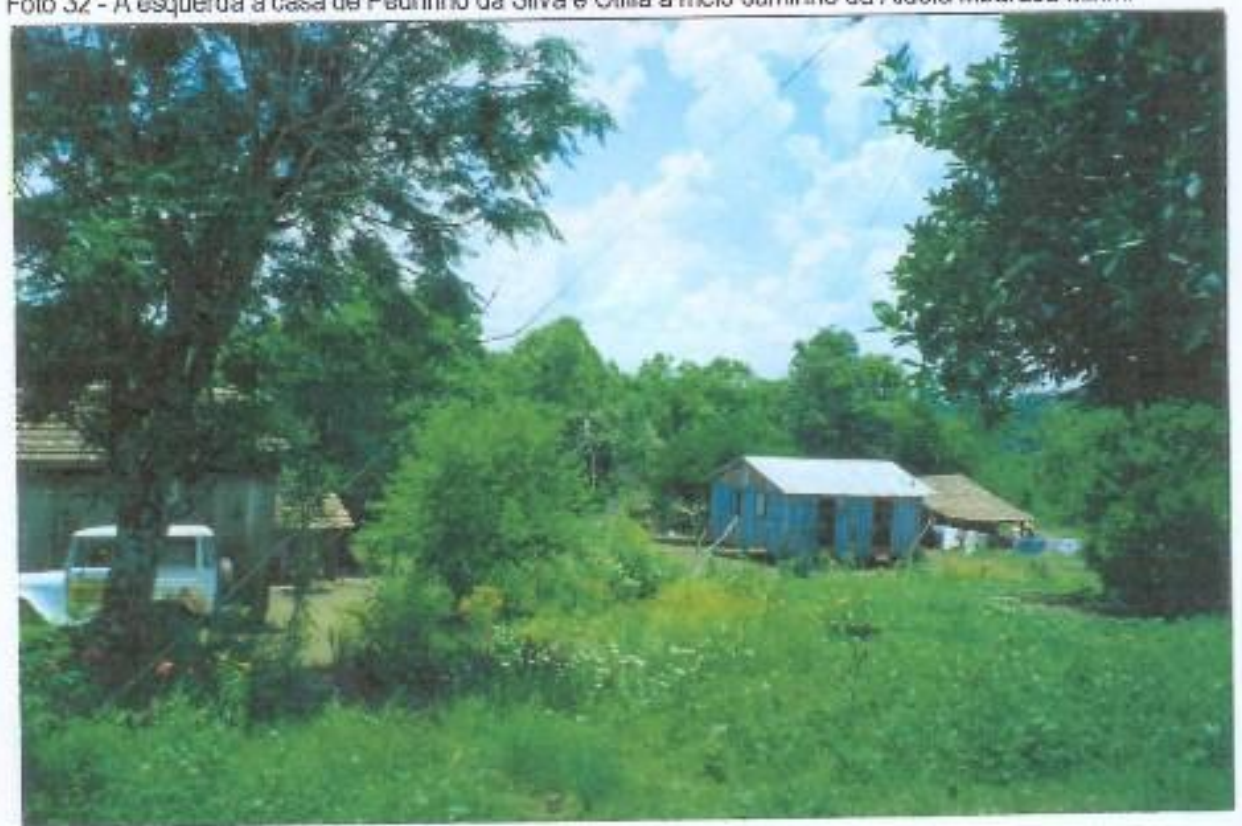

Espaço Ameríndio, Porto Alegre, v. 7, n. 2, p. 277-556, jul./dez. 2013. 
KIMIYE TOMMASINO - Relatório de Identificação e Delimitação da Terra Indígena...

\section{OS GUARANI DA ALDEIA KAINGANG DA TI NONOAI - SEDE}

Foto 33 - Tereza de Paula e seu filho Anlonio de Paula.

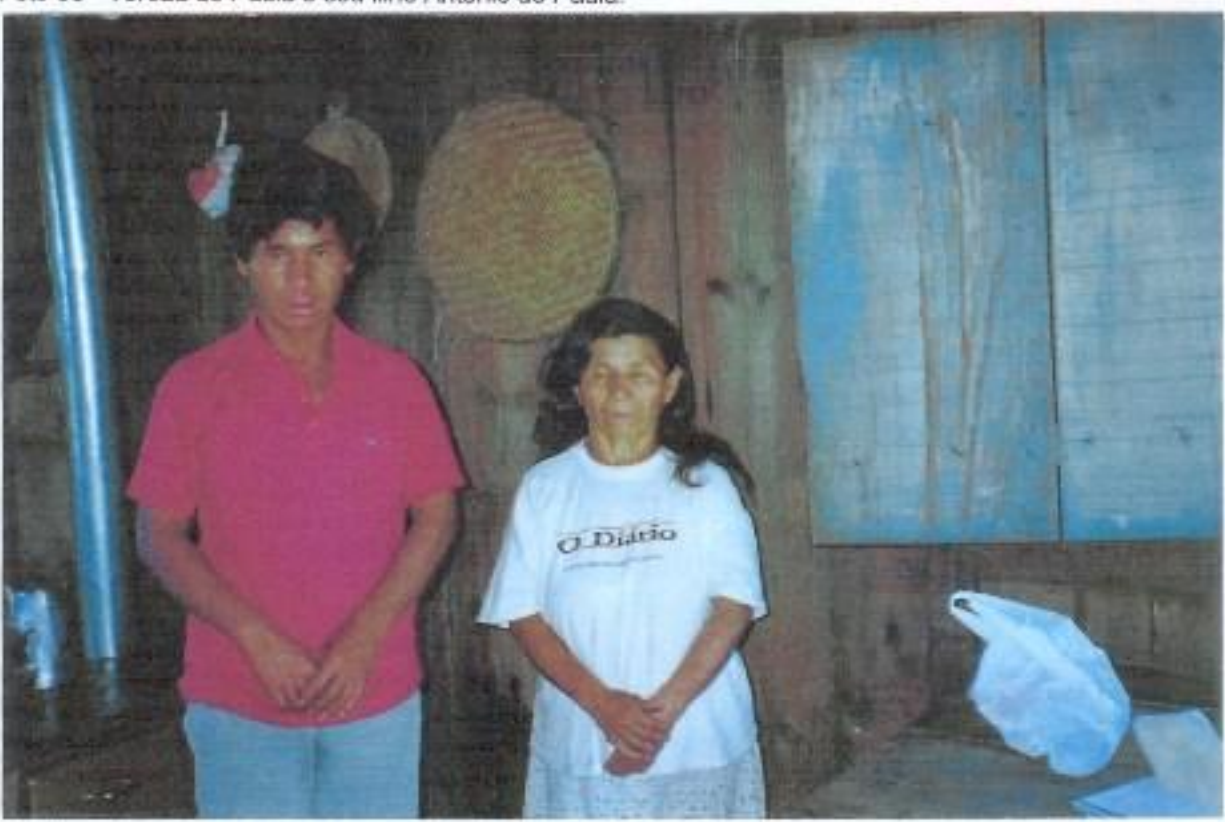

Foto 34 - Rosalina da Silva (a direita), sua irmaa Tereza de Paula e netas.

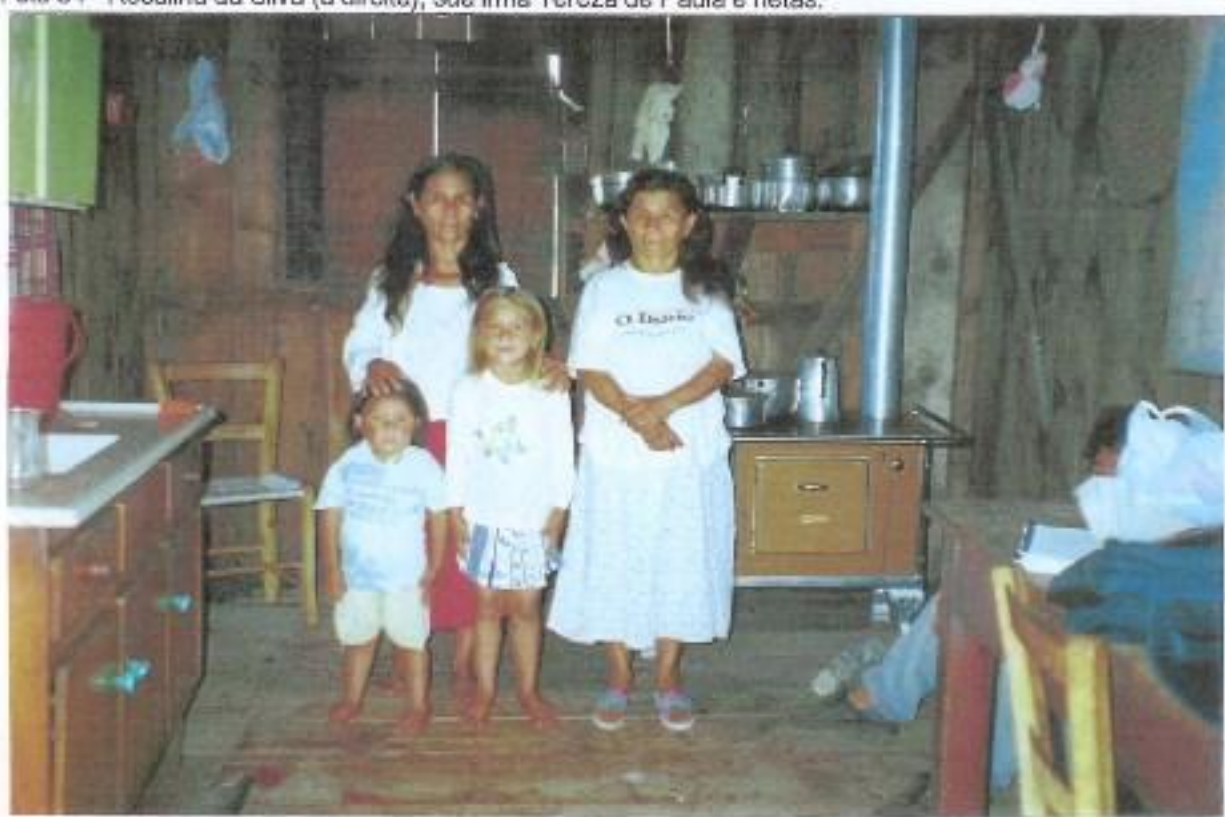

Espaço Ameríndio, Porto Alegre, v. 7, n. 2, p. 277-556, jul./dez. 2013. 
KIMIYE TOMMASINO - Relatório de Identificação e Delimitação da Terra Indígena...

\subsection{FAMÍLIAS QUE CONTINUARAM MORANDO NOS MUNICÍPIOS PRÓXIMOS À TERRA GUARANI DE ARAÇA'Í}

OS GUARANI QUE VIVEM NO MUNICIPIO DE MARAVILHA, NO OESTE CATARINENSE

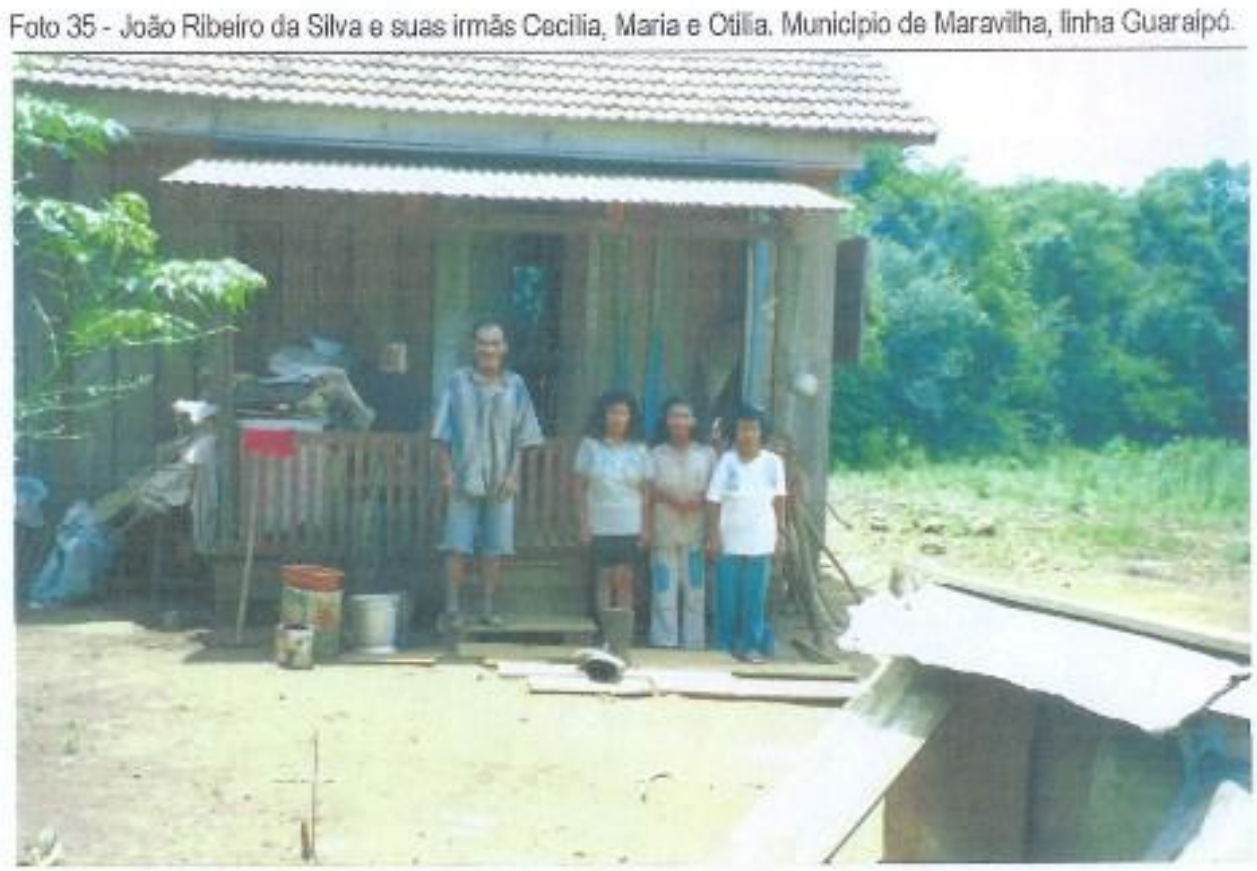

Foto 36 - O casal Alcides Ribeiro e Zulmira com os filhos Nelci $\theta$ Vanessa.

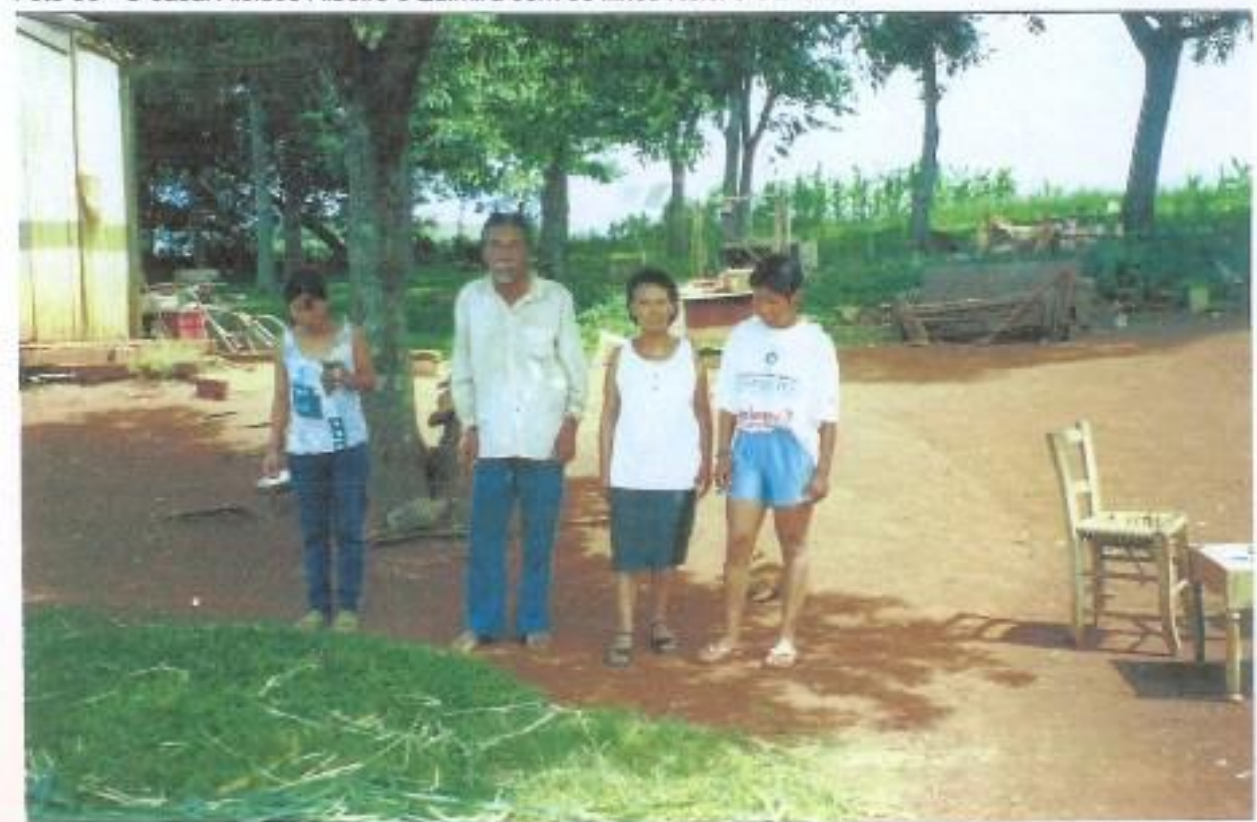

Espaço Ameríndio, Porto Alegre, v. 7, n. 2, p. 277-556, jul./dez. 2013. 
KIMIYE TOMMASINO - Relatório de Identificação e Delimitação da Terra Indígena...

\section{OS GUARANI QUE VIVEM NO MUNICIPIO DE MARAVILHA, NO OESTE CATARINENSE}

Foto 37 - Dario Aves no local de trabalho na zona rural de Maravilha.

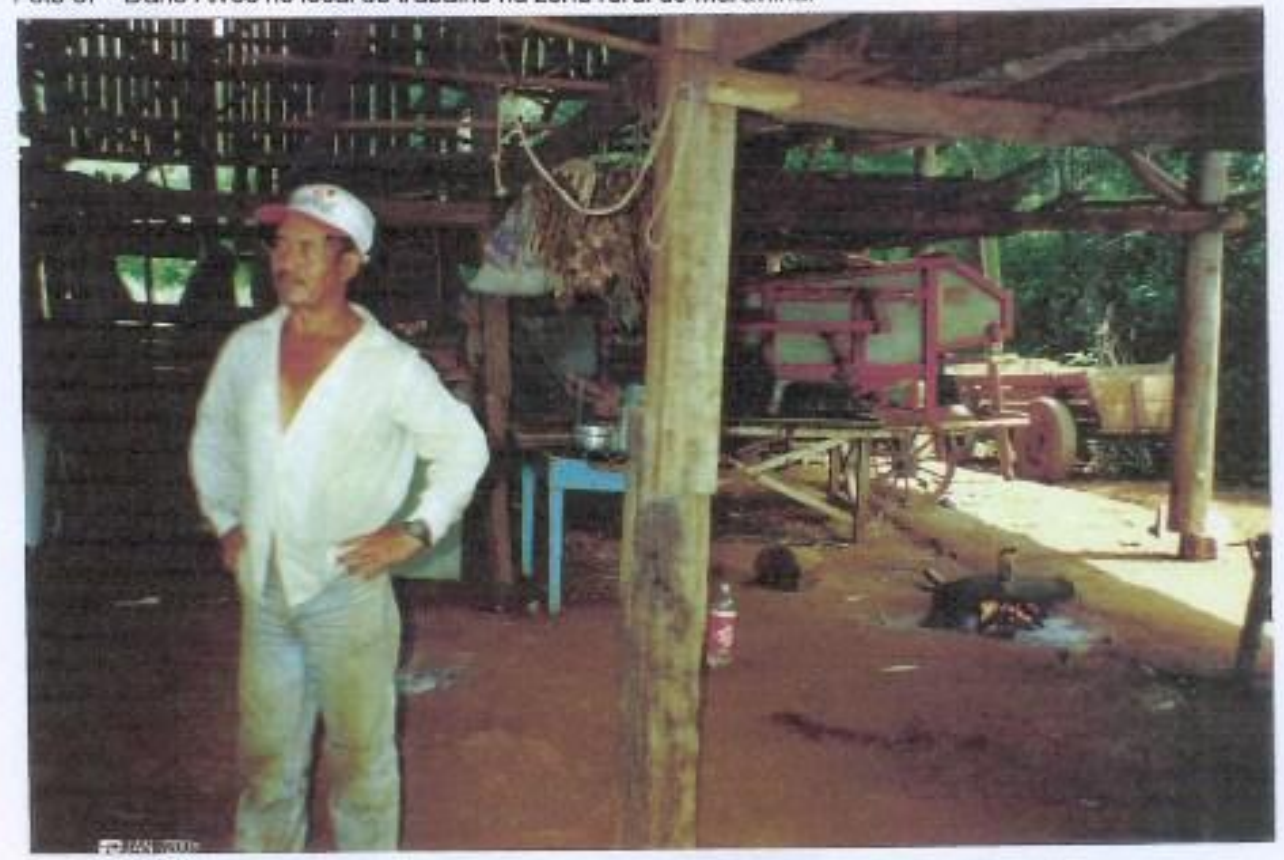

Foto 38 - Placa na entrada da propriedade onde vive Levino Ribeiro.

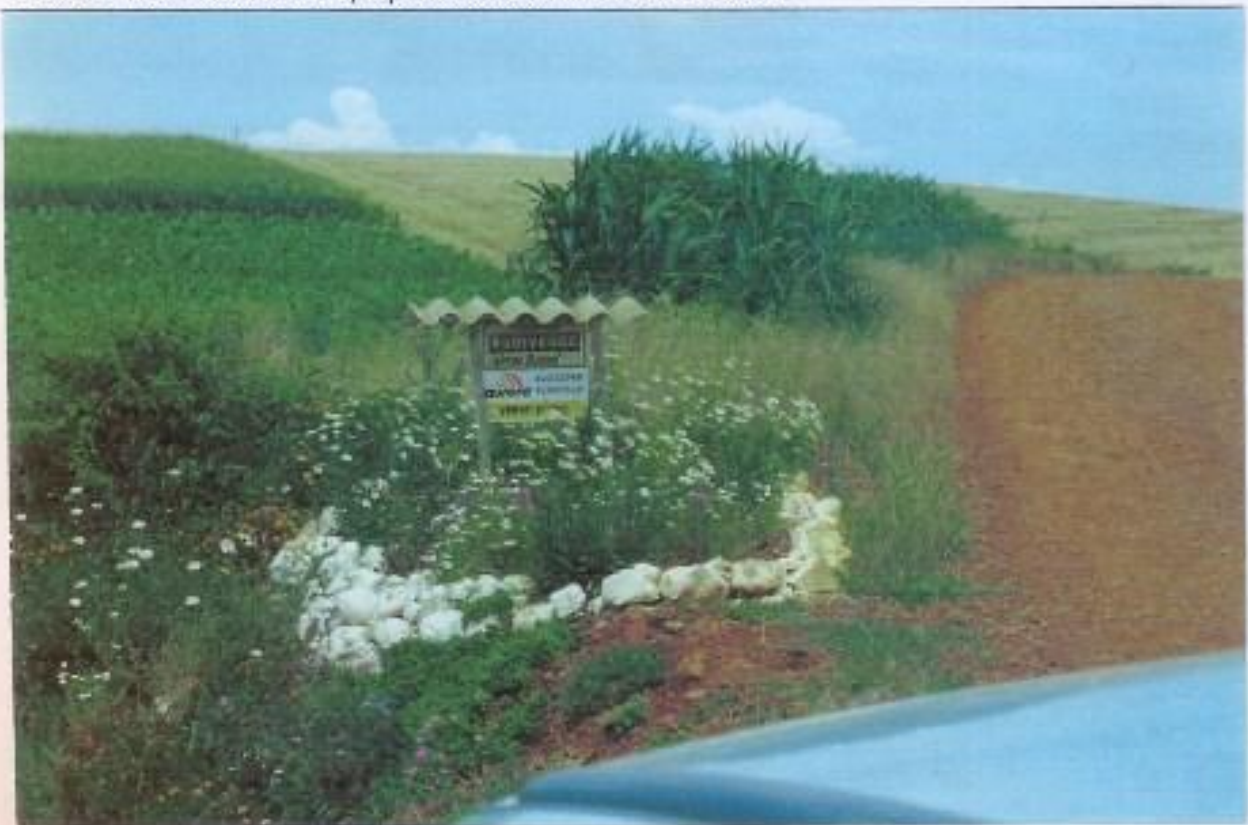

Espaço Ameríndio, Porto Alegre, v. 7, n. 2, p. 277-556, jul./dez. 2013. 
KIMIYE TOMMASINO - Relatório de Identificação e Delimitação da Terra Indígena...

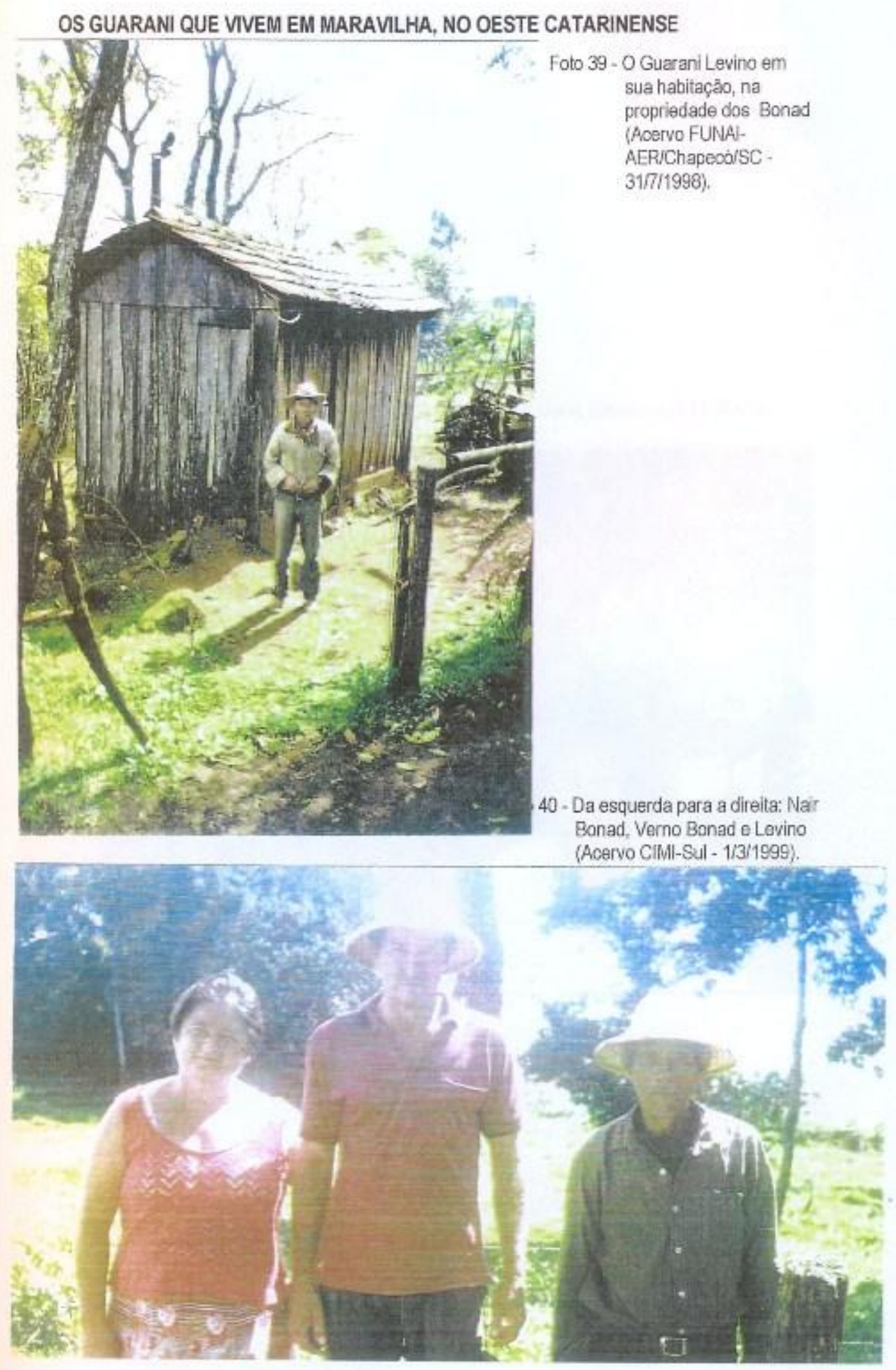

Espaço Ameríndio, Porto Alegre, v. 7, n. 2, p. 277-556, jul./dez. 2013. 
KIMIYE TOMMASINO - Relatório de Identificação e Delimitação da Terra Indígena...

OS GUARANI QUE VIVEM EM MARAVILHA, NO OESTE CATARINENSE

Foto 41 - Da esquerda para a direita: Joāo Ribeiro, Cecilia, Angelina, Maria, Odorico e Otilia (Acervo CIMI-Sul - 18/5/1999)

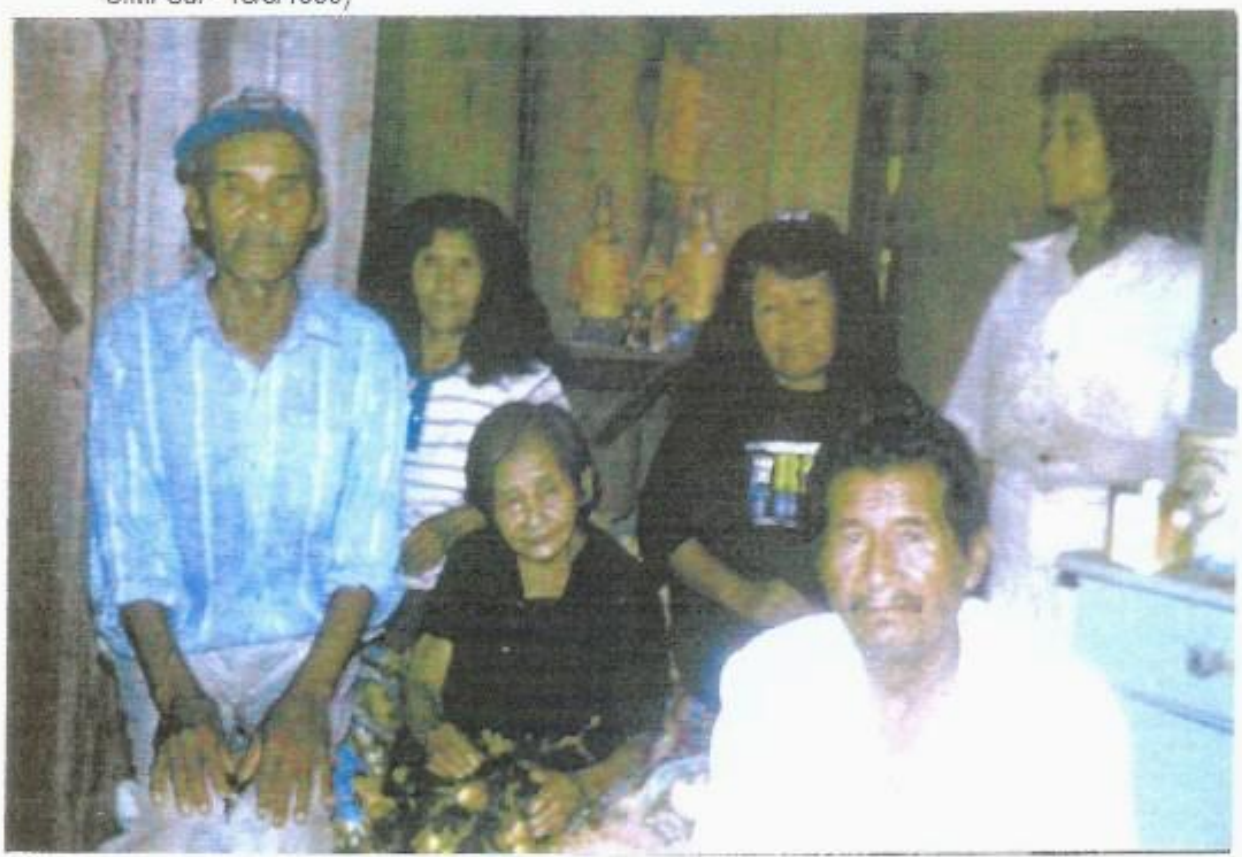

Espaço Ameríndio, Porto Alegre, v. 7, n. 2, p. 277-556, jul./dez. 2013. 
KIMIYE TOMMASINO - Relatório de Identificação e Delimitação da Terra Indígena...

\subsection{FAIXAS CONTRA A REIVINDICAÇÃO DOS GUARANI}

\section{FAIXAS EM DIVERSOS LOCAIS EM CUNHA PORĂ (SC), APOIANDO OS AGRICULTORES}

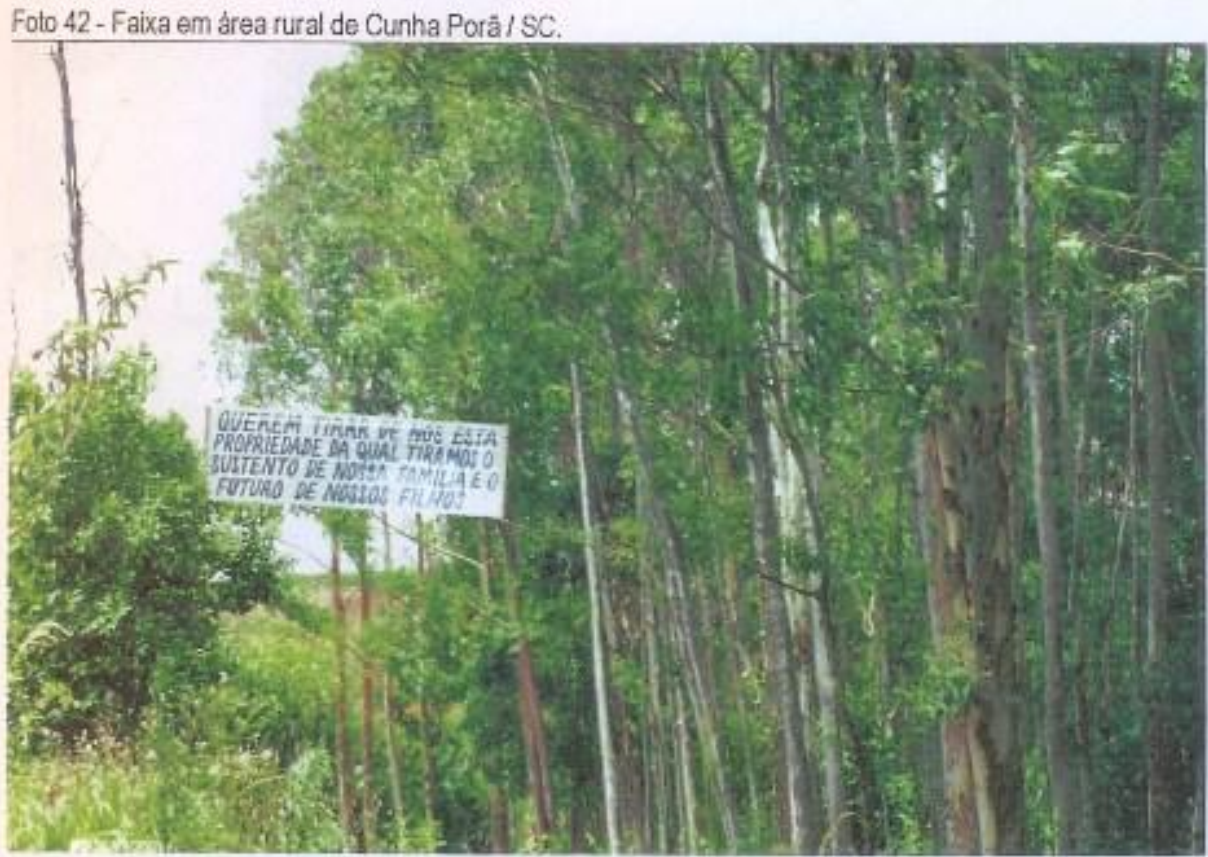

Folo 43 - Faixa em residéncia na cidade de Cunha Porâ / SC

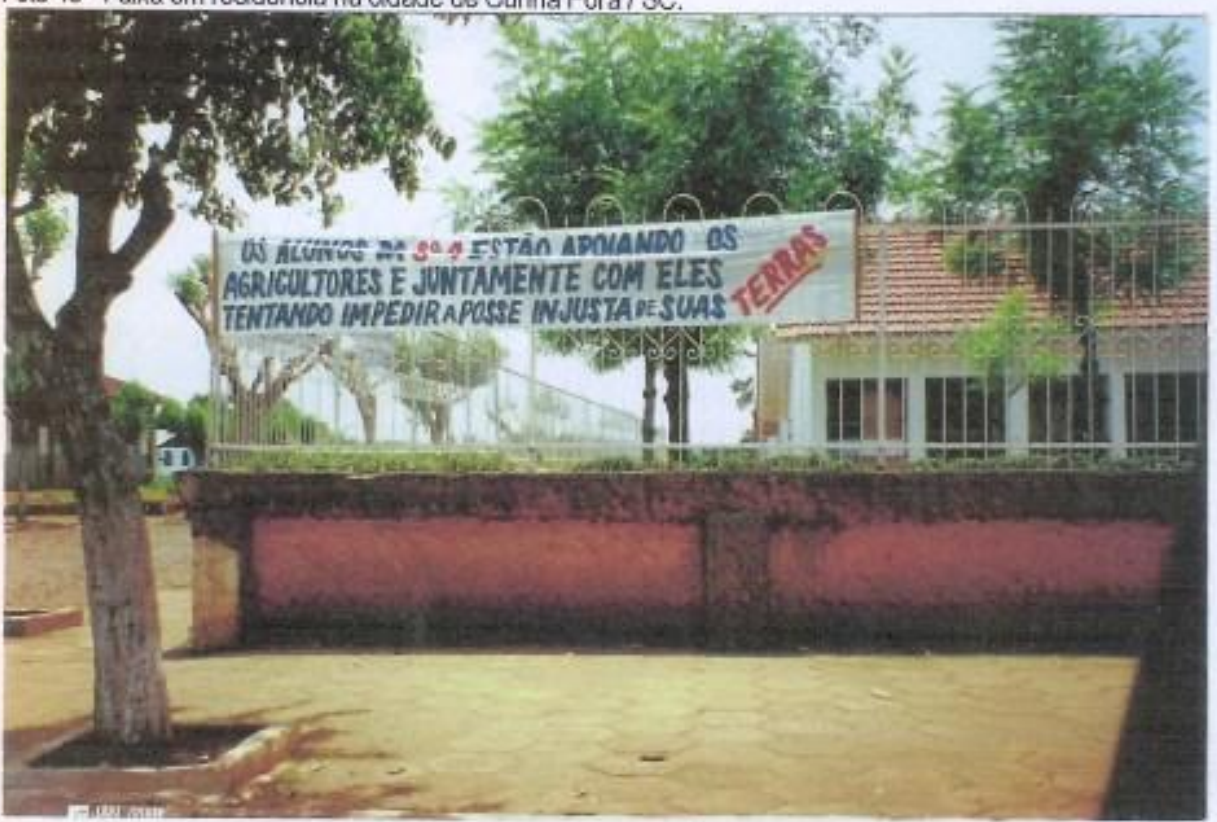

Espaço Ameríndio, Porto Alegre, v. 7, n. 2, p. 277-556, jul./dez. 2013. 
KIMIYE TOMMASINO - Relatório de Identificação e Delimitação da Terra Indígena...

FAIXAS EM DIVERSOS LOCAIS DE CUNHA PORÅ (SC), APOIANDO OS AGRICULTORES
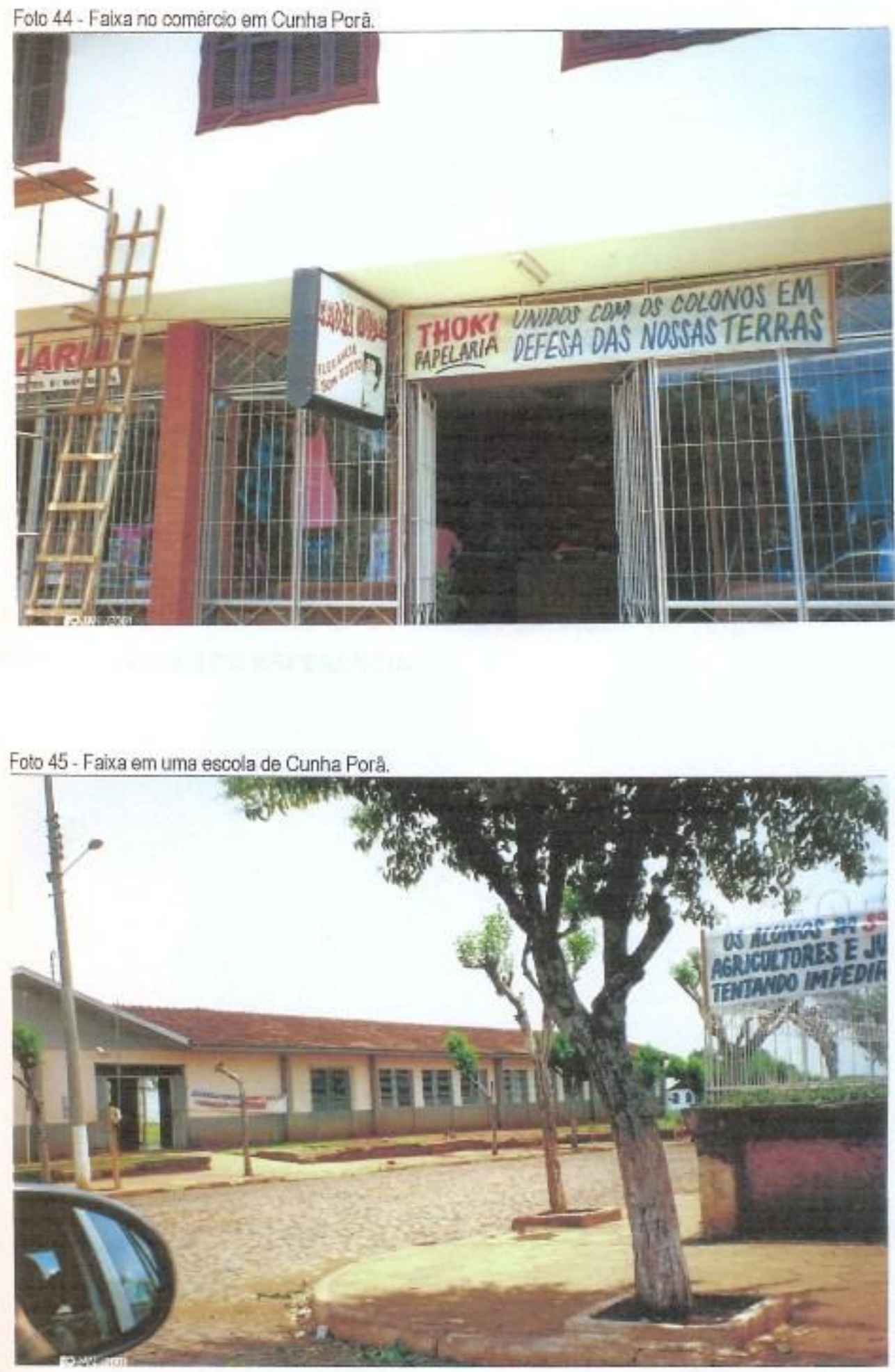

Espaço Ameríndio, Porto Alegre, v. 7, n. 2, p. 277-556, jul./dez. 2013. 
KIMIYE TOMMASINO - Relatório de Identificação e Delimitação da Terra Indígena...

\subsection{PRIMÓRDIOS DA COLONIZAÇÃO / CASAL FUNDADOR DO TEKOHÁ ARAÇA'Í / LOCAIS DE REFERÊNCIA}

\section{OS GUARANI NOS PRIMÓRDIOS DA COLONIZAÇĀO DA REGIÅO DE ARAÇA'Í}

Foto 46 - Familias Guarani contratadas para trabalhar para os primeiros brancos que chegaram à regiào (Acervo familia Keller/Fonte CIMI-Sul - 1931).

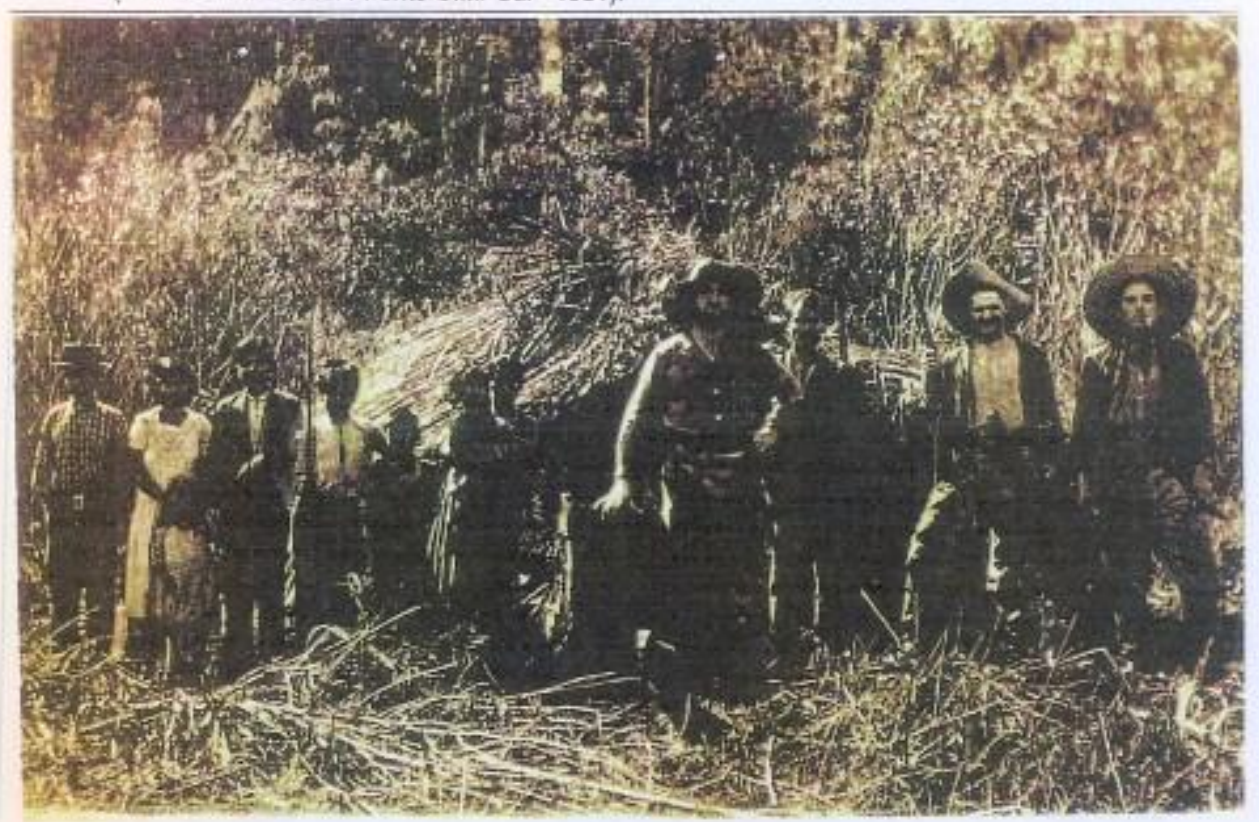

Foto 47 - Familias Guarani contratadas para trabalhar para os primeiros brancos que chegaram à regiäo(Acervo familia Keller / Fonte CIMI-Sul - 1931

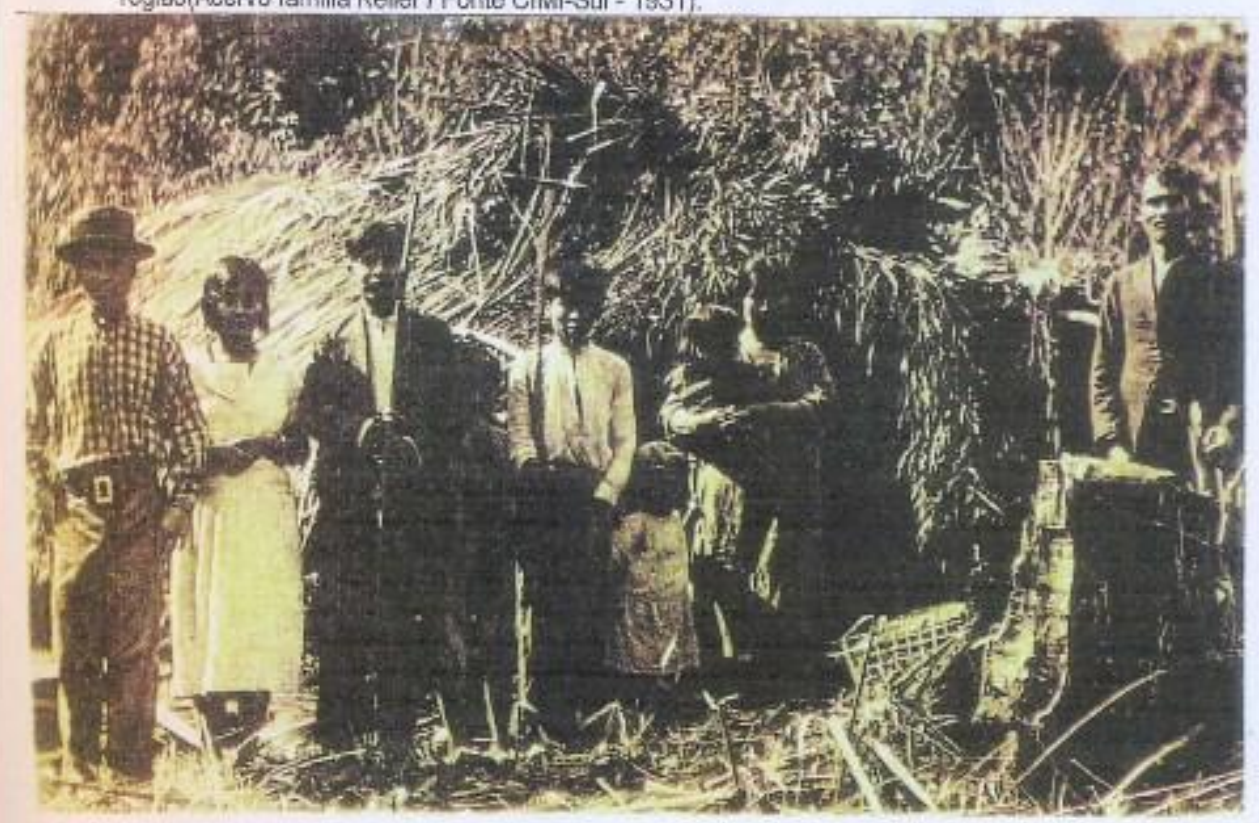

Espaço Ameríndio, Porto Alegre, v. 7, n. 2, p. 277-556, jul./dez. 2013. 
KIMIYE TOMMASINO - Relatório de Identificação e Delimitação da Terra Indígena...

CASAL JOAQUIM E PAULINA (FALECIDO), FUNDADOR DO TEKOHÁ ARAÇA'Í

Foto 4B - Da esquerda para a direita: Joaquim Mariano de Morais, Cecilia Barbosa, Paulina Morais e Maximino Mariano de Morais (Acervo CIMI/Sul - 1/3/1999).

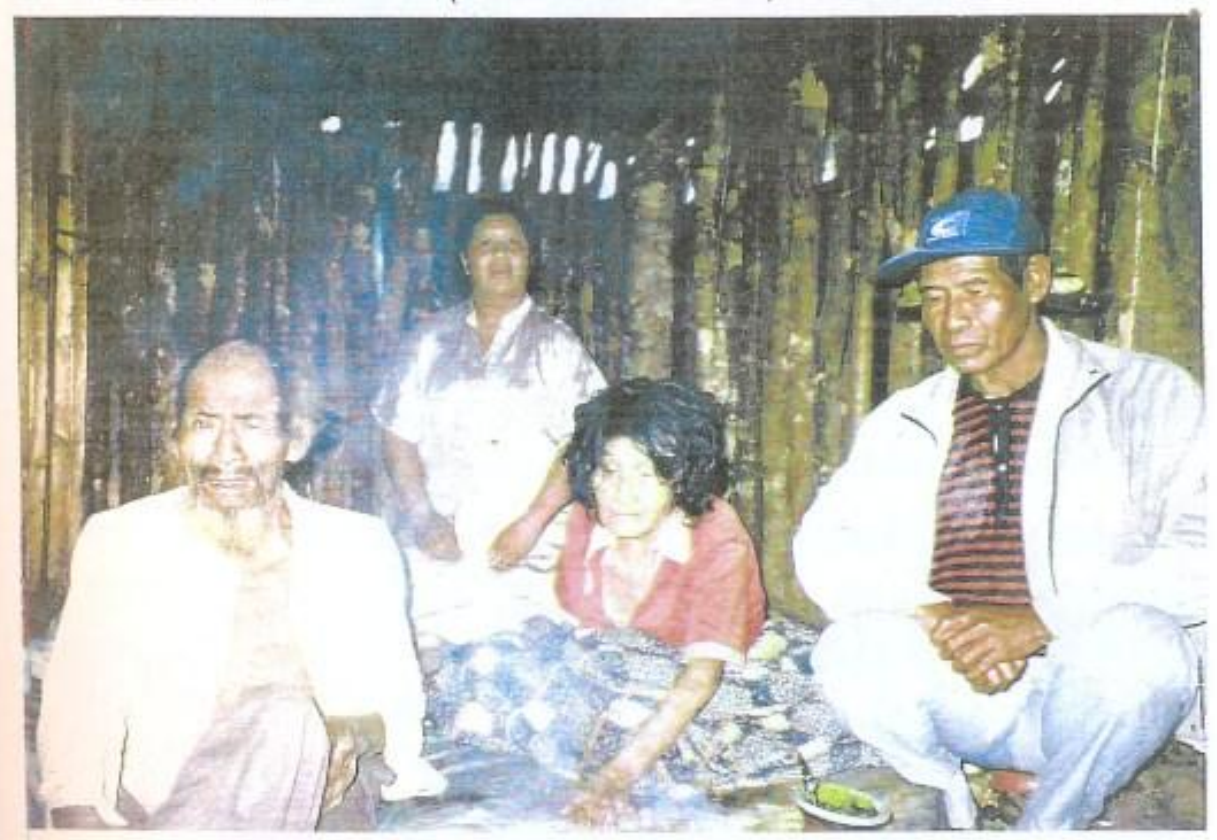

Espaço Ameríndio, Porto Alegre, v. 7, n. 2, p. 277-556, jul./dez. 2013. 
KIMIYE TOMMASINO - Relatório de Identificação e Delimitação da Terra Indígena...

\section{LOCAIS DE REFERÊNCIAS DO TEKHOÁ ARAÇA'Í / SC}

Foto 49 - Local da segunda aldeia Guarani (Acervo FUNAI-AERiChapecó/SC - 31/7/1998).

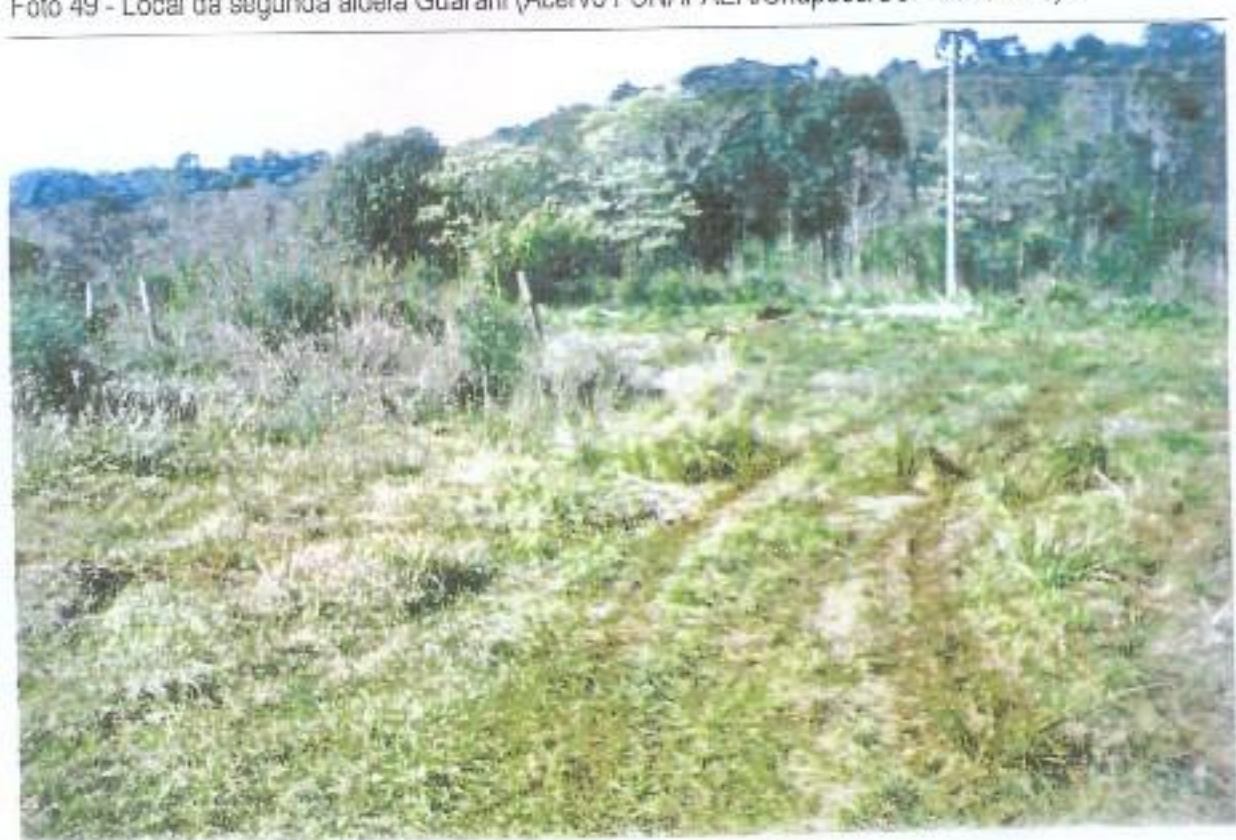

Foto 50 - Local do antigo cemitério Guarani em Araça'i, hoje utilizado como potreiro (Acervo FUNALAER/Chapeco/SC - 31/7/1998)

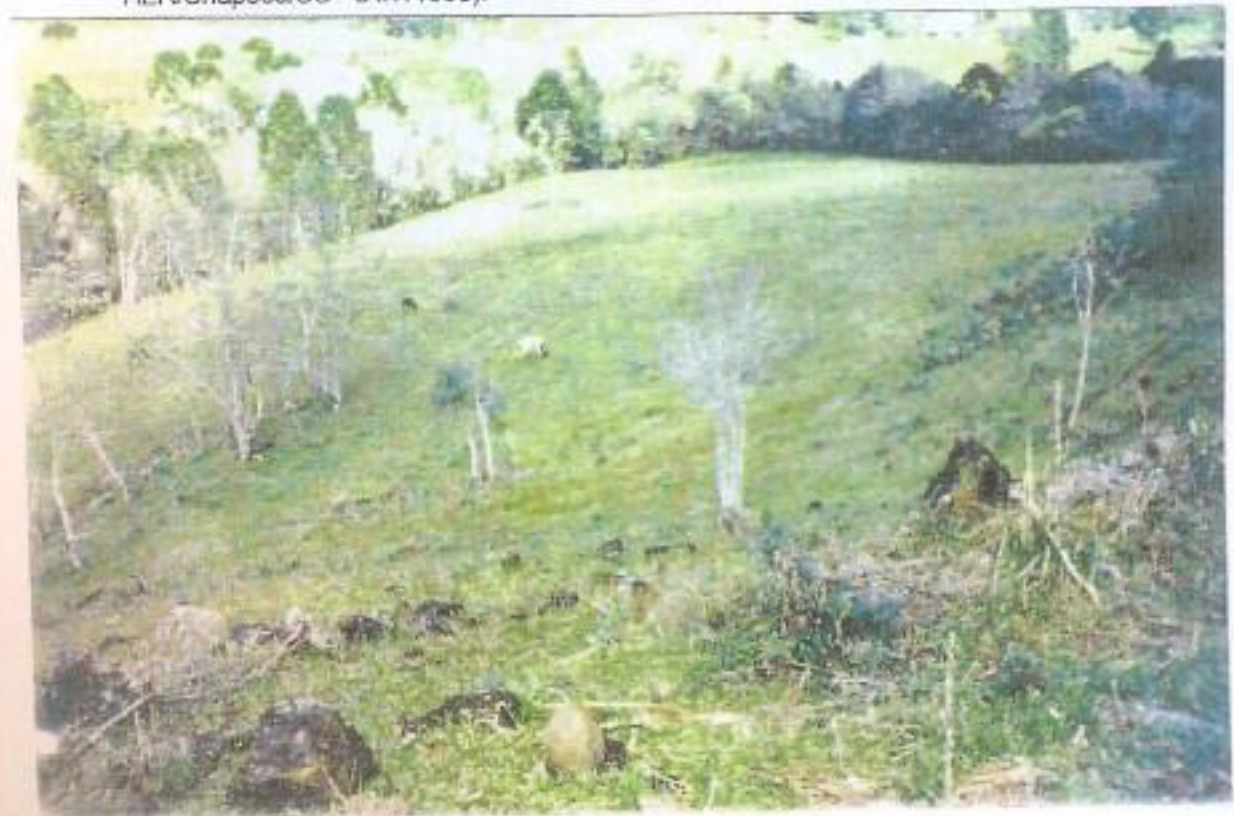

Espaço Ameríndio, Porto Alegre, v. 7, n. 2, p. 277-556, jul./dez. 2013. 
KIMIYE TOMMASINO - Relatório de Identificação e Delimitação da Terra Indígena...

LOCAIS DE REFERÊNCIAS DO TEKHOÁ ARAÇA'Í/SC

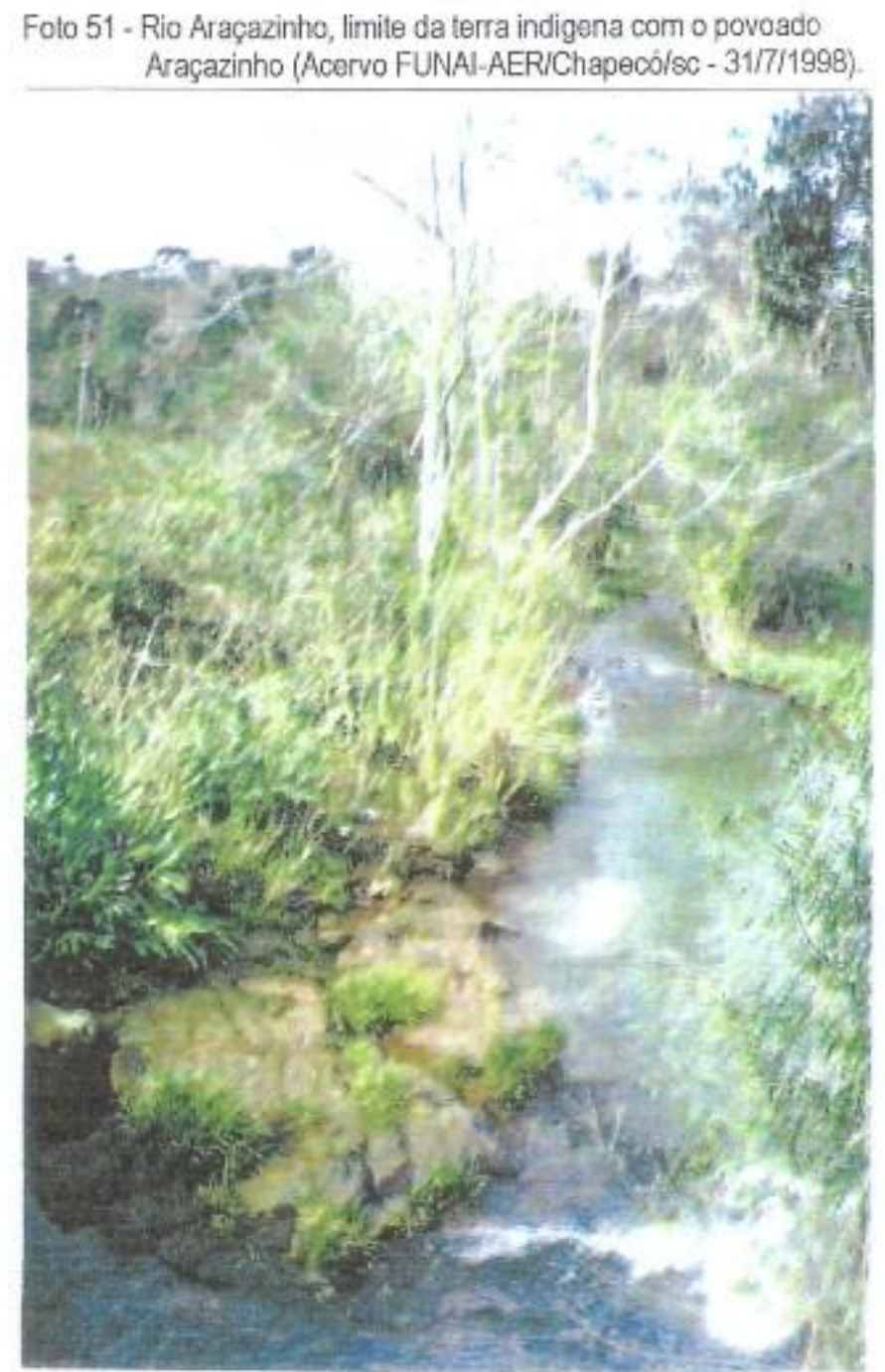

Espaço Ameríndio, Porto Alegre, v. 7, n. 2, p. 277-556, jul./dez. 2013. 


\section{CAPÍTULO V - RESUMO, CONCLUSÃO E DELIMITAÇÃO}

\section{Resumo e Conclusão}

Os Guarani pertencem à família linguística tupi-guarani, do tronco tupi. No Brasil são estimados em 30 mil e é a sociedade indígena de maior população no país. A pesquisa realizada pelo GT Terra Indígena Guarani de Araça'í, apresentada na forma de relatório, demonstrou que os Guarani do Tekohá Araça'í constituem uma família extensa, Te'yi, da imensa nação guarani da parcialidade chiripá (nhandeva).

\section{I- HISTÓRICO}

No século XVI os Guarani já eram encontrados ocupando um território que se estendia do litoral atlântico até as terras hoje pertencentes ao Mato Grosso do Sul, São Paulo, Paraná, Santa Catarina e Rio Grande do Sul, no Brasil e até o norte da Argentina e o sudeste do Paraguai. Mesmo com a experiência de conquista e dominação européia, os Guarani continuaram movendo-se nesse espaço físico e, apesar da expropriação e fragmentação territorial, mantiveram sua territorialidade até os dias atuais. Esse fato está comprovado nos mapas que revelam não ter havido grandes alterações na sua espacialidade deslocando-se os Guarani dentro desse território transnacional.

Foi demonstrado que os Guarani sofreram baixas imensas em sua população do século XVII ao XIX e os sobreviventes tornaram-se quase invisíveis e muitos se integraram biológica e culturalmente à sociedade nacional. No entanto alguns mantiveram-se unidos e organizados segundo seu modo de ser. Sobreviventes da população guarani missioneira ou da que viveu nas encomendas permaneceram na região dos Sete Povos das Missões e se relacionaram com os Kaygua e Montaraces, Guarani livres das florestas do Paraguai que passaram a se deslocar para o leste do rio Uruguai, fugindo da Guerra do Paraguai. Os casamentos entre as diferentes parcialidades guarani e destas com 
outras etnias indígenas ou juruá apontam para a existência de espaços de negociação interétnica, sendo que a incorporação de pessoas estrangeiras não significa necessariamente perda cultural e abandono das regras sociais e princípios organizatórios. Muito ao contrário, a sociabilidade guarani apresenta uma flexibilidade suficiente para fazer frente às necessidades que foram enfrentando ao longo da história. Nesse sentido, pode-se dizer que a cultura guarani sofreu transformações profundas, mas ela foi capaz de absorver e incorporar novos objetos e significados, mantendo-se, porém, os Guarani sempre orientados pela lógica dos conceitos tradicionais.

A família extensa/Te'yi saiu do oeste de seu território e migrou na direção leste atravessando o rio Uruguai movidos, de um lado, pelo contexto histórico imediato da Guerra do Paraguai e, de outro, pela crença na Terra-sem-Mal/Yvy marane'y, dentro de um movimento religioso, de caráter talvez mediato. Se nos séculos passados eram mais evidentes as razões míticas, hoje são as razões históricas e práticas que movem essas populações, seja porque as condições de vida se encontram no limite do suportável por total falta de espaço físico onde possam viver e realizar o tekó, seja porque a mudança das condições sociais e políticas favorecem mobilizações de luta pela reconquista de seus direitos, principalmente em relação à terra da qual ficaram privados, a maioria vivendo em terras de outras etnias. Nos relatos do grupo de Araça'í feitos a Rambo em 1947 ficou evidente que ambas as razões estavam presentes em seus deslocamentos. Isso ocorre porque a experiência histórica é inseparável da dimensão mítica, processo que na teoria de Sahlins (1990) é denominada mito-práxis.

Foi visto que a família extensa/te'yi do Tekohá Araça'í atravessou do lado argentino para o brasileiro e se fixou na região de Soledade-RS, seguindo uma parte para o oeste catarinense onde fundaram o Tekohá entre os rios Araçá e Araçazinho, hoje parcialmente pertencente a dois municípios: Saudades e Cunha Porã.

Inicialmente fundaram uma aldeia/ Tataypy Rupa à margem do rio Araçá e mais tarde outra, à margem do Araçazinho. Na primeira permaneceram pouco tempo, talvez entre dez e 13 anos (Antonio Ribeiro da Silva teria chegado na região em 1901), e lá enterraram os primeiros mortos. Na segunda aldeia permaneceram pelo menos 50 
KIMIYE TOMMASINO - Relatório de Identificação e Delimitação da Terra Indígena...

anos, porque em 1914 já tinham se estabelecido no rio Araça'í (Araçazinho) e as últimas famílias abandonaram (foram forçados a) o Tekohá em 1963.

Levando-se em consideração as pesquisas arqueológicas realizadas na bacia do Uruguai, o oeste catarinense é comprovadamente área de ocupações específicas guarani cujas datações vão até 1070 AP. Além da memória guarani agregamos algumas memórias dos colonos que chegaram à região de Araça'í e relacionaram-se, desde os primeiros anos, com famílias guarani, seja social e amigavelmente, seja contratando-as como mão-de-obra. Alguns Guarani trabalharam na medição das terras que foram loteadas pela Companhia Territorial Sul Brasil e teriam recebido dois lotes em pagamento, principalmente João Ribeiro da Silva. A família Ribeiro da Silva foi a que não deixou a região e permanece até hoje vivendo nos municípios próximos ao local do Tekohá. Pode-se dizer mesmo que famílias guarani de Araça'í nunca deixaram aquela região e, se deixaram as terras do seu Tekohá, é porque foram pressionadas a isso: Sebastião de Oliveira foi espancado e ficou aleijado das pernas e Sebastião André teve sua casa incendiada quando estava trabalhando numa colônia fora dali. As ameaças eram tantas que a mãe de João Ribeiro convenceu-o a sair do Tekohá e a mudar-se para o município vizinho de Cunhataí.

\section{II- HABITAÇÃO PERMANENTE}

A população que elaborou o documento de reivindicação de sua terra tradicional/Tekohá Araça'í é constituída pelas pessoas que viviam nas aldeias Passo Feio e Mbaraca Mirim e, segundo consta da lista, perfazem 133 pessoas, num total de 24 famílias. No acampamento de Araça'í foram computadas 21 famílias num total de 88 pessoas porque algumas tinham retornado para a aldeia Passo Feio.

No entanto, levando em consideração as famílias que se dispersaram para outras áreas indígenas e para fora das aldeias em diversos municípios do Rio Grande do Sul e de Santa Catarina, o presente Grupo Técnico estimou que, com a soma dessas famílias, a comunidade de Araça'í possui 151 pessoas, mas pode ter esse número 
KIMIYE TOMMASINO - Relatório de Identificação e Delimitação da Terra Indígena...

alargado.

Atualmente os Guarani não vivem mais em casas-grandes, mas em ranchos unifamiliares. As aldeias/Tataypy Rupa não constituem um conjunto habitacional formando "vilas", mas vivem espalhados a uma certa distância, de tal forma que não se percebe um "centro". A "unidade" é mais evidente quando analisamos a rede de sociabilidade entre as famílias: na produção, distribuição e consumo, nas atividades religiosas e políticas, no sentimento de pertencimento ao Tekohá. Continuam, mesmo fora daquela terra, fortemente ligados à terra onde nasceram e onde ainda estão enterrados os seus mortos. Trata-se, sem nenhuma dúvida de uma terra sagrada.

Enquanto sobreviveram das roças e recursos florestais, mantiveram sua casa de rezas e até os dias atuais possuem seu nhanderu que é autoridade religiosa. A migração de parte das famílias para a TI Nonoai começou no início dos anos 20, quando começaram a chegar os primeiros juruá e lá fundaram as aldeias Mbaraca Mirim e Passo Feio. No presente momento as famílias estão acampadas em barracas de lona em local próximo à aldeia Sede da TI Nonoai, vivendo de cestas básicas e trabalhos avulsos.

\section{III- ATIVIDADES PRODUTIVAS}

Enquanto estiveram no Tekohá Araça'í, as famílias viveram primeiramente dos recursos florestais e depois começaram a fazer roças de subsistência, pois toda a região era coberta por florestas.

Nas roças abertas em clareiras na mata plantavam milho, batatadoce, abóbora, mandioca e feijão. As matas continuaram a fornecer a caça, as plantas medicinais e rituais, a matéria-prima para seus arcos e flechas, utensílios domésticos e cestaria; os rios lhes davam peixes.

Quando os primeiros Juruá chegaram aos municípios que surgiram no oeste catarinense, os Guarani passaram a trabalhar nas colônias, nas mais variadas tarefas. Essas atividades como mão-de-obra temporária longe de suas casas, a venda de artesanato e raízes, somadas às pressões que os Juruá e empresas colonizadoras passaram a lhes fazer foram gradativamente tornando inviável a permanência no 
seu Tataypy Rupa à margem do rio Araçazinho. As ameaças constantes de pessoas atirando em seus telhados, o espancamento do Guarani Sebastião de Oliveira e o incêndio da casa de Sebastião André inviabilizaram de vez a permanência no Tekohá Araça'í. Ao longo dos últimos anos, de 1923 até 1963, todas as famílias se retiraram: umas para a TI Nonoai e outras para os municípios do oeste catarinense. Algumas vivem hoje em outras áreas indígenas da região sul e há ainda um grupo que foi levado para o Estado do Maranhão pelos proprietários de uma serraria para trabalharem numa filial, naquele estado.

\section{IV- MEIO AMBIENTE}

Quando os Guarani construíram o Tekohá Araça'í o meio ambiente oferecia as condições idealizadas pela sua cultura: toda a região era coberta por densas florestas com recursos alimentares, medicinais e rituais, os rios abundavam em peixes.

Viveram alguns anos apenas dos recursos naturais, depois abriram clareiras nas florestas e passaram a plantar roças de subsistência.

A reivindicação das terras do Tekohá Araça'í é resultado da política do estado que não demarcou terras para os Guarani e a colonização moderna invadiu as terras do Tekohá. A maior parte das famílias foi viver na TI Nonoai. O fato de estarem em terra kaingang foi gradativamente produzindo atritos com os Kaingang que passaram a pressionar os Guarani por estarem em terra alheia e porque as áreas indígenas não mais comportam a população que vem crescendo, e as terras, além de serem insuficientes, encontram-se desgastadas pelo constante reuso. Os Guarani, então, resolveram se organizar para reconquistar a terra do Tekohá Araça'í, para poderem retornar para sua terra tradicional/Tekohá, como disseram, "para viver na nossa terra".

Hoje as terras do Tekohá Araça'í se encontram ocupadas por famílias de colonos que compraram, certamente de boa fé, da Companhia Territorial Sul Brasil e são em sua maioria minifúndios dedicados a atividades agropecuárias. Em consequência, as densas florestas deram lugar a campos e pastagens, e a degradação ambiental 
é visível.

\section{V- REPRODUÇÃO FÍSICA E CULTURAL}

No Tekohá Araça'í, os Guarani viveram durante décadas segundo a orientação mítico-histórica herdada de seus ancestrais. Sua organização social continuou baseada na tradição e os sistemas econômico, social, político e religioso permaneceram até os dias atuais, quando os Guarani foram viver na TI Nonoai, nas aldeias/Tataypy Rupa Mbaraca Mirim e Passo Feio.

Do ponto de vista antropológico, o modo de ser guarani é experienciado no Tekohá Araça'í, e mesmo desterritorializados, buscam conciliar os ensinamentos e a sabedoria recebidos de seus ancestrais com as atividades práticas do cotidiano. Dessa maneira, viver a vida nesta terra possui objetivos imediatos, ligados à sobrevivência física e cultural, e objetivos mediatos, de fundamentação mitológica, tanto uns quanto outros, dimensões constitutivas da cosmologia guarani.

A recuperação de sua terra tradicional, isto é, do Tekohá Araça'í, representa para as famílias, a possibilidade de (re)viverem livremente, sem as pressões dos Kaingang que reivindicam as terras das aldeias Passo Feio e Mbaraca Mirim e sem também se sentirem invasores da terra de outra etnia. Isso exigirá que os órgãos públicos, após a devolução de suas terras, desenvolvam programas de recuperação do meio ambiente já bastante degradado pela ocupação intensiva dos colonos que lá se estabeleceram. O reflorestamento de parte das terras e a recuperação das águas serão fundamentais para que possam viver segundo seus padrões e costumes.

\section{VI- LEVANTAMENTO FUNDIÁRIO}

Desde que os trabalhos da equipe do GT Terra Indígena Guarani de Araça'í, Portaria 928/2000, foram iniciados, o forte movimento dos prefeitos, advogados, associações e sindicatos rurais, colonos e proprietários rurais de Cunha Porã e Saudades não permitram que se 
realizasse o levantamento fundiário. Somente foi permitido o acesso da equipe à área do acampamento guarani no município de Saudades. Mesmo assim foi possível tomar impressões através de excursões pelas estradas que cortam a região e chegar até as proximidades dos limites indicados pela comissão indígena.

O levantamento fundiário deverá ser realizado após a avaliação deste relatório antropológico e com as devidas condições de segurança para a equipe técnica.

No entanto, a equipe conseguiu se reunir com a comissão indígena e, a partir das informações sobre os limites naturais do Tekohá Araça'í, o engenheiro agrimensor responsável conseguiu realizar a delimitação da área do Tekohá Araça'í e o memorial descritivo que acompanham este trabalho.

\section{VII- CONCLUSÃO}

O presente relatório, fundamentado em dados de pesquisa arqueológica, histórica, sociológica e antropológica, de posse de informações etnográficas e da memória coletiva dos Guarani e de alguns Juruá, de bibliografia e documentação significativa, concluiu que a área reivindicada pelos Guarani nos municípios de Saudades e Cunha Porã é Terra Tradicional Guarani da parcialidade chiripá (nhandeva) que lá vivia antes da ocupação de origem nacional.

Tendo em vista os resultados da pesquisa, o Grupo Técnico constituído pela Portaria 928/2000, propõe a delimitação da Terra Indígena do Tekohá Araça'í, cujos limites constam no Memorial Descritivo de Identificação e Mapa. Tal proposta visa garantir aos Guarani a retomada de uma terra tradicional com respaldo no disposto do artigo 231 da Constituição Federal do Brasil. 


\section{Memorial Descritivo da Terra Indígena Guarani de Araça'í}
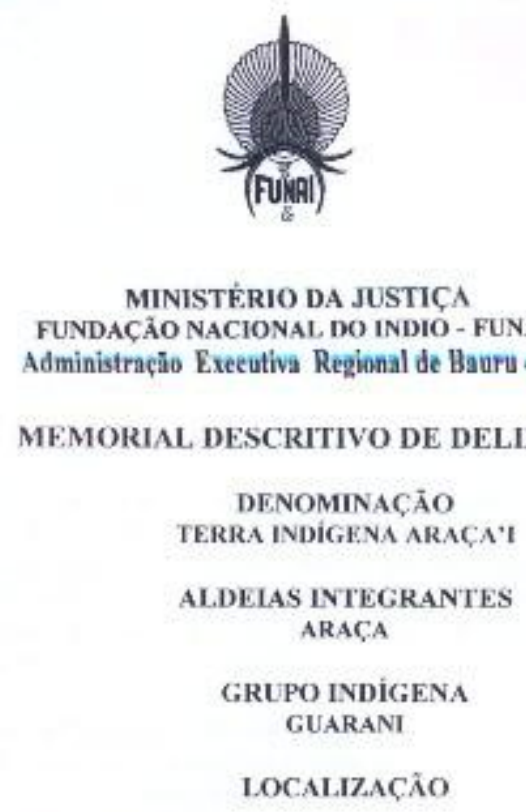

MUNICIPIO: SAUDADES E CUNHA PORÃ

ESTADO: SANTA CATARINA

A E R : CHAPECÓ

COORDENADAS DOS EXTREMOS

$\begin{array}{lcc}\text { EXTREMOS } & \text { LATITUDE } & \text { LONGITUDE } \\ \text { NORTE } & -26^{\circ} 50^{\prime} 38,43^{\prime \prime} \mathrm{s} & -53^{\circ} 05^{\prime} 56,91^{\prime \prime} \mathrm{Wgr} \text {. } \\ \text { LESTE } & -26^{\circ} 51^{\prime} 39,42^{\prime \prime} \mathrm{s} & -53^{\circ} 04^{\prime} 02,12^{\prime \prime} \mathrm{Wgr} \text {. } \\ \text { SUL } & -26^{\circ} 53^{\prime} 27,57^{\prime \prime} \mathrm{s} & -53^{\circ} 07^{\prime} 32,79^{\prime \prime} \mathrm{Wgr} \text {. } \\ \text { OESTE } & -26^{\prime \prime} 53^{\prime} 03,98^{\prime \prime} \mathrm{s} & -53^{\circ} 09^{\prime} 01,12^{\prime \prime} \mathrm{Wgr} .\end{array}$

BASE CARTOGRÁFICA

NOMENCLATURA

ESCAL.A

1: 50.000

ANO

SG-22-Y-A-V-4

DIMENSÕES

ÁREA : 2.721,28 ha (Dois Mil Setecentes e Vinte Um Hectares e Vinte Oito Ares)

PERIMETRO $: 29.426,00 \mathrm{~m}$

RUIA ANHANKTIFRA S-39 BALTUSAOPALLO CEP 17013.191 TELEFAX-224-2955

Espaço Ameríndio, Porto Alegre, v. 7, n. 2, p. 277-556, jul./dez. 2013. 
KIMIYE TOMMASINO - Relatório de Identificação e Delimitação da Terra Indígena...

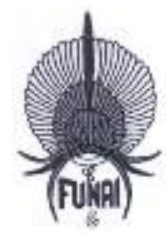

\author{
MINISTÉRIO DA JUSTIÇA \\ FUNDAČ̃O NACIONAL DO INDIO - FUNAI \\ Administração Executiva Regional de Bauru - SP
}

Continuaçâo do Memorial da Terra Indigena Araça'i.

NORTE Partindo do ponto denominado de Marco $\mathrm{N}^{\mathrm{n}} 01$ de coordenadas geográficas aproximadas $26^{\circ} 51^{\prime} 04,317^{\prime \prime} \mathrm{S}$ e $-53^{\circ} 08^{\prime} 46,178^{\prime \prime} \mathrm{Wgr}$., situado na cabeceira do Lajeado Itapé. Dai, segue pela margem direita do referido lajeado a jusante, numa distîncia aproximada de $8.015,00$ metros, até encontrar o ponto denominado de Mareo N." 02 de coordenadas geográficas aproximadas $-26^{\circ} 50^{\circ} 50,928^{\prime \prime} \mathrm{S}$ e $-53^{\circ} \quad 05^{+} 35,772^{\prime \prime}$ Wgr., situado na confluência com o Lajeado Araçá.

LESTE Do ponto anteriormente descrito, segue pela margem direita do Lajeado Araçá a jusante, numa distância aproximada de 6.950,00 metros, até encontrar o ponto denominado de Marco N. 03 de coordenadas geográficas aproximadas $-26^{\circ} 52^{\prime} 14,897^{\prime \prime} \mathrm{S}$ e $-53^{\circ} 04^{\prime} 19,791^{\prime \prime}$ Wgr., situado na confluência com o Lajeado Araçazinho.

SUL

Do ponto anteriormente descrito, segue pela margem esquerda do Lajeado Araçazinho a montante, numa distância aproximada de $6.788,00$ metros, até encontrar o ponto denominado de Marco N." 04 de coordenadas geográficas aproximadas $-26^{\circ} 53^{\prime} 15,580^{\prime \prime} \mathrm{S}$ e $-53^{\circ} 06^{\prime}$ 58,148 " Wgr., situado na confluência com o Lajeado M'borevi. Daí, segue pela margem esquerda do Lajeado M'borevi a montante, numa distância aproximada de 3,882,00 metros, até encontrar o ponto denominado de Marco N" 05 de coordenadas geográficas aproximadas $-26^{\circ} 53^{\circ} 03,976^{\prime \prime} \mathrm{S}$ e $-53^{\circ} 09^{\prime} 01,120^{\prime \prime} \mathrm{Wgr}$., situado na cabeceira do referido lajeado.

OESTE. Do ponto anteriormente descrito, segue com azimute de $17^{\circ} 32^{\prime} 28,77^{\prime \prime}$ e distância de $1.824,86$ metros, até encontrar o ponto denominado de Marco $\mathrm{N}^{*} \mathbf{0 6}$ de coordenadas geográficas aproximadas - $26^{\circ} 52^{\prime} 07,764^{\prime \prime} \mathrm{S}$ e $-53^{\circ} 08^{\prime} 40,130^{\prime \prime}$ Wgr., situado na cabeceira de uma sanga denominada Maina. Daí, segue com azimute de $352^{\circ} 14^{\prime} 05,40^{\prime \prime}$ e distância de $1.110,18$ metros, até encontrar o ponto denominado de Marco $\mathbf{N}^{\circ} \mathbf{0 7}$ de coordenadas geográficas aproximadas $-26^{\circ} 51^{\prime} 31,953^{\prime \prime} \mathrm{S}$ e $-53^{\circ} 08^{\prime} 44,888^{\prime \prime} \mathrm{Wgr}$, situado na cabeceira de um lajeado denominado Tangara. Do ponto anteriormente descrito, segue com azimute de $356^{\circ} 38^{\prime} 00,74^{\prime \prime}$ e distância de 851,47 metros, até encontrar o ponto denominado de Marco $\mathbf{N}^{\circ} 01$, início desta descrição perimétriça.

Data...16 de Outubro 2000,

Responsável Técnico péla Identificação

Responsável Técnico pela Delimitạ̣̃o
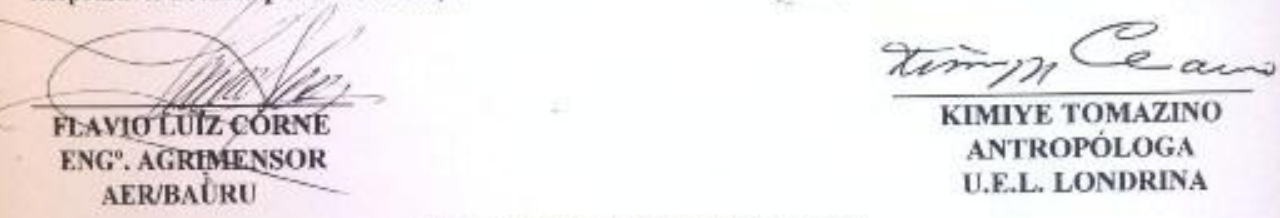

RUAANHANGIIFRA 5.39 BAURU SÃO PAULO CEP 17013-191 THIFAAX-224-2955

Espaço Ameríndio, Porto Alegre, v. 7, n. 2, p. 277-556, jul./dez. 2013. 
KIMIYE TOMMASINO - Relatório de Identificação e Delimitação da Terra Indígena...

\section{Delimitação da Terra Indígena Guarani de Araça'í}

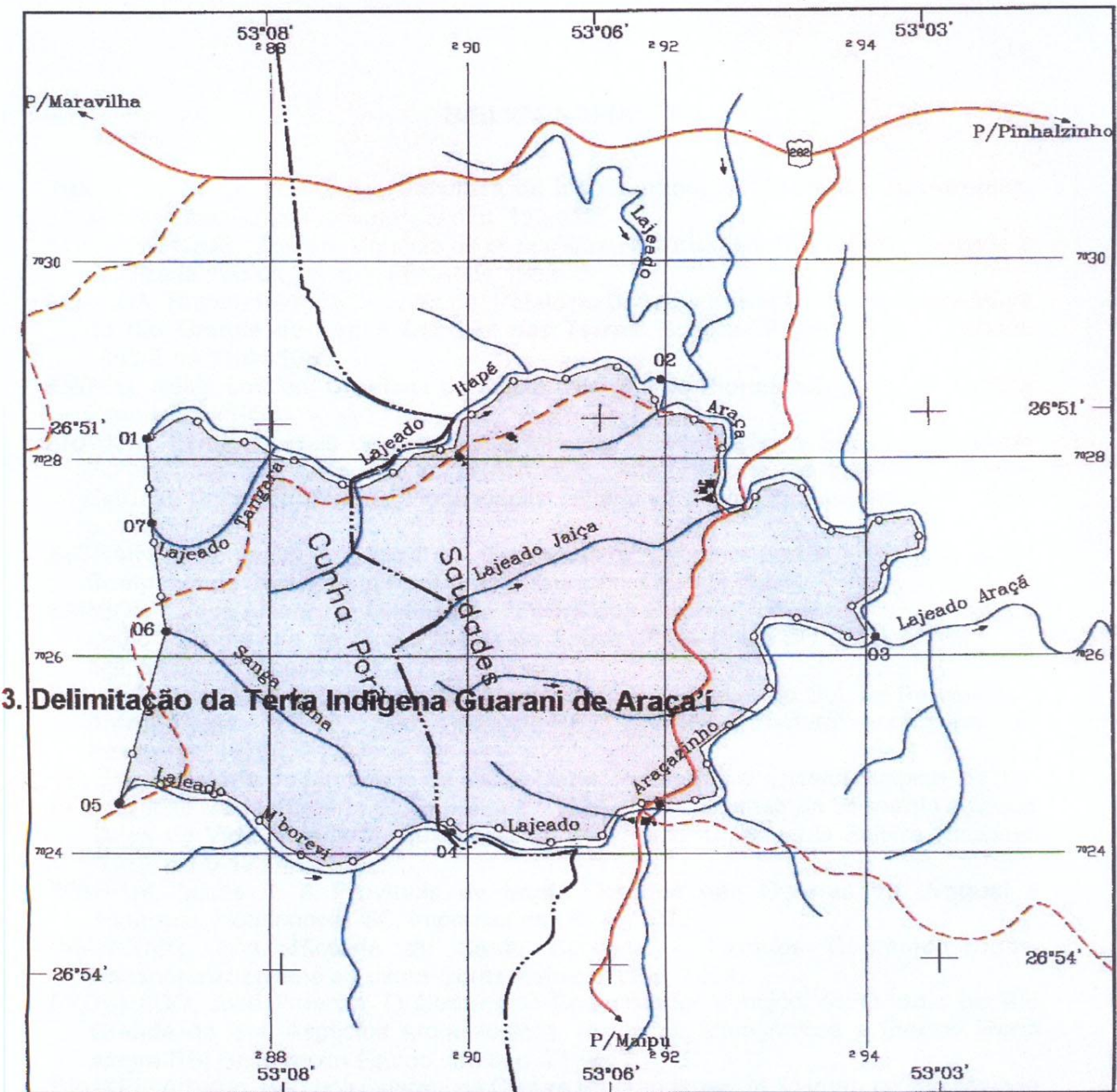

SINAIS CONVENCIDNAIS

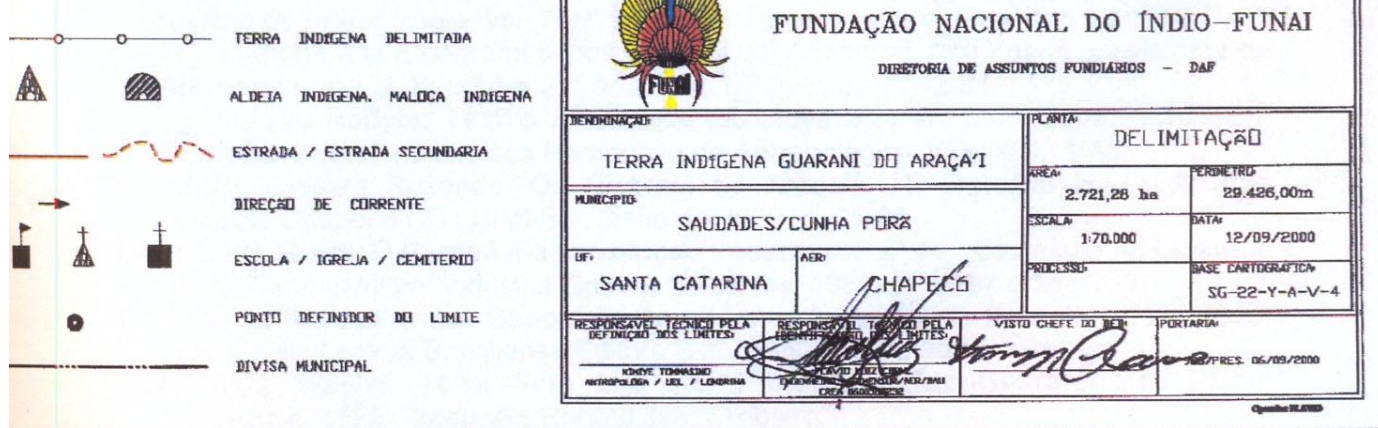




\section{LISTA DE SIGLAS}

\begin{tabular}{|c|c|}
\hline CIMI & Conselho Indígena Missionáro \\
\hline $\mathrm{TI}$ & Terra Indígena \\
\hline GT & Grupo de Trabalho \\
\hline $\mathrm{Al}$ & Área Indígena \\
\hline FUNAI & Fundação Nacional do Índio \\
\hline UNOESC & Universidade do Oeste de Santa Catarina \\
\hline TCC & Trabalho de Conclusão de Curso \\
\hline SPI & Serviço de Proteção ao Índio \\
\hline EIA/RIMA & $\begin{array}{l}\text { Estudo de Impacto Ambiental/Relatório de Impacto ao Meio } \\
\text { Ambiente }\end{array}$ \\
\hline USP & Universidade de São Paulo \\
\hline CEOM & $\begin{array}{l}\text { Centro de Organização da Memória do Oeste de Santa } \\
\text { Catarina }\end{array}$ \\
\hline ACARESC & Associação de Crédito e Assistência Rural de Santa Catarina \\
\hline DAF & Diretoria de Assuntos Fundiários \\
\hline DEF & Departamento Fundiário \\
\hline AER & Administração Executiva Regional \\
\hline INCRA & Instituto Nacional de Colonização e Reforma Agrária \\
\hline UNIJUÍ & Universidade de ljuí \\
\hline IPHAN & Instituto do Patrimônio Histórico e Arqueológico Nacional \\
\hline PUCRS & Pontífice Universidade Católica do Rio Grande do Sul \\
\hline UFSC & Universidade Federal de Santa Catarina \\
\hline PETI & Projeto Estudo Sobre Terras Indígenas no Brasil \\
\hline ANAI/RS & $\begin{array}{l}\text { Associação Nacional de Apoio ao Índio do Rio Grande do } \\
\text { Sul }\end{array}$ \\
\hline ISA & Instituto Sócioambiental \\
\hline COMIN & Conselho de Missão entre Índios \\
\hline PKG & Programa Kaiowa Guarani \\
\hline UNICAMP & Universidade de Campinas \\
\hline
\end{tabular}

\section{Referências bibliográficas}

ABOU, Sélim. La "República" Jesuítica de los Guaranis (1609-1768) y su Herencia. s/l.: Mantique Zago Ediciones, s/d. p. 112-155.

ALBUQUERQUE, Manoel Maurício de et al. Atlas Histórico Escolar. Rio de Janeiro: 
KIMIYE TOMMASINO - Relatório de Identificação e Delimitação da Terra Indígena...

FENAME, 1983.

ALMEIDA, Rubem Ferreira Thomaz de. Relatório Sobre a Situação dos GuaraniMbyá do Rio Grande do Sul: A Questão das Terras. Portaria 1852-E de 11/04/1985. Brasília: GT FUNAI, 1985.

ANGELI, Heitor Lothien. Crônicas do Oeste (História de Pioneiros). Cascavel: Gráfica Farroupilha, 1998.

ARAÚJO, Hermetes Reis de. Fronteiras Internas: Urbanização e Saúde Pública em Florianópolis nos Anos 20. In: BRANCHER, Ana. História de Santa Catarina Estudos Contemporâneos. Florianópolis: Livraria e Editora Obra Jurídica Ltda, 1999. p. 102-113.

ASTRAIN, Antonio S. I. Jesuítas, Guaraníes y Encomenderos - História de la Compania de Jesus en el Paraguay. Assunción: CEPAG, 1995.

BARBOSA, José Alberto. O Mistério de "Pedra dos Bugres"/ Xilogravura de Dirceu Marés de Souza. Traço de União, Porto União, 13 jun. 1972. 3 p. (mimeo).

BECKER, Ítala Irene Basele. O Índio Kaingang do Rio Grande do Sul. Pesquisas Antropologia, São Leopoldo, n. 29, 1976.

BELÉM, J. História do Município de Santa Maria. Porto Alegre: Livraria Slebach, 1933.

BELLO, José Maria. História da República - 1889-1954. Síntese de Sessenta e Cinco Anos de Vida Brasileira. São Paulo: Companhia Editora Nacional, 1969.

BOITEUX, Lucas A. A Província de Santa Catarina nas Guerras do Uruguai e Paraguai. Florianópolis: Imprensa da UFSC, 1972.

BRANCHER, Ana. História de Santa Catarina - Estudos Contemporâneos. Florianópolis: Livraria e Editora Obras Jurídicas Ltda, 1999.

BROCHADO, José Proenza. O Guarani: O Conquistador Vencido. In: O Índio no Rio Grande do Sul. Aspectos Arqueológicos, Históricos, Etnográficos e Étnicos. Porto Alegre: Governo do Estado do Rio Grande do Sul, 1975. p. 71-95.

BRUXEL, Arnaldo. Herança Guarani na Cultura Riograndense. In: O Índio no Rio Grande do Sul. Aspectos Arqueológicos, Históricos, Etnográficos e Étnicos. Porto Alegre: Governo do Estado do Rio Grande do Sul, 1975. p. 83-88.

CADOGAN, Léon. Como Interpretan Los Chiripá (Avá Guarani) La Danza Ritual. Revista de Antropologia, São Paulo, v. 7, n. 1 e 2, jun.-dez. 1959.

Aporte a la Etnografia de los Guaraní del Amambaí, Alto Ypané. Revista de Antropologia, São Paulo, v. 10, n. 1 e 2, p. 42-91, 1962.

Espaço Ameríndio, Porto Alegre, v. 7, n. 2, p. 277-556, jul./dez. 2013. 
KIMIYE TOMMASINO - Relatório de Identificação e Delimitação da Terra Indígena...

Ayvu Rapyta: Textos Míticos de los Mbyá-Guaraní del Guairá. Assunción: CEADUC-CEPAG, Biblioteca Paraguaya de Antropologia, 1992. v. 16.

CAPUCCI, Jussara Rezende. Os Guarani do Araça'í - O Retorno ao Lugar dos Antigos. Chapecó: CIMI-Sul, 2000.

CARNEIRO, David. O Paraná e a Revolução Federalista. Curitiba: Indústria Gráfica Golçalves, 1982.

CHIAVEnATTO, Julio Jose. Genocídio Americano: A Guerra do Paraguai. São Paulo: Livraria Brasiliense Editora S.A., 1980.

CLASTRES, Hélène. Terra Sem Mal - O Profetismo Tupi-Guarani. São Paulo: Brasiliense, 1978.

COSTA, Luis César Amad; MELlO, Leonel I. A. História do Brasil. São Paulo: Editora Scipione, 1993.

DARELlA, Maria Dorothea P. Breve Relato Obtido em Pesquisa de Campo. Relatório. Florianópolis, 19 fev. 2001. (mimeo).

DOOLEY, Robert A. Apontamentos Preliminares Sobre Nhandeva Guarani Contemporâneo. Brasília, 1991. (Arquivo Lingüístico n. 197).

EGLER, Valter Alberto. A Colonização no Norte da Argentina e Sudoeste do Paraguai. Boletim Geográfico - Conselho Nacional de Geografia, Rio de Janeiro, p. 931-941, dez. 1949.

Enciclopédia dos Municípios Brasileiros. Rio de Janeiro: IBGE, 1959. v. 32. p. 75-77 e 321-324.

ESPÍRITO SANTO, Enelise. A Agricultura no Estado de Santa Catarina. Chapecó: Grifos, 1999.

FALCÃO, Luis Felipe. A Guerra Interna (Integralismo, Nazismo e Nacionalização). In: BRANCHER, Ana (Org.). História de Santa Catarina - Estudos Contemporâneos. Florianópolis: Livraria e Editora Obras Jurídicas Ltda.,1999.

FERREIRA, Olavo Leonel. História do Brasil. São Paulo: Editora Ática, 1988.

FERRARI, Jussara Louzada. A Colonização do Tupi-Guarani no Nordeste do Rio Grande do Sul. In: SIMPÓSIO NACIONAL ESTUDOS MISSIONEIROS - As Reduções na Época dos Sete Povos, 3., 1979. Anais... Santa Rosa: FFCL Dom Bosco, 1979. p. 221-286.

FISCHER, Martin. Iraí: Cidade Saúde: Trechos Característicos de Sua História. Ijuí: Livraria e Tipografia "Progresso" de Muraro / Rech \& Cia. Ltda., 1954.

Espaço Ameríndio, Porto Alegre, v. 7, n. 2, p. 277-556, jul./dez. 2013. 
KIMIYE TOMMASINO - Relatório de Identificação e Delimitação da Terra Indígena...

FOLADOR, David. História de Campo Erê. Campo Erê: Prefeitura Muncipal de Campo Erê, 1991.

FRANZEN, Beatriz Vasconcelos. Os Jesuítas Portugueses e Espanhóis e sua Ação Missionária no Sul do Brasil e Paraguai (1580-1640). São Leopoldo: Unisinos. 1999.

GADELHA, Regina A. F. (Ed.). As Missões Jesuíticas do Itatim: Um Estudo das Estruturas Sócio-econômicas Coloniais do Paraguai (séculos XVI e XVII). Rio de Janeiro: Paz e Terra, 1980.

1999.

Missões Guarani: Impacto na Sociedade Contemporânea. São Paulo: EDUC,

GARLET, Ivori; ASSIS, Valéria S. de. Diagnóstico da População Mbyá-Guarani no Sul do Brasil. Cadernos do COMIN, São Leopoldo, n. 7, dez. 1998.

GARLET, Ivori J. Mobilidade Mbyá: História e Significação. 1997. Dissertação (Mestrado) - PUCRS, Porto Alegre, 1997.

GAY, João Pedro. História da República Jesuítica do Paraguay, desde o Descobrimento do Rio da Prata até Nossos Dias, anno de 1861. Revista Trimestral do Instituto Histórico, Geographico e Ethnographico do Brasil, Rio de Janeiro, 1. trim. 1863.

História da República Jesuítica do Paraguay, Desde o Descobrimento do Rio da Prata até Nossos Dias, anno de 1861. Revista Trimestral do Instituto Histórico, Geographico e Ethnographico do Brasil, Rio de Janeiro, 3. trim. 1863.

GOLIN, Tau. Etnocídio e Herança Índígena. Passo Fundo: EDIUPF, 1999.

HELD, Almir de Amorim Von (Org). Acampamento Guarani na Terra Indígena NONOAI, dos Índios Kaingang. Relatório da FUNAI-ERA. Chapecó, nov. 2000.

IGNEZ, Antonio Teixeira Guerra; GUERRA, Amélia L. Teixeira. Subsídios para uma Nova Divisão Política para o Brasil. Boletim Geográfico, Rio de Janeiro, p. 03-13, fev. 1964.

INDÍGENAS do Rio Grande do Sul. Levantamento sócio-econômico e cultural elaborado pelos jesuítas Thomaz de Aquino Lisboa, Egídio Schwade e Hans Born. São Leopoldo: SUDESUL, 1967.

ISA. RICARDO, Carlos Alberto (Ed.). Povos Indígenas no Brasil, 1991-1995. São Paulo: Instituto Sócio-Ambiental, 1996.

ISA. RICARDO, Carlos Alberto (Ed.). Povos Indígenas no Brasil, 1996-2000. São Paulo: Instituto Sócio-Ambiental, 2000.

ISQUERDO, Aparecida Negri. A Palavra Sagrada na Cultura Guarani: uma Cultura do

Espaço Ameríndio, Porto Alegre, v. 7, n. 2, p. 277-556, jul./dez. 2013. 
KIMIYE TOMMASINO - Relatório de Identificação e Delimitação da Terra Indígena...

"Ayvu Rapyta". Terra Indígena - Revista do Centro de Estudos Indígenas da F.C.L., Araraquara, ano 9, n. 62, p. 04-13, jan.-mar. 1992.

JAMES, Preston. A Expansão das Colônias do Brasil Meridional. Boletim Geográfico, Rio de Janeiro, ano 5, n. 49, p. 21-34, abr. 1947.

JECUPÉ, Kaka Werá. Tupã Tenondé: A Criação da Terra e do Homem Segundo a Tradição Oral Guarani. São Paulo: Petrópolis, 2001.

KRINDGES, Nanci Laufer. Experiências e Relações Sociais: Uma Análise do Cotidiano de Homens e Mulheres em Cunha Porã/SC - 1930-1945. 1999. Trabalho de Conclusão de Curso (Graduação em História) -UNOESC, Chapecó, 1999.

LACOMBE, Américo Jacobina. História do Brasil. São Paulo: Companhia Editora Nacional, 1979.

LADEIRA, Maria Inês. Os Índios Guarani e as Ilhas do Paraná. São Paulo: CPI, 1990. (mimeo).

O Caminhar sob a Luz: o Território Mbyá-Guarani à Beira do Oceano. 1992. Dissetação (Mestrado) - PUC-SP, São Paulo, 1992.

Os Guarani da Mata Atlântica. In: ISA. RICARDO, Carlos Alberto (Ed.). Povos Indígenas no Brasil: 1991-1995. São Paulo: Instituto Sócioambiental, 1996. p. 773-780.

Migrações Guarani Mbyá. Travessia, São Paulo, p. 21-24, jan.-abr. 1996.

LADEIRA, Maria Inês; AZANHA, Gilberto. Os Índios da Serra do Mar: A presença Mbyá-Guarani em São Paulo. São Paulo: Nova Estella Editorial, 1988.

LAYTANO, Dante de. Populações Indígenas: Estudo Histórico de Suas Condições Atuais no Rio Grande do Sul. Revista do Museu Júlio de Castilhos e Arquivo Histórico do Rio Grande do Sul, Porto Alegre, n. 8, p. 49-114, 1957.

LOHN, Reinaldo Lindolffo. A Cidade Contra o Campo. In: BRANCHER, Ana. História de Santa Catarina - Estudos Contemporâneos. Florianópolis: Livraria e Editora Obras Jurídicas Ltda, 1999.

MACHON, Jorge Francisco. La Reducion de Guayanas del Alto Paraná San Francisco de Paula. Argentina: Edicion del Autor, 1996.

Mapa Etno-histórico do Brasil e Regiões adjacentes adaptado do Mapa de Curt Nimuendaju - 1944. Rio de Janeiro: Fundação IBGE / Secretaria de Planejamento da Presidência da República, 1980.

Mapa - Terras Indígenas - Brasil: Situação das 561 Terras Indígenas. Brasília: Ministério da Justiça - MJ/FUNAI/DAF: 1999. 
KIMIYE TOMMASINO - Relatório de Identificação e Delimitação da Terra Indígena...

MELATTI, Julio César. Índios da América do Sul. 2001. Disponível em: Knewman@altavista.net. Acesso em: 29 dez. 2013.

MELIÀ, Bartomeu. Aspectos da Cultura Guarani. Porto Alegre: [s.n.], 1977. (mimeo.)

Informação Etnográfica e Histórica Sobre os Kaingang do Rio Grande do Sul. Publicações do Museu Municipal de Paulínia, Paulínia, v. 26, p. 11-24, 1983.

O Índio no Rio Grande do Sul. Frederico Westphalen: [s.n.], 1984. (Apostila, 19 de julho de 1984).

El Guaraní Conquistado y Reducido. Ensayos de Etnohistória. Asunción:

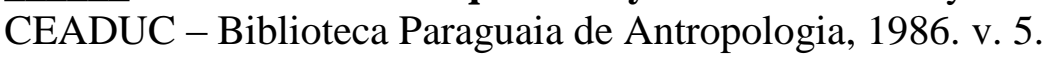

O Guarani: uma Bibliografia Etnológica. Santo Ângelo: Fundação Missioneira de Ensino Superior, 1987.

A Experiência Religiosa Guarani. In: O Rosto Índio de Deus. São Paulo: Vozes, 1989. (Desafios da Religião, tomo 1, série 7). p. 293-347. 33-46, 1990.

A Terra Sem Mal dos Guarani. Revista de Antropologia, São Paulo, v. 33, p.

MENDES, Nicolau. O Império dos Coroados. Porto Alegre: Centro de Tradições Gaúchas Ronda Crioula, 1954.

MÉTRAUX, Alfred. O Índio Guarani. In: Handbook of South American Indians. Washington: Smithsonian Institution Washington, 1948. v. 3.

MONTICELLI, Gislene. Correspondência Enviado ao GT Araça'í. Relatório. Porto Alegre, 20 de janeiro de 2001. (mimeo).

MONTOYA, Antonio Ruiz de. Conquista Espiritual Feita pelos Religiosos da Companhia de Jesus nas Províncias do Paraguai, Paraná, Uruguai e Tape. Porto Alegre: Martins Livreiro Editor, 1985.

MOREIRA, Luis Felipe Viel. Correspondência do Pe. Bernardo Parés de 14/01/1851 e Observações. Passo Fundo: Arquivo Histórico do Rio Grande do Su, 1851.

Correspondência do Sr. Antonio de Almeida Leite Penteado, Diretor do Aldeamento de Nonoai ao sr. Presidente da Província em 04 de julho de 1855. Passo Fundo: Arquivo Histórico do Rio Grande do Sul, 1855.

Correspondência do Sr. Antonio de Almeida Leite Penteado, Diretor do Aldeamento de Nonoai ao sr. Tiburcio Alvares de Siqueira Fortes em 04 de julho de 1855. Passo Fundo: Arquivo Histórico do Rio Grande do Sul, 1855. 
KIMIYE TOMMASINO - Relatório de Identificação e Delimitação da Terra Indígena...

Correspondência do Sr. Antonio de Almeida Leite Penteado, Diretor do Aldeamento de Nonoai ao Imº. Exmo ${ }^{\circ}$ Snr. Dr. Felisberto Pereira da Silva em 03 de abril de 1879, Vila da Palmeira. Passo Fundo: Arquivo Histórico do Rio Grande do Sul, 1879.

MOREIRA NETO, Carlos de Araújo. Alguns Dados para a História Recente dos Índios Kaingang. In: La Situación del Indígena en América del Sur. Montevideo: Biblioteca Científica, 1971. p. 395-407.

MOTA, Lúcio Tadeu. O Aço, a Cruz e a Terra: Índios e Brancos no Paraná Provincial (1853-1889). 1998. Tese (Doutorado) - UNESP, 1998.

MUNICÍPIO de Chapecó: Legislação e Evidências - 1917-1931. Cadernos do Centro de Organização da Memória Sócio-Cultural do Oeste de Santa-Catarina, Chapecó, ano 4, ago. 1989. Ed. Especial. (Série: Documento 1).

NEUMAnN, Eduardo. O Trabalho Guarani Missioneiro no Rio da Prata Colonial, 1640-1750. Porto Alegre: Martins Livreiro Editor, 1996.

NIMUENDAJU, Curt. Apontamentos Sobre os Guarani. Revista do Museu Paulista, São Paulo, v. 8, p. 10-57, 1954.

As Lendas da Criação e Destruição do Mundo como Fundamentos da Religião dos Apapocúva-Guarani. São Paulo: HUCITEC / Editora da Universidade de São Paulo, 1987.

NOELLI, Francisco Silva. Sem Tekohá Não Há Tekó. 1993. Dissertação (Mestrado) PUCRS, Porto Alegre, 1993. v. 1 e 2.

A Ocupação Humana na Região Sul do Brasil: Arqueologia, Debates e Perspectivas: 1872 - 2000. Revista USP - Antes de Cabral: Arqueologia Brasileira II, São Paulo, n. 44, p. 218-269, dez.-jan.-fev. 1999-2000.

PIAZZA, Walter Fernando. A Colonização de Santa Catarina. Florianópolis: Banco Regional de Desenvolvimento do Extremo Sul, 1982.

POLI, Odilon. Leituras em Movimentos Sociais. Chapecó: Grifos, 1999.

PORTO BORGES, Paulo Humberto. Ymã, Ano Mil e Quinhentos: Relatos e Memórias Indígenas Sobre a Conquista. Campinas/Cascavel: Mercado de Letras/Unipar, 2000.

ENCONTRO DE CIENTISTAS SOCIAIS - Problemática Regional e Aportes Para o Futuro, 2., 1994. Anais... Chapecó/Ijuí: UNOESC/UNIJUÍ, 1994. v. 2.

PROUS, André. Arqueologia Brasileira. Brasília: UnB, 1992.

Espaço Ameríndio, Porto Alegre, v. 7, n. 2, p. 277-556, jul./dez. 2013. 
KIMIYE TOMMASINO - Relatório de Identificação e Delimitação da Terra Indígena...

RAMBO, Balduíno. Os Índios Rio-grandenses Modernos. In: Província de São Pedro. Rio de Janeiro/Porto Alegre/São Paulo: Globo, 1947. p. 80-88.

RELATÓRIOS dos Representantes Estaduais Apresentados à VII Reunião Ordinária da Assembléia Geral do C.N.G. Boletim Geográfico, Rio de Janeiro, n. 51, p. 322-326, jun. 1947.

RELATÓRIO com que abri a primeira sessão ordinária da segunda Legislatura da Província de São Pedro do Rio Grande do Sul. O exmº. Sr. Conde de Caxias, presidente da mesma província. Porto Alegre: Typographia de I. J. Lopes, $1^{\circ}$ de março de 1846.

RELATÓRIO do presidente da província de São Pedro do Rio Grande do Sul o Senador conselheiro Manoel Antonio Galvão na abertura da Assembléia Provincial. Porto Alegre: Typographia dos Anjos, J. C. Barreto, 05 de outubro de 1847.

RELATÓRIO do Vice Presidente da Província de São Pedro do Rio Grande do Sul João Capistrano de Miranda Castro na abertura da Assembléia Legislativa Provincial. Porto Alegre: Typographia Portoalegrense, 04 de março de 1848.

RELATÓRIO: aditamento feito ao relatório, que perante a Assembléia Provincial do Rio Grande de São Pedro do Sul dirigio o Exmº. Vice-Presidente da Província em sessão de 4 de março de 1848, pelo ILMO. Exmº. Sr. Presidente da Província e Comandante de exército em Guarnição Francisco José de Souza Soares de Andréa, para ser presente à mesma Assembléia. Porto Alegre: Typographia do "Comércio", 1849.

RELATÓriO do Presidente da Província de São Pedro do Rio Grande do Sul ao Tenente Central Francisco José de Souza Soares de Andrea. Assembléia Legislativa Provincial. Porto Alegre: Typographia Portoalegrense, $1^{\circ}$ de junho de 1849.

RELATÓRIO do Presidente da Província de São Pedro do Rio Grande do Sul ao Conselheiro José Antonio Pimenta Bueno. Assembléia Legislativa Provincial. Porto Alegre: Typographia de Pomatelli, $1^{\circ}$ de outubro de 1850.

RELATÓRIO do Vice Presidente da Província de São Pedro do Rio Grande do Sul Patricio Corrêa da Camara na abertura da Assembléia Legislativa Provincial. Porto Alegre: Typographia Mercantil, 02 de outubro de 1851.

RELATÓRIO do Vice Presidente da Província de São Pedro do Rio Grande do Sul Luis Alves Leite de Oliveira Bello na abertura da Assembléia Legislativa Provincial. Porto Alegre: Typographia Portoalegrense, $1^{\mathrm{o}}$ de outubro de 1852.

RELATÓRIO da Secretaria de Estado dos Negócios das Obras Públicas Apresentado ao Exmo. Sr. Dr. Carlos Barbosa Gonçalves, Presidente do Rio Grande do Sul, pelo Secretário de Estado Candido José de Godoy. Porto Alegre: Officinas Graphicas da Livraria do Globo, 13 de setembro de 1912.

RELATÓRIO da Diretoria de Obras Públicas. In: Relatório da Secretaria de Obras

Espaço Ameríndio, Porto Alegre, v. 7, n. 2, p. 277-556, jul./dez. 2013. 
KIMIYE TOMMASINO - Relatório de Identificação e Delimitação da Terra Indígena...

Públicas. Porto Alegre: 1912.

RELATÓRIO da Diretoria de Obras Públicas. In: Relatório da Secretaria de Obras Públicas. Porto Alegre: 1913.

RELATÓRIO da Secretaria de Obras Públicas/Estado do Rio Grande do Sul - Tenente Gonçalves. Proteção Fraterna aos Indígenas do Rio Grande do Sul. Rio Grande do Sul, 1915.

RELATÓRIO do Secretário dos Negócios das Obras Públicas/Estado do Rio Grande do Sul. Proteção Fraterna aos Indígenas do Rio Grande do Sul. Rio Grande do Sul, 1916.

RENK, Arlene. A luta da Erva: Um Ofício Étnico no Oeste Catarienese. Chapecó: Grifos, 1997.

Migrações. Chapecó: Grifos, 1999.

RIBEIRO, Darci. SPI - Relatório das Atividades do Serviço de Proteção aos Índios Durante o Ano de 1954.

Os Índios e a Civilização. Civilização Brasileira: Rio de Janeiro, 1970.

RICARDO, Carlos Alberto. "Os Índios" e a Sociodiversidade Nativa Contemporânea no Brasil. In: SILVA, Aracy Lopes da; GRUPIONI, Luis Donizete Benzi (Orgs.). A Temática Indígena na Escola: Novos Subsídios para Professores de $1^{\circ}$ e $2^{\circ}$ Graus. Brasília: MEC/MARI/UNESCO, 1995. p. 29-60.

RODRIGUES, Aryon Dall'Igna. Línguas Brasileiras: Para o Conhecimento das Línguas Indígenas. São Paulo: Edições Loyola, 1986.

ROYER, Venida. Colonização, Memória e Experiências em Saudades. Cadernos do CEOM, Chapecó, p. 99-136, 1999.

RÜCKERT, Aldomar A. A Trajetória da Terra: Ocupação e Colonização do CentroNorte do Rio Grande do Sul - 1827-1931. Passo Fundo: EDIUPF, 1997.

SAINT-HILAIRE. Auguste de. Viagem ao Rio Grande do Sul. Porto Alegre: ERUS/ Martins Livreiro, 1987.

SAHLINS, Marshall. Ilha de História. Rio de Janeiro: Jorge Zahar, 1990.

SALZANO, Francisco Mauro. Estudos Genéticos e Demográficos Entre os Índios do Rio Grande do Sul. 1961. Tese de Livre-docência - URGS, Porto Alegre, 1961.

SCHADEN, Egon. A Mitologia Heróica de Tribos Indígenas do Brasil - Ensaio Etno-Sociológico. Rio de Janeiro: Departamento de Imprensa Nacional, 1959. 
KIMIYE TOMMASINO - Relatório de Identificação e Delimitação da Terra Indígena...

do Livro, 1962.

Aspectos Fundamentais da Cultura Guarani. São Paulo: Difusão Européia

. Caracteres Específicos da Cultura Mbüá-Guarani. Revista de Antropologia, São Paulo, v. 11, n. 1 e 2, p. 83-94, jun.-dez. 1963.

Paulo, 1969.

Aculturação Indígena. São Paulo: Livraria Pioneira/Universidade de São

A Religião Guarani e o Cristianismo - Contribuição ao Estudo de um Processo

Histórico de Comunicação Intercultural. Revista de Antropologia, São Paulo, v. 25, p. 01-24, 1982.

SCHADEN, Francisco S. G. Índios, Cablocos e Colonos: Páginas de Etnografia, Sociologia e Folclore. São Paulo: USP, 1963. (Coleção da Revista de Antropologia).

SERVICE, Elman R. Os Caçadores. Rio de Janeiro: ZAHAR Editores, 1971.

SEVERAL, Rejane da Silveira. A Guerra Guaranítica. Porto Alegre: Martins Livreiro Editor, 1995.

Jesuítas e Guaranis Face aos Impérios Coloniais Ibéricos no Rio da Prata.

Revista de História Régio, v. 3, n. 1, p. 01-12, 1998.

SIMON, Mário. Os Sete Povos das Missões: Trágica Experiência. Porto Alegre: Martins Livreiro Editor, 1993.

SIMONIAN, Lígia T. L. Visualização: Estado Expropria e Domina Povo Guarani e Kaingang. Cadernos do Museu - Museu Antropológio Diretor Pestana, Ijuí, n. 9, p. 01-26, maio 1980.

Terra de Posseiros - Um Estudo Sobre as Políticas de Terras Indígenas. 1981. Dissertação (Mestrado) - UFRJ, Rio de Janeiro, 1981.

A Luta Pela Terra em Nonoai: Morte e Vida. In: PETI/ANAÍ-RS: Expropriação e Luta: As Terras Indígenas no Rio Grande do Sul. Rio de Janeiro: PETI PPGAS/Museu Naciona/UFRJ: 1990/93. p. 54-62. (1ª e $2^{\text {a }}$ Versão).

Discriminação, Demarcação e Expropriação de Terras Guarani-Xiripá: Ações do Governo Estadual e/ou Com Seu Respaldo. In: PETI/ANAÍ-RS: Expropriação e Luta: As Terras Indígenas no Rio Grande do Sul. Rio de Janeiro: PETI - PPGAS/Museu Naciona/UFRJ: 1990/93. p. 122-126. (1 $1^{\mathrm{a}}$ e $2^{\mathrm{a}}$ Versão).

AI Salto Grande. In: PETI/ANAÍ-RS: Espropriação e Luta: As Terras Indígenas no Rio Grande do Sul. Rio de Janeiro: PETI - PPGAS/Museu Naciona/UFRJ: 1990/93. p. 183-185. (1 ${ }^{\mathrm{a}}$ e $2^{\mathrm{a}}$ Versão).

SOARES, André Luis R. Guarani: Organização Social e Arqueologia. Porto Alegre:

Espaço Ameríndio, Porto Alegre, v. 7, n. 2, p. 277-556, jul./dez. 2013. 
KIMIYE TOMMASINO - Relatório de Identificação e Delimitação da Terra Indígena...

EDIPUCRS, 1997.

SOUZA FILHO, Carlos Frederico Marés. O Renascer dos Povos Indígenas para o Direito. Curitiba: Juruá, 1998.

SUSNIK, Branislava. Dispersión Tupí-Guaraní Prehistórica: Ensayo Analítico. Asunción: Museo Etnográfico “Andres Barbero”, 1975.

TESCHAUER, Carlos. Os Caingang ou Coroados no Rio Grande do Sul. Boletim do Museu Nacional, Rio de Janeiro, v. 3, n. 3, p. 37-56, 1927.

TERRA indígena Guarani de Cunha Porã - SC. Dossiê organizado pela FUNAIAER. Chapecó: FUNAI/AER, 1998.

THOMÉ, Nélson. Formação Antropológica do Homem do Oeste Catarinense. Caçador: Impressora Universal Ltda, 1984.

TOMMASINO, Kimiye. A História dos Kaingáng da Bacia do Tibagi: Uma Sociedade Jê Meridional em Movimento. 1995. Dissertação (Mestrado) - USP, São Paulo, 1995.

TURNER, Terence. History, Mith, and Social Consciusness Among the Kayapó of Central Brazil. In: HILL, J. Rethinking History and Mith: Indigenous south American Perspectives on the Past. University of Illinois: Chicago, 1988.

De Cosmologia a História: Resistência, Adaptação e Consciência Social entre os Kayapó. In: CASTRO, Eduardo V.; CUNHA, Manoela C. da (Orgs.). Amazonia, Etnologia e História Indígena. São Paulo: Cia das Letras, 1992.

VENZON, Rodrigo A. Os Guarani Missioneiros: Incorporação e Sobrevivência. In: PETI/ANAÍ-RS: Expropriação e Luta: As Terras Indígenas no Rio Grande do Sul. Rio de Janeiro: PETI - PPGAS/Museu Naciona/UFRJ: 1990/93a. p. 118-121. (1 ${ }^{\mathrm{a}}$ e $2^{\mathrm{a}}$ Versão).

. Migração e Territoriedade Mbyá no Rio Grande do Sul (1). In: PETI/ANAÍRS: Expropriação e Luta: As Terras Indígenas no Rio Grande do Sul. Rio de Janeiro: PETI - PPGAS/Museu Naciona/UFRJ: 1990/93b. p. 169-172. (1 a e 2 $2^{\text {a }}$ Versão).

WACHOWICZ, Ruy Christovam. Paraná, Sudeste: Ocupação e Colonização. Curitiba: Ed. Vicentina Ltda., 1987.

História do Paraná. Curitiba: Gráfica Vicentina Ltda., 1988.

WAIBEL, Leo. Princípios da Colonização Européia no Sul do Brasil. Revista Brasileira de Geografia, Rio de Janeiro, ano 50, Número Especial Clássicos da Geografia, jan.-mar. 1988. Tomo1.

WERLANG, Alceu Antonio. A Colonização às Margens do Rio Uruguai no Extremo

Espaço Ameríndio, Porto Alegre, v. 7, n. 2, p. 277-556, jul./dez. 2013. 
KIMIYE TOMMASINO - Relatório de Identificação e Delimitação da Terra Indígena...

Oeste Catarinense: Atuação da Cia. Territorial Sul Brasil - 1925 a 1954. 1992. Dissertação (Mestrado) - UFSC, Florianópolis, 1992.

Processo de Colonização no Oeste de Santa Catarina - Atuação da Cia. Territorial Sul Brasil. Cadernos do CEOM, Chapecó, ano 9, n. 9., p. 09-46, jul. 1995.

WITT, Francisco Aureliano Dorneles. Breve Relatório Sobre os Índios Mbyá e Nhandeva Guarani Atuais do Litoral do Rio Grande do Sul, Santa Catarina e Paraná. Osório: FUNAI - 13º DR, 1993.

Relatório de Estágio Com os Índíos Mbyá Guarani no Rio Grande do Sul. Passo Fundo: FUNAI - $13^{\circ}$ DR, s/d.

WOLLF, Juçara Nair. Festa do Kerb: Espaços de Sociabilidade, Conflitos e Resistências. Cadernos do CEOM, Chapecó, p. 55-98, 1999. 